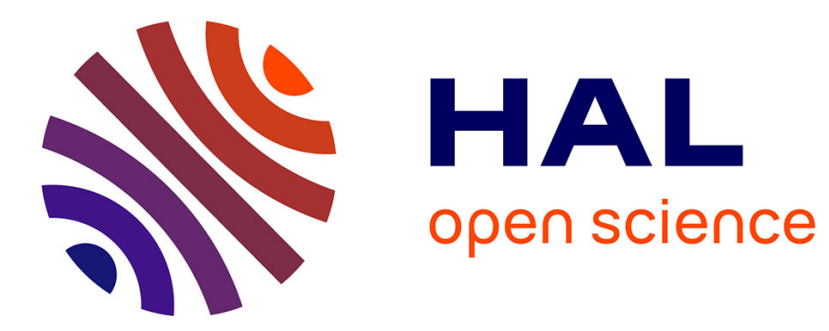

\title{
Biostratigraphic distribution of orbitolinids in the ammonite biozones (Urgonian platform of southeastern France). Part 2: Barremian p.p.
}

Bruno Granier, Bernard Clavel, Robert Busnardo, Jean Charollais, Pierre Desjacques, Didier Bert

\section{To cite this version:}

Bruno Granier, Bernard Clavel, Robert Busnardo, Jean Charollais, Pierre Desjacques, et al.. Biostratigraphic distribution of orbitolinids in the ammonite biozones (Urgonian platform of southeastern France). Part 2: Barremian p.p.. Carnets de Geologie, 2021, 21 (18), pp.399-521. 10.2110/carnets.2021.2118. insu-03403861

\section{HAL Id: insu-03403861 \\ https://hal-insu.archives-ouvertes.fr/insu-03403861}

Submitted on 26 Oct 2021

HAL is a multi-disciplinary open access archive for the deposit and dissemination of scientific research documents, whether they are published or not. The documents may come from teaching and research institutions in France or abroad, or from public or private research centers.
L'archive ouverte pluridisciplinaire HAL, est destinée au dépôt et à la diffusion de documents scientifiques de niveau recherche, publiés ou non, émanant des établissements d'enseignement et de recherche français ou étrangers, des laboratoires publics ou privés.

\section{(ㅇ)(1)(2)}

Distributed under a Creative Commons Attribution - NonCommercial - ShareAlikel 4.0 


\title{
Biostratigraphic distribution of orbitolinids in the ammonite biozones (Urgonian platform of southeastern France). \\ Part 2: Barremian p.p.
}

\author{
Bruno Granier ${ }^{1}$ \\ Bernard Clavel $(t)$ \\ Robert BUSNARDO $(+)$ \\ Jean Charollais ${ }^{2}$ \\ Pierre Desjacques ${ }^{3}$ \\ Didier BERT ${ }^{4}$
}

\begin{abstract}
The biostratigraphic distribution of orbitolinids for the Barremian of SE France proposed hereafter is calibrated on the ammonite biozonation. This work is based on the study of eleven sections with orbitolinids associated to macrofossils (ammonites and/or echinids) significant in terms of biostratigraphy or overlain with levels bearing the above macrofossils.
\end{abstract}

\section{Key-words:}

- Barremian;

- Urgonian;

- orbitolinid foraminifers;

- ammonites;

- biostratigraphy;

- SE France

Citation: Granier B., Clavel B., Busnardo R., Charollais J., Desjacques P. \& Bert D. (2021).- Biostratigraphic distribution of orbitolinids in the ammonite biozones (Urgonian platform of southeastern France). Part 2: Barremian p.p.- Carnets Geol., Madrid, vol. 21, no. 18, p. 399-521.

Résumé :Répartition biostratigraphique des orbitolinidés dans la biozonation à ammonites (plate-forme urgonienne du Sud-Est de la France). 2e partie : Barrémien p.p.- La répartition biostratigraphique des orbitolinidés du Barrémien présentée ci-dessous est calibrée sur la biozonation des ammonites. Ce travail est basé sur l'étude de onze coupes de terrain qui ont livré des orbitolinidés de niveaux encadrés ou surmontés par des faciès à ammonites et/ou à échinides significatifs sur le plan biostratigraphique.

Mots-clefs :

- foraminifères ;

- Orbitolinidae ;

- taxinomie :

- phylogénie ;

- biostratigraphie ;

- SE France

${ }^{1}$ 2, impasse Charles Martel, 29217 Plougonvelin (France)

brcgranier@free.fr

${ }^{2}$ Département de Géologie et de Paléontologie, Sciences de la Terre, 13, r. Maraîchers, CH-1211 Genève 4 (Switzerland);

Muséum d'Histoire naturelle de la Ville de Genève, 1 route Malagnou, CH-1206 Genève (Switzerland) jdcharollais@bluewin.ch

${ }^{3}$ 7, avenue de l'Aurore, $\mathrm{CH}-1225$ Chêne-Bourg (Switzerland)

pi_desjacques@bluewin.ch

${ }^{4}$ Réserve Naturelle Nationale Géologique de Haute-Provence, Service Environnement, Conseil départemental des Alpes de Haute-Provence, 13, rue du Docteur-Romieu, CS 70216, 04995 Digne-Les-Bains cedex 9 (France);

Laboratoire Géosciences, UMR-CNRS 6118, Université de Rennes-1, campus Beaulieu, bâtiment 15, 35042 Rennes cedex (France);

Laboratoire du Groupe de Recherche en Paléobiologie et Biostratigraphie des Ammonites, Bois-Mésanges, quartier Saint-Joseph, 04170 La Mure-Argens (France)

didier.paleo@gmail.com

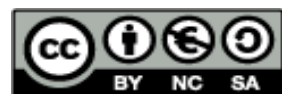

Published online in final form (pdf) on October 24, 2021

[Editor: Michel MOULLADE; language editor: Phil SALVADOR; technical editor: Bruno GRANIER] 


\section{Introduction}

This publication focuses on Barremian orbitolinid species [and a lookalike, Moulladella jourdanensis (FouRY \& MOULLADE, 1966), which will appear preceded by a spade sign $\$$ in the rest of the text, figures, and plates. As a matter of fact, this species was recently excluded from the family Orbitolinidae and transfered to the family Pfenderinidae by BUCUR and SCHLAGINTWEIT (2018). According to M. SEPTFONTAINE (personal communication, 27/09/2021), it is possibly an isomorph of Conicopfenderina SEPTFONTAINE, 1988] from sections logged with diagnostic ammonites (and echinids, using Clavel's range chart, 1984). It is the second publication in a row because it follows a first one that dealt with slightly older orbitolinid assemblages, i.e., late Hauterivian to earliest Barremian in age (CLAVEL et al., 2010). The eleven sections studied (Fig. 1) span environments ranging from the shallower inner platform (Serre de Tourre, Pont d'Arc) to deeper basinal areas (e.g., La Charce). These data supplement and corroborate the observations carried out from the debris flows and turbidites at L'Estellon, the "Rosetta Stone of the Urgonian biostratigraphy" (BUSNARDo et al., 2013; Granier et al., 2013, 2014, 2017; ClaVel et al., 2014; BeRT, 2017). They also contribute to demonstrating that, contrary to the misleading claims of ARNAUD-VANNEAU (1980 et seq.), most orbitolinid species previously reported from Urgonian and coeval facies mostly ascribed late Barremian or Bedoulian (early Aptian sensu lato) ages were already extensively present from the dawn of the Barremian.

\section{Material and method}

The ammonites were initially studied by the late Robert BUSNARDO 1926-2018 whereas the micropaleontological analyses are mostly the work of the late Bernard CLAVEL 1938-2018 (CHAROLLAIS \& GRANIER, 2020).

The ammonites (Ammonitina, Ancyloceratina, Lytoceratina and Phylloceratina) were identified by Robert BUSNARDO the material of whom, identified with a FSL numbering, is stored in the collections of Faculté des Sciences de Lyon, Université Claude BERNARD (Lyon). One may find in our publication some illustrations of material (ammonites and orbitolinids) with an ID numbering, which stands for Institut DolomiEu, Université Joseph FOURIER (Grenoble); this material is mostly reused from publications of ARNAUD-VANNEAU (1980) and ARNAUD et al. (1998). There could be some disagreements regarding the generic and/or specific identifications between our colleague's original views and other options following Didier BERT's quick review (the latter joined our working group just before the passing of Robert BUSNARDO). However, that should not affect significantly the stratigraphic ascription of the strata bearing the orbitolinids.

Regarding the orbitolinids, the large number of plates and photomicrographs emphasizes the purpose of the project leader, the late Bernard CLAVEL, to include the various orbitolinid species because they usually occur in most samples studied and not only in a few sections particularly illustrative of specimens perfectly preserved but seldom found, hence of limited value for biostratigraphical purposes. These thin sections and the related material will be deposited at the "Muséum d'Histoire naturelle de Genève" (Switzerland).

Some species benefit from a larger number of photomicrographs than others. They correspond to:

1) forms previously described but never reported in the biostratigraphic range charts published by ARNAUD-VANNEAU (see ARNAUD et al., 1998; ARNAUD-VANNEAU et al., 2005), among which A) Montseciella arabica (HENSON, 1948) [Pls. 93, 113 ], clearly identified throughout the studied area and included in our list of species cited, as well as B) Montseciella glanensis (FourY, 1968) and C) Paracoskinolina querolensis CANÉROT \& PEYBERnÈs, 1981, and

2) forms (e.g., Orbitolinopsis briacensis ARNAUD-VANNEAU, 1980, O. buccifer ARNAUD-VANNEAU \& ThieuloY, 1972, O. cuvillieri Moullade, 1960, and O. kiliani (PREVER, 1905)) the occurrences of which were supposedly restricted to various levels of the upper Barremian or the Bedoulian (lower Aptian sensu lato) as erroneously claimed by the same author (see ARNAUD et al., 1998; ARNAUD-VANNEAU et al., 2005).

Although the specific features of Paleodictyoconus cuvillieri are indifferently distributed in both $P$. cuvillieri and $P$. actinostoma starting from the upper Hauterivian strata and upwards, this question will not be addressed here but in a forthcoming paper. Finally, in our opinion, Orbitolinopsis pygmaea ARNAUD-VANNEAU, 1980, first recorded in lowermost Barremian strata, actually corresponds to the early growth stage in the ontogenetic development (= juvenile specimens) of several Orbitolinopsis species and should not be considered as an individual species.

The workflow and techniques developed by the late Bernard CLAVEL to study orbitolinids have already been discussed in several earlier publications (Clavel et al., 2010, 2014; Clavel in Granier et al., 2013, 2017). We assume that they provide a simple explanation of the huge discrepancies, eventually exceeding one full stage, in the biostratigraphic ranges published respectively by ARNAUD et al. (1998) and ARNAUD-VANNEAU (2005), on one side, and by CLAVEL et al. (2007, 2009a, 2009b, 2009c, 2010, 2014), CHAROLLAIS et al. (2008), and GRANIER et al. (2013, 2014, 2016, 2017), on the other side.

At the very beginning of any orbitolinid study, any geologist is urged to correctly sample rock material from the outcrops (PI. 31, fig. A). To start with, a close examination with hand lenses on the field is required to undertaking the selection of rich and representative rock samples, commonly reaching half a kilogram in weight. 


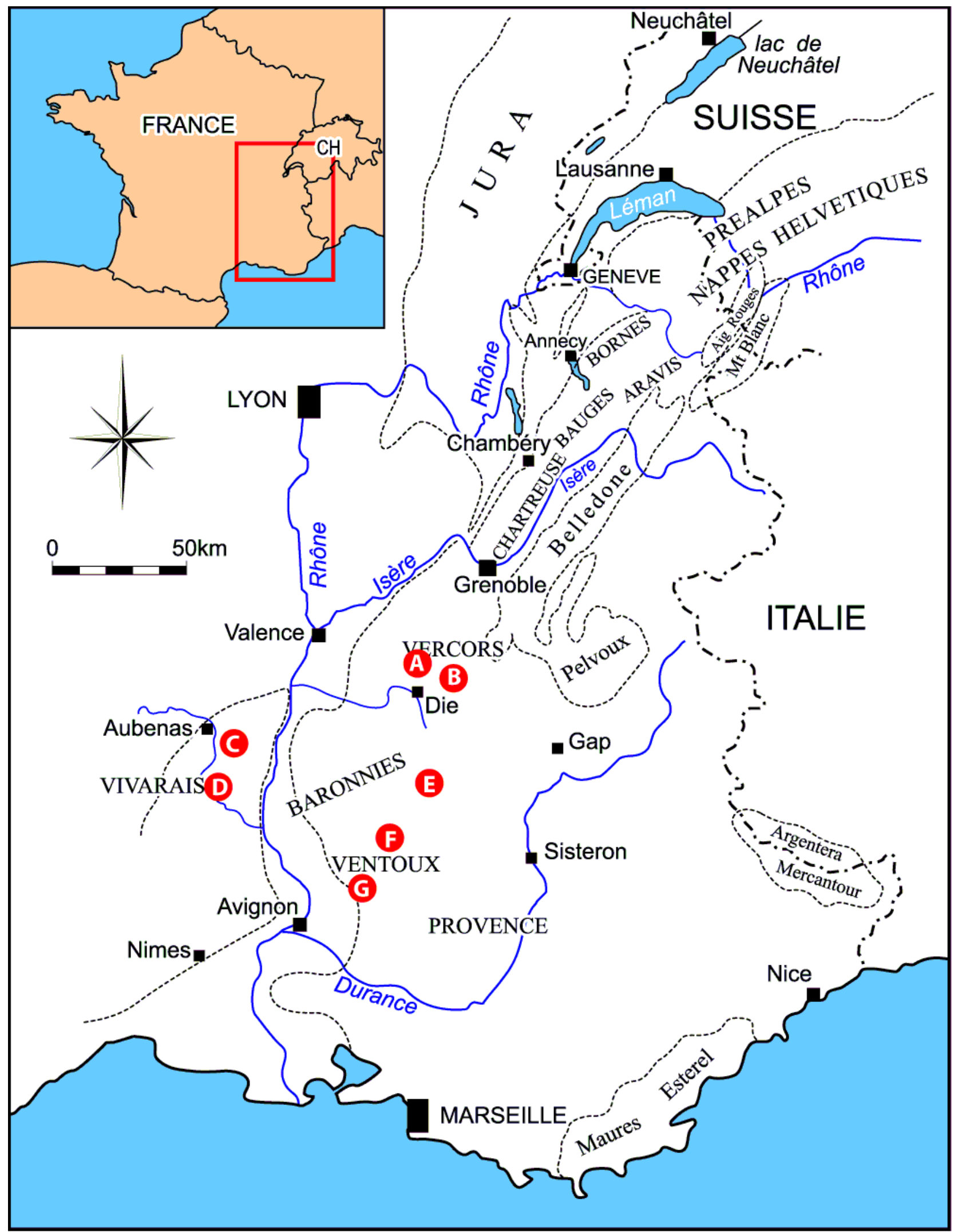

Figure 1: Location map of the sections studied. Section labels are a continuation of the numbering used in the first part of this study (CLAVEL et al., 2010): A) La Béguère [12], Col de Rousset [16]; B) La Montagnette [10]; C) Rochecolombe [13]; D) Mas de Gras [9], Serre de Tourre [11], Pont d'Arc [18], Orgnac [19]; E) La Charce [17], L'Estellon; F) Mas Thibaud [14]; G) Gorges de la Nesque [15]. 
In the case of limestones, the samples are slabbed in the laboratory (PI. 31, fig. C). Then each piece of slab is planed and polished (PI. 31, fig. D) before careful examination under a binocular microscope to locate sections of various orbitolinid species with orientations suitable for their taxonomic identification (PI. 31, figs. E-G). The most characteristic sections, e.g., axial sections cutting through the embryo, are photographed. Later they are possibly used to prepare discrete petrographic thin sections (PI. 31, figs. IJ). Unfortunately, during this last process, some specimens could be destroyed: In this case, the only material left will be a low-resolution photomicrograph. Photomicrographs of specimens only available from polished slabs are marked by the sample numbering followed of an asterisk *; in the case no photomicrograph record exists in the electronic archives of the late Bernard CLAVEL (CD, DVD, external hard drive), the sample numbering is preceded by a question mark ? and once again followed of an asterisk * plus a note [NF] standing for "not found" (which applies to 10 photomicrographs only). Most of the time the petrographic thin sections of the selected samples allow the taking of photomicrographs in transmitted light with a better resolution than those of the polished slabs taken in reflected light.

In the case of marls, a larger volume of rock is required. For instance, samplings of not less than ten kilograms in both hemipelagic layers underlying the bioclastic facies and marly layers occurring within the Urgonian Limestone Formation were necessary to obtain residues sufficiently rich in microfauna for analysis after washing, drying and sieving (PI. 31, fig. K).

Experience has shown that this selection task, which requires several days of sample handling and examination, is the only way to obtain a significant diversity in the fossil assemblage, on the one hand, and characteristic sections of the various orbitolinid species that make up it, on the other hand. When studying the "Gorges du Nan" section, one of us (BC) computed that more than $85 \mathrm{~kg}$ of rocks where collected, out of which polished slabs and 350 thin sections were made representing respectively some $5.7 \mathrm{~m}^{2}$ and less than $0.2 \mathrm{~m}^{2}$ in surface. As a result, the surface covered when observing polished slabs is 36 times larger than that for thin sections, increasing significantly the number of orbitolinid specimens observed. Another extremely demonstrative example is given by comparison of the results of BERNAUS (1998) versus those of BECKER (1999). Both authors successively worked on the Organyà section (Catalan Pyrenees) but, on a $70 \mathrm{~m}$ thick interval of this section, BERNAUS (1998; BERNAUS et al., 2000) identified only one species of orbitolinid with no real biostratigraphic value whereas BECKER (1999) identified 13 taxa (Schroeder et al., 2000; ConRAd et al., 2004: Fig. 2) and documented his finds with some fifteen photomicrographs of the most significant species.

\section{Summary descriptions of the studied sections}

In the first part of this study, Clavel et al. (2010) documented the fossil assemblages (ammonites, echinids, orbitolinids, Moulladella jourdanensis, and Dasycladales) from 8 sections:

1. the "Pic de l'Oeillette" section (38 Isère, Chartreuse) logged along RD (departmental road) $520 \mathrm{~B}$ in the vicinity of the peak [GPS: $45^{\circ} 21^{\prime} 00.1^{\prime \prime} \mathrm{N} 5^{\circ} 46^{\prime} 12.6^{\prime \prime E]}$ (ARNAUd-VANNEAU, 1980: p. 219-220),

2. the "Combe de Bella Cha" section (74 HauteSavoie, Aravis) based on several spots of observation and fossil collection (CHAROLLAIs et al., 2009),

3. the "Grands Goulets" section (26 Drôme, Vercors), starting at $675 \mathrm{~m}$ altitude, GPS coordinates: $45^{\circ} 00^{\prime} 37.5^{\prime \prime} \mathrm{N} 5^{\circ} 24^{\prime} 33.1^{\prime \prime} \mathrm{E}$, and ending at $675 \mathrm{~m}$ altitude, GPS: $45^{\circ} 00^{\prime} 07.9^{\prime \prime} \mathrm{N} \mathrm{5} 5^{\circ} 25^{\prime}$ 17.7"E (ARnaud-Vanneau, 1980: p. 238),

4. the "Pont de Laval" section (07 Ardèche, Vivarais), starting at the $353 \mathrm{~m}$ marked spot [GPS: $44^{\circ} 24^{\prime} 07.4^{\prime \prime} \mathrm{N} 4^{\circ} 28^{\prime} 55.6^{\prime \prime E}$ ] and ending at the $601 \mathrm{~m}$ marked spot [GPS: 44.24' 27.2"N 4²9'00.5"E] (ChAROLLAIs et al., 1998: p. $103,105,107)$,

5. the "Mont Aiguille" section (38 Isère, Vercors), A) lower part in the Aiguille mountain stream, starting at $1491 \mathrm{~m}, \mathrm{GPS}$ coordinates:

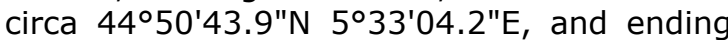
at $1750 \mathrm{~m}$, GPS coordinates: circa 4450' 33.5"N 5०33'08.8"E, and B) upper part East of the Aupet mountain pass at $1750 \mathrm{~m}$ altitude, GPS coordinates: circa 4450'23.9"N $5^{\circ}$ 32'44.4"E (Busnardo et al., 1991),

6. the "Pas de I'Essaure" section (38 Isère, Vercors), in Combau valley below the pass at $1662 \mathrm{~m}$ altitude, GPS coordinates: 444ㄱ 33.7"N 5०33'31.4"E (Arnaud-VANneau, 1980: p. 267),

7. the Arredons section (07 Ardèche, Vivarais), West of Saint-Remèze, in the vicinity of the 382 m marked spot, GPS coordinates: 44 ${ }^{\circ} 23^{\prime}$ 04.3"N 4²8'36.3"E (ChAROLLAIS et al., 1998: p. $103,105,107)$.

8. the Chames section (07 Ardèche, Vivarais) in the "Gorges de l'Ardèche", starting at $98 \mathrm{~m}$ altitude, GPS coordinates: $44^{\circ} 22^{\prime} 36.5^{\prime \prime} \mathrm{N} 4^{\circ}$ 25'28.9"E (ChAROLLAIS et al., 1998: p. 104$105,107)$.

\section{La Vignasse, Mas de Gras (07 Ardèche, Vivarais) \\ (Fig. 2.9)}

lower Barremian (Ba2 LST): Pulchella Zone (Pls. 32 - 45)

The "La Vignasse" section [beginning at UTM 31 (WGS84) X: 620804.545, Y: 4920393.199; GPS: $44^{\circ} 25^{\prime} 36.3^{\prime \prime} \mathrm{N} 4^{\circ} 31^{\prime} 03.7^{\prime \prime E}$ ending at UTM 31 (WGS84) X: 623168.416, Y: 4921520.324; GPS: $44^{\circ} 26^{\prime} 11.4^{\prime \prime} \mathrm{N} 4^{\circ} 32^{\prime} 51.5^{\prime \prime E}$ ) is located ap- 
proximately $5 \mathrm{~km}$ northeastward of the area of "Pont de Laval" (CLAVEL et al., 2010: § 4. Pont de Laval, Fig. 2.4). It is a section of major interest for the biostratigraphic calibration of the orbitolinids on the lower Barremian ammonite zones. First studied by LAFARGE (1978), it was later revisited by CLAVEL et al. (2007, 2014). For a better understanding of the regional framework, one should refer to the 1:50 000 scale geological maps of "Bourg-Saint-Andéol" (PASCAL et al., 1989) and "Aubenas" (ELMI et al., 1996), as well to the Geological Guide no. 8 of the University of Geneva (ChAROLLAIs et al., 1998).

At Mas de Gras, the first biocalcarenitic levels with orbitolinids and dasycladalean algae are found interbedded with hemipelagic facies that yield numerous ammonites of the Ohmi, Hugii, Pulchella, Compressissima, and Moutonianum zones (Fig. 2.9). Emericiceras emerici (LÉVEILLÉ, 1837), cf. Pseudothurmannia mortilleti (PICTET \& LORIOL, 1858) [PI. 32, fig. B, FSL 89581], and Taveraidiscus hugii (OOSTER, 1860) [PI. 32, fig. A, FSL 89641] are found at the base of the section whereas its upper part yields Astieridiscus sp., Dissimilites dissimilis (OrBIGNY, 1841) [PI. 33, fig. A, FSL 89719], ? Holcodiscus caillaudianus (ORBIGNY, 1850) -RB- \{or Amohaldites aff. camelinus (ORBIGNY, 1850) -DB- $\}$ [PI. 33, fig. H, FSL 89677], Holcodiscus perezianus (ORBIGNY, 1850) [PI. 32, figs. E-F, H, FSL 89613, FSL 89674, FSL 89707, respectively], ? Kotetischvilia compressissima (ORBIGNY, 1840) -RB- \{or Heinzia communis (BüRGL, 1956) -DB-\} [PI. 33, fig. E, FSL 89697], ? Kotetishvilia compressissima -RB- \{or ? Nicklesia didayana (ORBIGNY, 1841) -DB- [PI. 32, fig. G, FSL 89704], Kotetishvilia compressissima [PI. 33, fig. G, FSL 89703], Nicklesia didayana (ORBIGNY, 1841) [PI. 33, figs. D, F, FSL 89705 \& FSL 89703b, respectively], Nicklesia pulchella (ORBIGNY, 1841) [PI. 32, figs. C-D, FSL 89615 \& FSL 89616, respectively; PI. 33, fig. B, FSL 89617], Torcapella capillosa BusNARDo, 1970, and Moutoniceras moutonianum ORBIGNY, 1850 [PI. 33, fig. C, FSL 89718].

The study of thin sections and polished slabs prepared from 8 rock samples (no. 375, 376 , $377,381,409,410,6873,6874)$ of the Ba2 LST interval led to the identification of the following list of species (each coming with its specific identification and the label of the corresponding thin section or polished slab $*$ ):

- Moulladella jourdanensis (PI. 36), and the orbitolinids:

- Cribellopsis elongata (DIENI et al., 1963) (PI. 42),

- Cribellopsis neoelongata (CHERCHI \& SCHROEDER, 1978) (PI. 43),

- Cribellopsis schroederi Arnaud-Vanneau, 1980 (PI. 43),

- Cribellopsis thieuloyi Arnaud-Vanneau, 1980 (PI. 42),

- Dictyorbitolina carthusiana SCHROEDER et al., 1990 (PI. 34),
- Eopalorbitolina charollaisi SCHROEDER, 1968 (PI. 34). Note that PI. 34, fig. 410-1 is duplicated from ClaVel et al. (2007, PI. 4, fig. F);

- Falsurgonina pileola ARnAUd-VANNEAU \& ARGOT, 1973 (PI. 36),

- Falsurgonina vanneauae ClAVEL et al., 2009 (PI. 36),

- Montseciella alguerensis CHERCHI \& SCHROEDER, 1999 (PI. 45),

- Montseciella glanensis (PI. 37),

- Orbitolinopsis briacensis ARnaud-VAnneau, 1980 (PI. 39),

- Orbitolinopsis buccifer (Pls. 38 - 39),

- Orbitolinopsis cuvillieri (PI. 40),

- Orbitolinopsis debelmasi Moullade \& THIEULoY, 1965 (PI. 41),

- Orbitolinopsis kiliani (PI. 39),

- Paleodictyoconus actinostoma ARNAUd-VANNEAU \& SCHROEDER, 1976 (PI. 44),

- Paleodictyoconus cuvillieri (Foury, 1963)

(Pls. 44 - 45),

- Paracoskinolina hispanica PeYBernès, 1976

(PI. 35)

- Paracoskinolina maynci (Chevalier, 1961) (PI. 35),

- Paracoskinolina ? praereicheli CLAVEL et al., 2009 (PI. 43),

- Paracoskinolina querolensis (PI. 35),

- Paracoskinolina ? reicheli (GUILLAUME, 1956)

(PI. 43). Note that PI. 43, fig. 381-30a is duplicated from ClaVEL et al. (2007, PI. 5, fig. L) and fig. 381-30b from ClaVel et al. (2007, PI. 5, fig. K) as "Dictyoconus ? reicheli GuILLAUME";

- Paracoskinolina aff. sunnilandensis (MAYNC, 1955) (PI. 35),

- Praedictyorbitolina claveli Schroeder, 1994 (PI. 34)

- Urgonina alpillensis (FouRY, 1963) (PI. 37),

- Valserina broennimanni SCHROEDER \& CONRAD, 1968 (PI. 34),

- Valserina turbinata (FouRY, 1968) (PI. 34),

- Vanneauina vercorii (ARnAUd-VANnEAU, 1980) (PI. 45).

Out of 34 species ( Moulladella jourdanensis included) identified until now in Barremian sections, 29 are already present in the Pulchella Zone of the lower Barremian.

\section{La Montagnette (26 Drôme, Vercors)} (Fig. 2.10)

\section{lower Barremian (Ba2 LST): Pulchella Zone} (Pls. $46-52$ )

The "La Montagnette" section [beginning at UTM 31 (WGS84) X: 702029.191, Y: 4962746. 656; GPS: 444' $22.4^{\prime \prime} \mathrm{N} 5^{\circ} 33^{\prime} 14.4^{\prime \prime E}$ ending at UTM 31 (WGS84) X: 701873.128, Y: 4960817.

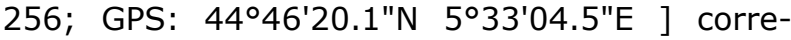
sponds to the middle part of the "Plateau de Glandasse" section the lower part of which has been published by Clavel et al. (CLAVEL et al., 2010: § 6. Pas de l'Essaure, Fig. 2.6). This section also appears in several earlier publications of ARNAUD-VANNEAU and coauthors (ARNAUD-VANNEAU, 1980, p. 267; ARNAUD, 1981; ARNAUD et al., 1998). 


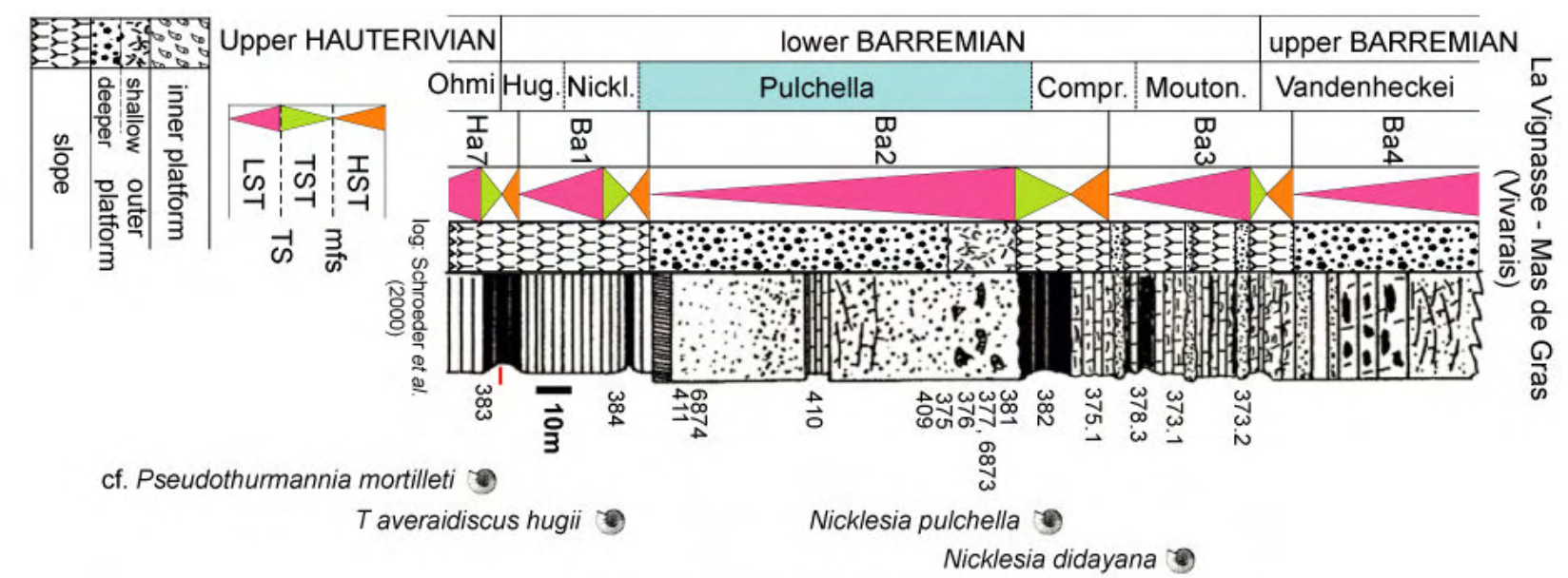

? Holcodiscus caillaudianus or? Nicklesia didayana

? Holcodiscus caillaudianus or? Amoaldites aff. camelinus

Holcodiscus perezianus

? Kotetischvilia compressissima or? Heinzia communis

Kotetischvilia compressissima

Moutoniceras moutonianum

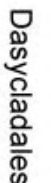

Salpingoporella genevensis

Clypeina paucicalcarea

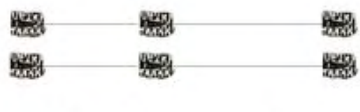

gan

Toxaster seynensis

ח.
두․
흠

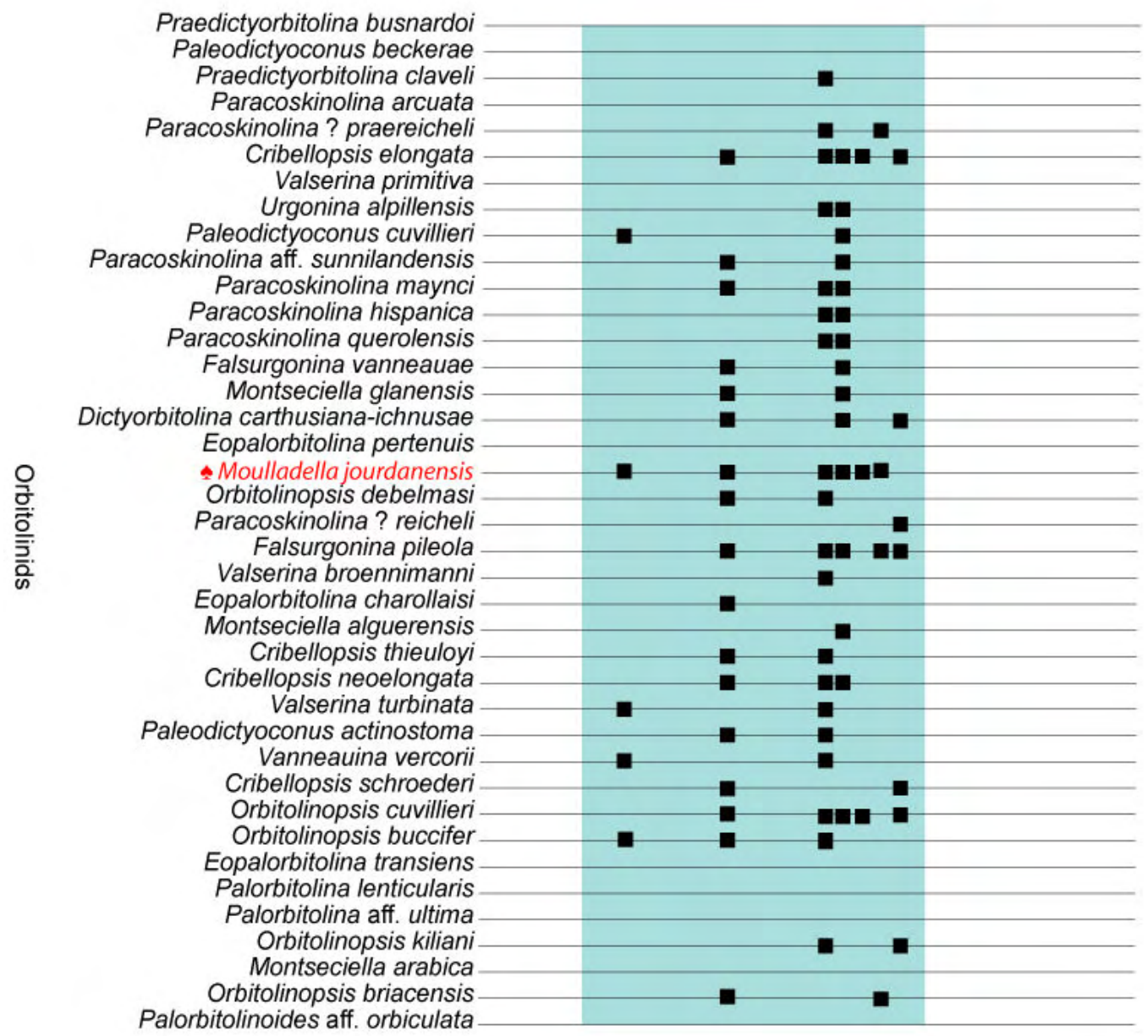

Figure 2.9: La Vignasse section. 
The biocalcarenitic levels with orbitolinids and dasycladalean algae are interspersed with hemipelagic facies in the lower part of the section and overlained by hemipelagic facies at the top of the section. These hemipelagic facies provided rare ammonites belonging to the Nicklesi, Pulchella, and Compressissima zones (Fig. 2.10).

The lower part of the section is characterized by Paraspiticeras (Paraspiticeras) guerinianum (ORBIGny, 1850) [ARNAud et al., 1998: Pl. 2, fig. 4, UJF-ID 10569; herein PI. 46, fig. E1, E2', E2"], Torcapella fabrei (TORCAPEL, 1884) [ARNAUD et al., 1998: PI. 2, fig. 1, UJF-ID 10566; herein PI. 46, fig. D], Torcapella gr. falcata BusNARDo, 1970, Torcapella suessiformis BUSNARDO, 1970, and Moutoniceras gr. nodosum (ORBIGNY, 1850) [ARNAUD et al., 1998: PI. 2, fig. 3, UJF-ID 10568; herein PI. 46, fig. B], whereas the upper part provided Cassidoiceras sp., Duyeina cf. boutini (CoQUAND in MATHERON, 1879), Torcapella cf. suessiformis BUSNARDO, 1970 [PI. 46, fig. A, FSL 88731], and Nikolovites gr. charrierianus (ORBIGNY, 1842) [PI. 46, fig. C, FSL 88827].

In a single sampling (no. 492) in the Ba2 LST interval at the top of Montagnette, we identified the following list of species (coming with their specific identification and the label of the corresponding thin section or polished slab $*$ ):

- Moulladella jourdanensis (PI. 47), and the orbitolinids:

- Cribellopsis elongata (PI. 50),

- Cribellopsis neoelongata (PI. 50),

- Cribellopsis schroederi (PI. 51),

- Cribellopsis thieuloyi (PI. 50). Note that PI. 50, fig. ID 21179 is duplicated from ARNAUDVANNEAU (1980, PI. 96, fig. 15);

- Dictyorbitolina carthusiana (PI. 47),

- Eopalorbitolina charollaisi (PI. 47),

- Falsurgonina pileola (PI. 48),

- Montseciella alguerensis (PI. 49). Note that PI. 49, fig. ID 21244 is duplicated from ARNAUDVANNEAU (1980, PI. 106, fig. 5a);

- Montseciella glanensis (PI. 49),

- Orbitolinopsis buccifer (PI. 51)

- Orbitolinopsis cuvillieri (PI. 51). Note that PI. 51, fig. ID 21118 is duplicated from ARNAUDVANNEAU (1980, PI. 93, fig. 1);

- Orbitolinopsis debelmasi (PI. 51),

- Paleodictyoconus actinostoma (PI. 52),

- Paleodictyoconus cuvillieri (PI. 52). Note that PI. 52, fig. ID 21241 is duplicated from ARNAUDVANNEAU (1980, Pl. 106, fig. 1a);

- Paracoskinolina hispanica (PI. 48),

- Paracoskinolina maynci (PI. 48),

- Paracoskinolina querolensis (PI. 48),

- Paracoskinolina ? reicheli (PI. 47). Note that the blured photomicrograph $492 \mathrm{bb} 2$ from the polished plug, which was used to make the thin section 492-73b, looks very similar to a Paracoskinolina ? praereicheli;

- Paracoskinolina aff. sunnilandensis (PI. 47),

- Urgonina alpillensis (PI. 48),

- Valserina broennimanni (PI. 47),
- Valserina turbinata (PI. 47).

Out of the 34 species ( Moulladella jourdanensis included) reported until now in Barremian sections, 23 were observed in the Pulchella Zone of this section.

\section{Serre de Tourre (07 Ardèche, Vivarais)} (Fig. 2.11)

Barremian (Ba2 LST to Ba4 HST):

Pulchella, Compressissima, Moutonianum, and Vandenheckei zones

(Pls. 53 - 72)

The "Serre de Tourre" section [beginning at UTM 31 (WGS84) X: 614493.842, Y: 4915104.

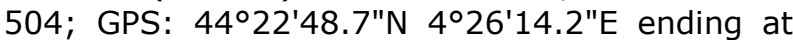
UTM 31 (WGS84) X: 617780.826, Y: 4911849. 545; GPS: $\left.44^{\circ} 21^{\prime} 01.3^{\prime \prime} \mathrm{N} 4^{\circ} 28^{\prime} 40.0^{\prime \prime} \mathrm{E}\right)$ constitutes the upper part of the "Gorges de l'Ardèche" cliff (East of the "Vallée du Tiourre", West of the "Plateau de Saint-Remèze") of which the lower part is the Arredons section (CLAVEL et al., 2010: § 7. Arredons, Fig. 2.7).

The levels with rudists and orbitolinids are interspersed in their middle part by two episodes of external platform environments, which provided ammonites belonging to the Compressissima, Moutonianum, and Vandenheckei zones (Fig 2.11): Astieridiscus menglonensis (SAYN, 1891) (PI. 53, fig. M, FSL 88967), Barremites sp. (PI. 53, fig. I, FSL 88971), Holcodiscus diversecostatus (CoQUAND, 1880) -RB- or Holcodiscus sp. DB-] (PI. 53, fig. H, FSL 89458), Holcodiscus sp. (PI. 53, figs. K-L, FSL 88970, FSL 89454), Puezalpella cf. uhligi (PI. 53, fig. A, FSL 89519), Puezalpella sp. (PI. 53, figs. B, D-G, J, respectively FSL 89457, FSL 88969, FSL 88968a, FSL 88968c, FSL $88968 d$, FSL 88968b), and Silesites cf. cirtense (SAYN, 1890) -RB- \{or Silesites vulpes (CoQUAND, 1878) -DB-\} PI. 53, fig. C, FSL 89456), as well as few echinids of the circalittoral domain, i.e., Toxaster seynensis (LAMBERT, 1920), and numerous echinids of the infralittoral domain, i.e., Heteraster couloni (AGASSIZ, 1839).

This section was described by LAFARGE (1978), right above the viewpoint ("Belvédère") de "Serre de Tourre" [GPS: 44²2'26.2"N 4²6'21.4"E] (Fig. 2.11). Its upper part, starting, from the basal part of the "Vire du Serre de Tourre" - Ba2 was supplemented along RD 290 - where strata crop out on several spots - up to its uppermost part - Ba5 -, which can be observed westward of RD 590.

This uppermost part is represented by a characteristic marly level with many rudists and Heteraster oblongus, of which it is the first occurrence. It also crops out on the opposite bank of the Ardèche river, near the "Combe de Sarran" at Orgnac-I'Aven (§ 19. Orgnac, Fig. 2.19). There one of us (B.C.) collected a specimen of Heteroceras cf. baylei REYNÈs, 1876 (PI. 120, fig. B, FSL 89455), an ammonite that is still present in the Sarasini Zone. The last appearance of $\mathrm{H}$. couloni (HST Ba4) and the appearance (FO) of $\mathrm{H}$. oblongus (TST Ba5, "vire 4") occur respectively at the 


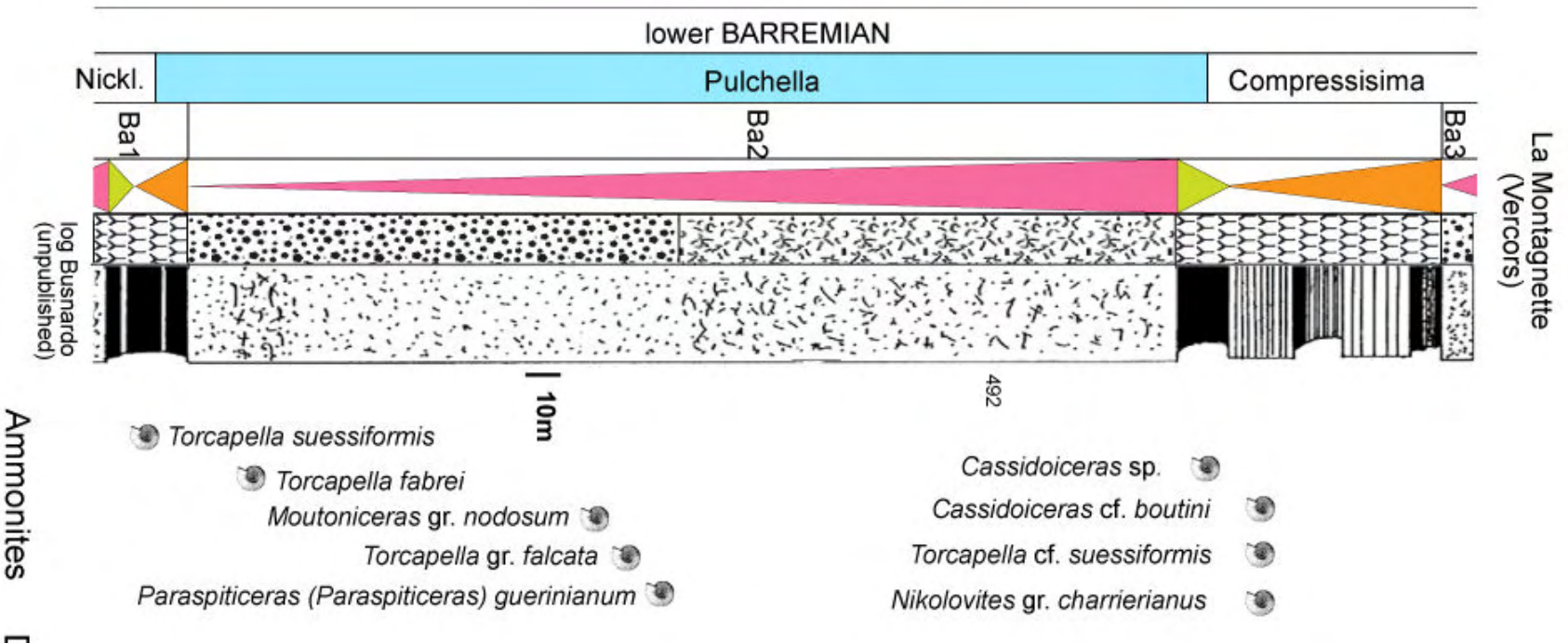

밈ำ
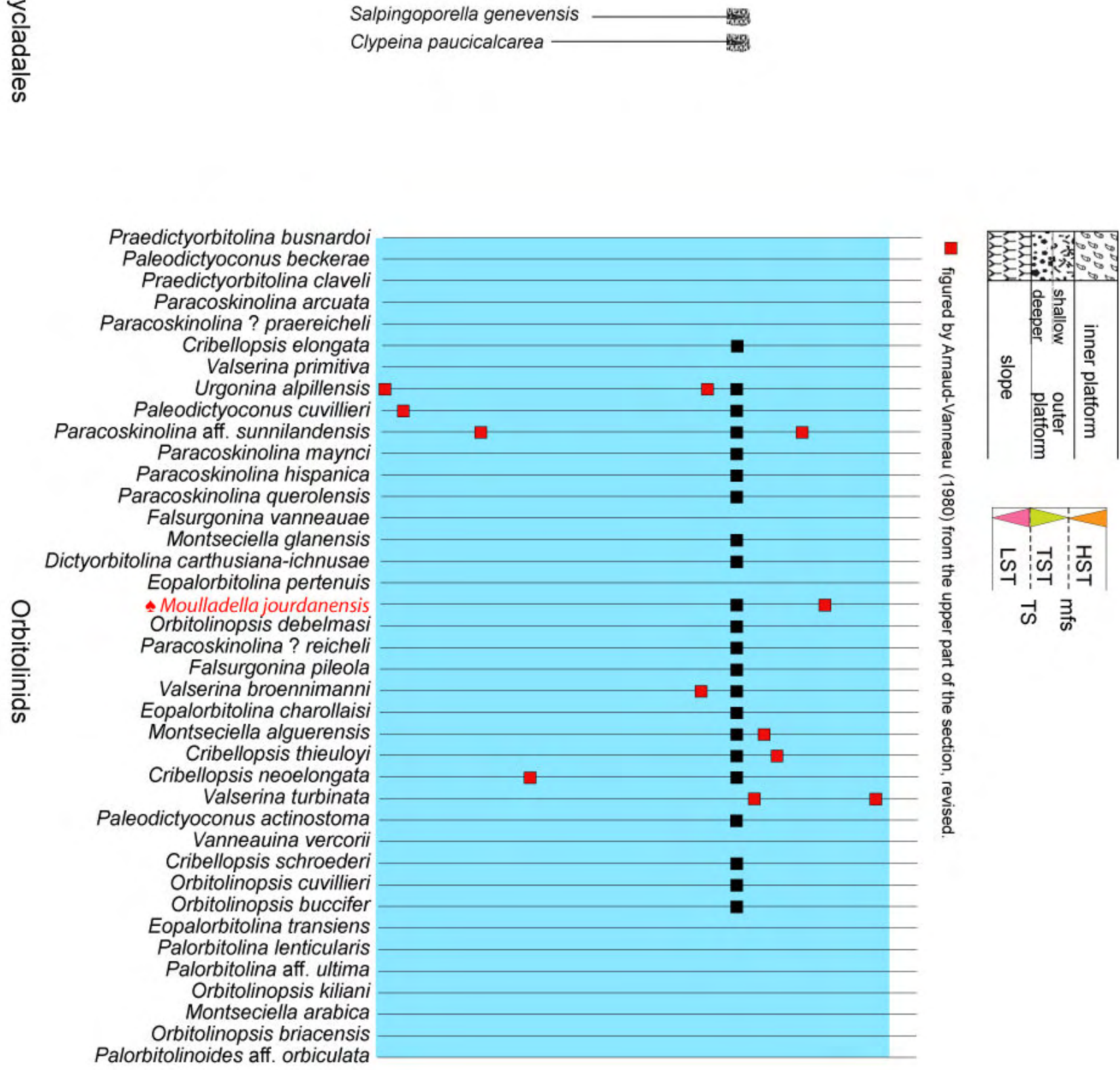

के

Figure 2.10: La Montagnette section. 
base and at the top of the Sarasini Zone (CLAVEL et al., $1995,2007,2014)$. Although the final sequence of the "Serre de Tourre" section is not formally identified by ammonites, it is marked by the first occurrence of Heteraster oblongus, less than $20 \mathrm{~m}$ above the last Heteraster couloni. Hence the orbitolinids from this interval are assigned to the Sarasini Zone.

Species identified in the discrete ammonite biozones are the following:

Pulchella Zone (Ba2 LST, samples no. 262.2 and 7400):

- Moulladella jourdanensis (Pls. 54, 57), and the orbitolinids:

- cf. Eopalorbitolina transiens (CHERCHI \& SCHROEDER, 1999) (Pls. 55 - 56), first appearance in the area,

- Cribellopsis elongata (PI. 58)

- Cribellopsis neoelongata (PI. 57),

- Cribellopsis schroederi (PI. 55),

- Falsurgonina pileola (PI. 54),

- Falsurgonina vanneauae (PI. 58),

- Montseciella glanensis (PI. 54),

- Orbitolinidae gen. et sp. indet. (PI. 56),

- Orbitolinopsis buccifer (PI. 56),

- Orbitolinopsis debelmasi (PIs. 56, 58),

- Paleodictyoconus actinostoma (Pls. 55, 58),

- Paleodictyoconus cuvillieri (PI. 58),

- Paracoskinolina hispanica (PI. 54),

- Paracoskinolina maynci (Pls. 54, 57),

- Paracoskinolina ? praereicheli (PI. 57),

- Paracoskinolina querolensis (PI. 54),

- Paracoskinolina ? reicheli (PI. 57),

- Paracoskinolina aff. sunnilandensis (PI. 54),

- Urgonina alpillensis (PI. 56),

- Valserina gr. broennimanni-turbinata (PI. 57);

Compressissima Zone (Ba2 TST-HST, samples no. 217 and 263):

- Cribellopsis neoelongata (PI. 61),

- Cribellopsis schroederi (PI. 61),

- Cribellopsis thieuloyi (PI. 61),

- Montseciella glanensis (PI. 61),

- Orbitolinopsis debelmasi (Pls. 60 - 61),

- Paleodictyoconus actinostoma (PIs. 59 - 60),

- Paleodictyoconus cuvillieri (PI. 59),

- Paracoskinolina maynci (PI. 61),

- Paracoskinolina ? praereicheli (PI. 60),

- Paracoskinolina ? reicheli (PI. 60),

- Paracoskinolina aff. sunnilandensis (PI. 60),

- Urgonina alpillensis (PI. 61);

219):

Moutonianum Zone (Ba3 TST, sample no.

- Moulladella jourdanensis (PI. 62, fig. A), and the orbitolinids:

- Orbitolinopsis buccifer (PI. 62, fig. A),

- Paleodictyoconus actinostoma (PI. 62, fig. A),

- Paleodictyoconus cuvillieri (PI. 62, fig. A);

Vandenheckei Zone (Ba3 HST, samples no. 7401 and 7402):

- Moulladella jourdanensis (PI. 65), and the orbitolinids:

- Cribellopsis neoelongata (PI. 63),

- Montseciella cf. alguerensis (PI. 64),
- Montseciella glanensis (Pls. 63 - 64),

- Orbitolinopsis debelmasi (PIs. 63 - 64),

- Paleodictyoconus actinostoma (PI. 64),

- Paracoskinolina maynci (PI. 65),

- Paracoskinolina querolensis (PI. 64),

- Paracoskinolina ? reicheli (PI. 65),

- Paracoskinolina aff. sunnilandensis (PI. 65),

- Urgonina alpillensis (PI. 63);

Giraudi and Sarasini zones (Ba4 HST, samples no. 336, 339, 340, and 348):

- Cribellopsis neoelongata (PI. 69),

- Cribellopsis schroederi (Pls. 70 I- 71),

- Eopalorbitolina transiens (PI. 66),

- Falsurgonina pileola (PI. 67),

- Montseciella alguerensis (PI. 67),

- Orbitolinopsis briacensis (PI. 69),

- Orbitolinopsis buccifer (Pls. 68 - 69),

- Orbitolinopsis cuvillieri (PI. 69),

- Paleodictyoconus actinostoma (PI. 72),

- Paleodictyoconus cuvillieri (Pls. 70, 72),

- Palorbitolina lenticularis (BLUMENBACH, 1805)

(PI. 66),

- Palorbitolina ultima Cherchi \& Schroeder in

SCHROEDER et al., 2010 (PI. 66),

- Paracoskinolina maynci (PI. 67),

- Paracoskinolina ? reicheli (PI. 67),

- Paracoskinolina aff. sunnilandensis (PI. 67).

Out of the 34 species ( Moulladella jourdanensis included) identified until now in Barremian sections, 21 are already present in the lower Barremian of this section.

\section{La Béguère (26 Drôme, Vercors)} (Fig. 2.12)

Barremian (Ba3):

Moutonianum and Vandenheckei zones (Pls. 73 - 82)

The "La Béguère" section [beginning at UTM 31 (WGS84) X: 691730.561, Y: 4970541.010; GPS: $44^{\circ} 51^{\prime} 45.0^{\prime \prime} \mathrm{N} 5^{\circ} 25^{\prime} 36.7^{\prime \prime E}$ ending at UTM 31 (WGS84) X: 692631.917, Y: 4970500.379; GPS: $44^{\circ} 51^{\prime} 42.8^{\prime \prime} 5^{\circ} 26^{\prime} 17.7^{\prime \prime E}$ ) is located at the upper part of the first bioclastic levels marking in the southern Vercors the progradation of the Urgonian platform towards the Vocontian trough.

At its uppermost part two marly levels decametric in thickness, called "Marnes de Font Froide" and "Marnes de la Béguère" by ARNAud (1981 et seq.), yield numerous Palorbitolinas as well as a sea urchin characteristic of the circalittoral domain, i.e., Toxaster seynensis. Marls are separated by argillaceous limestones at the top of which VIRLOUVET (1997: PI. 4, "photographie A", UJF-ID 10574; herein PI. 73, fig. A-A') reported a "Camereiceras limentinus (juv.)". ARnAud et al. (1998: Pl. 4, fig. 3) refer it to "? Camereiceras sp." whereas CLAVEL et al. (2014: p. 29) reascribe it to "Toxancyloceras gr. vandenheckei" (ASTIER, 1851) -RB-, i.e., to the ammonite species marker of the eponymous zone for ? Camereiceras limentinus -DB- $\}$. The first rudists appear in the last visible meters of the section, above the "Marnes de la Béguère". 


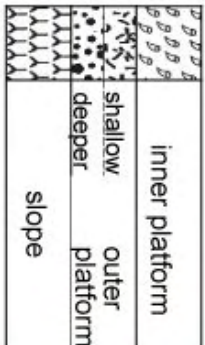

\begin{tabular}{l:l:l}
\hline$\infty$ & \multicolumn{1}{c}{$s$} & $\frac{1}{\omega}$ \\
\hline$\rightarrow$ & -1
\end{tabular}

का

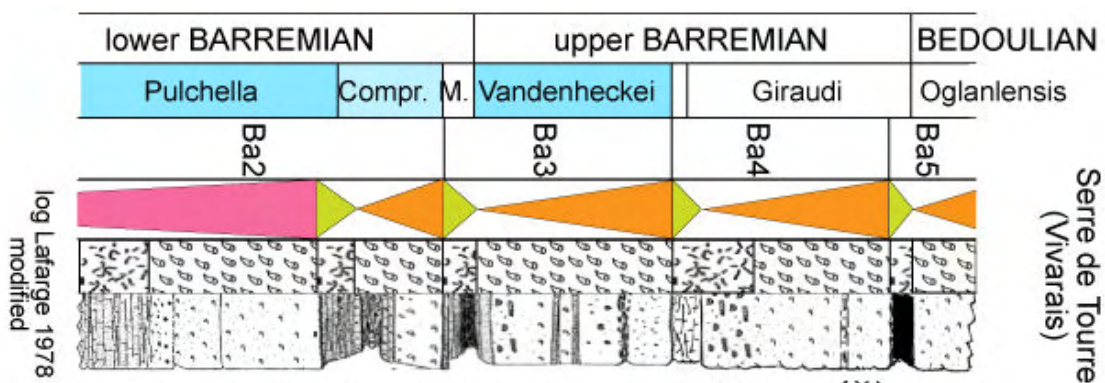

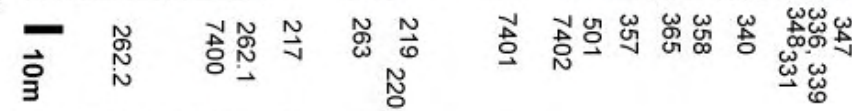

- Holcodiscus sp.

- Silesites cf. cirtense or Silesites vulpes

- Puezalpella cf. uhligi

- Puezalpella sp. Astieridiscus menglonensis or $A$. sp.

ige ges

Salpingoporella genevensis

20

Heg

Clypeina paucicalcarea

高.

Heteraster couloni

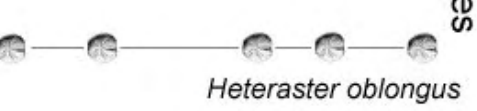

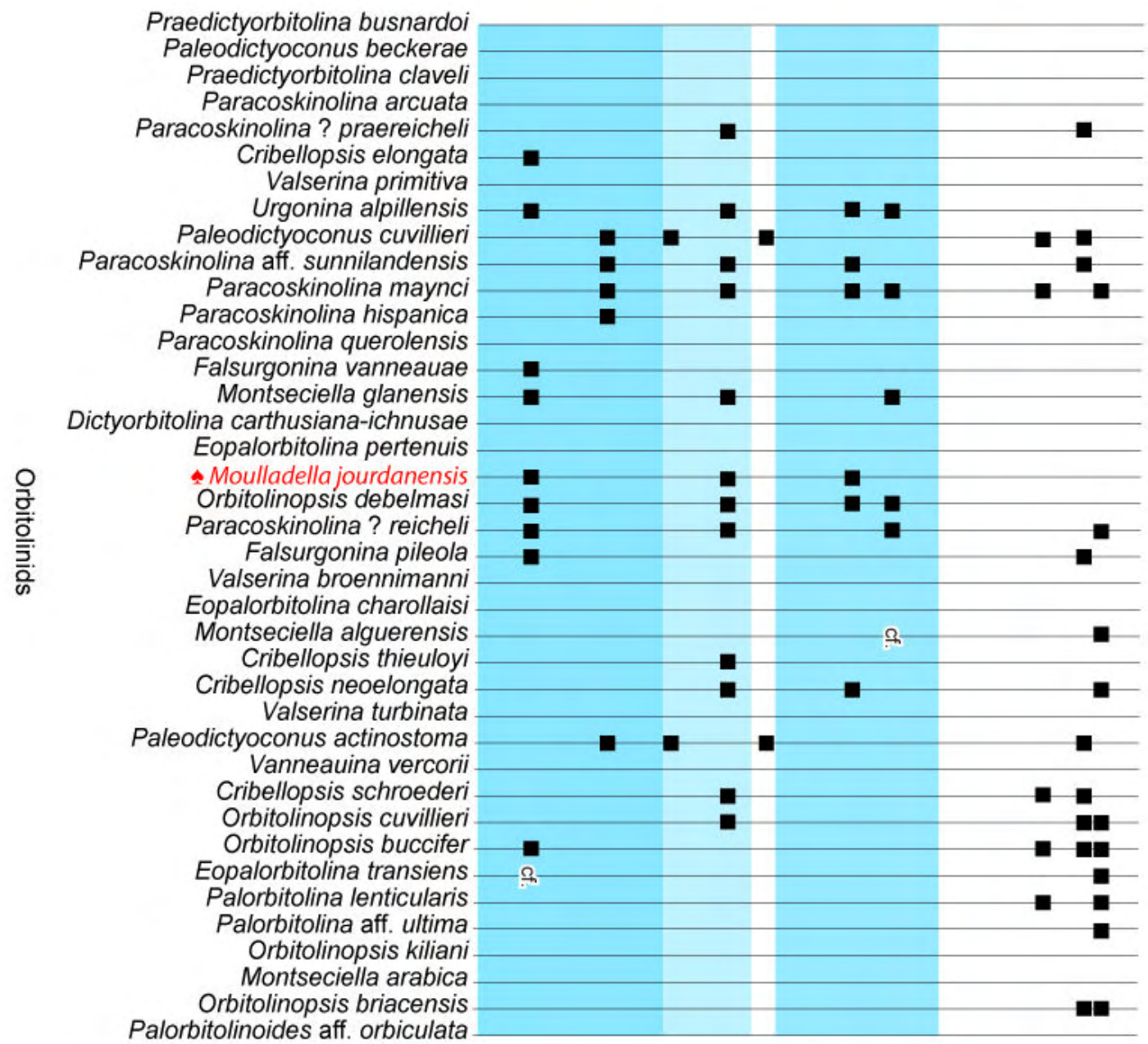

Figure 2.11: Serre de Tourre section. 
The orbitolinids identified in the ammonite biozones are the following:

Moutonianum Zone (Ba3 LST, samples no. 398, 464, and 465; Ba3 TST, sample no. 395):

- Cribellopsis elongata (PI. 78),

- Cribellopsis neoelongata (PI. 78),

- Cribellopsis schroederi (PI. 78),

- Cribellopsis thieuloyi (PI. 78),

- Eopalorbitolina transiens (PI. 73, fig. B),

- Falsurgonina pileola (PI. 79),

- Falsurgonina vanneauae (PI. 79),

- Montseciella glanensis (PI. 79),

- Orbitolinopsis briacensis (PI. 77),

- Orbitolinopsis buccifer (PI. 76),

- Orbitolinopsis cuvillieri (PI. 77),

- Orbitolinopsis kiliani (PI. 77),

- Paleodictyoconus actinostoma (PI. 80),

- Paleodictyoconus cuvillieri (PI. 80),

- ? Paracoskinolina arcuata (ARnAUd-VANneAu, 1976) (PI. 75)

- Paracoskinolina hispanica (PI. 75),

- Paracoskinolina maynci (PI. 75),

- Paracoskinolina ? praereicheli (PI. 74),

- Paracoskinolina querolensis (PI. 75),

- Paracoskinolina ? reicheli (PI. 74),

- Paracoskinolina aff. sunnilandensis (PI. 75).

Vandenheckei Zone (Ba3 HST, samples no. 243 and 394):

- Cribellopsis neoelongata (PI. 82),

- Eopalorbitolina transiens (PI. 82),

- Paleodictyoconus cuvillieri (PI. 82),

- Palorbitolina gr. lenticularis (PI. 81),

- Palorbitolina ultima (PI. 81),

- Paracoskinolina maynci (PI. 82),

- Paracoskinolina aff. sunnilandensis (PI. 82).

\section{Rochecolombe (09 Ardèche, Vivarais)} (Fig. 2.13)

upper Barremian (Ba4 LST): Vandenheckei Zone (Pls. 83 - 87)

The Rochecolombe section [beginning at UTM 31 (WGS84) X: 615028.010, Y: 4931900.036;

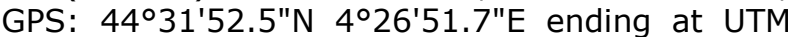
31 (WGS84) X: 614787.911, Y: 4931734.317; GPS: $44^{\circ} 31^{\prime} 47.3^{\prime \prime} \mathrm{N} 4^{\circ} 26^{\prime} 40.1^{\prime \prime E}$ ] is located at the northern edge of the "Plateau de Saint-Remèze" (ELMI et al., 1996) and more precisely in the "Serre Palas". It corresponds to the southwestward progradation of the bioclastic facies over the hemipelagic domain of the "faisceau de l'Ibie" (ELMI et al., 1996: p. 87).

This section spans the top of the hemipelagic marl-limestone alternations and the bottom of coarse calcarenitic intervals cropping out locally in the area. Numerous ammonites, e.g., Holcodiscus fallax (MATHERON, 1880) (PI. 84, fig. B, FSL 141538) and Nicklesia sp. -RB- \{or Kotetishvilia compressissima -DB- $\}$ (PI. 84, fig. A, FSL 141546) - Compressissima Zone -, Moutoniceras moutonianum - Moutonianum Zone -, and Toxancyloceras vandenheckei -RB- \{or Gassendiceras quelquejeui BERT et al., 2006 (PI. 83, fig. A, FSL 89187) and ? Pseudoshasticrioceras sp. (PI. 83, fig. B, FSL 47195) -DB-\} - Vandenheckei Zone -, were collected from this section.

Orbitolinids identified in the rock samples no. 361 and 362 are the following:

- Cribellopsis neoelongata (PI. 85),

- Cribellopsis schroederi (PI. 85),

- Montseciella glanensis (PI. 85),

- Orbitolinopsis buccifer (Pls. 85 - 86),

- Paleodictyoconus actinostoma (PI. 87),

- Paleodictyoconus cuvillieri (PI. 87),

- Paracoskinolina maynci (PI. 84, fig. C),

- Paracoskinolina ? praereicheli (PI. 85),

- Paracoskinolina querolensis (PI. 84, fig. C),

- Paracoskinolina aff. sunnilandensis (PI. 84, fig. C),

- Urgonina alpillensis (PI. 84, fig. C).

\section{Mas Thibaud \\ (84 Vaucluse, Montagne de Bluye) (Fig. 2.14) \\ upper Barremian (Ba4 LST): Vandenheckei Zone}

(Pls. 88 - 89)

Initially studied by FouRy (1972), the "Mas Thibaud" section [beginning at UTM 31 (WGS84) $X$ :

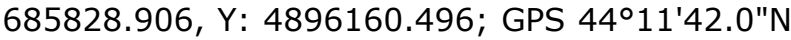
$5^{\circ} 19^{\prime} 28.3^{\prime \prime E}$ ending at UTM 31 (WGS84) X: 685364.129, Y: 4896360.906; GPS: 44ำ $48.9^{\prime \prime} 5^{\circ} 19^{\prime} 10.9^{\prime \prime E}$ ] is located in the hemipelagic domain $\mathrm{N}$ of "Mont Ventoux". Its lower part was partly logged along RD 40, W of Brantes. It consists of Vocontian-type limestone-marl alternations with slumps and thin bioclastic flows, overlain by an orbitolinid grainstone layer, followed by cherty mud-/wacke-stones with sponge spicules upward into the Bedoulian (lower Aptian). The Moutonianum Zone is characterized here by the occurrence of Moutoniceras nodosum (PI. 88, fig. A, FSL 88791), Holcodiscus fallax (PI. 88, fig. C, FSL 88972), and Nikolovites gr. charrierianus (PI. 88, fig. B, FSL 88794).

We only consider here the orbitolinids from sample no. 7335 that was collected in bioclastic flows within the marls with Heinzia sayni HyAT, 1903, an ammonite characteristic of the Vandenheckei Zone:

- Cribellopsis neoelongata (PI. 89),

- Cribellopsis schroederi (PI. 89),

- Montseciella glanensis (PI. 89),

- Orbitolinopsis buccifer (PI. 88, fig. D),

- Orbitolinopsis cuvillieri (PI. 88, fig. D),

- Paleodictyoconus cuvillieri (PI. 89),

- Palorbitolina lenticularis (PI. 89),

- Paracoskinolina maynci (PI. 89),

- Vanneauina vercorii (PI. 89). 

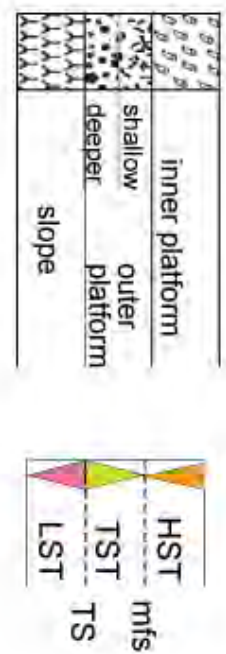

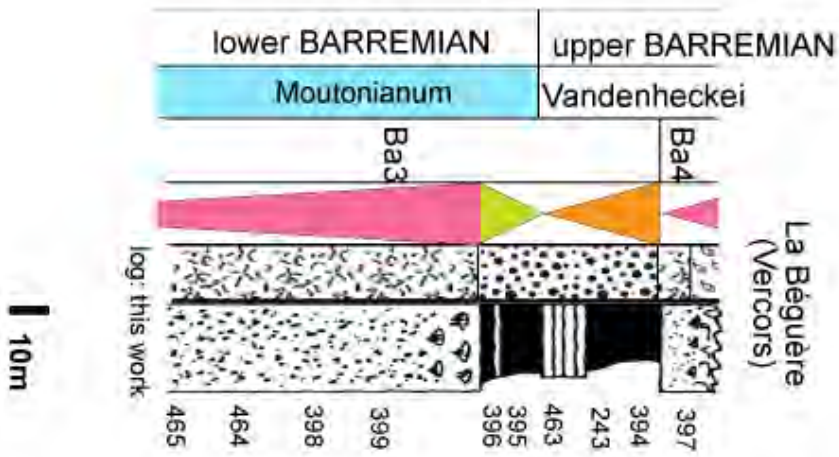

Toxancyloceras gr, vandenheckei

Ammonites

Clypeina paucicalcarea Dasycladales

Toxaster seynensis

Echinids

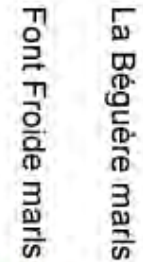

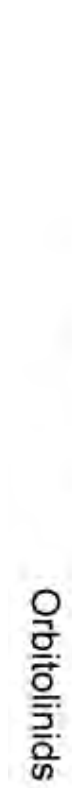

Praedictyorbitolina busnardoi Paleodictyoconus beckerae

Praedictyorbitolina claveli

Paracoskinolina arcuata

Paracoskinolina? praereicheli

Cribellopsis elongata

Valserina primitiva

Urgonina alpillensis

Paleodictyoconus cuvillieri

Paracoskinolina aff. sunnilandensis

Paracoskinolina maynci

Paracoskinolina hispanica

Paracoskinolina querolensis

Falsurgonina vanneauae

Montseciella glanensis

Dictyorbitolina carthusiana-ichnusae

Eopalorbitolina pertenuis

- Moulladella jourdanensís

Orbitolinopsis debelmasi

Paracoskinolina? reicheli

Falsurgonina pileola

Valserina broennimanni

Eopalorbitolina charollaisi

Montseciella alguerensis

Cribellopsis thieuloyi

Cribellopsis neoelongata Valserina turbinata

Paleodictyoconus actinostoma Vanneauina vercorii

Cribellopsis schroederi Orbitolinopsis cuvillieri

Orbitolinopsis buccifer

Eopalorbitolina transiens

Palorbitolina lenticularis

Palorbitolina aff. ultima

Orbitolinopsis kiliani

Montseciella arabica

Orbitolinopsis briacensis

Palorbitolinoides aff orbiculata

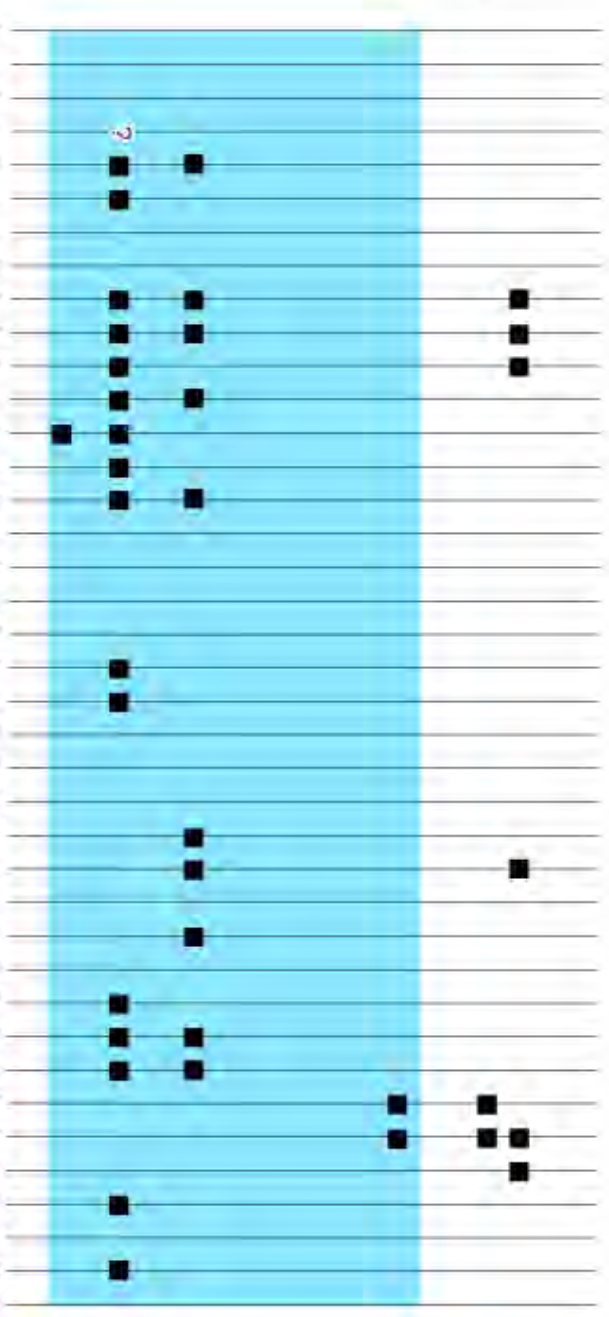

Figure 2.12: La Béguère section. 

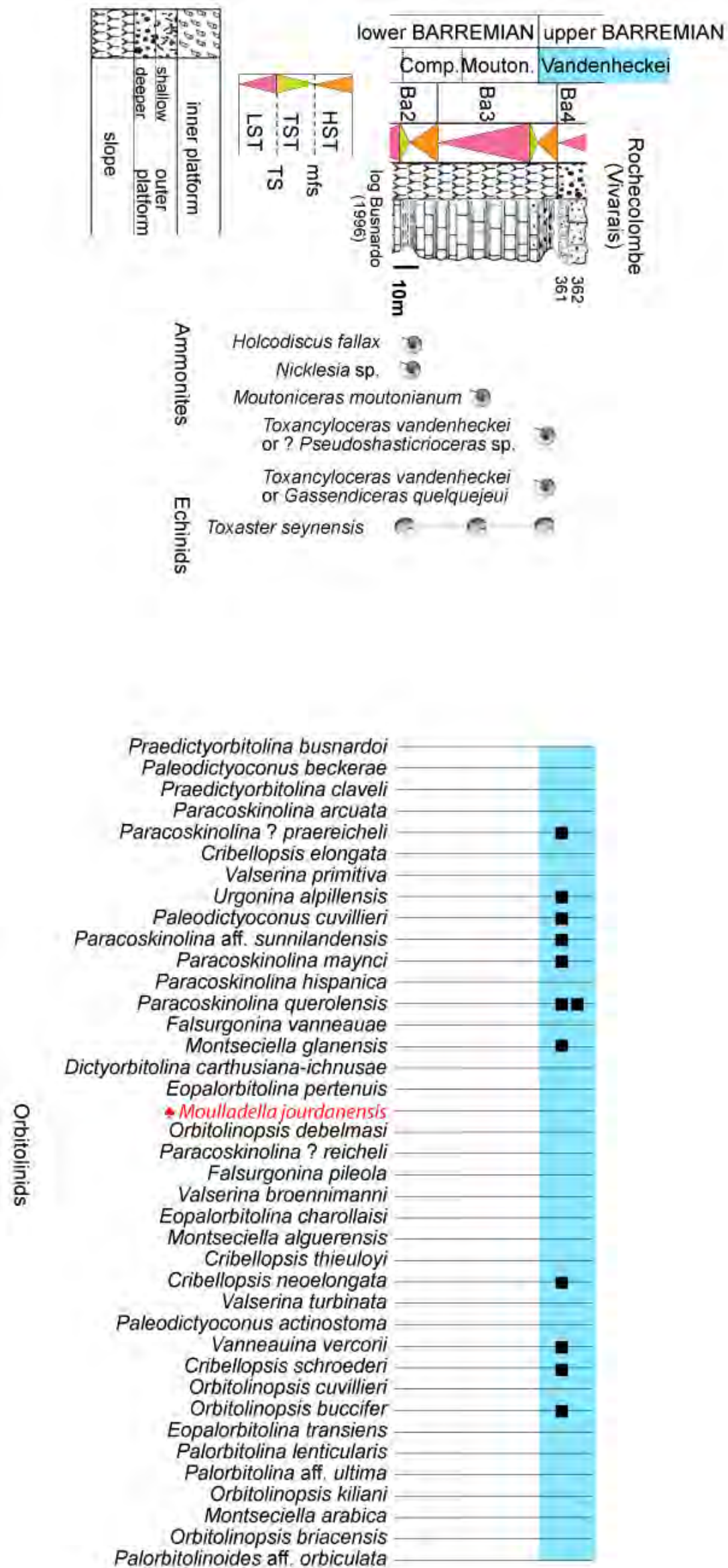

Figure 2.13: Rochecolombe section. 


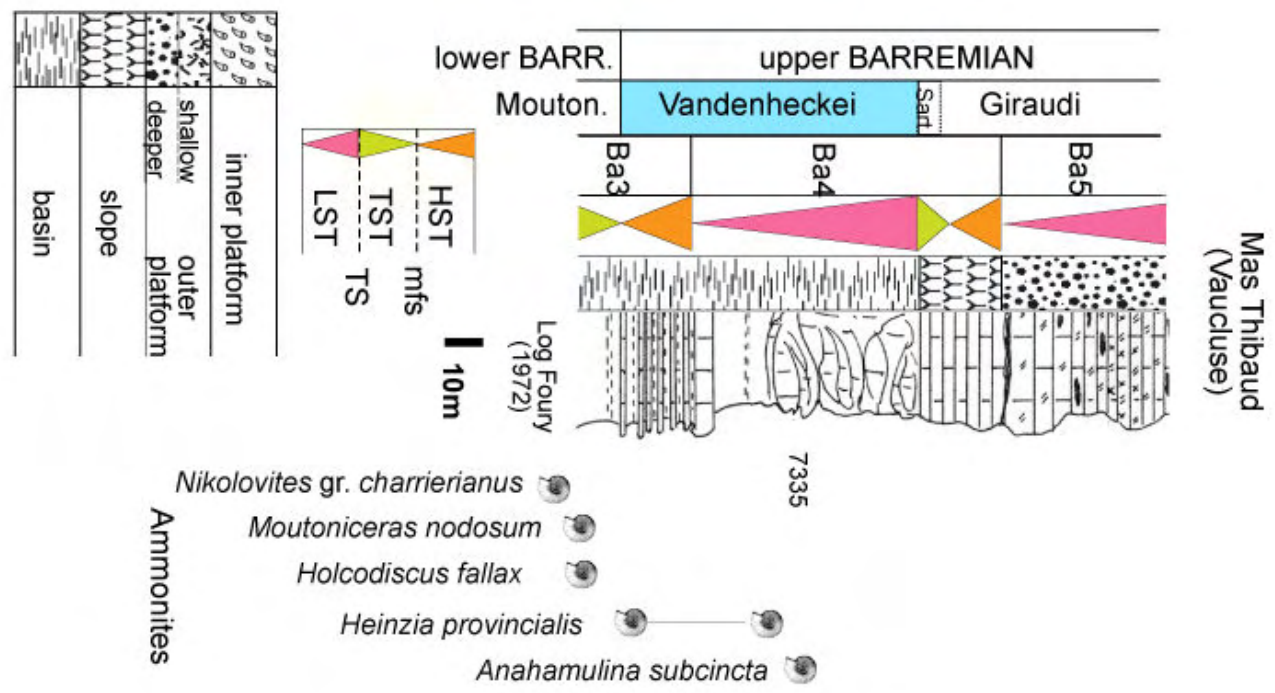

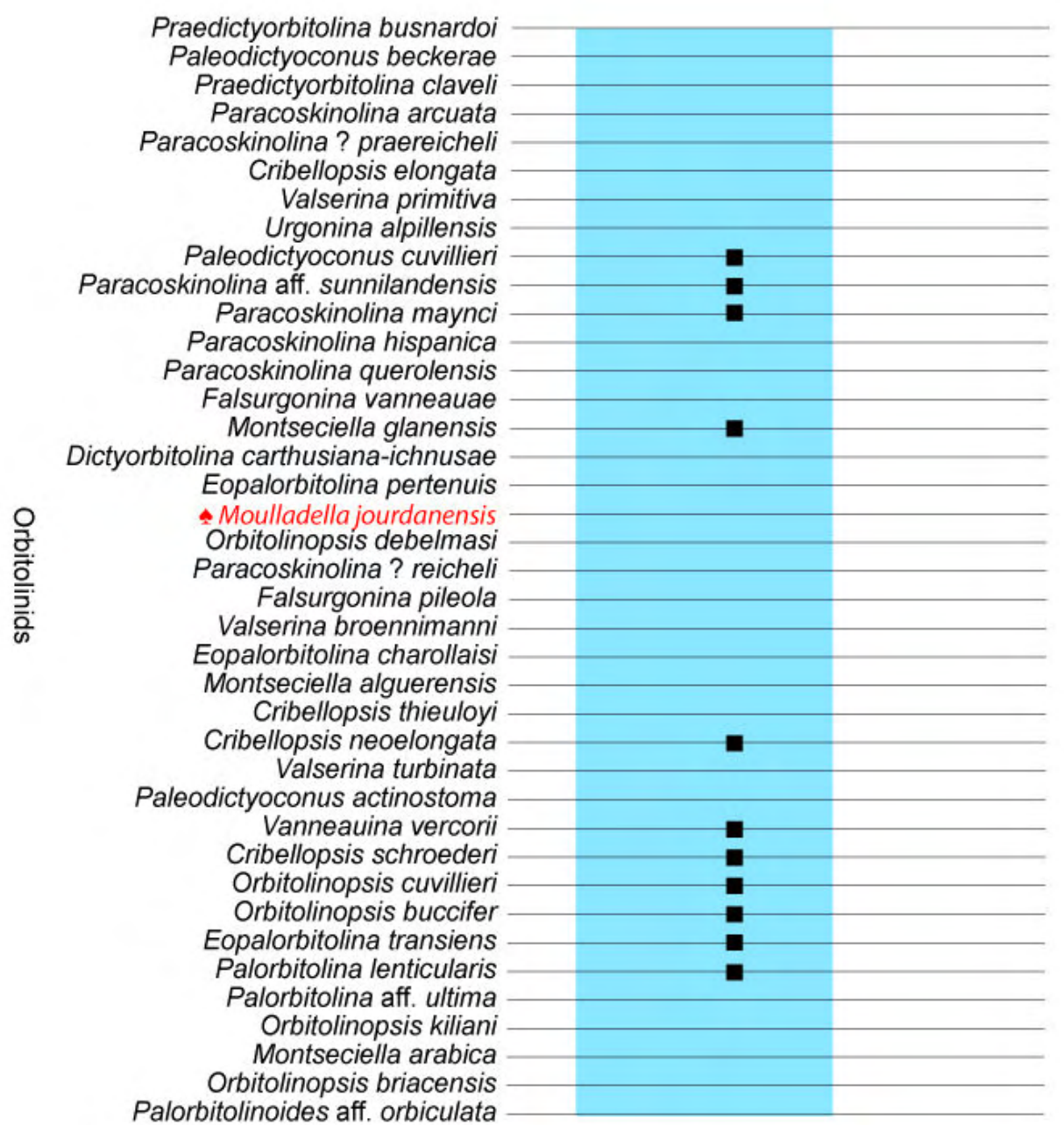

Figure 2.14: Mas Thibaud section. 

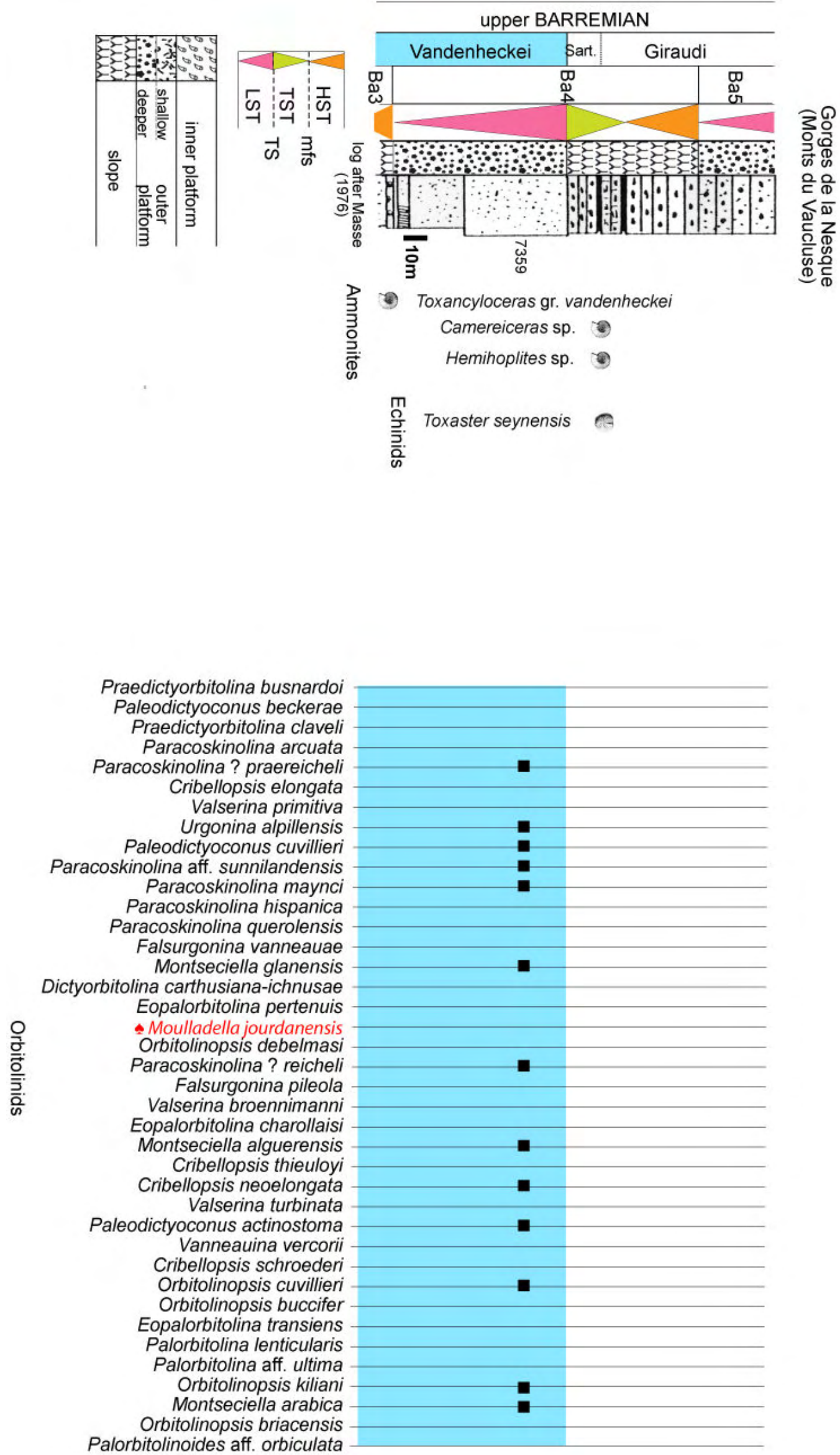

Figure 2.15: Gorges de la Nesque section. 


\section{Gorges de la Nesque (84 Vaucluse, Monts du Vaucluse) (Fig. 2.15) \\ upper Barremian (Ba4 LST): Vandenheckei Zone} (Pls. 90 - 93)

The Gorges de la Nesque section [beginning at UTM 31 (WGS84) X: 684764.332, Y: 4882018. 225; GPS: $44^{\circ} 04^{\prime} 05.0^{\prime \prime} \mathrm{N} 5^{\circ} 18^{\prime} 25.8^{\prime \prime E}$ ending at UTM 31 (WGS84) X: 684954.533, Y: 4881859. 029; GPS: $\left.44^{\circ} 03^{\prime} 59.6^{\prime \prime} \mathrm{N} \quad 5^{\circ} 18^{\prime} 34.1^{\prime \prime E}\right)$ was measured along RD 942, upstream of the "maison cantonnière". It marks a SW-NE progradation of the Urgonian platform towards the Vocontian trough, depositing external platform facies in an hemipelagic domain in the early late Barremian times.

The sampled level no. 3759 corresponds to the "biocalcarénites des Caranques" (level 4 of the section published by MASSE, 1976), overlain by argillaceous limestones and marls where several Hemihoplites sp. and many Toxaster seynensis were collected. The Camereiceras aff. limentinus (THIEULOY, 1979) -RB- \{or ? Hemihoplites feraudianus -DB- $\}$ collected at Rocher du Cire (LÉoNIDE et al., 2012: Fig. 6.G; herein PI. 90, fig. A$\left.A^{\prime}\right)$ indicates the bottom of the Sartousiana Zone -RB- $\{$ or ? the top of the Sartousiana Zone -DB-\}.

The orbitolinids identified from this sampling are the following:

- Cribellopsis neoelongata (PI. 91),

- Montseciella alguerensis (PI. 91),

- Montseciella arabica (PI. 93),

- Montseciella glanensis (PI. 90, fig. B; PI. 91),

- Orbitolinopsis cuvillieri (PI. 90, fig. B),

- Orbitolinopsis kiliani (PI. 90, fig. B),

- Paleodictyoconus actinostoma (PI. 93),

- Paleodictyoconus cuvillieri (PI. 93),

- Paracoskinolina maynci (PI. 91),

- Paracoskinolina ? praereicheli (PI. 92),

- Paracoskinolina ? reicheli (PI. 92),

- Paracoskinolina aff. sunnilandensis (PI. 91),

- Urgonina alpillensis (PI. 91).

\section{Col de Rousset (26 Drôme, Vercors)} (Fig. 2.16)

upper Barremian (Ba4 LST):

Vandenheckei Zone

(PIs. 94 - 103)

The "Col de Rousset" section, of which only the lower part [beginning at UTM 31 (WGS84) $X$ : 689739.581, Y: 4967466.041; GPS: 4450' $07.3^{\prime \prime} \mathrm{N} \mathrm{5} 24^{\circ} 01.9^{\prime \prime E}$ ending at UTM 31 (WGS84) X: 689859.947, Y: 4967528.812; GPS: 44ํำ $09.3^{\prime \prime} \mathrm{N} 5^{\circ} 24^{\prime} 07.5^{\prime \prime E}$ is studied here, illustrates the ultimate observable step of the Urgonian platform progradation from the Vercors region towards the Vocontian trough.

Above the hemipelagic lower Hauterivian-Barremian strata, the "Urgonian" carbonate platform is represented by two bioclastic units separated by a very thick ( $60 \mathrm{~m}$ ) hemipelagic interval consisting of argillaceous limestones and marls. This unit yields ammonites characteristic of the Sartousiana Zone (ARNAUD et al., 1998): Camereiceras limentinus (PI. 94, fig. A1, UJF-ID $10580-A 2$, UJF-ID 10579 - A.3, UJF-ID 10549, not ID 10289 as stated in the caption of PI. 5, fig. 8 in ARNAUD et al., 1998), C. sp. -RB- \{or Hemihoplites feraudianus -DB- $\}$ (PI. 94, fig. A4-A4', FSL 108225), Gerhardtia sartousiana, Hemihoplites cf. heberti $\{$ nomen dubium -DB-\}, $H$. cf. feraudianus, $H$. cf. soulieri $\{H$. soulieri is a junior synonym of $H$. feraudianus -DB- $\}$, etc., as well as some circalittoral echinids (Toxaster seynensis).

This section was already described by ARNAUD (1981); it was illustrated again by ARNAUD et al. (1998: Fig. 13) and dated as late Barremian (including both the "lower" Feraudianus and the "upper" Sartousiana subzones of the Sartousiana Zone). The uppermost marly level of the thick calcareo-argillaceous series above the first bioclastic deposits was correlated by these authors to the type-level of the "Marnes de La Béguère", the type-locality of which is some $4 \mathrm{~km}$ northeastward. This correlation is erroneous because, in the eponymous section, the marls lie on strata that provided an ammonite pointing to the lower part of the Alpinum Subzone of the Vandenheckei Zone (cf. § 12. La Béguère, PI. 73, fig. A-A'). The assemblage of orbitolinids at "Col de Rousset" (Ba4 LST) are also different from that at "La Béguère" (Ba3 HST).

Orbitolinids identified in samples no. 462, 7864, and 7865 are the following:

- Cribellopsis neoelongata (PI. 102),

- Cribellopsis schroederi (PI. 102),

- Falsurgonina pileola (PI. 94),

- Falsurgonina vanneauae (PI. 94),

- Montseciella alguerensis (PI. 101),

- Montseciella glanensis (PIs. ? 95, 101),

- Orbitolinopsis briacensis (PI. 100),

- Orbitolinopsis buccifer (Pls. 97 - 98, 100),

- Orbitolinopsis cuvillieri (PI. 99),

- Orbitolinopsis kiliani (PI. 100),

- Paleodictyoconus actinostoma (PI. 103),

- Paleodictyoconus cuvillieri (PI. 103),

- Paracoskinolina maynci (PI. 96),

- Paracoskinolina ? praereicheli (PI. 95),

- Paracoskinolina querolensis (PI. 96),

- Paracoskinolina ? reicheli (PI. 95),

- Paracoskinolina aff. sunnilandensis (PI. 96),

- Urgonina alpillensis (PI. 102).

\section{La Charce (26 Drôme, Baronnies)} (Fig. 2.17)

\section{upper Barremian (Ba4):}

\section{Vandenheckei, Sartousiana,} and Giraudi zones

(Pls. 104 - 109)

The "La Charce" section [beginning at UTM 31 (WGS84) (WGS84) X: 695113.430, Y: 4927406. 766; GPS: $44^{\circ} 28^{\prime} 25.1^{\prime \prime} \mathrm{N} 5^{\circ} 27^{\prime} 11.5^{\prime \prime E}$ ending at UTM 31 (WGS84) X: 695211.232, Y: 4927562.

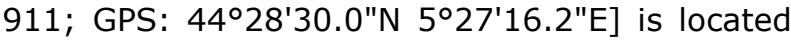
in the western border of the Vocontian trough. It 

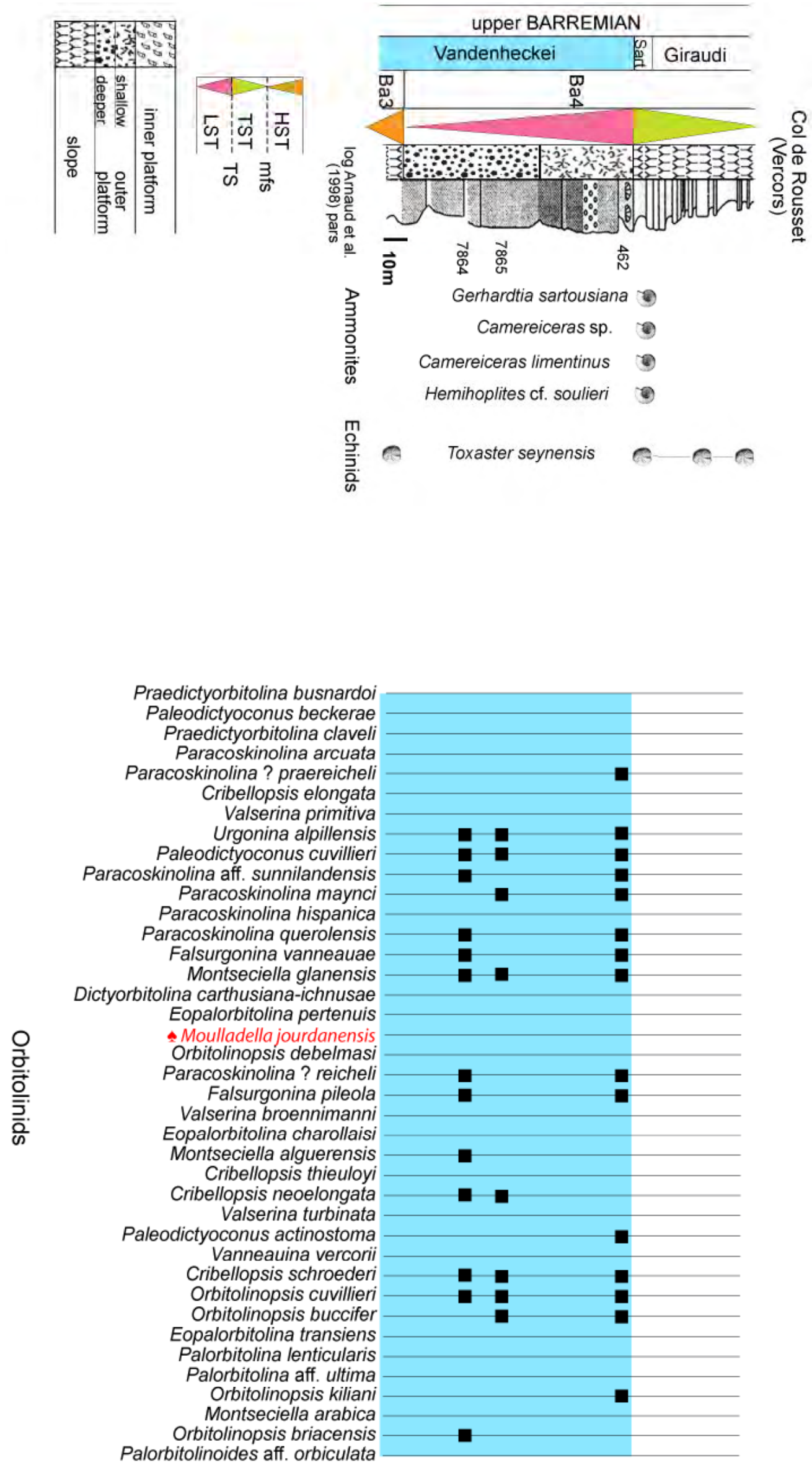

Figure 2.16: Col de Rousset section. 

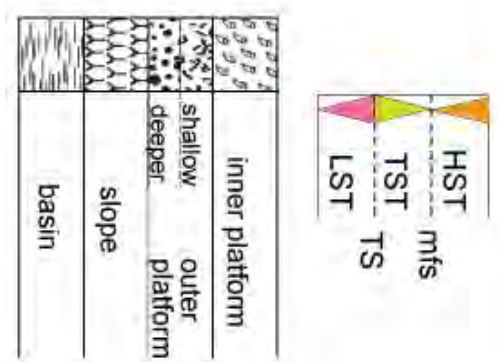

के 灵
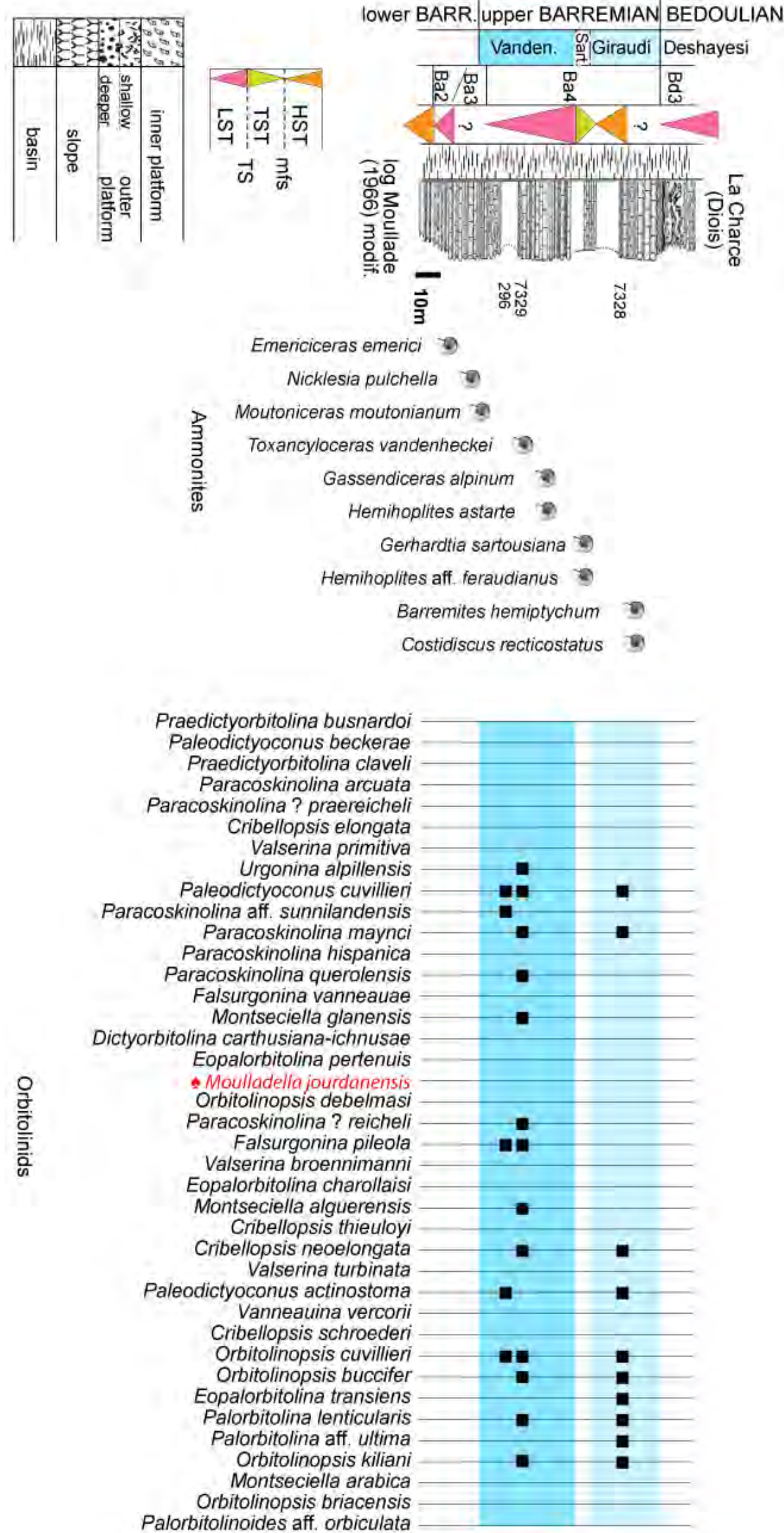

Figure 2.17: La Charce section. 
displays several bioclastic debris flows (and slumps) intercalated in the condensed and disturbed interval with the rather rich ammonite contents of the logged section (MoulLADE, 1966; FERRY, 1976).

Whereas faunas of lower Barremian do not allow a precise biozonation, those of the upper Barremian clearly identify the Vandenheckei (Toxancyloceras vandenheckei, Gassendiceras alpinum, Hemihoplites astarte, with samples no. 296 and 7329), Sartousiana (Gerhardtia sartousiana, Hemihoplites aff. feraudianus) and Giraudi (sample no. 7328) zones.

This section supplements the inventory of orbitolinids collected in the neighbouring "L'EstelIon" section (GRANIER et al., 2013, 2014, 2017) for the upper Barremian strata.

The lists of orbitolinids identified in the different biozones are as follows:

\section{Vandenheckei Zone:}

- Cribellopsis neoelongata (PI. 106),

- Cribellopsis schroederi (PI. 106),

- Falsurgonina pileola (PI. 106),

- Montseciella alguerensis (PI. 105),

- Montseciella glanensis (PI. 105),

- Orbitolinopsis buccifer (PI. 107),

- Orbitolinopsis cuvillieri (PI. 106),

- Orbitolinopsis kiliani (PI. 107),

- Paleodictyoconus actinostoma (PI. 107),

- Paleodictyoconus cuvillieri (PI. 107),

- Palorbitolina lenticularis (PI. 105),

- Paracoskinolina maynci (PI. 106),

- Paracoskinolina querolensis (PI. 107),

- Paracoskinolina ? reicheli (PI. 106),

- Paracoskinolina aff. sunnilandensis (PI. 106),

- Urgonina alpillensis (PI. 106).

Giraudi Zone:

- Cribellopsis neoelongata (PI. 109),

- Eopalorbitolina transiens (PIs. 108 - 109),

- Orbitolinopsis buccifer (PI. 108),

- Orbitolinopsis cuvillieri (PI. 108),

- Orbitolinopsis kiliani (PI. 108),

- Paleodictyoconus actinostoma (PI. 109),

- Paleodictyoconus cuvillieri (PI. 109),

- Palorbitolina lenticularis (PI. 108),

- Palorbitolina ultima (PI. 108),

- Paracoskinolina maynci (PI. 108).

\section{Pont d'Arc ( 07 Ardèche, Vivarais)} (Fig. 2.18)

upper Barremian (Ba4 LST - Ba5 TST): Giraudi/Sarasini zones

(Pls. 110 - 119)

The "Pont d'Arc" section [beginning at UTM 31 (WGS84) X: 612221.750, Y: 4915395.368; GPS: $44^{\circ} 22^{\prime} 59.4^{\prime \prime} \mathrm{N} 4^{\circ} 24^{\prime} 31.8^{\prime \prime E}$ ending at UTM 31 (WGS84) X: 612234.055, Y: 4915862.653; GPS: $44^{\circ} 23^{\prime} 14.5^{\prime \prime} \mathrm{N} 4^{\circ} 24^{\prime} 32.7^{\prime \prime E}$ ] constitutes the upper part of the "Gorges de l'Ardèche" cliff (westward of the Tiourre valley, westward of the "Plateau de Saint-Remèze"). A description of its lowermost part - the Chames section - was already published by Clavel et al. (2010: § 8. Chames, Fig. 2.8).
The equivalent of the "vire" of the "Serre de Tourre", i.e., v3 on the geological map of BourgSaint-Andéol (PASCAL et al., 1989), is found at the top of cliff, in line with the Cirque d'Estre and the famous Chauvet Cave. However, it is hardly visible nowadays due to the development of the vegetation cover on the "Plaine des Gras" that was a long time ago deserted by the flocks of sheep and goats whose grazing kept the rocks exposed. Only its most external upper part, very rich in Heteraster couloni, remains visible at the tennis courts of the Blachas campsite (Salavas), on the opposite side of the Ardèche river [at UTM 31 (WGS84) X: 611981.150, Y: 4915547.060; GPS: $44^{\circ} 23^{\prime} 04.4^{\prime \prime} \mathrm{N} 4^{\circ} 24^{\prime} 21.0^{\prime \prime E}$. Although the dolomitized level observed in the "Serre de Tourre" (cf. $\S 11$. Serre de Tourre) is still present at the base of the rudist limestones in the "Cirque d'Estre", some visibility gaps along departmental road D290 do not allow us to precisely correlate both sections.

Nonetheless, as in the very close "Serre de Tourre" section, the Ba4 sequence of the "Pont d'Arc" section is marked by the increasing rarity and then disappearance of $H$. couloni, which is replaced by Heteraster oblongus starting from the thin marly beds preceeding the "Grotte des Huguenot". This level also provided a fragment of ammonite that one of us (R.B.) ascribed to a Pseudocrioceras sp. (PI. 110, fig. B), typical of the upper part of the Sarasini Zone (uppermost Barremian).

Orbitolinids identified in the Giraudi/Sarasini zones comprise the following species:

- Cribellopsis neoelongata (PIs. 112, 115),

- Cribellopsis schroederi (PI. 115),

- Falsurgonina pileola (PI. 112),

- Montseciella alguerensis (PI. 112),

- Montseciella arabica (PI. 113),

- Orbitolinopsis briacensis (PI. 117),

- Orbitolinopsis buccifer (PI. 110, fig. A; PI. 116),

- Orbitolinopsis cuvillieri (PI. 110, fig. A; PI. 116),

- Orbitolinopsis kiliani (PI. 117),

- Paleodictyoconus actinostoma (PIs. 113, 118),

- Paleodictyoconus cuvillieri (Pls. 113, 118),

- Palorbitolina lenticularis (Pls. 114 - 115),

- Paracoskinolina maynci (PIs. 112, 115),

- Paracoskinolina ? praereicheli (PI. 110, fig. A),

- Paracoskinolina ? reicheli (PI. 111),

- Paracoskinolina aff. sunnilandensis (PIs. 112, 115),

- Vanneauina vercorii (PI. 119).

19. Orgnac (07 Ardèche, Vivarais) (Fig. 2.19)

Barremian: Sarasini Zone

(PIs. 120 - 125)

The Orgnac section [sited at UTM 31 (WGS84) $\mathrm{X}: 613252.000, \mathrm{Y}: 4908211.990$; GPS: 44ำ' $6.028^{\prime \prime N} 4^{\circ} 25^{\prime} 12.675^{\prime \prime E] ~ i s ~ l o c a t e d ~ w e s t w a r d ~ o f ~}$ the "Combe de Sarran". It comprises a marly interval occuring within Urgonian limestones with rudists, i.e., v4 on the geological map of BourgSaint-Andéol (PASCAL et al., 1989), that crops out 

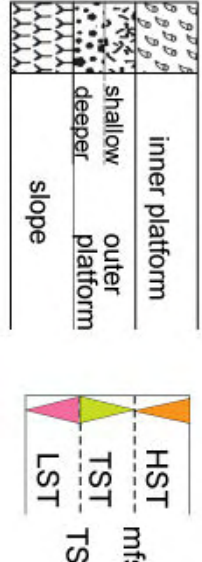

के

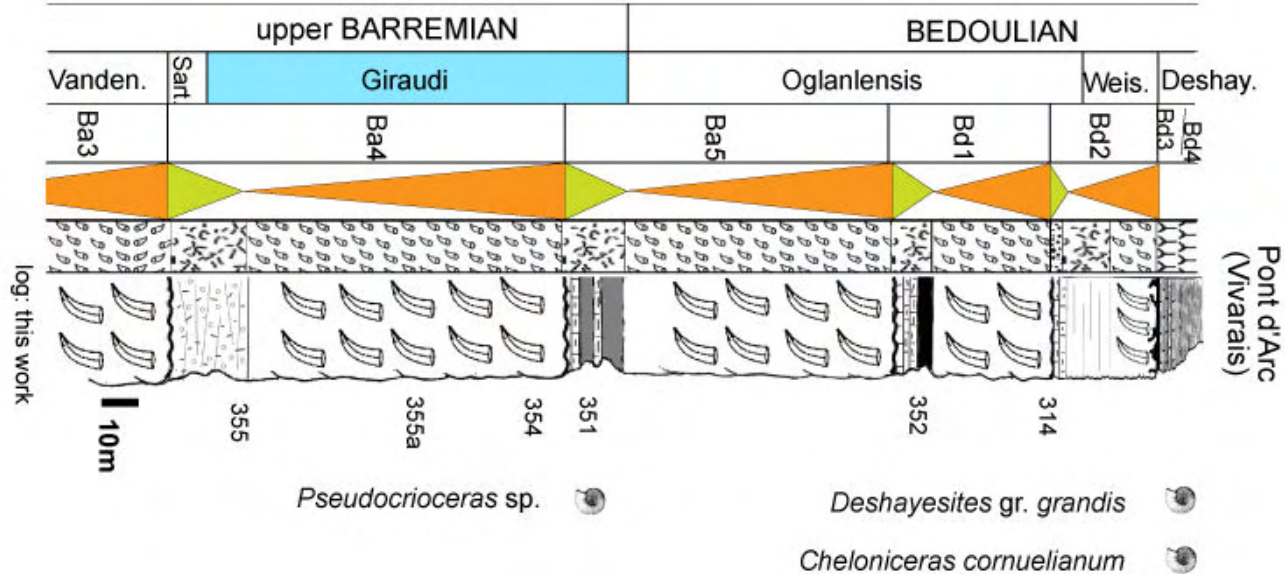

Heteraster couloni

Heteraster oblongus

Toxaster collegnoi

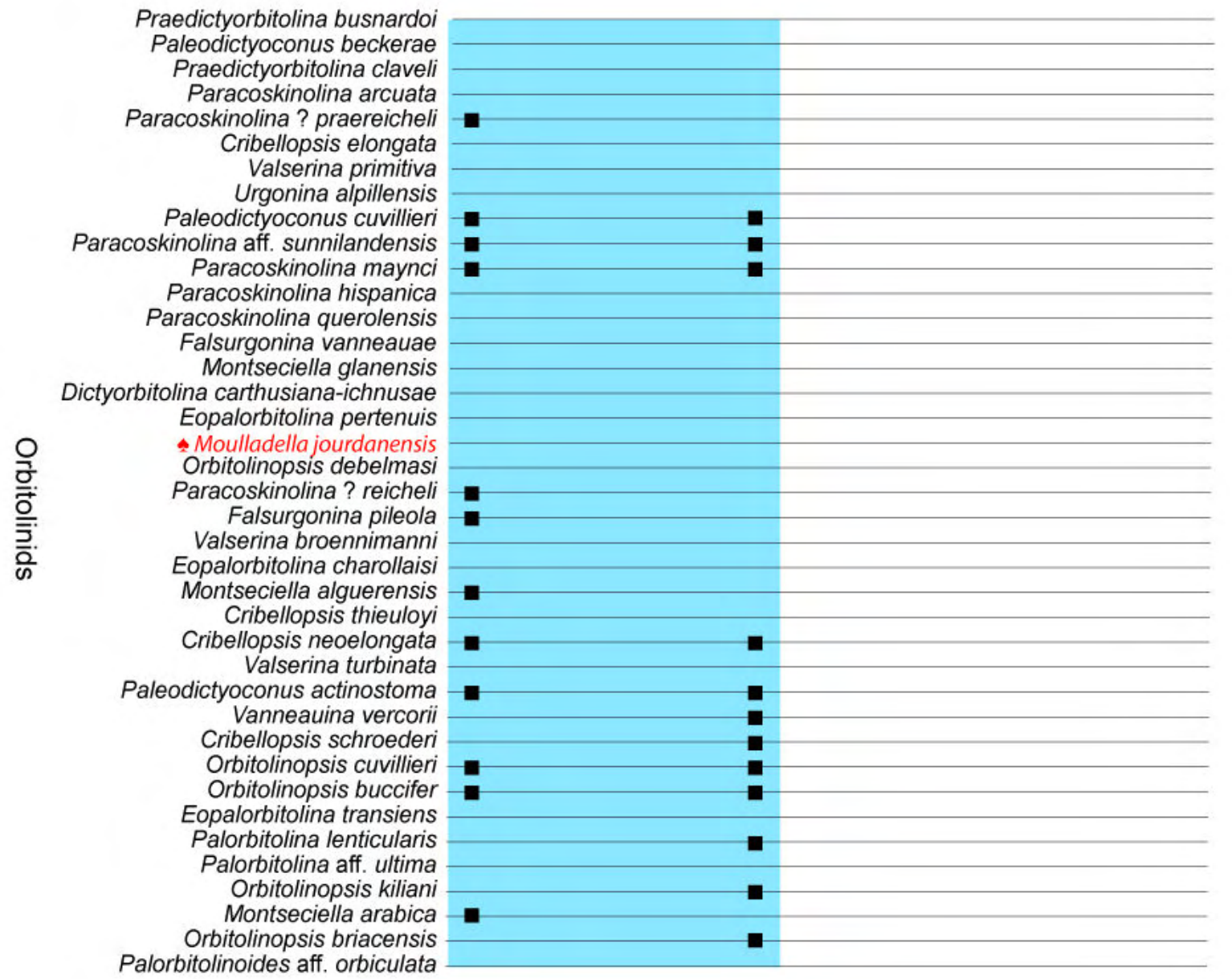

Figure 2.18: Pont d'Arc section. 


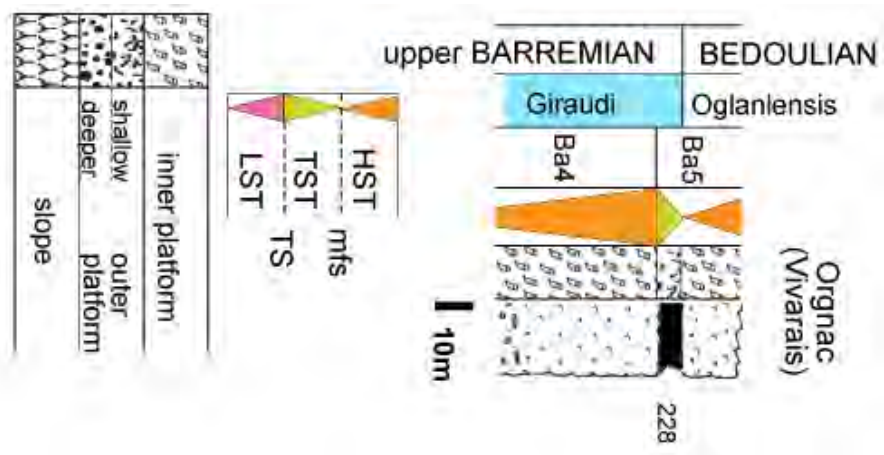

Ammonites Heteroceras cf baylei $\geqslant$
Echinids Heteraster oblongus $=$

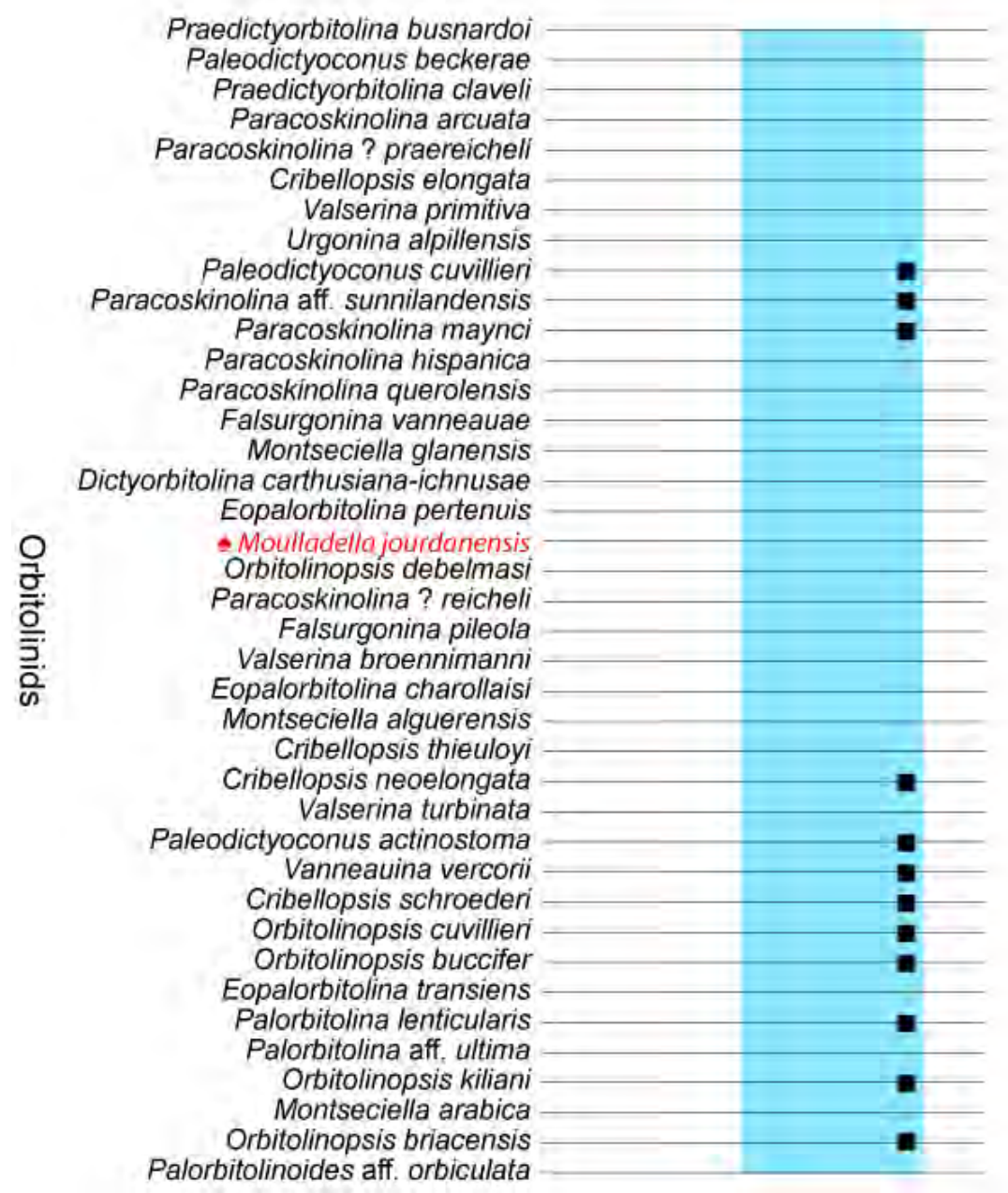

Figure 2.19: Orgnac section. 
along an agricultural road connecting RD 317 (to the SW) and RD 217 (to the NE). Besides the numerous rudists unearthed on the structural surface, this level also provided a fragment of ammonite ascribed to Heteroceras cf. baylei (fide R.B., PI. 120, fig. B, FSL 89455). The occurrence of numerous Heteraster oblongus argues for its ascription to the uppermost part of the Sarasini Zone.

Orbitolinids identified in rock sample no. 228 are the following:

- Cribellopsis neoelongata (PI. 124),

- Cribellopsis schroederi (PI. 124),

- Orbitolinopsis briacensis (PI. 121),

- Orbitolinopsis buccifer (PI. 122),

- Orbitolinopsis cuvillieri (PI. 121),

- Orbitolinopsis kiliani (PI. 121),

- Paleodictyoconus actinostoma (PI. 125),

- Paleodictyoconus cuvillieri (PI. 125),

- Palorbitolina gr. lenticularis (PI. 120, fig. A),

- Paracoskinolina aff. sunnilandensis (PI. 123),

- Paracoskinolina maynci (PI. 123)

- Vanneauina vercorii (PI. 123).

\section{Conclusions}

To summarize, the study of the orbitolinid records from 20 sections of SE France ( 8 in 2010, 1 in 2013, 11 today), all calibrated on ammonite biozones and ascribed ages ranging from the late Hauterivian to the late Barremian, marginally improves or consolidates our knowledge of the stratigraphic ranges of these foraminifers.

Figure 3 is the latest version of the biostratigraphic range chart of 38 orbitolinid species occurring in the Upper Hauterivian to Bedoulian (i.e., lower Aptian) interval of SE France and W Switzerland by CLAVEL et al. (2007), which was regularly updated since its first publication. This new version includes the latest information regarding the upper Berriasian first occurrences of 9 orbitolinid species (SCHLAGINTWEIT \& BUCUR, 2021) plus Moulladella jourdanensis, a species which was recently assigned to the family Pfenderinidae, hence which should not anymore be considered as part of the family Orbitolinidae (BUCUR \& SCHLAGINTWEIT, 2018).

On a biostratigraphic point of view:

- Upper Hauterivian interval: Three species (namely Paleodictyoconus beckerae, Praedictyorbitolina busnardoi, and Valserina primitiva) are not found in strata higher than the Upper Hauterivian in the composite stratigraphic column (Fig. 3). Based on current knowledge, the first two species (i.e., Paleodictyoconus beckerae and Praedictyorbitolina busnardoi) are apparently restricted to the Upper Hauterivian strata in SE France whereas a striking first occurrence of Valserina primitiva was recently documented from upper Berriasian limestones of $E$ Serbia (SCHLAgintWeit \& BucuR, 2021). Besides Valserina primitiva, SCHLAGINTWEIT and BUCUR
(2021) also reported from Kamenica Moulladella jourdanensis and 9 more orbitolinid species (namely Cribellopsis elongata, Cr. neoelongata, Cr. thieuloyi, Montseciella alguerensis, $M$. glanensis, Orbitolinopsis buccifer, Orb. debelmasi, Urgonina alpillensis, and Vanneauina vercorii), which have not been found yet in strata lower than the Upper Hauterivian [or even lower than the lower Barremian (namely Orbitolinopsis buccifer and Vanneauina vercorii)] in SE France or in W Switzerland. Although 10 out of the 38 orbitolinid species (26\%) from the Urgonian facies of SE France already existed in late Berriasian times in the Kamenica area (SCHLAGINTWEIT \& BUCUR, 2021), there are 15 (39\%), including 8 Berriasian orbitolinid species, that are first reported from Upper Hauterivian strata in SE France;

- Barremian interval: Barremian studied sections yield up to 33 orbitolinid species (plus Moulladella jourdanensis), out of which 28 $(85 \%)$ were already present in the Pulchella Zone of the lower Barremian. 9 Barremian orbitolinid species [namely Cribellopsis elongata, Cr. thieuloyi, Dictyorbitolina carthusiana-ichnusae, Eopalorbitolina charollaisi, Eop. pertenuis, Paracoskinolina hispanica, Pradictyorbitolina claveli, Valserina broennimanni, and $V$. turbinata (which is restricted to the sole lower Barremian)] do not reach upper Barremian strata. In contrast, 14 Barremian or older orbitolinid species $(38 \%)$ reach Bedoulian strata;

- Montseciella arabica [Pls. 93, 113 ] is the sole species to appear in upper Barremian strata. This species rare in SE France but rather common in the Middle East was found in the sequence Ba4 of two studied sections ( $\S 15$. Gorges de la Nesque; $\S 18$. Pont d'Arc), which is correlated to the Moutonianum to Vandenheckei zones. Its last record could be in the regressive tract (Ba5) following the Barremian/Bedoulian boundary (GRANIER \& BUSNARDO, 2013);

- The lowest occurrence of Palorbitolina lenticularis is first documented herein from the Vandenheckei Zone of the upper Barremian at la Béguère (Ba3 HST, § 12.), Mas Thibaud (Ba4 LST, § 14.), and La Charce (Ba4 LST, § 17.) whereas it occurs in the Pulchella Zone of the lower Barremian at L'Estellon (GRANIER et al., 2013: Ba2 LST), which contributes to justify calling it the "Rosetta Stone of the Urgonian biostratigraphy".

After testing the validity of two extant distribution charts of orbitolinids (1. ARNAUD-VANNEAU et al., 2005, versus 2. CLAVEL et al., 2007 et seq.), it turns out that the highest discrepancies appear with ARNAUD-VANNEAU's (ARNAUD-VANNEAU et al., 2005) and that by far the best match is obtained with Clavel's (Clavel et al., 2007 et seq., not to mention Granier et al., 2013, with the L'Estellon section). As for previous publications (e.g., CoNRAD et al., 2012; ChAROLLAIS et al., 2013), these 


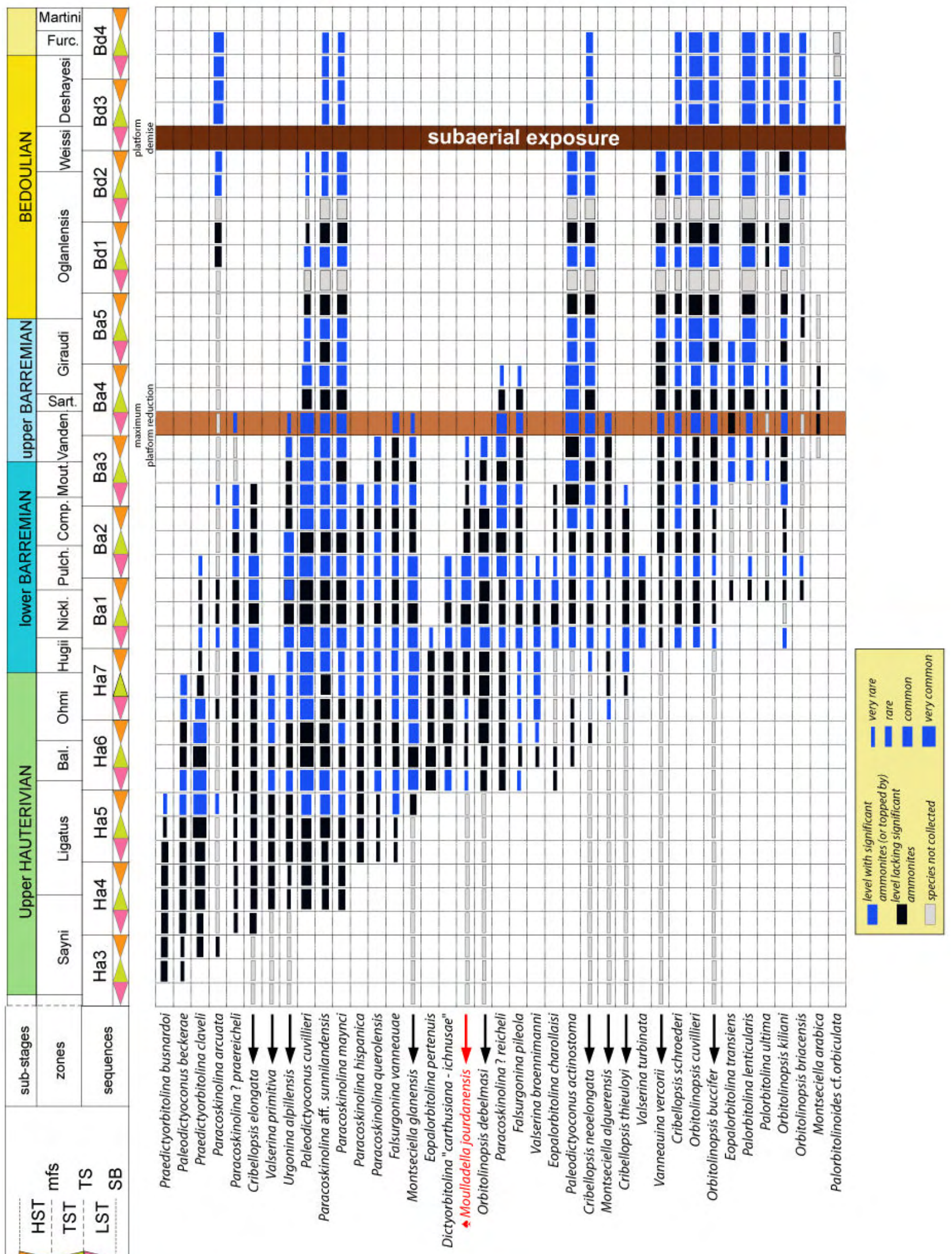

Figure 3: New biostratigraphic distribution of the orbitolinids from Upper Hauterivian to Bedoulian (lowermost Aptian) strata of southeastern France. 
observations question the relevance of the conclusions and hypotheses of any published work based on the biased stratigraphic distribution ranges for the orbitolinids, e.g., any work based on ARNAUD-VANNEAU's range chart (i.e., ARNAUDVANNEAU et al., 2005, and earlier versions).

\section{Acknowledgements}

Special thanks are due to Catherine HeRTER Clavel and Mathieu Clavel for entrusting the first author (BG) to complete the drafting of this unpublished manuscript of the late Bernard CLAVEL (1938-2018) and coauthors. The foraminiferal material presented here will be stored in the micropaleontological collection of the "Musée d'Histoire naturelle de Genève" curated by André PIUz. We are gratuful to Fabienne GUIRAUD and collaborators at Observatoire des Sciences de I'Univers de Grenoble - OSUG for having provided new photos of their ammonite collection. OSUG-COLLECTIONS is a database of rocks, minerals and fossils, https://web.collections.osug.fr, OSUG, UGA. DOI: 10.5072/OSUG-COLLECTIONS.all. The manuscript benefited from the constructive reviews of Felix SchlagintWeIt and Michel SePTFONTAINE. The first author (BG) would like to thank Phil SALVADOR for his appreciated help with the original (English) text.

\section{Bibliographic references}

ARNAUD H. (1981).- De la plate-forme urgonienne au bassin vocontien : Le Barrémo-Bédoulien des Alpes occidentales entre l'Isère et le Büech (Vercors méridional, Diois oriental et Dévoluy).- Thèse, Grenoble; Géologie Alpine, Grenoble, Mém. H.S., no. 12, 804 p. URL: https://tel.archives-ouvertes.fr/tel-00662966

Arnaud $\mathrm{H}$. , Arnaud-Vanneau A., Blanc-Alétru M.C., Adatte T., Argot M., Delanoy G., Thieuloy J.-P., Vermeulen J., Virgone A., Virlouvet B. \& WeRMEILle S. (1998).- Répartition stratigraphique des orbitolinidés de la plate-forme urgonienne subalpine et jurassienne (SE de la France).- Géologie Alpine, Grenoble, t. 74, p. 3-89.

ARNAUd-VANNEAU A. (1980).- Micropaléontologie, paléoécologie et sédimentologie d'une plateforme carbonatée de la marge passive de la Téthys : L'Urgonien du Vercors septentrional et de la Chartreuse (Alpes occidentales).- Thèse, Grenoble; Géologie Alpine, Grenoble, Mém. H.S., no. 11, 874 p. URL: https://tel. archives-ouvertes.fr/tel-00662977

Arnaud-Vanneau A., ARnaud H., CARrio-SchafFHAUSER H. \& RADDADI M.C. (2005).- Urgonian deposits and Barremian-Early Aptian sequence stratigraphy in the Vercors Massif. In : ADATTE T., Arnaud-Vanneau A., Arnaud H., Blanc-AléTRU M.-C., BODIN S., CARRIO-SchafFHAUSER E., Föllmi K., Godet A., RAdDAdi M.C. \& VermeuleN J. (eds.), The Hauterivian-Lower Aptian sequence stratigraphy from Jura platform to Vocontian basin: A multidisciplinary approach.Géologie Alpine (série spéciale "Colloques et
Excursions"), Grenoble, no. 7, p. 97-126.

BECKER E. (1999).- Orbitoliniden-Biostratigraphie der Unterkreide (Hauterive - Barrême) in den spanischen Pyrenäen (Profil Organyà, Prov. Lérida).- Revue de Paléobiologie, Genève, vol. 18 , no. 2, p. 359-489.

Bernaus J.-M. (1998).- L'Urgonien du bassin d'Organyà (NE Espagne) : Micropaléontológie, sédimentologie et stratigraphie séquentielle.Thèse de I'Université Joseph FOURIER - Grenoble I, 206 p. URL: https://tel.archivesouvertes.fr/tel-00723708

Bernaus J.-M., Caus E. \& Arnaud-Vanneau A. (2000).- Aplicación de los análysis micropaleontologicos cuantitativos en estratigrafía secuencial: el Cretácico inferior de la Cuenca de Organyà (Pirineos, España).- Revista de la Sociedad Geológica de España, Madrid, vol. 13, no. 1 , p. 55-63.

BERT D. (2017).- Barremian ammonite fauna from L'Estellon section (Baronnies, SE France): Additional identifications. In : GRANIER B. (ed.), Some key Lower Cretaceous sites in Drôme (SE France).- ISBN13: 978-2-916733-13-5, Carnets de Géologie, Madrid, Book 2017/01 (CG2017_B01), p. 102-109. DOI: 10.4267/ 2042/62543

Bucur I.I. \& SChlagintweit F. (2018).- Moulladella jourdanensis (FouRY \& MOULLADE, 1966) n. gen., n. comb.: Valanginian-early late Barremian larger benthic foraminifera from the Northern Neotethyan Margin.- Acta Palaeontologica Romaniae, Bucharest, vol. 14, no. 2, p. 45-59.

Busnardo R., Clavel B., Charollais J. \& Schroeder R. (1991).- Le passage Hauterivien-Barrémien au Mont Aiguille (Vercors, France) : Biostratigraphie et interprétation séquentielle.- Revue de Paléobiologie, Genève, vol. 10, no. 2, p. 359-364.

Busnardo R., Granier B., Clavel B. \& Charollais J. (2013).- Ammonitofaune du Barrémien de la coupe de L'Estellon (Baronnies, SE France) : Résultats biostratigraphiques préliminaires.Carnets Geol., Madrid, vol. 13, no. A03 (CG2013_A03), p. 139-162.

Charollais J., Clavel B. \& Busnardo R. (2008).Biostratigraphie et découpage séquentiel des formations du Crétacé inférieur de la plate-forme jurassienne (France, Suisse). In : A Terra. O Conflitos e Ordem. Homenagem ao Professor FerReira SoARes.- Museu Mineralógico e Geológico da Universidade de Coimbra, p. 197-207.

Charollais J., Clavel B., Busnardo R., Conrad M., MülleR A. \& DeCROUez D. (2009).- Olistolithes et coulées bioclastiques: Prémices de l'installation de la plate-forme urgonienne aux confins des Bornes et des Aravis (Haute-Savoie, France).- Archives des Sciences, Genève, vol. 62 , fasc. 1 , p. $35-70$.

Charollais J., Clavel B., Granier B., Busnardo R. \& CONRAD M.A. (2013).- Discussion of the paper by GODET et al. 2011, entitled "Reconciling 
strontium-isotope and $\mathrm{K}-\mathrm{Ar}$ ages with biostratigraphy: the case of the Urgonian platform, Early Cretaceous of the Jura Mountains, Western Switzerland" (Swiss Journal of Geosciences, 104, 147-160).- Swiss Journal of Geosciences, Basel, vol. 106, no. 3, p. 559-567.

Charollais J., Clavel B., Schroeder R., Busnardo R. \& MASSE J.-P. (1998).- La plate-forme urgonienne. Un exemple de plate-forme carbonatée : Biostratigraphie, stratigraphie séquentielle, sédimentologie, études régionales.- $P u$ blications du Département de Géologie et Paléontologie, Université de Genève, (Série "Guide géologique"), no. 8, $181 \mathrm{p}$.

Charollais J. \& Granier B. (2020).- Nécrologie. Bernard Clavel (1938-2018).- Archives des Sciences, Genève, vol. 71, p. 95-100.

Clavel B. (1984).- Échinides (tableau 6.9). In: DEBRAND-PASSARD S. (éd.), Synthèse géologique du Sud-Est de la France. I : Stratigraphie et paléogéographie.- Mémoires du Bureau de Recherches Géologiques et Minières, Orléans, no. 125 , p. 296.

Clavel B., Busnardo R., Charollais J., Conrad M.A. \& GRANIER B. (2010).- Répartition biostratigraphique des orbitolinidés dans la biozonation à ammonites (plate-forme urgonienne du Sud-Est de la France). Partie 1 : Hauterivien supérieur - Barrémien basal.- Carnets Geol., Madrid, vol. 10, no. A06 (CG2010_A06), p. 153.

Clavel B., Charollais J., Busnardo R., Granier B., ConRad M.A., Desjacques P. \& Metzger J. (2014).- La plate-forme carbonatée urgonienne (Hauterivien supérieur - Aptien inférieur) dans le Sud-Est de la France et en Suisse : Synthèse.- Archives des Sciences, Genève, vol. 67, p. 1-97.

Clavel B., Charollais J., Conrad M., Jan du Chêne R., Busnardo R., Gardin S., Erba E., Schroeder R., Cherchi A. Decrouez D., Granier B., SauvaGNAT J. \& WEIDMANN M. (2007).- Dating and progradation of the Urgonian limestone from the Swiss Jura to South-East France.- Zeitschrift der Deutschen Gesellschaft für Geowissenschaften, Stuttgart, vol. 158, no. 4, p. 1025-1062.

Clavel B., Charollais J., Schroeder R. \& Busnardo R. (1995).- Réflexions sur la biostratigraphie du Crétacé inférieur et sur sa complémentarité avec I'analyse séquentielle : Exemple de I'Urgonien jurassien et subalpin.- Bulletin de la Société géologique de France, Paris, vol. 166, no. 6, p. 663-680.

Clavel B., Decrouez D., Charollais J. \& Busnardo R. (2009a).- "Paracoskinolina" praereicheli n.sp., un orbitolinidé (Foraminifère) nouveau de l'Hauterivien supérieur et du Barrémien inférieur (Crétacé) à faciès urgonien (SE France, Jura franco-suisse, Préalpes suisses).- Archives des Sciences, Genève, vol. 62, fasc. 1, p. 1-10.
Clavel B., Decrouez D., Charollais J. \& Busnardo R. (2009b).- Falsurgonina vanneauae n.sp., un orbitolinidé (Foraminifère) nouveau de I'Hauterivien supérieur et du Barrémien (Crétacé) à faciès urgonien (SE France, Jura francosuisse, Pyrénées espagnoles).- Archives des Sciences, Genève, vol. 62, fasc. 1, p. 11-22.

Clavel B., Decrouez D., Charollais J. \& Busnardo R. (2009c).- Paleodictyoconus beckerae n. sp., un orbitolinidé (Foraminifère) nouveau de l'Hauterivien supérieur (Crétacé) à faciès urgonien (SE France, Jura franco-suisse, Pyrénées espagnoles).- Archives des Sciences, Genève, vol. 62, fasc. 1, p. 23-34.

Conrad M., Clavel B., Granier B., Charollais J., Busnardo R., ERBa E., Gardin S., Jan du ChÊNE R., Decrouez D., Cherchi A., Schroeder R., Sauvagnat J. \& Weidmann M. (2012).- "Stratigraphic, sedimentological and palaeoenvironmental constraints on the rise of the Urgonian platform in the western Swiss Jura", by A. GODET et al., Sedimentology (2010) 57, 10881125: Discussion.- Sedimentology, Oxford, vol. 59, no. 3, p. 1121-1125.

Conrad M.A., Schroeder R., Clavel B., Charollais J., Busnardo R., Cherchi A. \& Decrouez D. (2004).- Dating the Lower Cretaceous in the Organyà section (Catalan Pyrenees, NE Spain): A reinterpretation.- Cretaceous $R e$ search, vol. 25, no. 1, p. 35-41.

elmi S., Busnardo R., Clavel B., Camus G., Kieffer G., BÉRARD P. \& MiCHAËLY B. (1996).- Aubenas.- Carte géologique de la France, Notice, $865,170 \mathrm{p}$.

FERRY S. (1976).- Cônes d'épandage bioclastiques en eau profonde et glissements sous-marins dans le Barrémien et l'Aptien inférieur vocontiens de la Drôme. Implications paléostructurales.- Thèse de 3e Cycle, Université Claude BERNARD, Lyon, $143+51$ p. URL: https://tel. archives-ouvertes.fr/tel-00815666

FouRY G. (1972).- Deuxième journée. Les "faciès urgoniens" au Nord du Ventoux : La bluye et le Rissas. In: Arnaud-Vanneau A., Arnaud H., FOURY G. \& MASSE J.-P. (eds.), Excursion sur I'Urgonien de Haute-Provence et du Vercors (9-12 octobre 1972).- Excursions du Groupe français du Crétacé, Paris, 7 p. URL: https:// hal.archives-ouvertes.fr/hal-01114303

Granier B. \& Busnardo R. (2013).- New stratigraphic data on the Aptian of the Persian Gulf. In: Skelton P., Granier B. \& Moullade M. (eds.), Special issue: Spatial patterns of change in Aptian carbonate platforms and related events.- Cretaceous Research, vol. 39, p. 170182.

Granier B., Busnardo R., Clavel B., Moullade M., Charollais J., Tronchetti G. \& Desjacques P. (2014).- Refining the Urgonian biostratigraphy: A key section at L'Estellon, Drôme, France. In : RocHA R. et al. (eds.), STRATI 2013. First International Congress on Stratigraphy at the cutting edge of stratigraphy.Springer, Heidelberg, p. 1095-1097. 
Granier B., Clavel B. \& Charollais J. (2016).Comments on "Estimating the impact of early diagenesis on isotope records in shallow-marine carbonates: A case study from the Urgonian platform in western Swiss Jura" by A. GODET et al. [Palaeogeography Palaeoclimatology Palaeoecology 454 (2016) 125-138].Carnets Geol., Madrid, vol. 16, no. 17, p. 417429.

Granier B., Clavel B., Moullade M., Busnardo R., Charollais J., Tronchetti G. \& Desjacques P. (2013).- L'Estellon (Baronnies, France), a "Rosetta Stone" for the Urgonian biostratigraphy.Carnets Geol., Madrid, vol. 13, no. A04 (CG2013_A04), p. 163-207.

Granier B., Clavel B., Moullade M., Busnardo R., Charollais J., Tronchetti G. \& Desjacques P. (2017).- Biostratigraphic distribution of orbitolinids in the ammonite biozones (Urgonian platform of southeastern France). Part 1: Upper Hauterivian-lowermost Barremian. In : Granier B. (ed.), Some key Lower Cretaceous sites in Drôme (SE France).- ISBN13: 978-2916733-13-5, Carnets de Géologie, Madrid, Book 2017/01 (CG2017_B01), p. 111-157. DOI: $10.4267 / 2042 / 62543$

Giraud F. \& JANOTS É. (2020).- Collections géologiques de l'Observatoire des Sciences de I'Univers de Grenoble.- URL: https://web. collections.osug.fr/compactus/f. DOI: 10.5072/ OSUG-COLLECTIONS.all

LAFARGE D. (1978, unpublished).- Étude géologique du plateau de Saint Remèze, Ardèche. Stratigraphie, cartographie, sédimentologie, tectonique.- Thèse, Université Claude BERNARD, Lyon, $119 \mathrm{p}$.

LÉonide Ph., Borgomano J., MAsse J.-P. \& Doublet S. (2012).- Relation between stratigraphic architecture and multi-scale heterogeneities in carbonate platforms: The Barremian-lower Aptian of the Monts de Vaucluse, SE France.Cretaceous Research, vol. 265, p. 87-109.
MASSE J.-P. (1976).- Les calcaires urgoniens de Provence (Valanginien-Aptien inférieur). Stratigraphie, paléontologie, les paléoenvironnements et leur évolution.- Thèse Université AixMarseille II, $445 \mathrm{p}$.

Moullade M. (1966).- Étude stratigraphique et micropaléontologique du Crétacé inférieur de la "fosse vocontienne".- Documents des Laboratoires de Géologie de la Faculté des Sciences de Lyon, Villeurbanne, no. 15, 369 p. URL: https://tel.archives-ouvertes.fr/tel-00814787

Pascal M., Lafarge D., Chedhomme J. \& GlintzBOECKEL C. (1989).- Bourg-Saint-Andéol.- Carte géologique de la France, Notice, 889, 67 p.

SChlagintweIt F. \& BUCUR I.I. (2021).- The late Berriasian early evolutionary burst of the Orbitolinidae: New insights into taxonomy, origin, diversification and phylogeny of the family based on data from eastern Serbia.- Carnets Geol., Madrid, vol. 21, no. 15, p. 343-382.

Schroeder R., Clavel B. \& Charollais J. (1990).Praedictyorbitolina carthusiana n.gen. n. sp., Orbitolinidé (Foraminiferida) de la limite Hauterivien - Barrémien des Alpes occidentales.Paläontologische Zeitschrift, Stuttgart, vol. 64, no. 3-4, p. 193-202.

Schroeder R., Clavel B., Conrad M.A., Zaninetti L., Busnardo R., Charollais J. \& Cherchi A. (2000).- Corrélations biostratigraphiques entre la coupe d'Organyà (Pyrénées catalanes, NE de l'Espagne) et le Sud-Est de la France pour l'intervalle Valanginien-Aptien.- Treballs del Museu de Geologia de Barcelona, no. 9, p. 5-41.

VIRLOUVET B. (1997).- Étude géologique et modélisations sismiques d'une coupe de la bordure méridionale de la plate-forme urgonienne du Vercors (France); contribution à la caractérisation sismique d'un réservoir carbonaté.Thèse de l'Université Joseph FouRIER - Grenoble I, 197 p. URL: https://tel.archives-ouvertes. $\mathrm{fr} / \mathrm{tel}-00819747$ 
Appendix

\begin{tabular}{|c|c|c|c|}
\hline Sections & Easting, $\mathbf{X}(\mathbf{k m})$ & Northing, $Y(\mathbf{k m})$ & Latitude, Longitude \\
\hline 1. Pic de l'Oeillette & $868850 * * *$ & 3344000 & $45^{\circ} 20^{\prime} 43.6^{\prime \prime N}, 5^{\circ} 46^{\prime} 03.3^{\prime \prime E}$ \\
\hline ARNAUD, 1980, p. 219 & $868850 * * *$ & $334500[\mathrm{sic}]$ & $45^{\circ} 21^{\prime} 16.0^{\prime \prime N}, 5^{\circ} 46^{\prime} 05.2^{\prime \prime E}$ \\
\hline peak & $869031 * * *$ & 3344516 & $45^{\circ} 21^{\prime} 00.1^{\prime \prime N}, 5^{\circ} 46^{\prime} 12.6^{\prime \prime E}$ \\
\hline 2. Bella Cha & $922620 * *$ & 2108750 & $45^{\circ} 54^{\prime} 07.9^{\prime \prime} N, 6^{\circ} 29^{\prime} 45.4^{\prime \prime E}$ \\
\hline Adroit des Aravis & $920500 * *$ & 2105620 & $45^{\circ} 52^{\prime} 30.2^{\prime \prime N}, 6^{\circ} 27^{\prime} 59.6^{\prime \prime E}$ \\
\hline "Trou de la Mouche" & $923978 * * *$ & 410031 & $45^{\circ} 54^{\prime} 57.2^{\prime \prime} \mathrm{N}, 6^{\circ} 30^{\prime} 45.8^{\prime \prime} \mathrm{E}$ \\
\hline \multirow[t]{2}{*}{ 3. Grands Goulets } & start: $689800 *$ & 4987000 & $45^{\circ} 00^{\prime} 39.8^{\prime \prime N}, 5^{\circ} 24^{\prime} 31.1^{\prime \prime E}$ \\
\hline & end: $690170 *$ & 4986650 & $45^{\circ} 00^{\prime} 28.1^{\prime \prime N}, 5^{\circ} 24^{\prime} 47.5^{\prime \prime E}$ \\
\hline ARNAUD, 1980, p. 238 & $842900 * * *$ & 305100 & $45^{\circ} 00^{\prime} 17.9^{\prime \prime N}, 5^{\circ} 25^{\prime} 05.4^{\prime \prime E}$ \\
\hline 4. Pont de Laval & $617930 *$ & 4917770 & $44^{\circ} 24^{\prime} 13.0^{\prime \prime} \mathrm{N}, 4^{\circ} 28^{\prime} 51.6^{\prime \prime} \mathrm{E}$ \\
\hline start (353m) & & & $44^{\circ} 24^{\prime} 07.4^{\prime \prime} \mathrm{N}, 4^{\circ} 28^{\prime} 55.6^{\prime \prime} \mathrm{E}$ \\
\hline end (601 m) & & & $44^{\circ} 24^{\prime} 27.2^{\prime \prime N}, 4^{\circ} 29^{\prime} 00.5^{\prime \prime E}$ \\
\hline 5. Mont Aiguille (stream) & $854100 * * *$ & 3287750 & $44^{\circ} 50^{\prime} 42.3^{\prime \prime N}, 5^{\circ} 33^{\prime} 05.5^{\prime \prime E}$ \\
\hline (Aupet pass) & 853600 & 3287250 & $44^{\circ} 50^{\prime} 26.8^{\prime \prime N}, 5^{\circ} 32^{\prime} 41.9^{\prime \prime E}$ \\
\hline 6. Pas de l'Essaure & $854900 * * *$ & 3281950 & $44^{\circ} 47^{\prime} 33.6^{\prime \prime N}, 5^{\circ} 33^{\prime} 31.6^{\prime \prime E}$ \\
\hline 7. Arredons & $770750 * * *$ & 3241100 & $44^{\circ} 26^{\prime} 59.6^{\prime \prime N}, 4^{\circ} 28^{\prime} 55.9^{\prime \prime E}$ \\
\hline 8. Chames & $767100 * * *$ & 3233400 & $44^{\circ} 22^{\prime} 53.3^{\prime \prime} \mathrm{N}, 4^{\circ} 26^{\prime} 01.9^{\prime \prime} \mathrm{E}$ \\
\hline \multirow[t]{2}{*}{ 9. Mas de Gras } & $620804 *$ & 4920393 & $44^{\circ} 25^{\prime} 36.3^{\prime \prime N}, 4^{\circ} 31^{\prime} 03.7^{\prime \prime E}$ \\
\hline & $623168 *$ & 4921520 & $44^{\circ} 26^{\prime} 11.4^{\prime \prime N}, 4^{\circ} 32^{\prime} 51.5^{\prime \prime E}$ \\
\hline \multirow[t]{2}{*}{ 10. La Montagnette } & $702029 *$ & 4962746 & $44^{\circ} 47^{\prime} 22.4^{\prime \prime N}, 5^{\circ} 33^{\prime} 14.3^{\prime \prime E}$ \\
\hline & $701873 *$ & 4960817 & $44^{\circ} 46^{\prime} 20.1^{\prime \prime N}, 5^{\circ} 33^{\prime} 04.5^{\prime \prime E}$ \\
\hline ARNAUD, 1980 , p. 267 & $854200 * * *$ & 280900 & $44^{\circ} 47^{\prime} 00.5^{\prime \prime N}, 5^{\circ} 32^{\prime} 57.9^{\prime \prime E}$ \\
\hline \multirow[t]{2}{*}{ 11. Serre de Tourre } & $614493 *$ & 4915104 & $44^{\circ} 22^{\prime} 48.6^{\prime \prime N}, 4^{\circ} 26^{\prime} 14.1^{\prime \prime E}$ \\
\hline & $617780 *$ & 4911849 & $44^{\circ} 21^{\prime} 01.3^{\prime \prime} \mathrm{N}, 4^{\circ} 28^{\prime} 40.0^{\prime \prime} \mathrm{E}$ \\
\hline \multirow[t]{2}{*}{ 12. La Béguère } & $691731 *$ & 4970541 & $44^{\circ} 51^{\prime} 45.0^{\prime \prime N}, 5^{\circ} 25^{\prime} 36.7^{\prime \prime E}$ \\
\hline & $692632 *$ & 4970500 & $44^{\circ} 51^{\prime} 42.8^{\prime \prime N}, 5^{\circ} 26^{\prime} 17.7^{\prime \prime E}$ \\
\hline \multirow[t]{2}{*}{ 13. Rochecolombe } & $615028 *$ & 4931900 & $44^{\circ} 31^{\prime} 52.5^{\prime \prime N}, 4^{\circ} 26^{\prime} 51.7^{\prime \prime E}$ \\
\hline & $614787 *$ & 4931734 & $44^{\circ} 31^{\prime} 47.3^{\prime \prime} \mathrm{N}, 4^{\circ} 26^{\prime} 40.7^{\prime \prime E}$ \\
\hline \multirow[t]{2}{*}{ 14. Mas Thibaud (Mt. Bluye) } & $685364 *$ & 4896360 & $44^{\circ} 11^{\prime} 48.9^{\prime \prime N}, 5^{\circ} 19^{\prime} 10.9^{\prime \prime E}$ \\
\hline & $685339 *$ & 4896567 & $44^{\circ} 11^{\prime} 55.6^{\prime \prime N}, 5^{\circ} 19^{\prime} 10.0^{\prime \prime E}$ \\
\hline \multirow[t]{2}{*}{ 15. Gorges de la Nesque } & $684764 *$ & 4882018. & $44^{\circ} 04^{\prime} 05.0^{\prime \prime N}, 5^{\circ} 18^{\prime} 25.8^{\prime \prime E}$ \\
\hline & $684954 *$ & 4881859 & $44^{\circ} 03^{\prime} 59.6^{\prime \prime N}, 5^{\circ} 18^{\prime} 34.1^{\prime \prime E}$ \\
\hline \multirow[t]{2}{*}{ 16. Col de Rousset } & $689739 *$ & 4967466 & $44^{\circ} 50^{\prime} 07.3^{\prime \prime} \mathrm{N}, 5^{\circ} 24^{\prime} 01.9^{\prime \prime} \mathrm{E}$ \\
\hline & $689859 *$ & 4967528 & $44^{\circ} 50^{\prime} 09.2^{\prime \prime N}, 5^{\circ} 24^{\prime} 07.4^{\prime \prime E}$ \\
\hline \multirow[t]{2}{*}{ 17. La Charce } & $695113 *$ & 4927406 & $44^{\circ} 28^{\prime} 25.0^{\prime \prime N}, 5^{\circ} 27^{\prime} 11.5^{\prime \prime E}$ \\
\hline & $695211 *$ & 4927562 & $44^{\circ} 28^{\prime} 03.0^{\prime \prime N}, 5^{\circ} 27^{\prime} 16.2^{\prime \prime E}$ \\
\hline \multirow[t]{2}{*}{ 18. Pont d'Arc } & $612221 *$ & 4915395 & $44^{\circ} 22^{\prime} 59.3^{\prime \prime N}, 4^{\circ} 24^{\prime} 31.7^{\prime \prime E}$ \\
\hline & $612234 *$ & 4915862 & $44^{\circ} 23^{\prime} 14.5^{\prime \prime} \mathrm{N}, 4^{\circ} 24^{\prime} 32.7^{\prime \prime E}$ \\
\hline 19. Orgnac & $613252 *$ & 4908212 & $44^{\circ} 19^{\prime} 06.0^{\prime \prime N}, 4^{\circ} 25^{\prime} 12.7^{\prime \prime E}$ \\
\hline
\end{tabular}




\section{Plates}

Plate 31: A) Bernard CLAVEL sampling the "Pont d'Arc" section ( $\S 18$. Pont d'Arc) on the side of RD (departmental

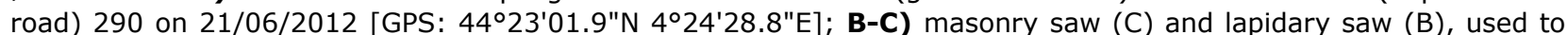
cut respectively rock slabs and the "sugar pieces" for thin sectionning. D-F) on 24/08/2014, Bernard CLAVEL at work, polishing the slabs (D), looking for diagnostic sections of foraminifer under the binocular microscope (E), and marking them of a slab (F); G) marks on slabs; H) sugar pieces cut from a limestone slab and plugs with one or several loose specimens obtained after sorting of the residue of marl sieving; I) on 15/07/2014, mounting of the sugar pieces and plugs with epoxy resin on a glass slide by Pierre DESJACQUES; J-K) examples of petrographic thin sections after the polishing to $25 \mu \mathrm{m}$ in thickness of the mounted pieces of rocks $(\mathrm{J})$ or specimens $(\mathrm{K})$. 

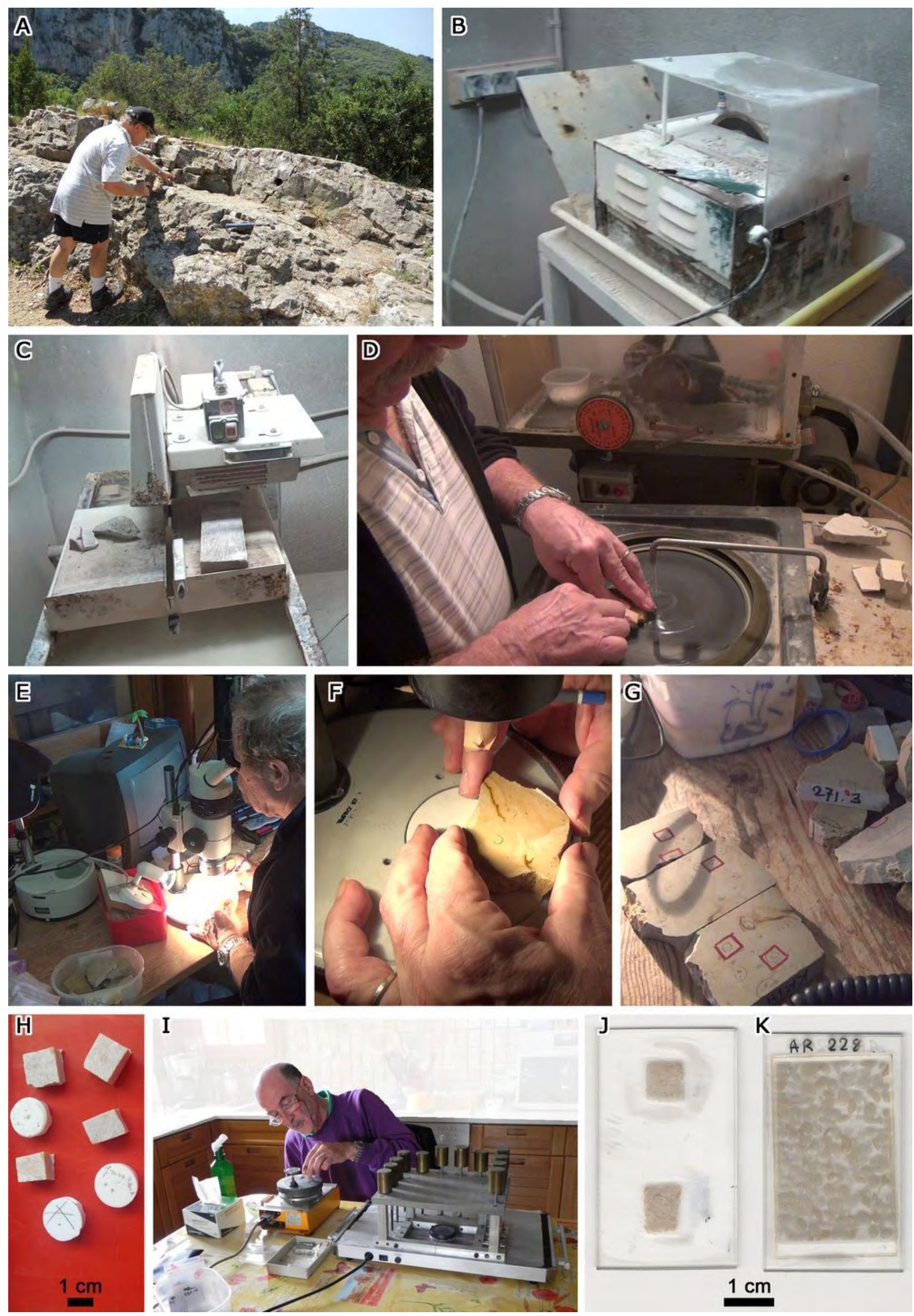

\section{I}
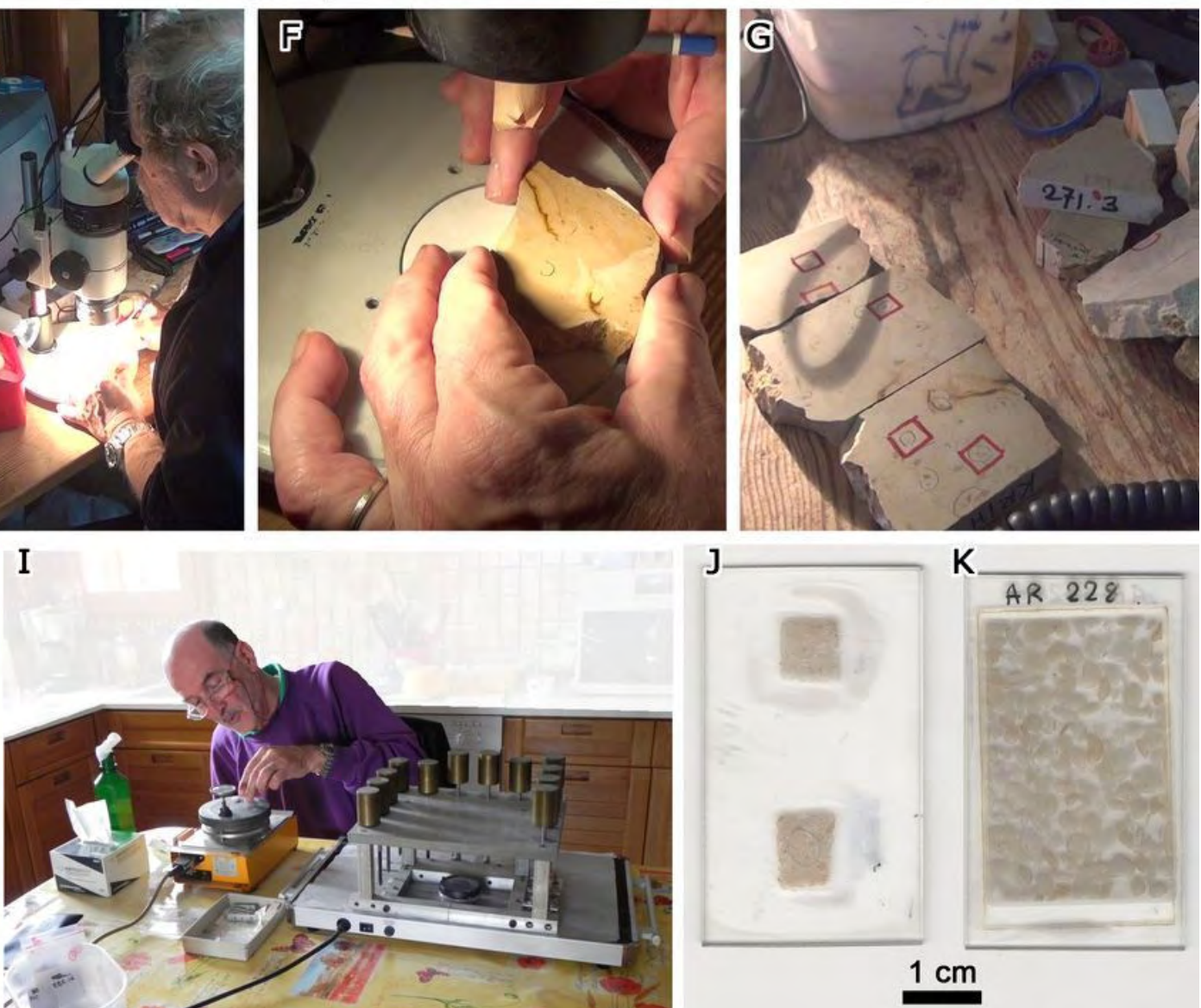

J

K

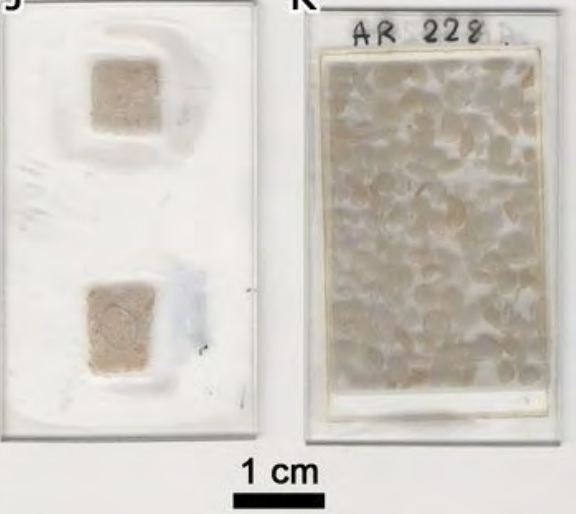



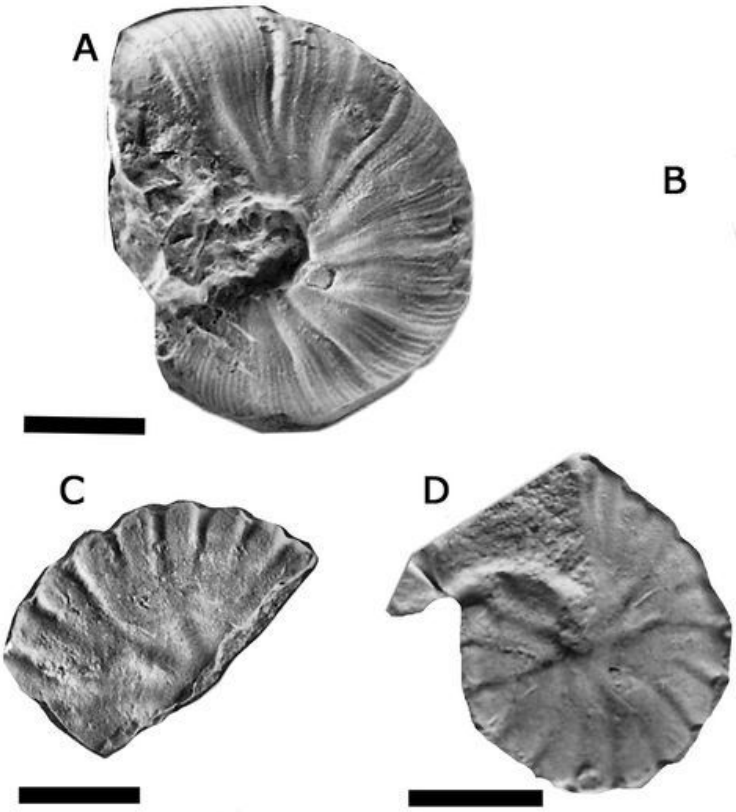

\section{B}
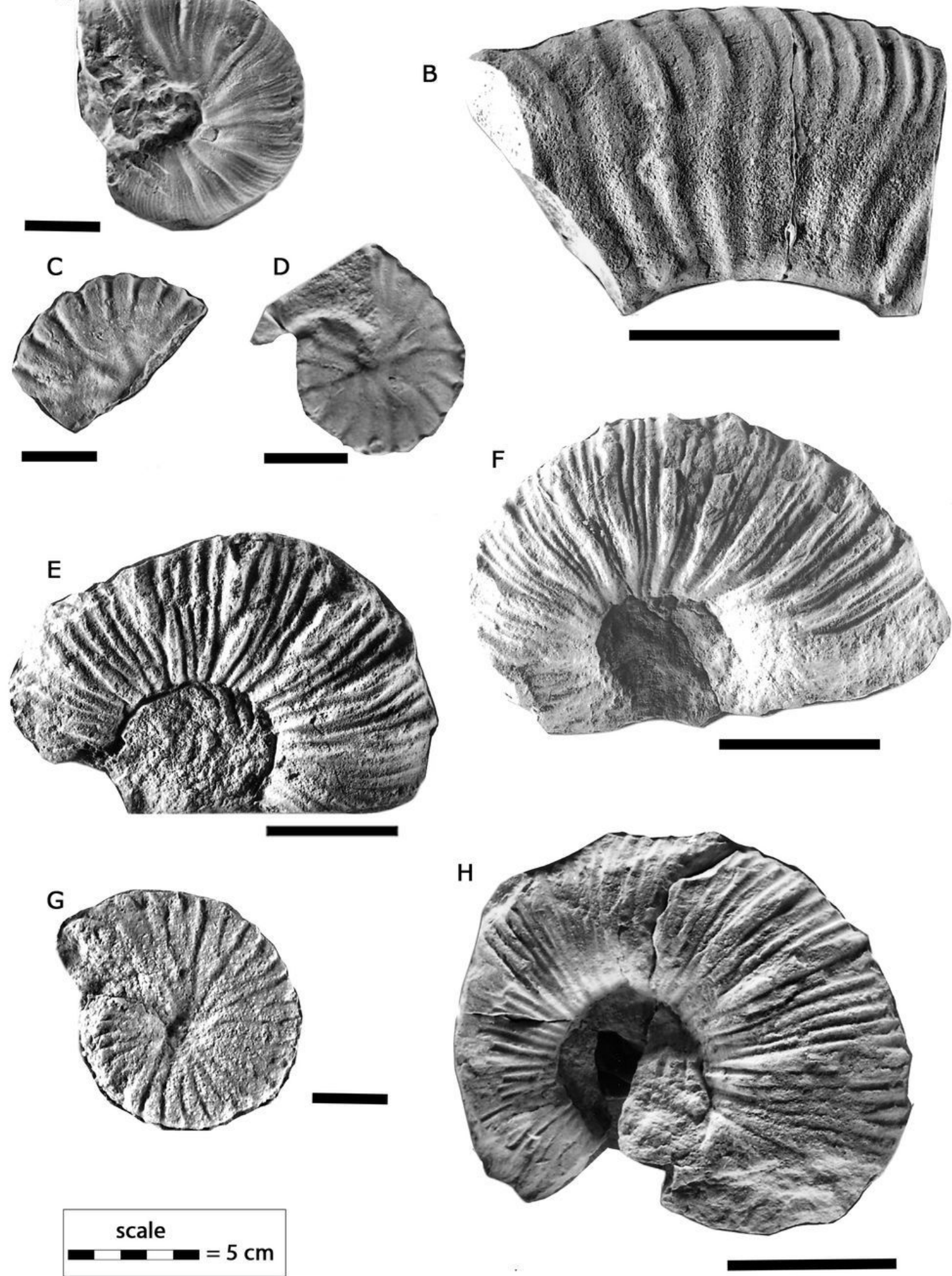

Plate 32: Ammonites of the Ohmi, Hugii, Nicklesi, Pulchella, Compressissima and Moutonianum zones at Mas de Gras. A) Taveraidiscus hugii, FSL 89641, bed 384; B) cf. Pseudothurmannia mortilleti, FSL 89581, bed 383; C) Nicklesia pulchella, FSL 89615, bed 382; D) Nicklesia pulchella, FSL 89616, bed 382; E) Holcodiscus perezianus (formerly identified a Holcodiscus caillaudianus), FSL 89613, bed 382; F) Holcodiscus perezianus, formerly identified as Holcodiscus caillaudianus (CLAVEL et al., 2007, Pl. 1, fig. H), FSL 89674, bed 375-1; G) ? Kotetischvilia compressissima (CLAVEL et al., 2007, Pl. 1, fig. K) \{or Nicklesia didayana-DB-\}, FSL 89704, bed 373-1; H) Holcodiscus perezianus, formerly identified as Holcodiscus caillaudianus (CLAVEL et al., 2007, Pl. 1, fig. I), FSL 89707, bed 378. All scale bars $=5 \mathrm{~cm}$. 

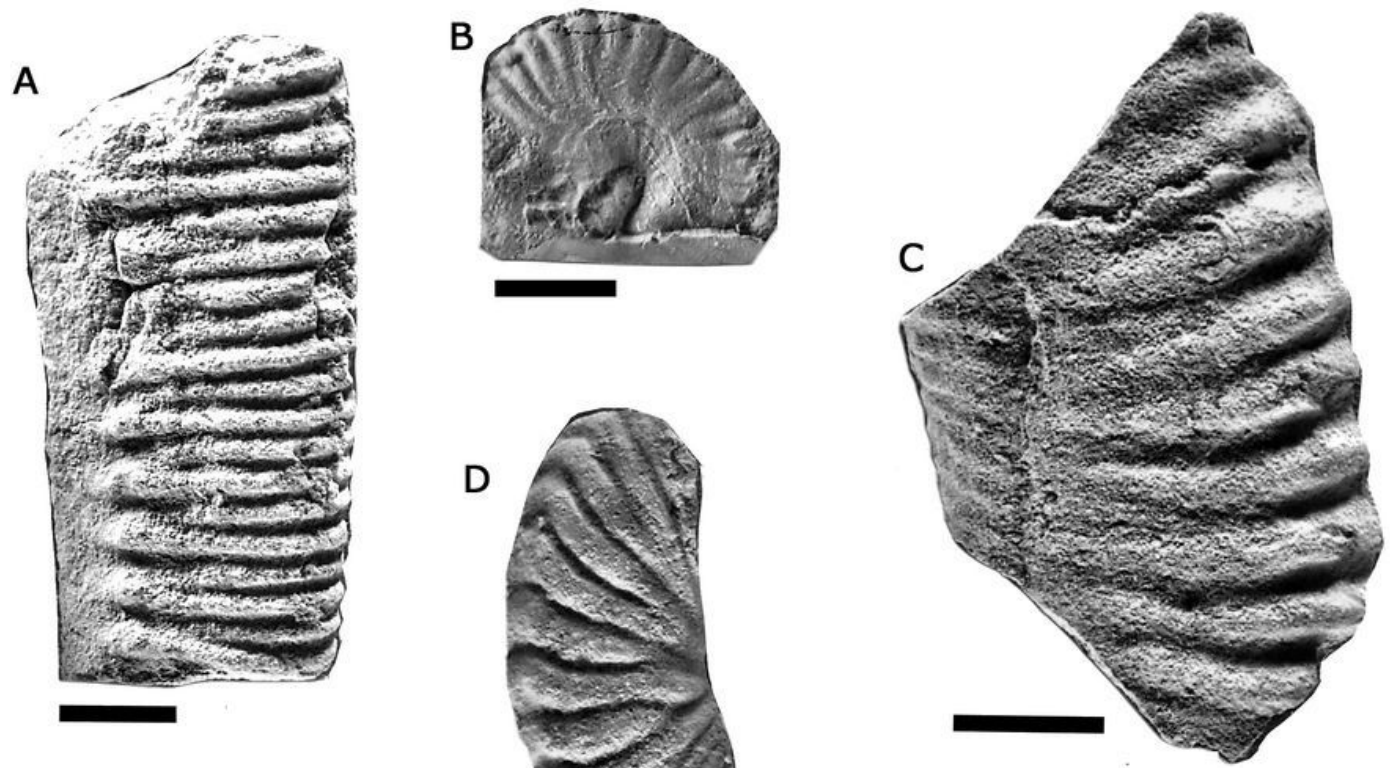

E
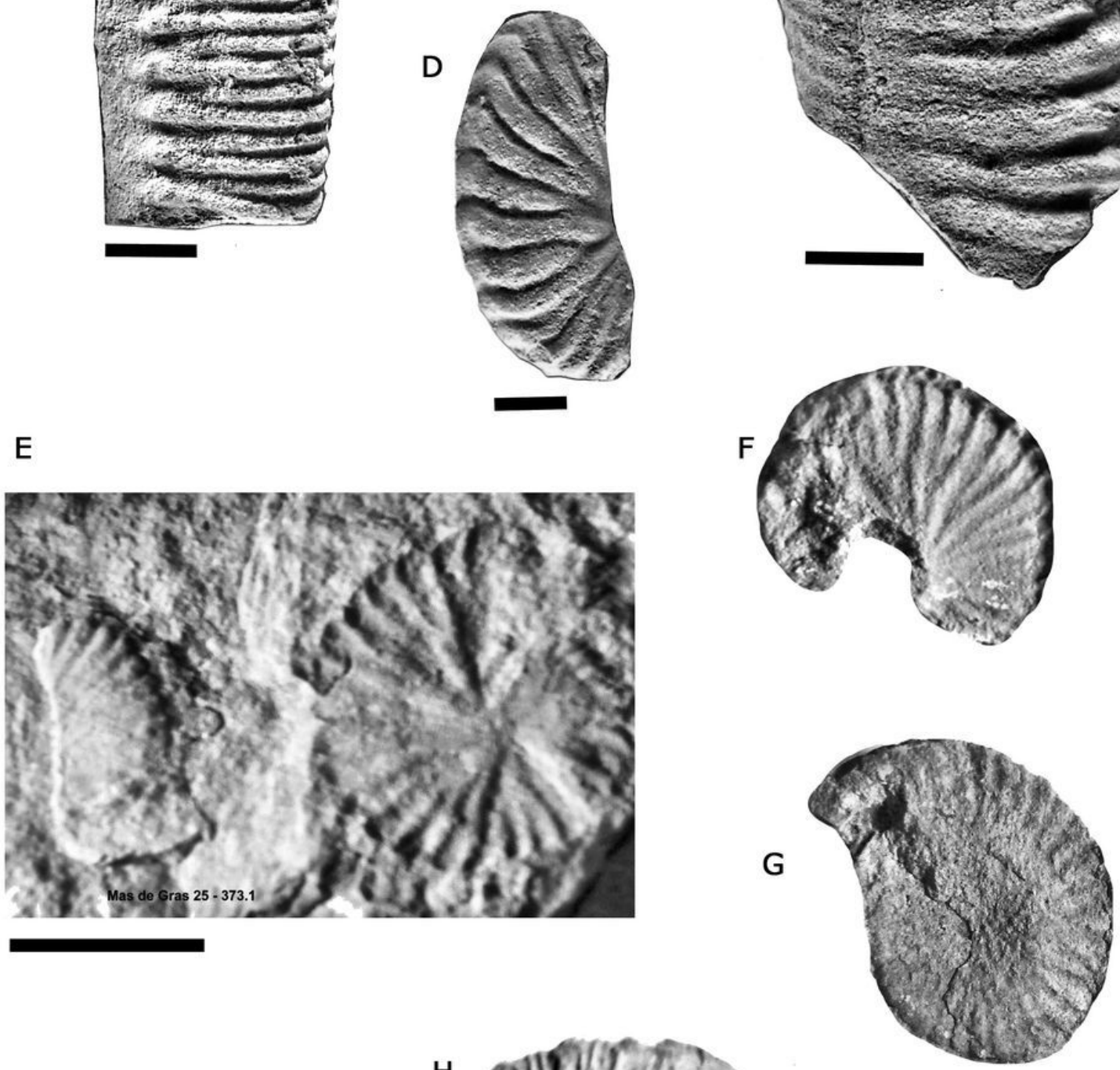

\section{scale \\ - $=5 \mathrm{~cm}$}

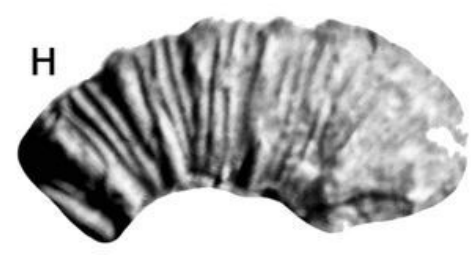

Plate 33: Ammonites of the Compressissima and Moutonianum zones at Mas de Gras. A) Dissimilites dissimilis (CLAVEL et al., 2007, PI. 1, fig. J), FSL 89719, bed 378; B) Nicklesia pulchella, FSL 89617, bed 382; C) Moutoniceras moutonianum (CLAVEL et al., 2007, PI. 1, fig. N), FSL 89718, bed 378; D) Nicklesia didayana (CLAVEL et al., 2007, PI. 1, fig. L), FSL 89705, bed 373; E) ? Kotetischvilia compressissima -RB- \{or Heinzia communis -DB-\}, FSL 89697, bed 373; F) Nicklesia didayana, FSL 89703b, bed 373; G) Kotetischvilia compressissima, FSL 89703, bed 373; H) ? Holcodiscus caillaudianus -RB- \{or Amohaldites aff. camelinus (ORBIGNY, 1849) -DB-\}, FSL 89677, bed 375. All scale bars $=5 \mathrm{~cm}$. 


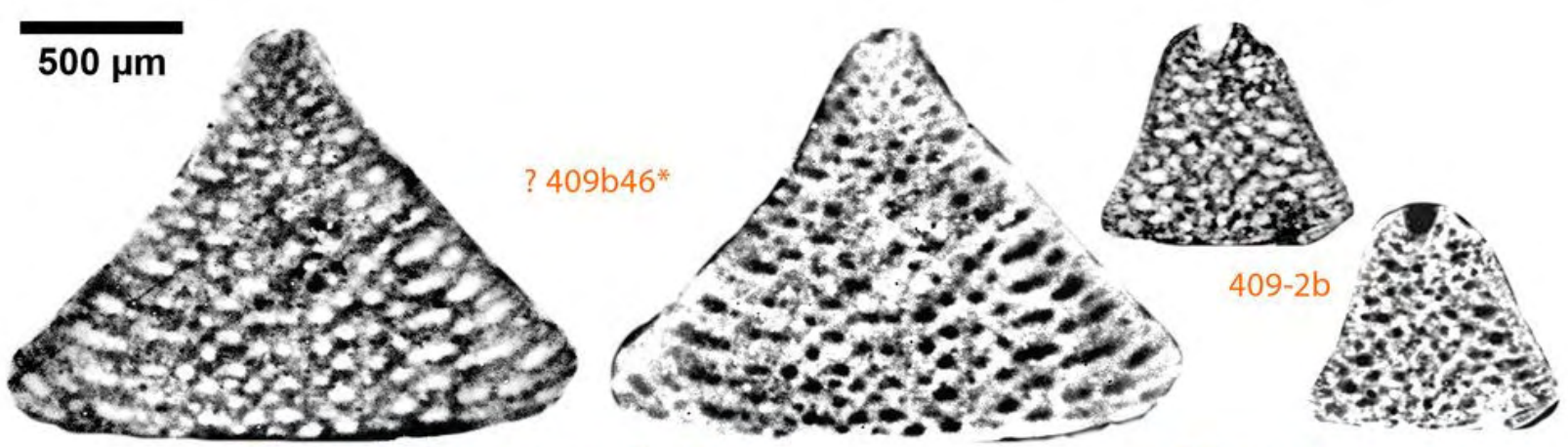

Valserina gr. broennimanni/turbinata

Valserina broennimanni

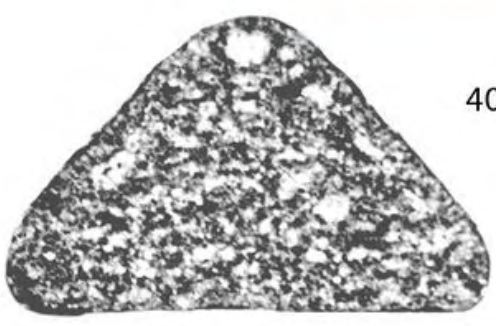

409-1a
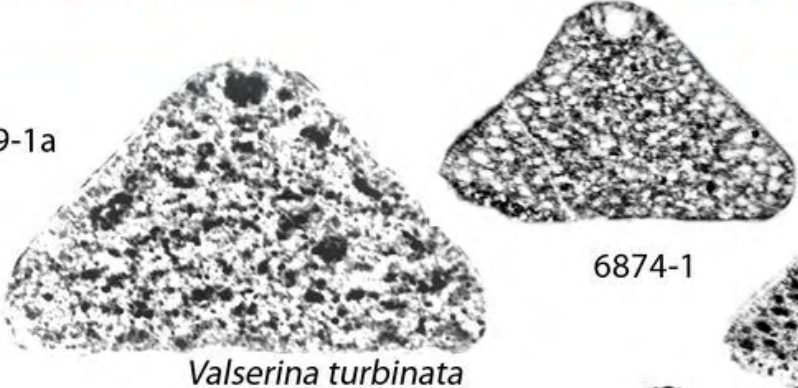

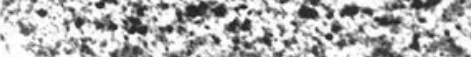

6874-1

Valserina turbinata
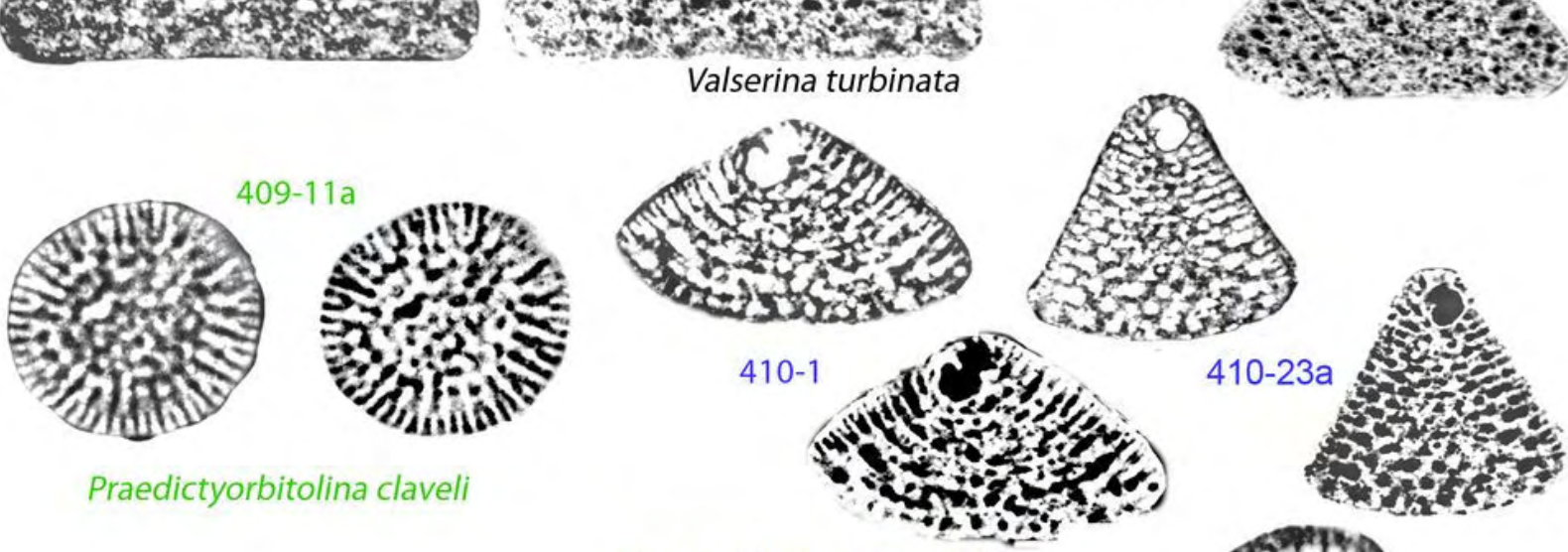

Praedictyorbitolina claveli
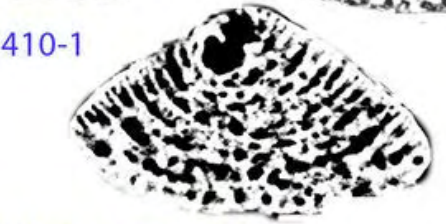<smiles></smiles>

Eopalorbitolina charollaisi
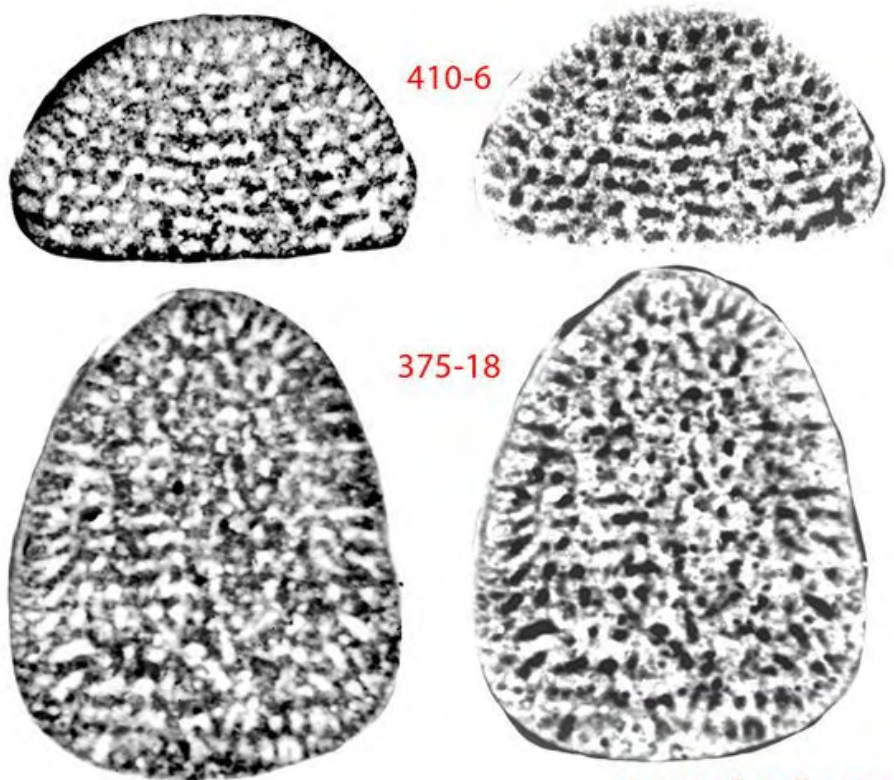

Dictyorbitolina carthusiana

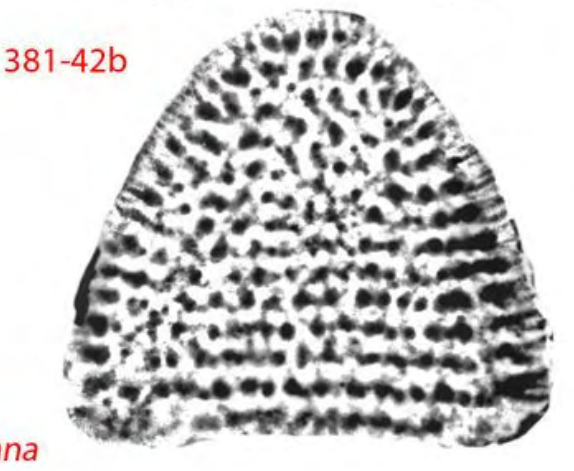

Plate 34: Orbitolinids of the Pulchella Zone at Mas de Gras. Dictyorbitolina carthusiana: 375-18, 381-42b, 410-6; Eopalorbitolina charollaisi: 410-1 (CLAVEL et al., 2007, PI. 4, fig. F), 410-23a; Praedictyorbitolina claveli: 409-11a; Valserina broennimanni: 409-2b; Valserina gr. broennimanni/turbinata: ? 409b46* [NF]; Valserina turbinata: 409$1 \mathrm{a}, 6874-1$. Scale bar $=500 \mu \mathrm{m}$. 


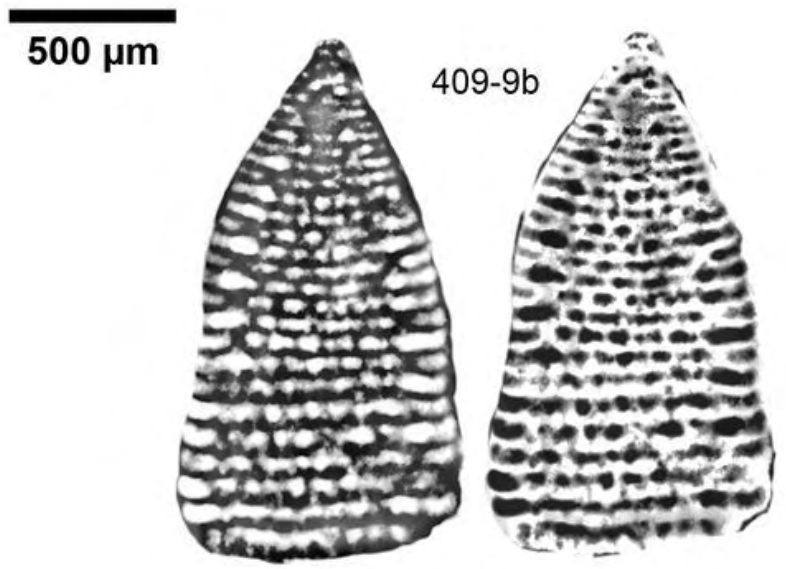

Paracoskinolina hispanica
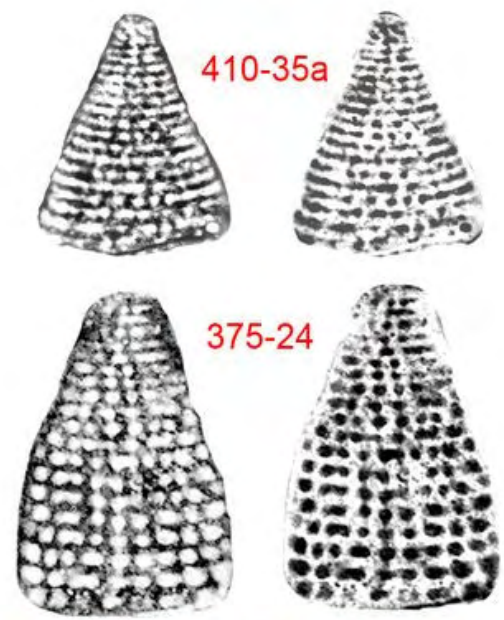

Paracoskinolina aff. sunnilandensis

$375-26$

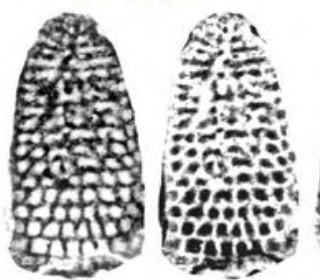

$375-24$
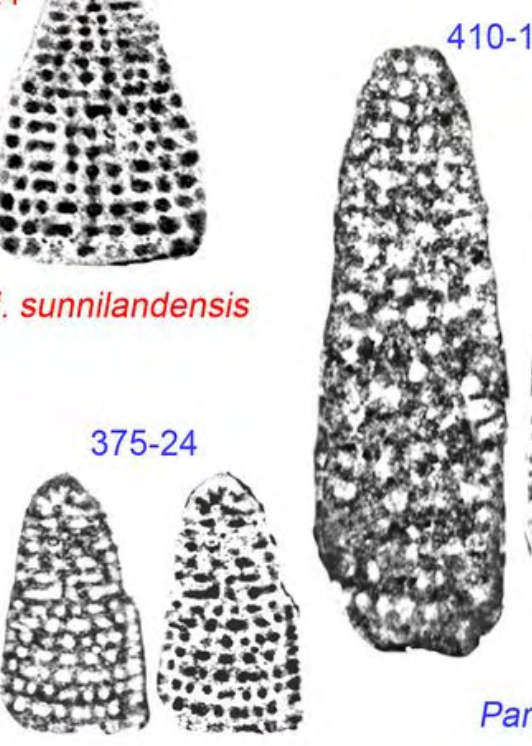

Paracoskinolina maynci
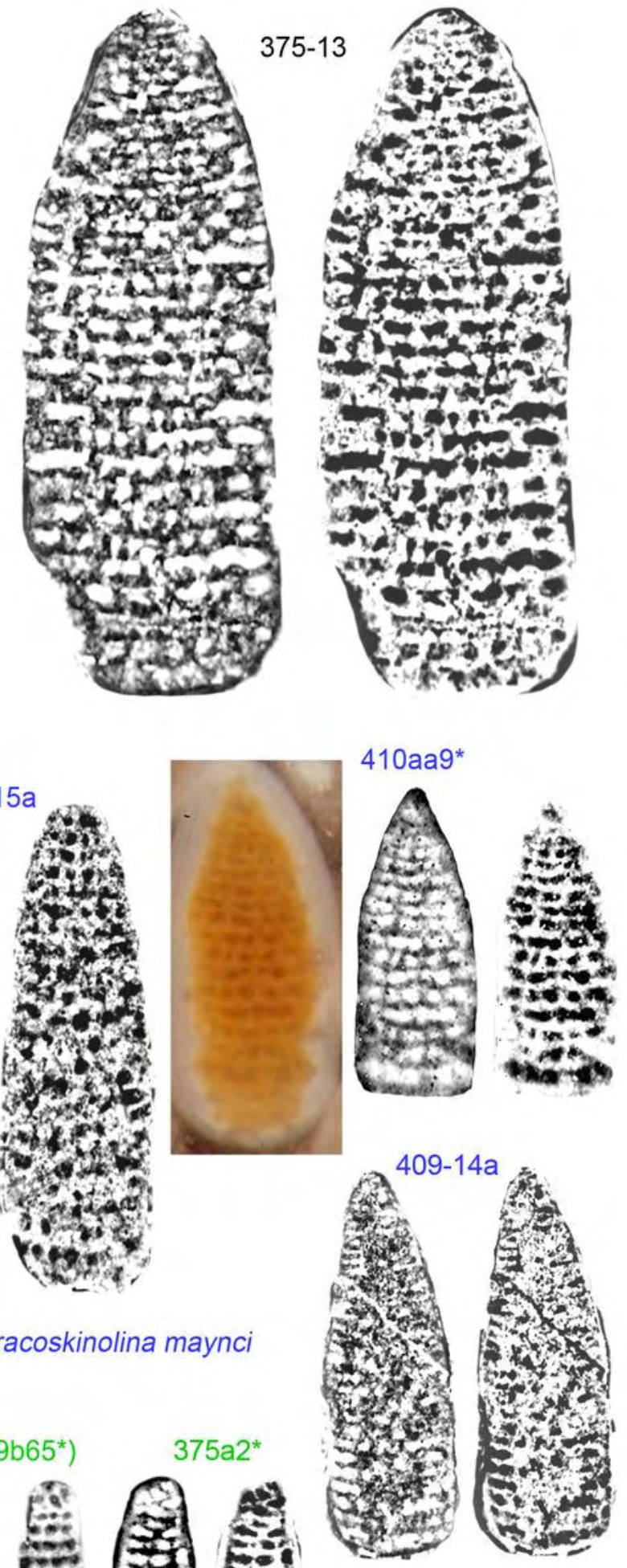
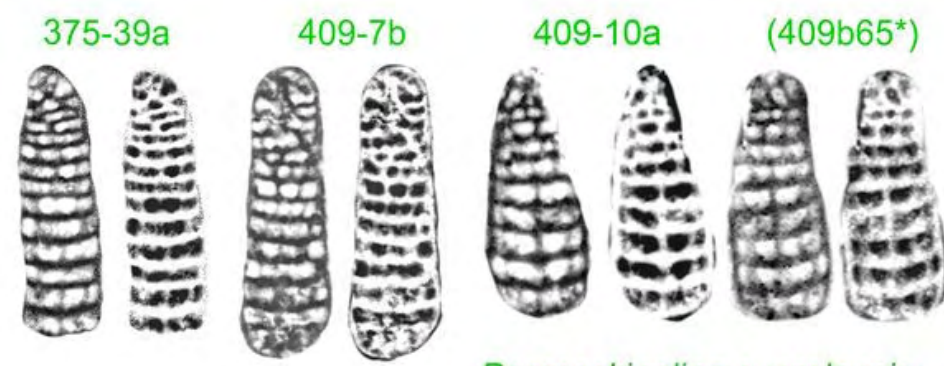

Paracoskinolina querolensis

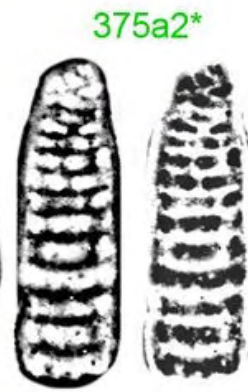

Plate 35: Orbitolinids of the Pulchella Zone at Mas de Gras. Paracoskinolina hispanica: 375-13, 409-9b; Paracoskinolina maynci: 375-24, 375-26, 409-14a, 410aa9*, 410-15a; Paracoskinolina querolensis: 375-39a, 375a2*, 4097b, 409-10a (409b65*); Paracoskinolina aff. sunnilandensis: 375-24, 410-35a. Scale bar $=500 \mu \mathrm{m}$. 


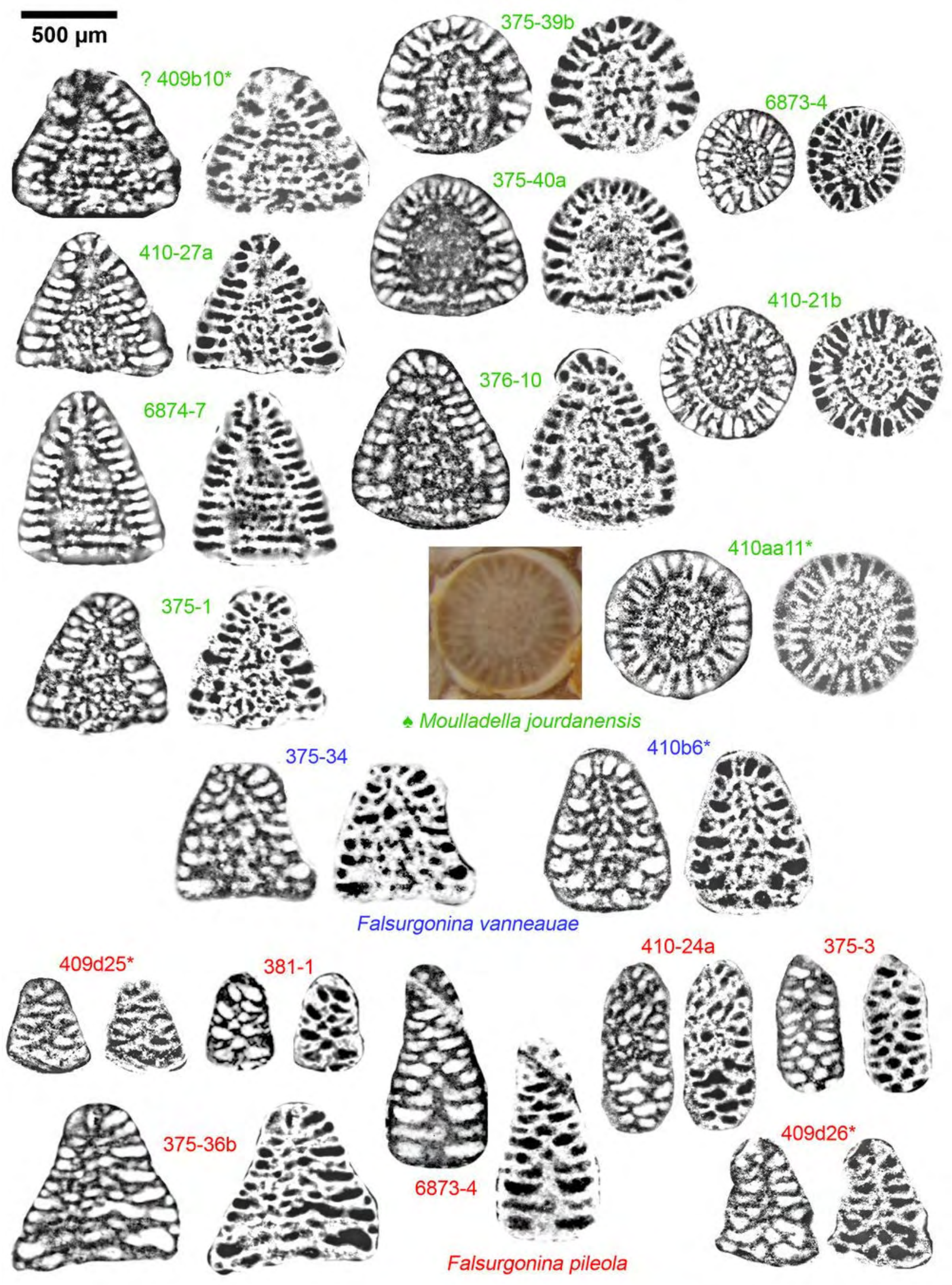

Plate 36: Moulladella and orbitolinids of the Pulchella Zone at Mas de Gras. Moulladella jourdanensis: 375-1, 37539b, 375-40a, 376-10, ? 409b10* [NF], 410-21b, 410-27a, 410aa11*, 6873-4, 6874-7; Falsurgonina pileola: 375-3, 375-36b, 381-1, 409d25*, 409d26*, 410-24a, 6873-4; Falsurgonina vanneauae: 375-34, 410b6*. Scale bar $=500 \mu \mathrm{m}$. 

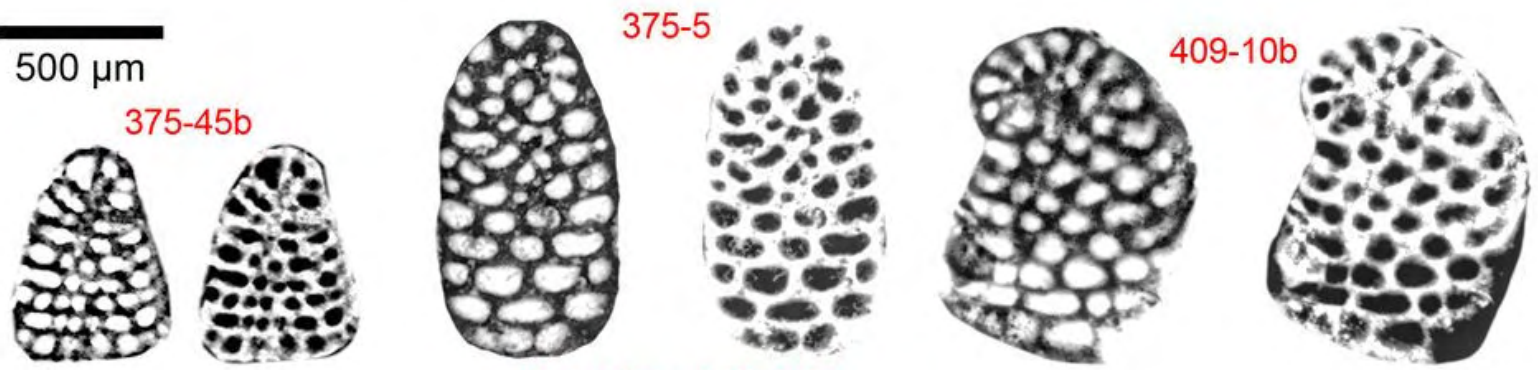

Urgonina alpillensis
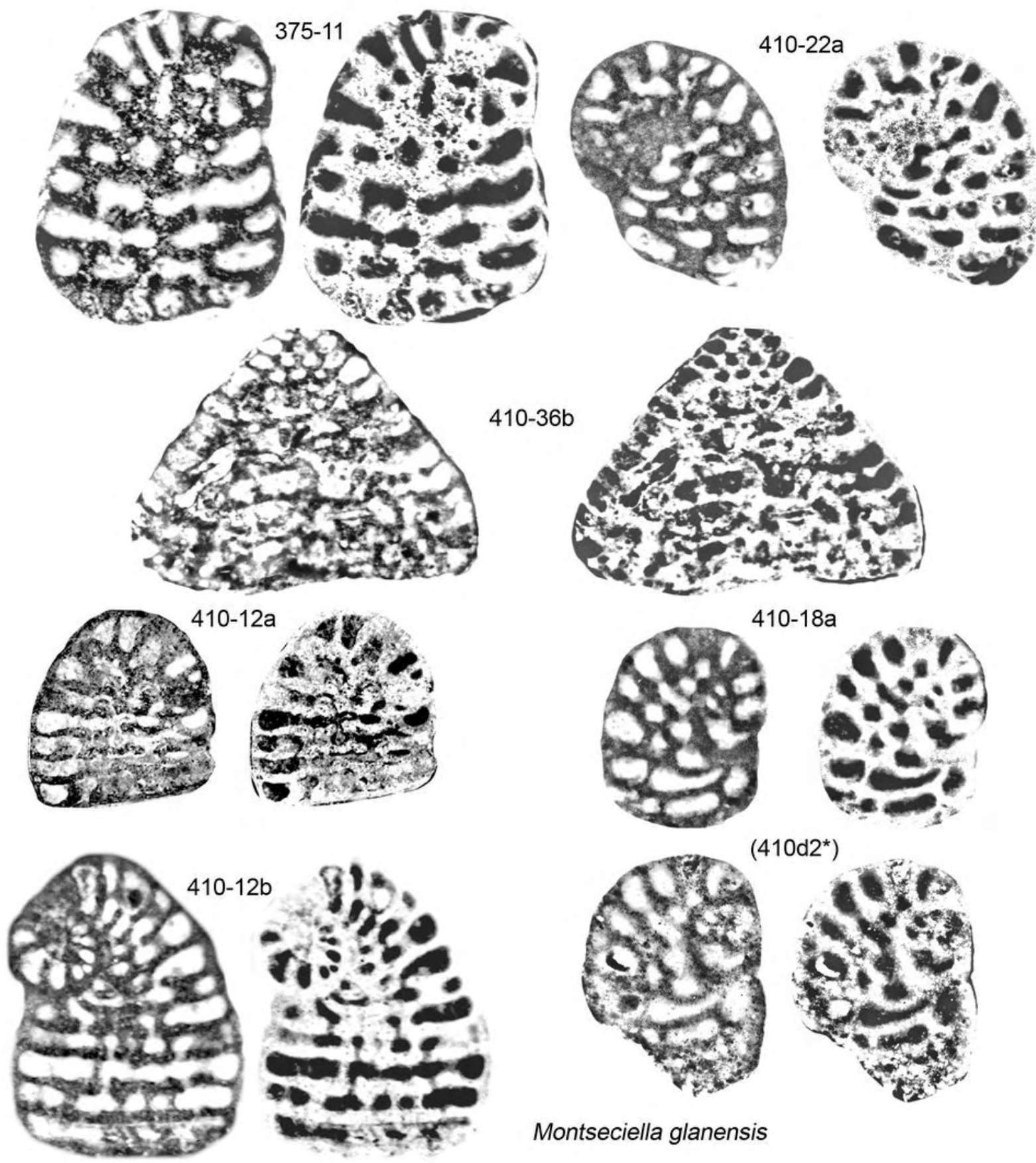

Plate 37: Orbitolinids of the Pulchella Zone at Mas de Gras. Montseciella glanensis: 375-11, 410-12a, 410-12b, 41018a, 410-22a, 410-36b (410d2*); Urgonina alpillensis: 375-5, 375-45b, 409-10b. Scale bar $=500 \mu \mathrm{m}$. 


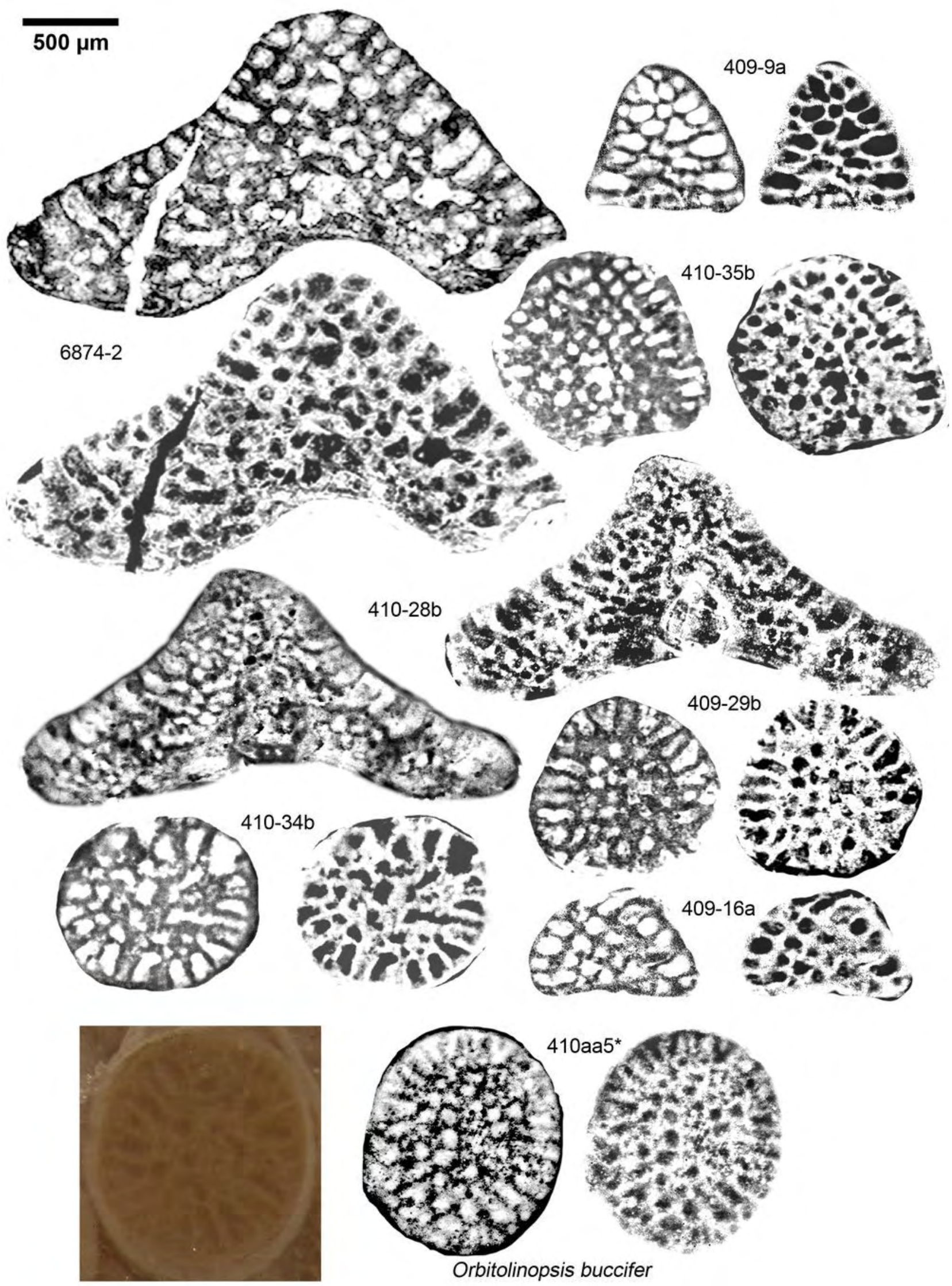

Plate 38: Orbitolinids of the Pulchella Zone at Mas de Gras. Orbitolinopsis buccifer : 409-9a, 409-16a, 409-29b, 410-28b, 410-34b, 410-35b, 410aa5*, 6874-2. Scale bar $=500 \mu \mathrm{m}$. 


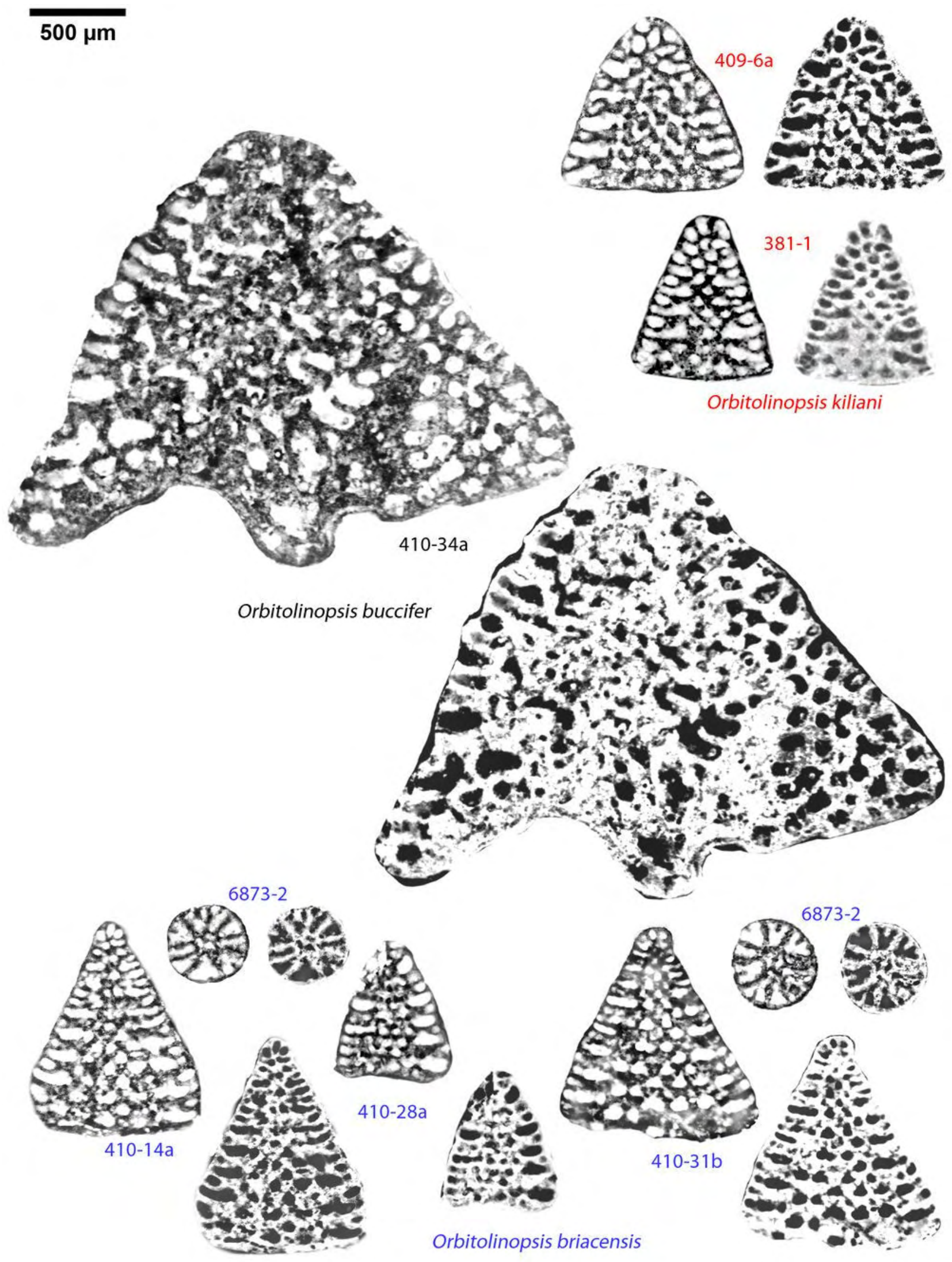

Plate 39: Orbitolinids of the Pulchella Zone at Mas de Gras. Orbitolinopsis briacensis: 410-14a, 410-28a, 410-31b, 6873-2; Orbitolinopsis buccifer: 410-34a; Orbitolinopsis kiliani: 381-1, 409-6a. Scale bar $=500 \mu \mathrm{m}$. 
$500 \mu \mathrm{m}$
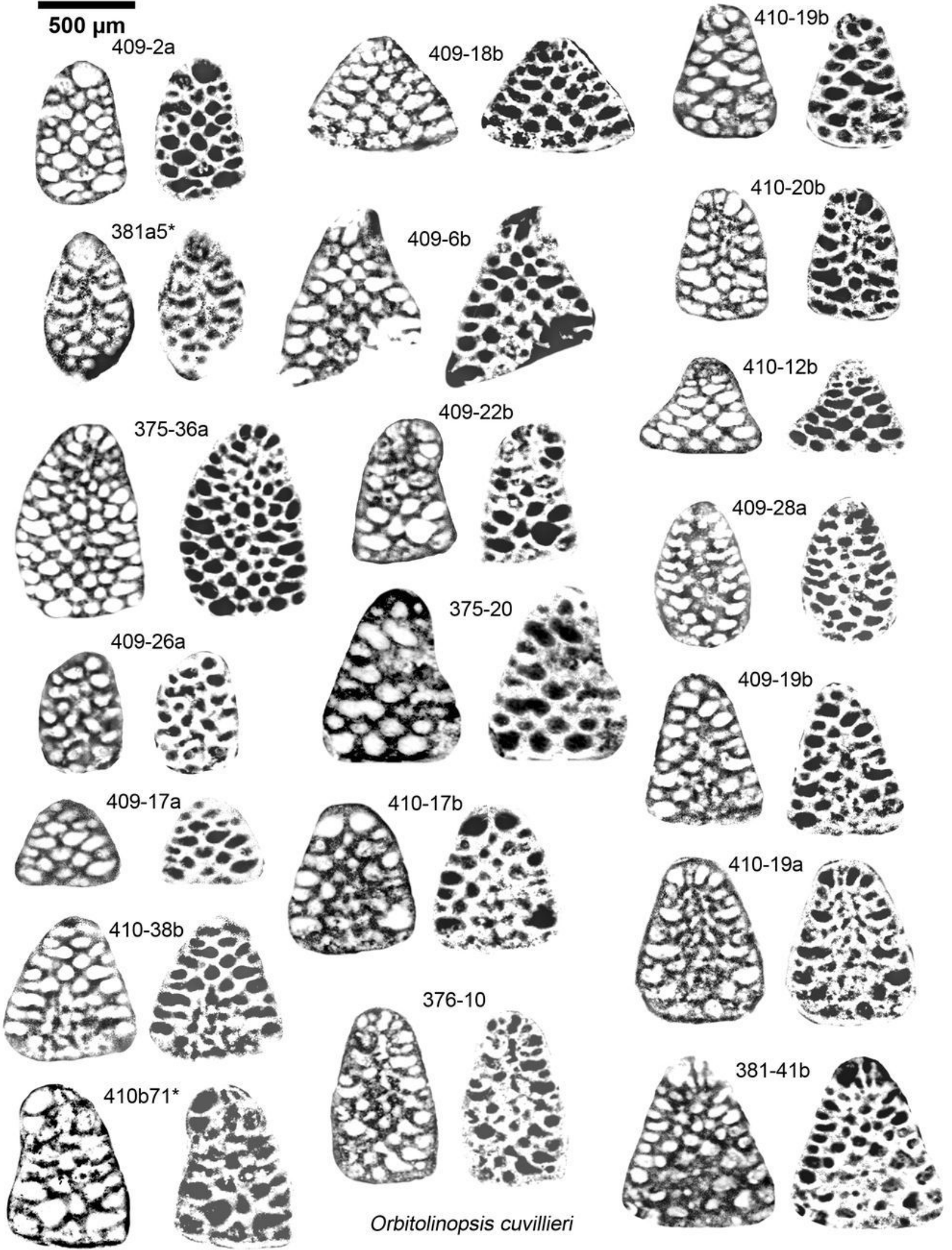

Plate 40: Orbitolinids of the Pulchella Zone at Mas de Gras. Orbitolinopsis cuvillieri : 375-20, 375-36a, 376-10, 381a5*, 381-41b, 409-2a, 409-6b, 409-17a, 409-18b, 409-19b, 409-22b, 409-26a, 409-28a, 410-12b, 410-17b, $410-19 a, 410-19 b, 410-20 b, 410-38 b, 410 b 71 *$. Scale bar $=500 \mu \mathrm{m}$. 

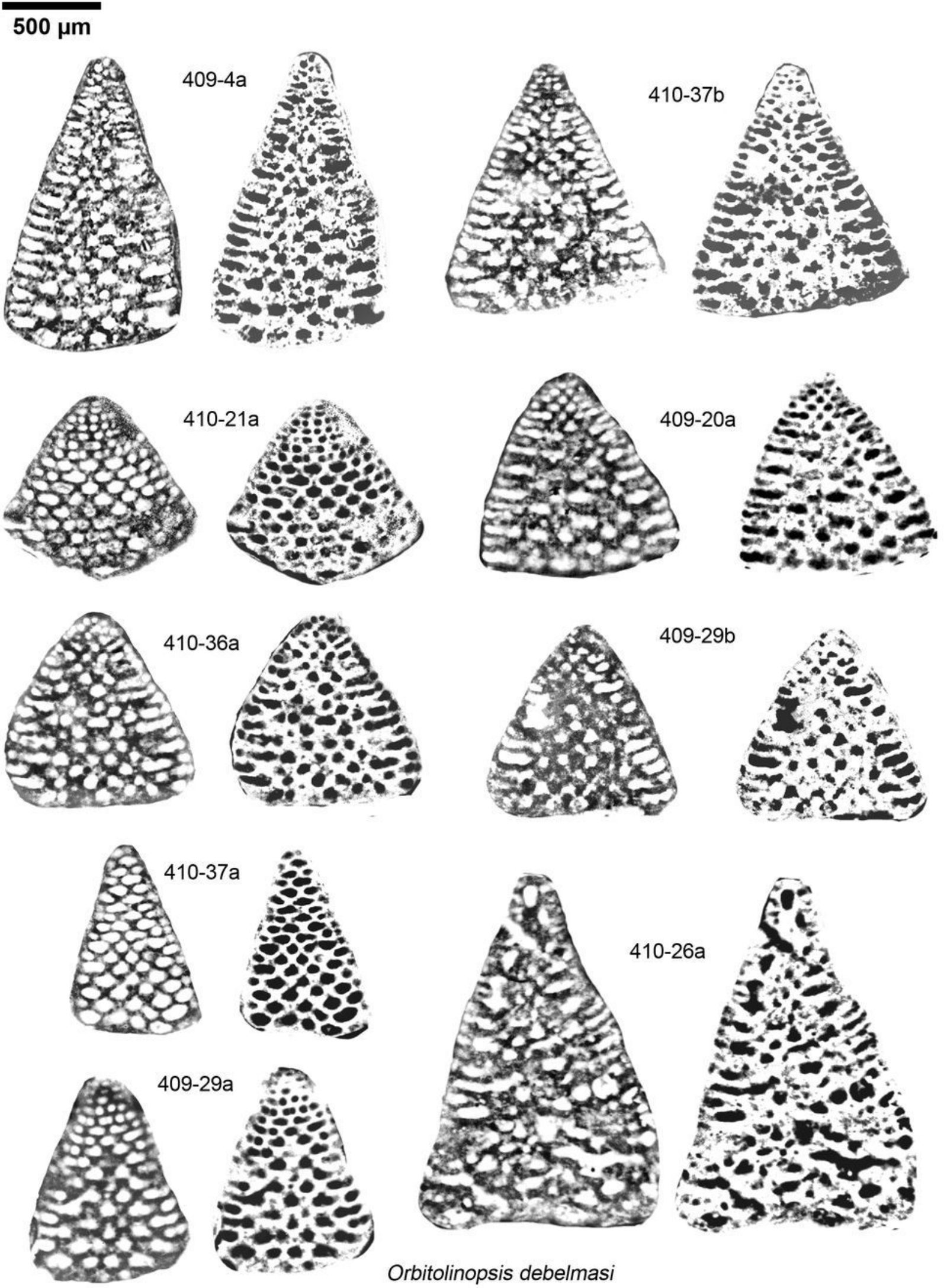

Orbitolinopsis debelmasi

Plate 41: Orbitolinids of the Pulchella Zone at Mas de Gras. Orbitolinopsis debelmasi : 409-4a, 409-20a, 409-29a, 409-29b, 410-21a, 410-26a, 410-36a, 410-37a, 410-37b. Scale bar $=500 \mu \mathrm{m}$. 

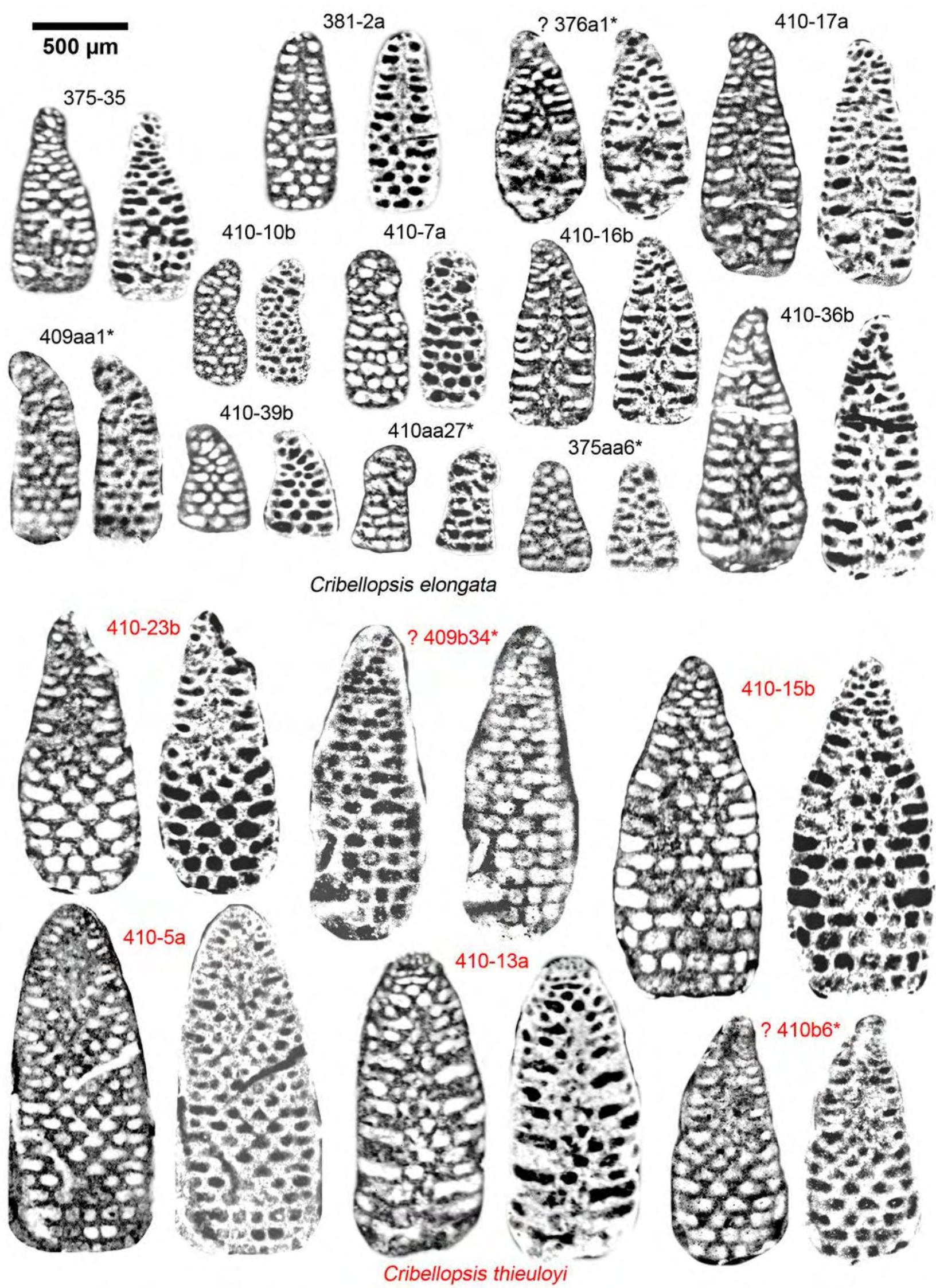

Plate 42: Orbitolinids of the Pulchella Zone at Mas de Gras. Cribellopsis elongata: 375aa6*, 375-35, ? 376a1* [NF], 381-2, 409aa1*, 410-7a, 410-10b, 410-16b, 410-17a, 410-36b, 410-39b, 410aa27*; Cribellopsis thieuloyi: ? 409b34* [NF], 410-5a, 410-13a, 410-15b, 410-23b, ? 410b6* [NF]. Scale bar $=500 \mu \mathrm{m}$. 


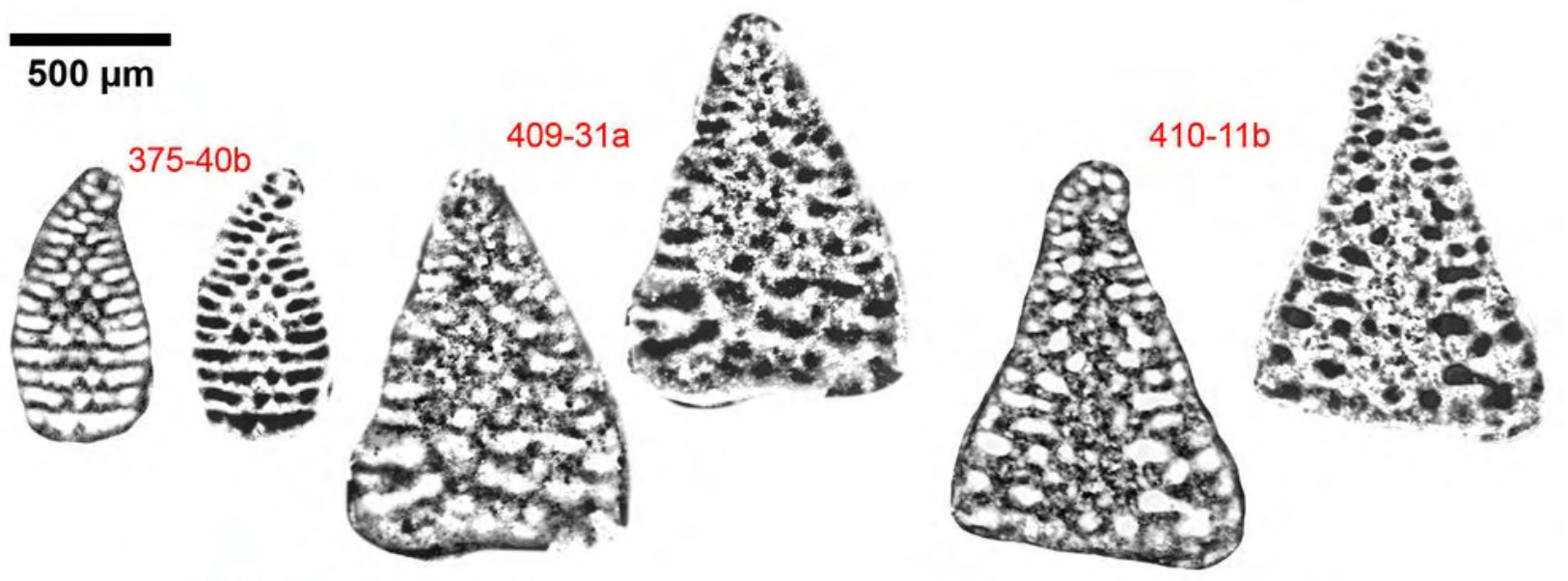

Cribellopsis neoelongata
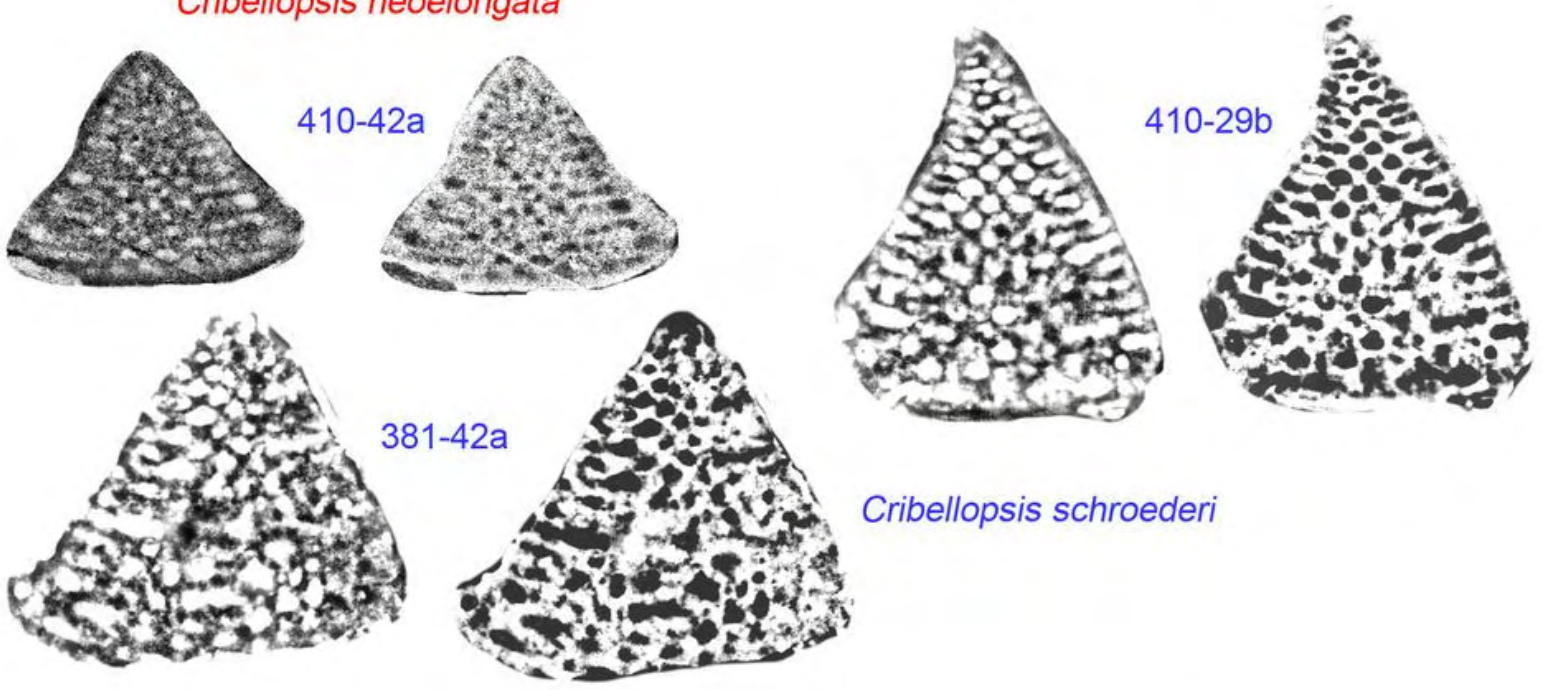

Cribellopsis schroederi
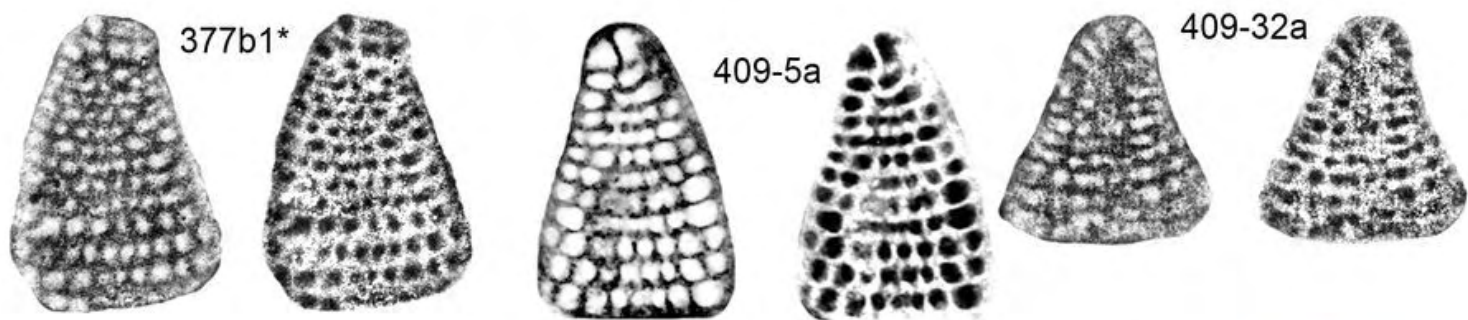

Paracoskinolina? praereicheli
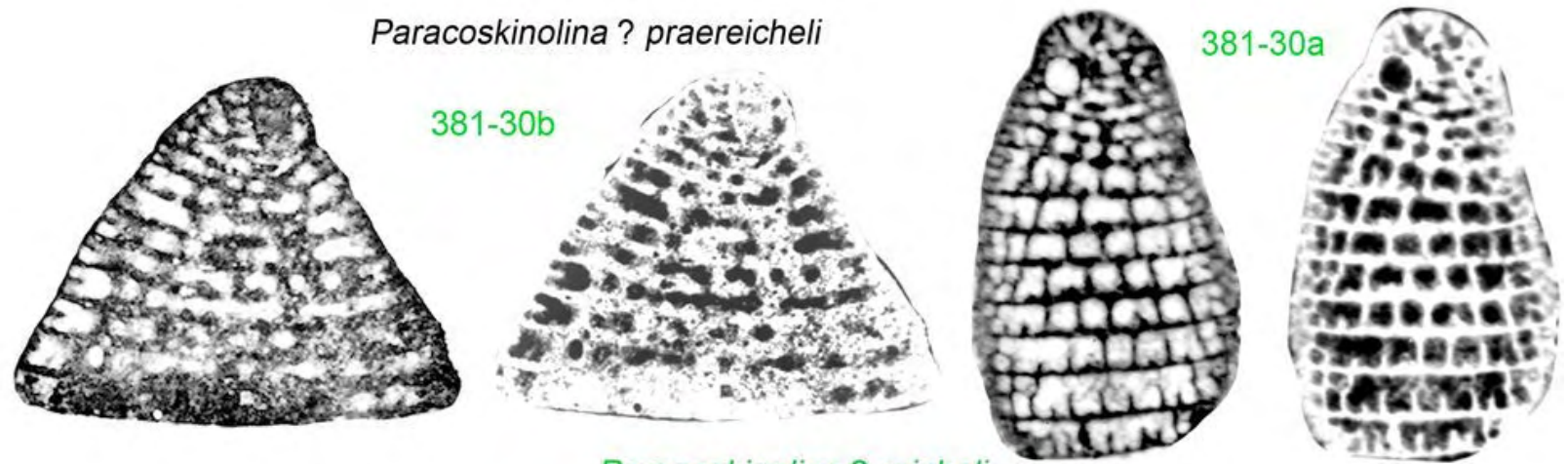

Plate 43: Orbitolinids of the Pulchella Zone at Mas de Gras. Cribellopsis neoelongata: 375-40b, 409-31a, 410-11b; Cribellopsis schroederi: 381-42a, 410-29b, 410-42a; Paracoskinolina ? praereicheli: 377b1*, 409-5a, 409-32a; Paracoskinolina ? reicheli: 381-30a, 381-30b. Note that PI. 43, fig. 381-30a is duplicated from CLAVEL et al. (2007, PI. 5, fig. L) and fig. 381-30b from Clavel et al. (2007, PI. 5, fig. K) as "Dictyoconus ? reicheli Guillaume". Scale bar $=500 \mu \mathrm{m}$. 

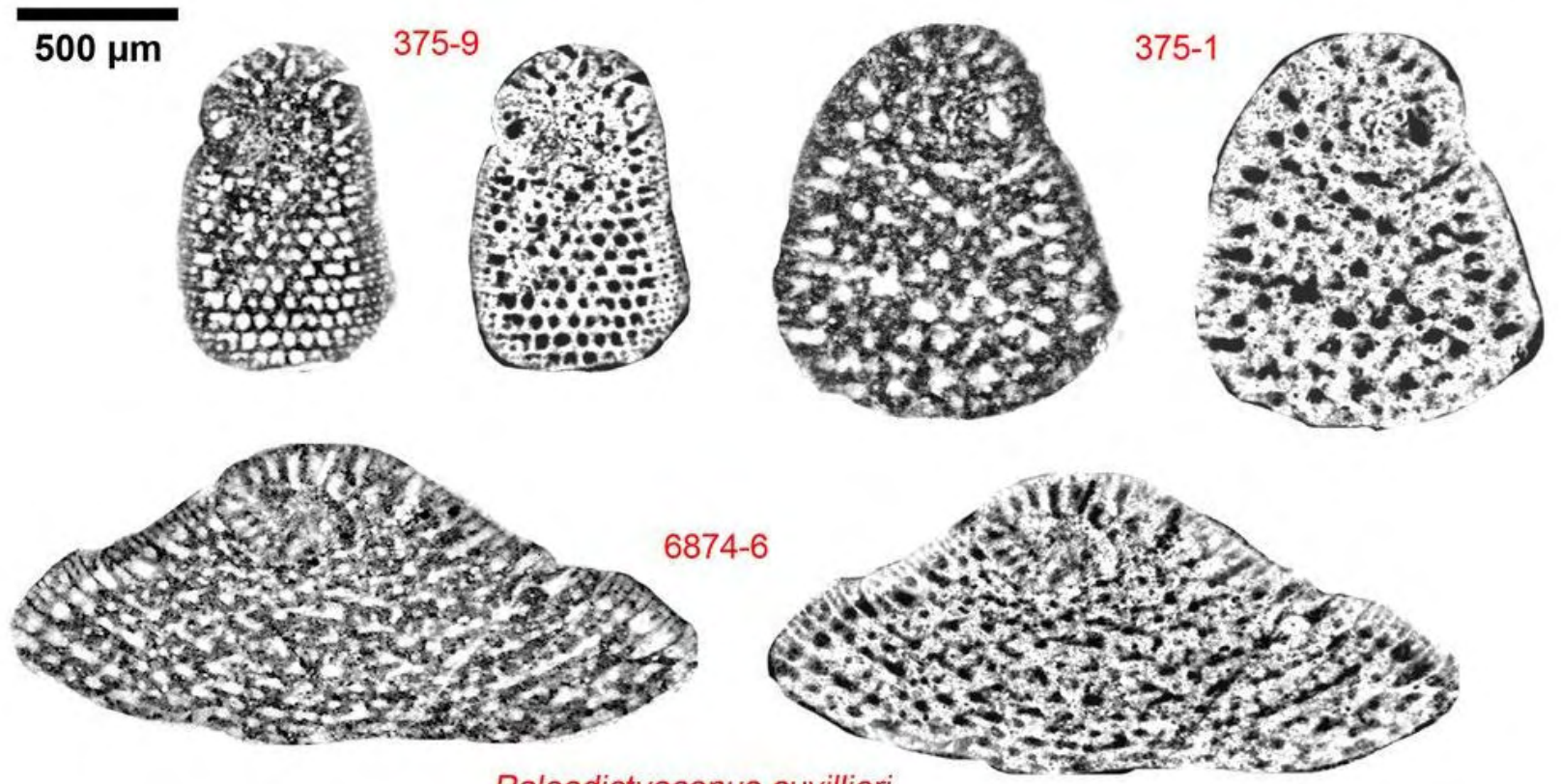

Paleodictyoconus cuvillieri
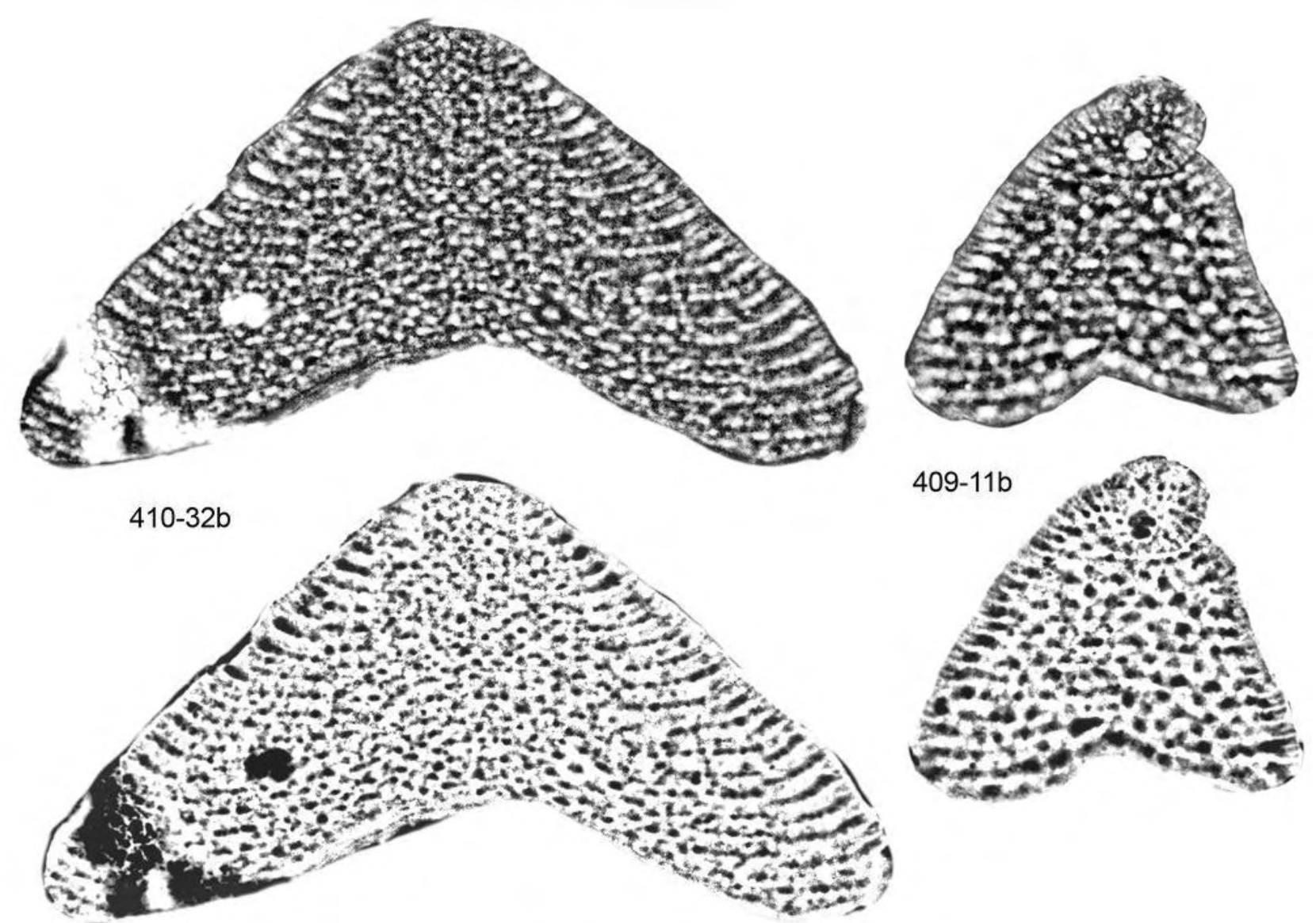

Paleodictyoconus actinostoma

Plate 44: Orbitolinids of the Pulchella Zone at Mas de Gras. Paleodictyoconus actinostoma: 409-11b, 410-32b; Paleodictyoconus cuvillieri : 375-1, 375-9, 6874-6. Scale bar $=500 \mu \mathrm{m}$. 


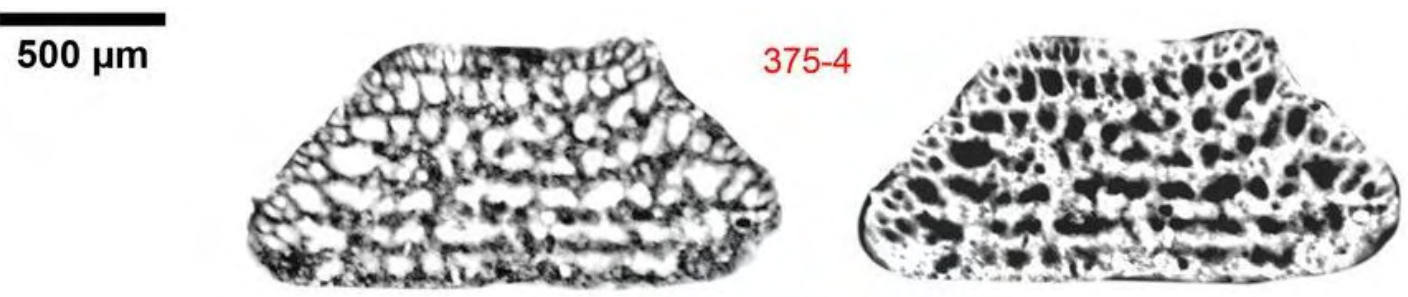

Montseciella alguerensis
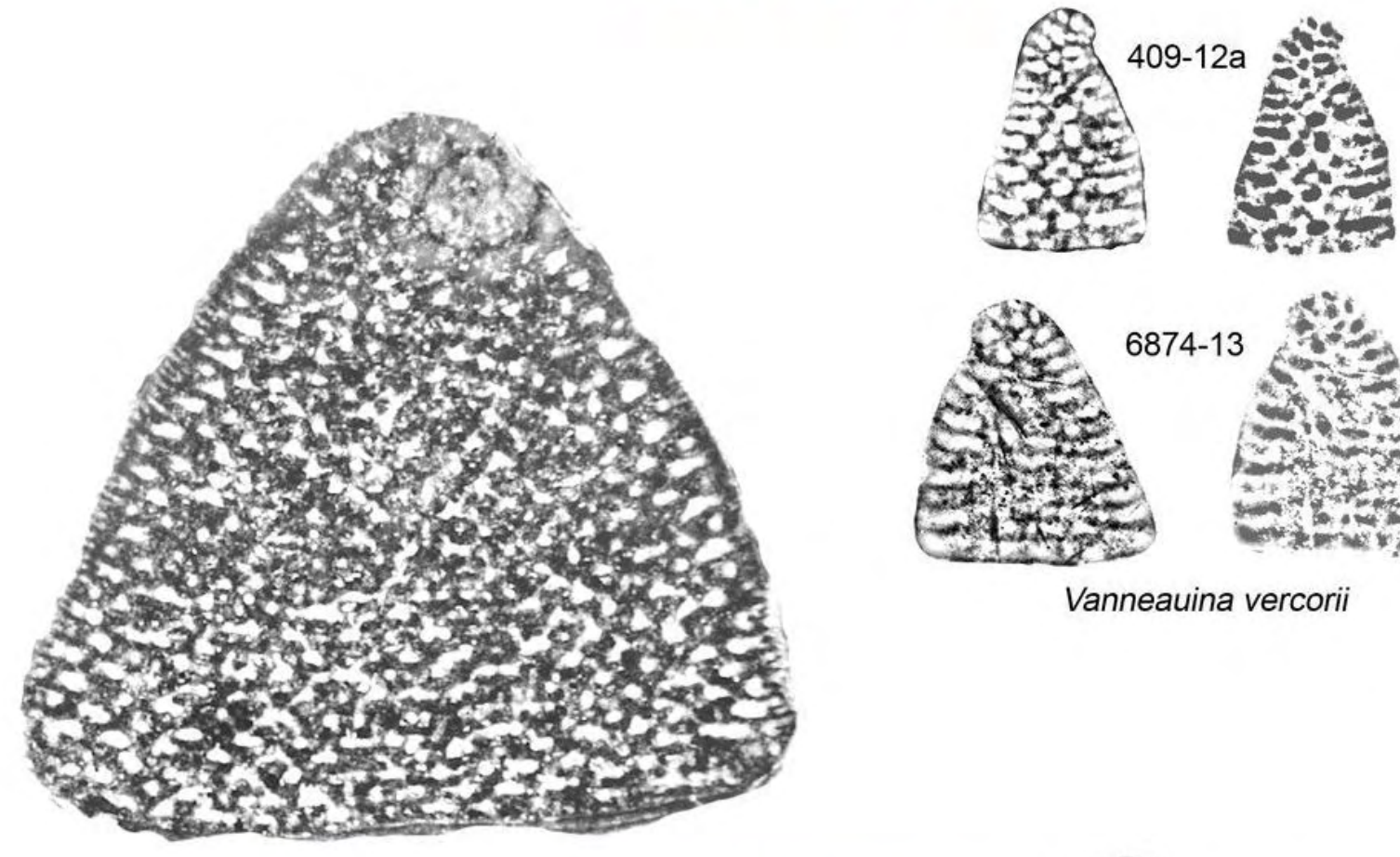

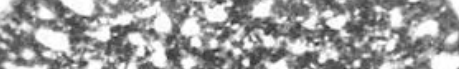

S12.0.

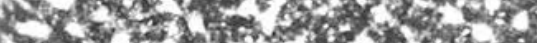

3. $x$.

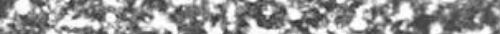

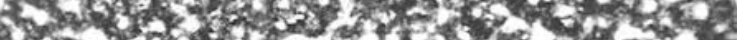

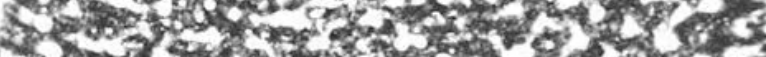

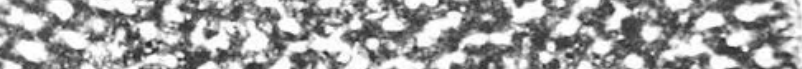

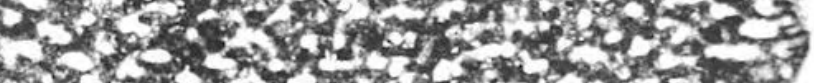

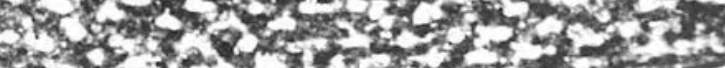

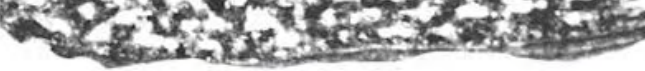

$376-12$

Paleodictyoconus cuvillieri
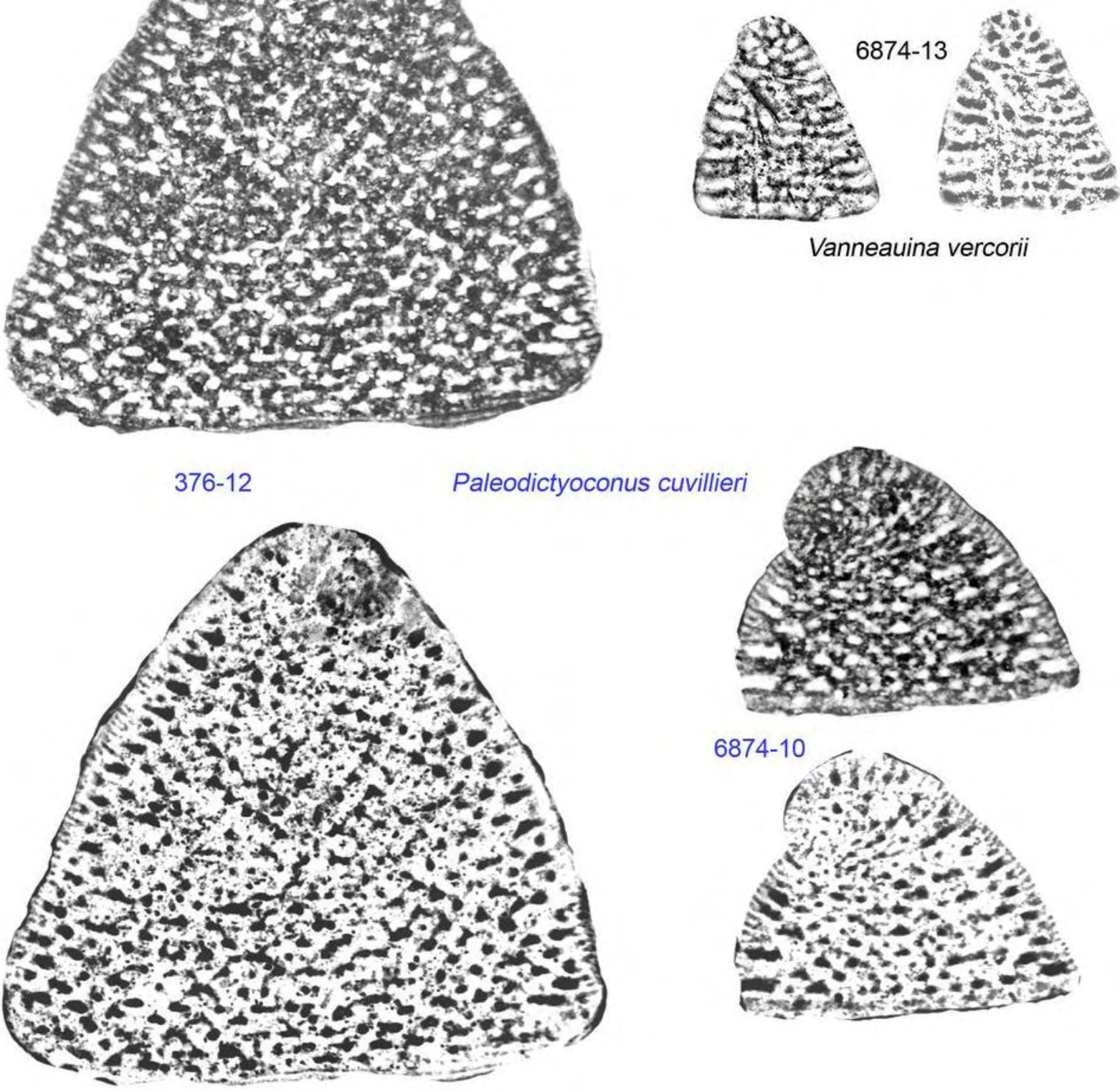

Vanneauina vercorii

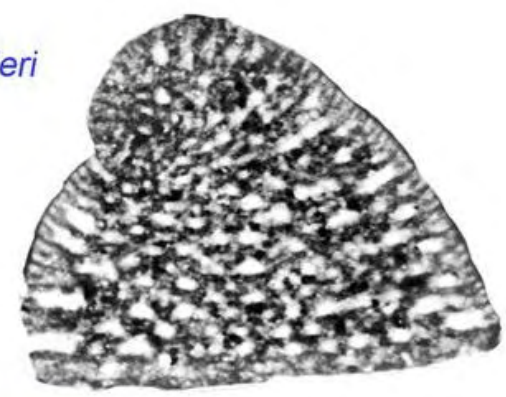

$6874-10$

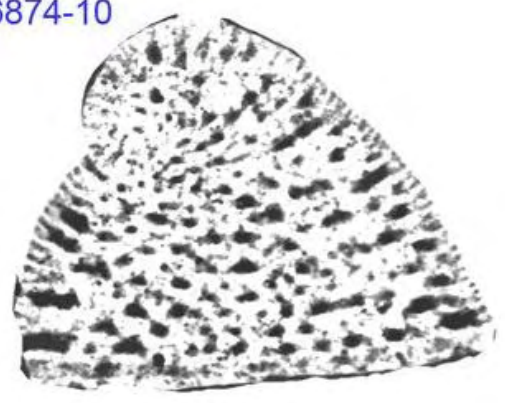

Plate 45: Orbitolinids of the Pulchella Zone at Mas de Gras. Montseciella alguerensis : 375-4; Paleodictyoconus cuvillieri: 376-12, 6874-10; Vanneauina vercorii: 409-12a, 6874-13. Scale bar $=500 \mu \mathrm{m}$. 

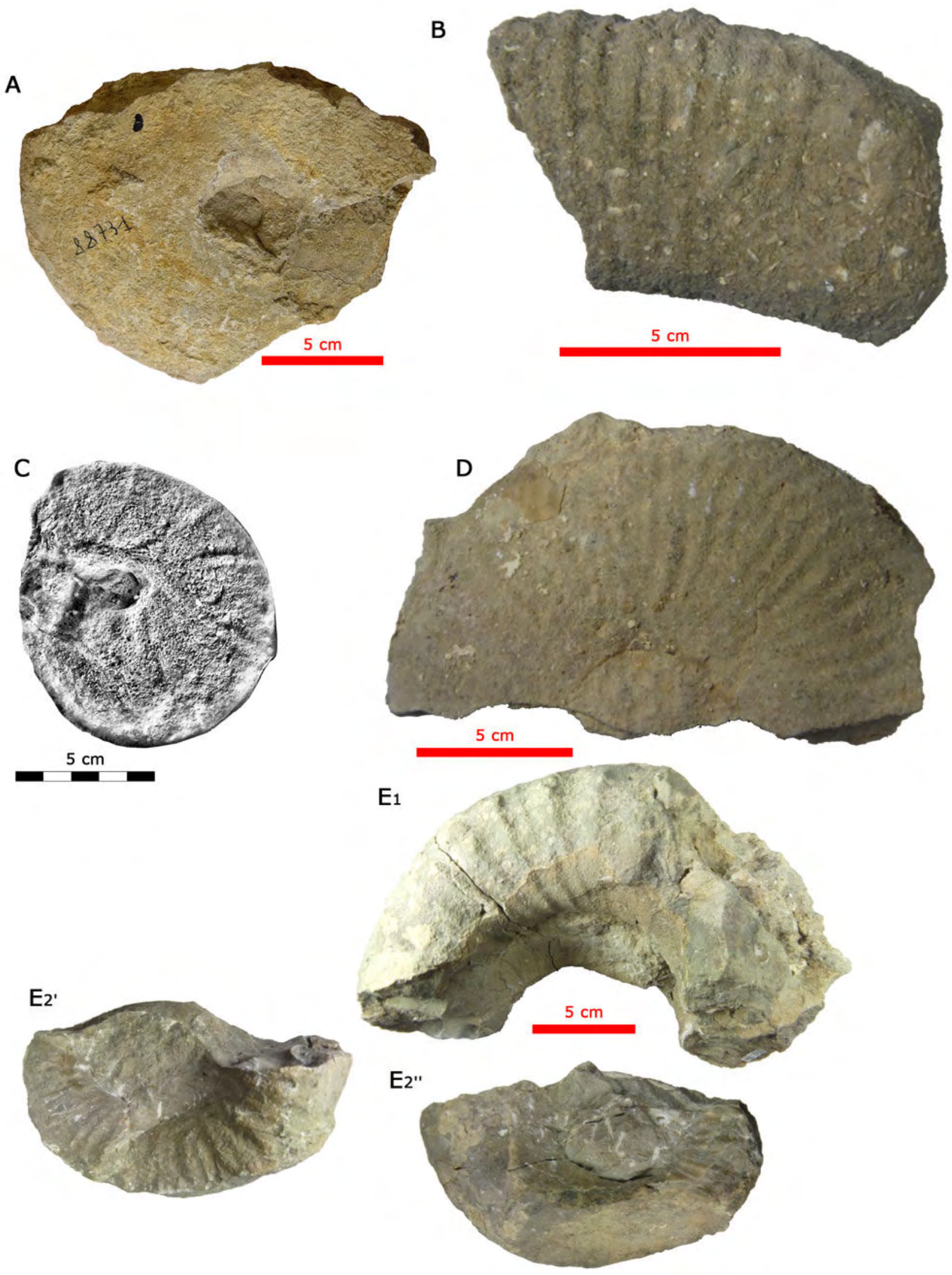

Plate 46: Ammonites of the Pulchella and Compressissima zones at La Montagnette. A) Torcapella cf. suessiformis, FSL 88731; B) Moutoniceras gr. nodosum, UJF-ID 10568 (c) OSUG (ARNAUD et al., 1998: PI. 2, fig. 3); C) Nikolovites gr. charrierianus, FSL 88827; D) Torcapella fabrei, UJF-ID 10566 (c) OSUG (ARNAUD et al., 1998: PI. 2, fig. 1); E1, E2', E2") Paraspiticeras (Paraspiticeras) guerinianum, UJF-ID 10569 (c) OSUG (ARNAUD et al., 1998: PI. 2, fig. 4). All scale bars $=5 \mathrm{~cm}$ 


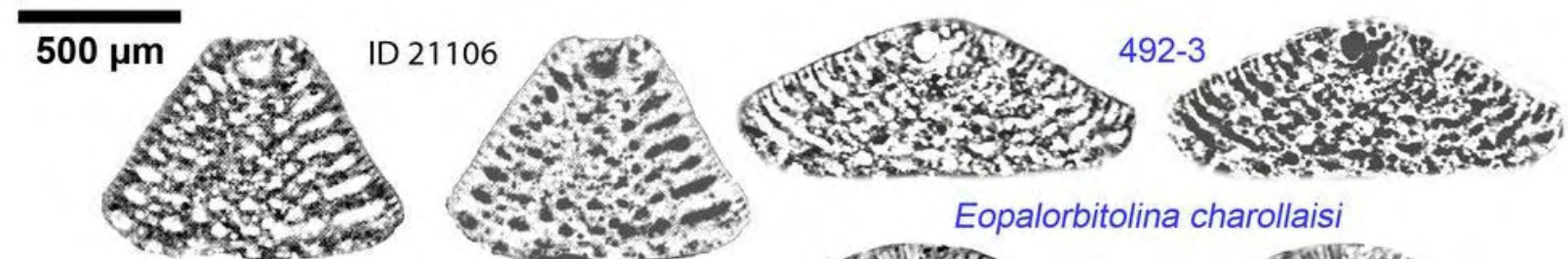

? Valserina turbinata
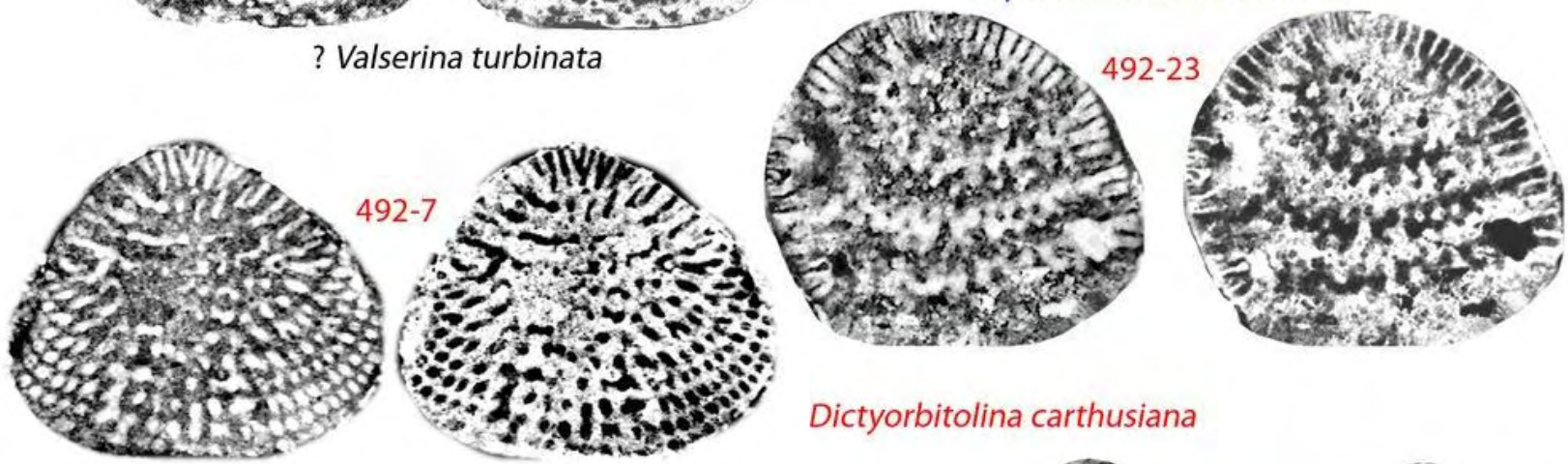

Dictyorbitolina carthusiana

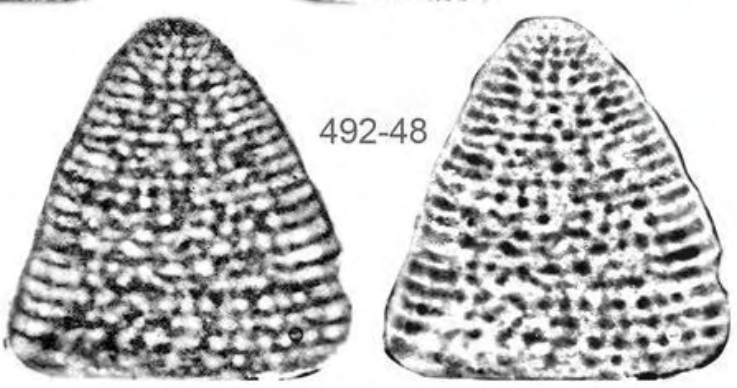

Paracoskinolina
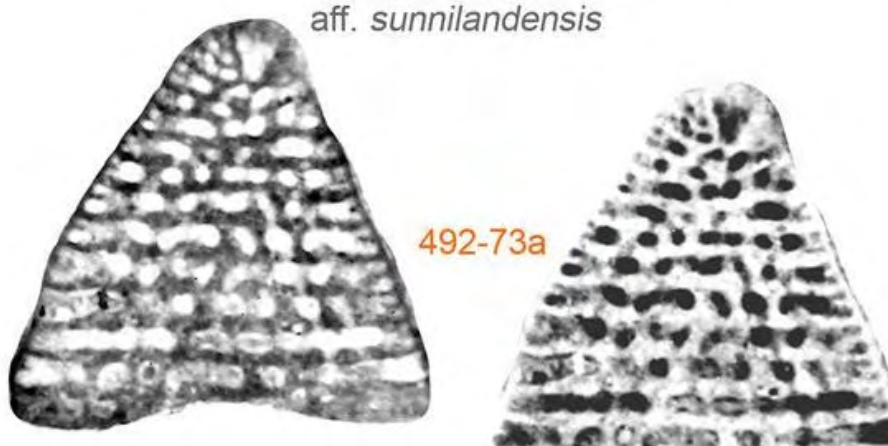

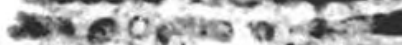

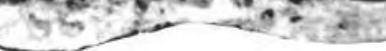

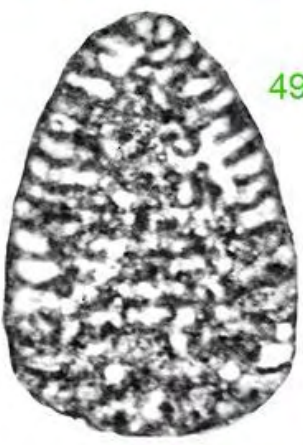

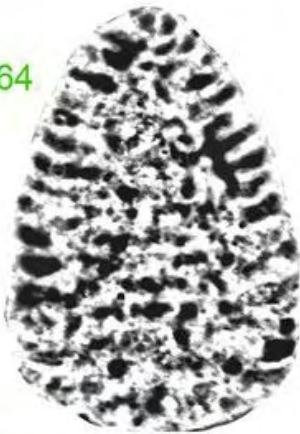

¿ Moulladella jourdanensis

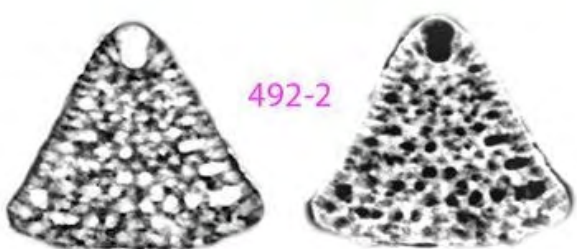

Valserina broennimanni
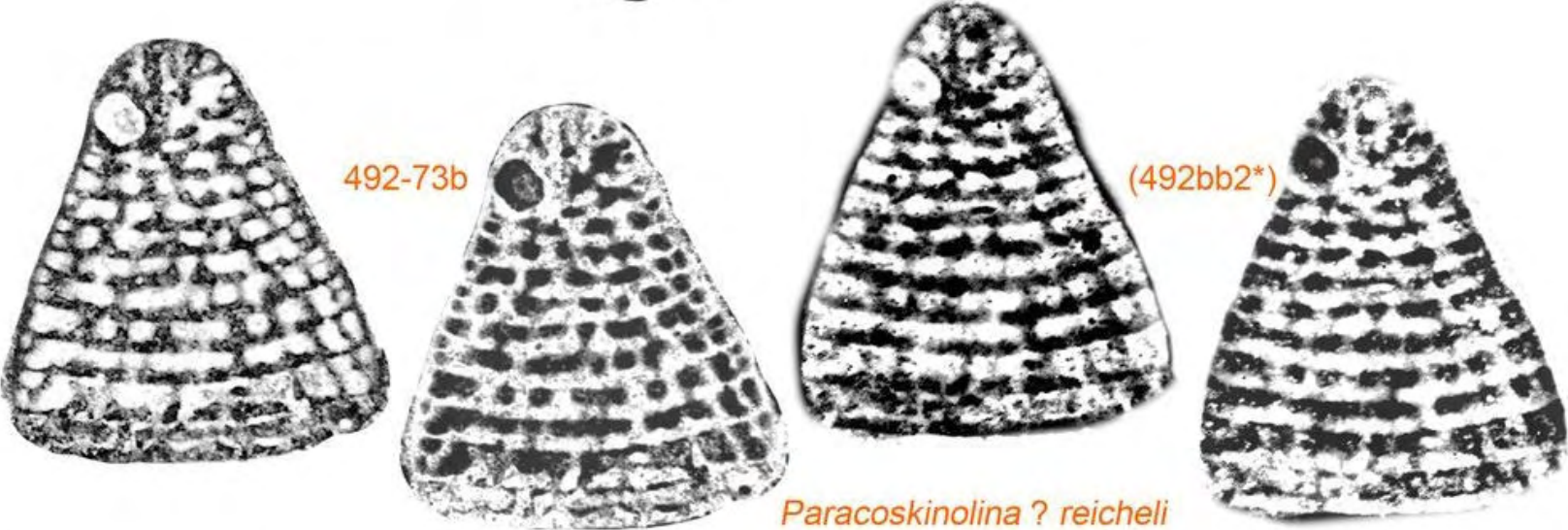

Plate 47: Moulladella and orbitolinids of the Pulchella Zone at La Montagnette. Moulladella jourdanensis : 492-64; Dictyorbitolina carthusiana: 492-7, 492-23; Eopalorbitolina charollaisi: 492-3; Paracoskinolina ? reicheli: 492-73a, 492-73b (492bb2*); Paracoskinolina aff. sunnilandensis: 492-48; Valserina broennimanni: 492-2; Valserina turbinata: ID 21106. Note that PI. 46, fig. ID 21106 is duplicated from ARNAUD-VANNEAU (1980, PI. 105, fig. 5) as "Alpillina antiqua". Note that the blured photomicrograph $492 \mathrm{bb} 2$ from the polished plug, which was used to make the thin section 492-73b, looks very similar to a Paracoskinolina ? praereicheli. Scale bar $=500 \mu \mathrm{m}$. 

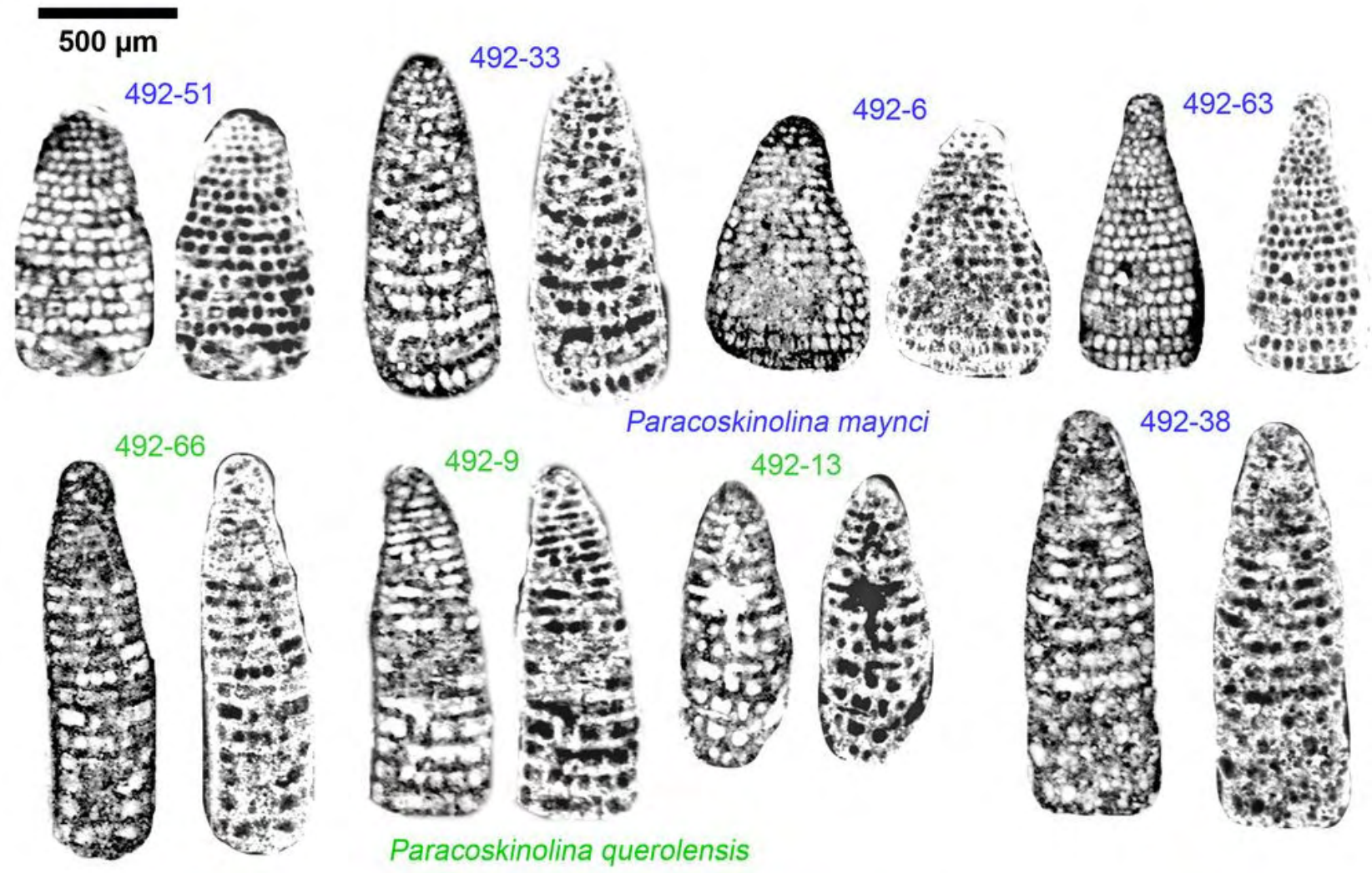

Paracoskinolina maynci

Paracoskinolina querolensis
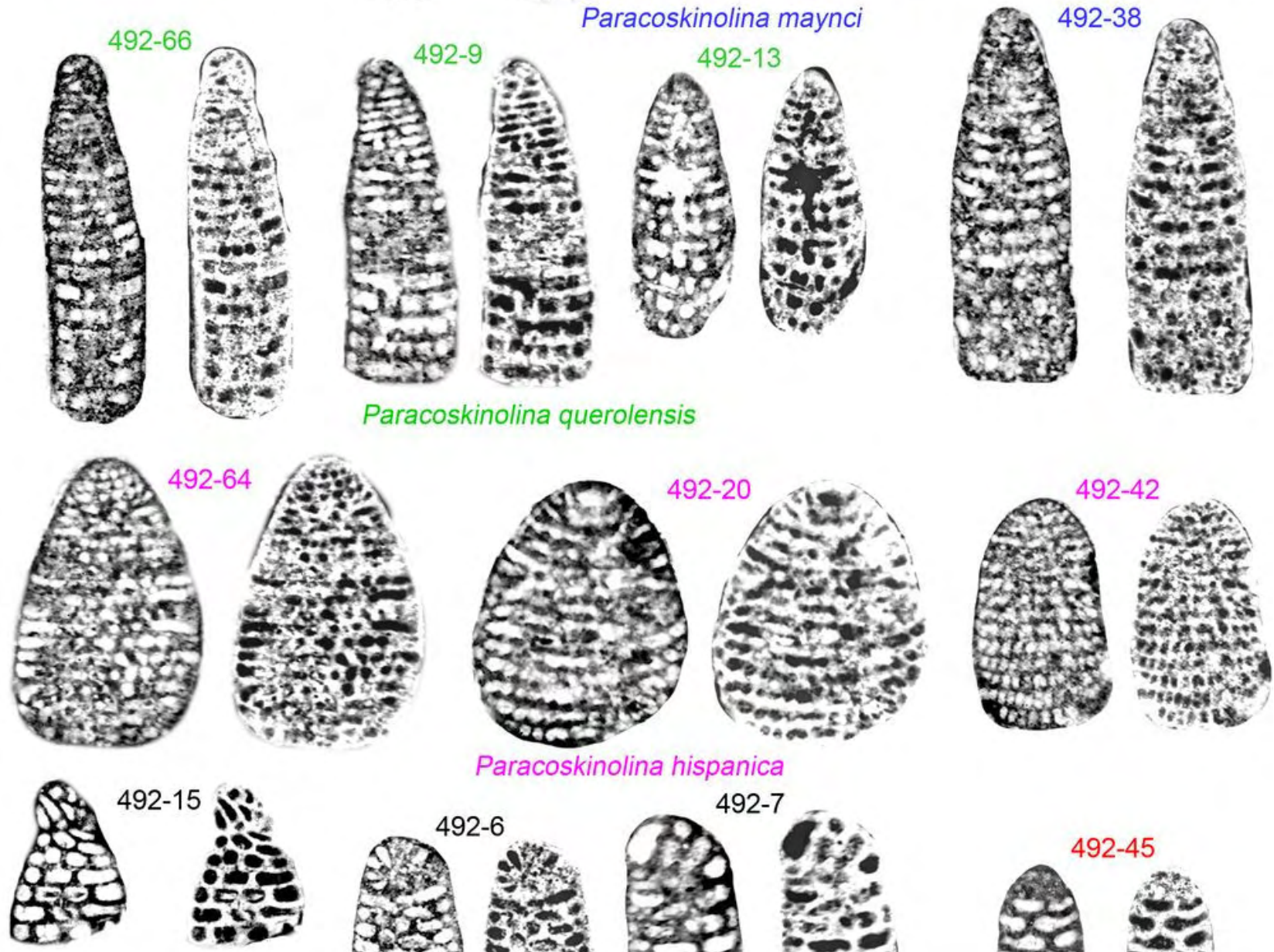

Paracoskinolina hispanica
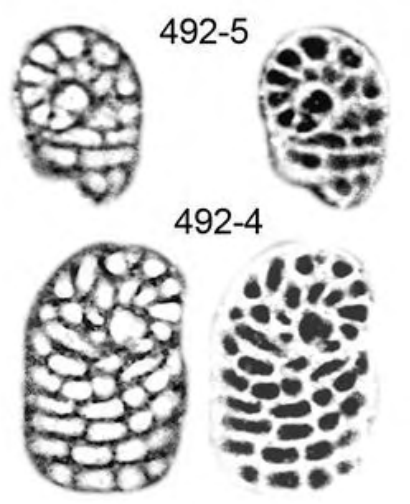
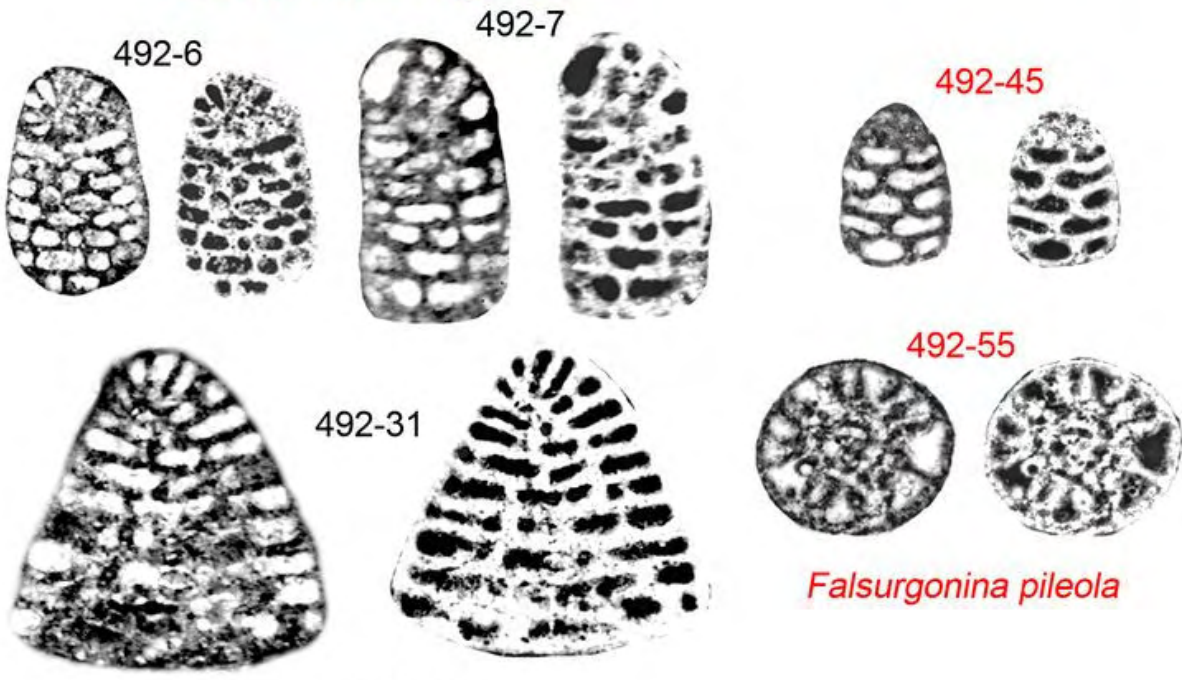

Falsurgonina pileola

Plate 48: Orbitolinids of the Pulchella Zone at La Montagnette. Falsurgonina pileola : 492-45, 492-55; Paracoskinolina hispanica: 492-20, 492-42, 492-64; Paracoskinolina maynci: 492-6, 492-33, 492-38, 492-51, 492-63; Paracoskinolina querolensis: 492-9, 492-13, 492-66; Urgonina alpillensis: 492-4, 492-5, 492-6, 492-7, 492-15, 492-31. Scale bar $=500 \mu \mathrm{m}$. 
$500 \mu \mathrm{m}$
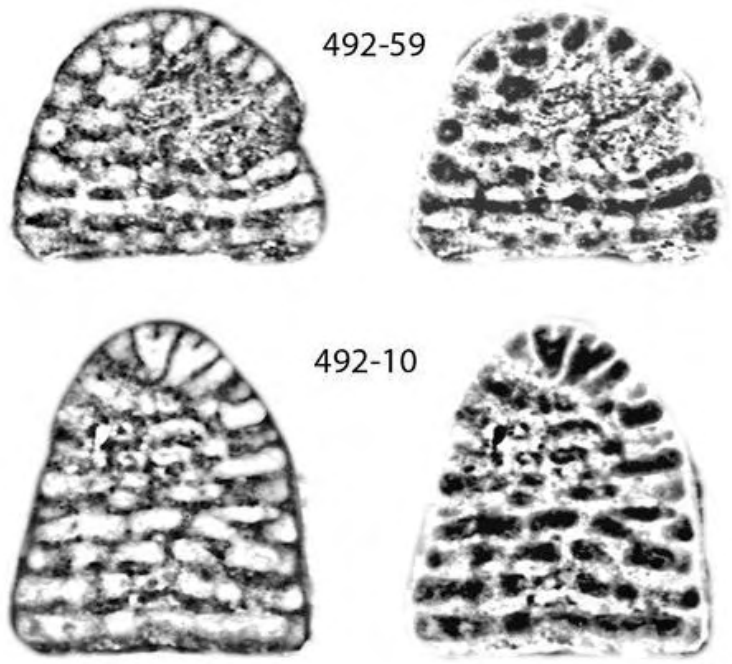

$492-10$
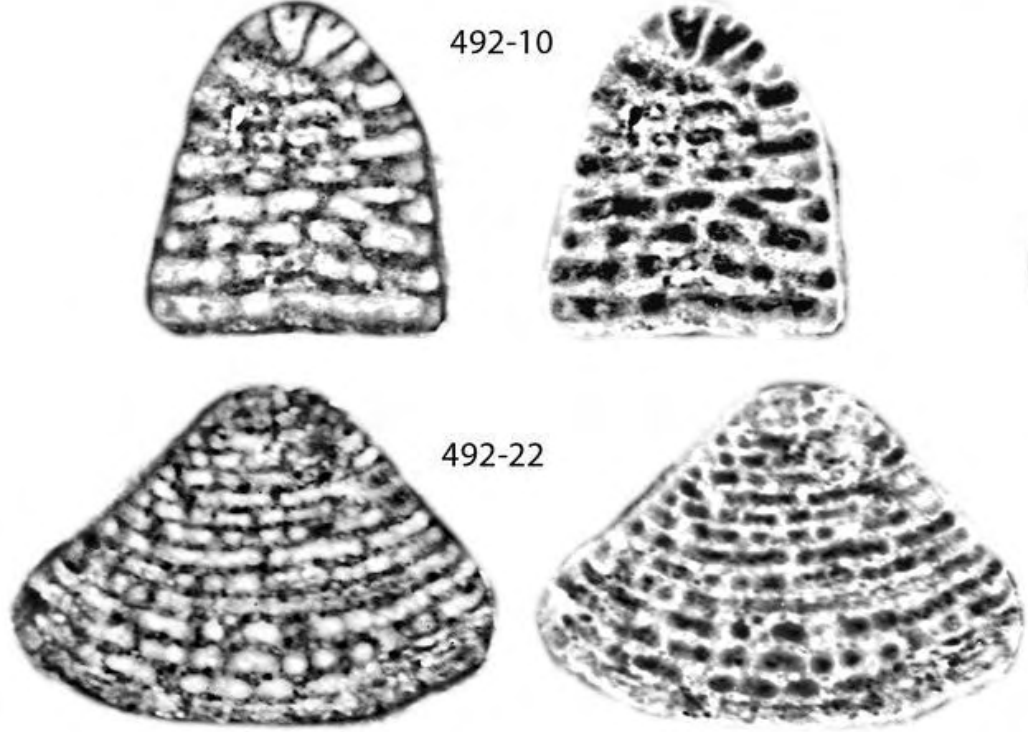

Montseciella glanensis
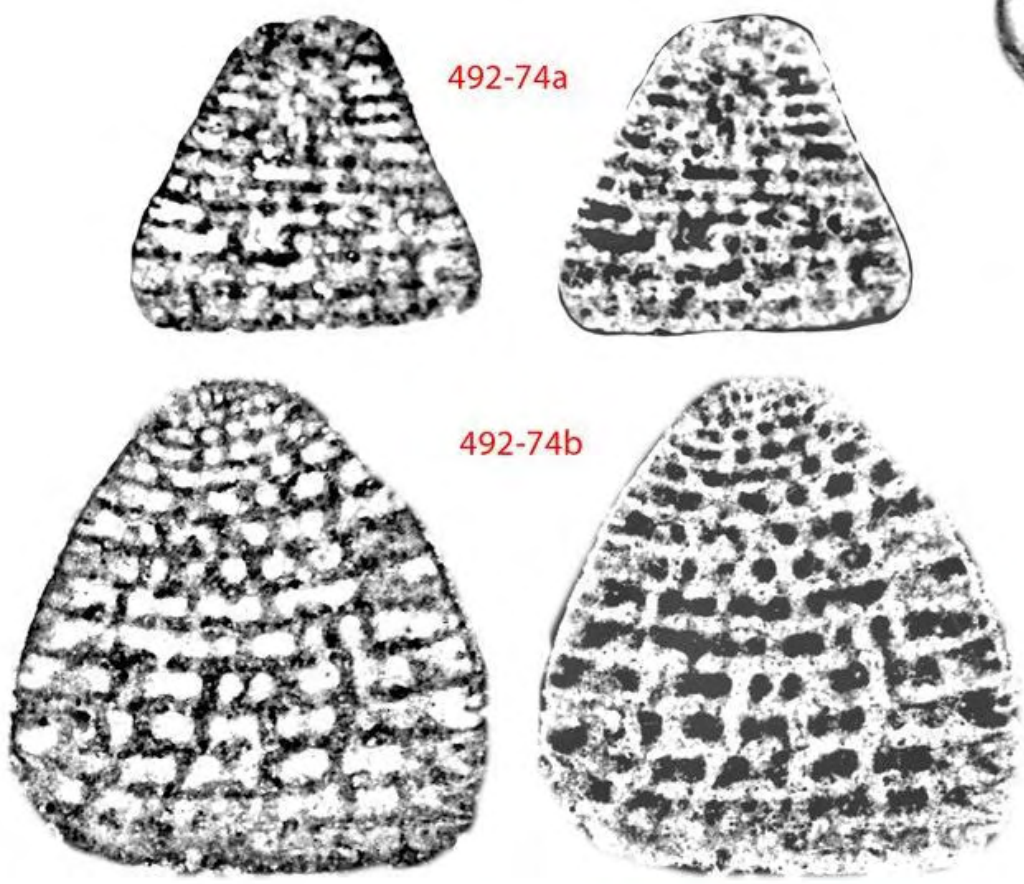

Montseciella alguerensis

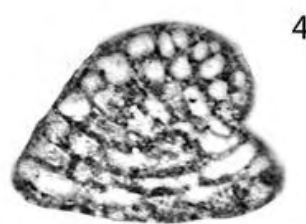

492-14
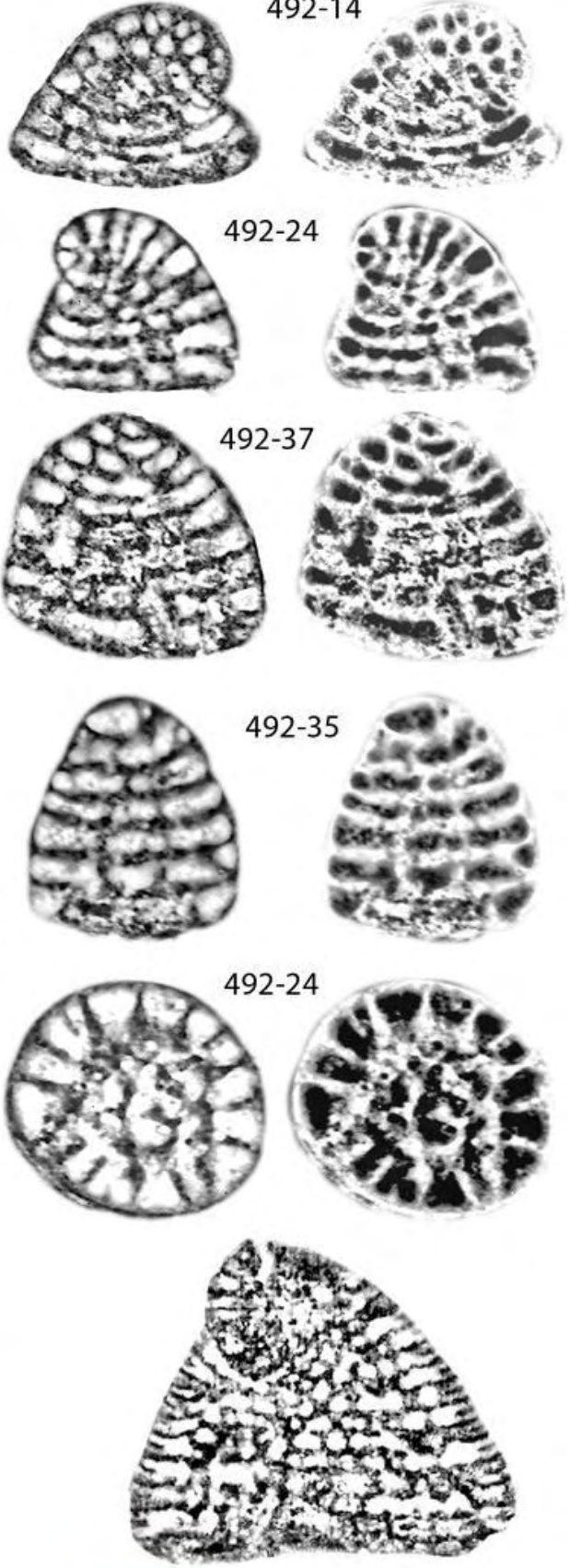

ID 21244

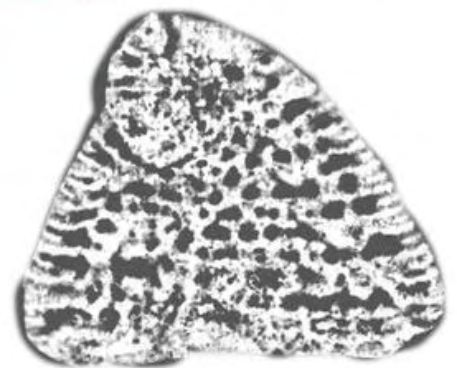

Plate 49: Orbitolinids of the Pulchella Zone at La Montagnette. Montseciella alguerensis: 492-74a, 492-74b, ID 21244; Montseciella glanensis: 492-10, 492-14, 492-22, 492-24, 492-35, 492-37, 492-59. Note that Pl. 48, fig. ID 21244 is duplicated from ARnaud-Vanneau (1980, PI. 106, fig. 5a) as "Paleodictyoconus n. sp. 2". Scale bar $=500 \mu \mathrm{m}$. 

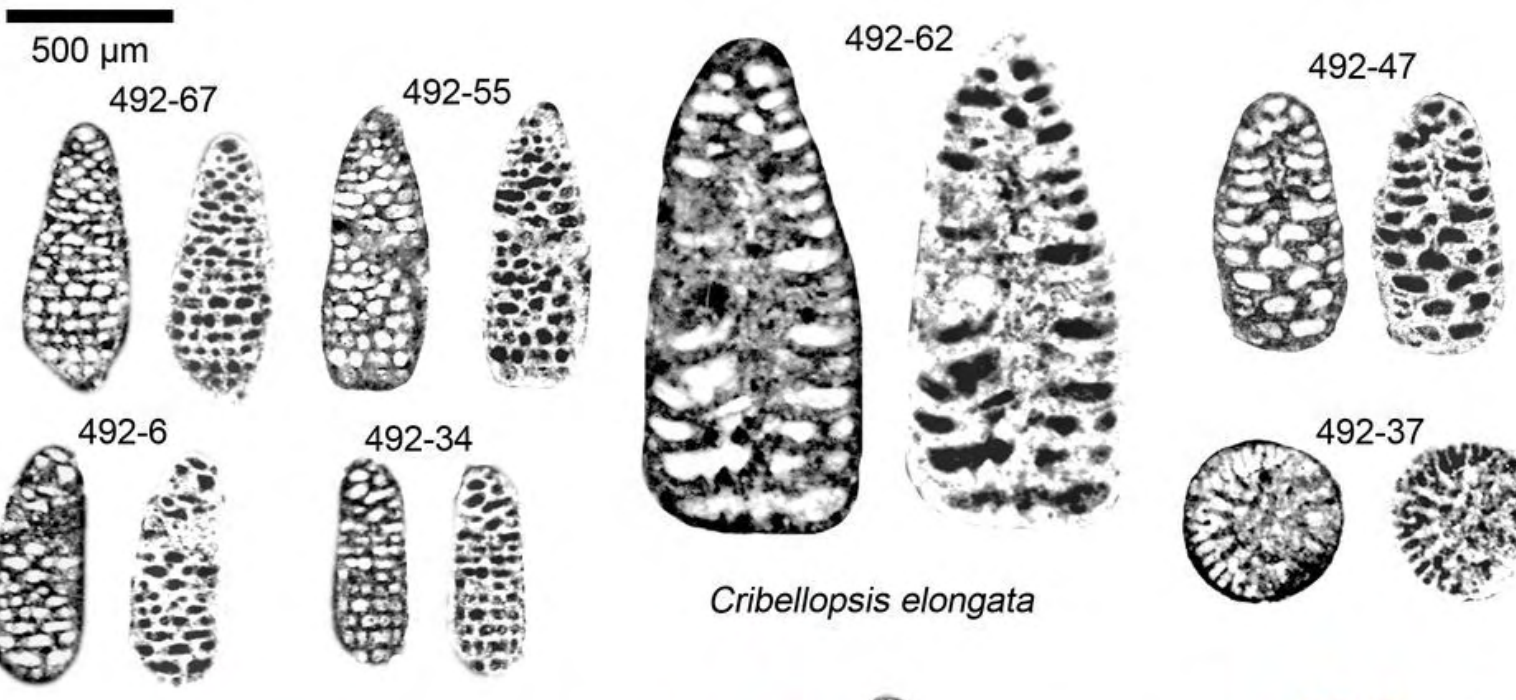

Cribellopsis elongata
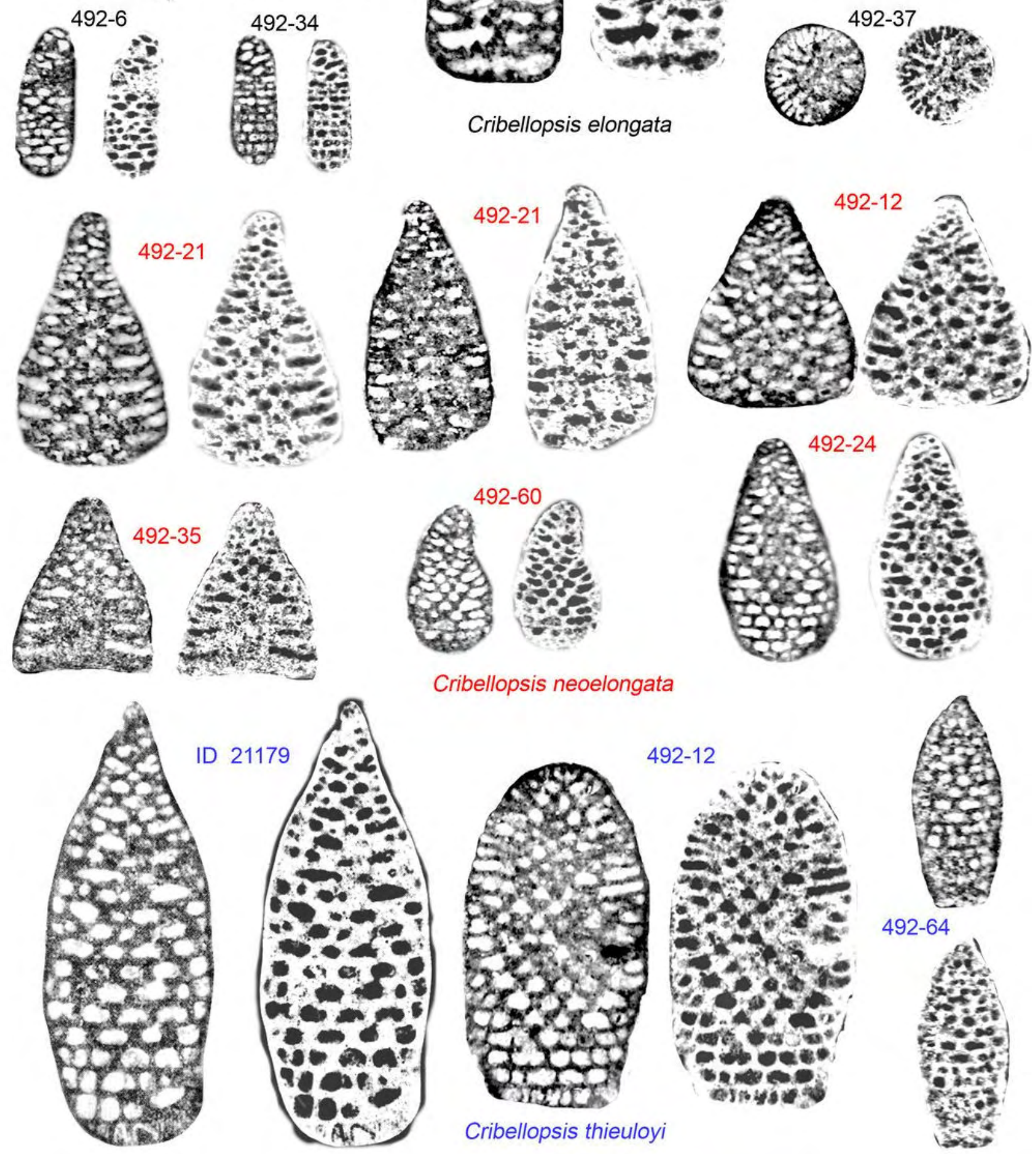

Cribellopsis neoelongata

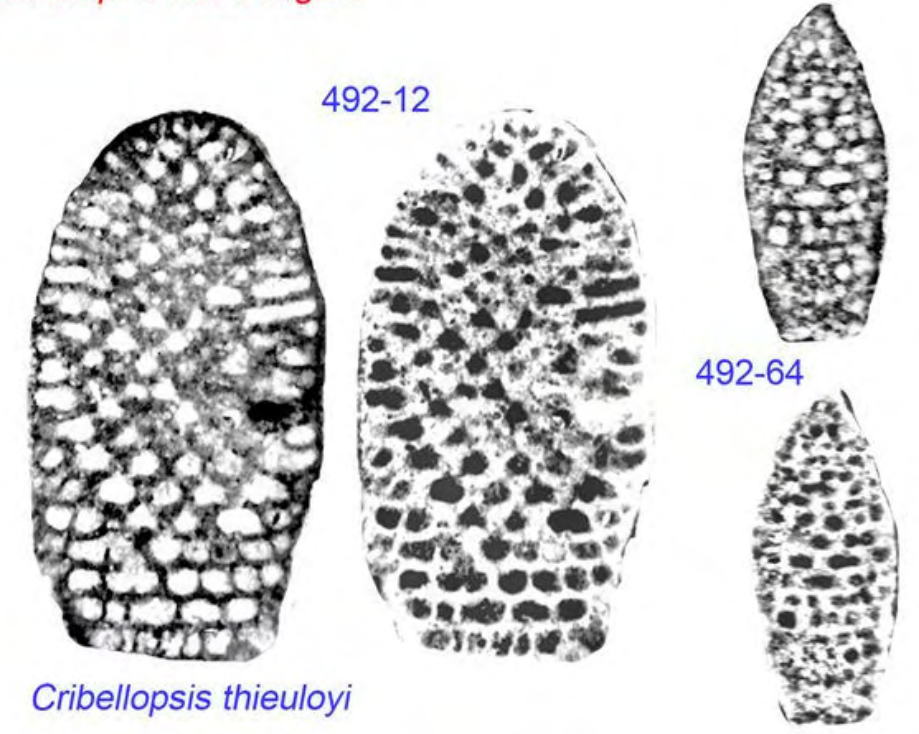

Plate 50: Orbitolinids of the Pulchella Zone at La Montagnette. Cribellopsis elongata : 492-6, 492-34, 492-37, 49247, 492-55, 492-62, 492-67; Cribellopsis neoelongata: 492-12, 492-21, 492-24, 492-35, 492-60; Cribellopsis thieuloyi: 492-12, 492-64, ID 21179. Note that PI. 49, fig. ID 21179 is duplicated from ARNAUD-VANNEAU (1980, PI. 96, fig. 15). Scale bar $=500 \mu \mathrm{m}$. 


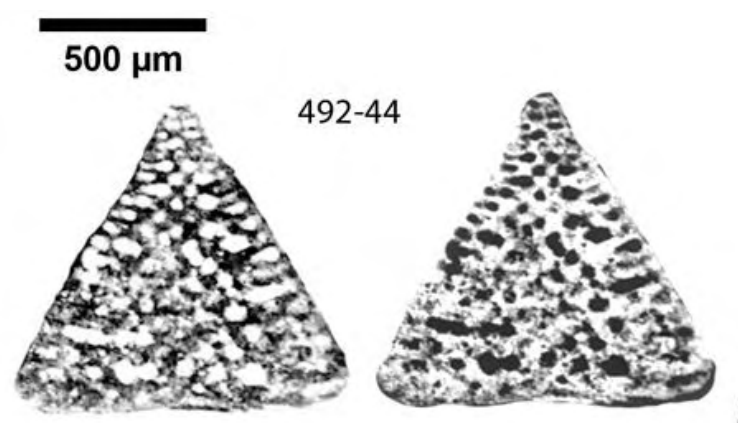

Cribellopsis schroederi
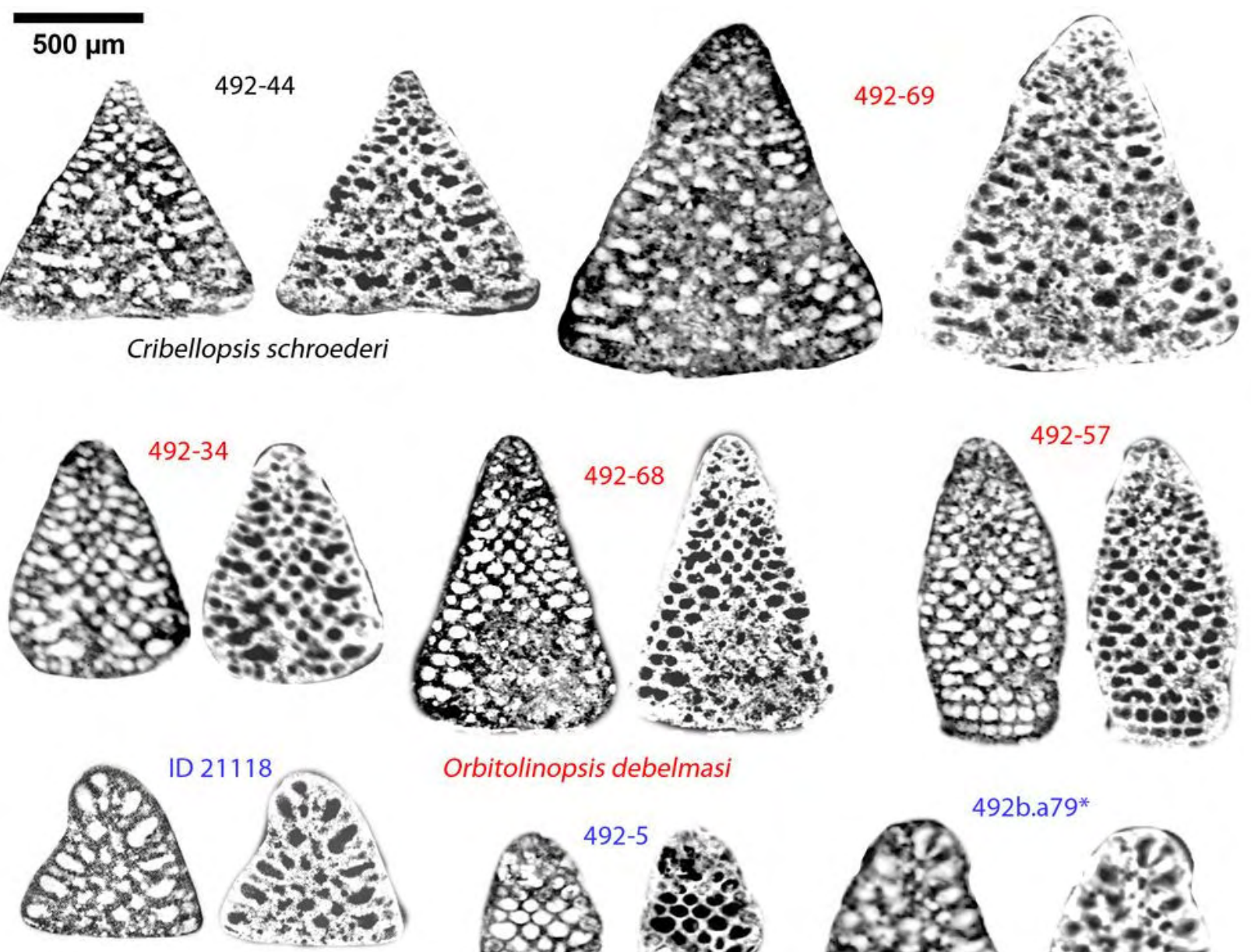

Orbitolinopsis debelmasi

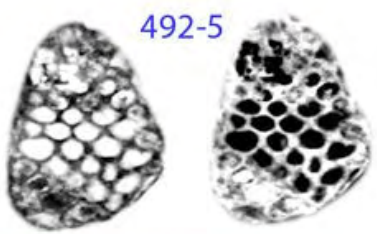

Obitolinopsis cuvillieri

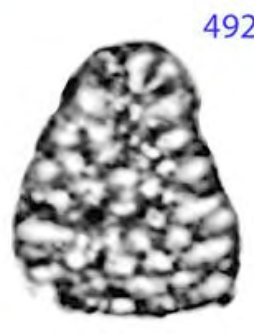

492b.a79*
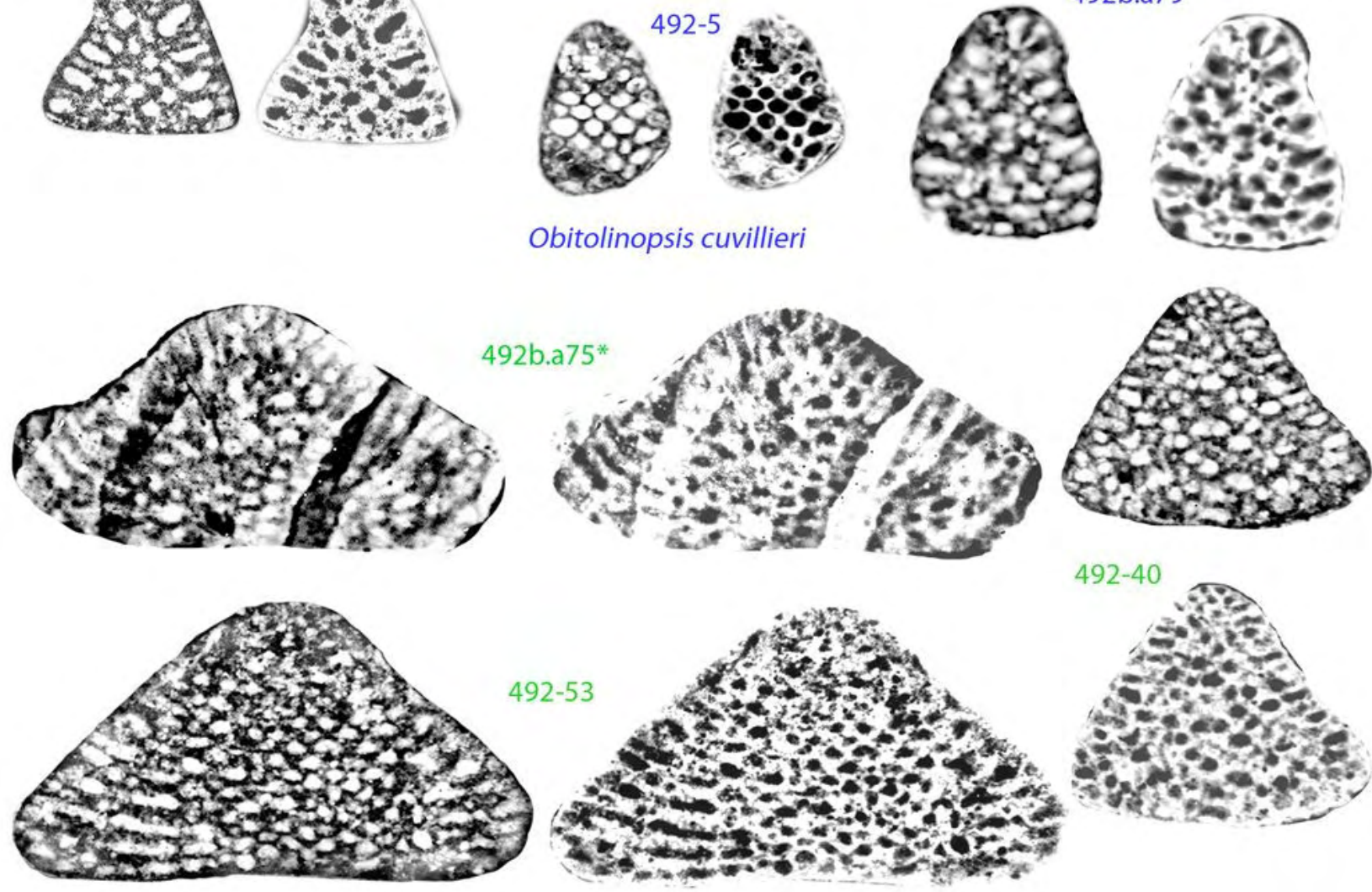

492-40

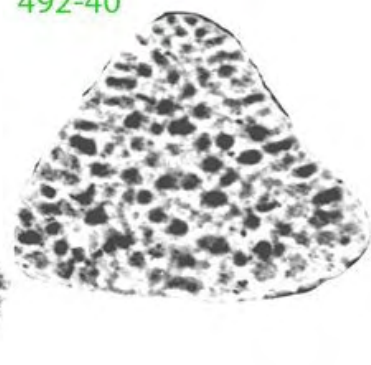

Orbitolinopsis buccifer

Plate 51: Orbitolinids of the Pulchella Zone at La Montagnette. Cribellopsis schroederi : 492-44; Orbitolinopsis buccifer: 492-53, 492-40, 492b.a75*; Orbitolinopsis cuvillieri: 492-5, 492b.a79*, ID21118; Orbitolinopsis debelmasi: 492-34a, 492-44, 492-57, 492-68, 492-69. Note that PI. 50, fig. ID 21118 is duplicated from ARNAUD-VANNEAU (1980, Pl. 93, fig. 1). Scale bar $=500 \mu \mathrm{m}$. 


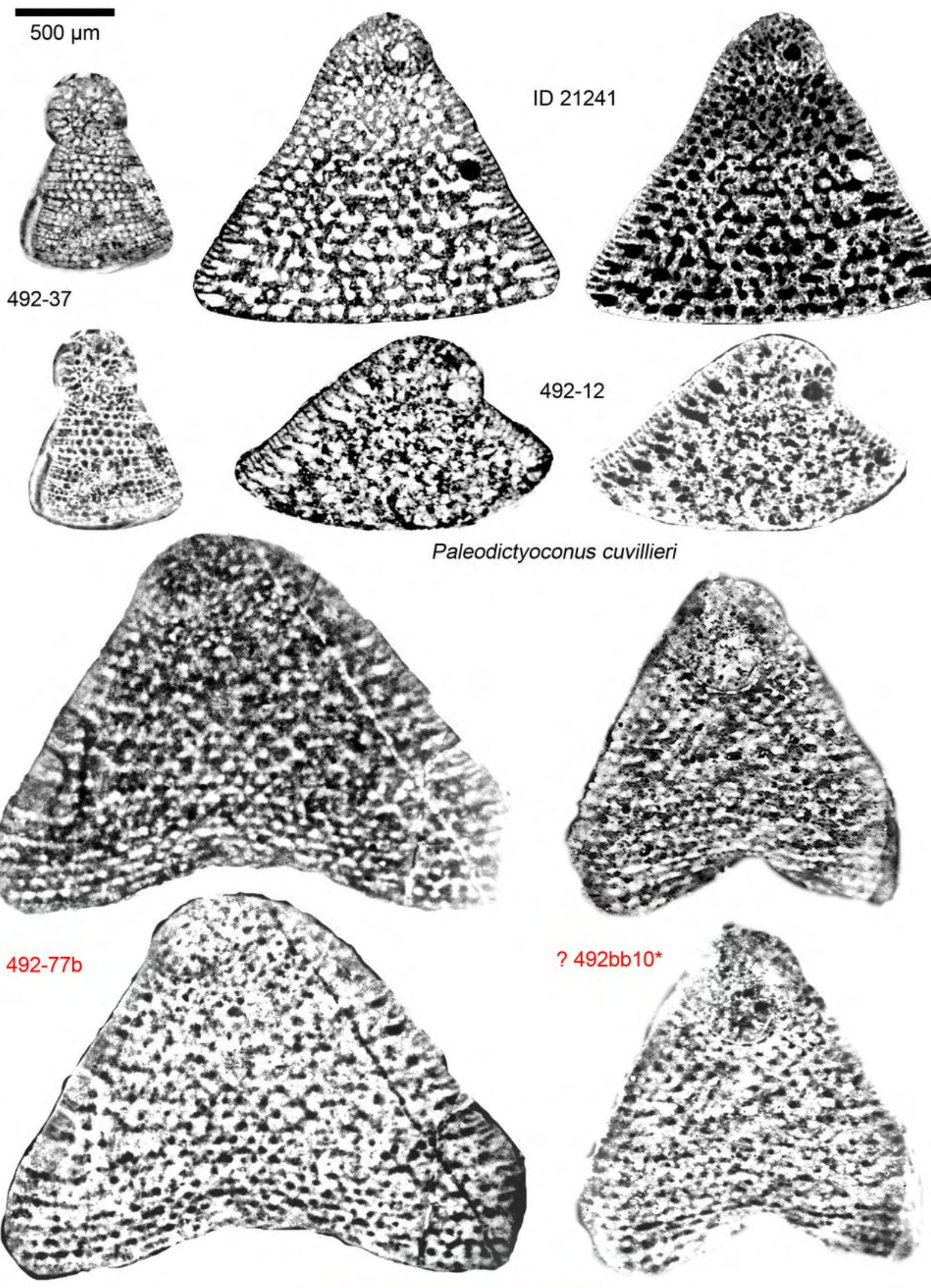

Paleodictyoconus actinostoma

Plate 52: Orbitolinids of the Pulchella Zone at La Montagnette. Paleodictyoconus actinostoma : 492-77b, ? 492bb10* [NF]; Paleodictyoconus cuvillieri: 492-12, 492-37, ID21241. Note that PI. 51, fig. ID 21241 is duplicated from ARNAUD-VANNEAU (1980, PI. 106, fig. 1a). Scale bar $=500 \mu \mathrm{m}$. 

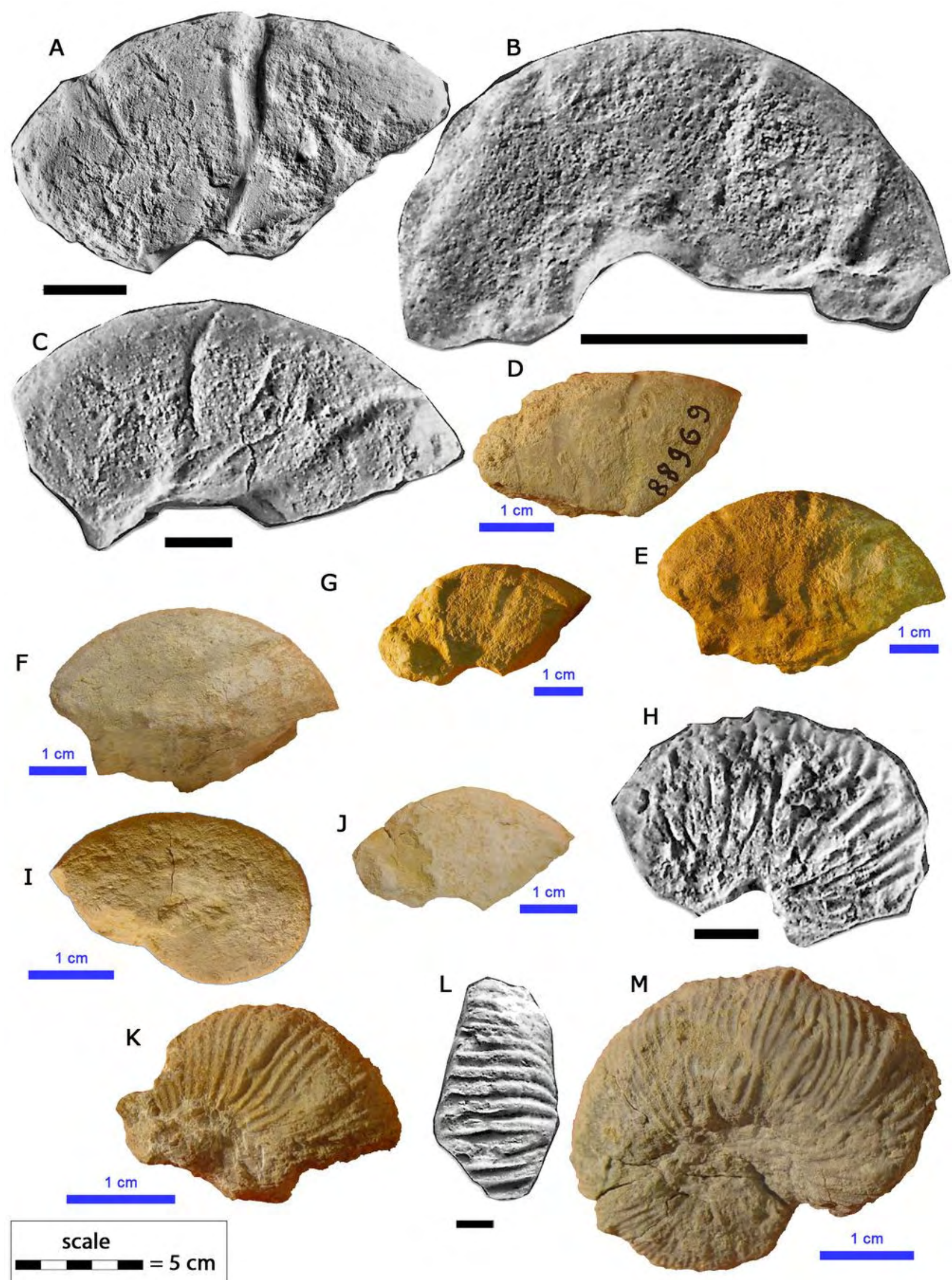

Plate 53: Ammonites of the Compressissima, Moutonianum, and Vandenheckei zones in the Serre de Tourre section. A) Puezalpella cf. uhligi, FSL 89519; B) Puezalpella sp., FSL 89457; C) Silesites cf. cirtense -RB- \{or Silesites vulpes -DB-\}, FSL 89456; D) Puezalpella sp., FSL 88969; E) Puezalpella sp., FSL 88968a; F) Puezalpella sp., FSL 88968c; G) Puezalpella sp., FSL 88968d; H) Holcodiscus diversecostatus -RB- \{or Holcodiscus sp. -DB-\}, FSL 89458; I) Barremites sp., FSL 88971; J) Puezalpella sp., FSL 88968b; K) Holcodiscus sp., FSL 88970; L) Holcodiscus sp., FSL 89454; M) Astieridiscus menglonensis, FSL 88967. All scale bars $=1 \mathrm{~cm}$. 


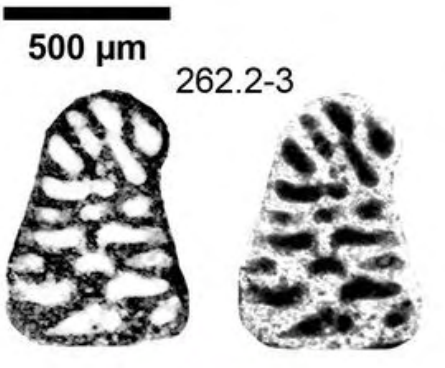

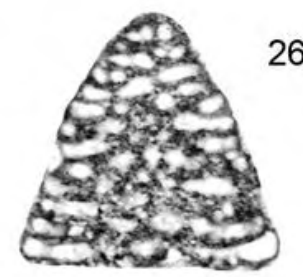

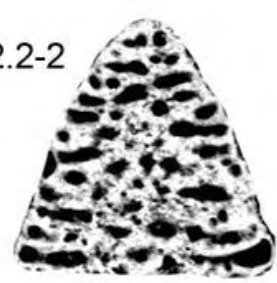

Falsurgonina pileola
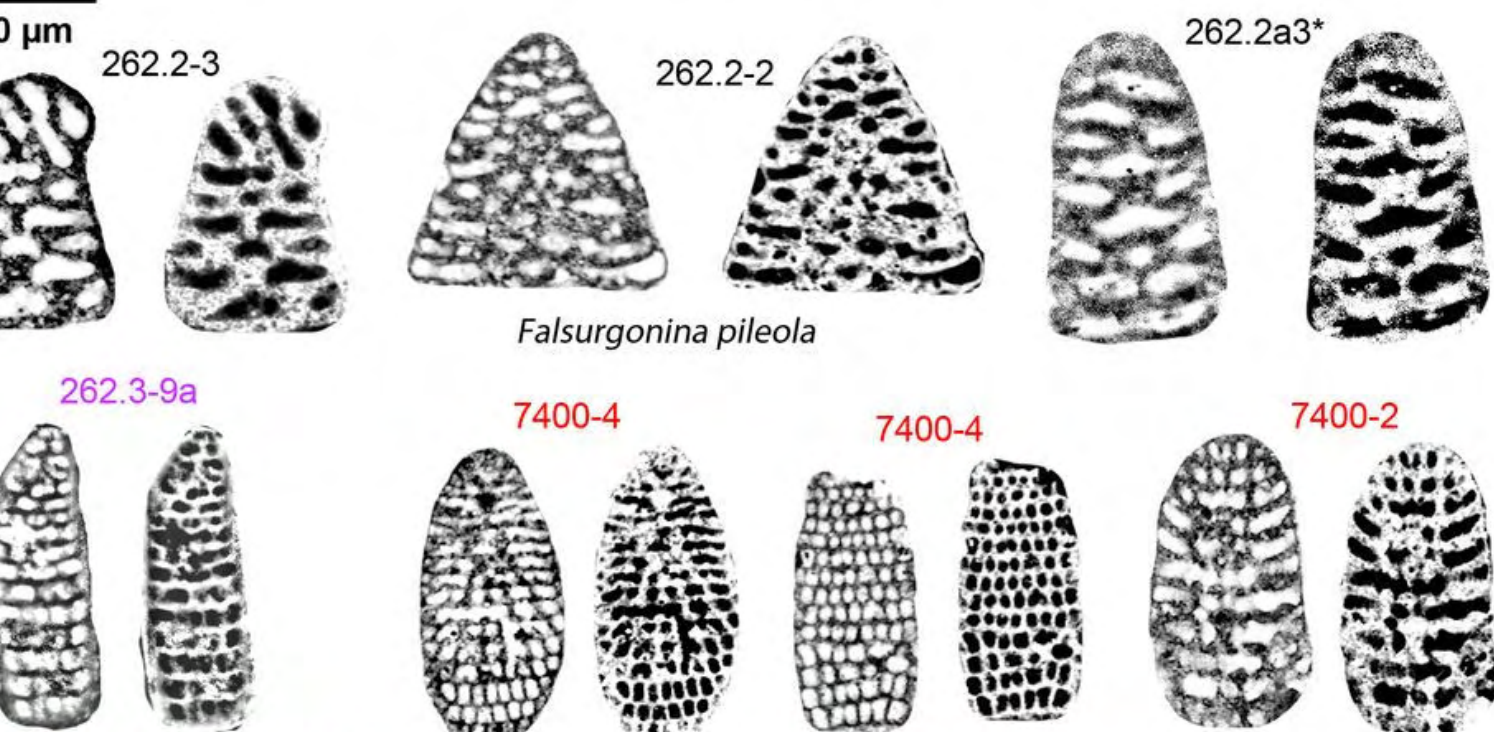

Paracoskinolina querolensis
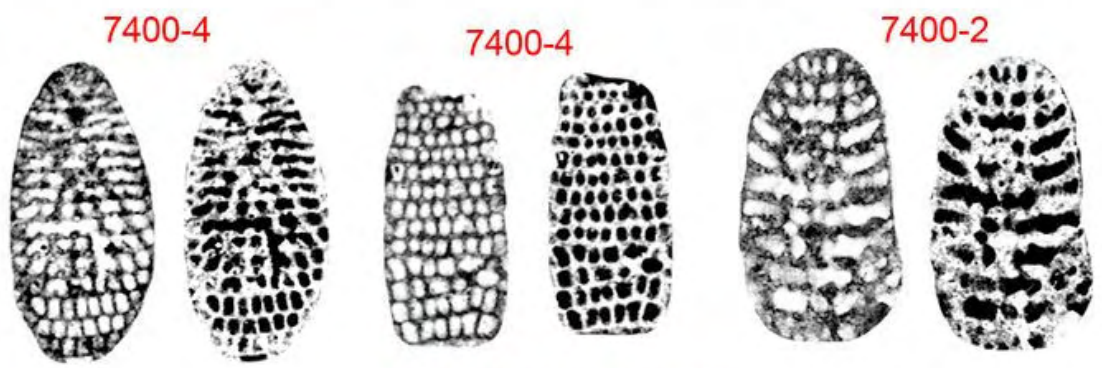

Paracoskinolina maynci
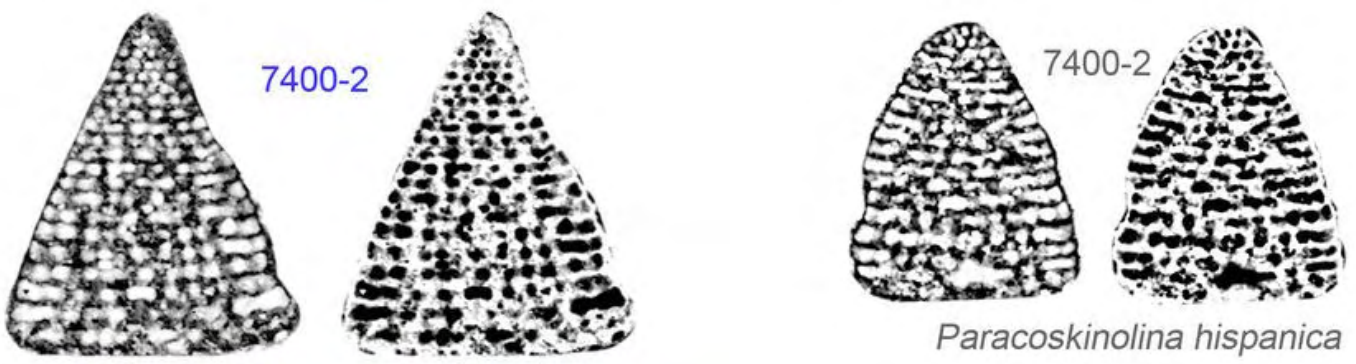

Paracoskinolina hispanica

Paracoskinolina aff. sunnilandensis
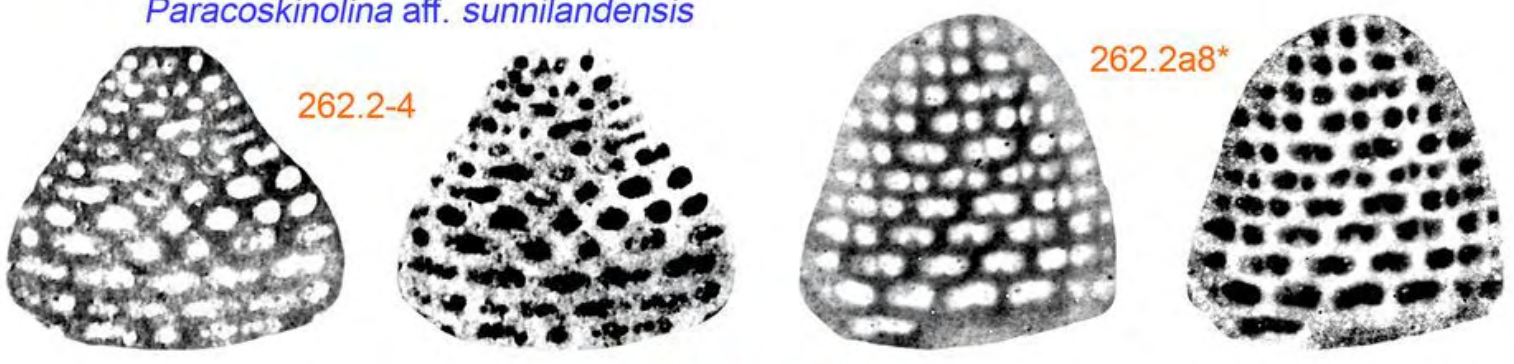

Montseciella glanensis
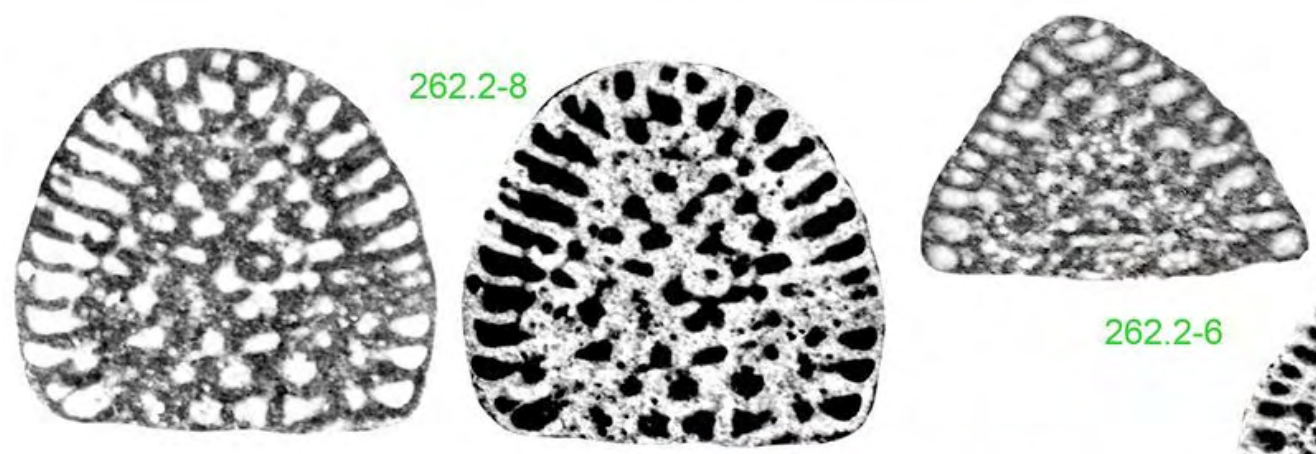

- Moulladella jourdanensis
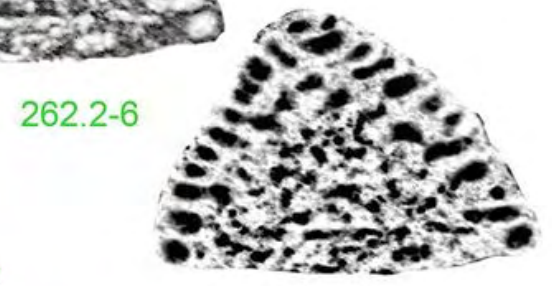

Plate 54: Moulladella and orbitolinids of the Pulchella zone in the Serre de Tourre section. Moulladella jourdanensis: 262.2-6, 262.2-8; Falsurgonina pileola: 262.2-2, 262.2-3, 262.2a3*; Montseciella glanensis: 262.2-4, 262.2a8*; Paracoskinolina hispanica: 7400-2; Paracoskinolina maynci: 7400-2, 7400-4; Paracoskinolina querolensis: 262.3-9a; Paracoskinolina aff. sunnilandensis: 7400-2. Scale bar $=500 \mu \mathrm{m}$. 


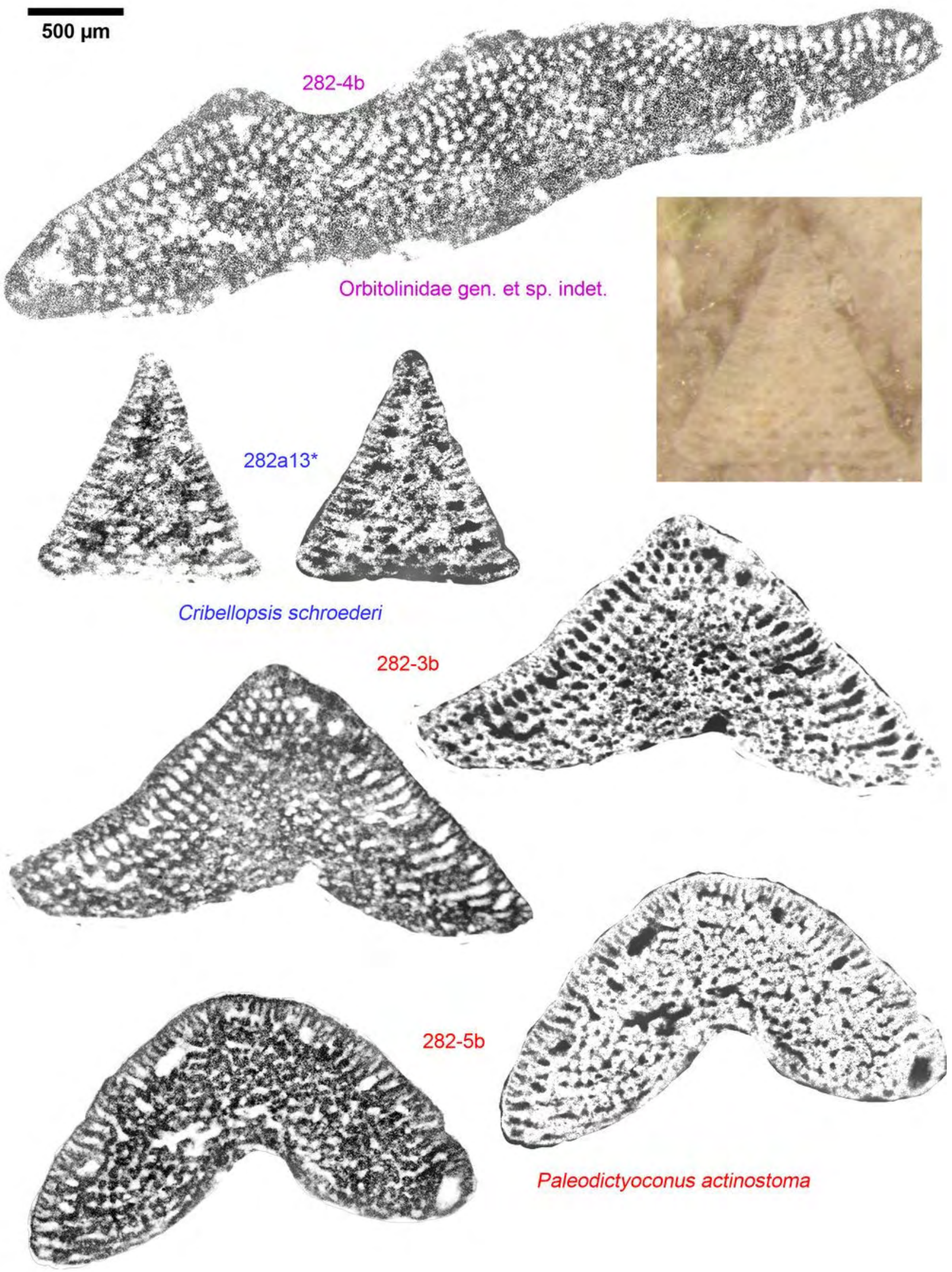

Plate 55: Orbitolinids of the Pulchella zone in the Serre de Tourre section. Orbitolinidae gen. et sp. indet.: 282-4b; Cribellopsis schroederi: 282a13*; Paleodictyoconus actinostoma: 282-3b, 282-5b. Scale bar $=500 \mu \mathrm{m}$. 

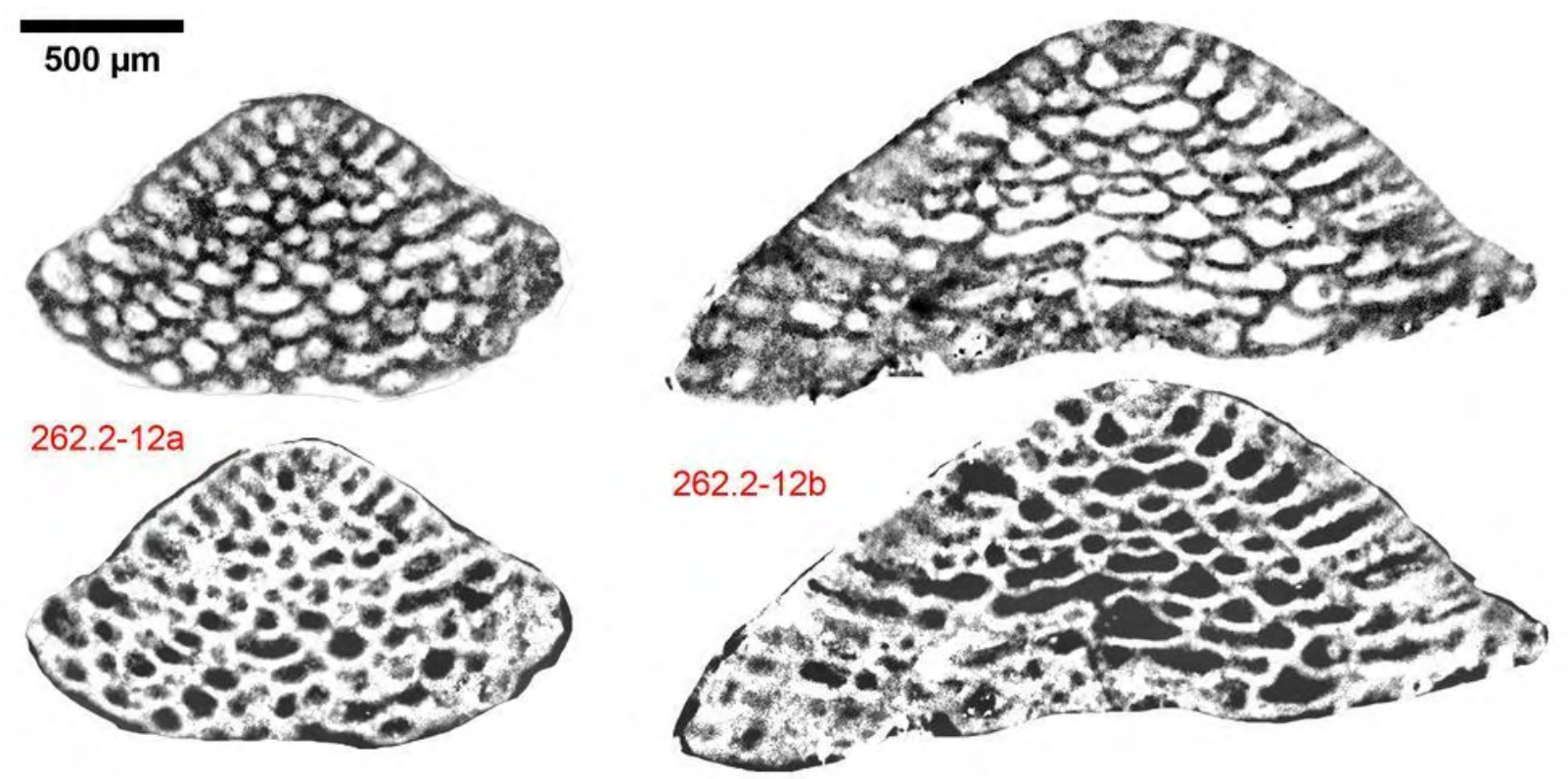

Orbitolinopsis buccifer

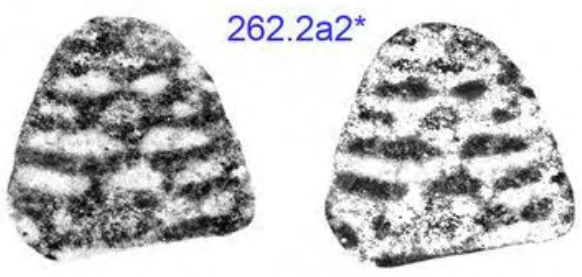

Urgonina alpillensis

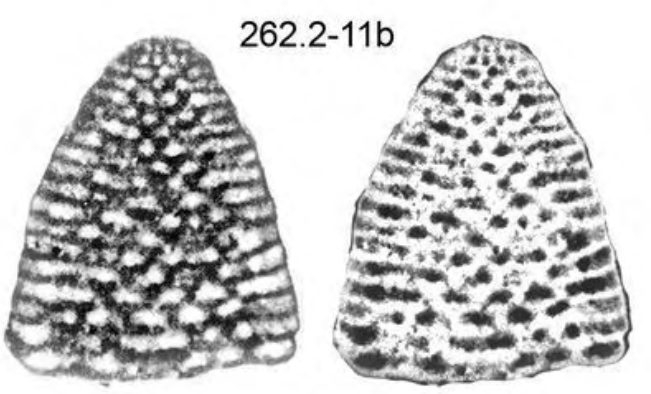

Orbitolinopsis debelmasi
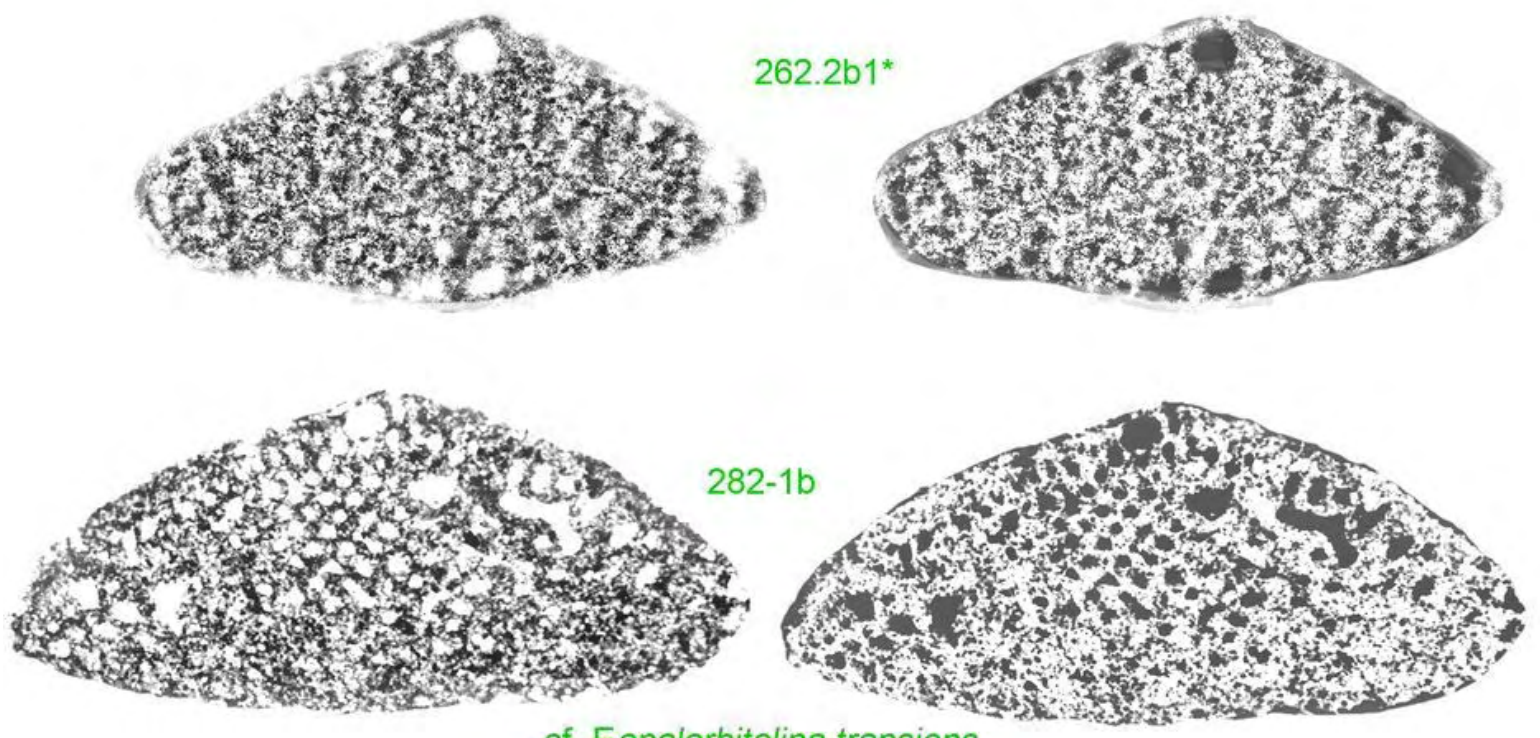

cf. Eopalorbitolina transiens

Plate 56: Orbitolinids of the Pulchella zone in the Serre de Tourre section. cf. Eopalorbitolina transiens: 282-1b, 262.2b1*; Orbitolinopsis buccifer: 262.2-12a, 262.2-12b; Orbitolinopsis debelmasi: 262.2-11b; Urgonina alpillensis: 262.2a2*. Scale bar $=500 \mu \mathrm{m}$. 

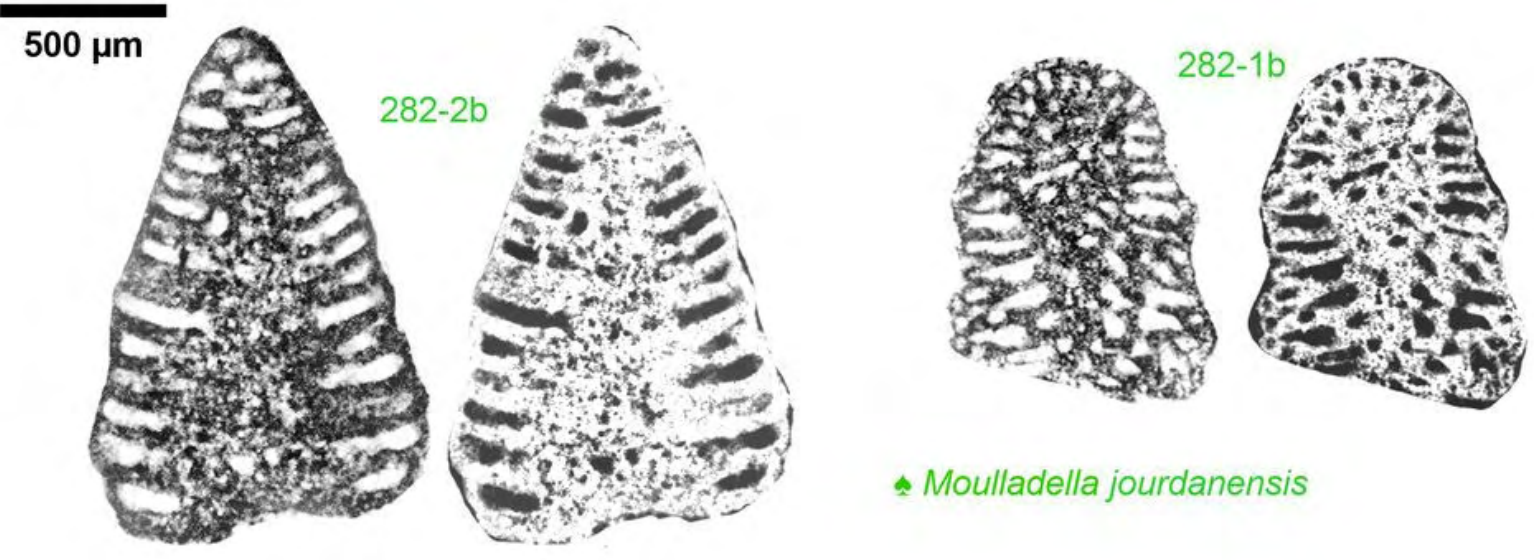

- Moulladella jourdanensis
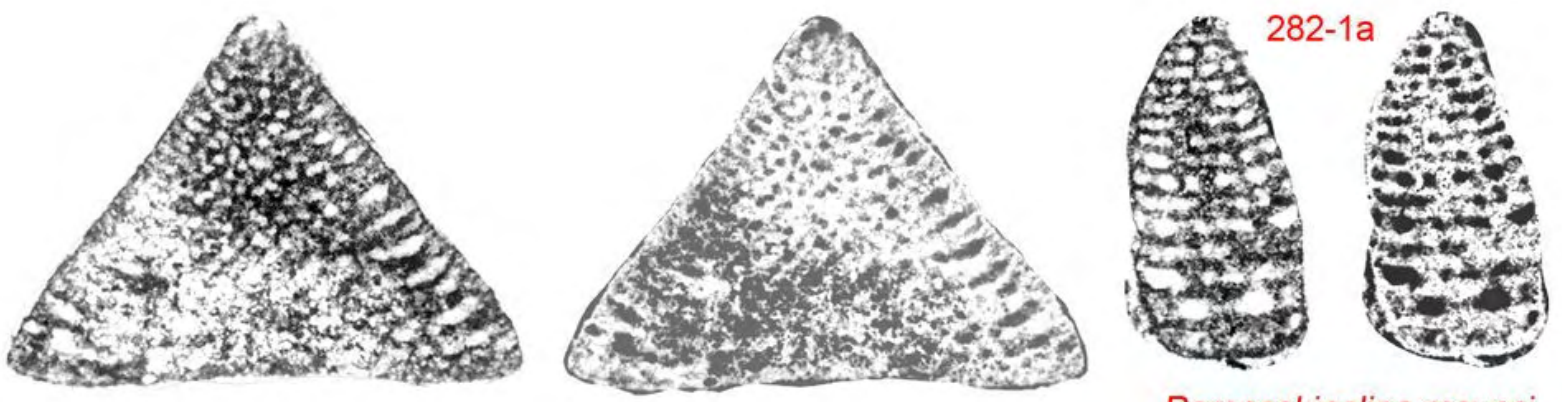

Valserina gr. broennimanni-turbinata 282-2a

Paracoskinolina maynci
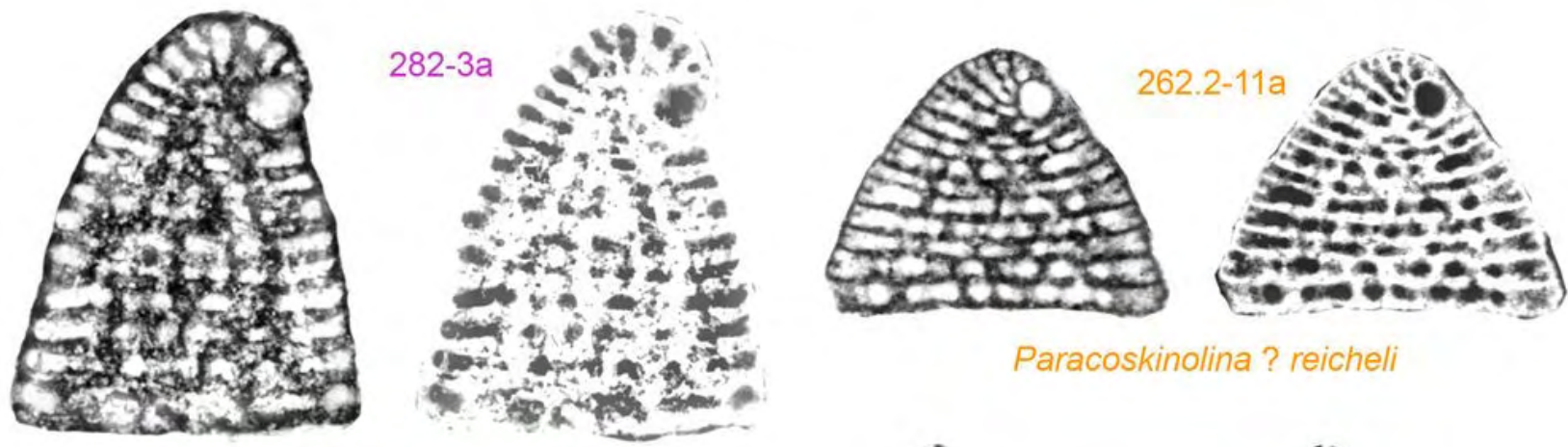

Paracoskinolina? reicheli

Paracoskinolina? praereicheli
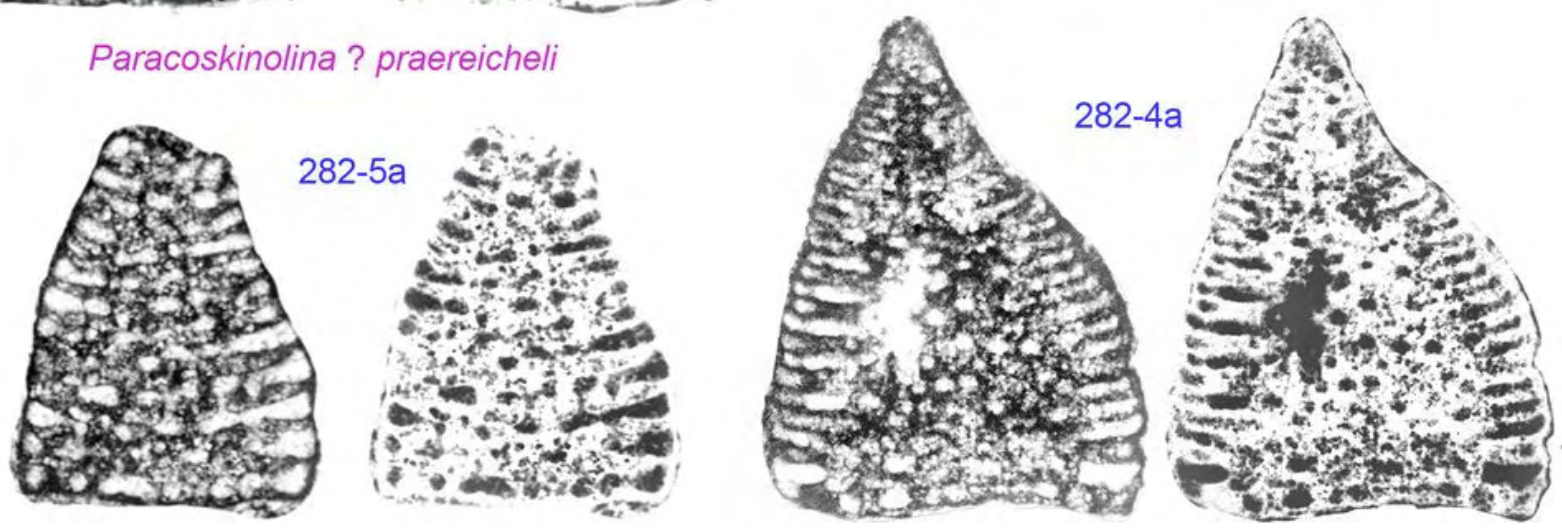

Cribellopsis neoelongata

Plate 57: Moulladella and orbitolinids of the Pulchella zone in the Serre de Tourre section. Moulladella jourdanensis: 282-1b, 282-2b; Cribellopsis neoelongata: 282-4a, 282-5a; Paracoskinolina maynci: 282-1a; Paracoskinolina ? praereicheli: 282-3a; Paracoskinolina ? reicheli: 262.2-11a; Valserina gr. broennimanni-turbinata: 282-2a. Scale bar $=500 \mu \mathrm{m}$. 


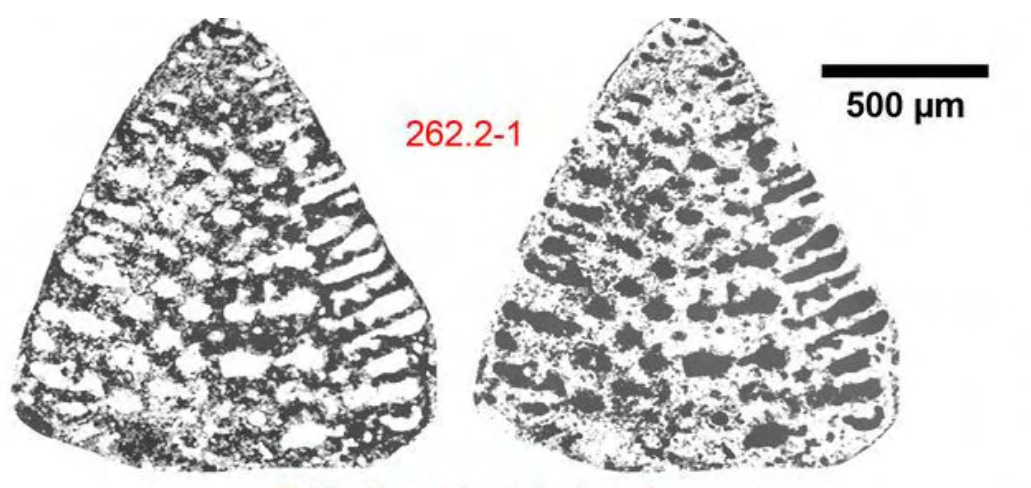

262.2-10a

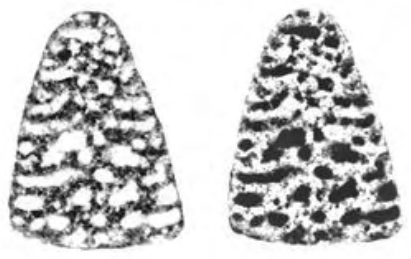

Falsurgonina vanneauae

Orbitolinopsis debelmasi

262.2-6
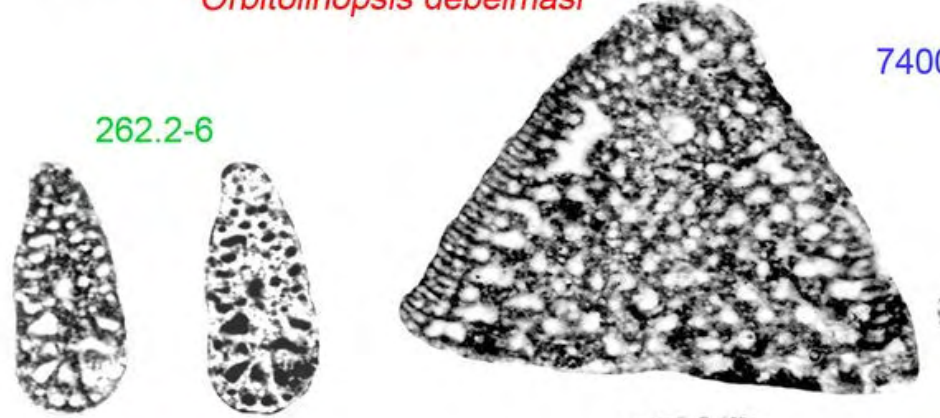

$7400-9$
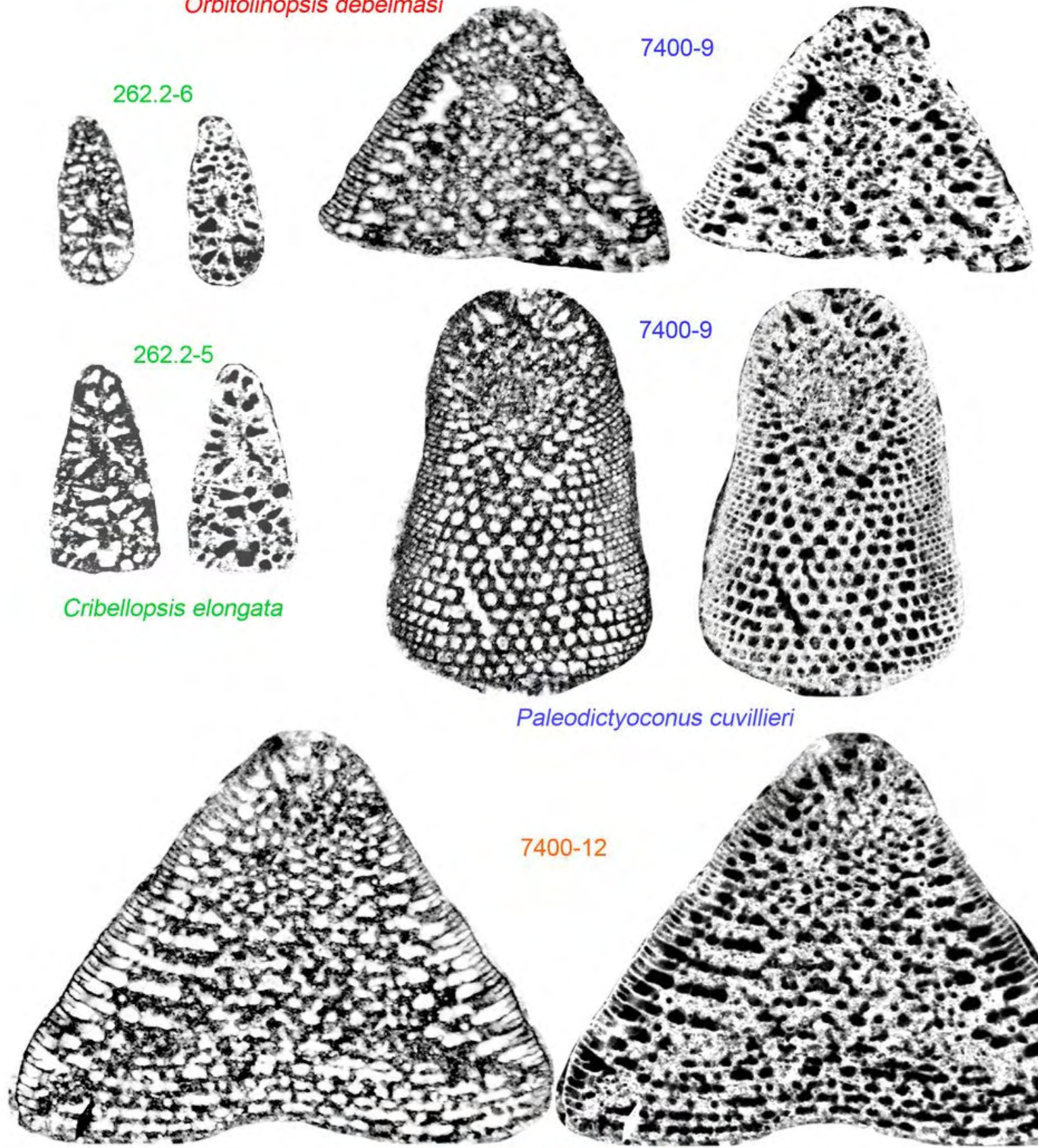

Paleodictyoconus cuvillieri

Cribellopsis elongata

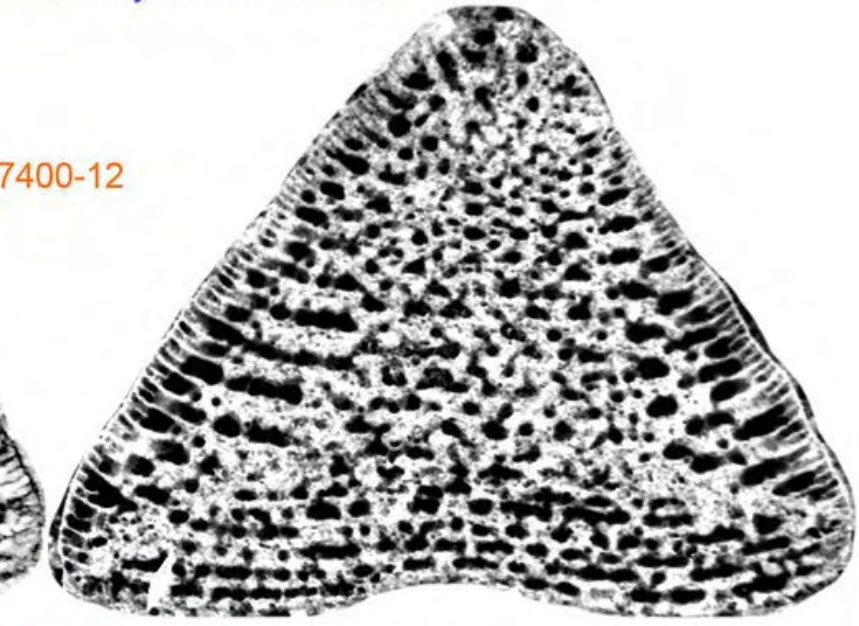

Paleodictyoconus actinostoma

Plate 58: Orbitolinids of the Pulchella zone in the Serre de Tourre section. Cribellopsis elongata: 262.2-5, 262.2-6; Falsurgonina vanneauae: 262.2-10a; Orbitolinopsis debelmasi: 262.2-1; Paleodictyoconus actinostoma: 7400-12; Paleodictyoconus cuvillieri: 7400-9. Scale bar $=500 \mu \mathrm{m}$. 

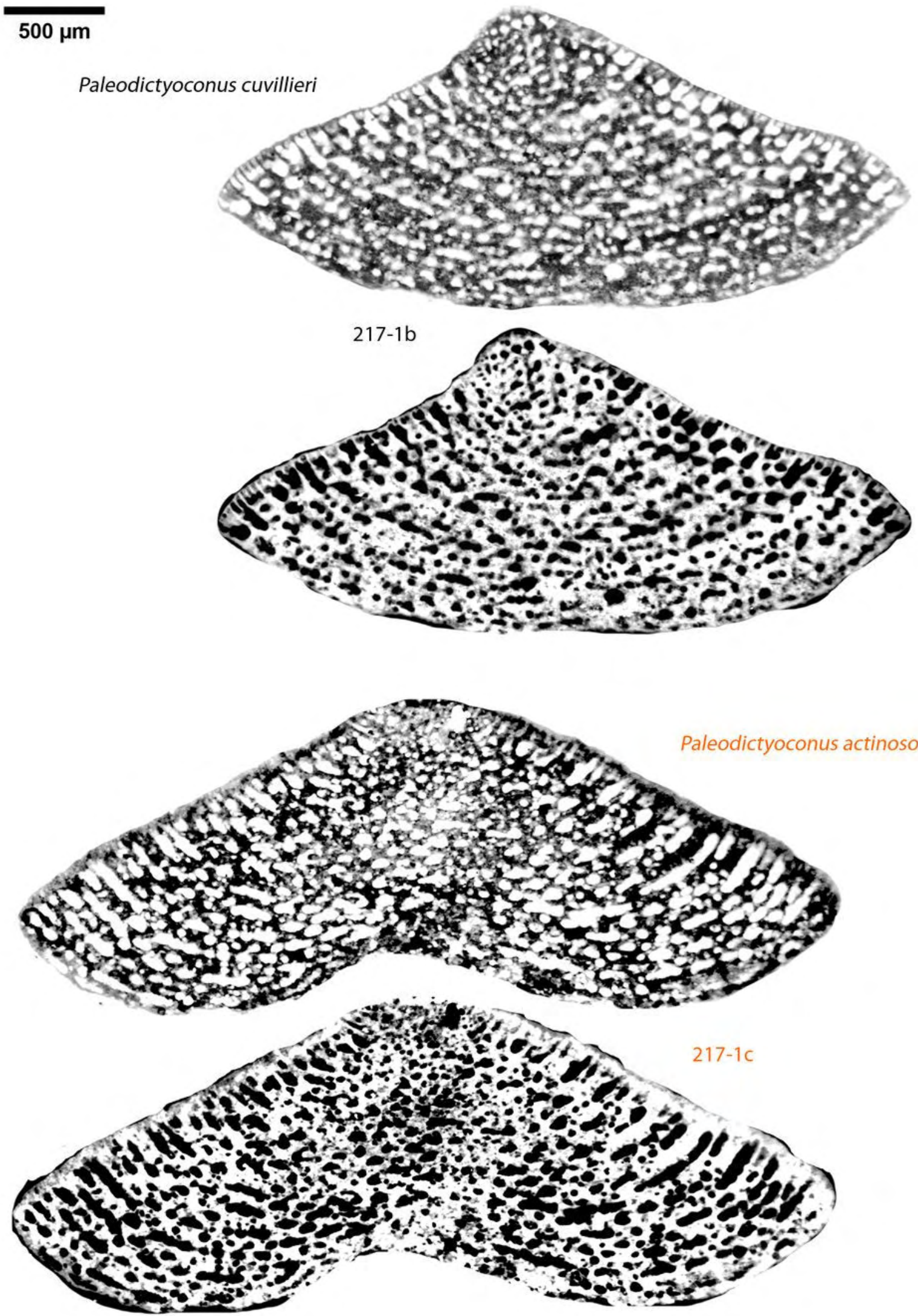

Plate 59: Orbitolinids of the Compressissima zone in the Serre de Tourre section. Paleodictyoconus actinostoma: 217-1c; Paleodictyoconus cuvillieri: 217-1b. Scale bar $=500 \mu \mathrm{m}$. 


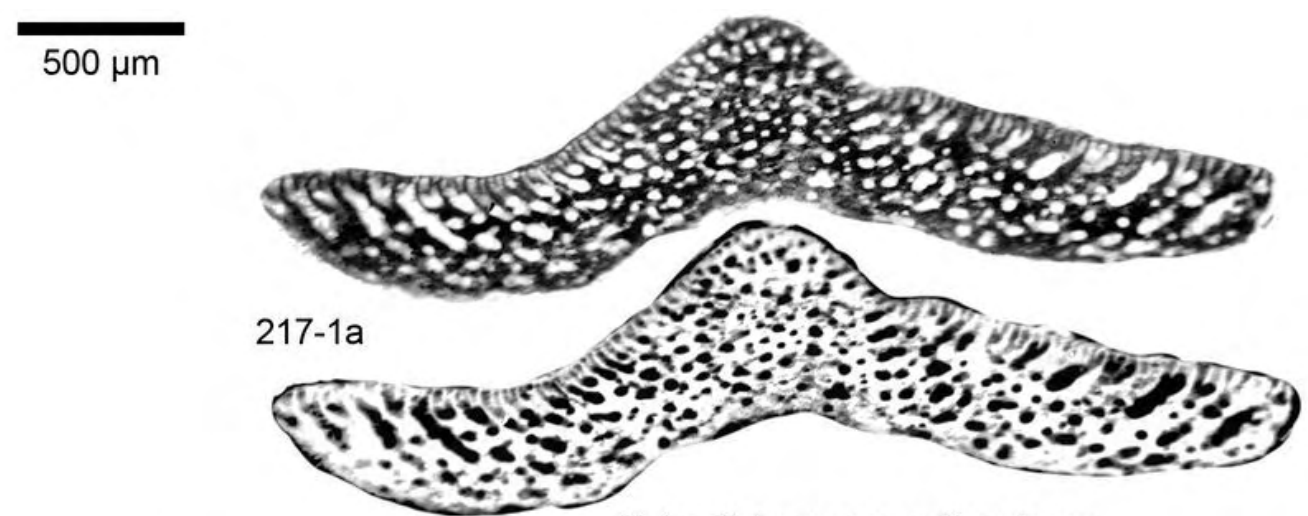

Paleodictyoconus actinostoma
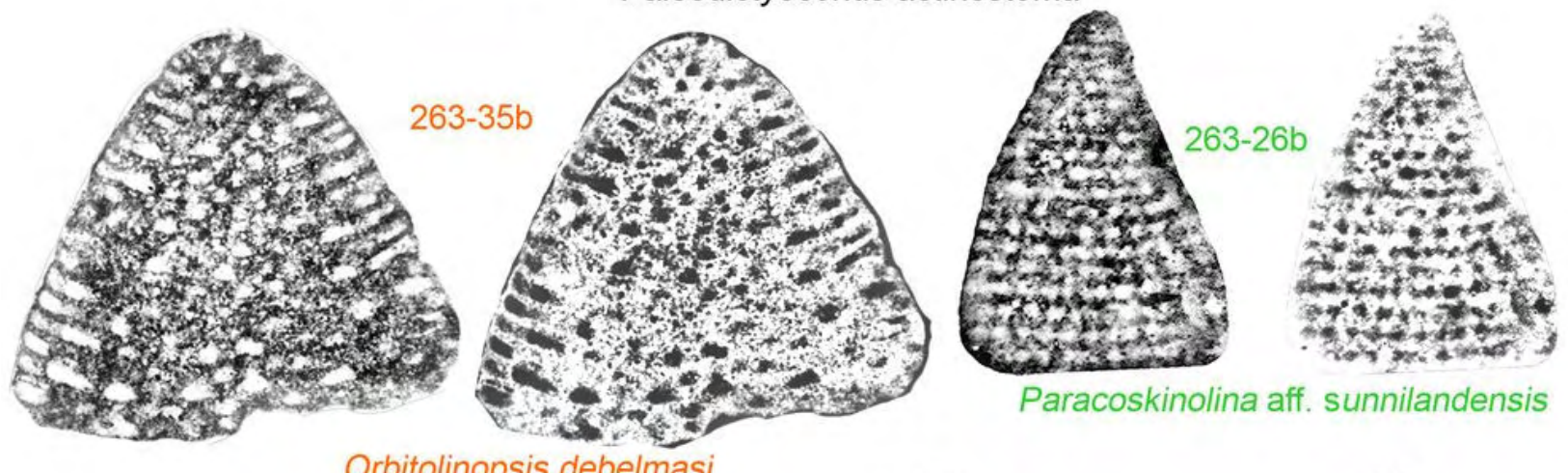

Paracoskinolina aff. sunnilandensis

Orbitolinopsis debelmasi
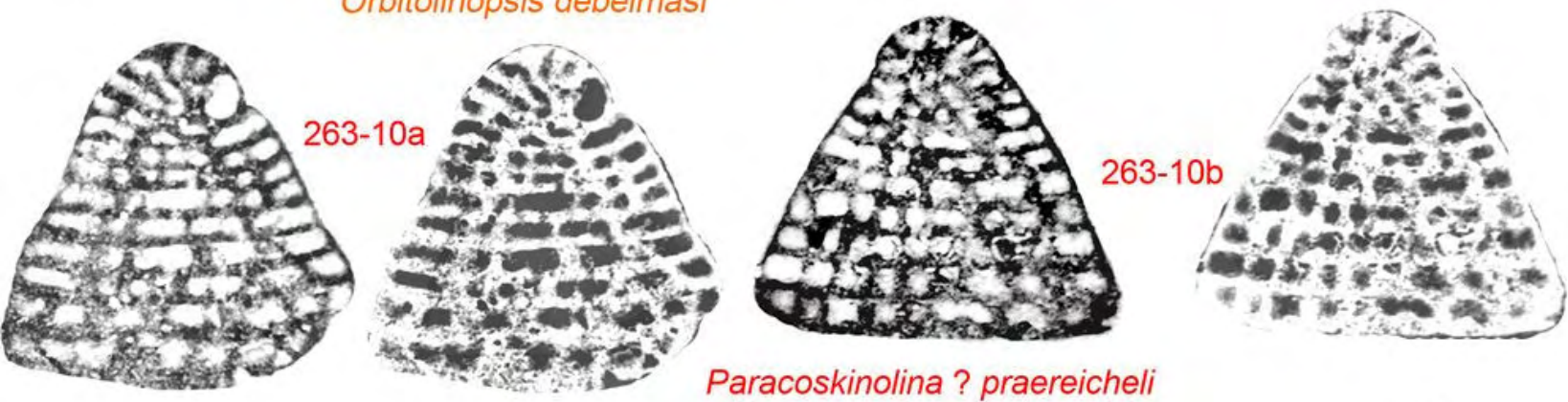

Paracoskinolina ? praereicheli
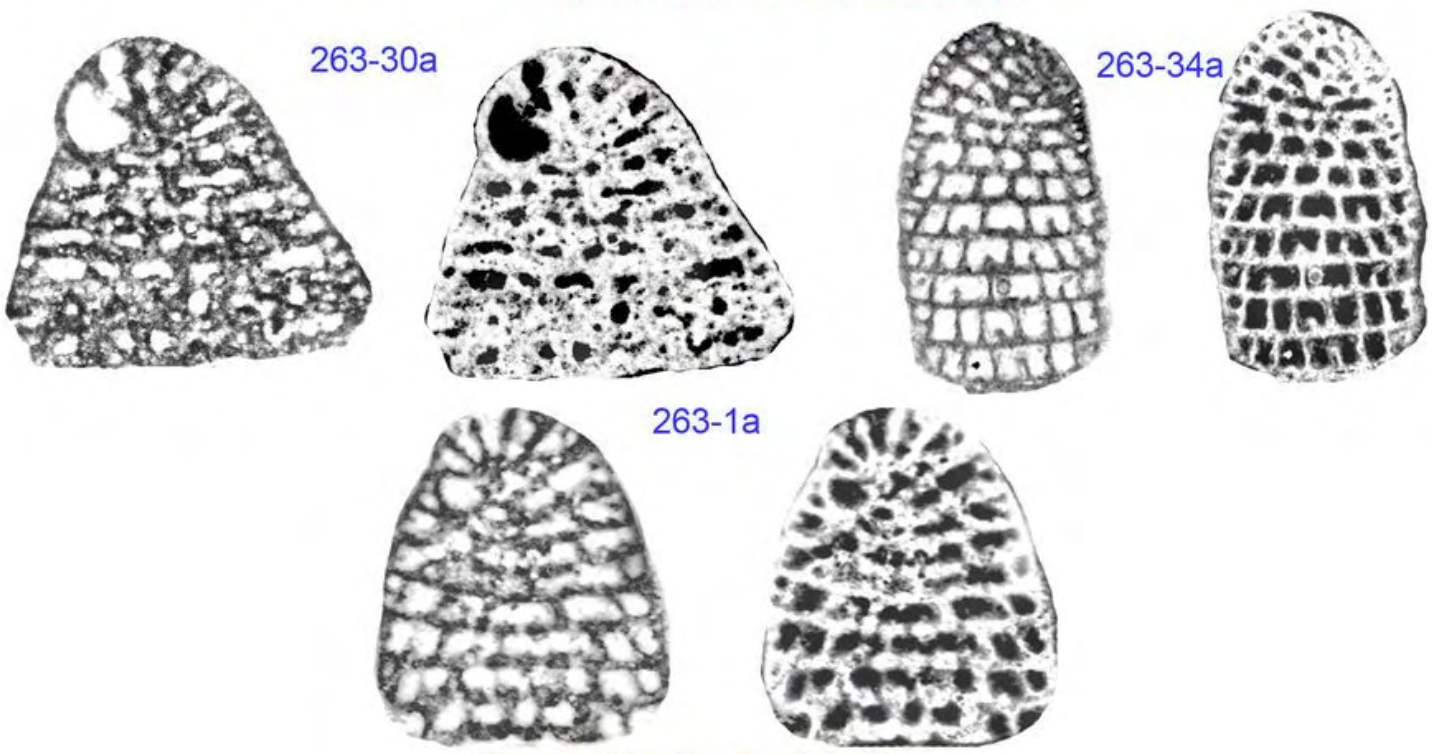

Paracoskinolina ? reicheli

Plate 60: Orbitolinids of the Compressissima zone in the Serre de Tourre section. Orbitolinopsis debelmasi: 26335b; Paleodictyoconus actinostoma: 217-1a; Paracoskinolina ? praereicheli: 263-10a, 263-10b; Paracoskinolina ? reicheli: 263-1a, 263-30a, 263-34a; Paracoskinolina aff. sunnilandensis: 263-26b. Scale bar $=500 \mu \mathrm{m}$. 


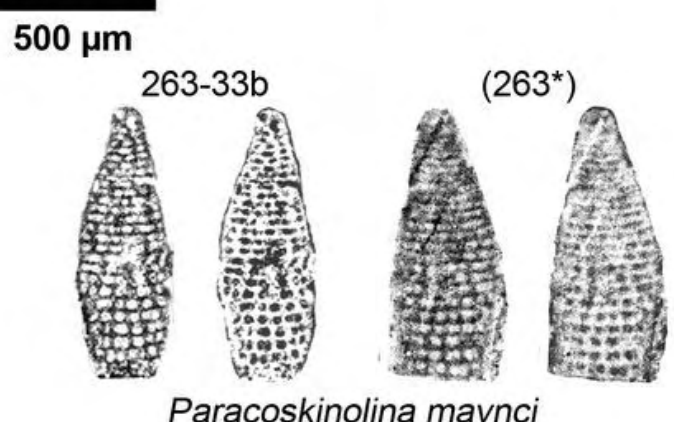

Paracoskinolina maynci

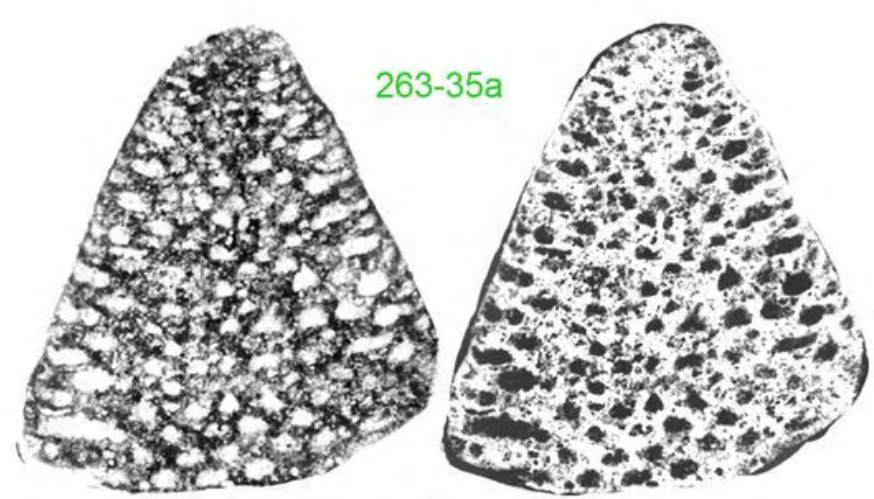

Orbitolinopsis debelmasi
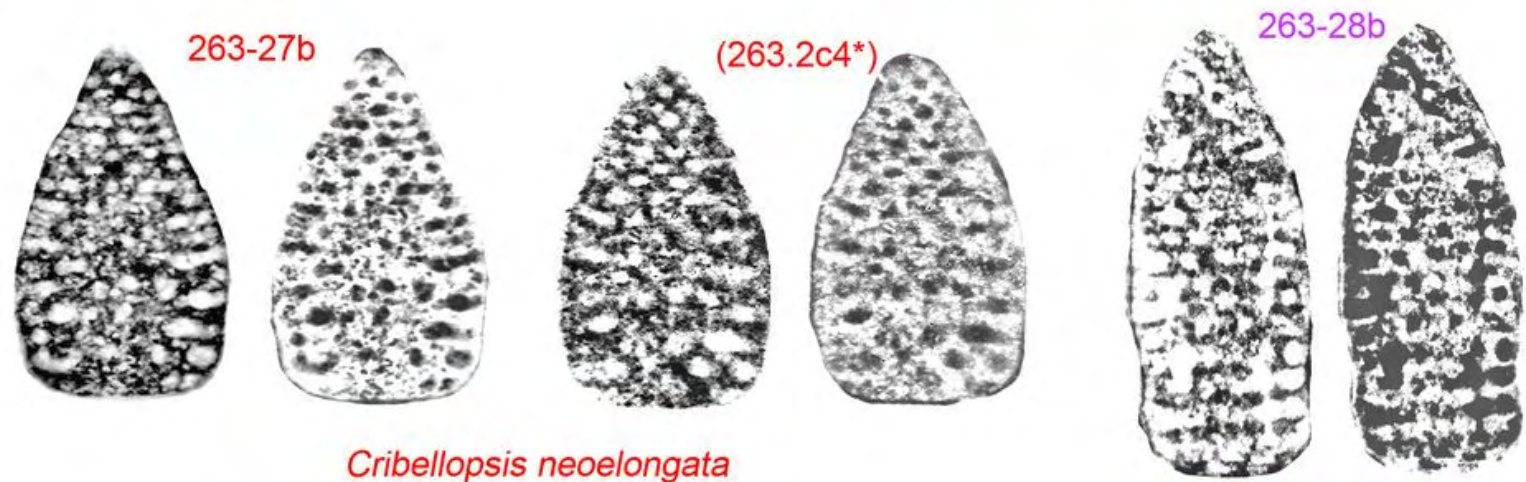

Cribellopsis neoelongata
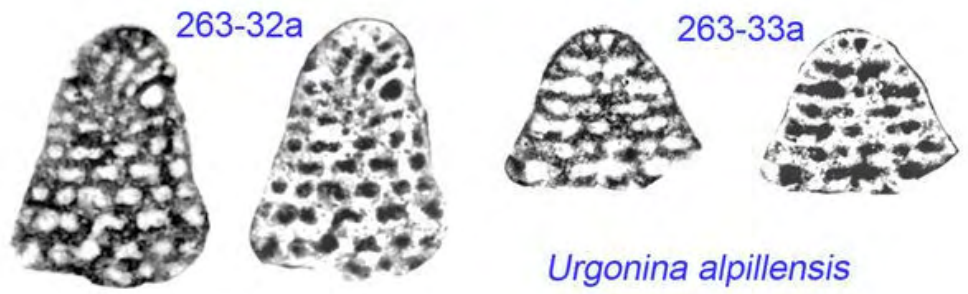

Urgonina alpillensis
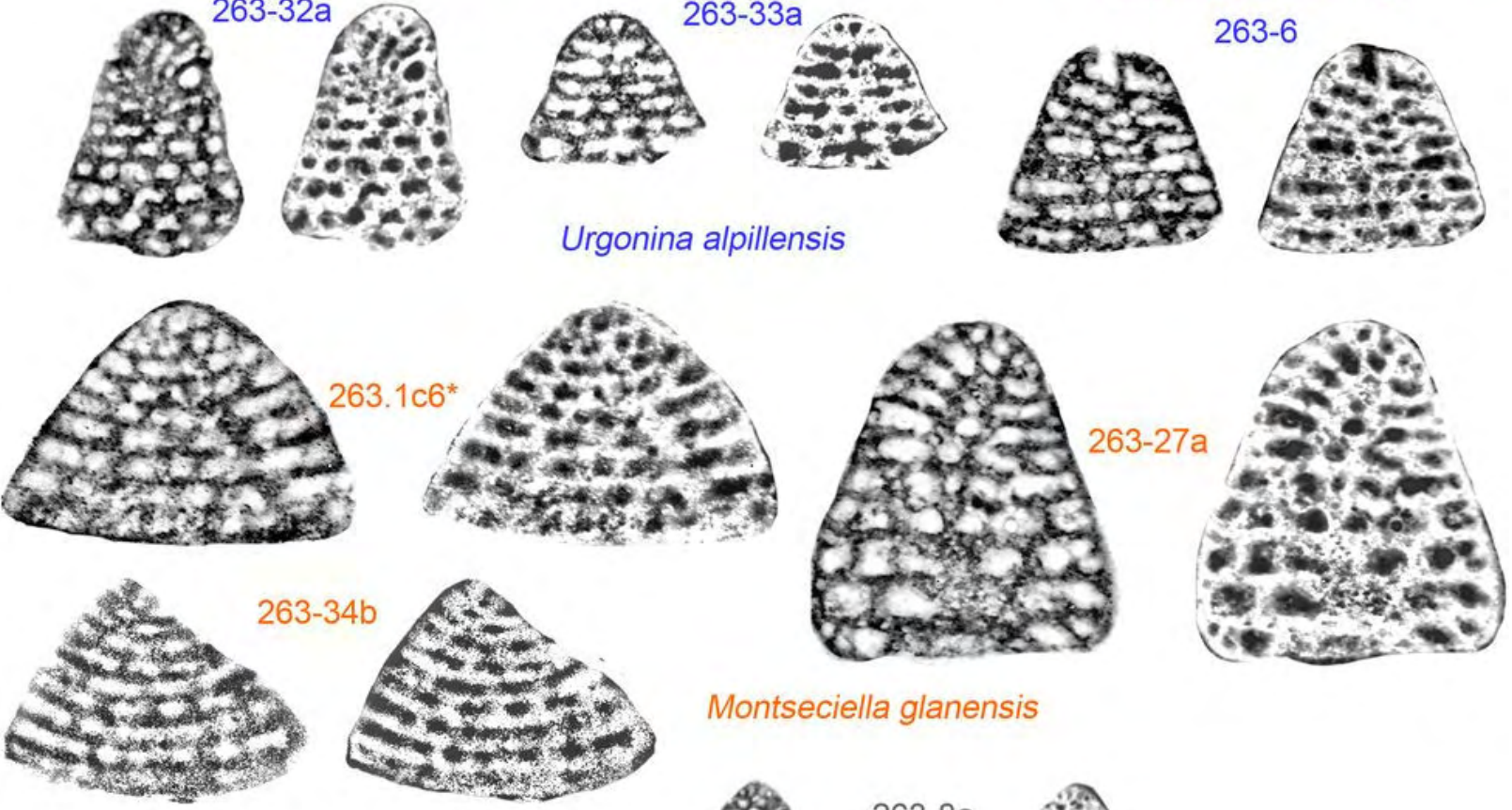

Montseciella glanensis

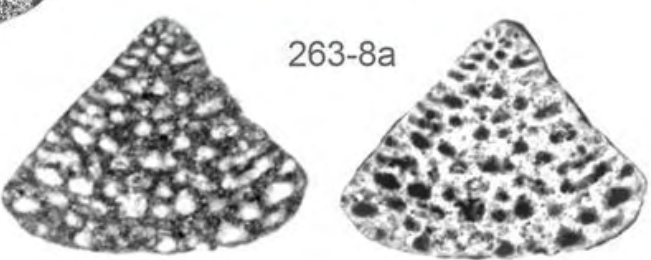

Cribellopsis schroederi

Plate 61: Orbitolinids of the Compressissima zone in the Serre de Tourre section. Cribellopsis neoelongata: 263-27b

(263.2c4*); Cribellopsis schroederi: 263-8a; Cribellopsis thieuloyi: 263-28b; Montseciella glanensis: 263.1c6*, 26327a, 263-34b; Orbitolinopsis debelmasi: 263-35a; Paracoskinolina maynci: 263-33b (263*); Urgonina alpillensis: 263-6, 263-32a, 263-33a. Scale bar $=500 \mu \mathrm{m}$. 


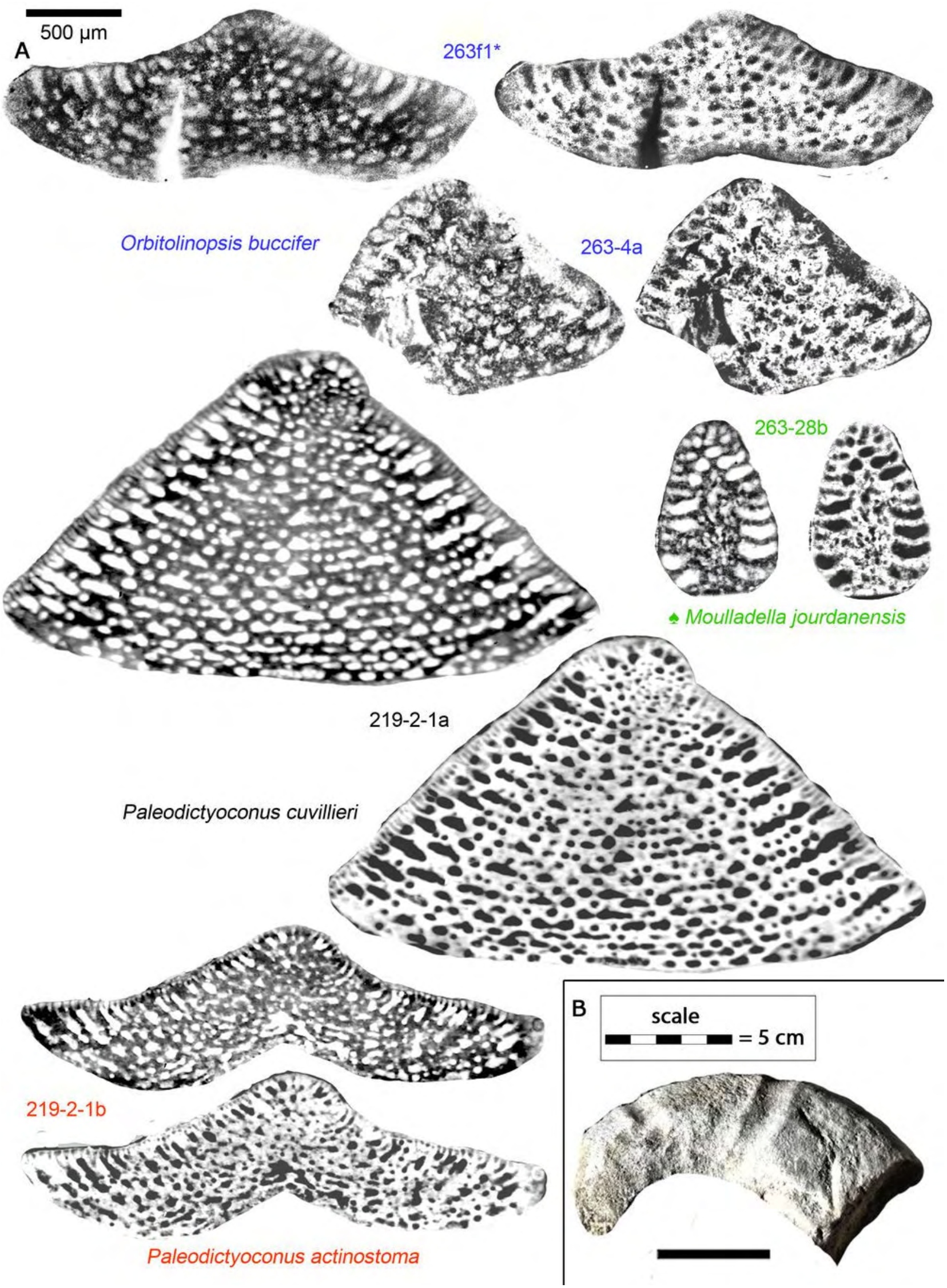

Plate 62: A) Moulladella and orbitolinids of the Moutonianum zone in the Serre de Tourre section. Moulladella jourdanensis: 263-28b; Orbitolinopsis buccifer: 263f1*, 263-4a; Paleodictyoconus actinostoma: 219-2-1b; Paleodictyoconus cuvillieri: 219-2-1a. B) Puezalpella cf. uhligi, FSL 88968e. Scale bar (A) = $500 \mu \mathrm{m}$, and ammonite scale bar (B) $=5 \mathrm{~cm}$. 

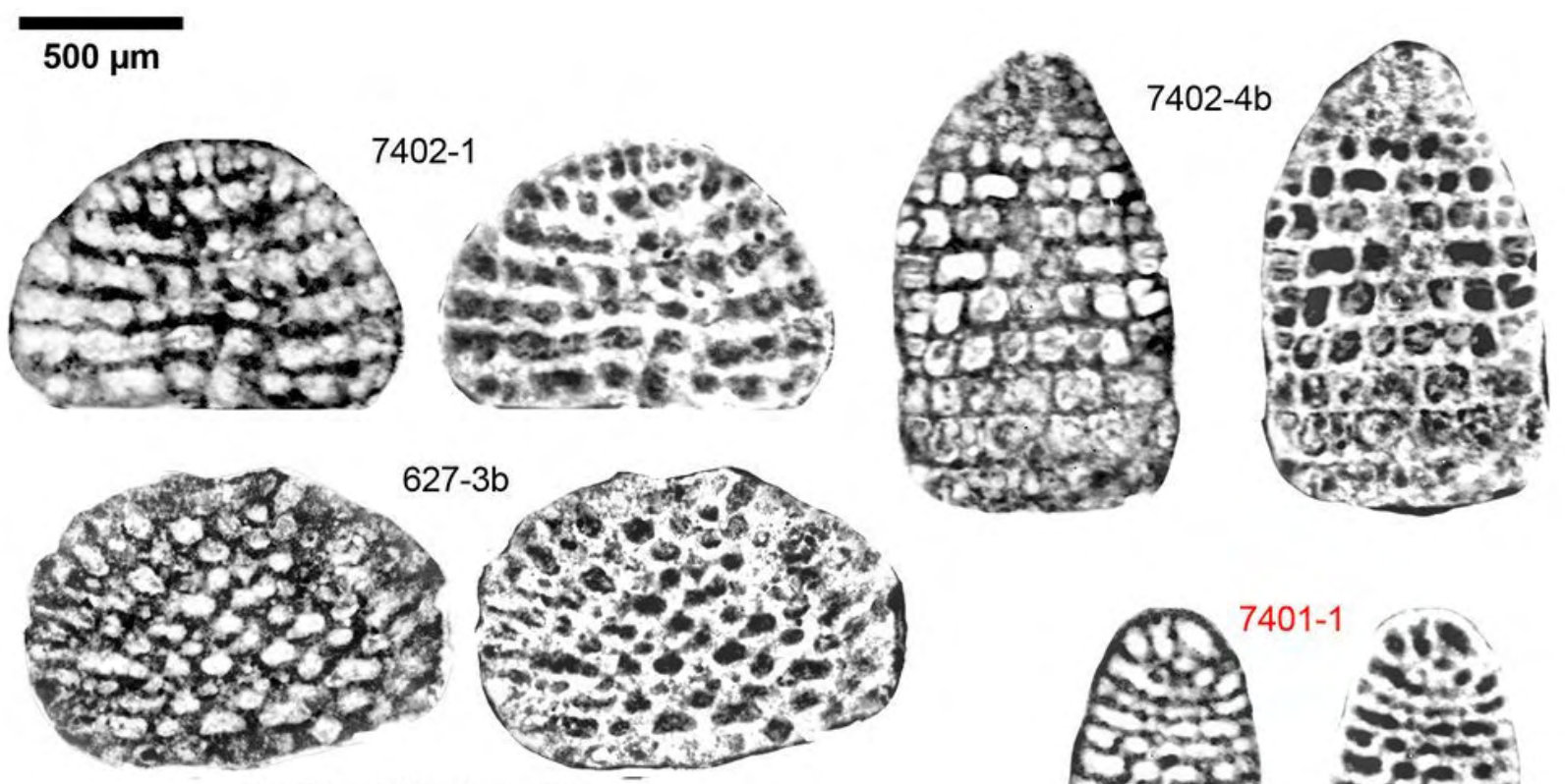

Montseciella glanensis
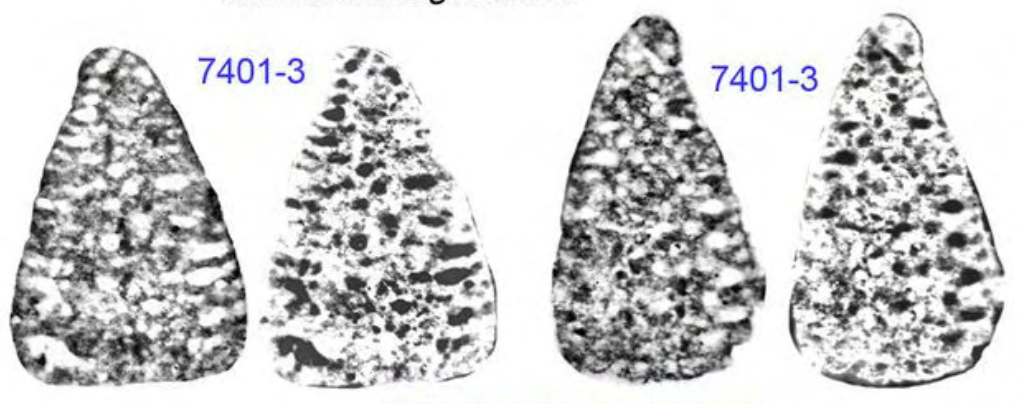

Cribellopsis neoelongata
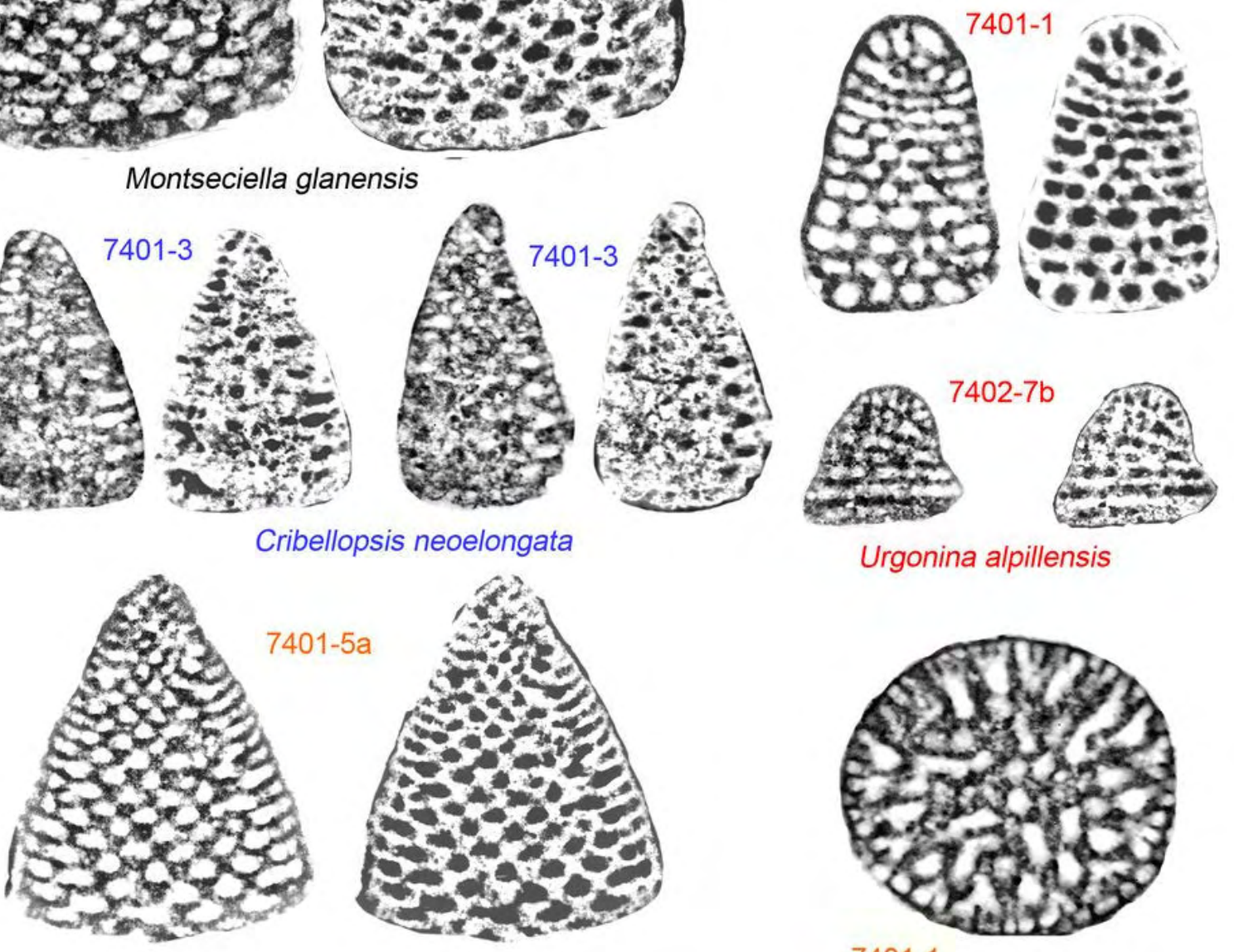

Urgonina alpillensis
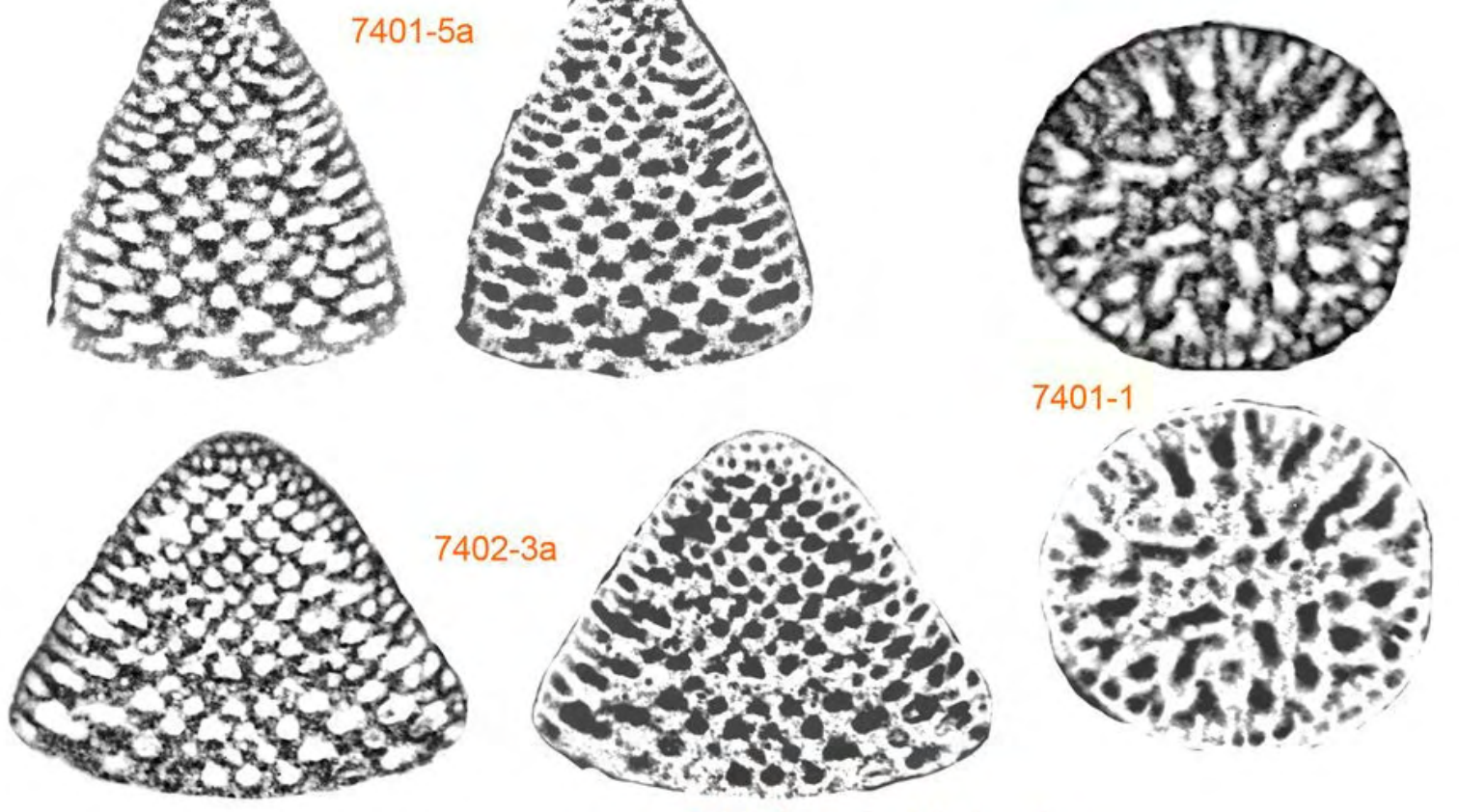

Orbitolinopsis debelmasi

Plate 63: Orbitolinids of the Vandenheckei zone in the Serre de Tourre section. Cribellopsis neoelongata: 7401-3; Montseciella glanensis: 627-3b, 7402-1, 7402-4b; Orbitolinopsis debelmasi: 7401-1, 7401-5a, 7402-3a; Urgonina alpillensis: $7401-1,7402-7 \mathrm{~b}$. Scale bar $=500 \mu \mathrm{m}$. 


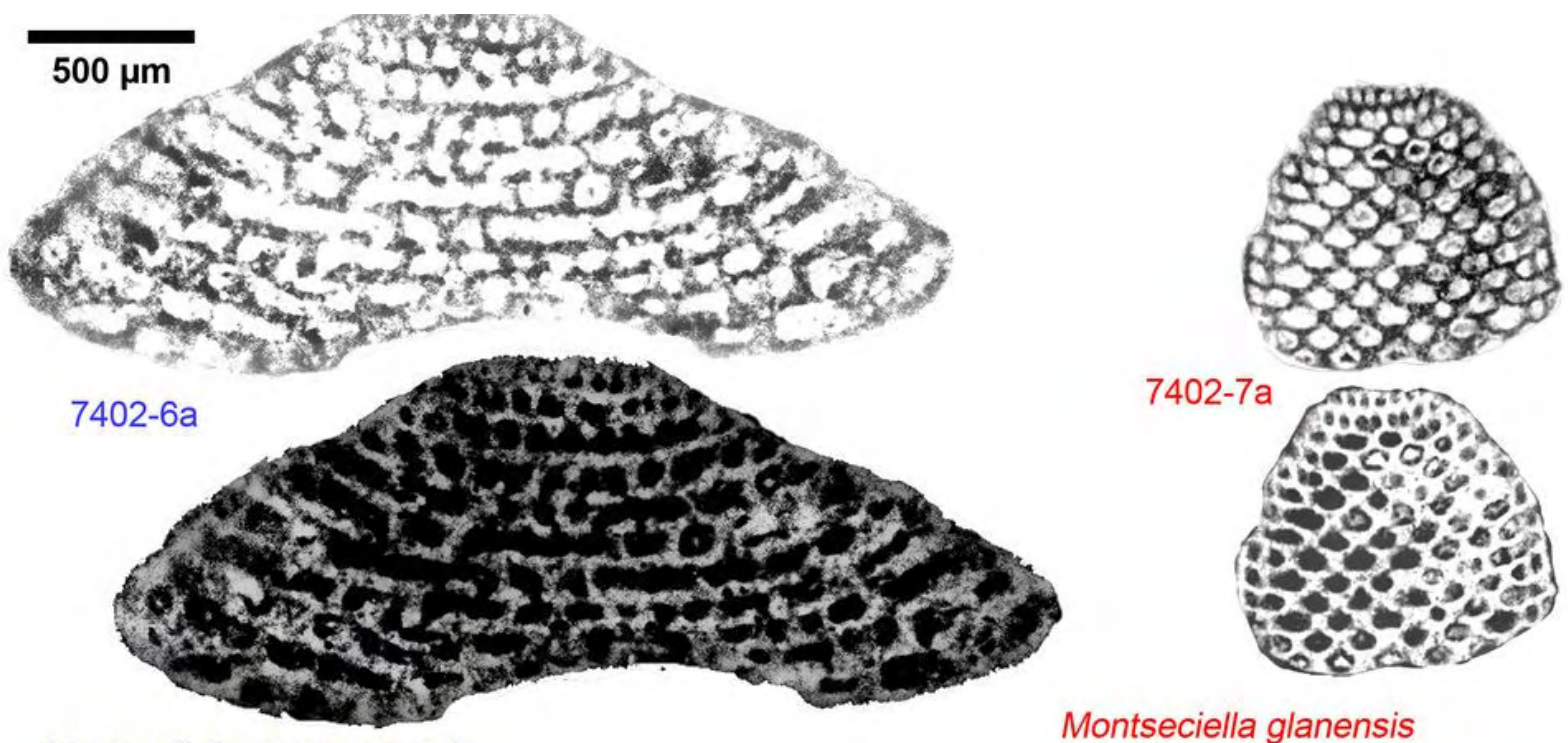

Montseciella cf. alguerensis
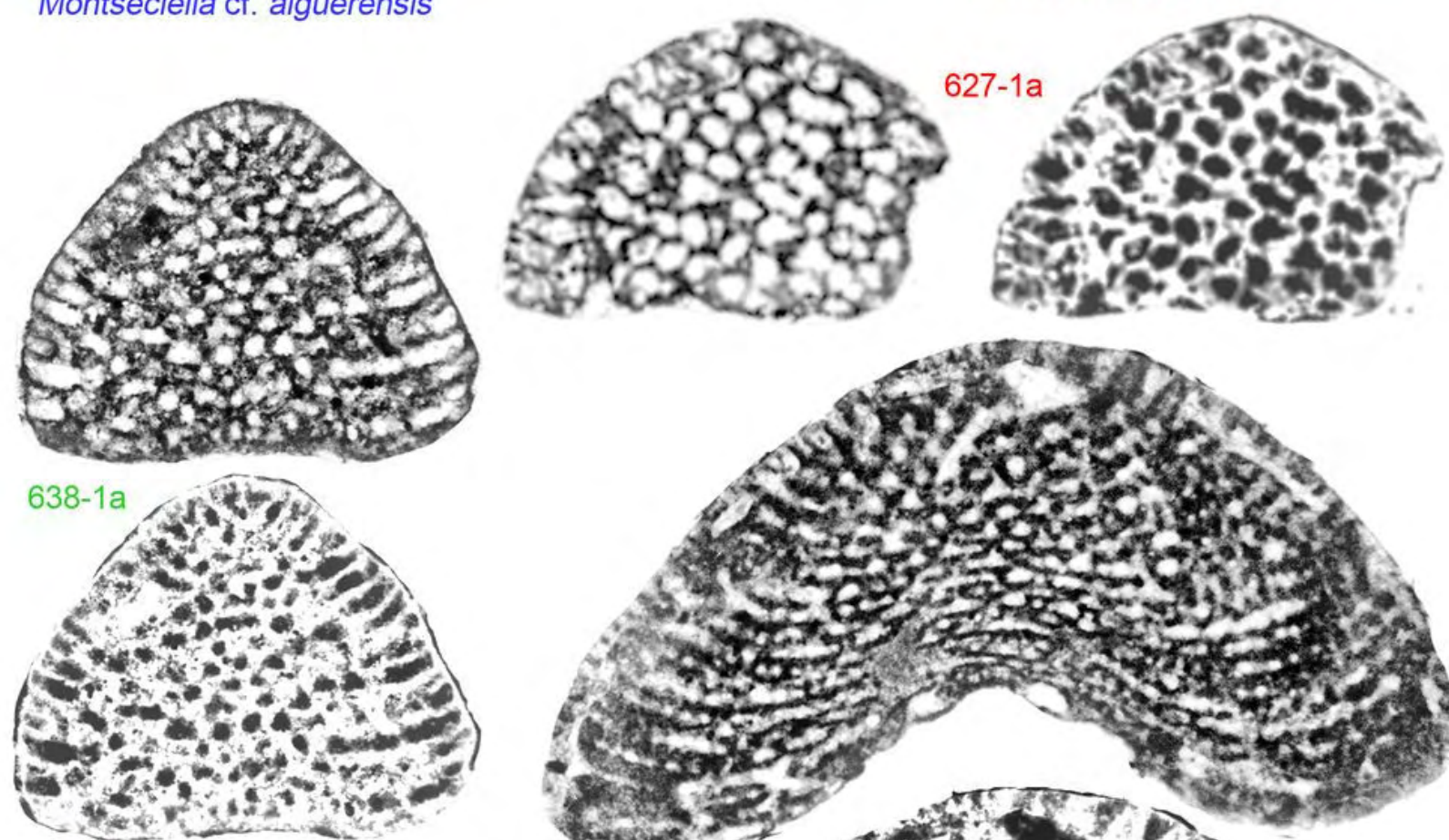

Orbitolinopsis debelmasi

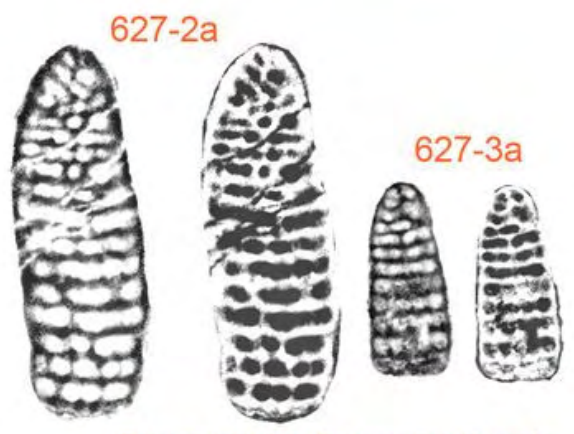

Paracoskinolina querolensis

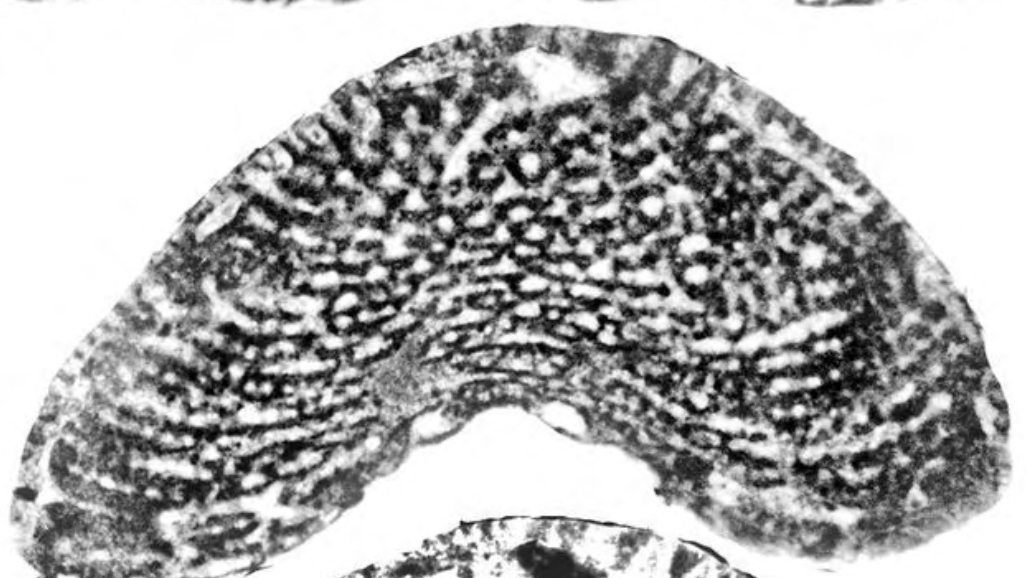

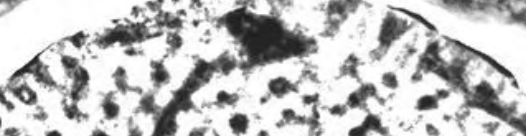

$627-2 b$

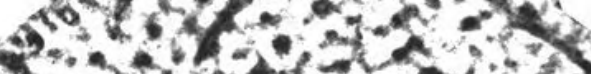

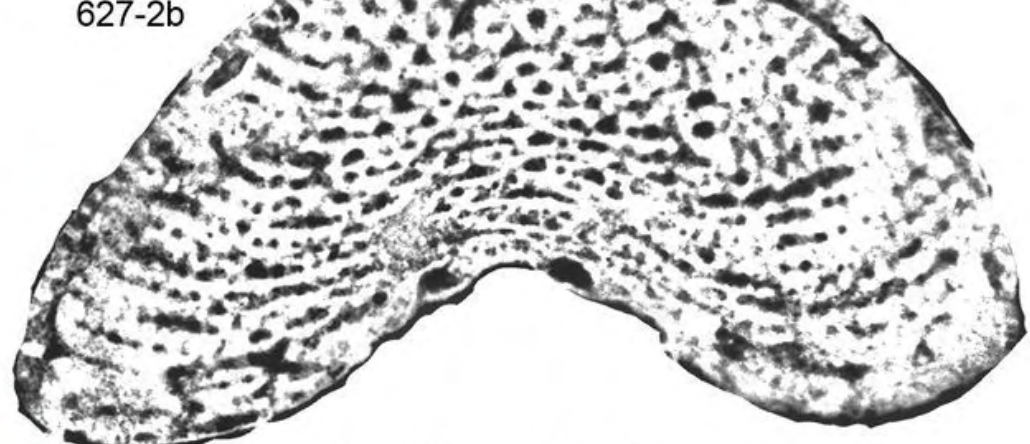

Paleodictyoconus actinostoma

Plate 64: Orbitolinids of the Vandenheckei zone in the Serre de Tourre section. Montseciella cf. alguerensis: $7402-$ 6a; Montseciella glanensis: 627-1a, 7402-7a; Orbitolinopsis debelmasi: 638-1a; Paleodictyoconus actinostoma: 6272b; Paracoskinolina querolensis: 627-2a, 627-3a. Scale bar $=500 \mu \mathrm{m}$. 

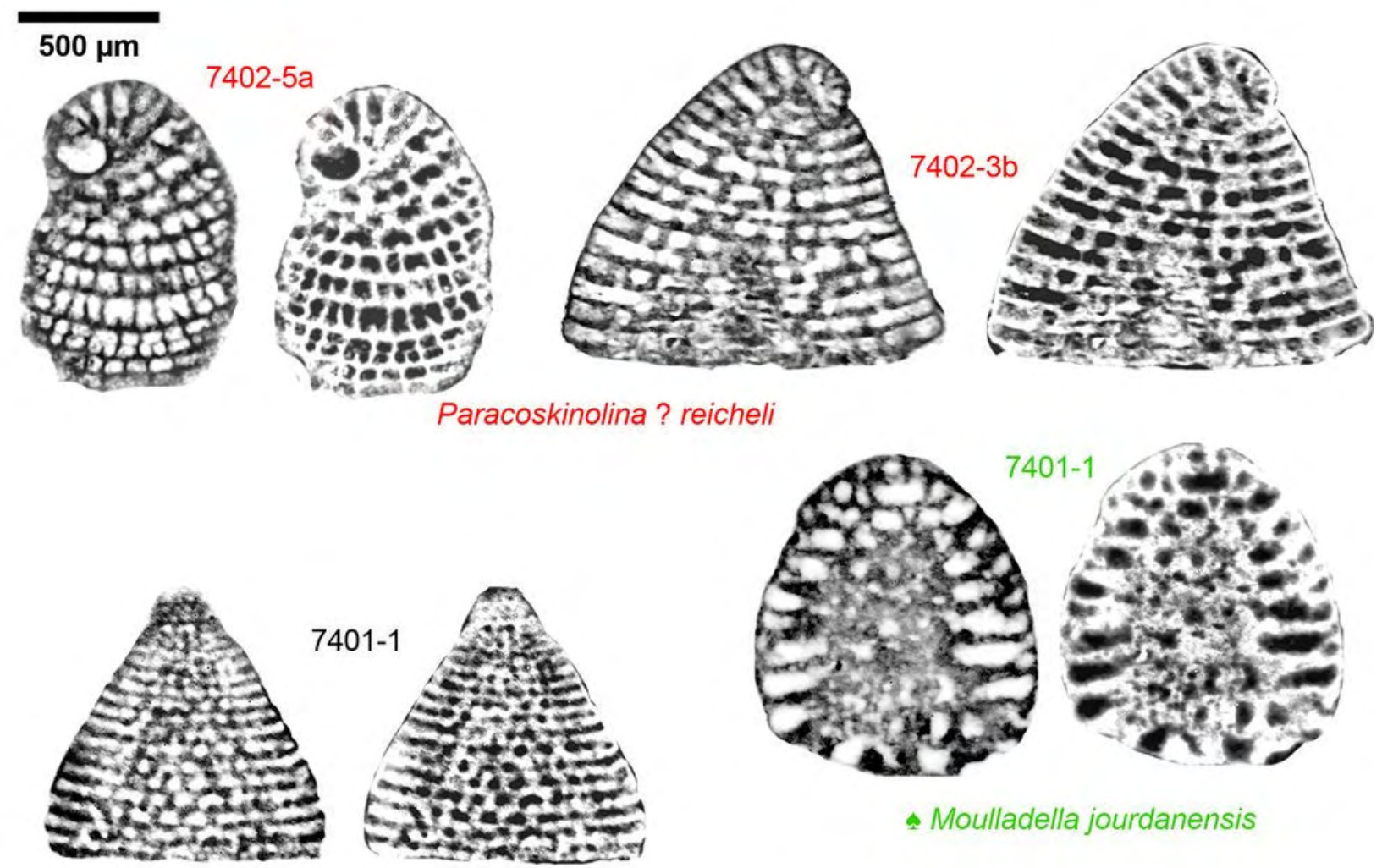

- Moulladella jourdanensis
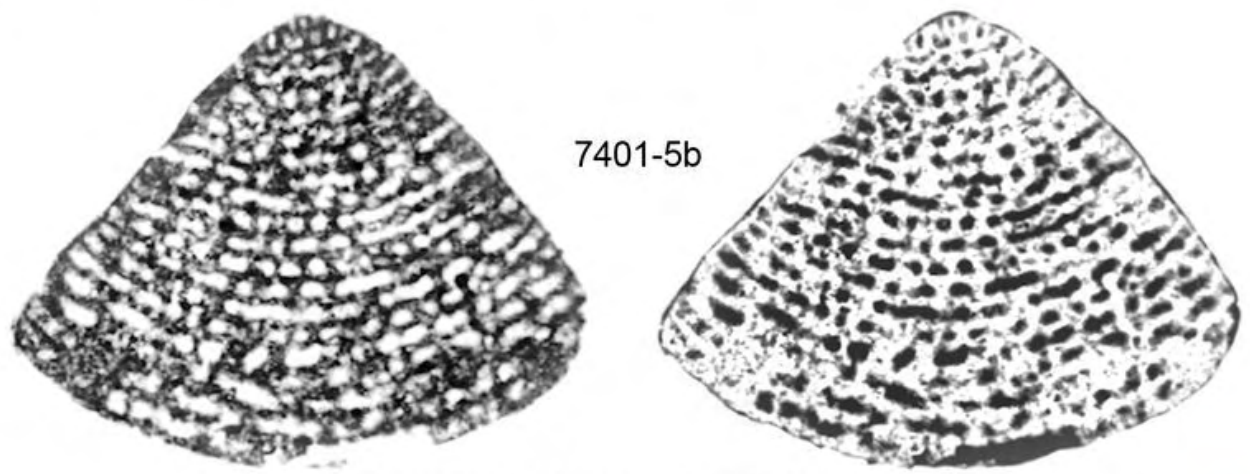

Paracoskinolina aff. sunnilandensis
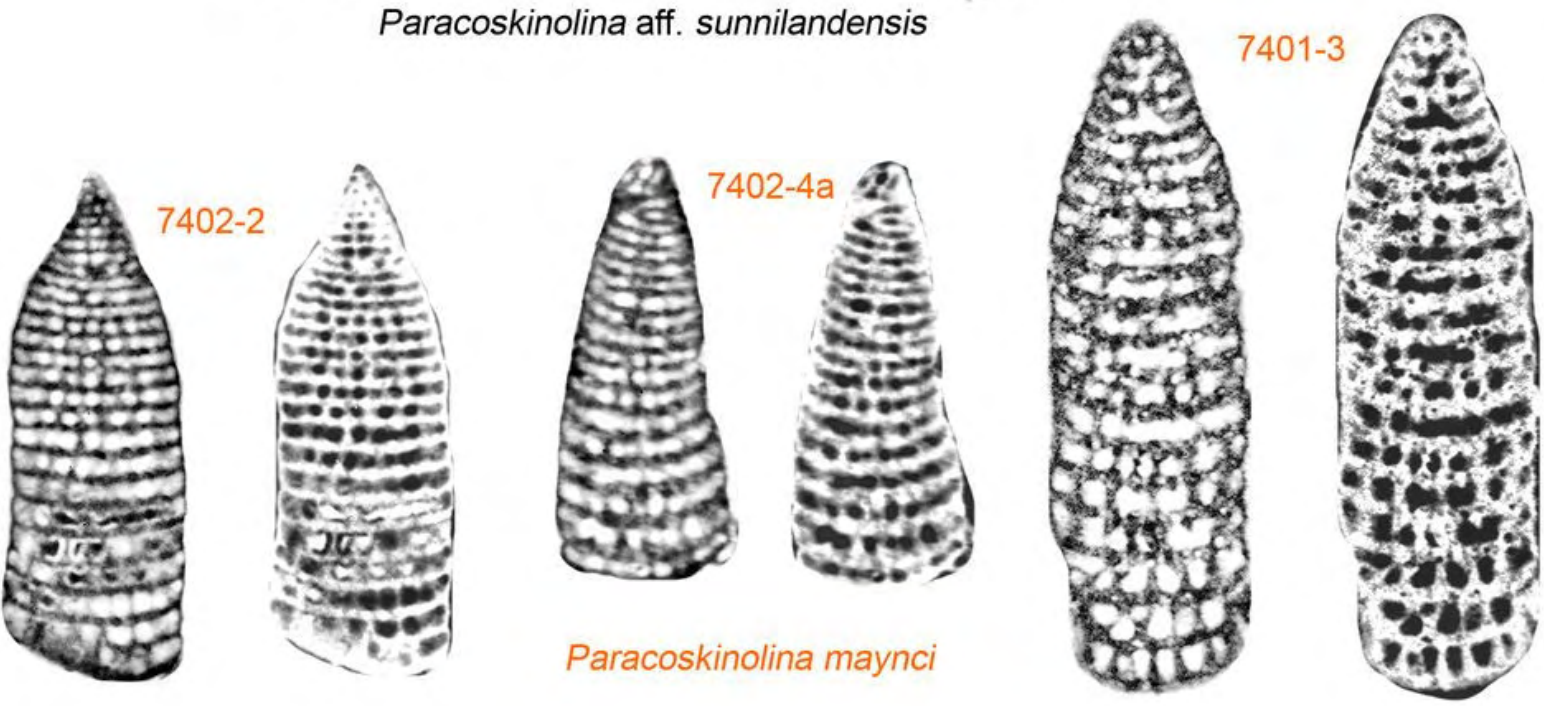

Plate 65: Moulladella and orbitolinids of the Vandenheckei zone in the Serre de Tourre section. Moulladella jourdanensis: 7401-1; Paracoskinolina maynci: 7401-3, 7402-2, 7402-4a; Paracoskinolina ? reicheli: 7402-3b, 7402-5a; Paracoskinolina aff. sunnilandensis: 7401-1, 7401-5b. Scale bar $=500 \mu \mathrm{m}$. 

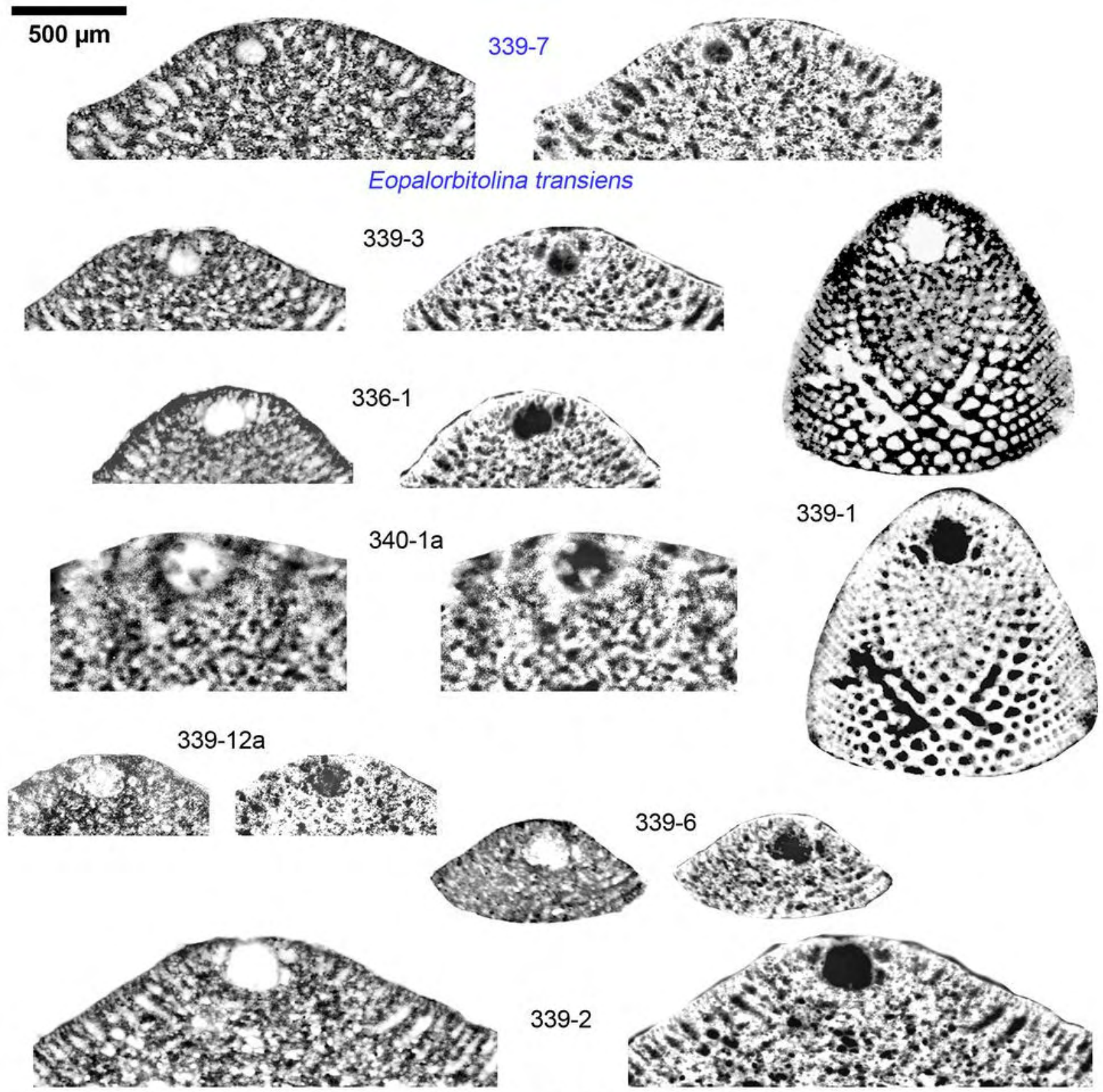

$339-2$

Palorbitolina lenticularis
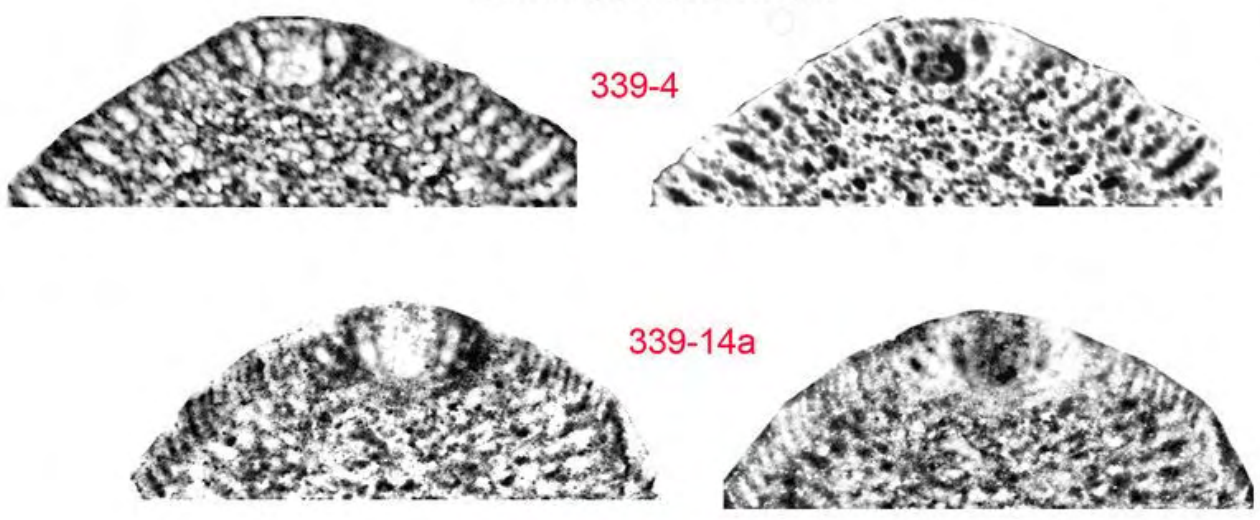

Palorbitolina ultima

Plate 66: Orbitolinids of the Giraudi and Sarasini zones in the Serre de Tourre section. Eopalorbitolina transiens: 339-7; Palorbitolina lenticularis: 336-1, 339-1, 339-2, 339-3, 339-6, 339-12a, 340-1a; Palorbitolina ultima: 339-4, 339-14a. Scale bar $=500 \mu \mathrm{m}$. 

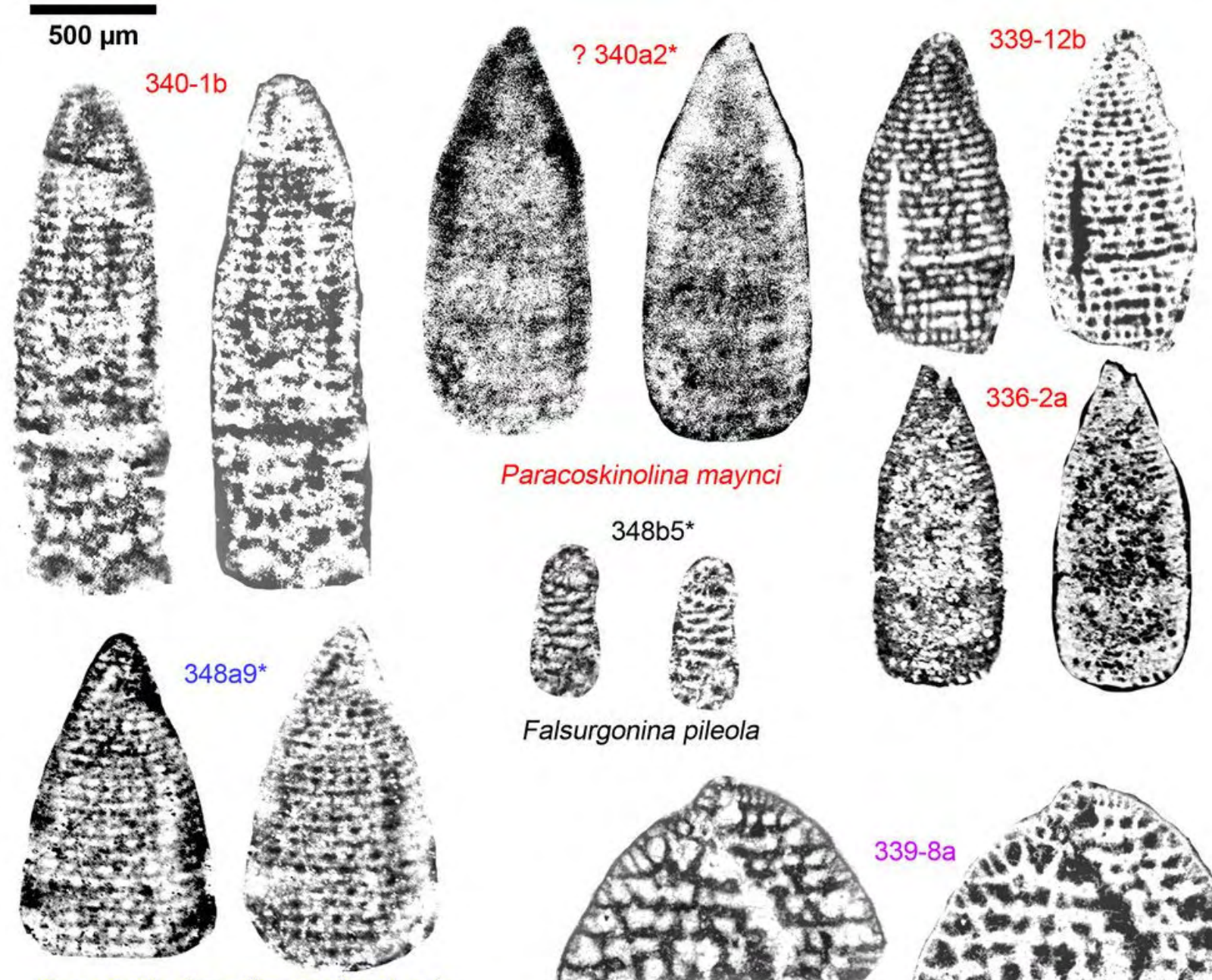

Paracoskinolina maynci

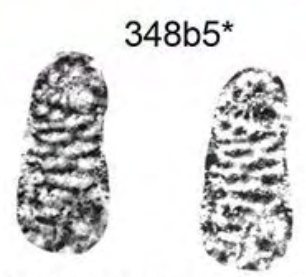

Falsurgonina pileola

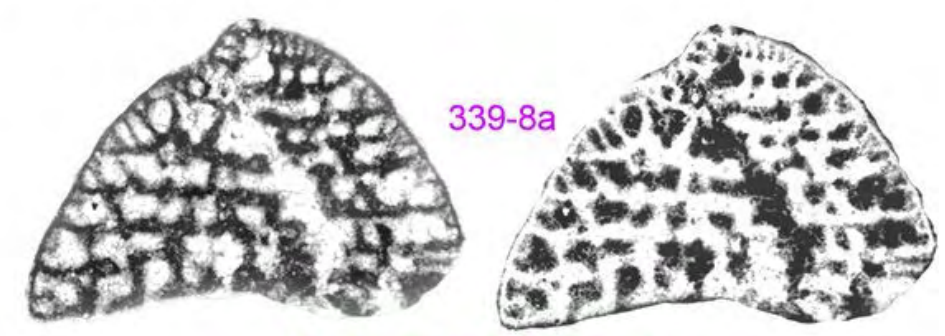

Montseciella alguerensis
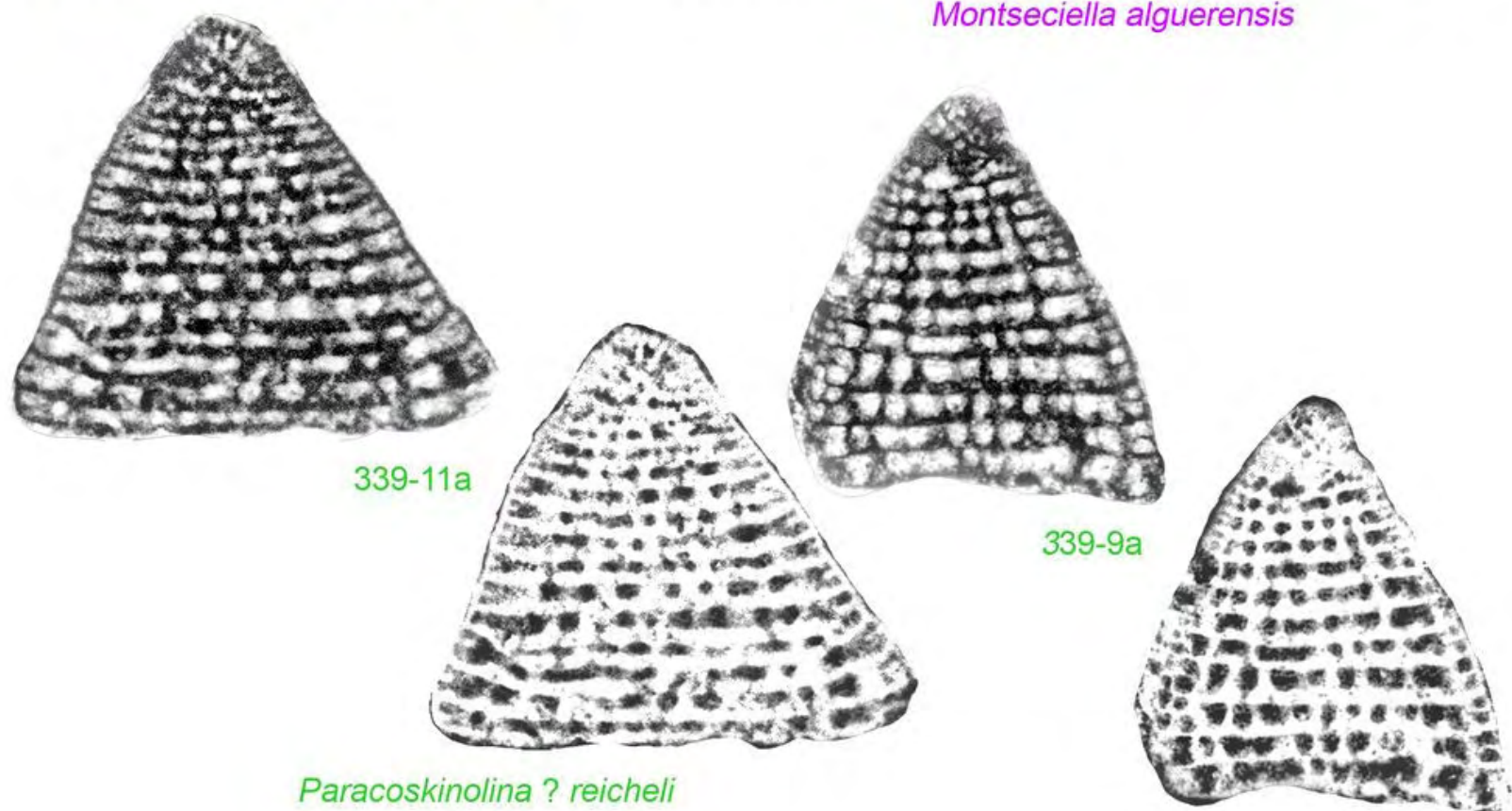

Plate 67: Orbitolinids of the Giraudi and Sarasini zones in the Serre de Tourre section. Falsurgonina pileola: 348b5*; Montseciella alguerensis: 339-8a; Paracoskinolina maynci: 336-2a, 339-12b, ? 340a2* [NF], 340-1b; Paracoskinolina ? reicheli: 339-9a, 339-11a.; Paracoskinolina aff. sunnilandensis: 348a9*. Scale bar $=500 \mu \mathrm{m}$. 


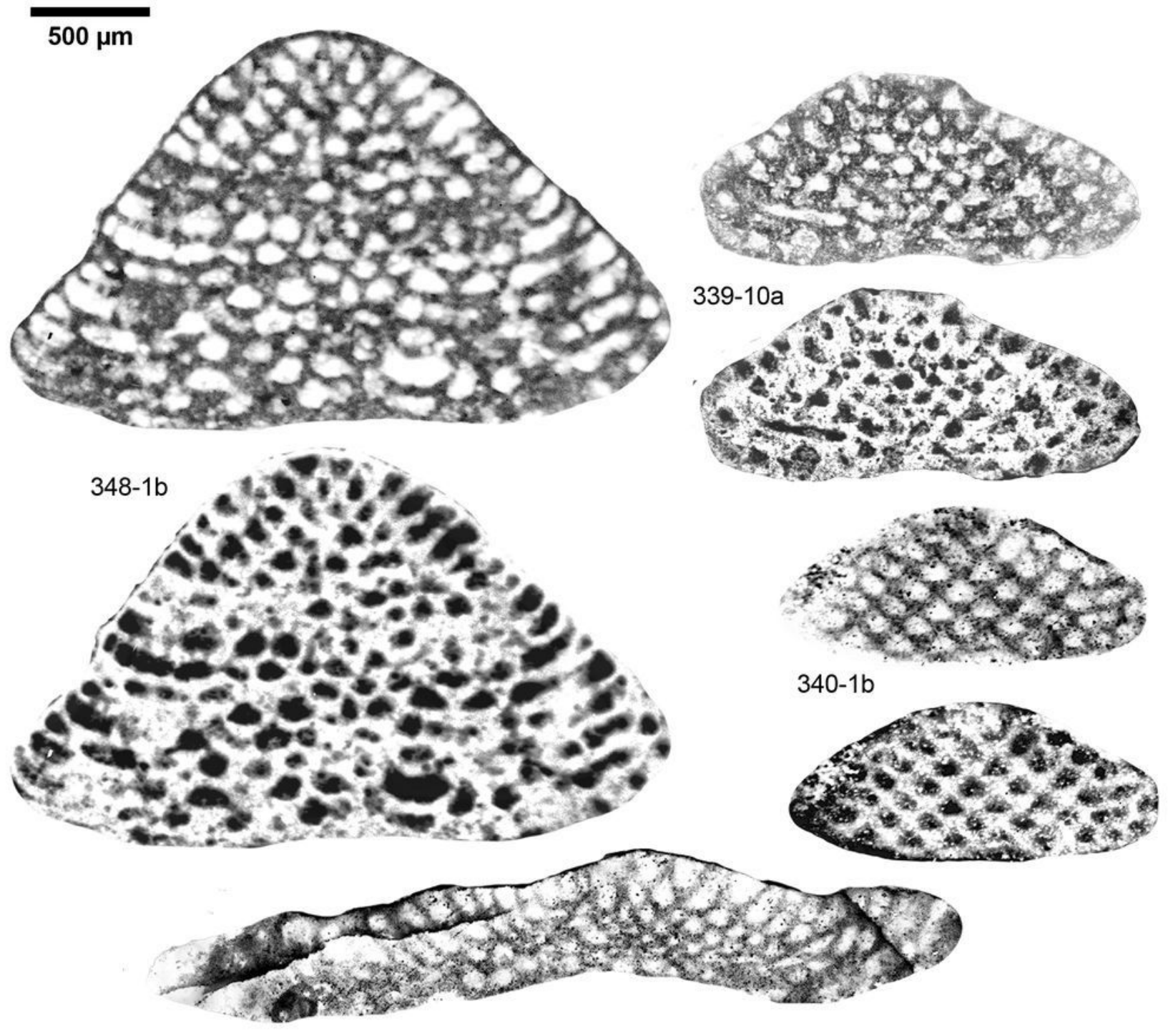

$348 \mathrm{~b} 10$

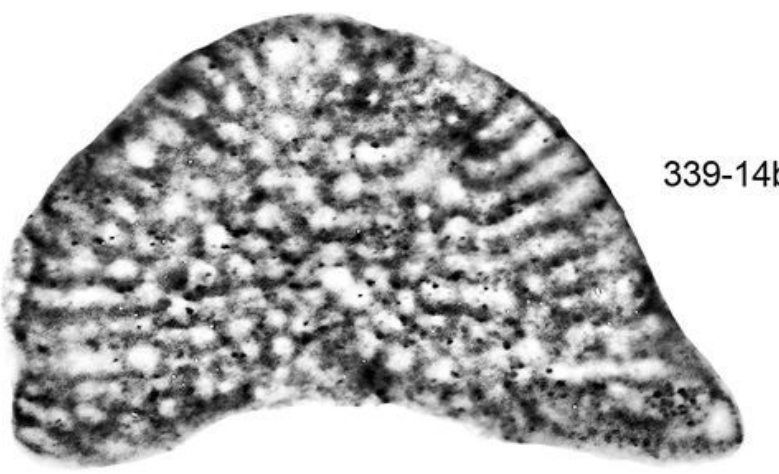

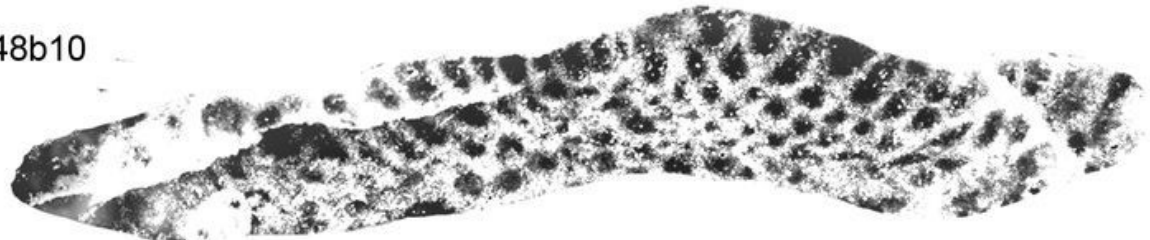

Orbitolinopsis buccifer

Plate 68: Orbitolinids of the Giraudi and Sarasini zones in the Serre de Tourre section. Orbitolinopsis buccifer: 339$10 a, 339-14 b, 340-1 b, 348-1 b$, ? 348b10*[NF]. Scale bar $=500 \mu \mathrm{m}$. 

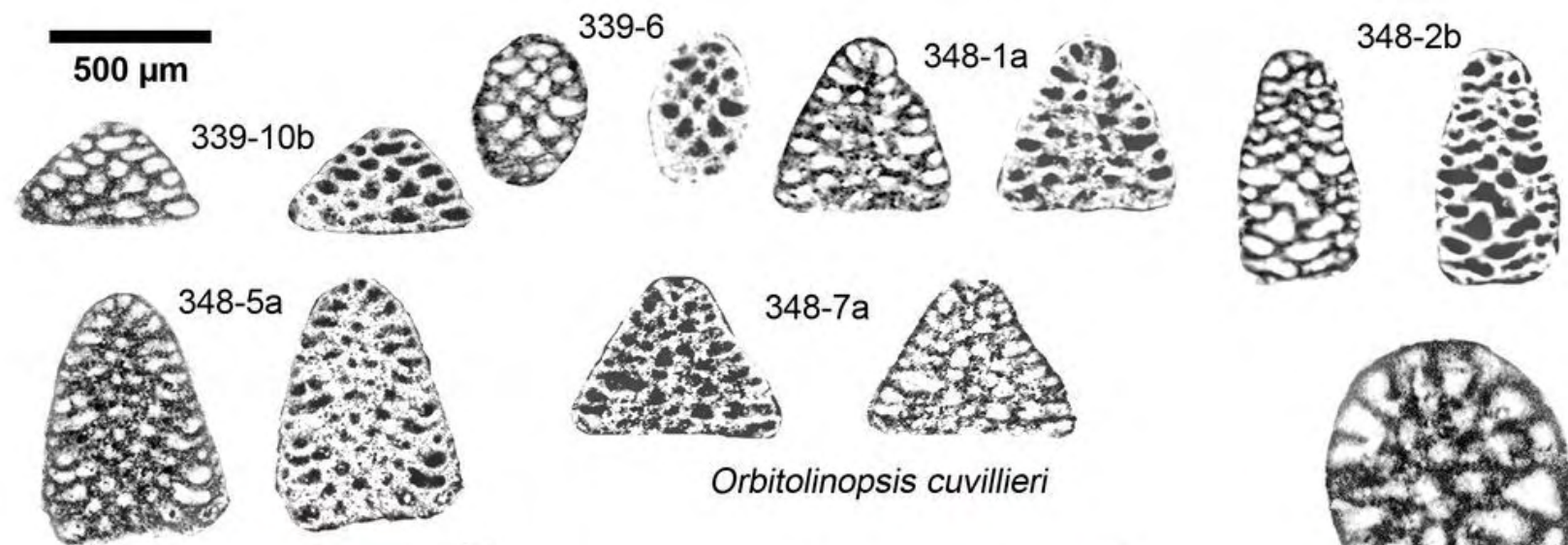

Orbitolinopsis cuvillieri
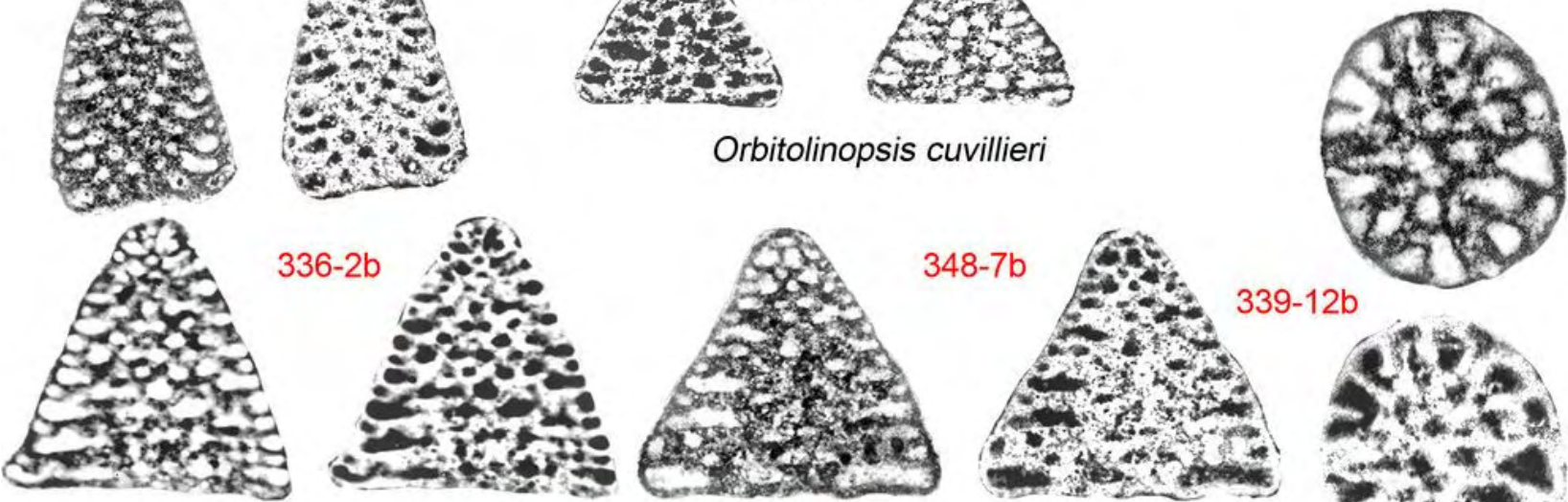

Orbitolinopsis briacensis

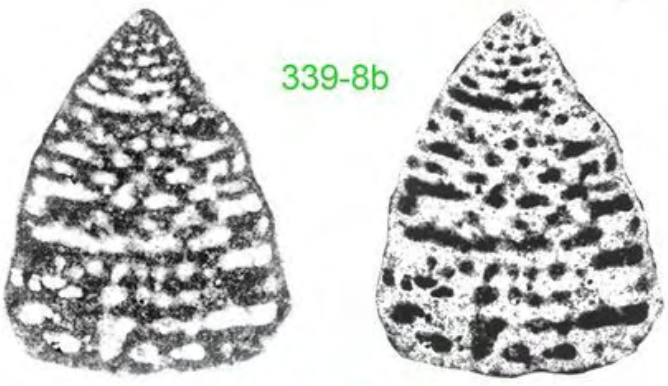

Cribellopsis neoelongata

\section{339-8b}

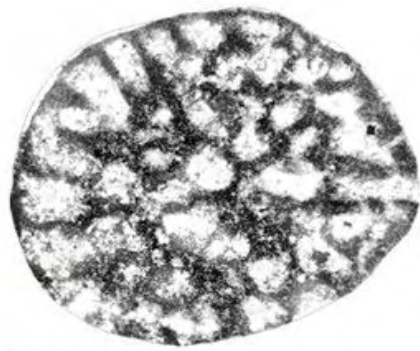

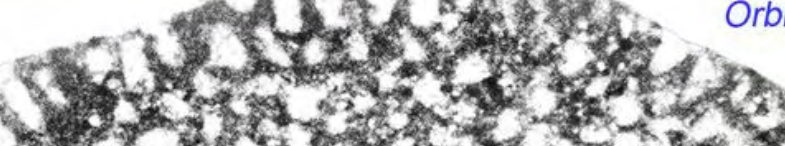

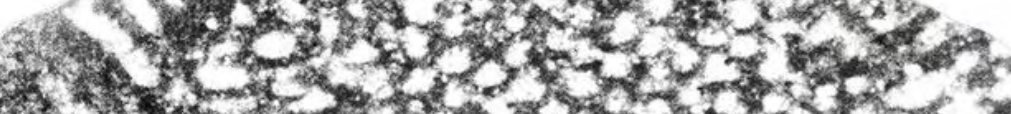
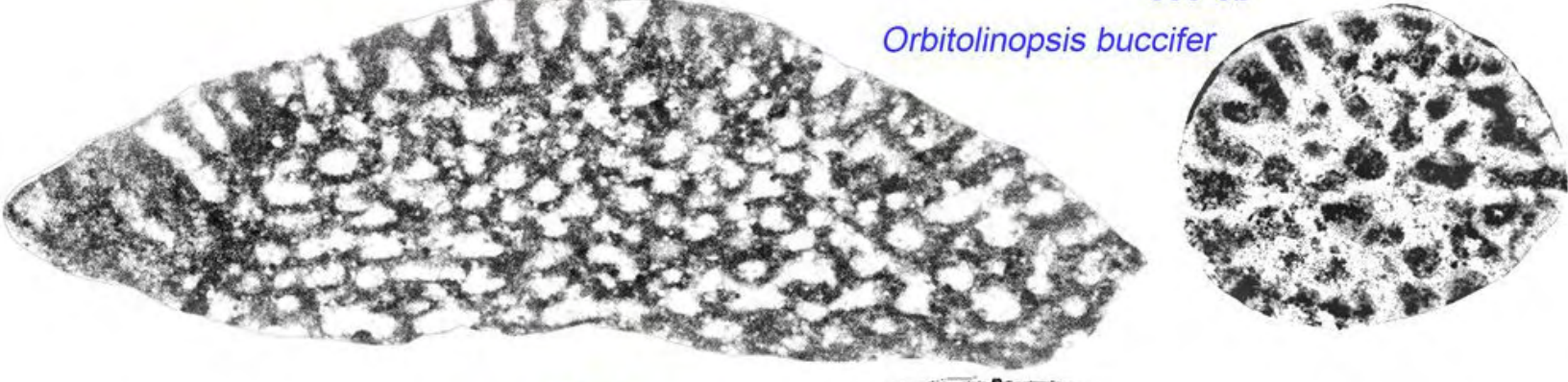

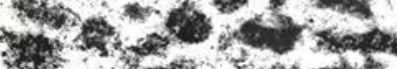

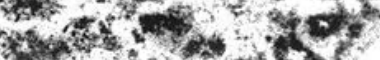

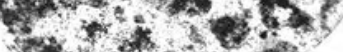

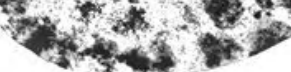

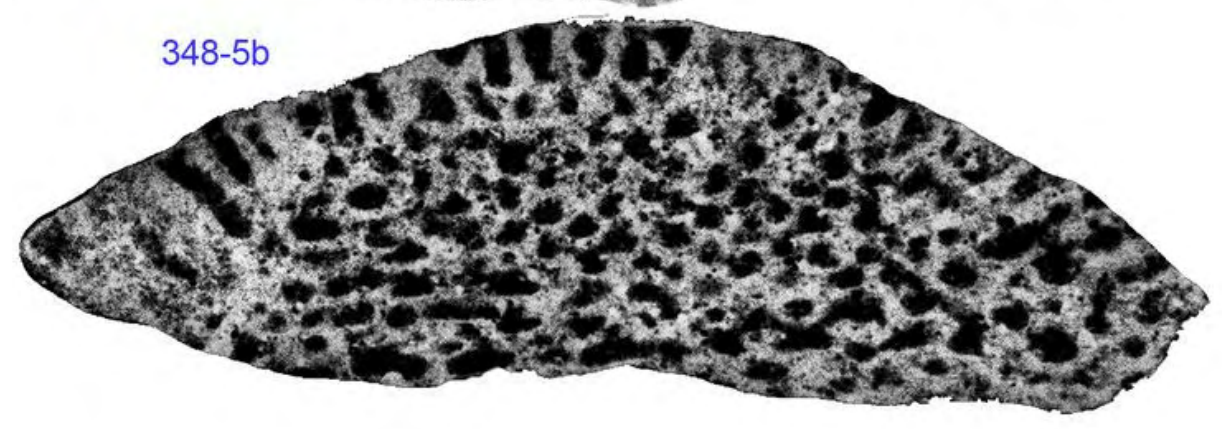

Plate 69: Orbitolinids of the Giraudi and Sarasini zones in the Serre de Tourre section. Cribellopsis neoelongata: 339-8b; Orbitolinopsis briacensis: 336-2b, 339-12b, 348-7b; Orbitolinopsis buccifer: 339-8b, 348-5b; Orbitolinopsis cuvillieri: 339-6, 339-10b, 348-1a, 348-2b, 348-7a, 348-54. Scale bar $=500 \mu \mathrm{m}$. 

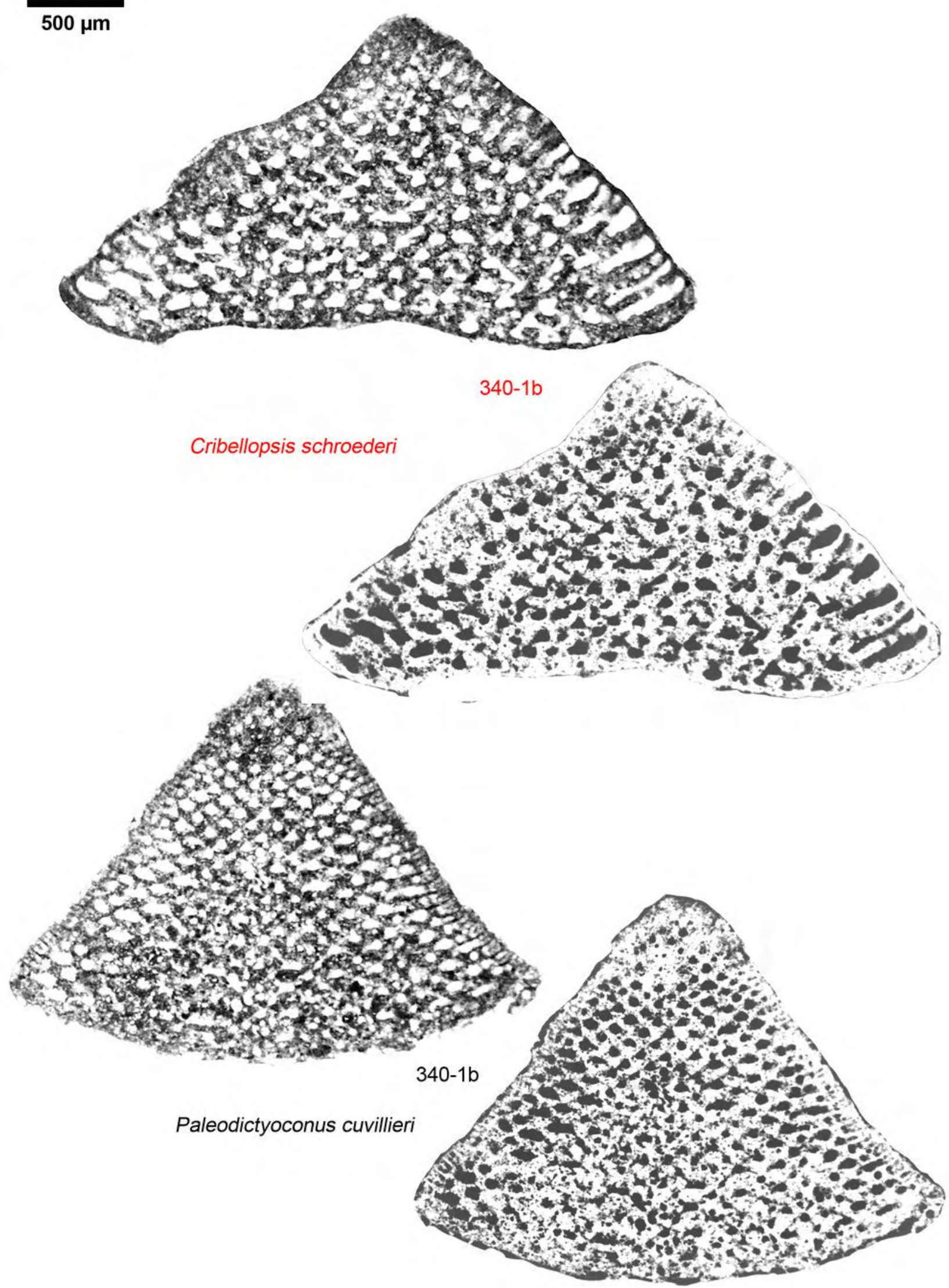

Plate 70: Orbitolinids of the Giraudi and Sarasini zones in the Serre de Tourre section. Cribellopsis schroederi: 340$1 \mathrm{~b}$; Paleodictyoconus cuvillieri: 340-1b. Scale bar $=500 \mu \mathrm{m}$. 


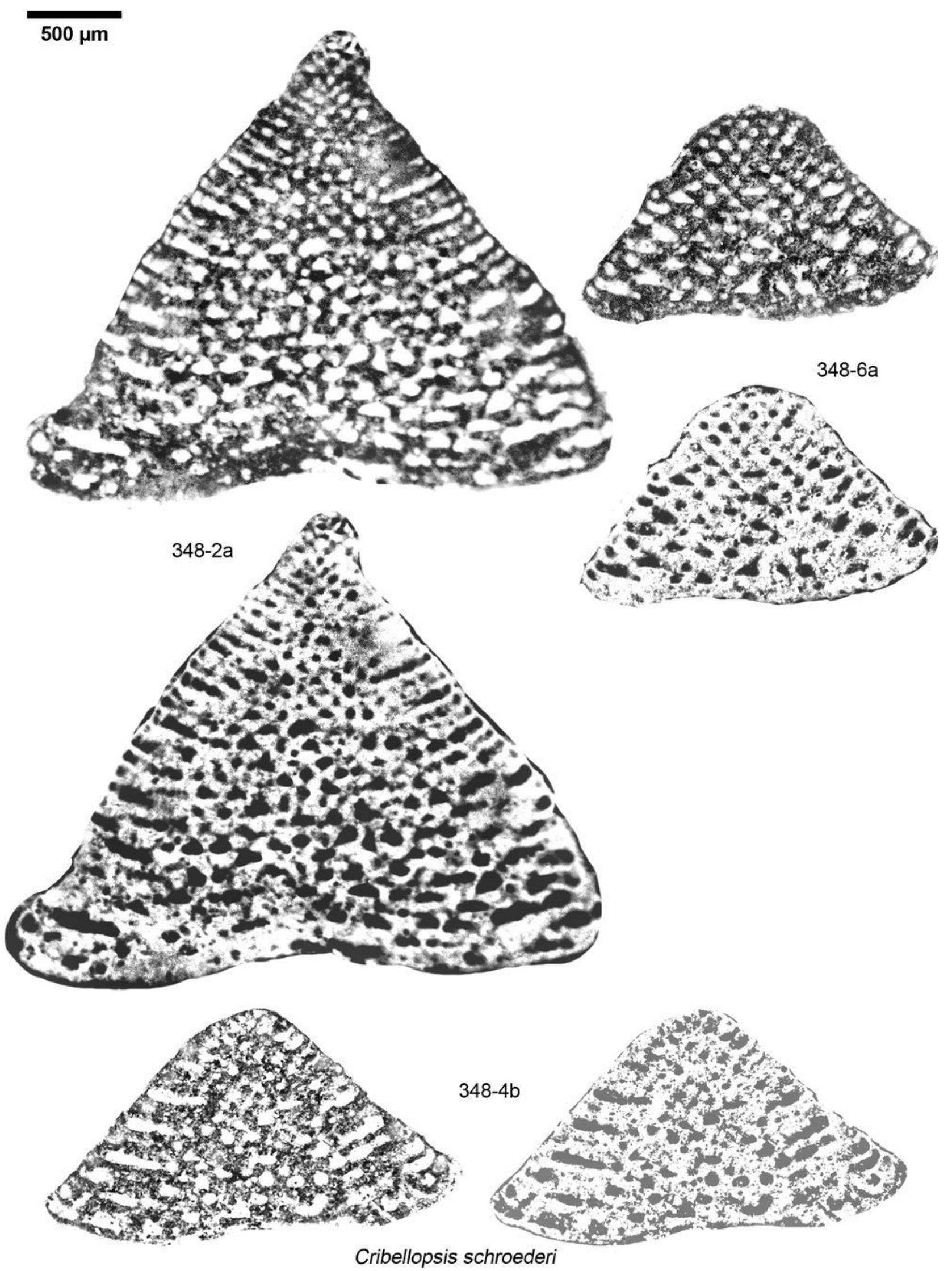

Plate 71: Orbitolinids of the Giraudi and Sarasini zones in the Serre de Tourre section. Cribellopsis schroederi: 348$2 a, 348-4 b, 348-6 a$. Scale bar $=500 \mu \mathrm{m}$. 

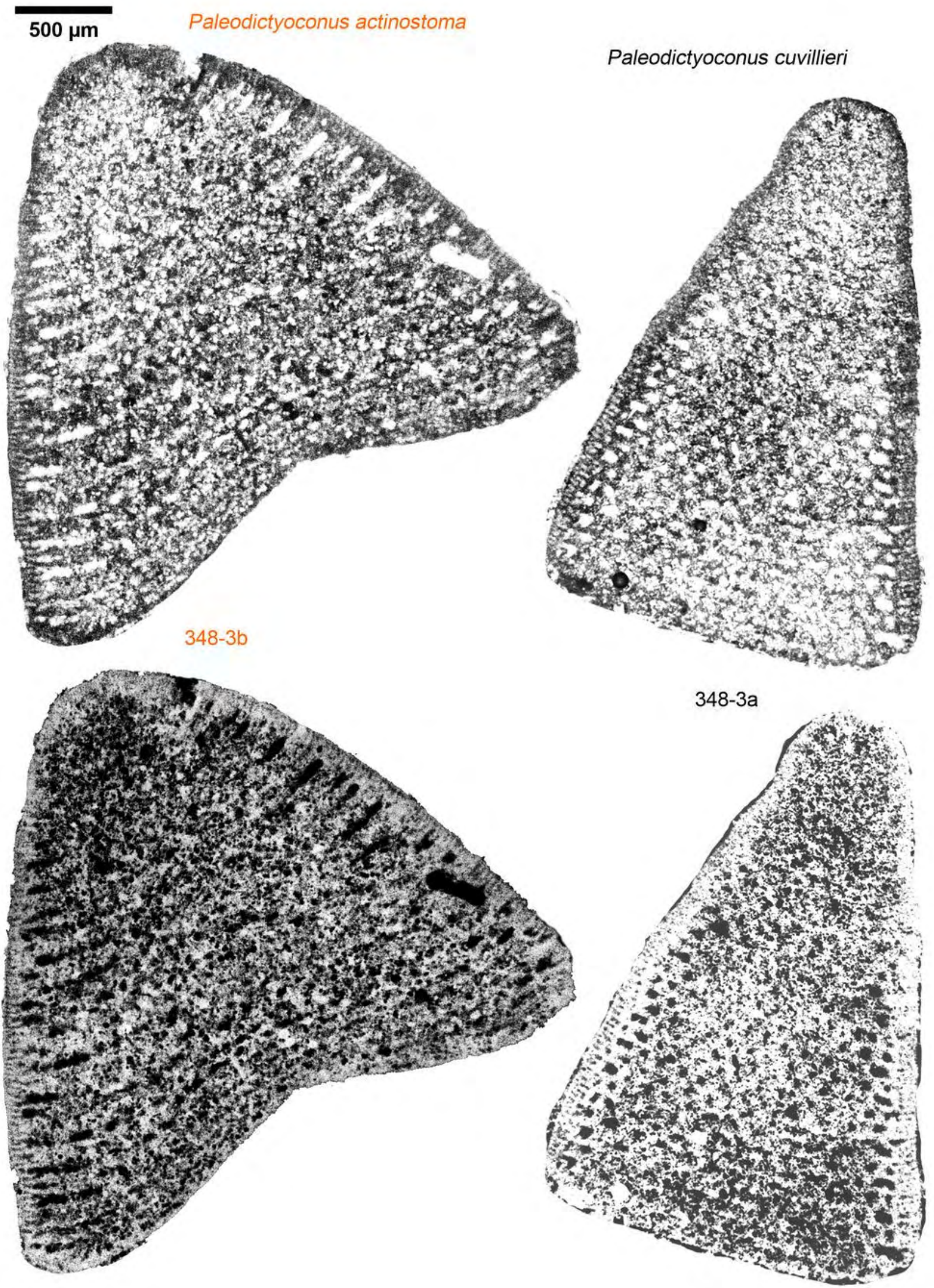

Plate 72: Orbitolinids of the Giraudi and Sarasini zones in the Serre de Tourre section. Paleodictyoconus actinostoma: 348-3b; Paleodictyoconus cuvillieri: 348-3a. Scale bar $=500 \mu \mathrm{m}$. 

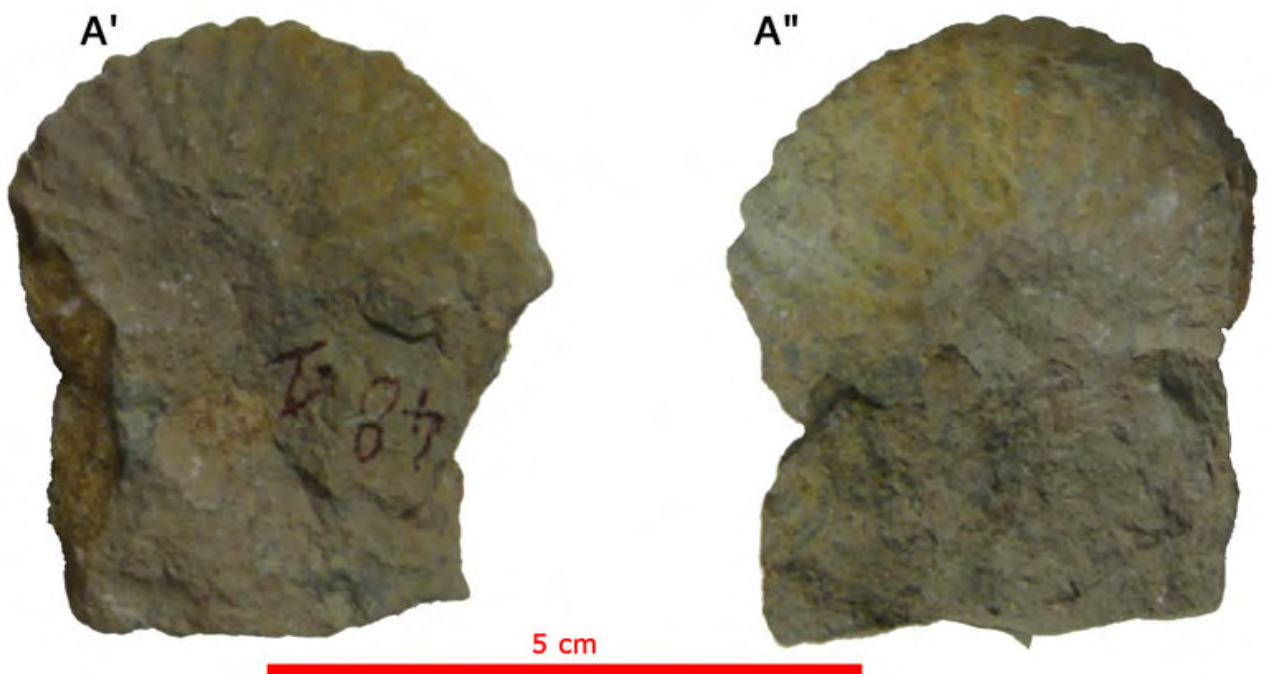

B
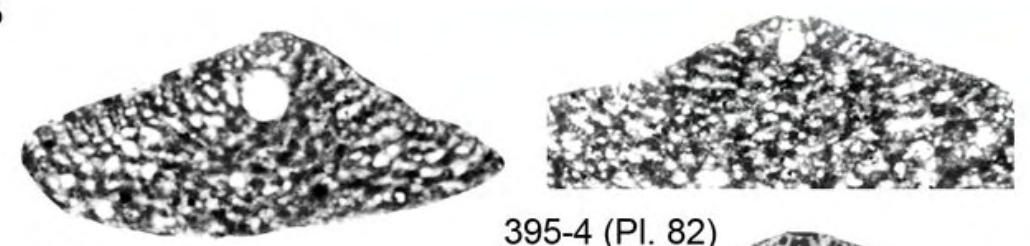

395-4 (PI. 82)
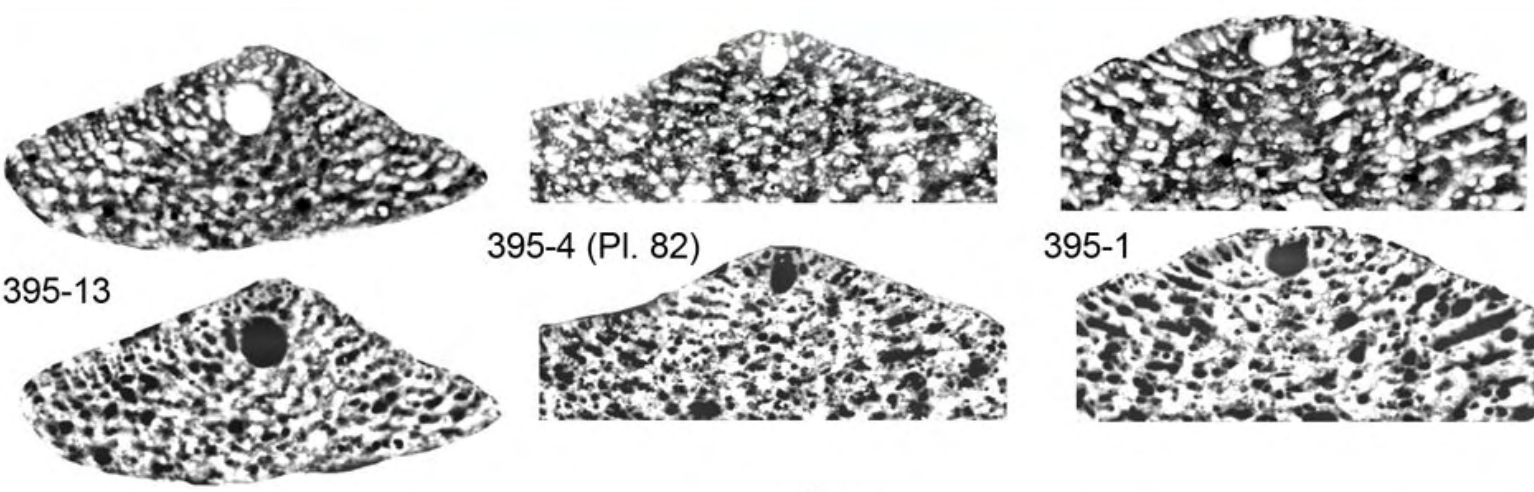

395-1
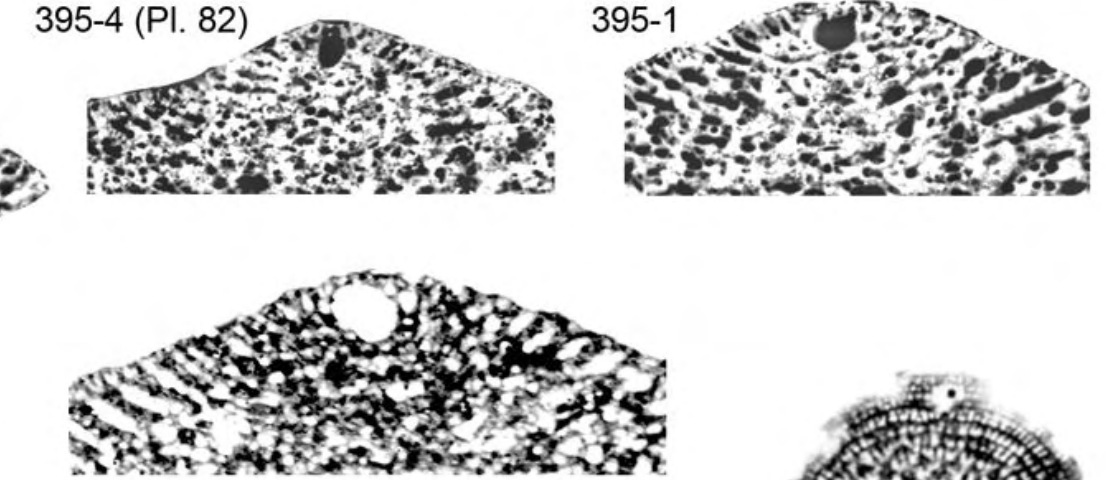

243.2-24

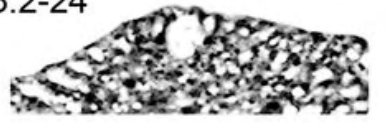

$243.2-13 \quad x 2$
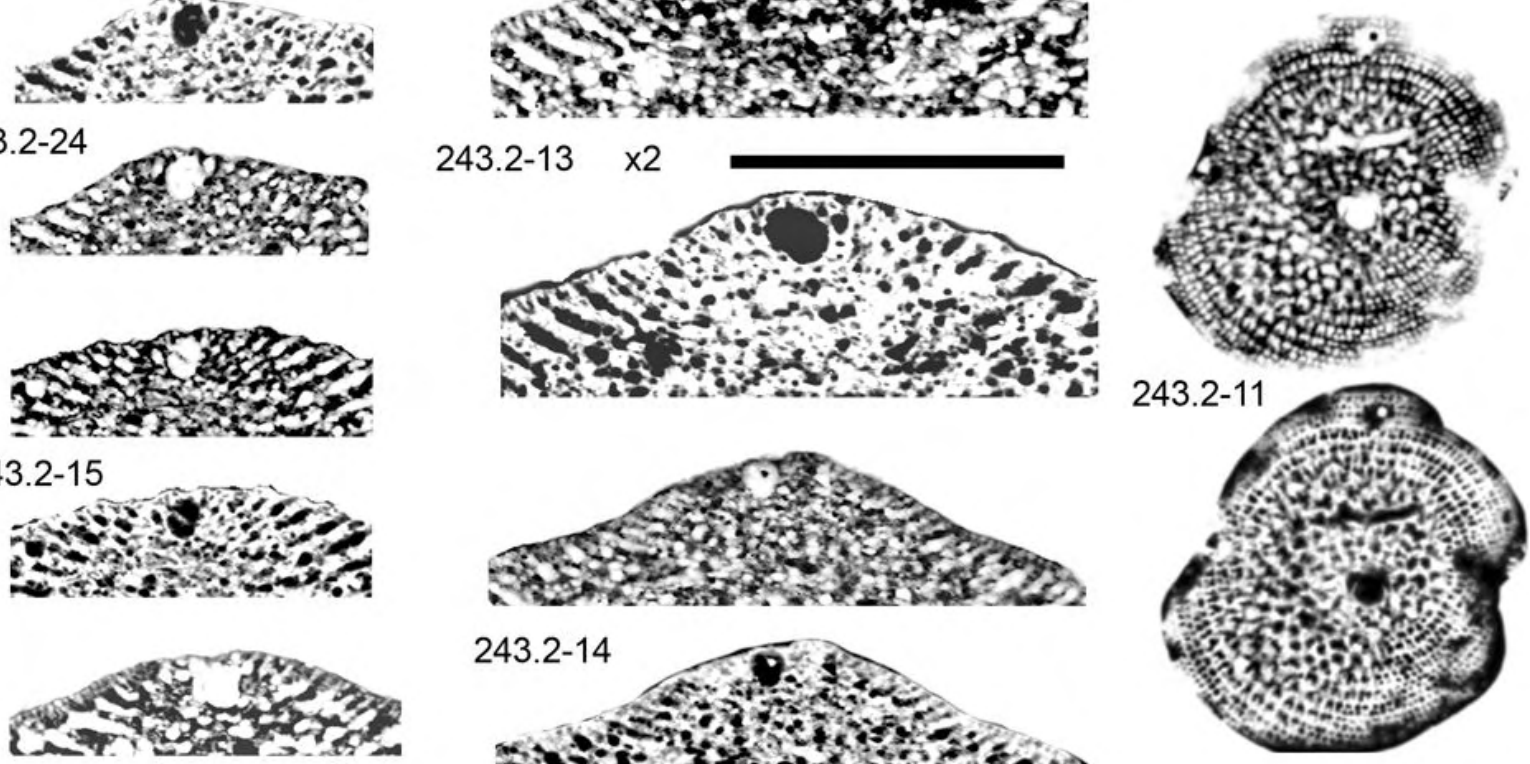

243.2-11
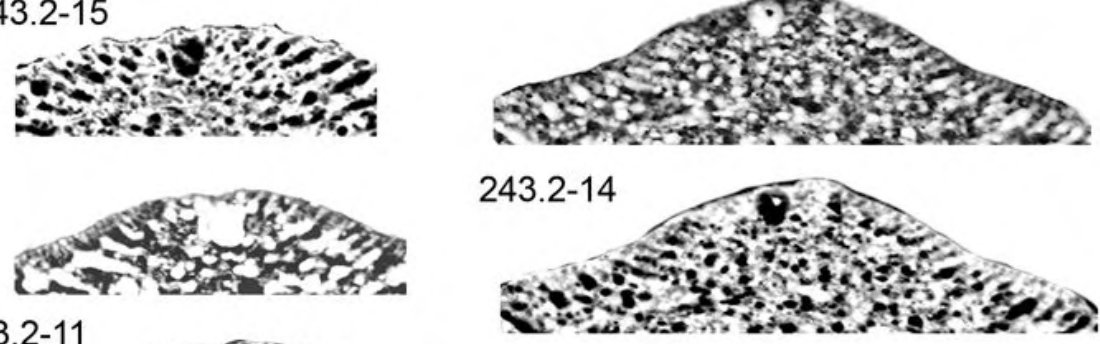

Eopalorbitolina transiens

$500 \mu \mathrm{m}$

Plate 73: $\left.A, A^{\prime}\right)$ Ammonite of the Vandenheckei zone below the Béguère marls at "Plateau du Veymont". Toxancyloceras gr. vandenheckei -RB- \{or ? Camereiceras limentinus -DB-\} duplicated from ARNAUD et al. (1998, PI. 4, fig. 34) as "? Camereiceras sp.", UJF-ID 10574, B. VIRLOUVET legit (c) OSUG (1997, PI. 4, fig. 3). B) Orbitolinids of the Moutonianum and Vandenheckei zones at La Béguère. Eopalorbitolina transiens : 243.2-11, 243.2-13, 243.2-14, 243.2-15, 243.2-24, 395-1, 395-4, 395-13. Ammonite scale bar $(A)=5 \mathrm{~cm}$, and scale bar $(B)=500 \mu \mathrm{m}$. 


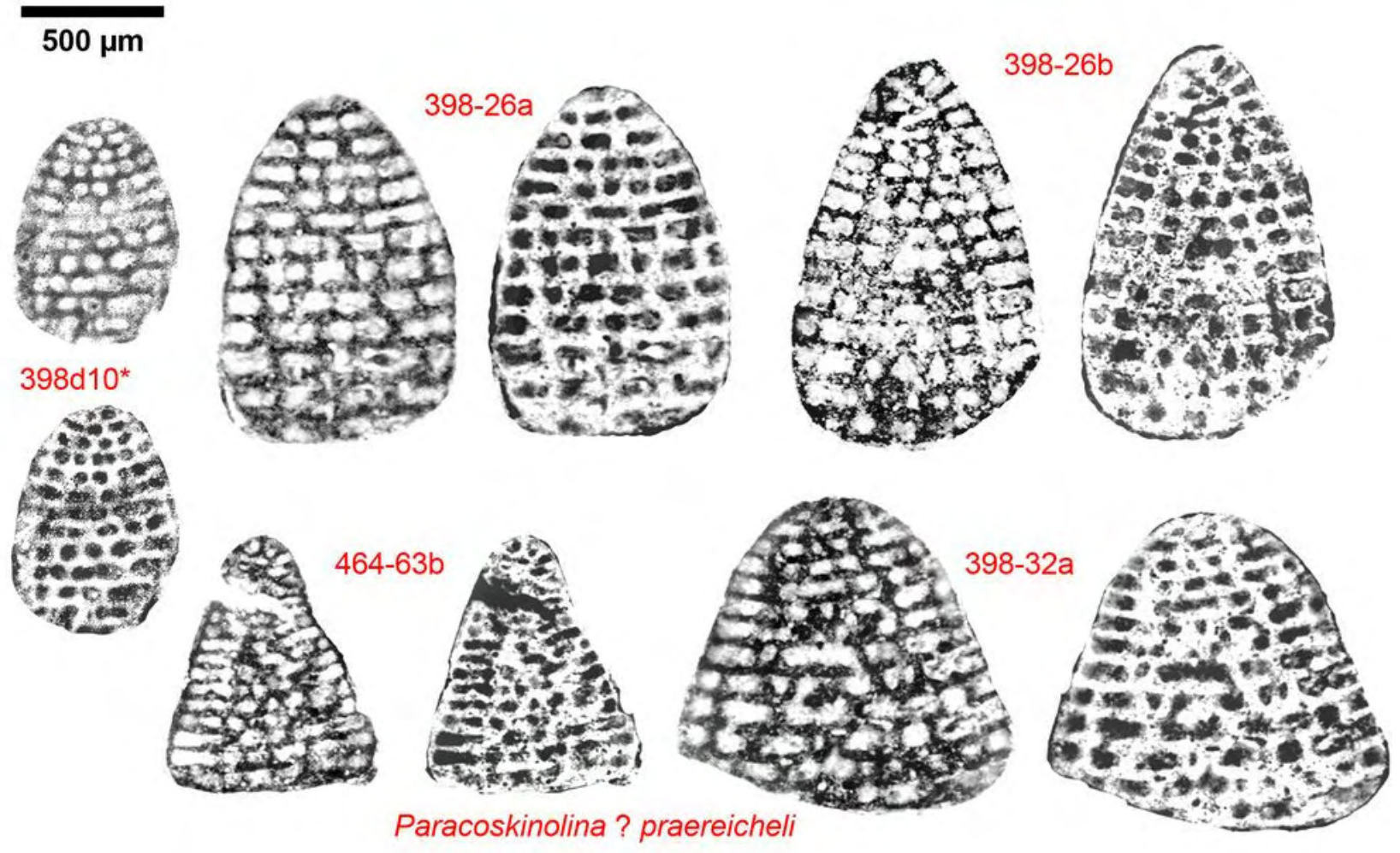

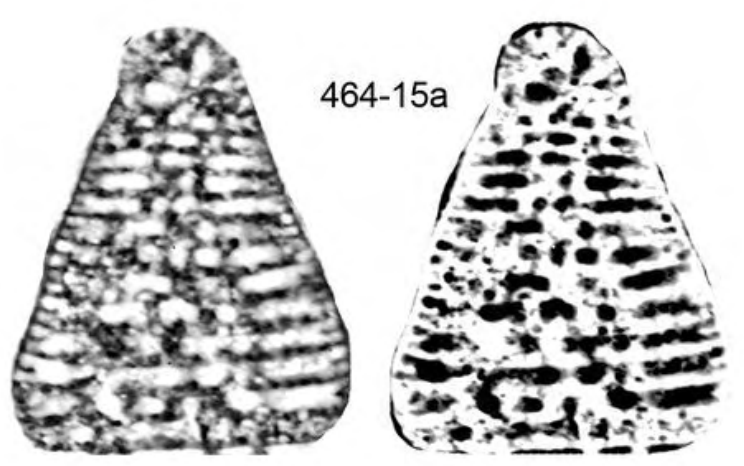
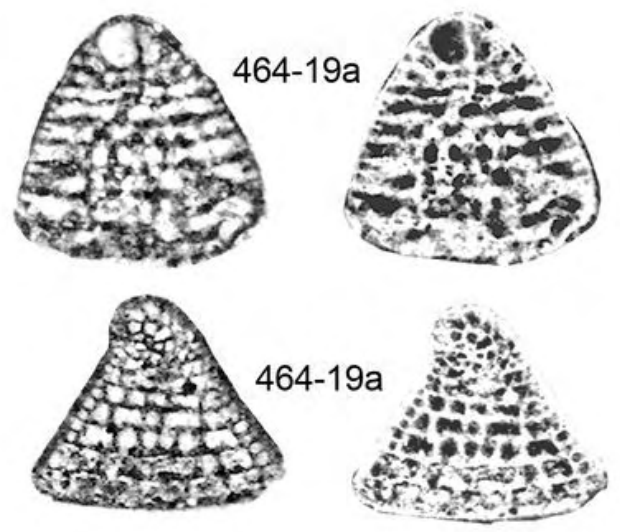
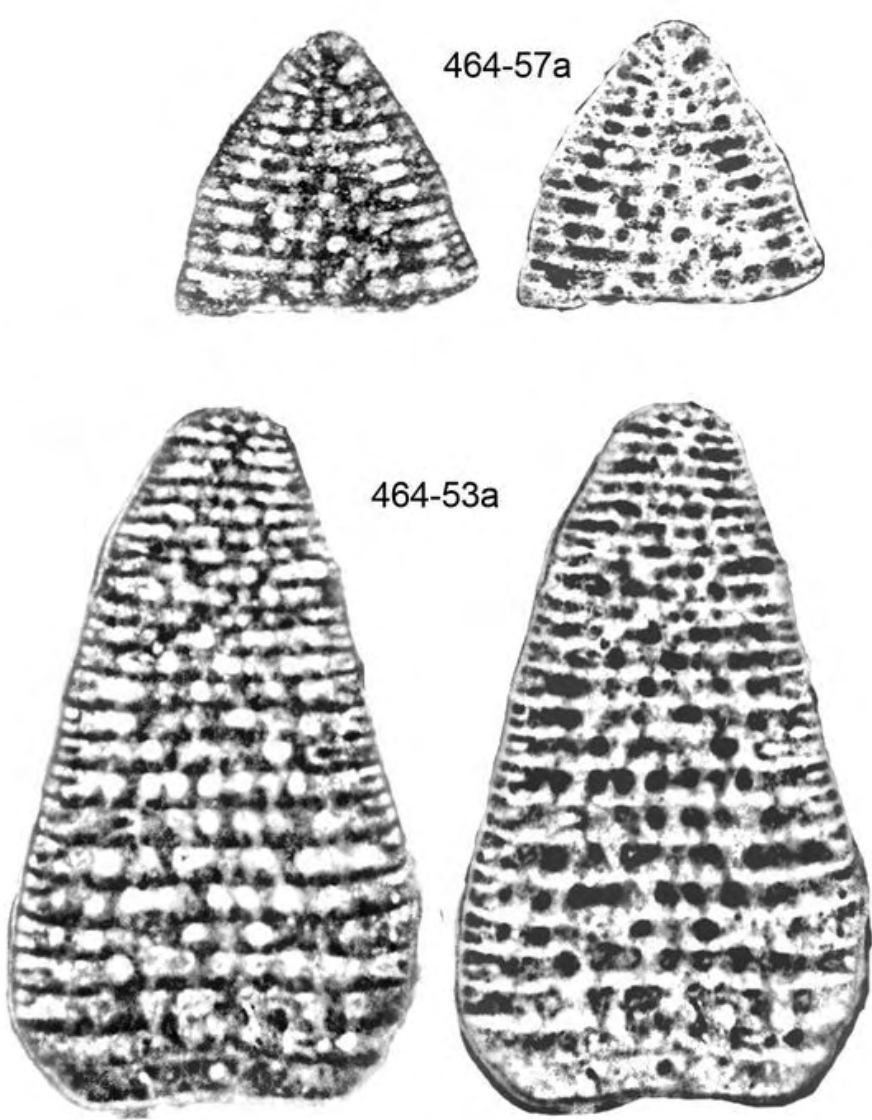

Paracoskinolina? reicheli

Plate 74: Orbitolinids of the Moutonianum Zone at La Béguère. Paracoskinolina ? praereicheli: 398-26a, 398-26b, 398-32a, 398d10*, 464-63b; Paracoskinolina ? reicheli: 464-15a, 464-19a, 464-53a, 464-57a. Scale bar $=500 \mu \mathrm{m}$. 

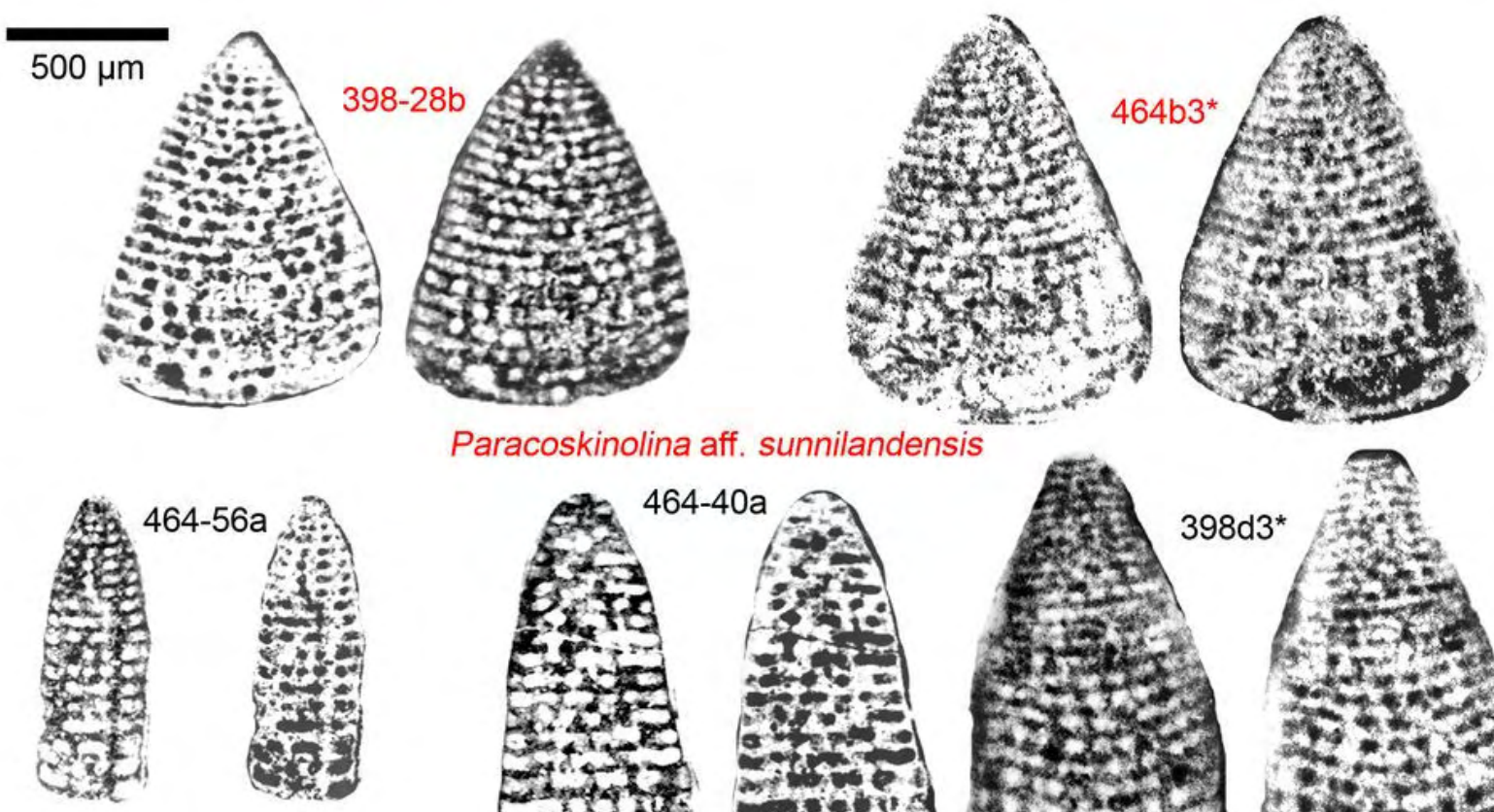

Paracoskinolina aff. sunnilandensis

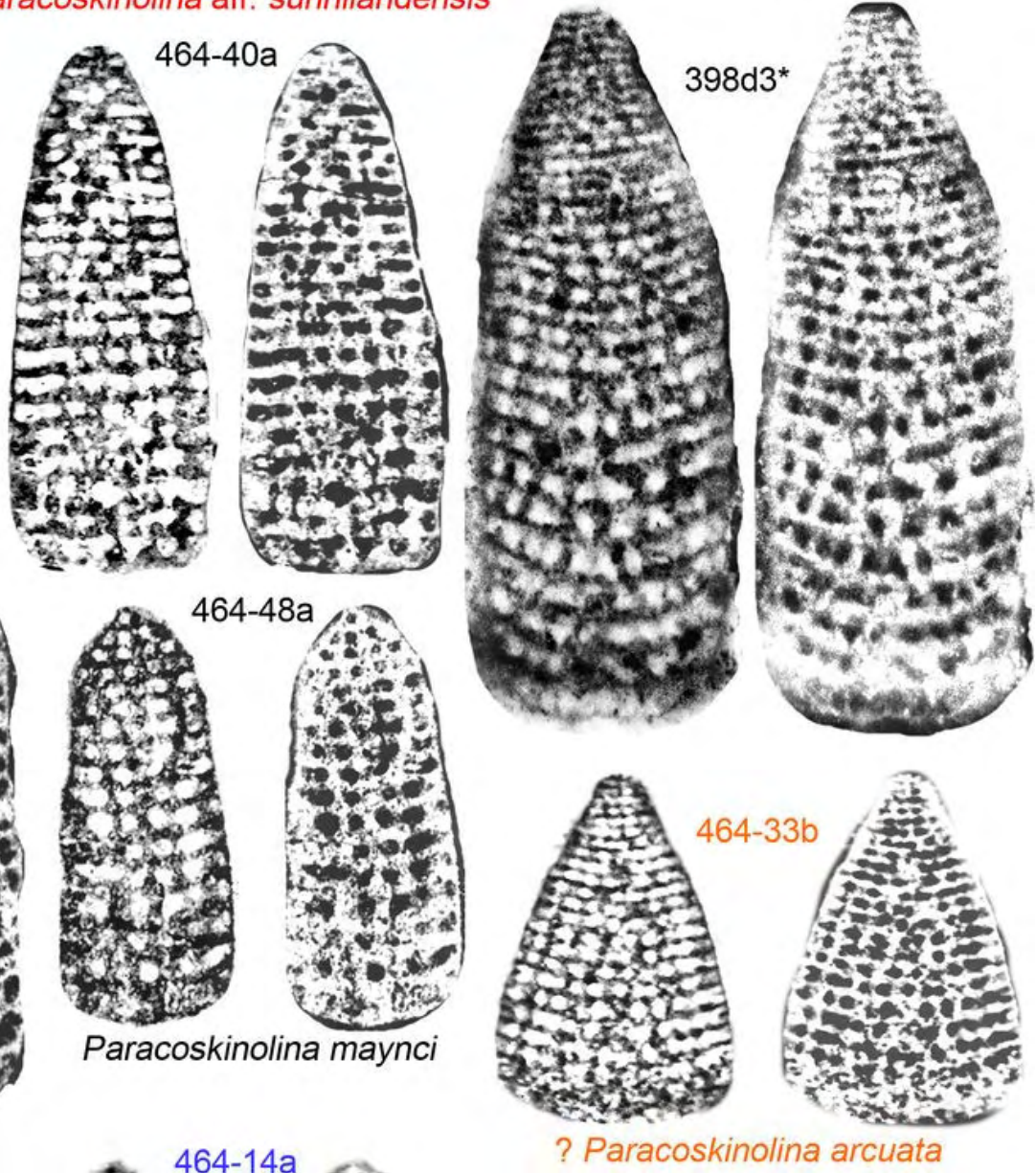

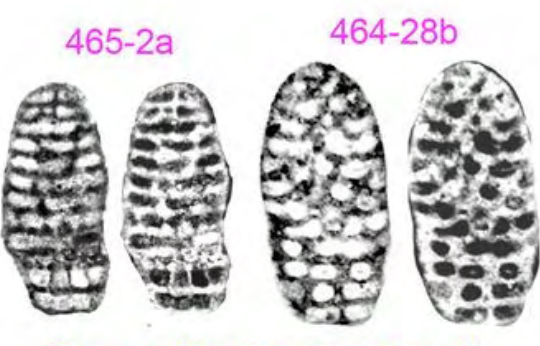

Paracoskinolina querolensis

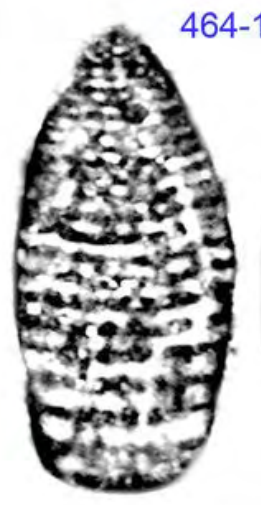

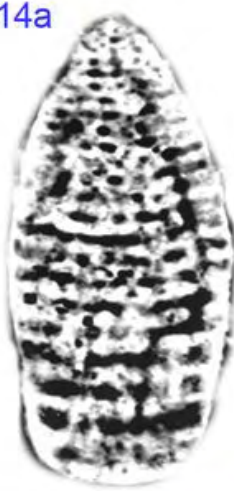
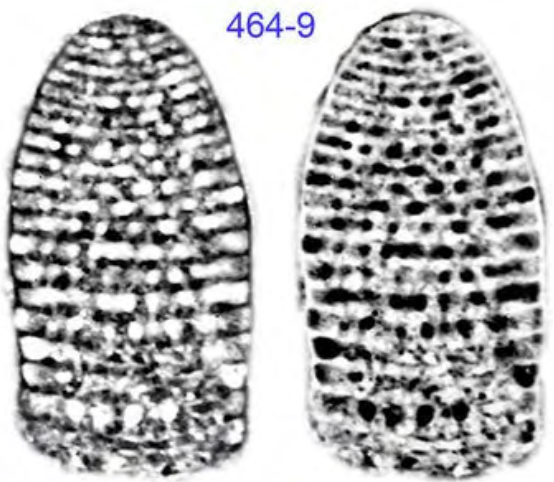

Paracoskinolina hispanica

Plate 75: Orbitolinids of the Moutonianum Zone at La Béguère. ? Paracoskinolina arcuata: 464-33b; Paracoskinolina hispanica: 464-9, 464-14a; Paracoskinolina maynci: 398d3*, 464-40a, 464-48a, 464-56a, 464-58a; Paracoskinolina querolensis: 464-28b, 465-2a; Paracoskinolina aff. sunnilandensis: 398-28b, 464b3*. Scale bar $=500 \mu \mathrm{m}$. 


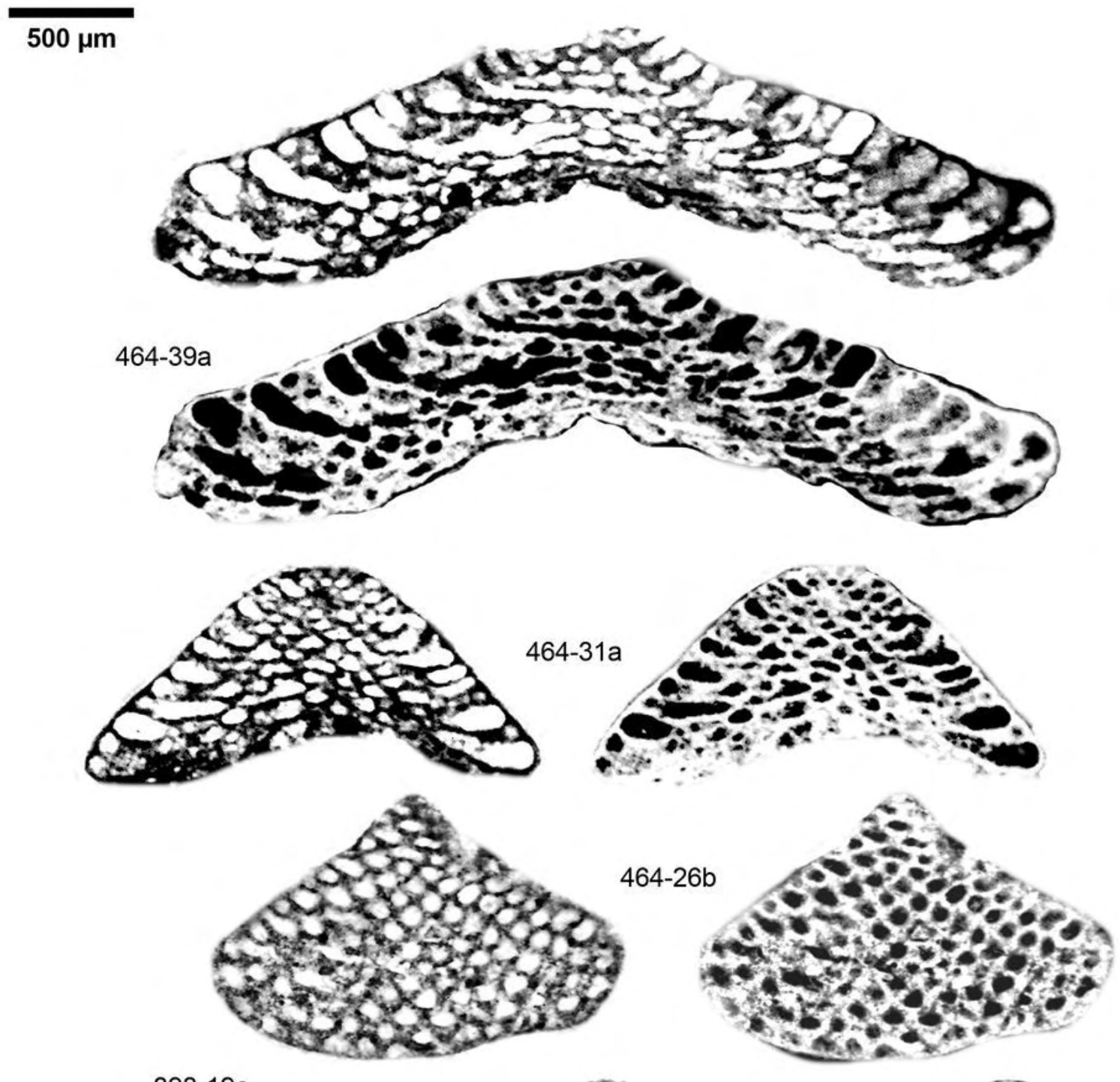

398-19a
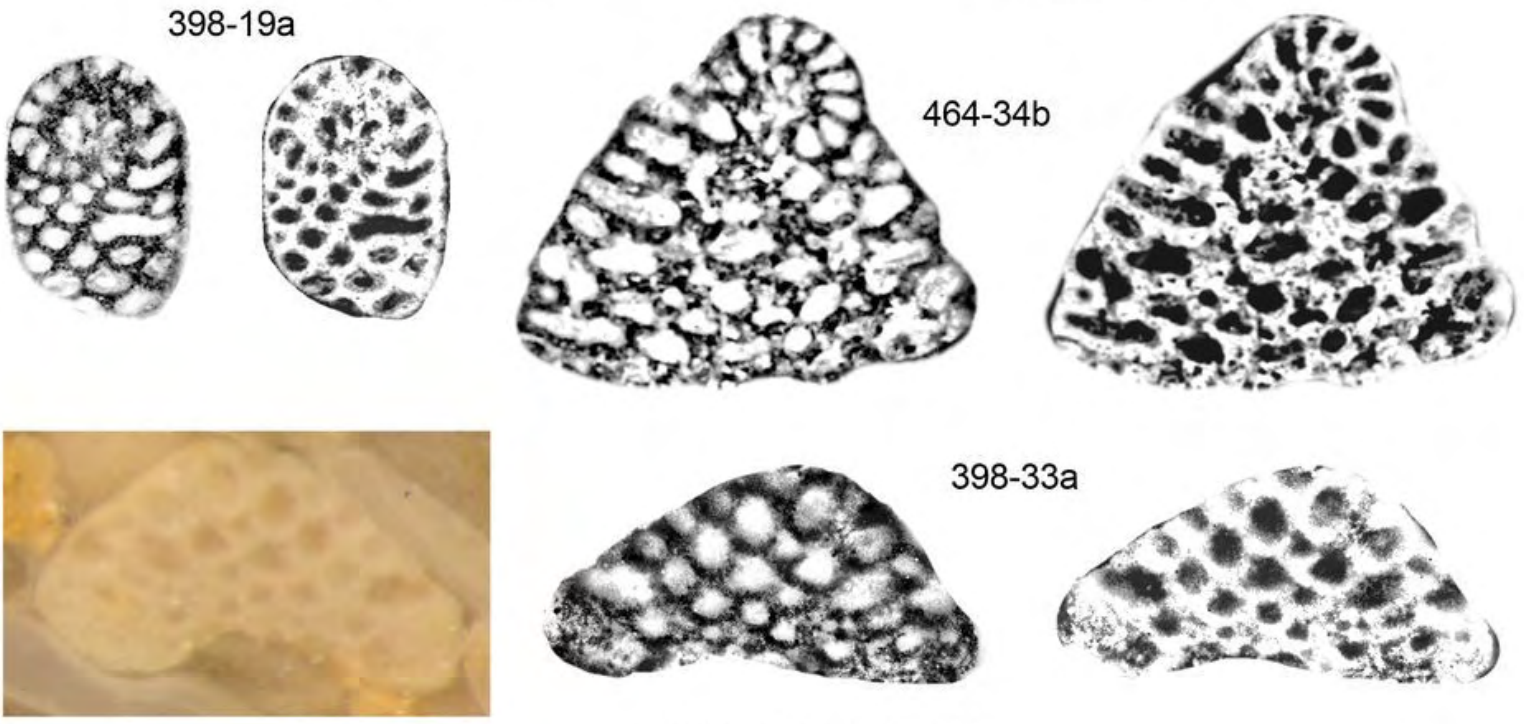

398-33a

Orbitolinopsis buccifer

Plate 76: Orbitolinids of the Moutonianum Zone at La Béguère. Orbitolinopsis buccifer: 398-19a, 398-33a, 464-26b, 464-31a, 464-34b, 464-39a. Scale bar $=500 \mu \mathrm{m}$. 

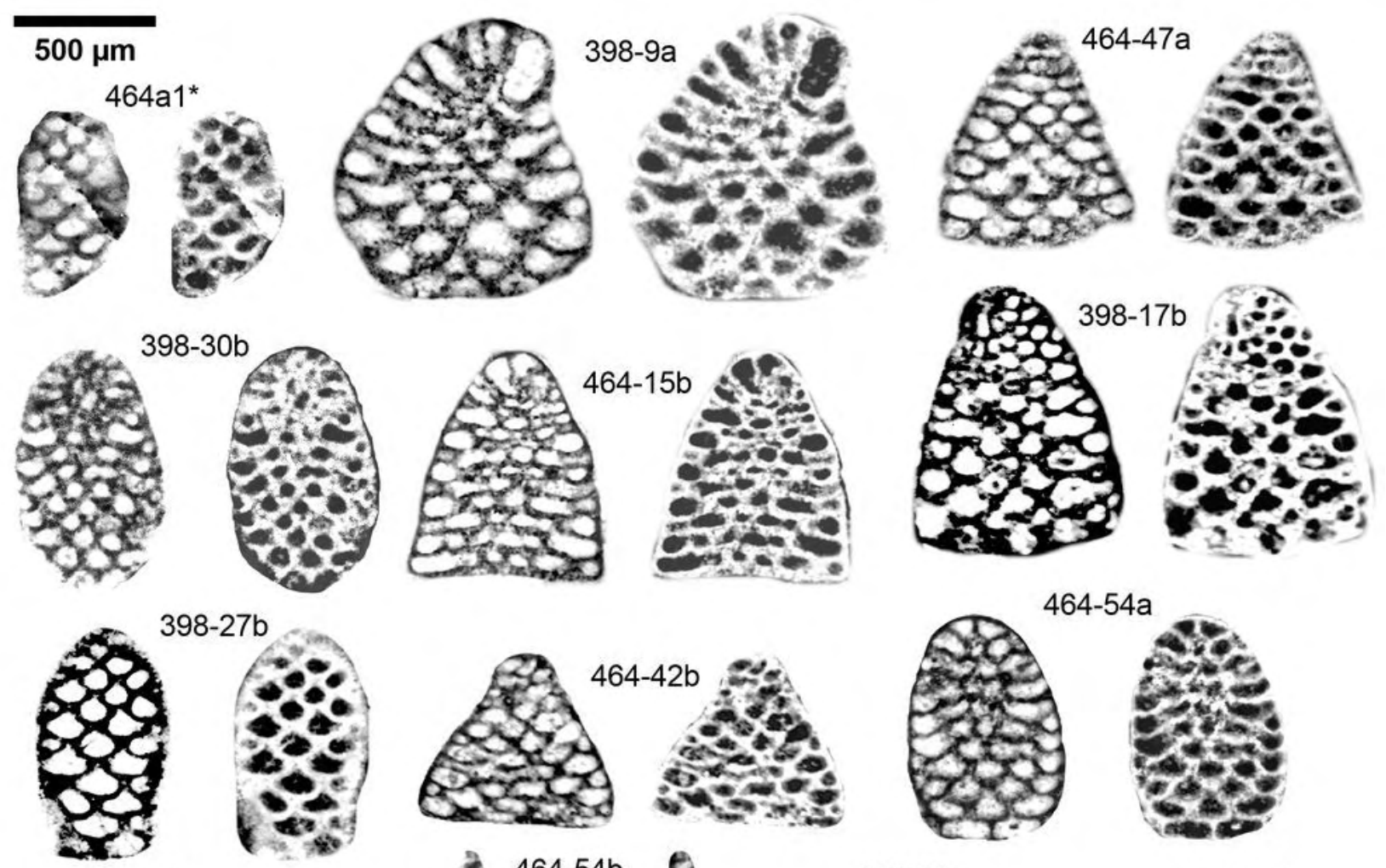

464-54a
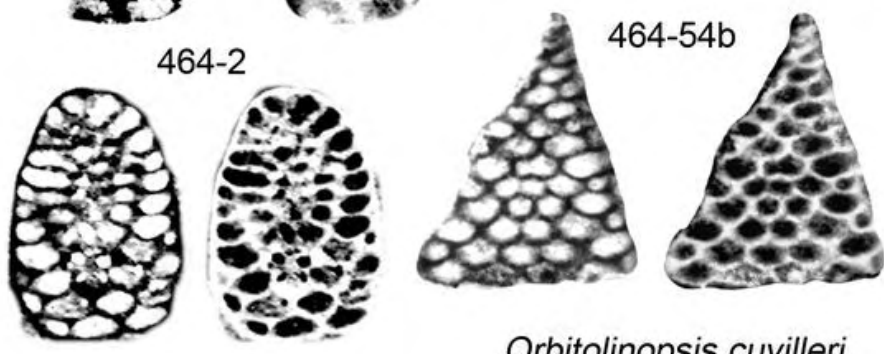

464-55a
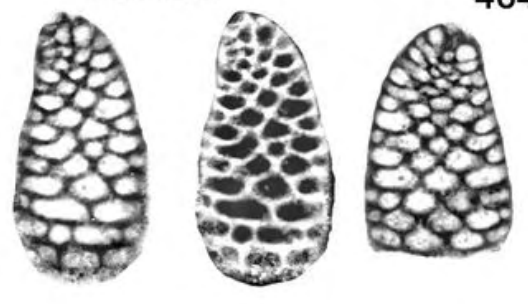

464-55b
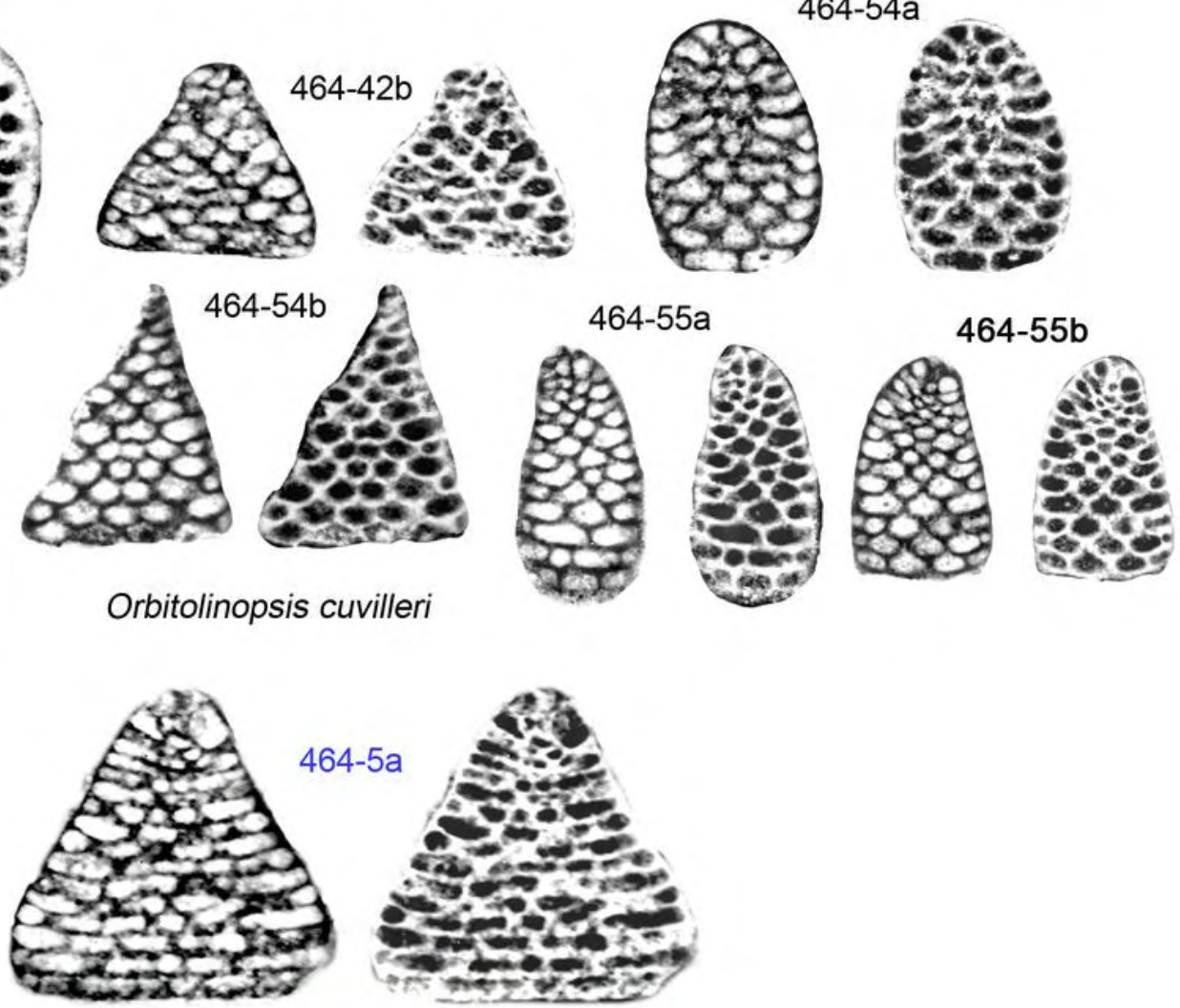

Orbitolinopsis kiliani
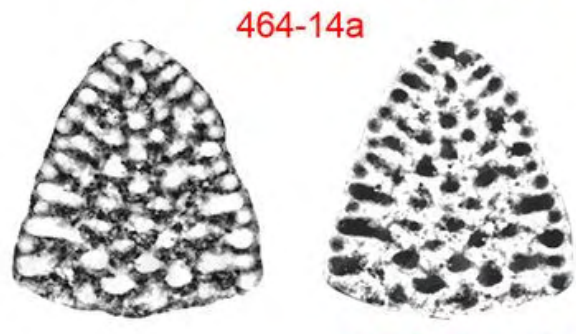

Orbitolinopsis briacensis

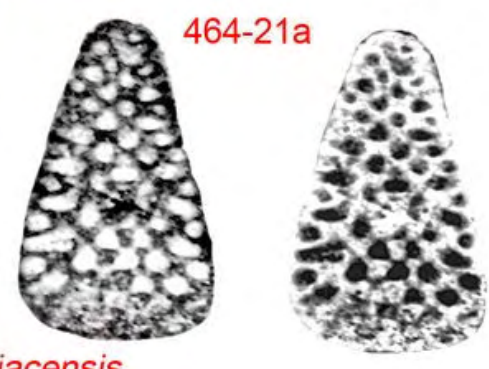

Plate 77: Orbitolinids of the Moutonianum Zone at La Béguère. Orbitolinopsis briacensis: 464-14a, 464-21a; Orbitolinopsis cuvillieri: 398-9a, 398-17b, 398-27b, 398-30b, 464-2, 464-15b, 464-42b, 464-47a, 464-54a, 464-54b, 46455a, 464-55b, 464a1*; Orbitolinopsis kiliani: 464-5a. Scale bar $=500 \mu \mathrm{m}$. 


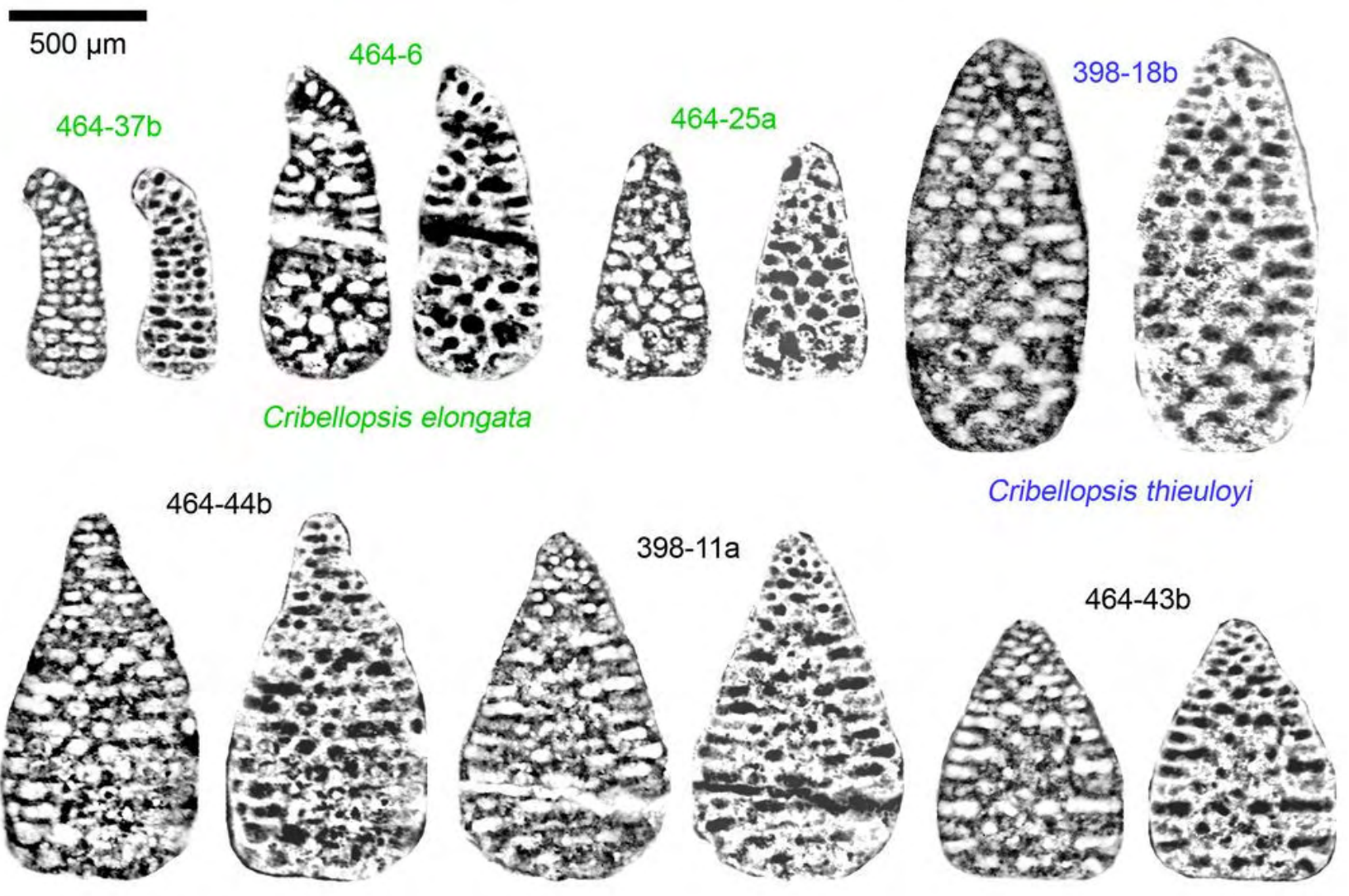

Cribellopsis neoelongata
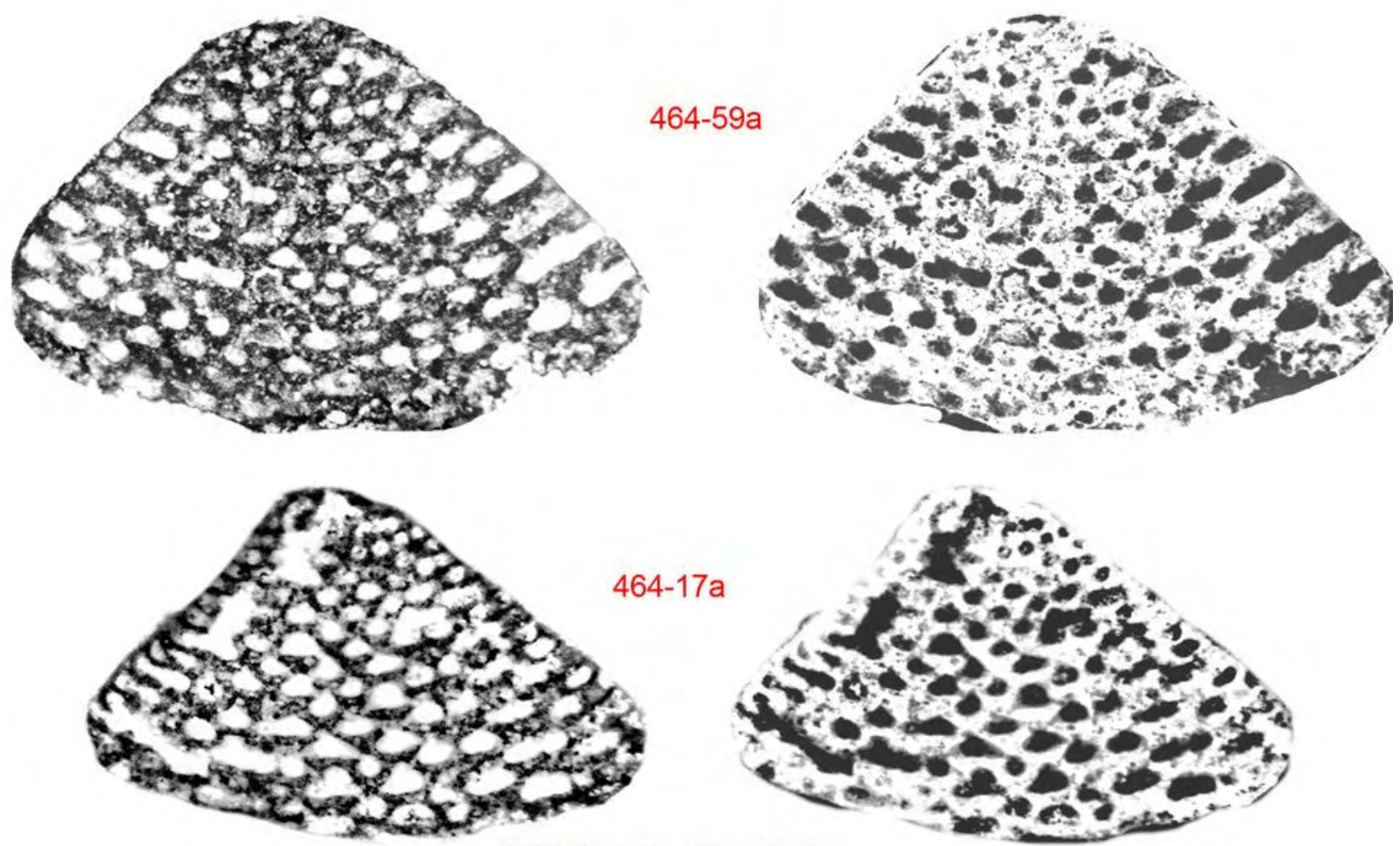

Cribellopsis schroederi

Plate 78: Orbitolinids of the Moutonianum Zone at La Béquère. Cribellopsis elongata: 464-6, 464-25a, 464-37b; Cribellopsis neoelongata: 398-11a, 464-43b, 464-44b; Cribellopsis schroederi: 464-17a, 464-59a; Cribellopsis thieuloyi: 398-18b. Scale bar $=500 \mu \mathrm{m}$. 
$500 \mu \mathrm{m}$
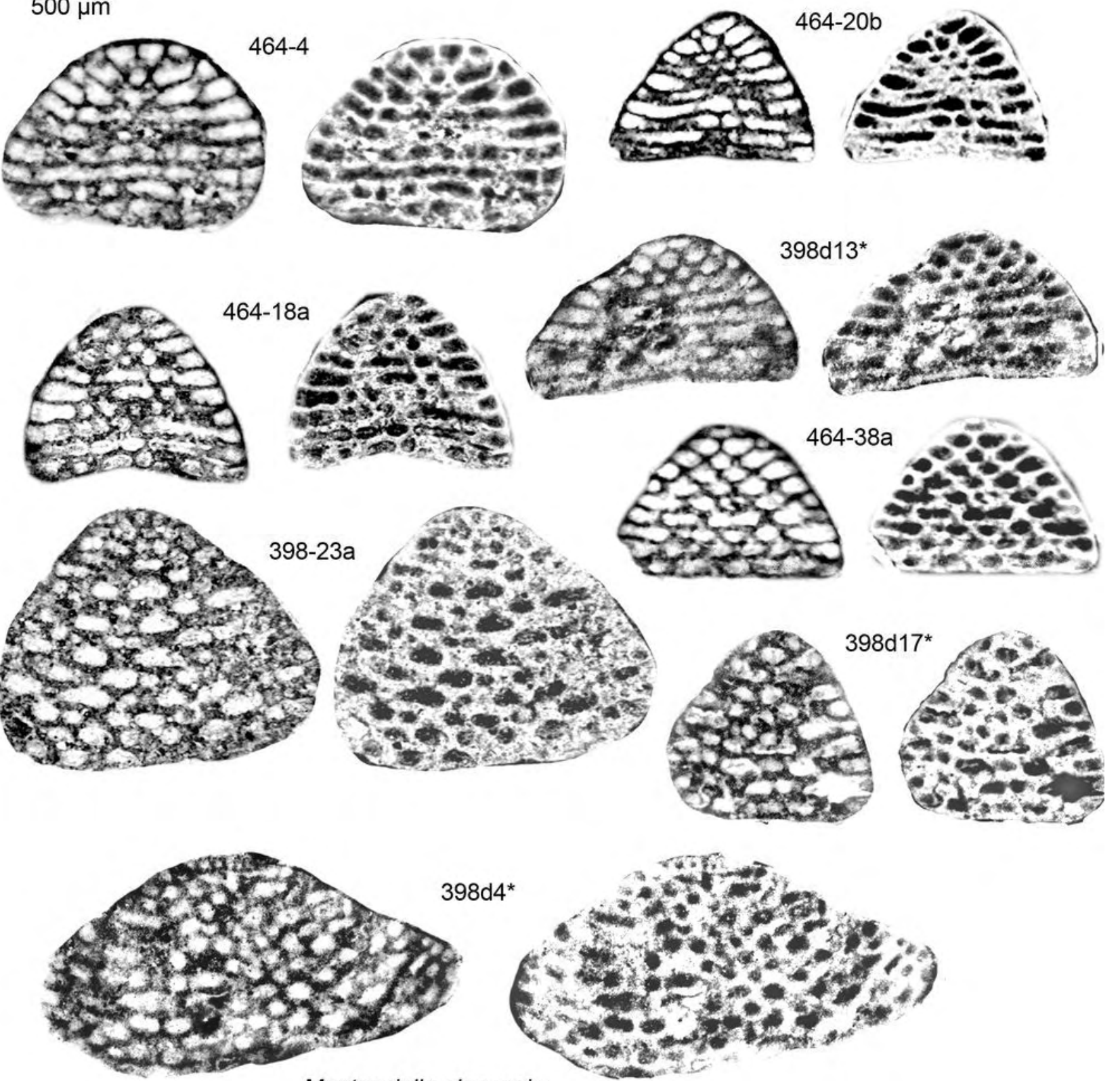

Montseciella glanensis

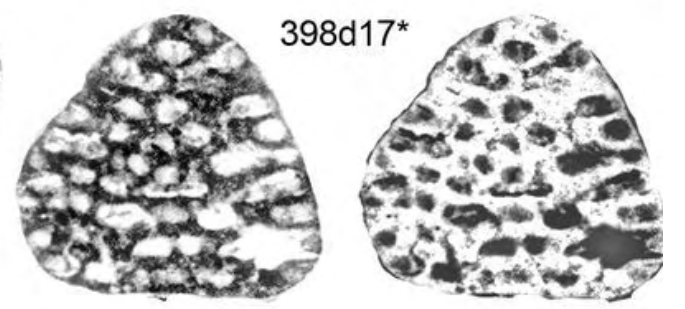

$98 d 4^{*}$

- $0^{2}+y^{2}$

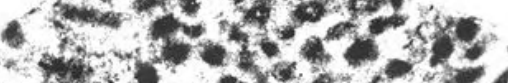

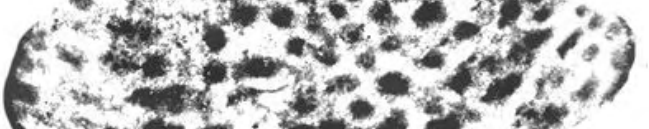

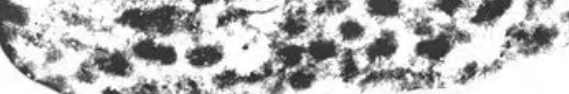

$4+2$
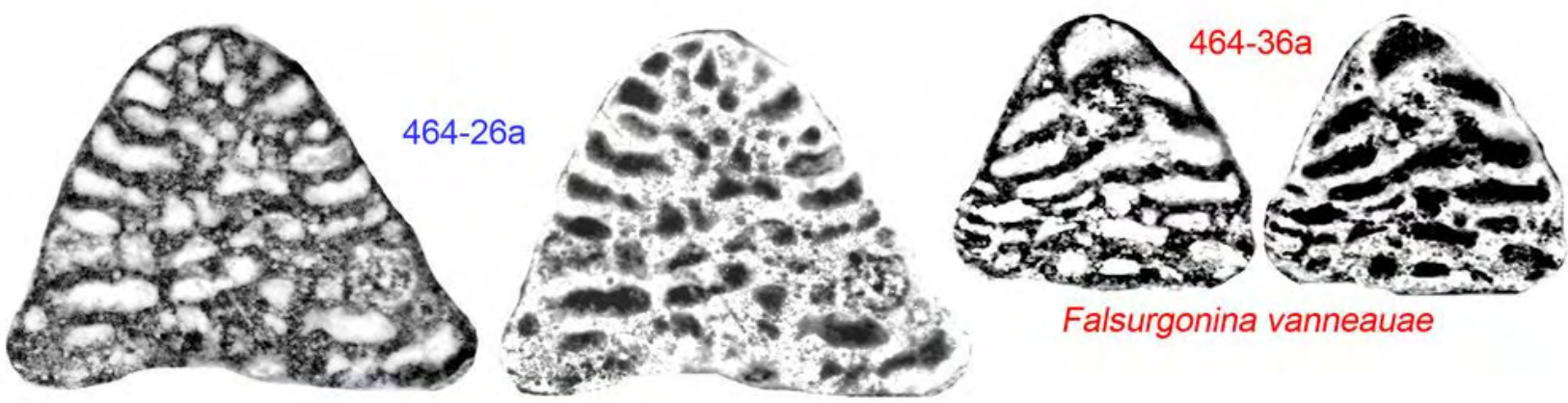

Falsurgonina vanneauae

Falsurgonina pileola

Plate 79: Orbitolinids of the Moutonianum Zone at La Béguère. Falsurgonina pileola: 464-26a; Falsurgonina vanneauae: 464-36a; Montseciella glanensis: 398-23a, 398d4*, 398d13, 398d17*, 464-4, 464-18a, 464-20b, 464-38a. Scale bar $=500 \mu \mathrm{m}$. 

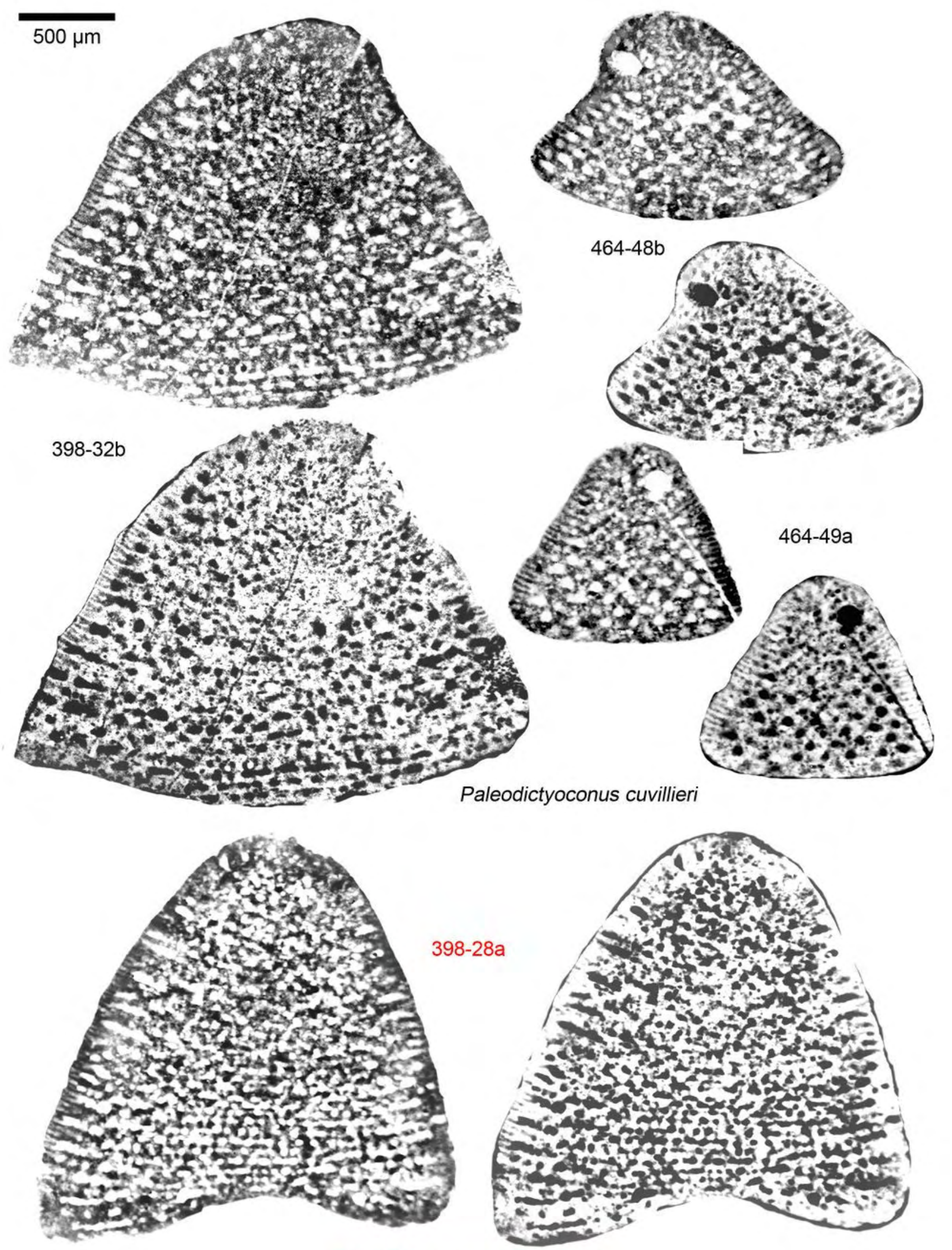

Paleodictyoconus actinostoma

Plate 80: Orbitolinids of the Moutonianum Zone at La Béguère. Paleodictyoconus actinostoma: 398-28a; Paleodictyoconus cuvillieri: 398-32b, 464-48b, 464-49a. Scale bar $=500 \mu \mathrm{m}$. 

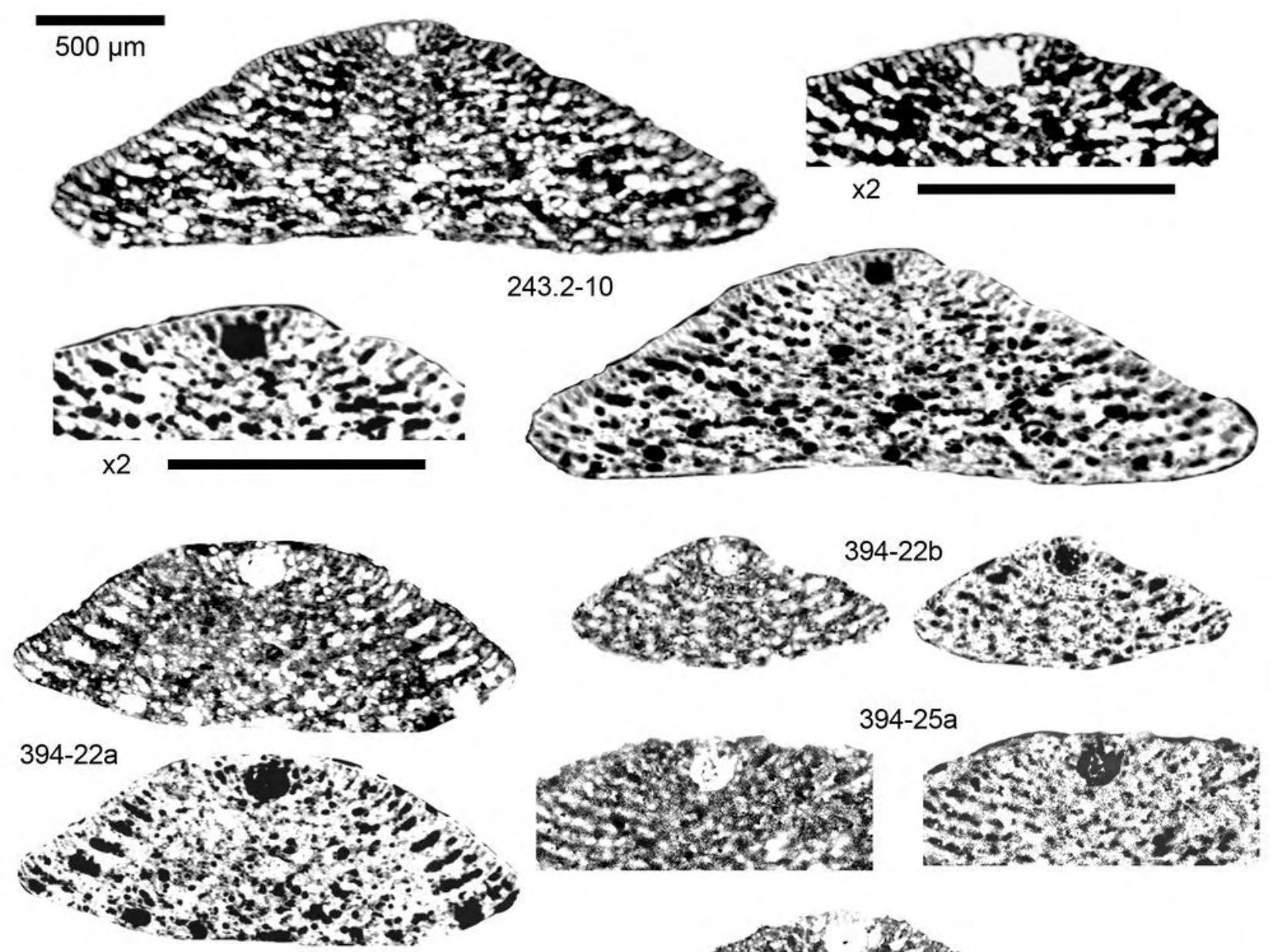

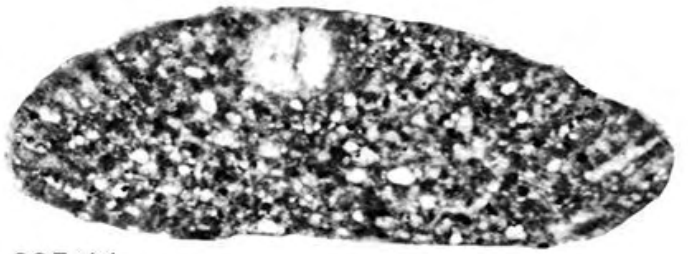

395-14

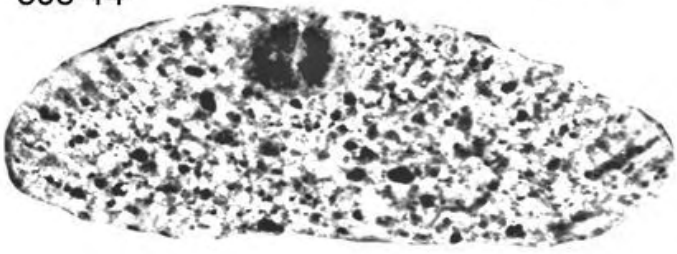

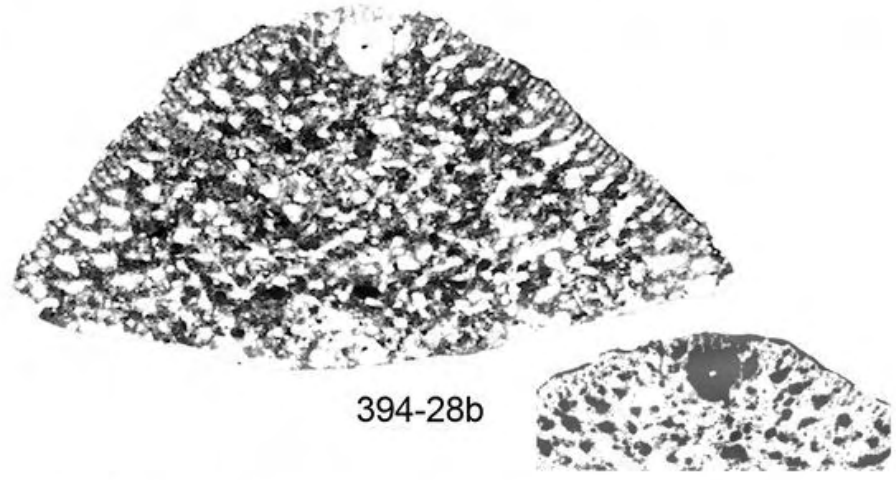

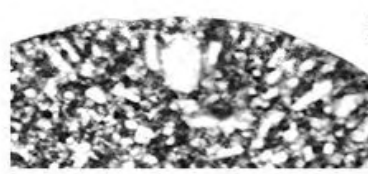

$395-10$

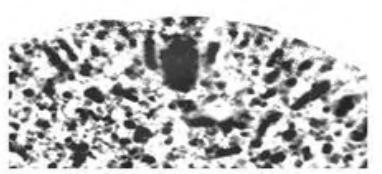

Palorbitolina gr. lenticularis

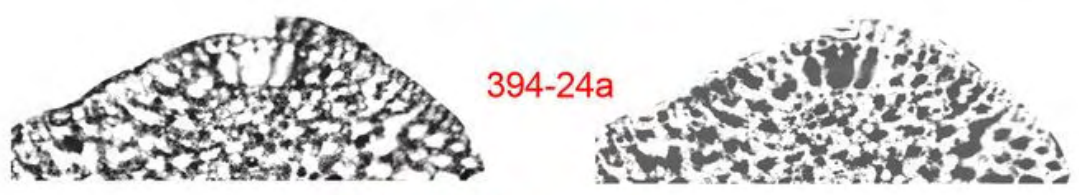

Palorbitolina ultima

Plate 81: Orbitolinids of the Moutonianum and Vandenheckei $(243,394)$ zones at La Béguère. Palorbitolina gr. lenticularis: 243.2-10, 394-22a, 394-22b, 394-25a, 394-28b, 395-10, 395-14; Palorbitolina ultima: 394-24a. Scale bar = $500 \mu \mathrm{m}$. 

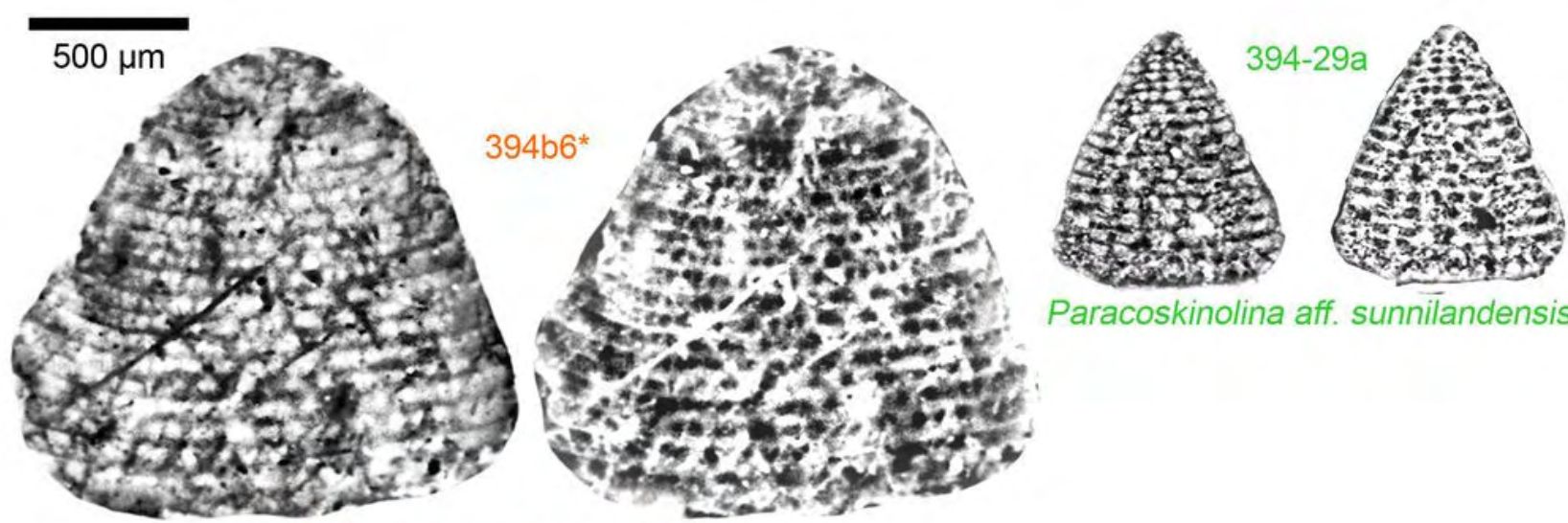

Paracoskinolina aff. sunnilandensis

Paleodictyoconus cuvillieri
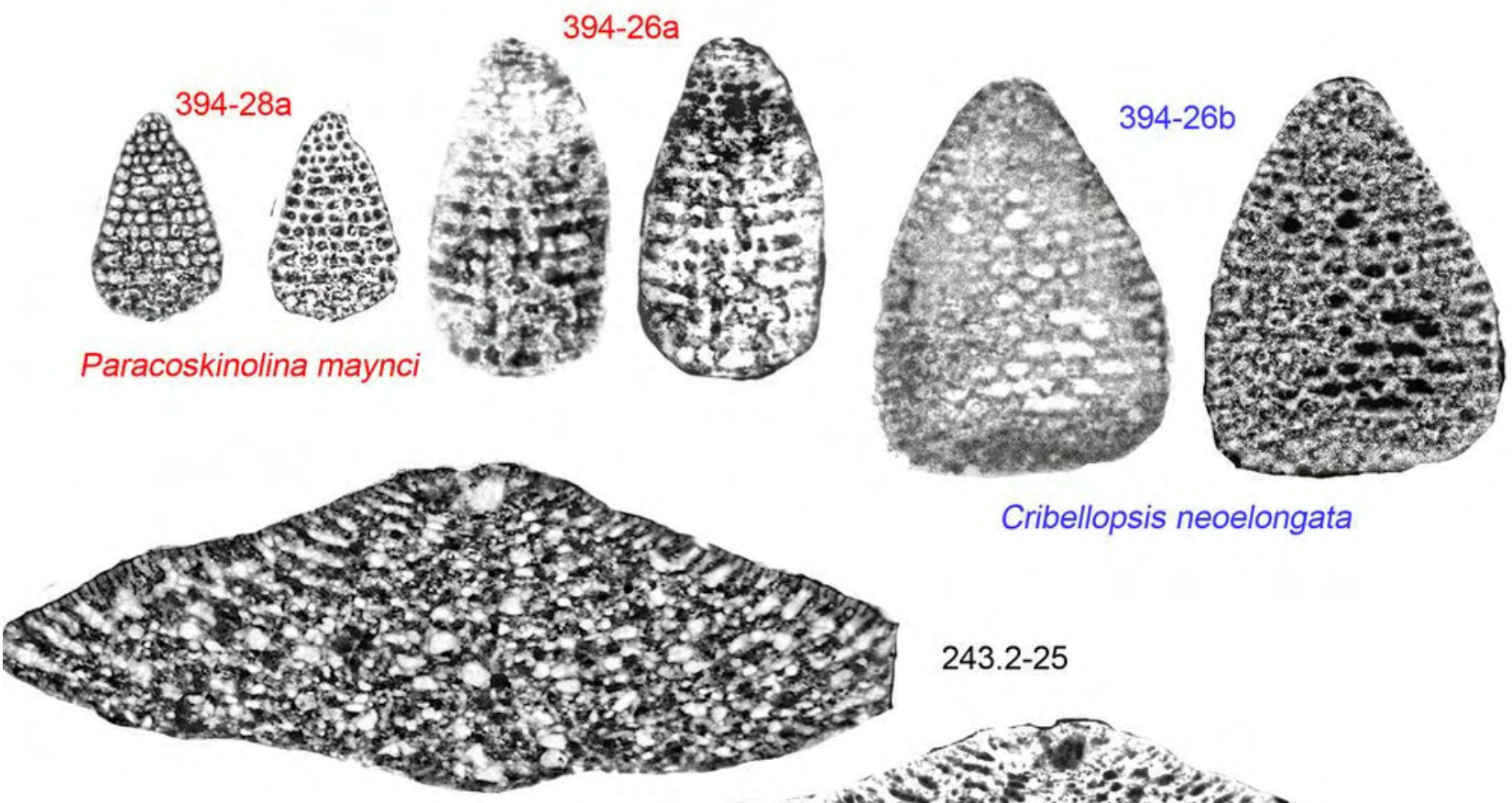

Cribellopsis neoelongata

\section{2-25}

\section{Eopalorbitolina transiens}
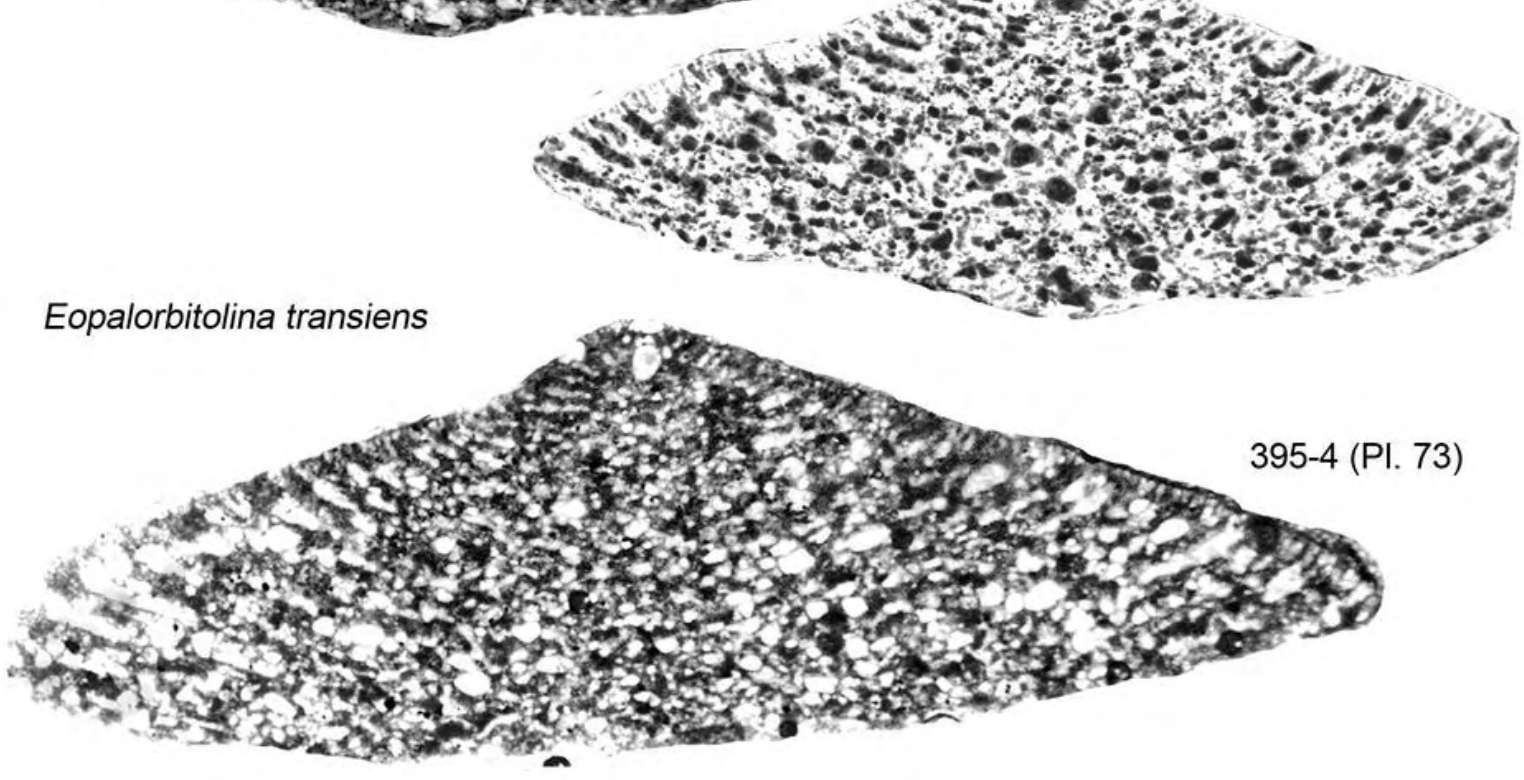

Plate 82: Orbitolinids of the Moutonianum and Vandenheckei zones at La Béguère. Cribellopsis neoelongata: 39426b; Eopalorbitolina transiens: 243.2-25, 395-4; Paleodictyoconus cuvillieri: 394b6*; Paracoskinolina maynci: 39426a, 394-28a; Paracoskinolina aff. sunnilandensis: 394-29a. Scale bar $=500 \mu \mathrm{m}$. 

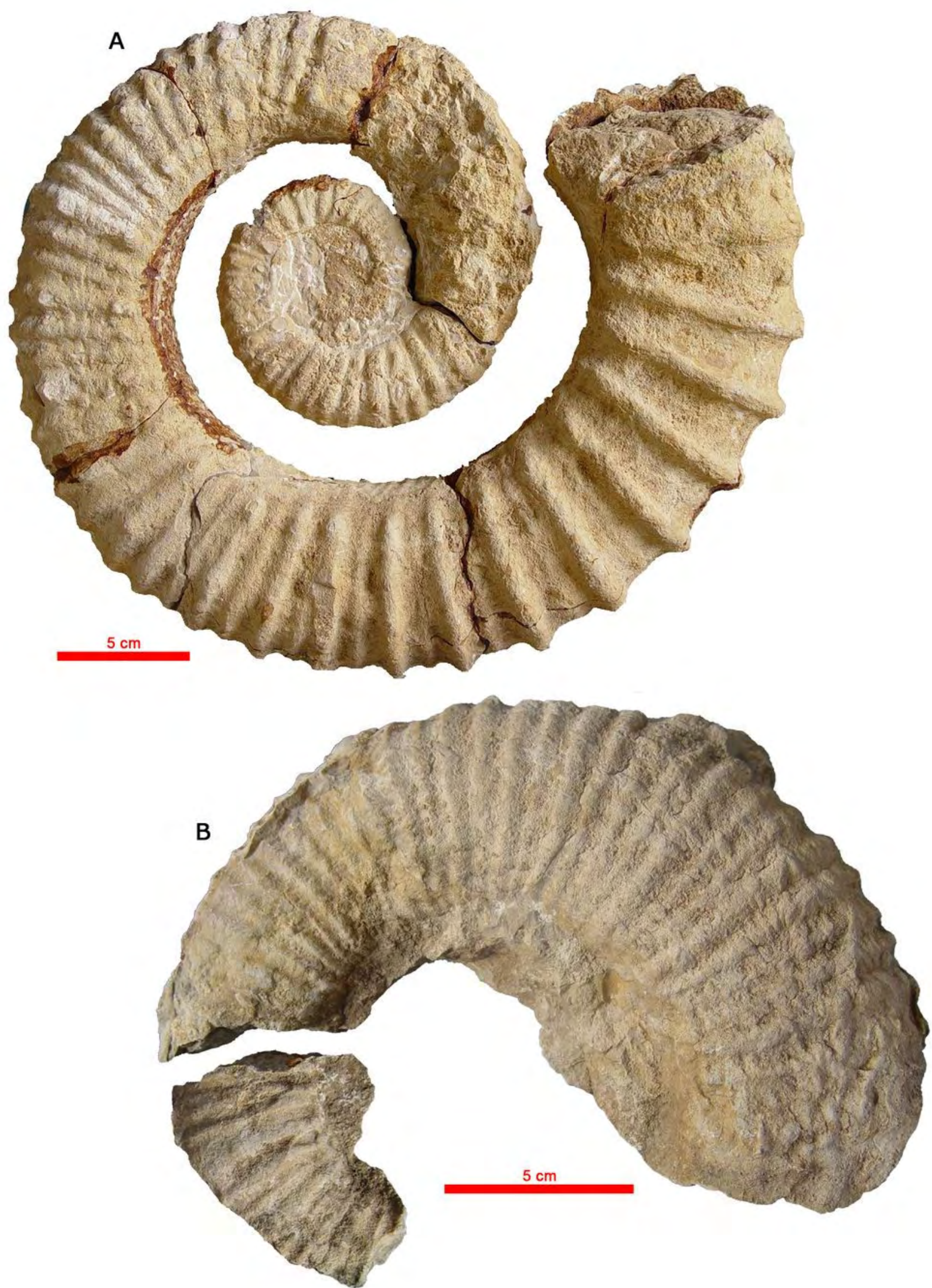

Plate 83: Ammonites of the Vandenheckei Zone at Rochecolombe. A) Toxancyloceras vandenheckei -RB- \{or Gassendiceras quelquejeui -DB-\}, FSL 89187; B) Toxancyloceras vandenheckei -RB- \{or ? Pseudoshasticrioceras sp. DB- $\}, F S L 47195$. All scale bars $=5 \mathrm{~cm}$. 

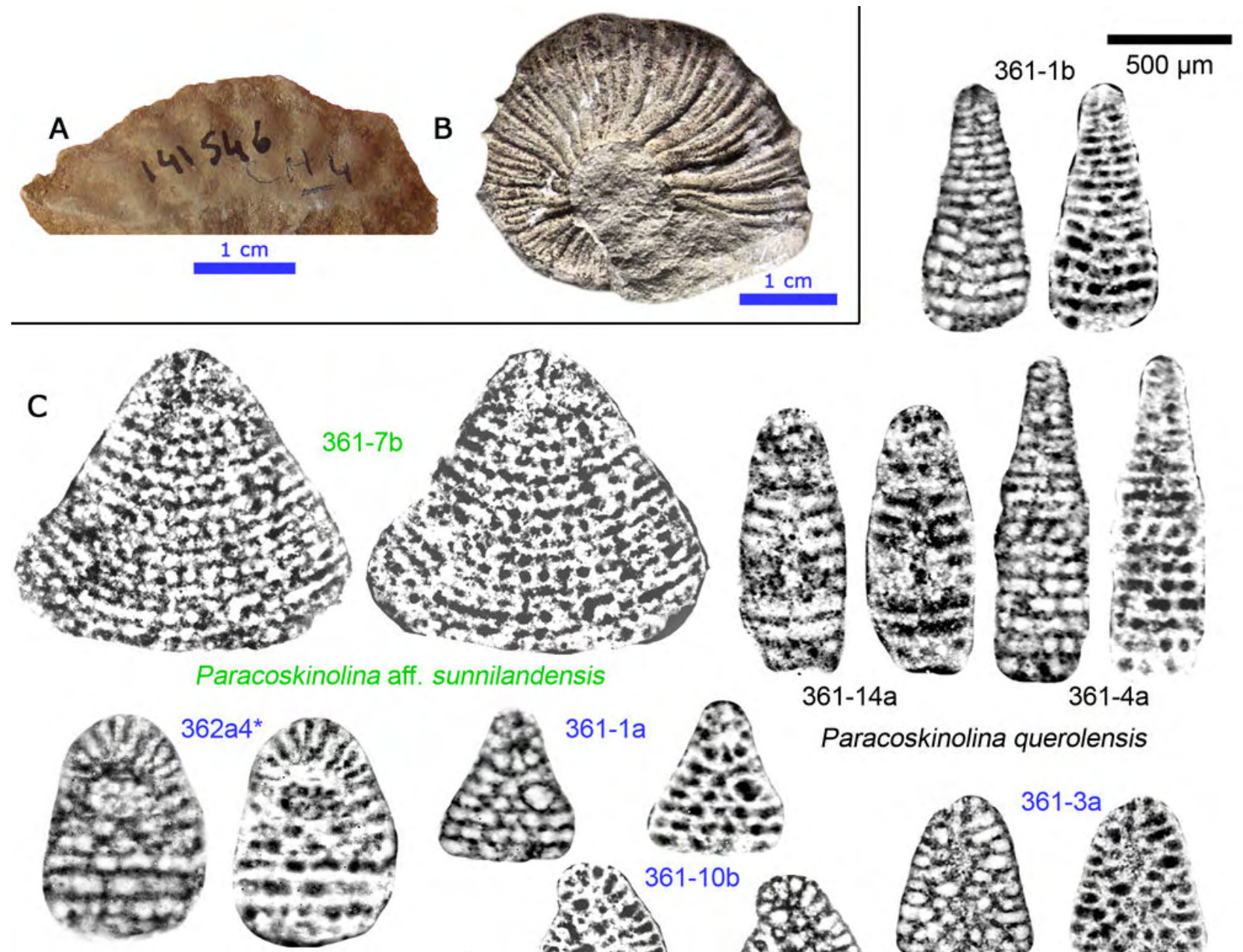

$361-14 a$

$361-4 a$

Paracoskinolina querolensis
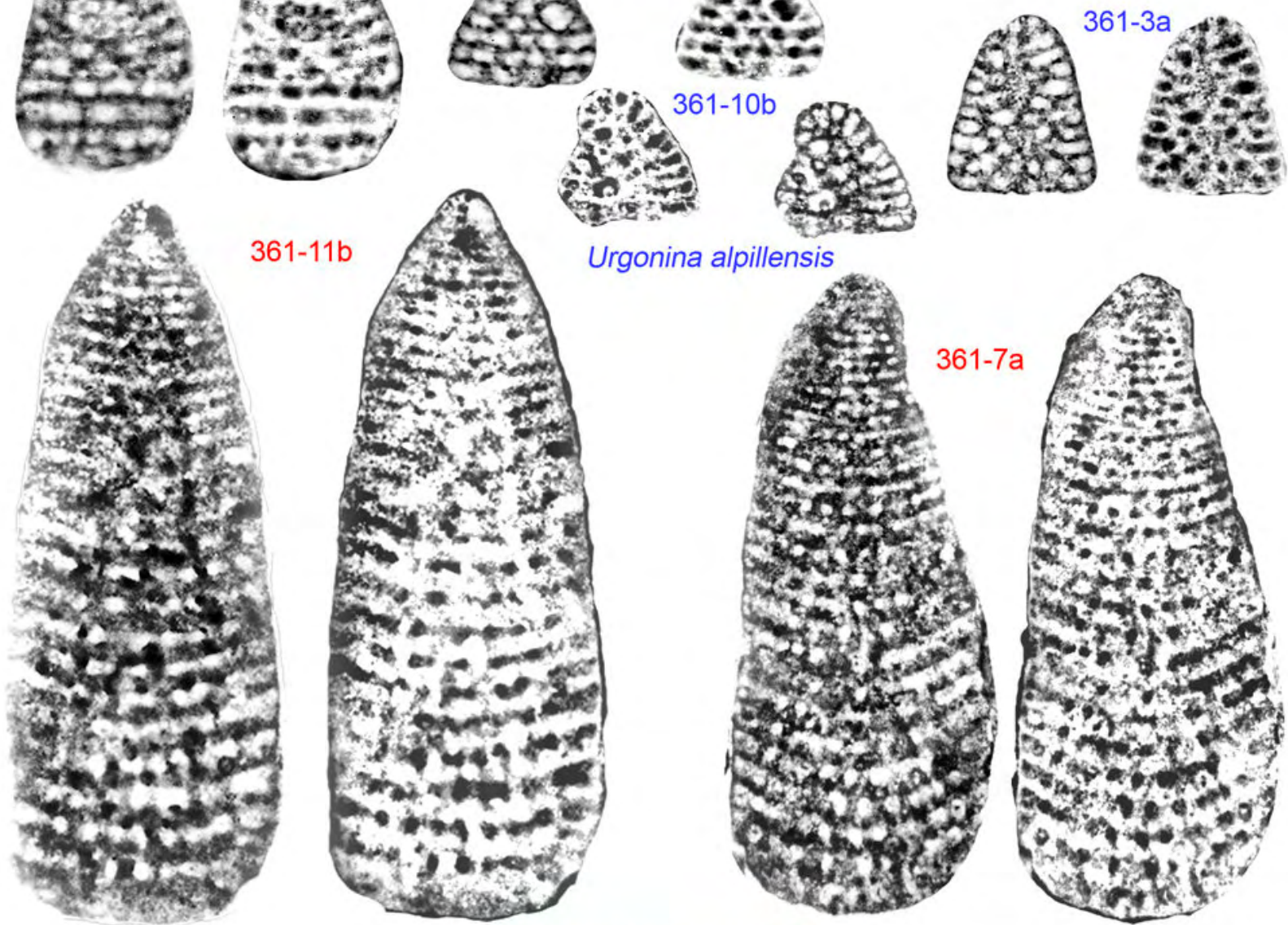

Urgonina alpillensis
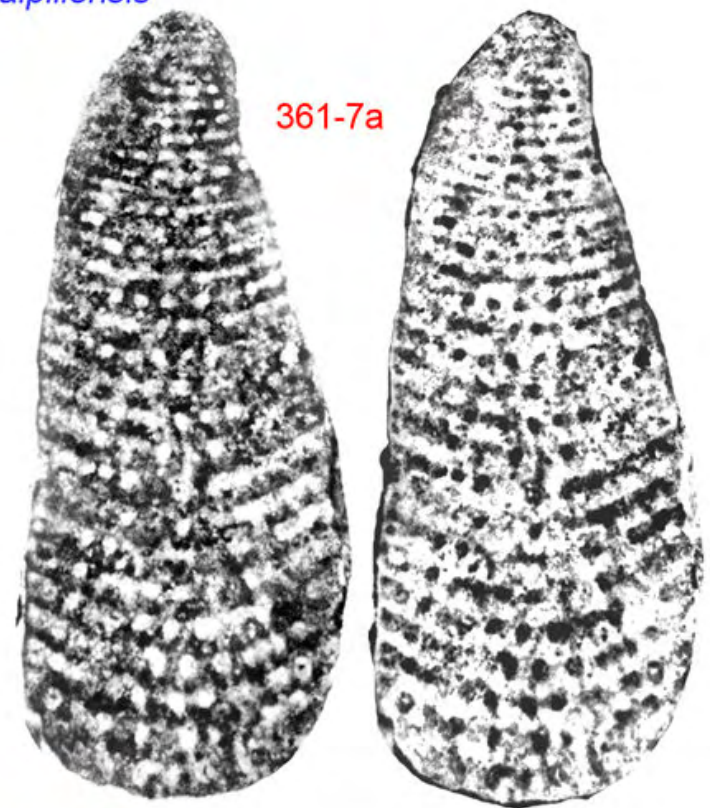

Paracoskinolina maynci

Plate 84: A-B) Ammonites of the Compressissima Zone at Rochecolombe. A) Nicklesia sp. -RB- \{or Kotetishvilia compressissima -DB-\}, FSL 141546; B) Holcodiscus fallax, FSL 141538. C) Orbitolinids of the Vandenheckei Zone at Rochecolombe. Paracoskinolina maynci: 361-7a, 361-11b; Paracoskinolina querolensis: 361-1b, 361-4a, 362-14a; Paracoskinolina aff. sunnilandensis: 361-7b; Urgonina alpillensis: 361-1a, 361-3a, 361-10b, 361a4*. Ammonite scale bar $(A-B)=5 \mathrm{~cm}$, and scale bar $(C)=500 \mu \mathrm{m}$. 

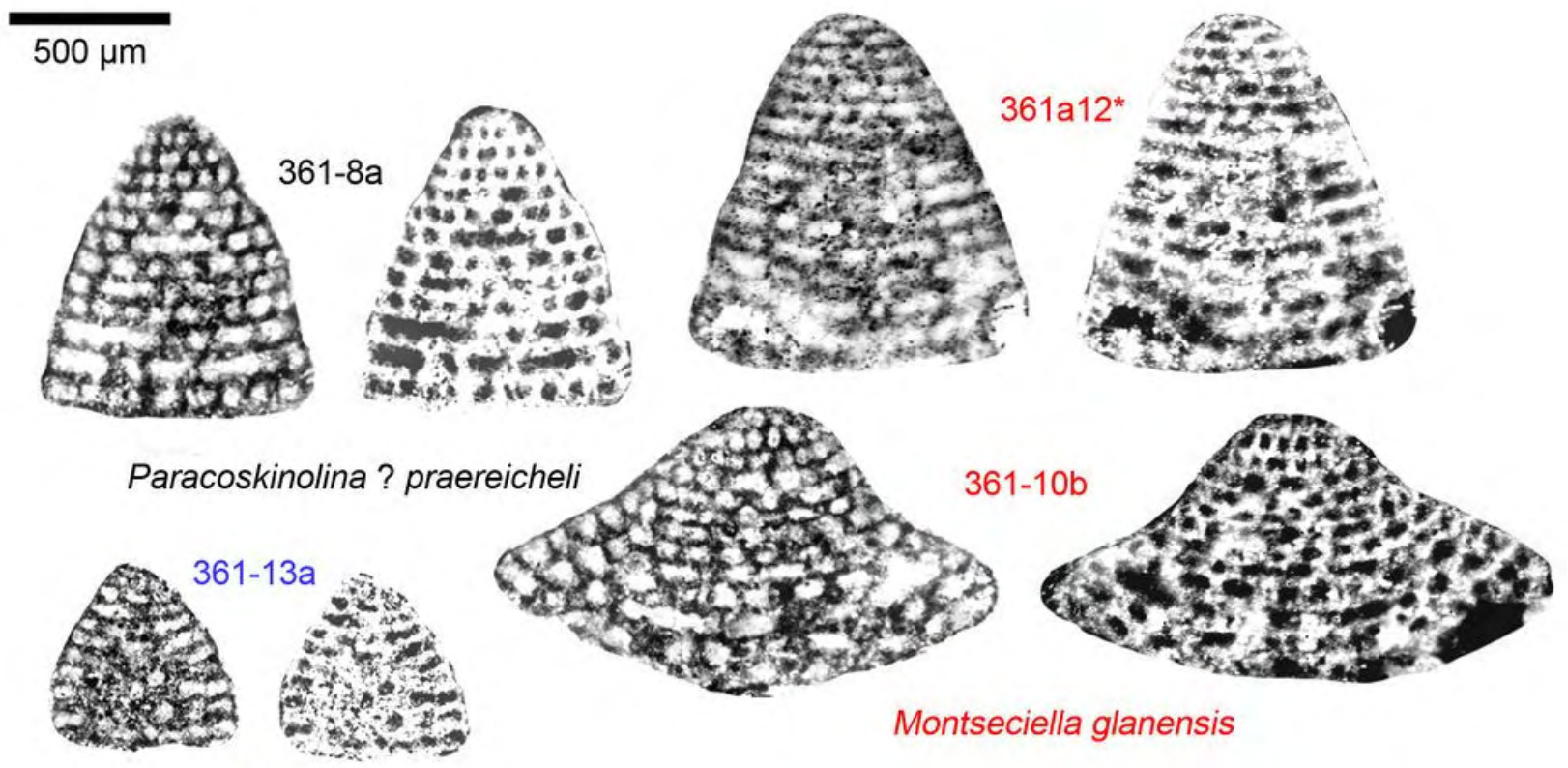

?
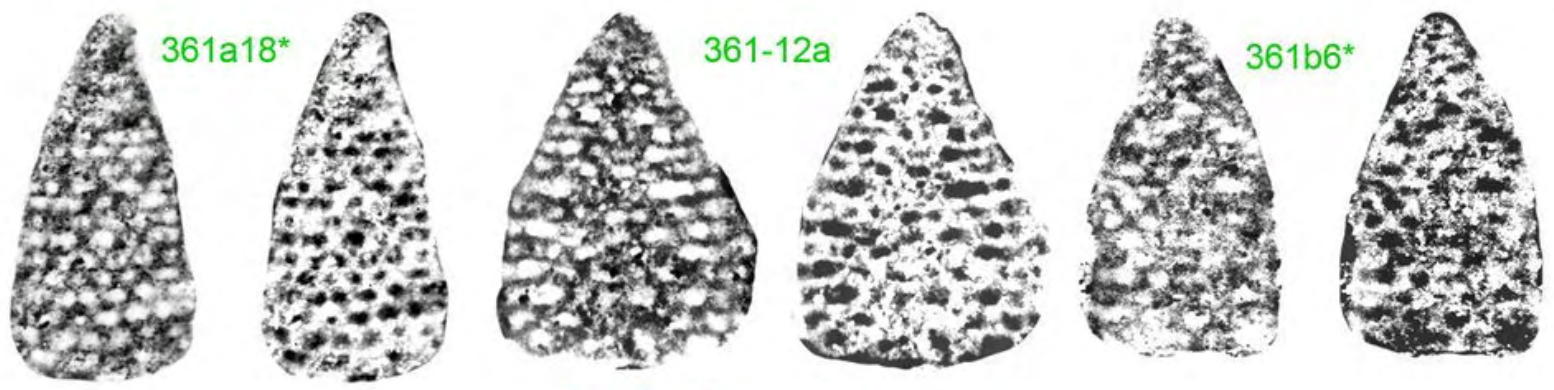

Cribellopsis neoelongata

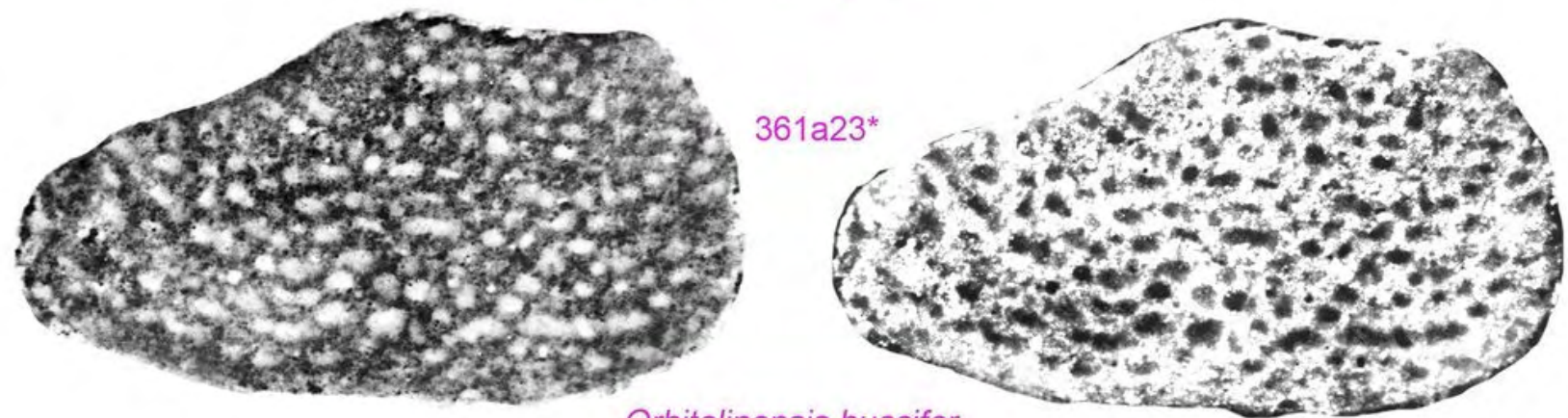

Orbitolinopsis buccifer
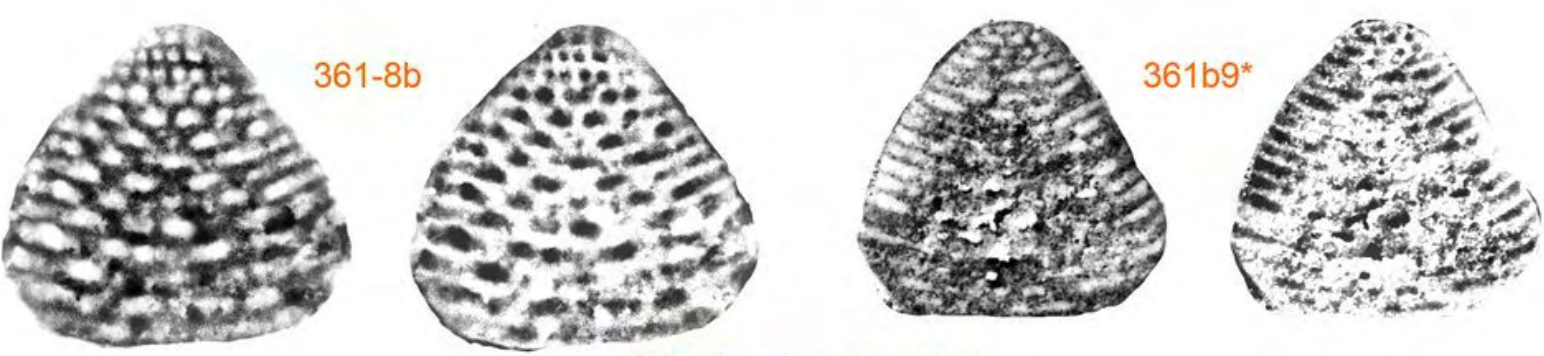

Cribellopsis schroederi

Plate 85: Orbitolinids of the Vandenheckei Zone at Rochecolombe. ?: 361-13a; Cribellopsis neoelongata: 361-12a, 361a18*, 361b6*; Cribellopsis schroederi: 361-8b, 361b9*; Montseciella glanensis: 361-10b, 361a12*; Orbitolinopsis buccifer: 361a23*; Paracoskinolina ? praereicheli: 361-8a. Scale bar $=500 \mu \mathrm{m}$. 
$500 \mu \mathrm{m}$
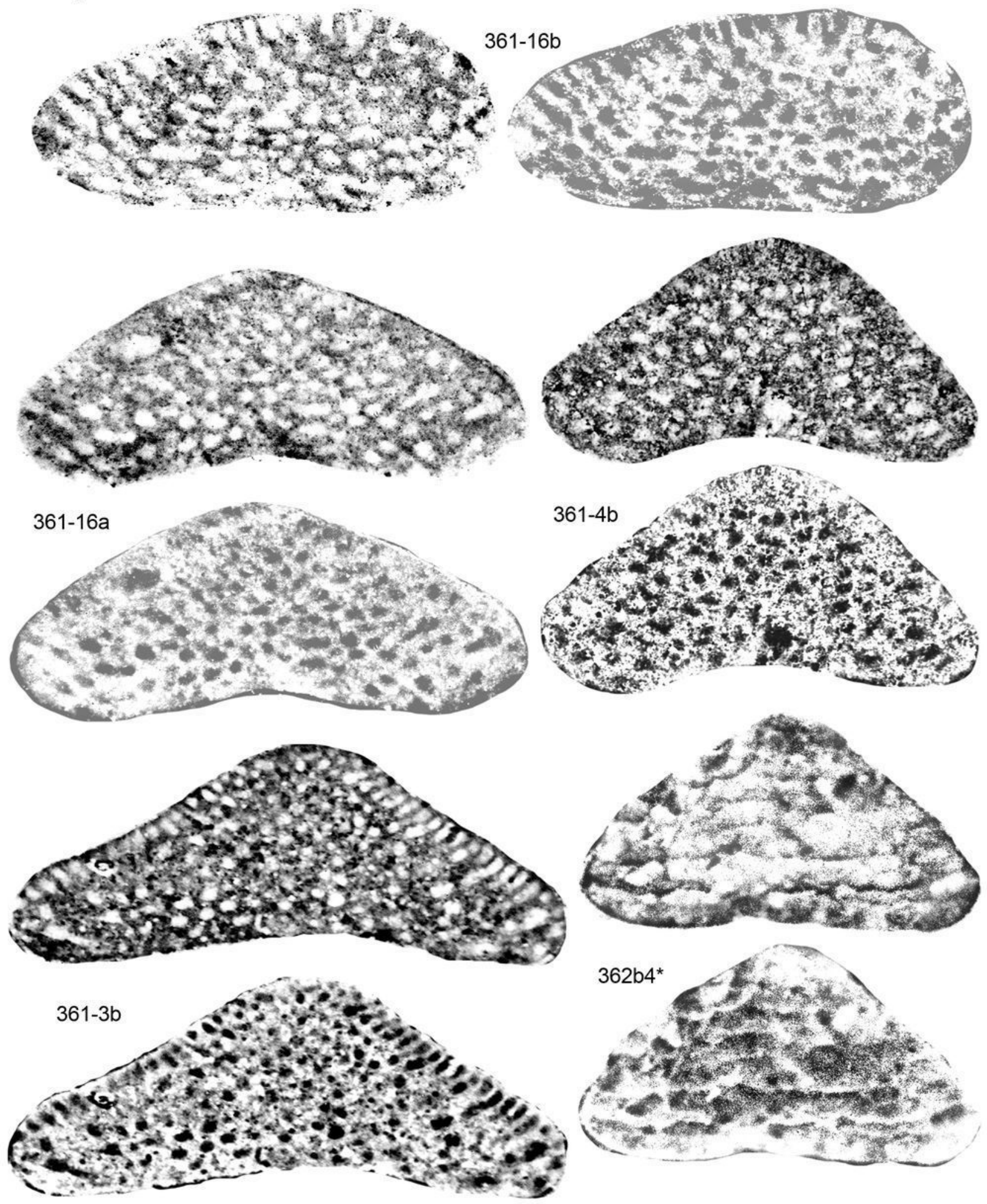

Orbitolinopsis buccifer

Plate 86: Orbitolinids of the Vandenheckei Zone at Rochecolombe. Orbitolinopsis buccifer: 361-3b, 361-4b, 361$16 \mathrm{a}, 361-16 \mathrm{~b}, 361 \mathrm{~b} 4 *$. Scale bar $=500 \mu \mathrm{m}$. 
$500 \mu \mathrm{m}$

Paleodictyoconus cuvillieri
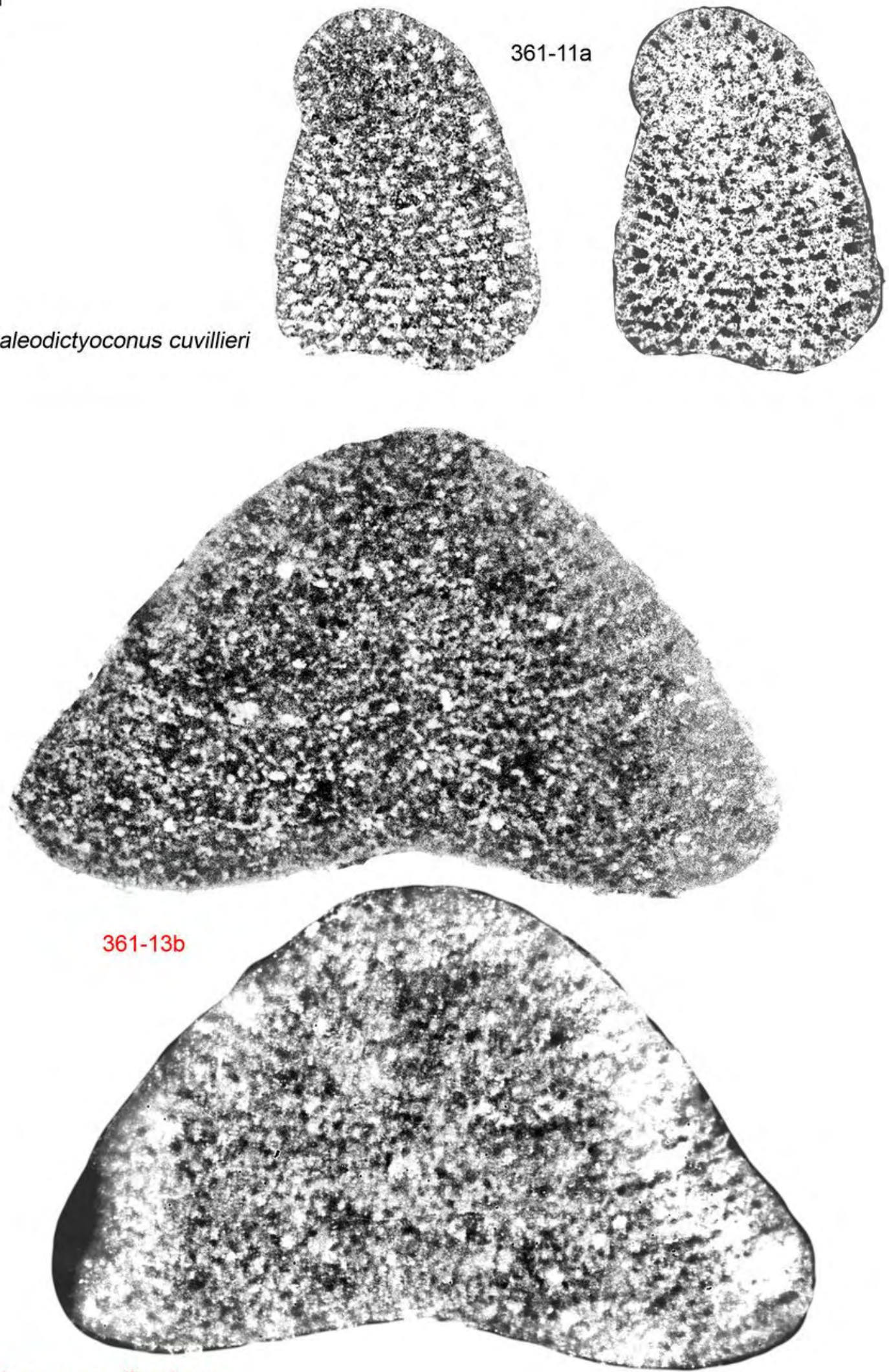

Paleodictyoconus actinostoma

Plate 87: Orbitolinids of the Vandenheckei Zone at Rochecolombe. Paleodictyoconus actinostoma: 361-13b; Paleodictyoconus cuvillieri: 361-11a. Scale bar $=500 \mu \mathrm{m}$. 

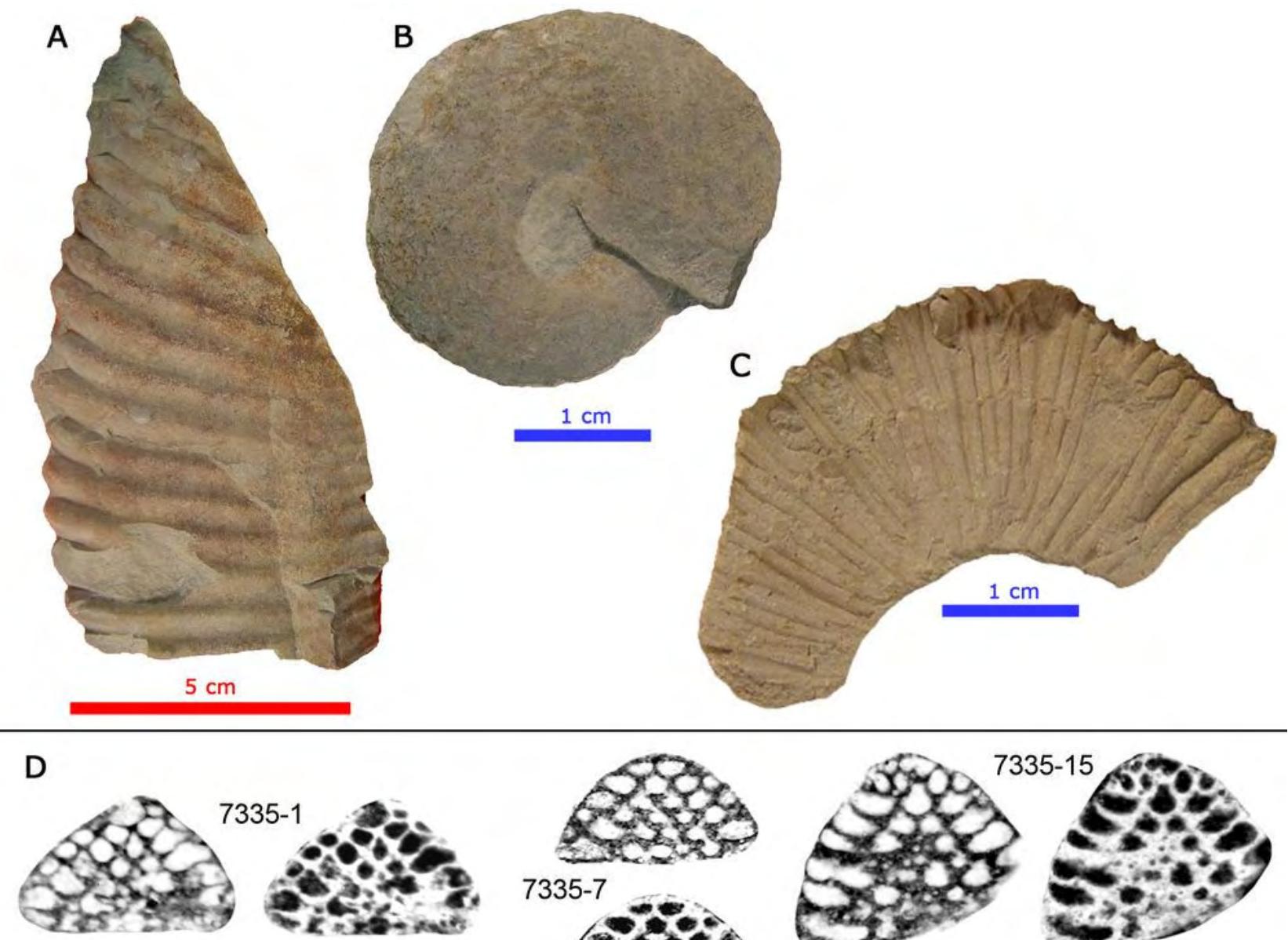

\section{5-7}
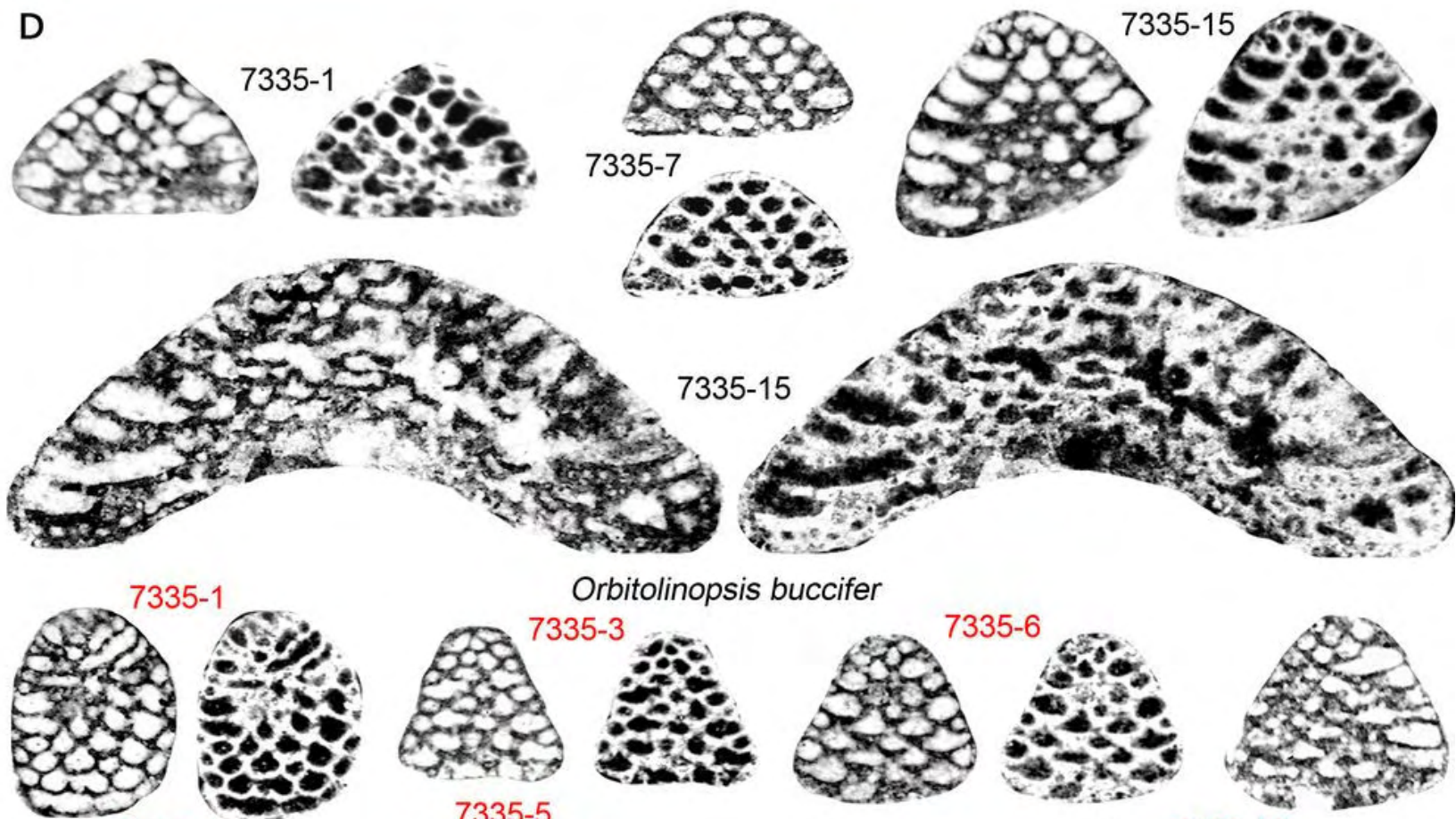

Orbitolinopsis buccifer

7335-1
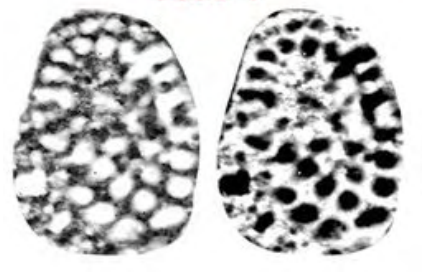

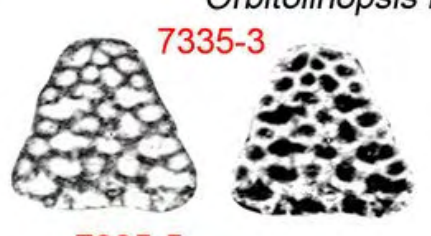

$7335-5$

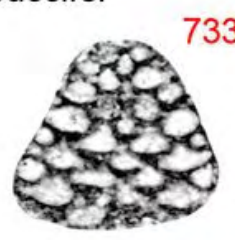

$7335-6$
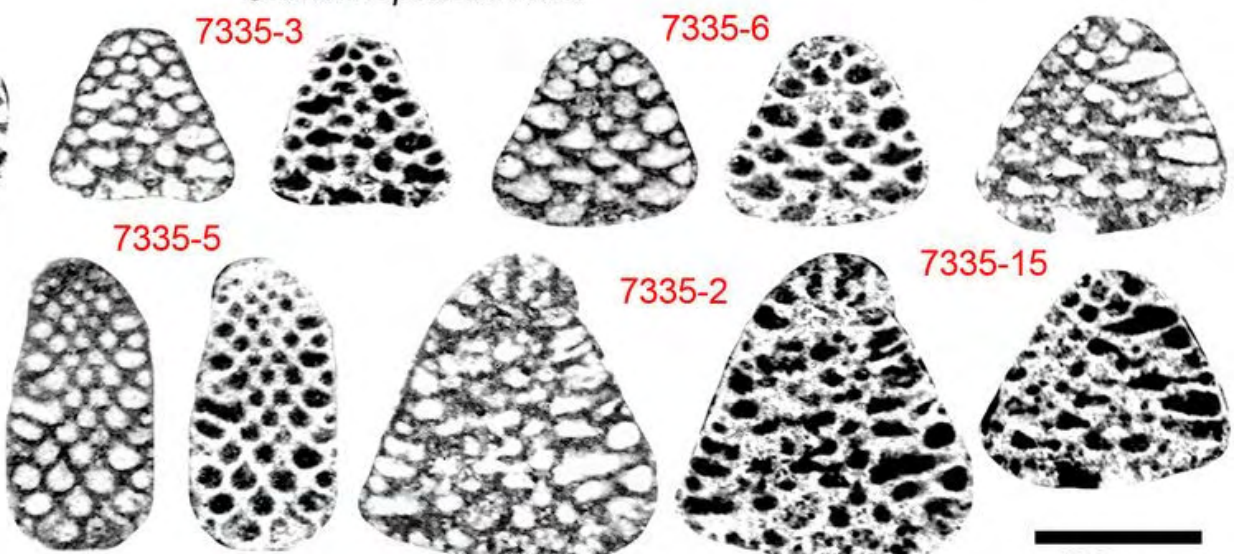

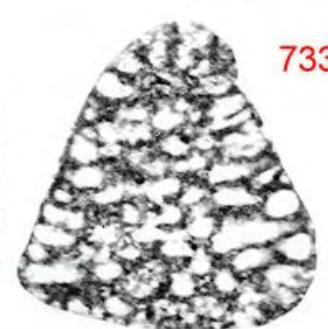

Orbitolinopsis cuvillieri
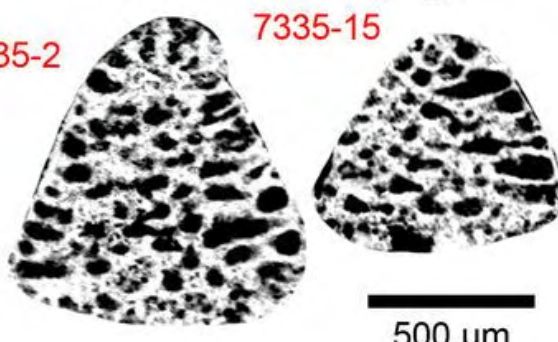

Plate 88: A-C) Ammonites of Moutonianum Zone at Mas Thibaud (Bluye). A) Moutoniceras nodosum, FSL 88791; B) Nikolovites gr. charrierianus, FSL 88794; C) Holcodiscus fallax -RB- (or Holcodiscus sp. -DB-\}, FSL 88792; D) Orbitolinids of the Vandenheckei Zone at Mas Thibaud (Bluye). Orbitolinopsis buccifer: 7335-1, 7335-7, 7335-15; Orbitolinopsis cuvillieri: 7335-1, 7335-2, 7335-3, 7335-5, 7335-6, 7335-15. Ammonite scale bars $(A)=5 \mathrm{~cm},(B-C)=1$ $\mathrm{cm}$, and orbitolinid scale bar (D) $=500 \mu \mathrm{m}$. 

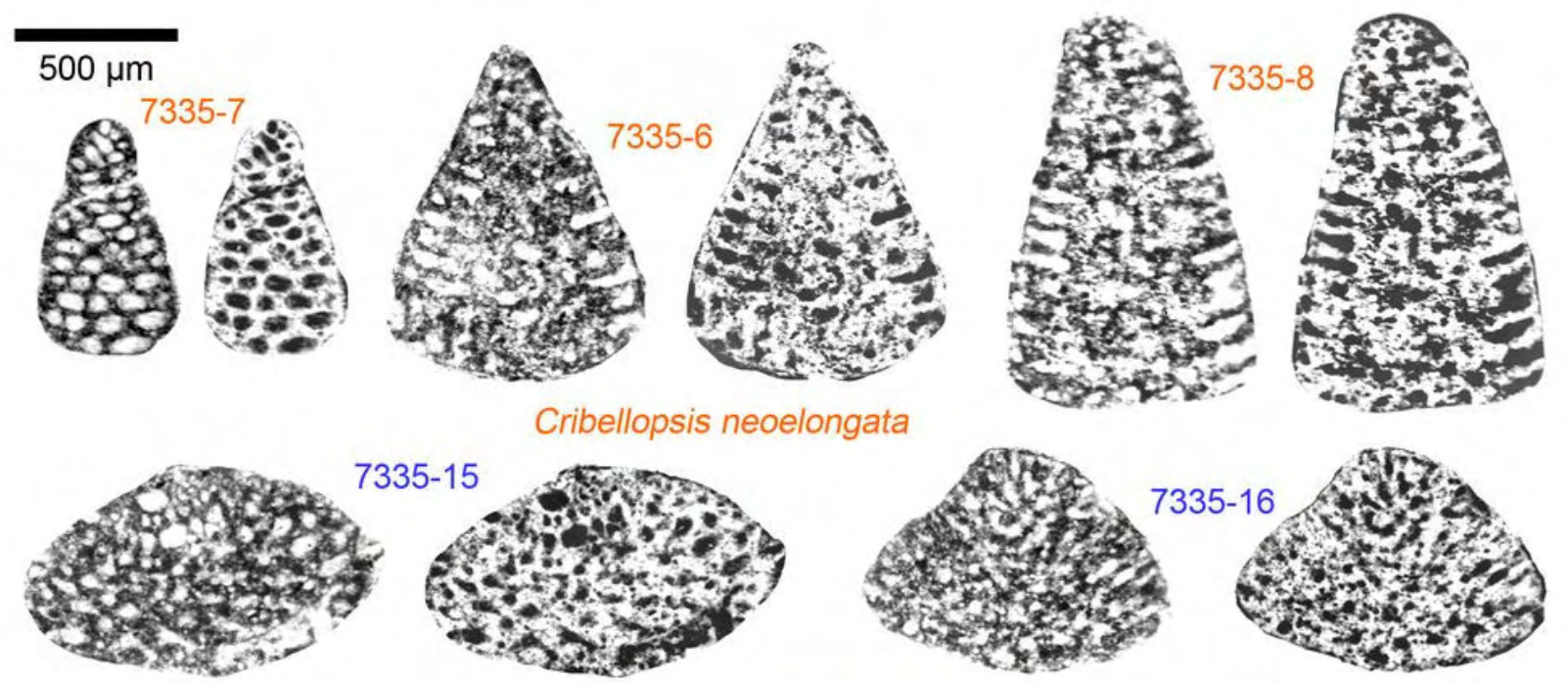

Paleodictyoconus cuvillieri
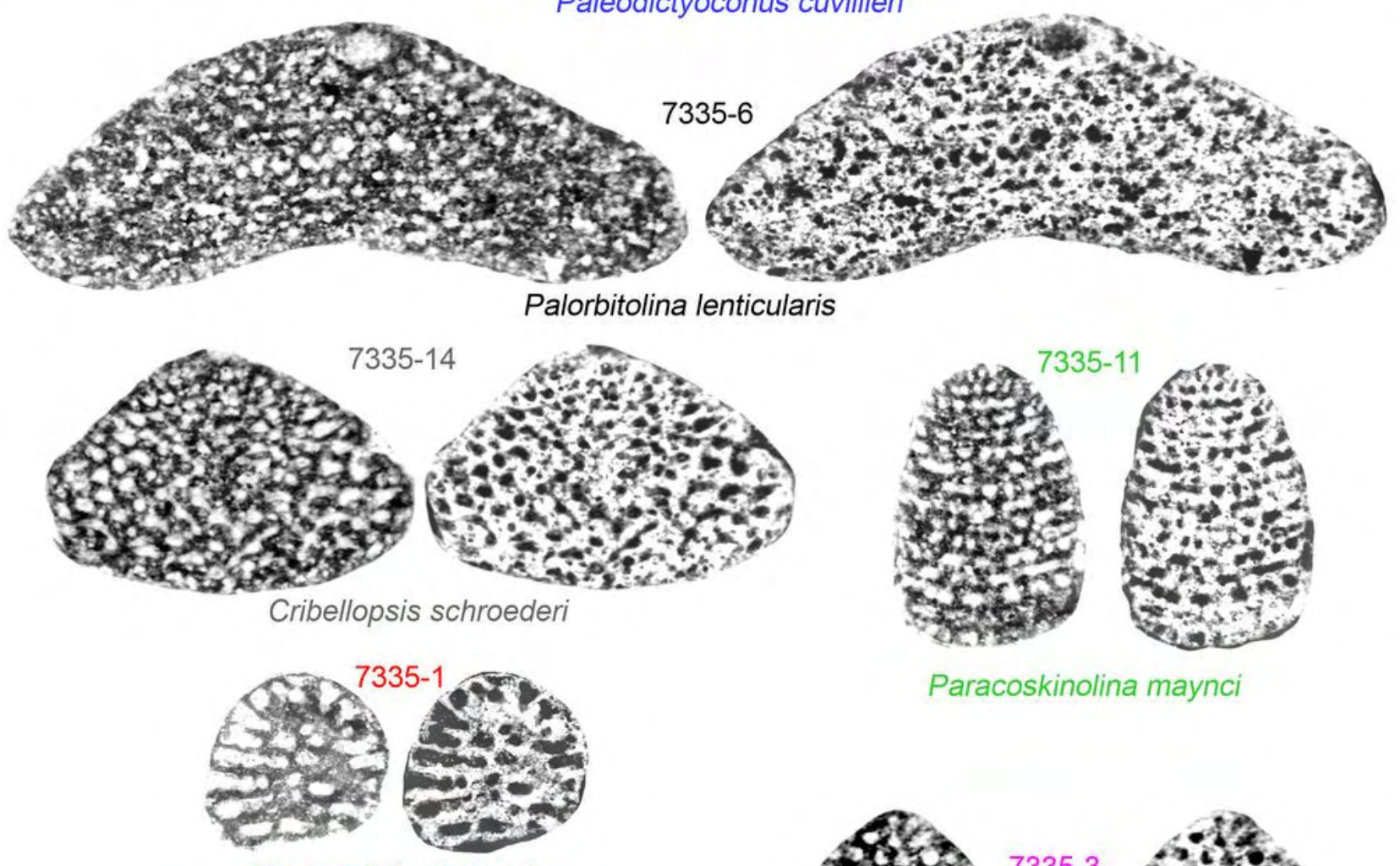

Montseciella glanensis
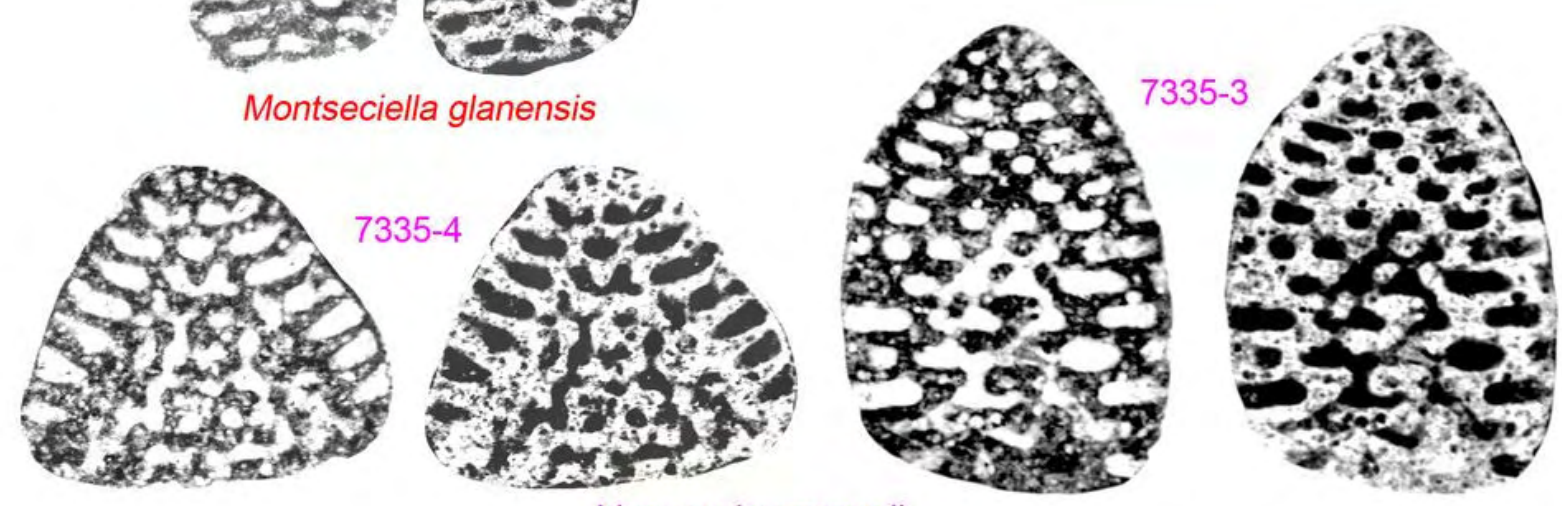

Vanneauina vercorii

Plate 89: Orbitolinids of the Vandenheckei Zone at Mas Thibaud (Bluye). Cribellopsis neoelongata: 7335-6, 7335-7, 7335-8; Cribellopsis schroederi: 7335-14; Montseciella glanensis: 7335-1; Paleodictyoconus cuvillieri: 7335-15, 7335-16; Palorbitolina lenticularis: 7335-6; Paracoskinolina maynci: 7335-11; Vanneauina vercorii: 7335-3, 7335-4. Scale bar $=500 \mu \mathrm{m}$. 

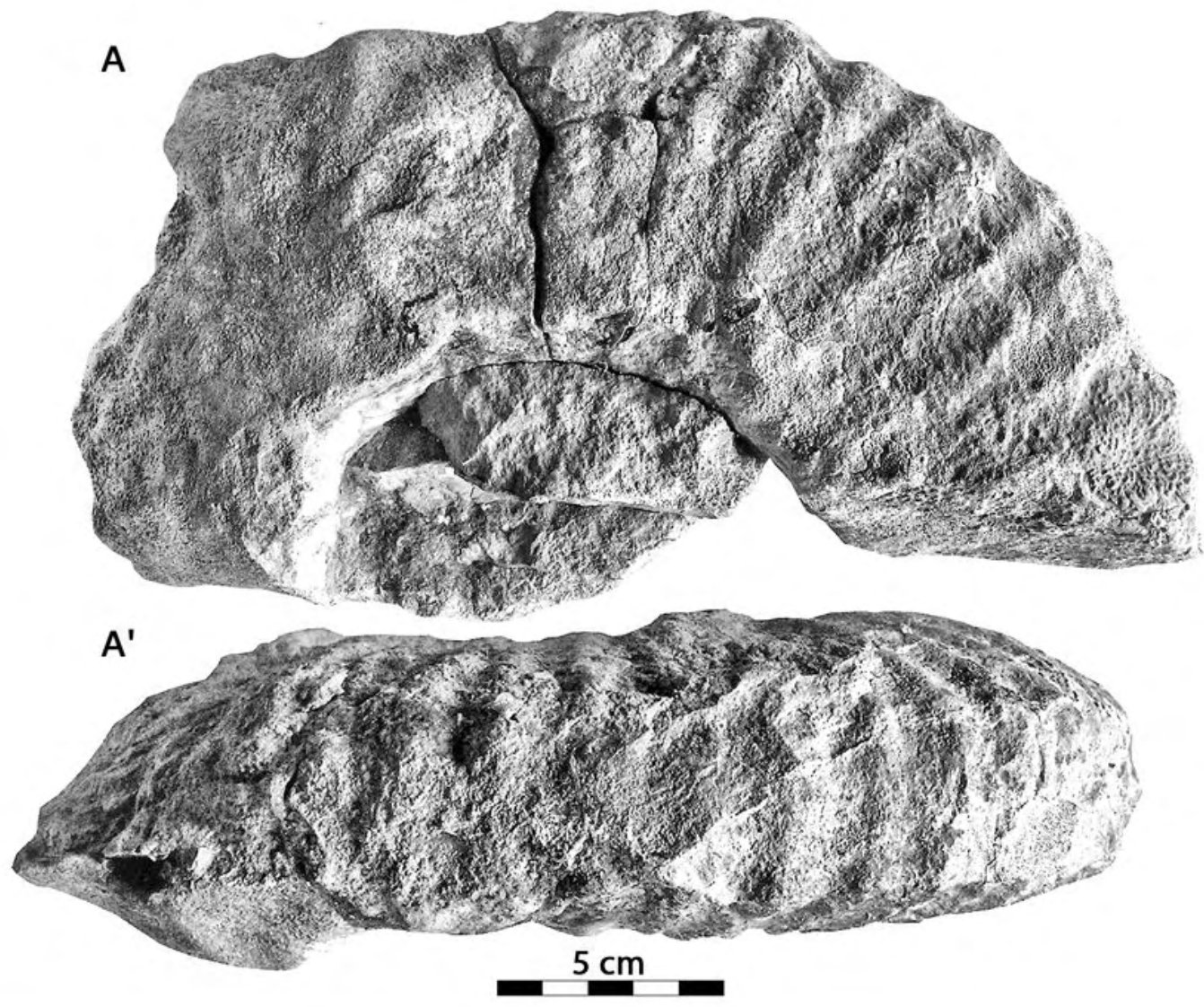

B
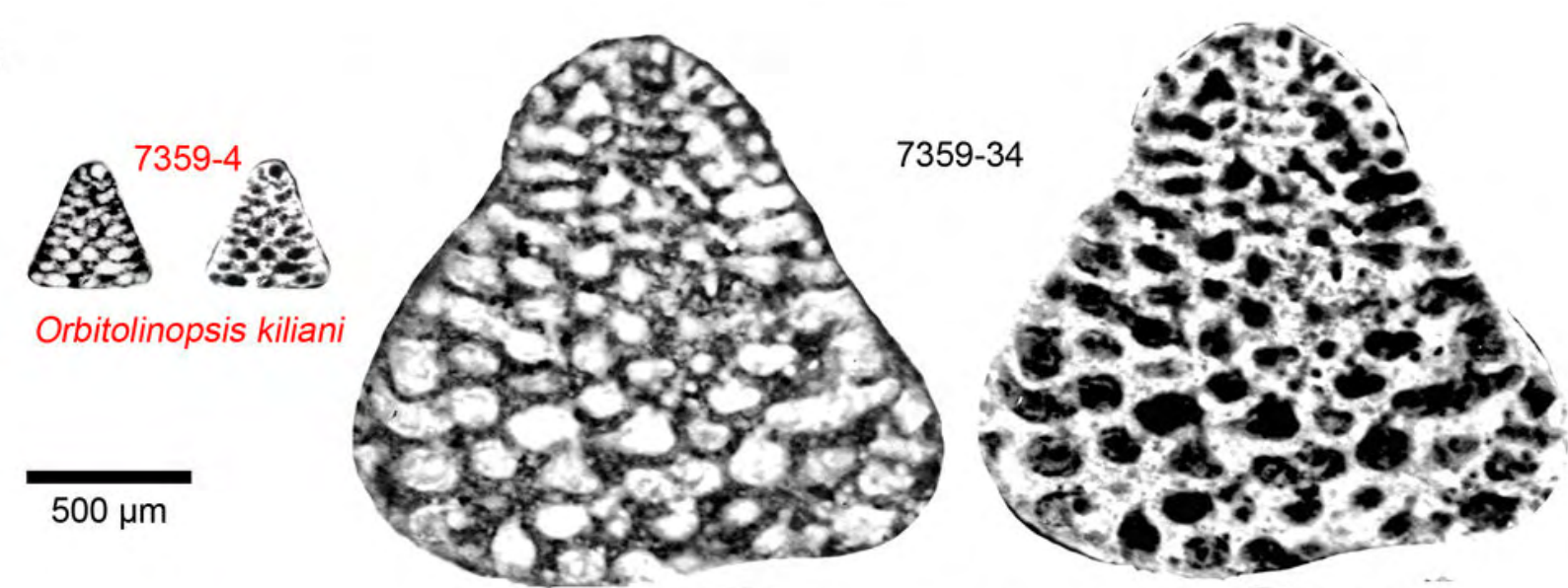

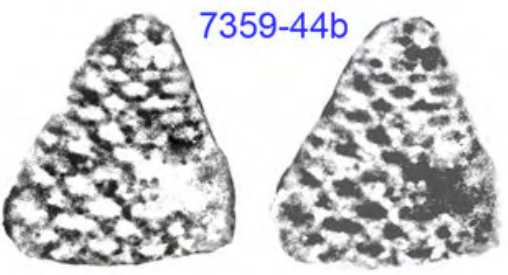

Orbitolinopsis cuvillieri

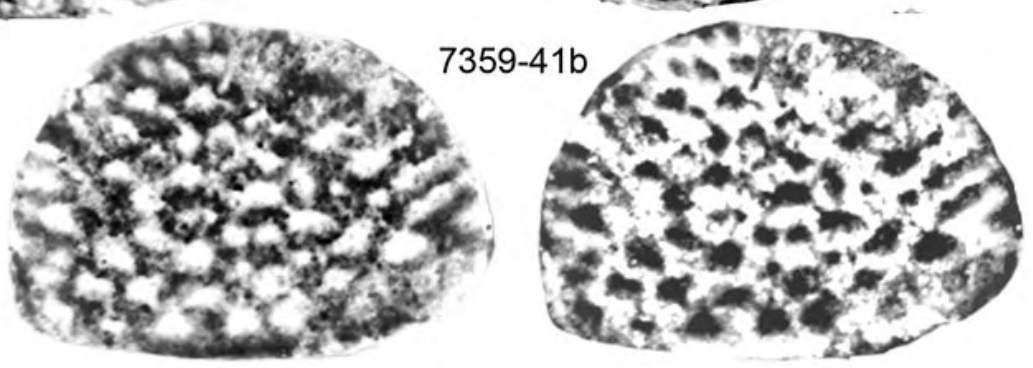

Montseciella glanensis

Plate 90: A-A') Ammonite of the Sartousiana Zone in the Gorges de la Nesque section. Camereiceras aff. limentinus -RB- \{or? Hemihoplites feraudianus -DB-\}, Rocher du Cire, Ph. LÉONIDE legit (LÉONIDE et al., 2012: Fig. 6.G, photo by courtesy of J.-P. MASSE); B) Orbitolinids of the Vandenheckei Zone in the Gorges de la Nesque section. Montseciella glanensis: 7359-34b, 7359-41b; Orbitolinopsis cuvillieri: 7359-44b; Orbitolinopsis kiliani: 7359-4. Ammonite scale bar $(A)=5 \mathrm{~cm}$, and scale bar $(B)=500 \mu \mathrm{m}$. 

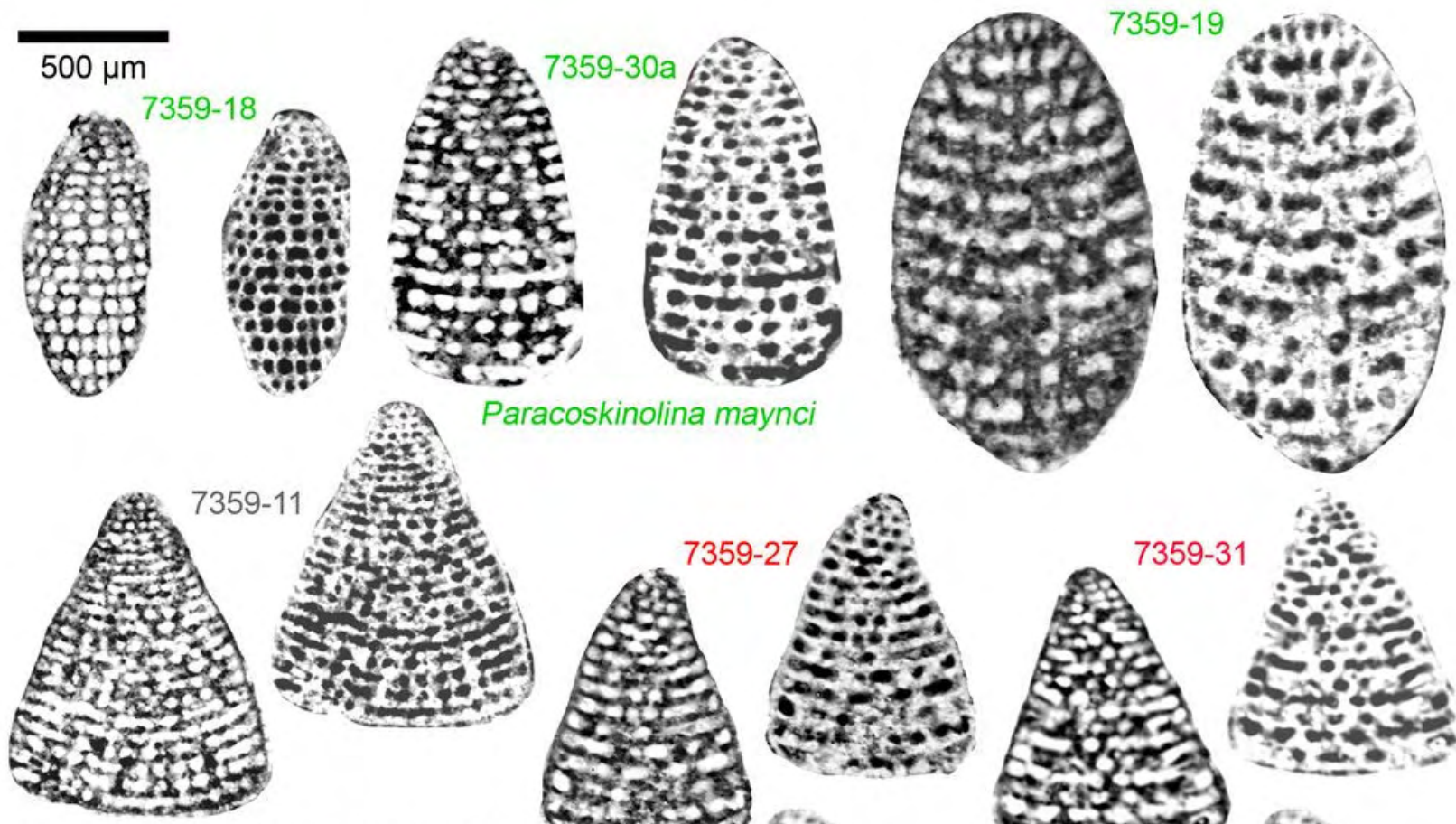

Paracoskinolina aff. sunnilandensis
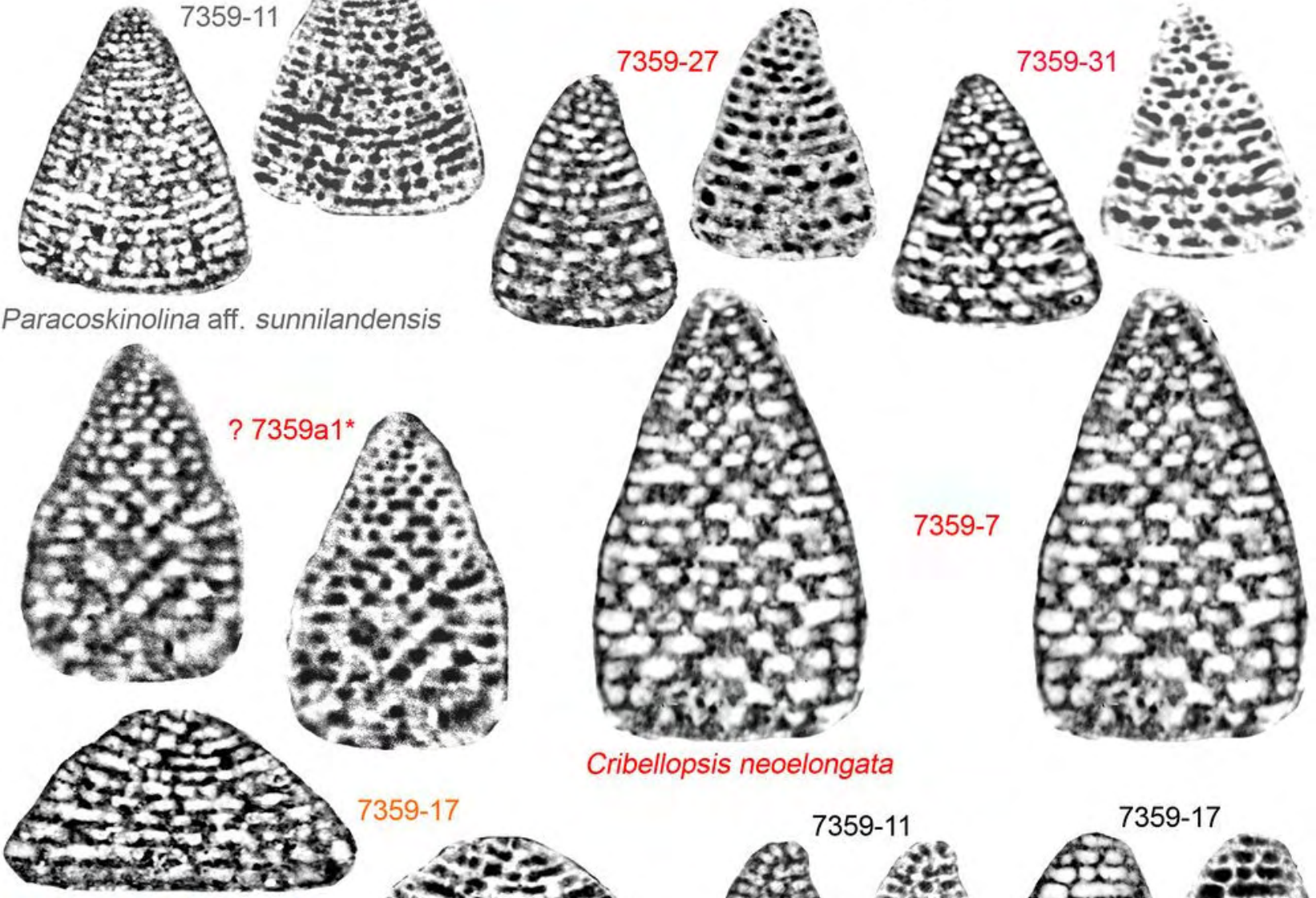

Cribellopsis neoelongata
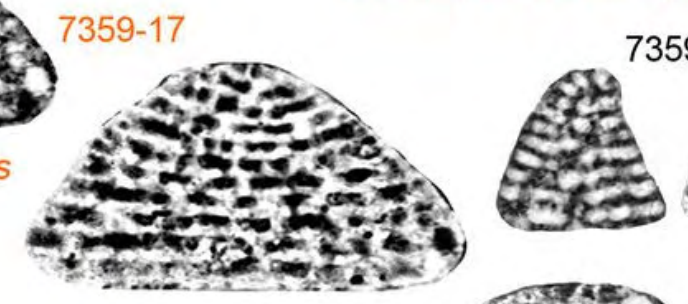

$359-11$
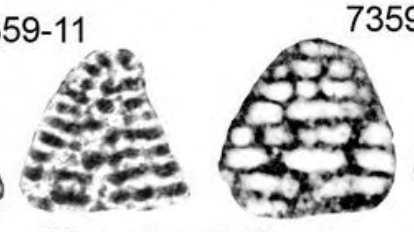

7359-17

Montseciella alguerensis
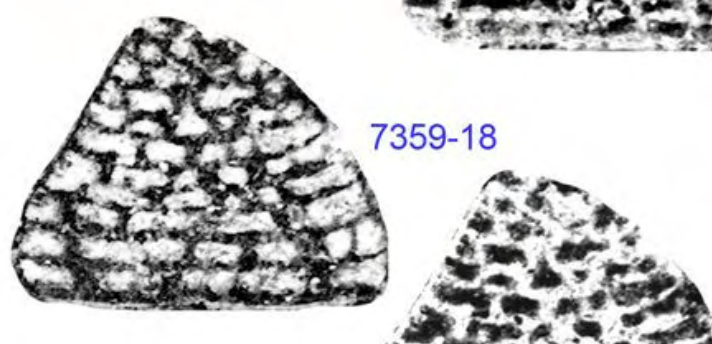

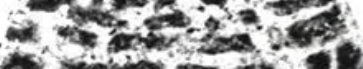

to thos $\rightarrow$ in

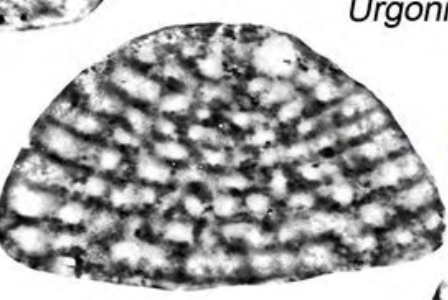

Urgonina alpillensis

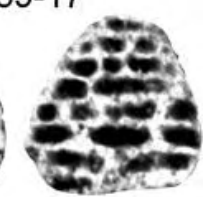

Montseciella glanensis

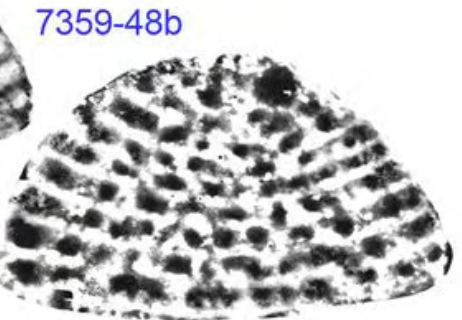

Plate 91: Orbitolinids of the Vandenheckei Zone in the Gorges de la Nesque section. Cribellopsis neoelongata: 735927, 7359-31, 7359a1*; Montseciella alguerensis: 7359-17; Montseciella glanensis: 7359-18, 7359-48b; Paracoskinolina maynci: 7359-18, 7359-19, 7359-30a; Paracoskinolina aff. sunnilandensis: 7359-11; Urgonina alpillensis: 7359$11,7359-17$. Scale bar $=500 \mu \mathrm{m}$. 

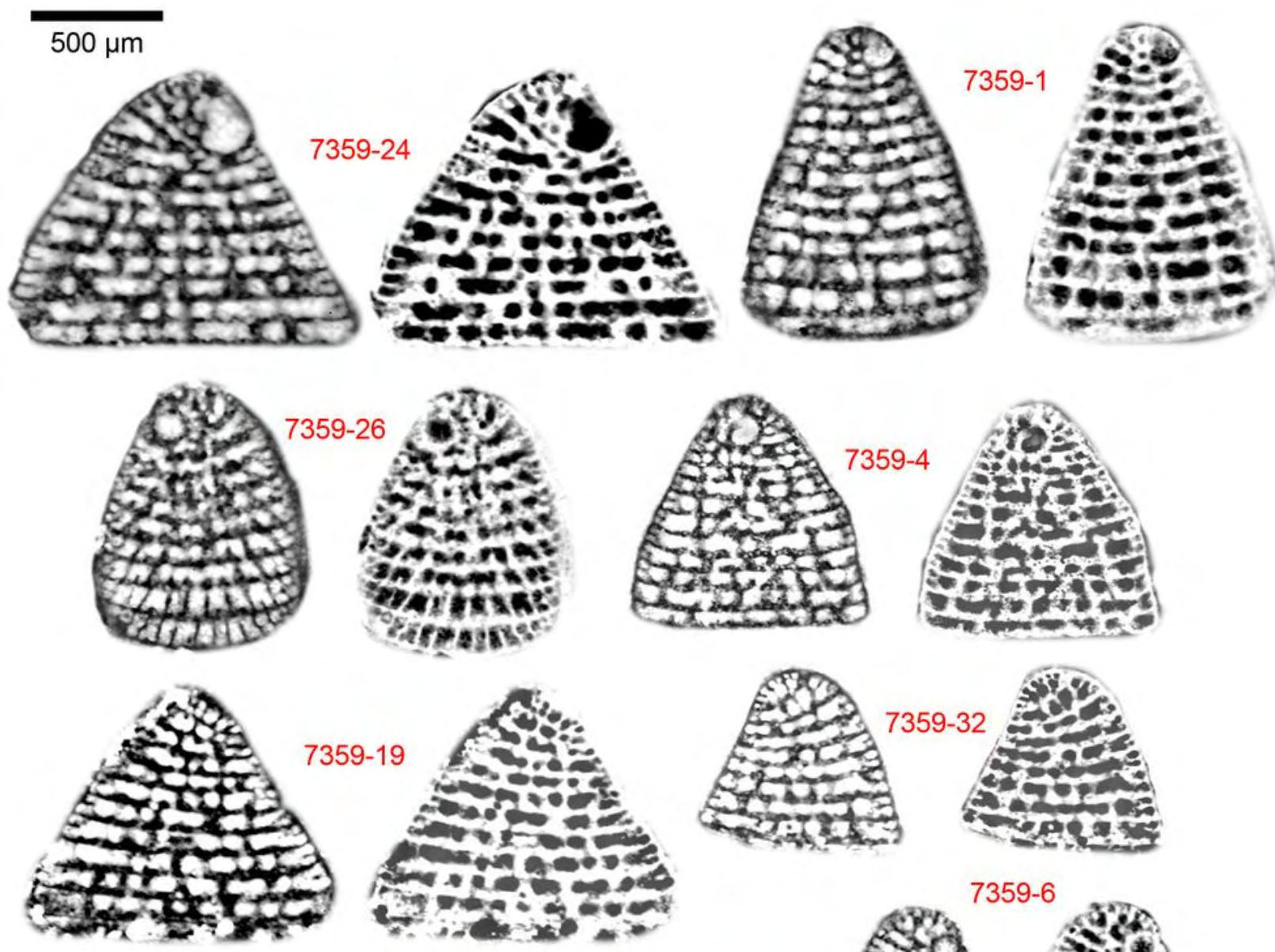

Paracoskinolina? reicheli
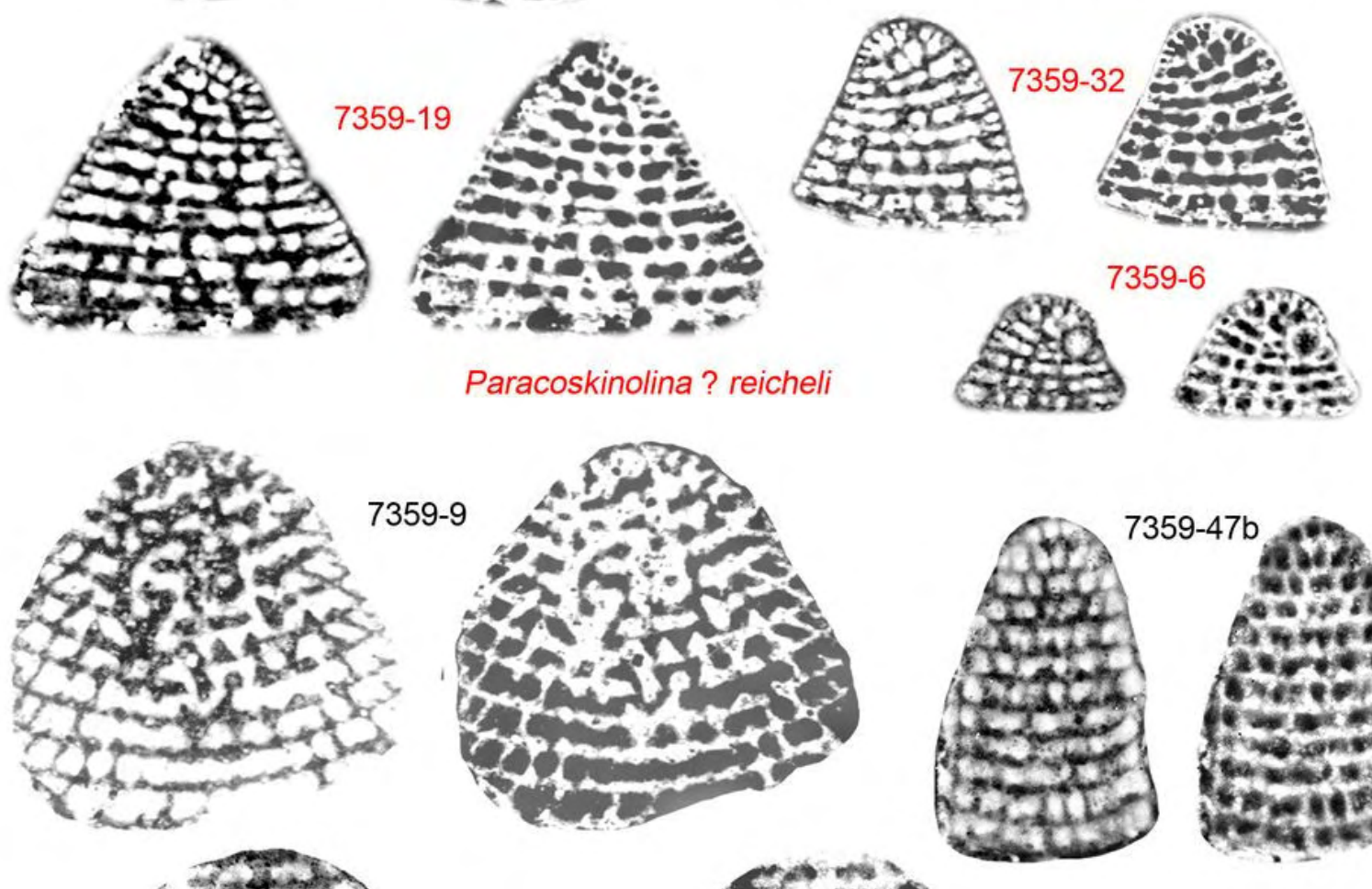

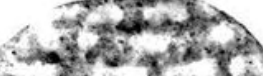

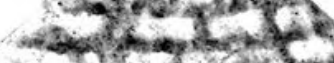

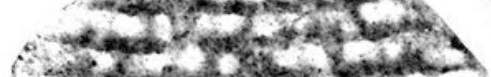

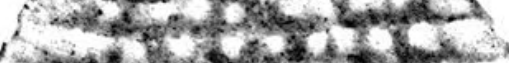

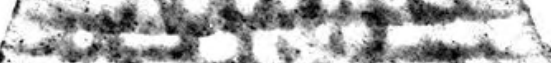

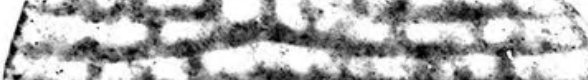
Bn.
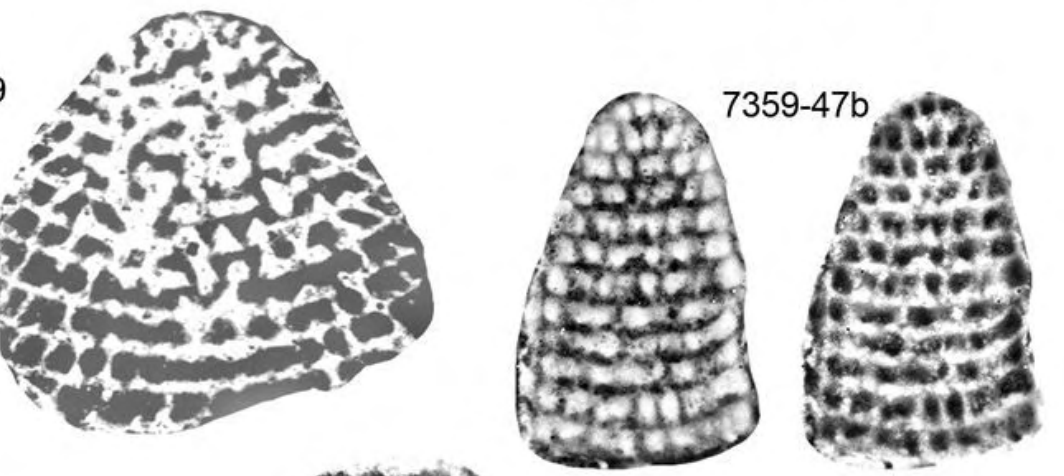

for 10

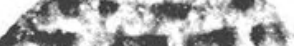

7359-41a

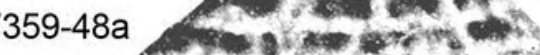

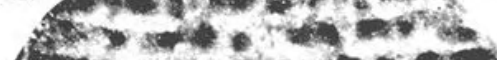
2.4.

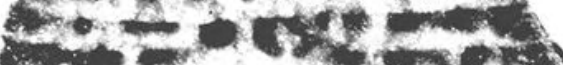

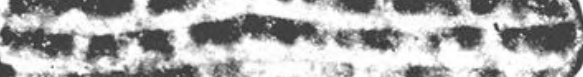

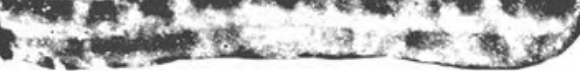

Paracoskinolina ? praereicheli

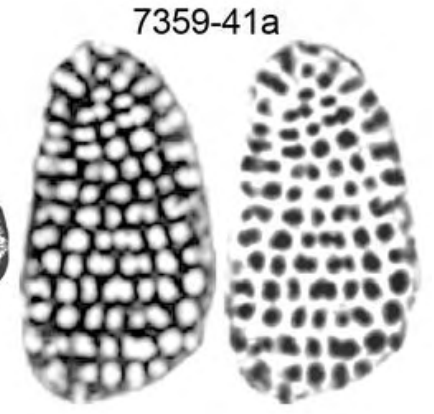

Plate 92: Orbitolinids of the Vandenheckei Zone in the Gorges de la Nesque section. Paracoskinolina ? praereicheli: 7359-1, 7359-4, 7359-6, 7359-19, 7359-24, 7359-26, 7359-32; Paracoskinolina ? reicheli: 7359-9, 7359-41a, 7359-47b, 7359-48a. Scale bar $=500 \mu \mathrm{m}$. 


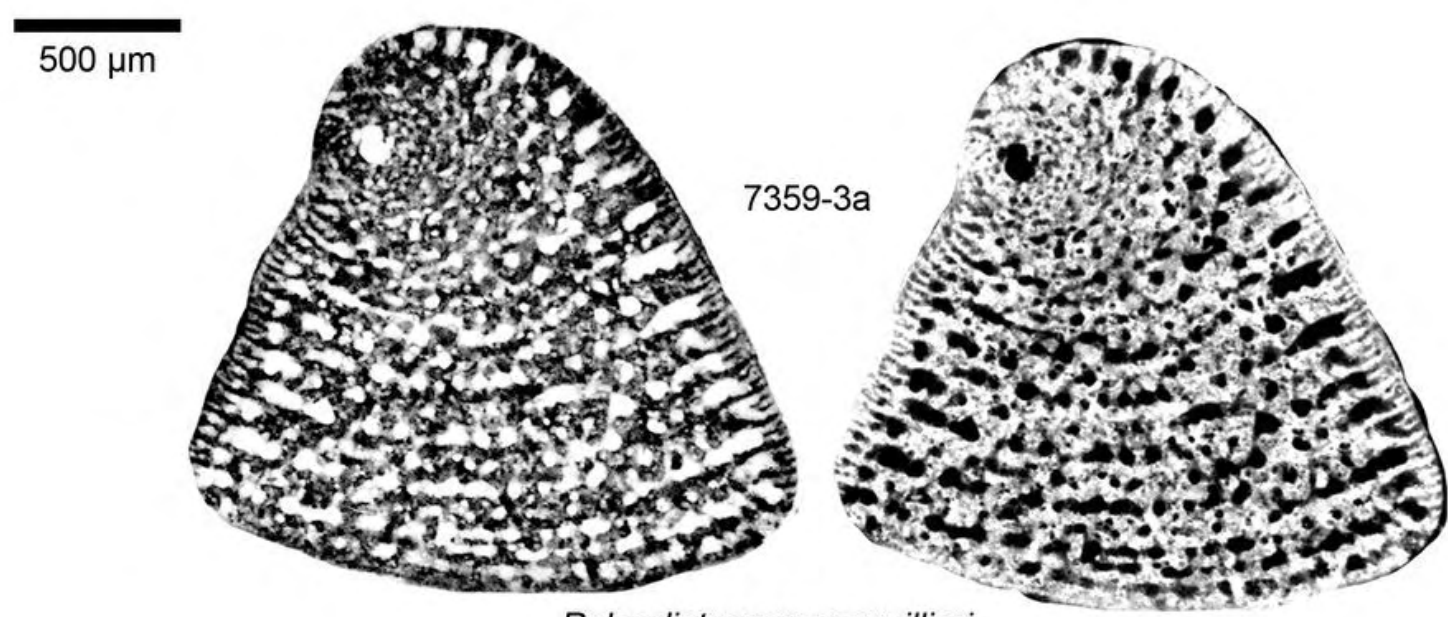

Paleodictyoconus cuvillieri

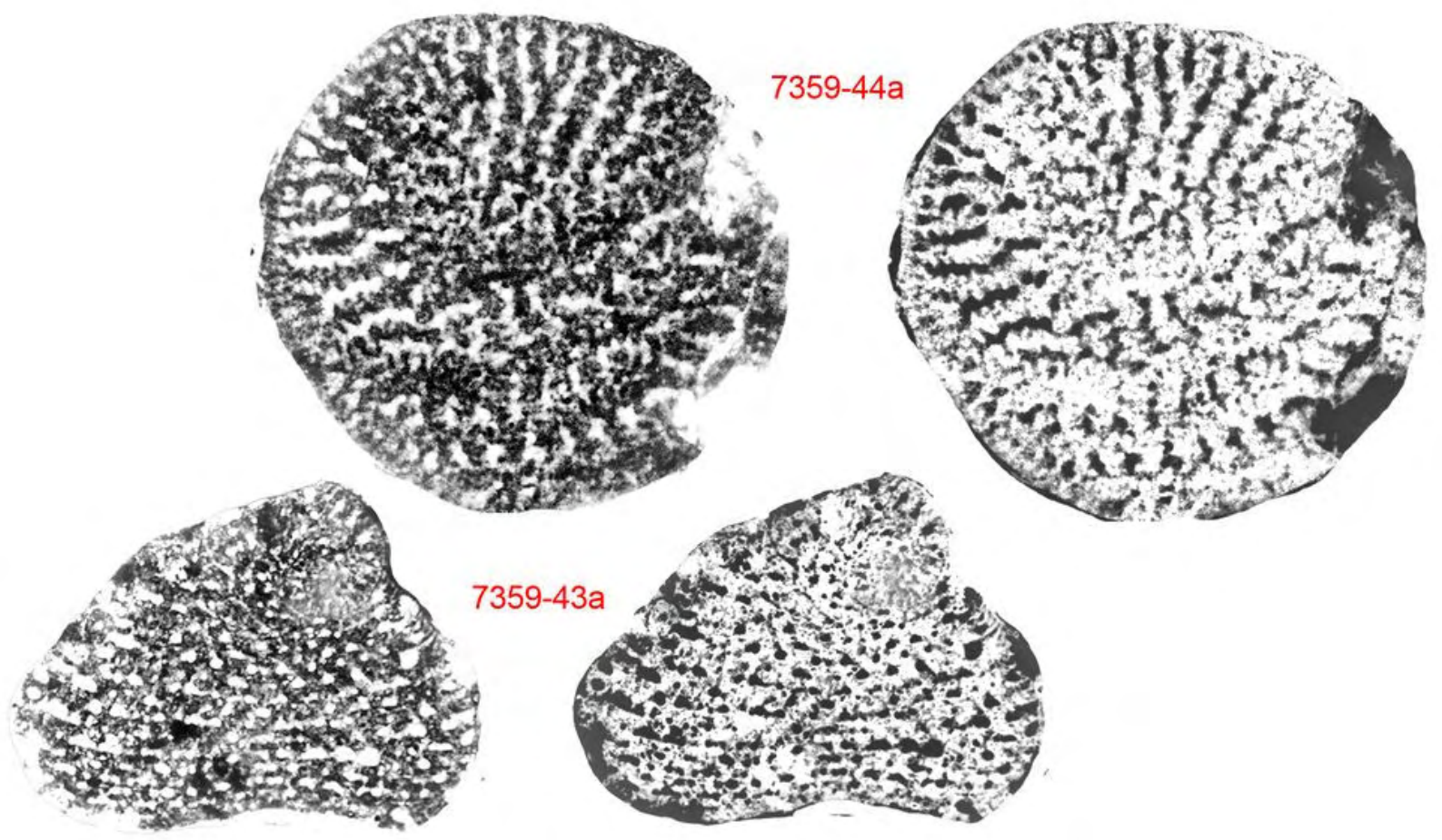

Paleodictyoconus actinostoma
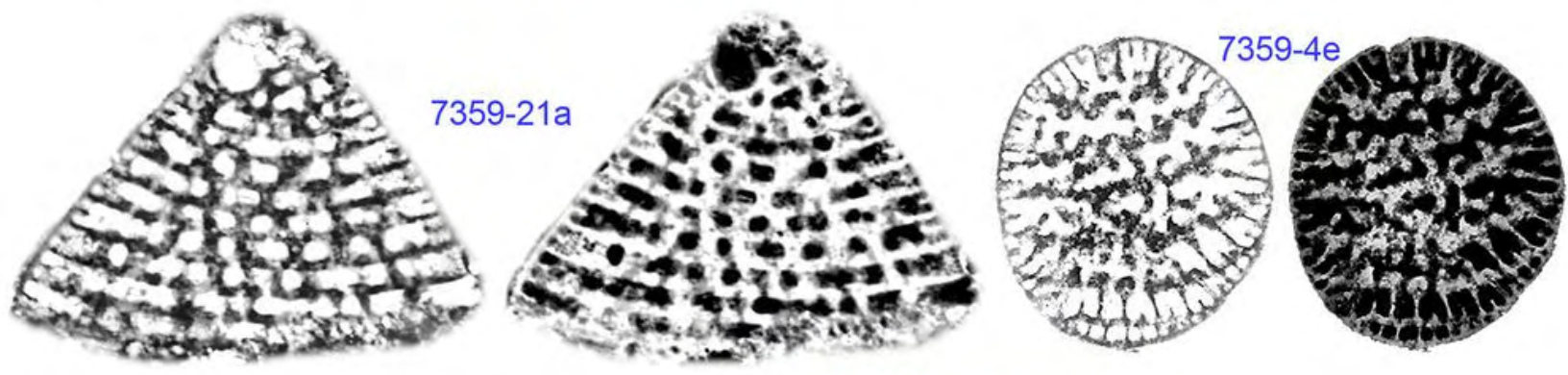

Montseciella arabica

Plate 93: Orbitolinids of the Vandenheckei Zone in the Gorges de la Nesque section. Montseciella arabica: 7359-4, 7359-21; Paleodictyoconus actinostoma: 7359-43a, 7359-44a; Paleodictyoconus cuvillieri: 7359-3. Scale bar = 500 $\mu \mathrm{m}$. 

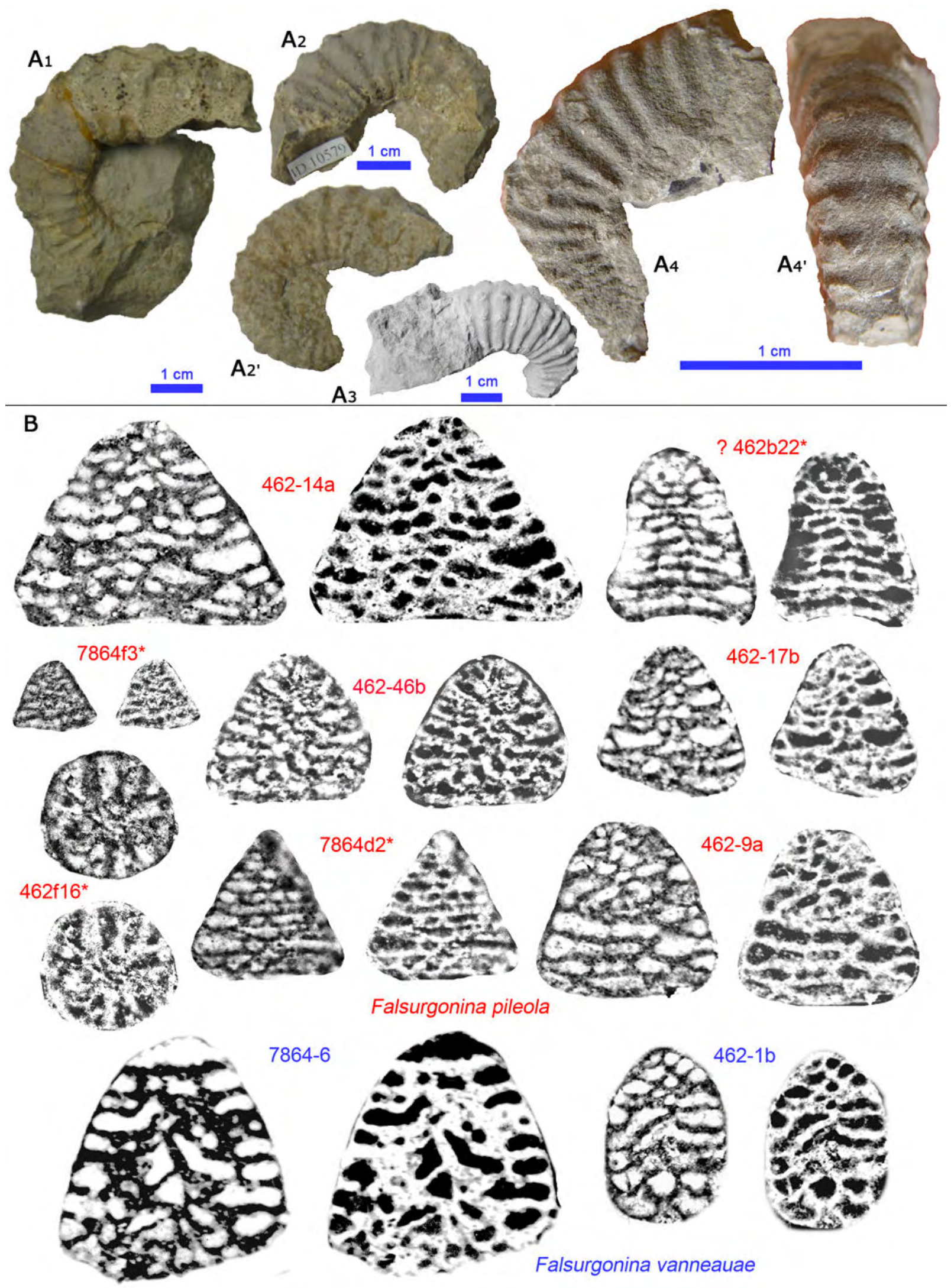

Plate 94: A) Ammonites of Sartousiana Zone at Col de Rousset: A1) Camereiceras limentinus, UJF-ID 10580 (c) OSUG; A2-A2') Camereiceras limentinus, UJF-ID 10579 (C) OSUG; A3) Camereiceras limentinus, UJF-ID 10549 (C) OSUG; A4-A4') Camereiceras sp. -RB- \{or Hemihoplites feraudianus -DB-\}, FSL 108225. B) Orbitolinids of the Vandenheckei Zone at Col de Rousset. Falsurgonina pileola: 462-9a, 462-14a, 462-17b, 462-46b, ? 462b22* [NF], 462f16*, 7864d2*, 7864f3*; Falsurgonina vanneauae: 462-1b, 7864-6. Ammonite scale bar $(\mathrm{A}-\mathrm{C})=5 \mathrm{~cm}$, and scale bar $(D)=500 \mu \mathrm{m}$. Note that PI. 94, A3 ID 10289 [sic, actually UJF-ID 10589] is duplicated from ARNAUD et al. (1998) Pl. 5, fig 8. 


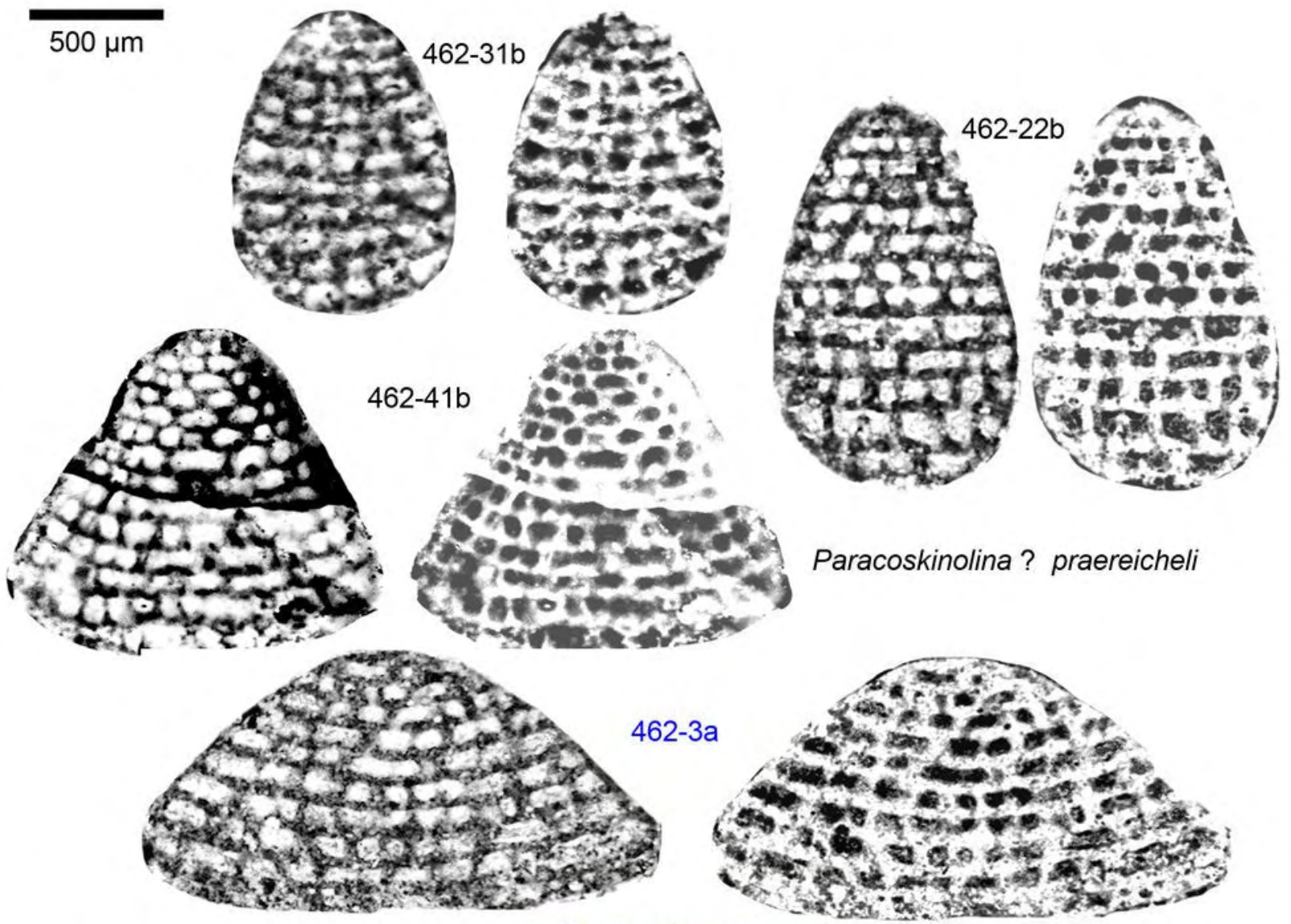

? Montseciella glanensis
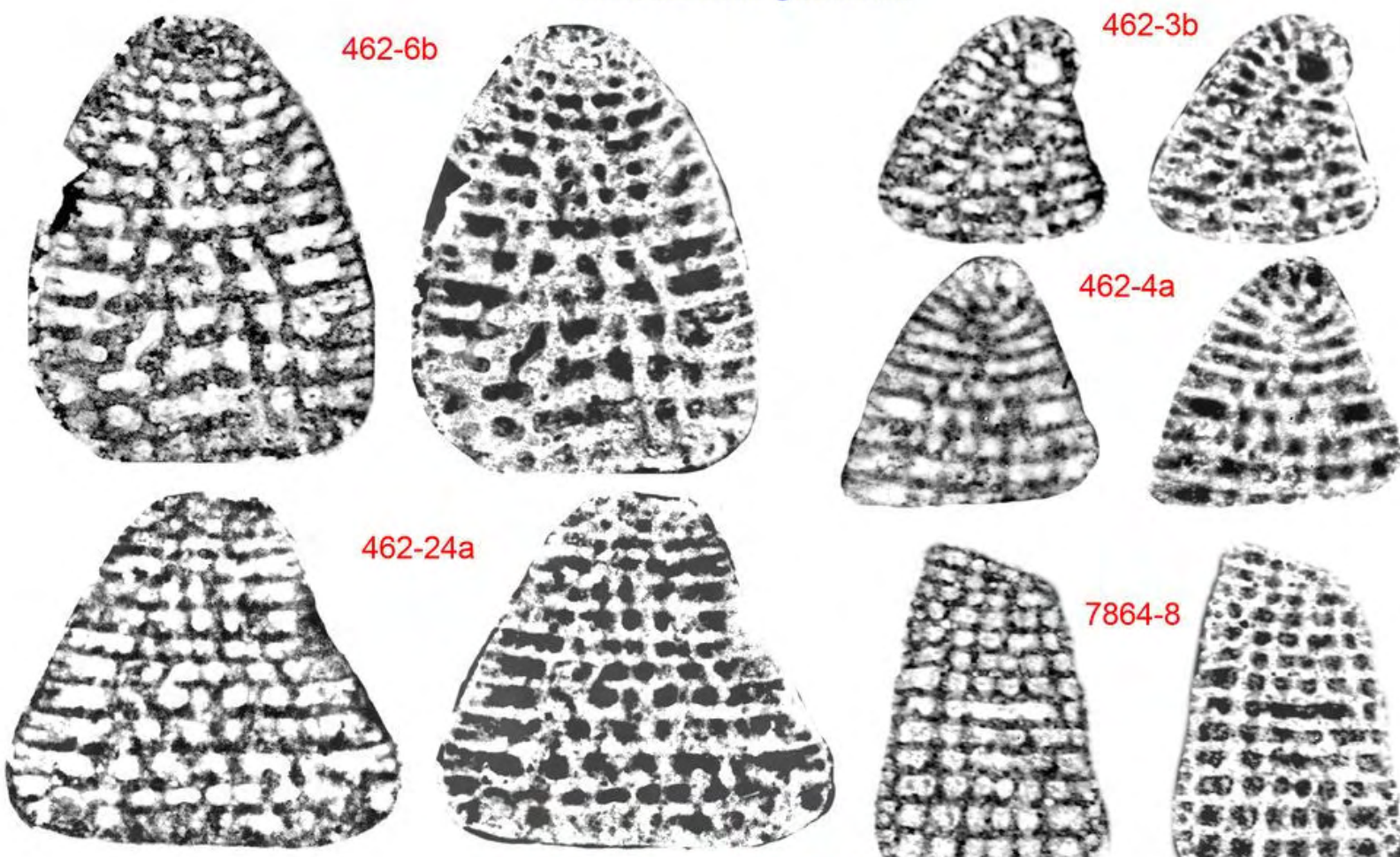

Paracoskinolina ? reicheli

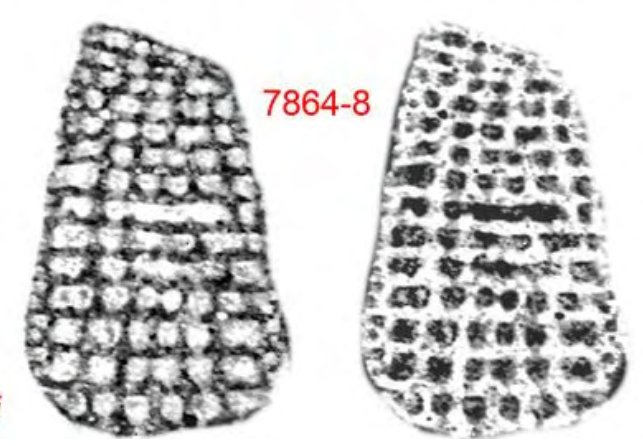

Plate 95: Orbitolinids of the Vandenheckei Zone at Col de Rousset. ? Montseciella glanensis: 462-3a; Paracoskinolina ? praereicheli: 462-22b, 462-31b, 462-41b; Paracoskinolina ? reicheli: 462-3b, 462-4a, 462-6b, 462-24a, 78648. Scale bar $=500 \mu \mathrm{m}$. 

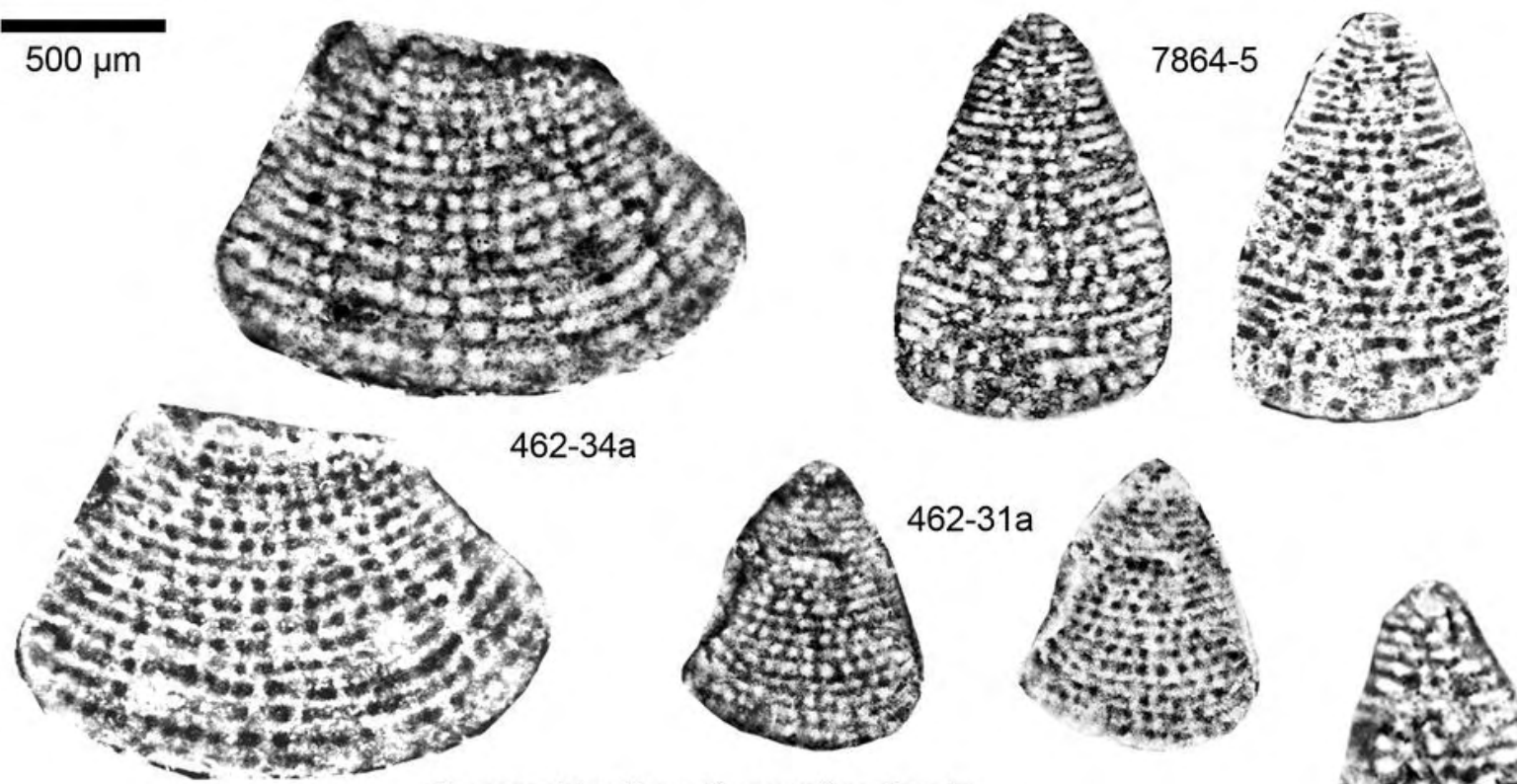

$462-34 a$

Paracoskinolina aff. sunnilandensis

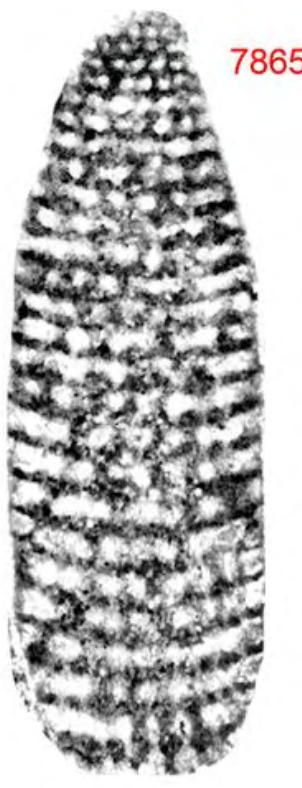

7864-13

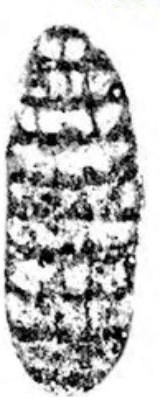

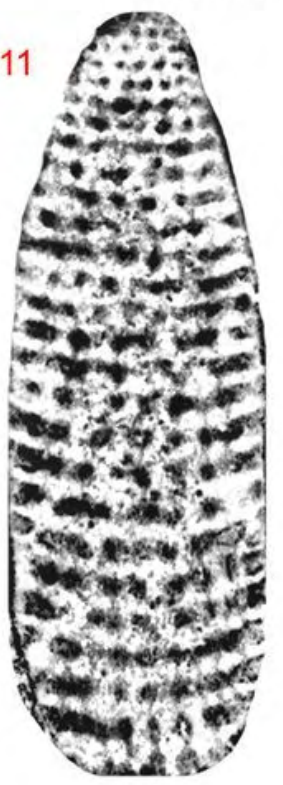

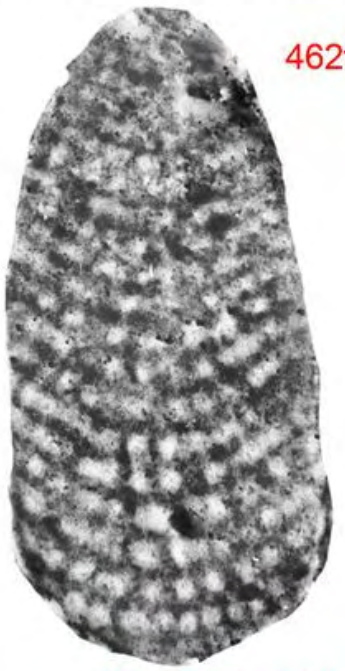

Paracoskinolina maynci
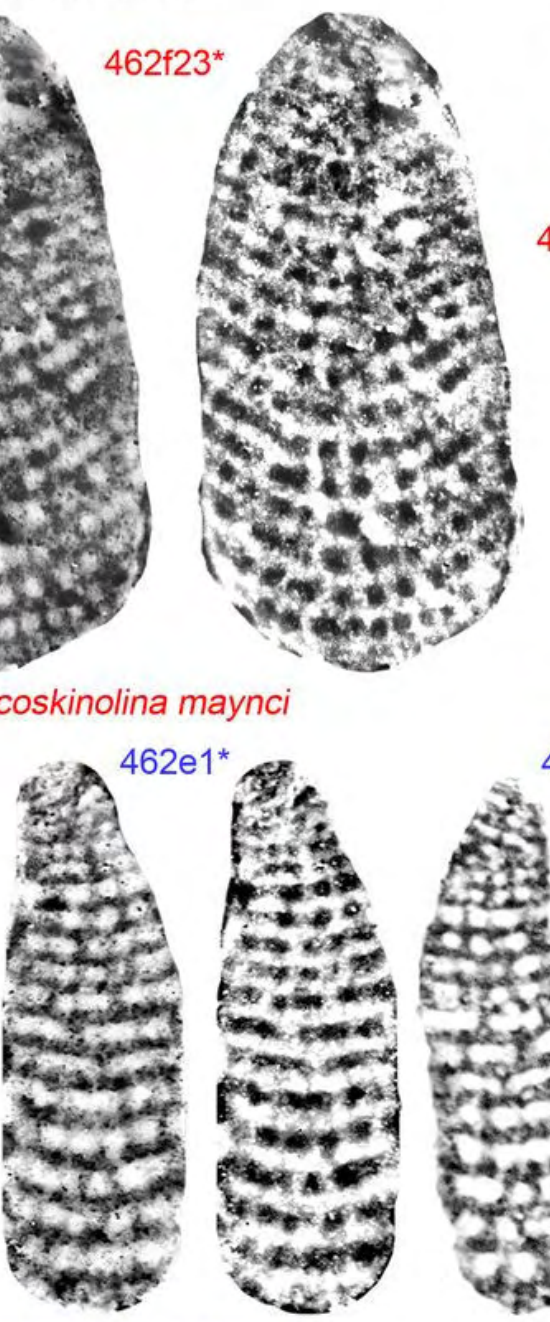
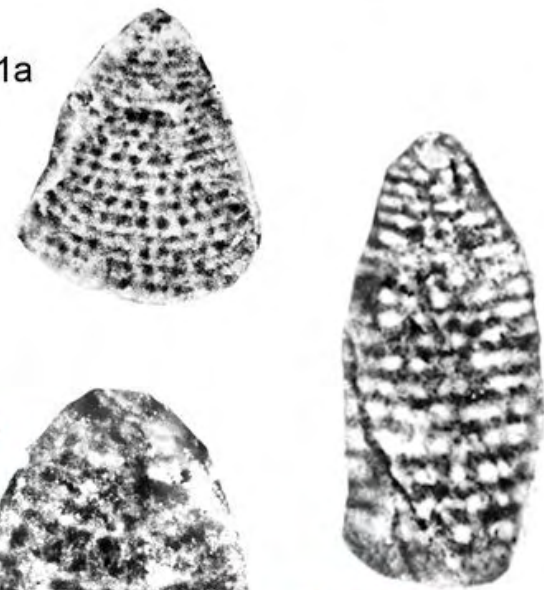

462f5*

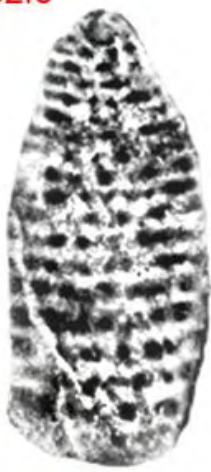

462-19a
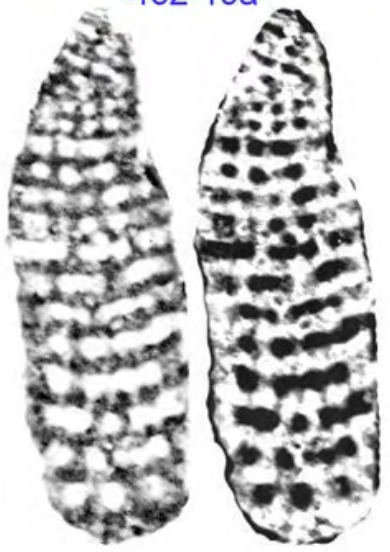

Paracoskinolina querolensis

Plate 96: Orbitolinids of the Vandenheckei Zone at Col de Rousset. Paracoskinolina maynci: 462f5*, 462f23*, 786511; Paracoskinolina querolensis: 462-12b, 462-19a, 462e1*, 7864-13; Paracoskinolina aff. sunnilandensis: 462-31a, 462-34a, 7864-5. Scale bar $=500 \mu \mathrm{m}$. 


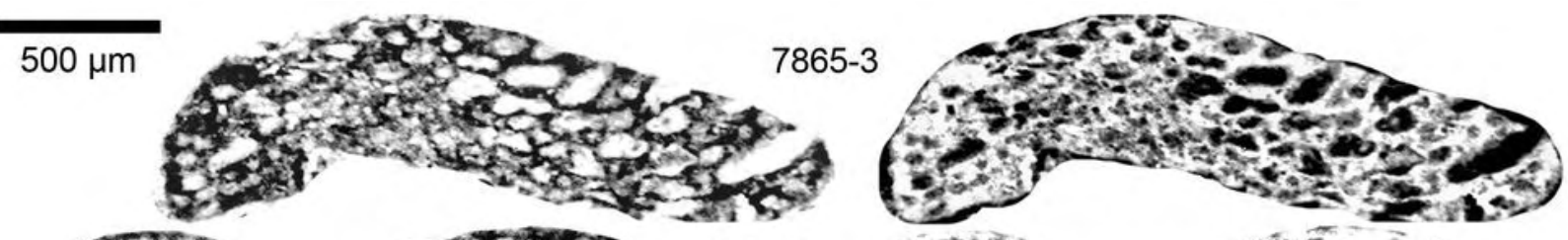

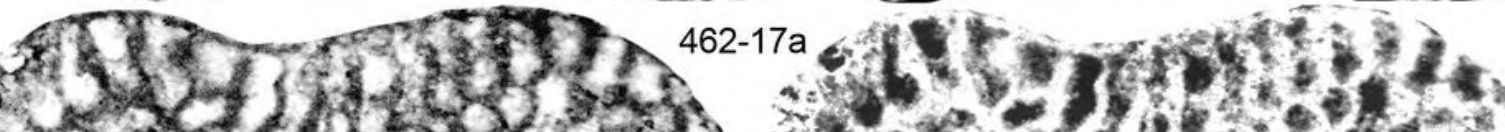

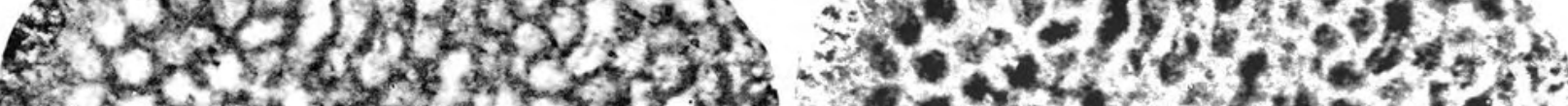

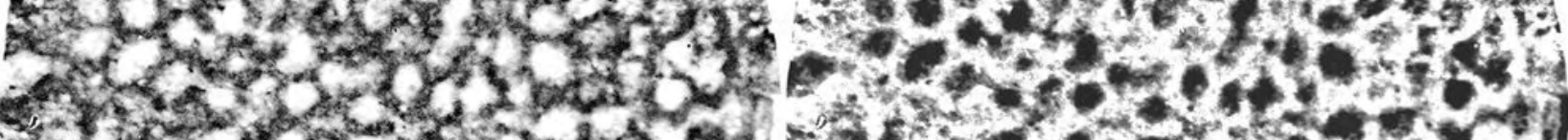

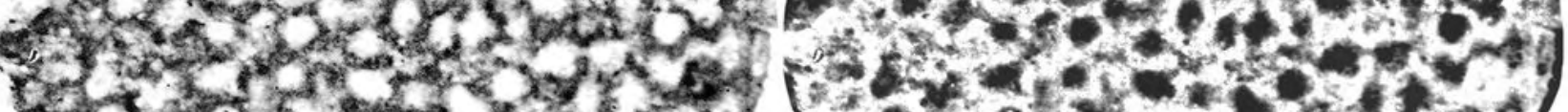

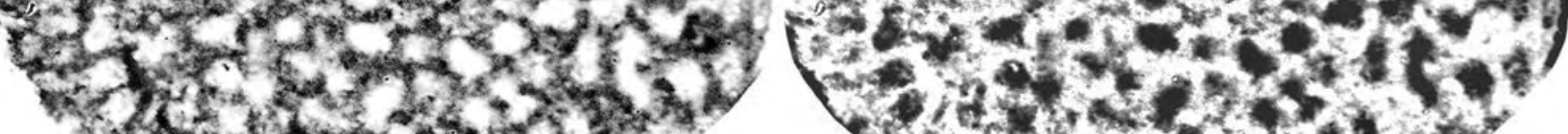
7.

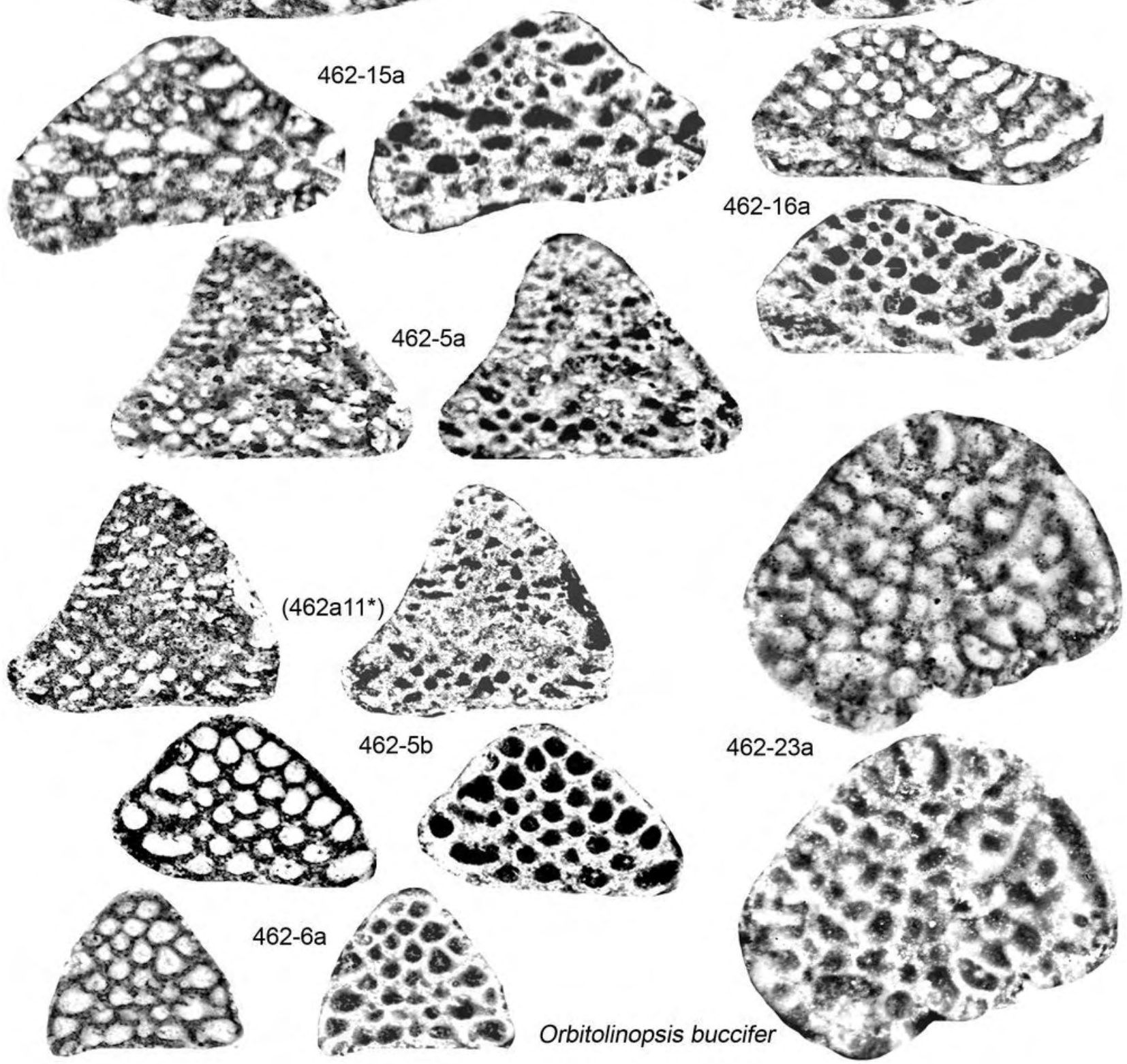

Plate 97: Orbitolinids of the Vandenheckei Zone at Col de Rousset. Orbitolinopsis buccifer: 462-5a (462a11*), 462$5 \mathrm{~b}, 462-6 \mathrm{a}, 462-15 \mathrm{a}, 462-16 \mathrm{a}, 462-17 \mathrm{a}, 462-23 \mathrm{a}, 7865-3$. Scale bar $=500 \mu \mathrm{m}$. 

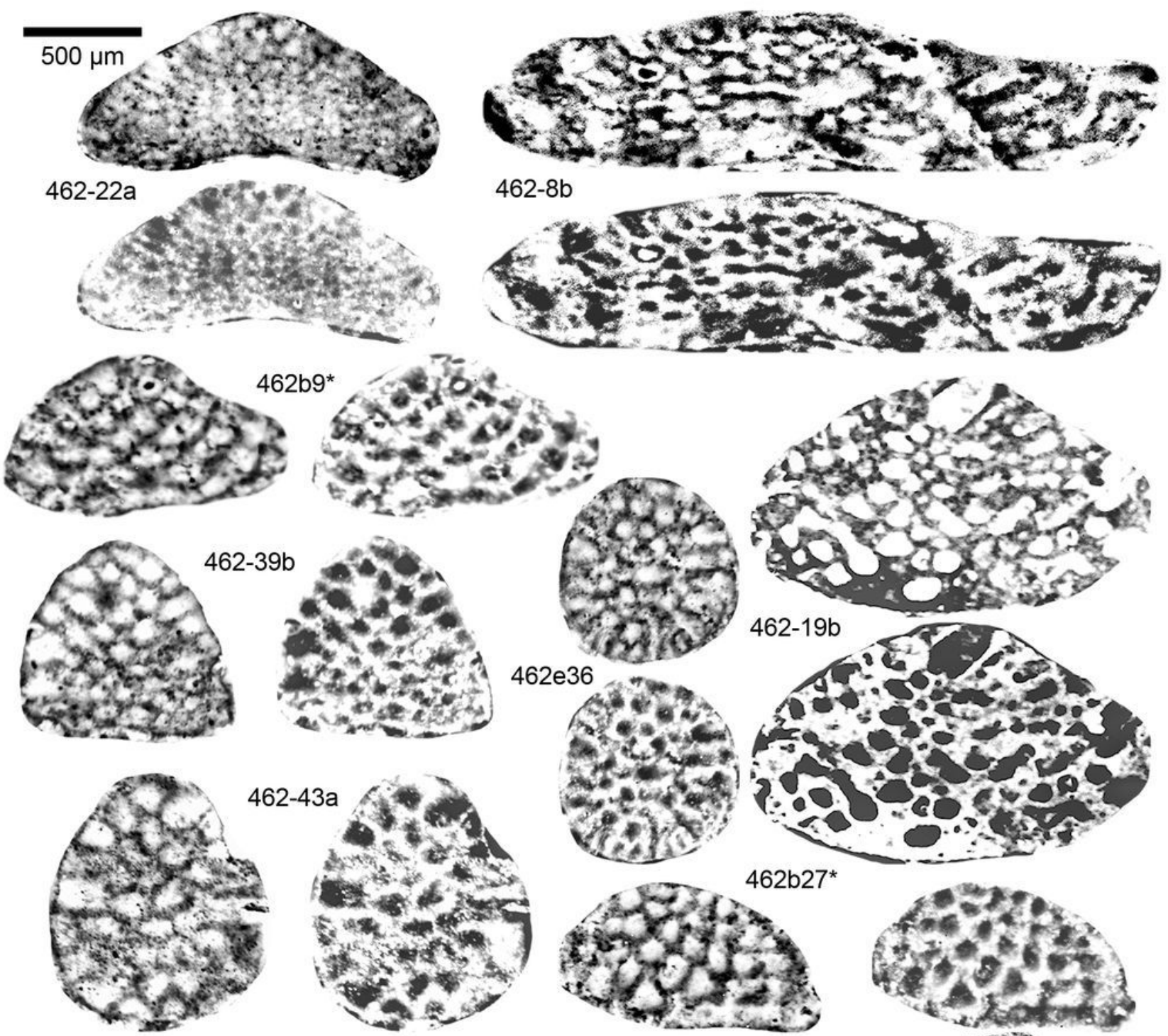

1. 1.2.2.

$32,2=$ ate 30. sense. 10int

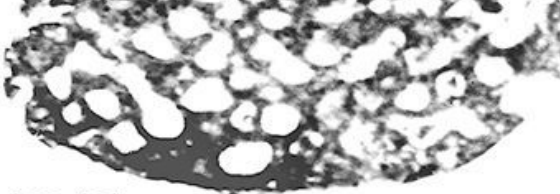

$462-19 b$
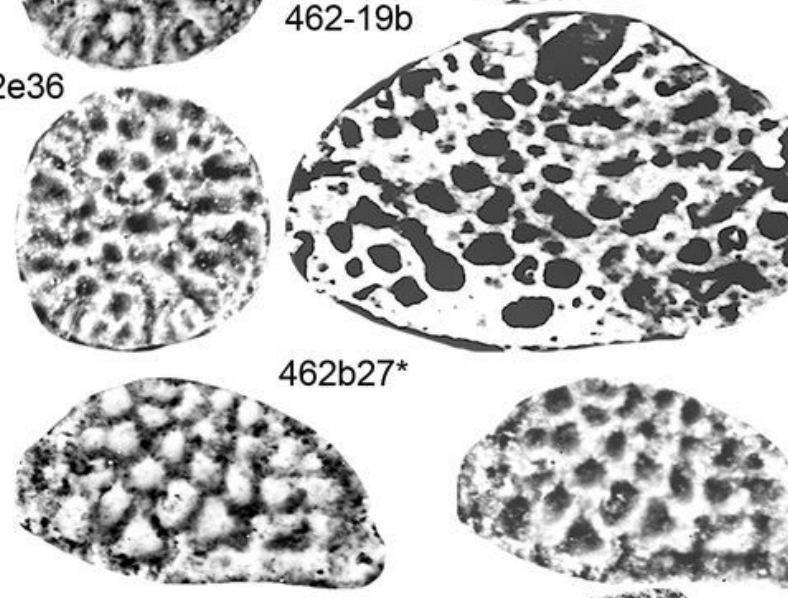

$30-5=2000$
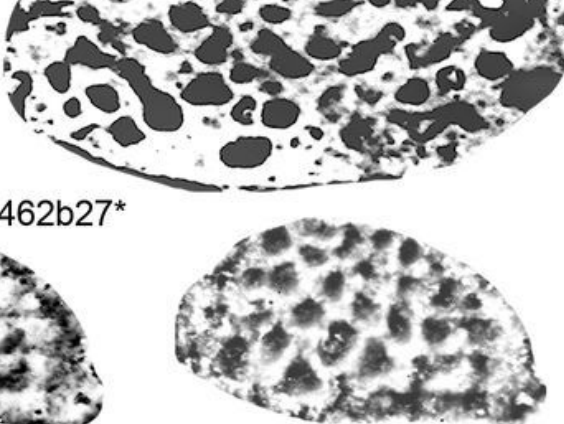

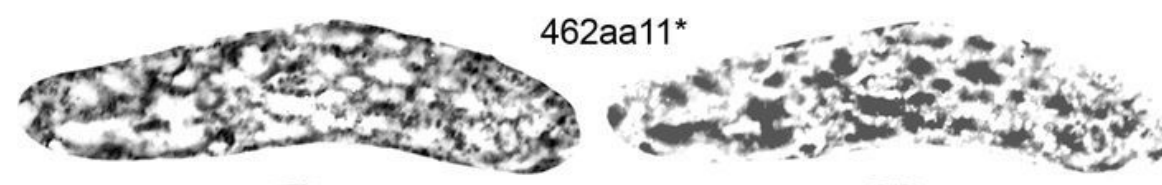
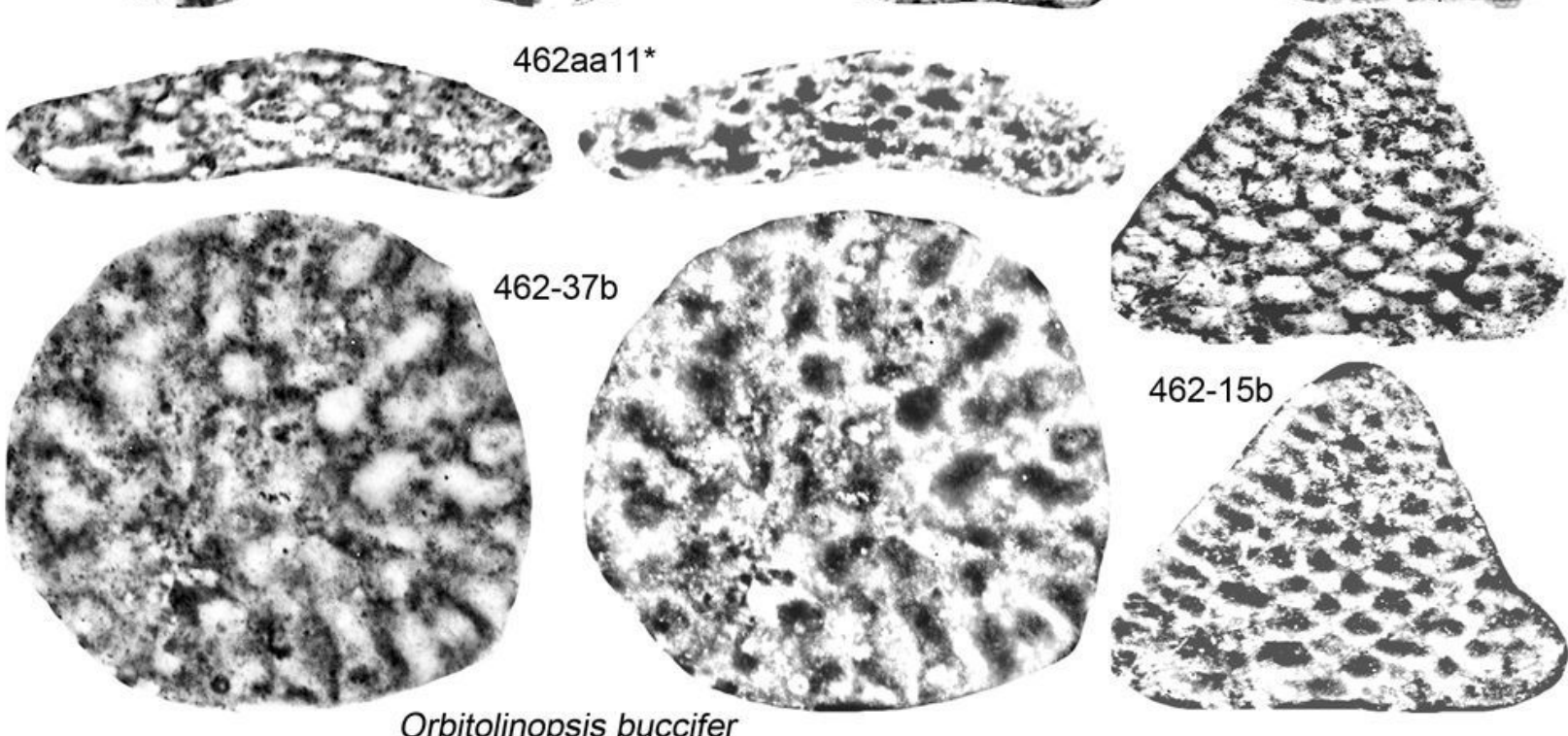

Plate 98: Orbitolinids of the Vandenheckei Zone at Col de Rousset. Orbitolinopsis buccifer: 462-8b, 462-15a, 462$19 b, 462-22 a, 462-32 a, 462-37 b, 462-39 b, 462-43 a, 462 a a 11 *, 462 b 9 *, 462 b 27 *$. Scale bar $=500 \mu \mathrm{m}$. 

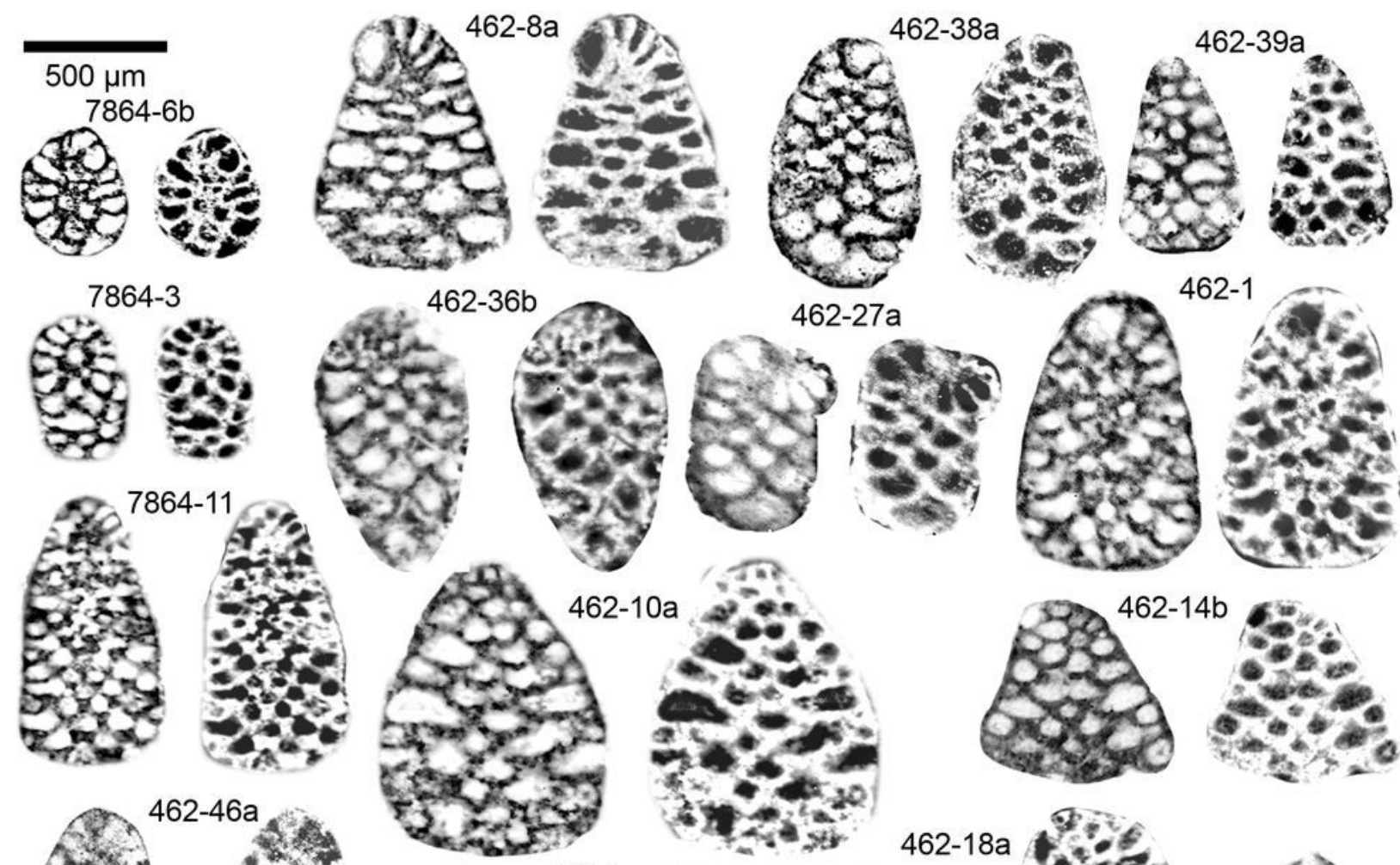

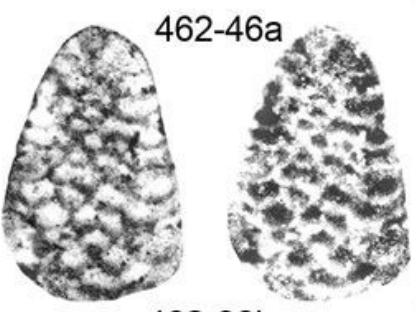
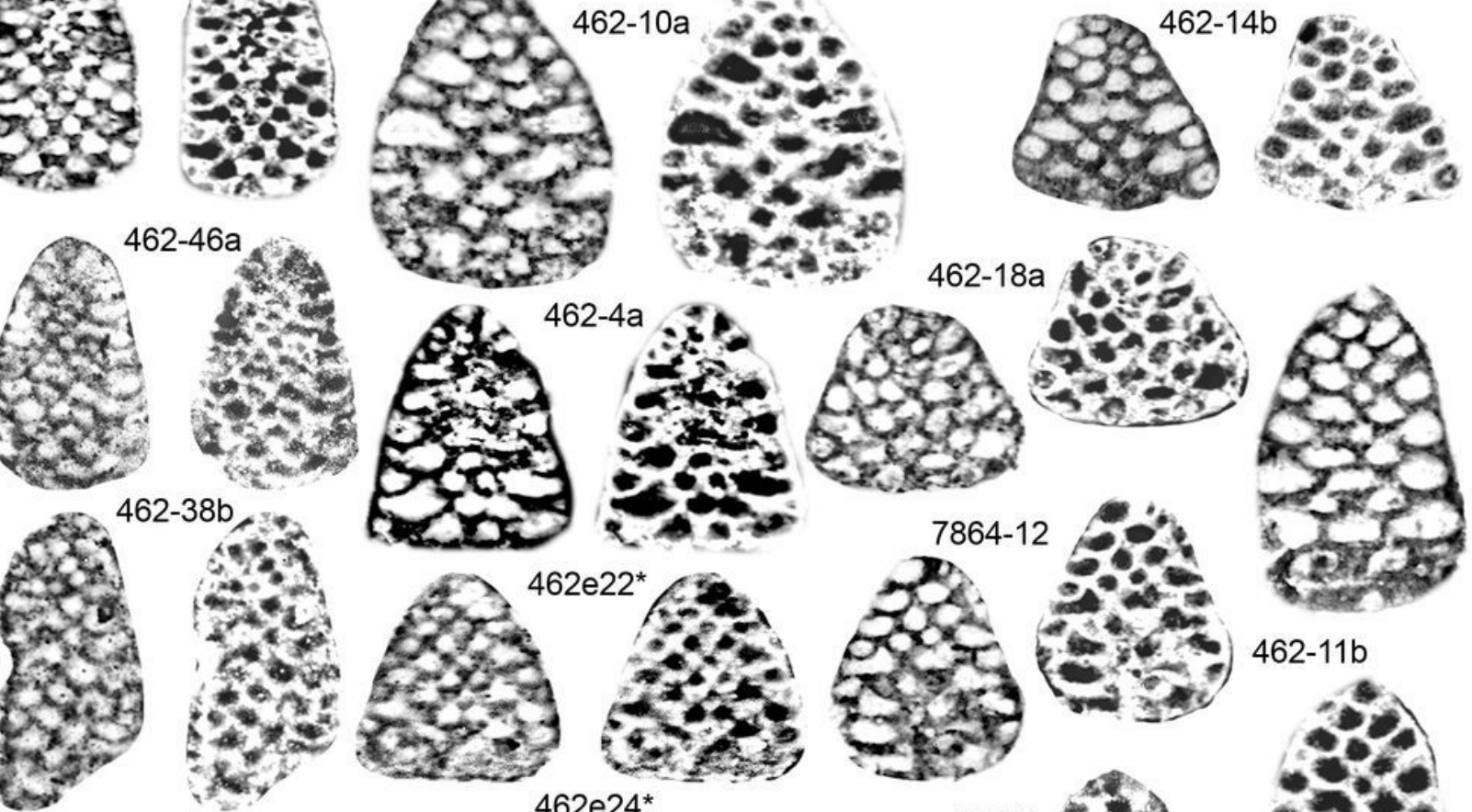

$462-33 a$
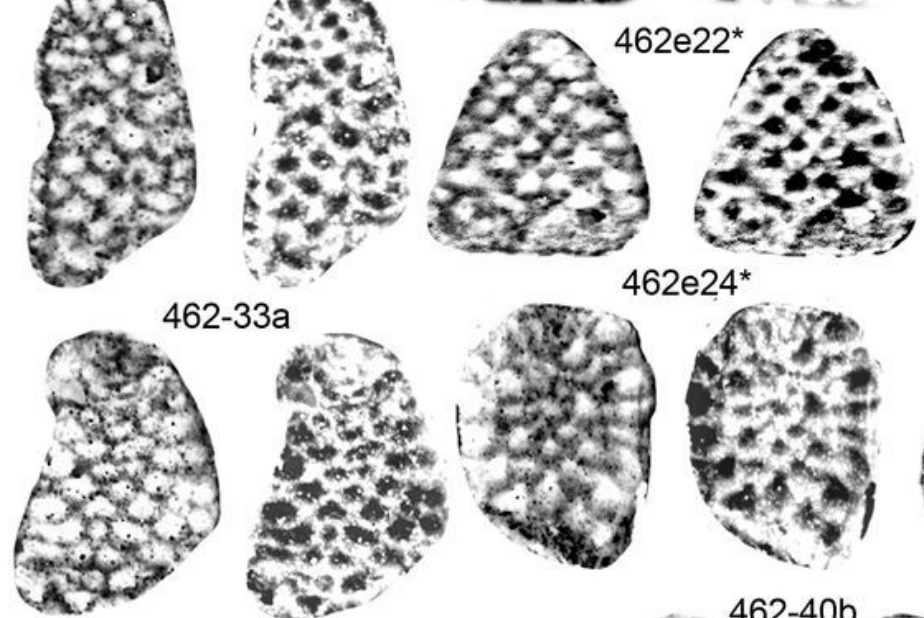

\section{$462 e 24^{*}$}
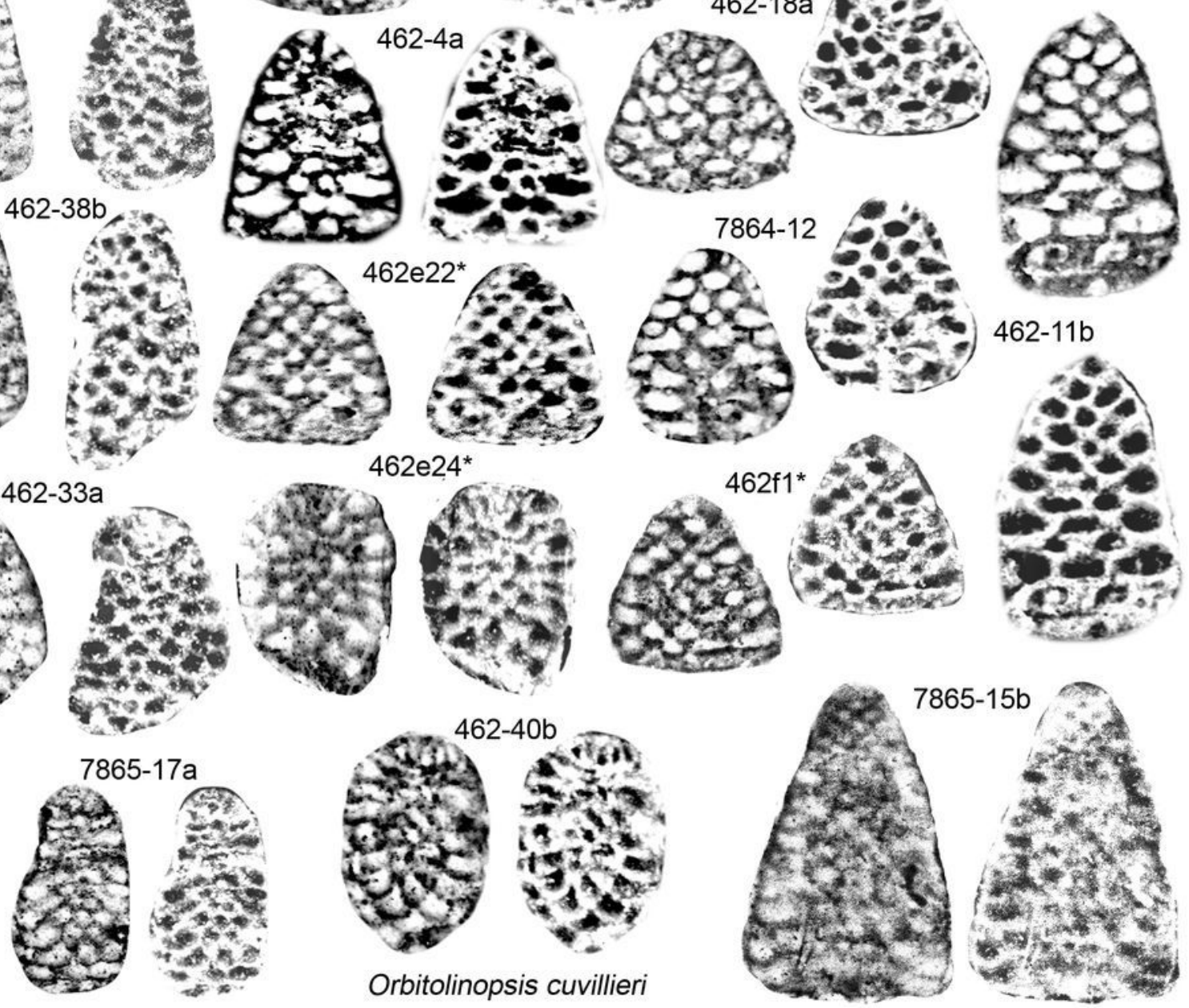

Plate 99: Orbitolinids of the Vandenheckei Zone at Col de Rousset. Orbitolinopsis cuvillieri: 462-1b, 462-4a, 462-8a, 462-10a, 462-11b, 462-14b, 462-18a, 462-27a, 462-33a, 462-36b, 462-38a, 462-38b, 462-39a, 462-40b, 462-46a, 462e22*, 462e24*, 462f1*, 7864-3, 7864-6, 7864-11, 7864-12, 7865-15b, 7865-17a. Scale bar = $500 \mu \mathrm{m}$. 

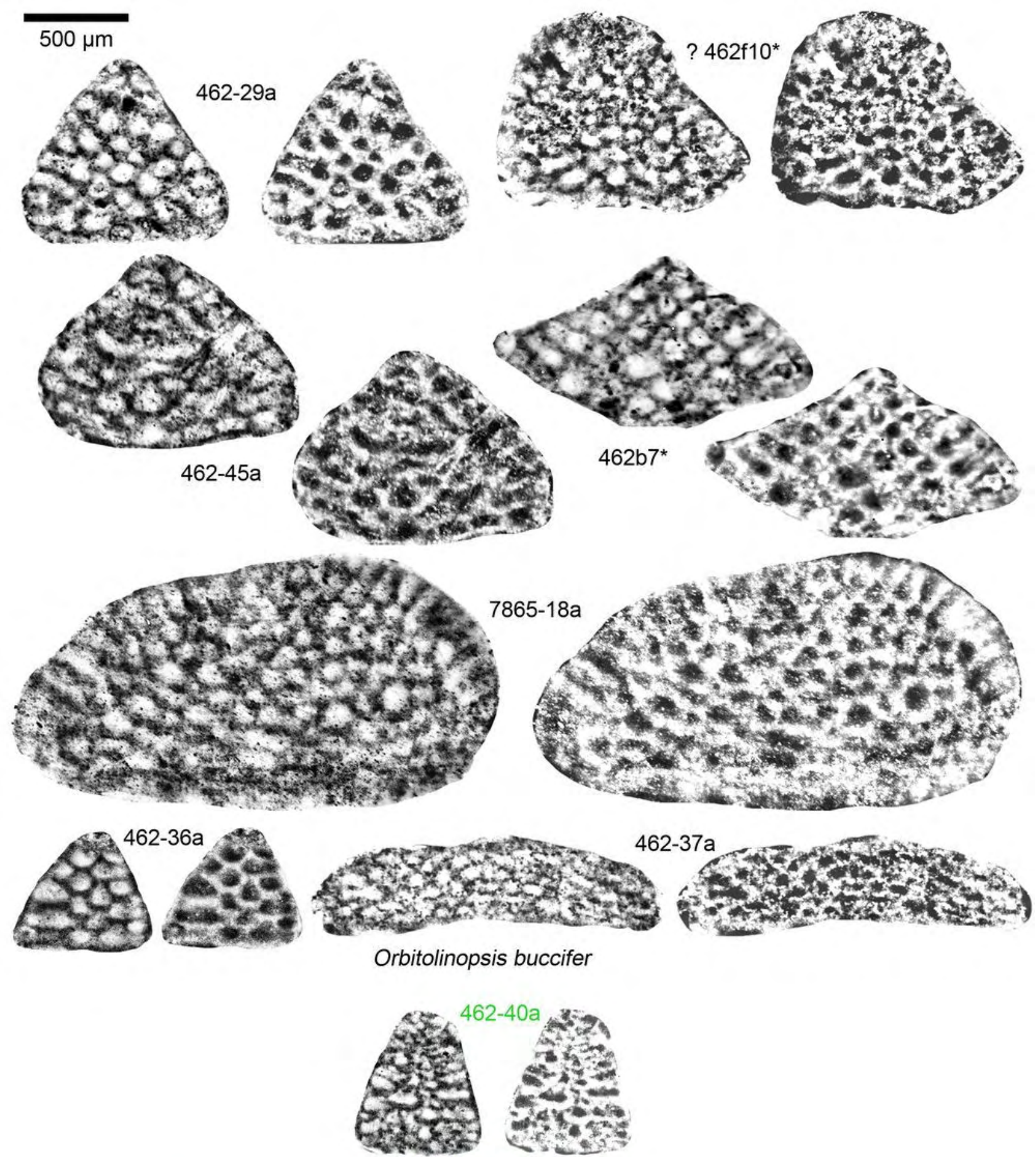

Orbitolinopsis kiliani
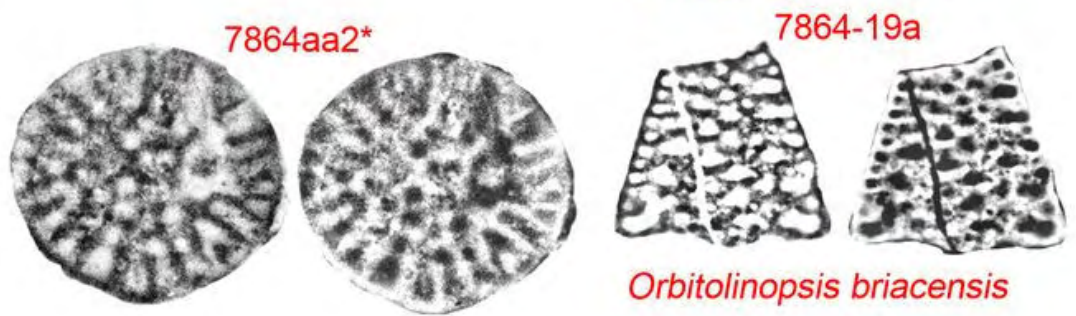

Orbitolinopsis briacensis

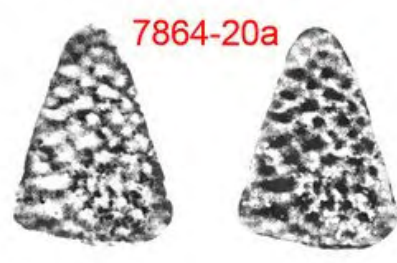

Plate 100: Orbitolinids of the Vandenheckei Zone at Col de Rousset. Orbitolinopsis briacensis: 7864-19a, 7864-20a 7864aa2*; Orbitolinopsis buccifer: 462-29a, 462-36a, 462-37a, 462-45a, 462b7*, ? 462f10* [NF], 7865-18a; Orbitolinopsis kiliani: 462-40a. Scale bar $=500 \mu \mathrm{m}$. 

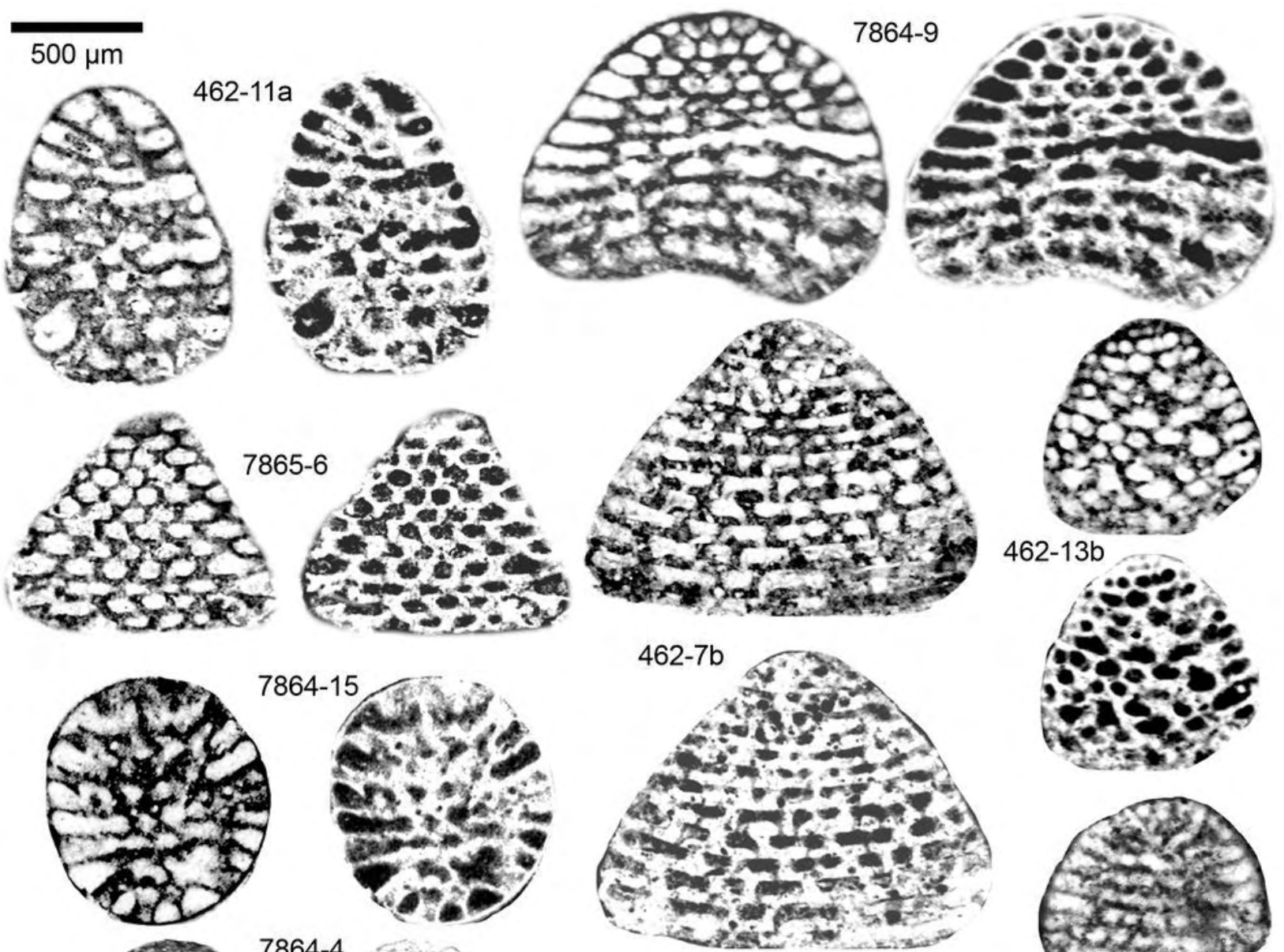

$462-13 b$
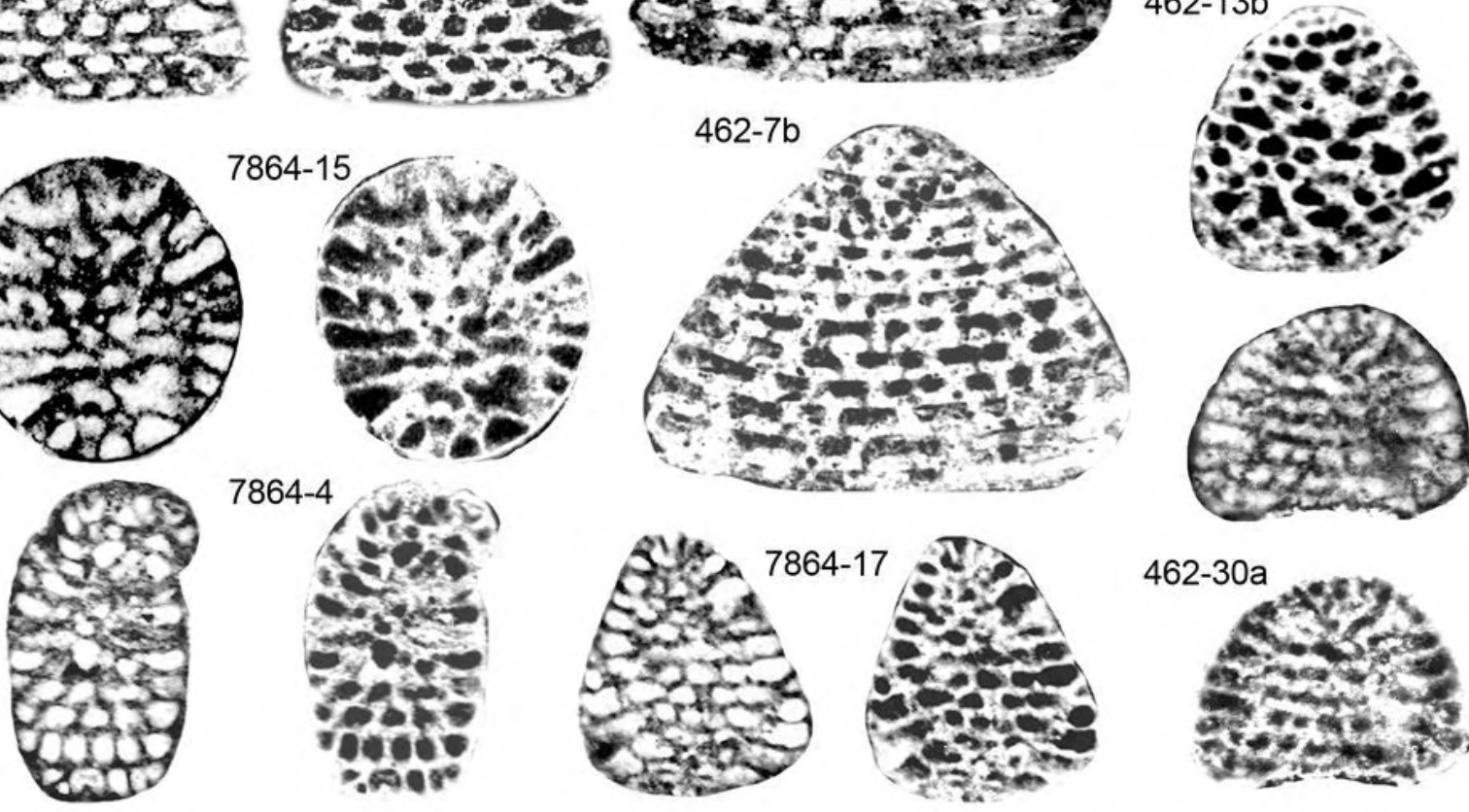

7864-4
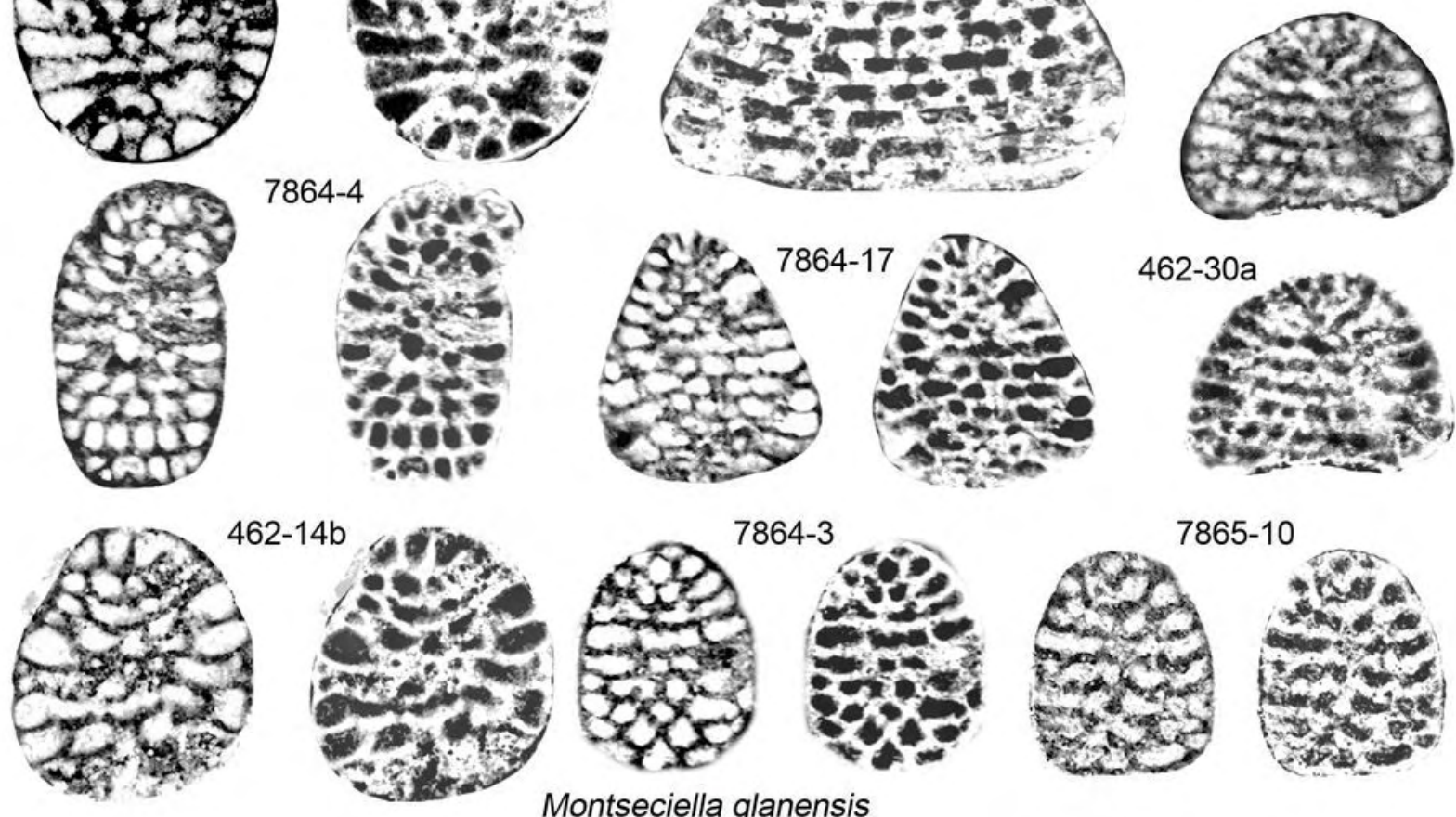

Montseciella glanensis

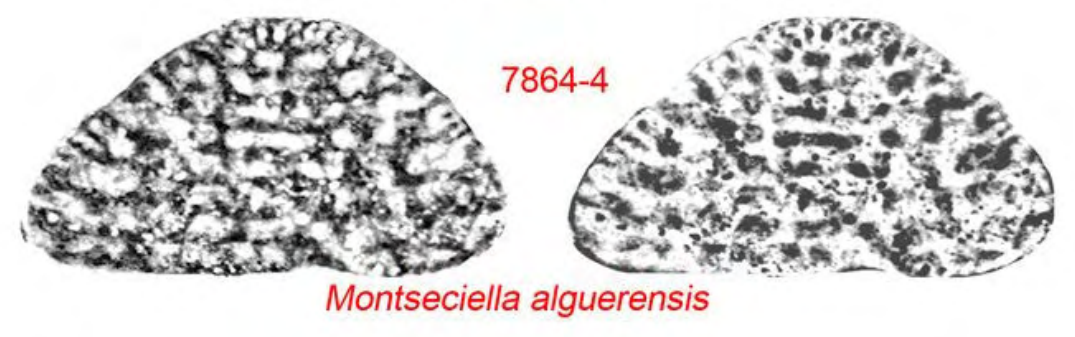

Plate 101: Orbitolinids of the Vandenheckei Zone at Col de Rousset. Montseciella alguerensis: 7864-4; Montseciella glanensis: 462-7b, 462-11a, 462-13b, 462-14b, 462-30a, 7864-3, 7864-4, 7864-9, 7864-15, 7864-17, 7865-6, 7865-10. Scale bar $=500 \mu \mathrm{m}$. 


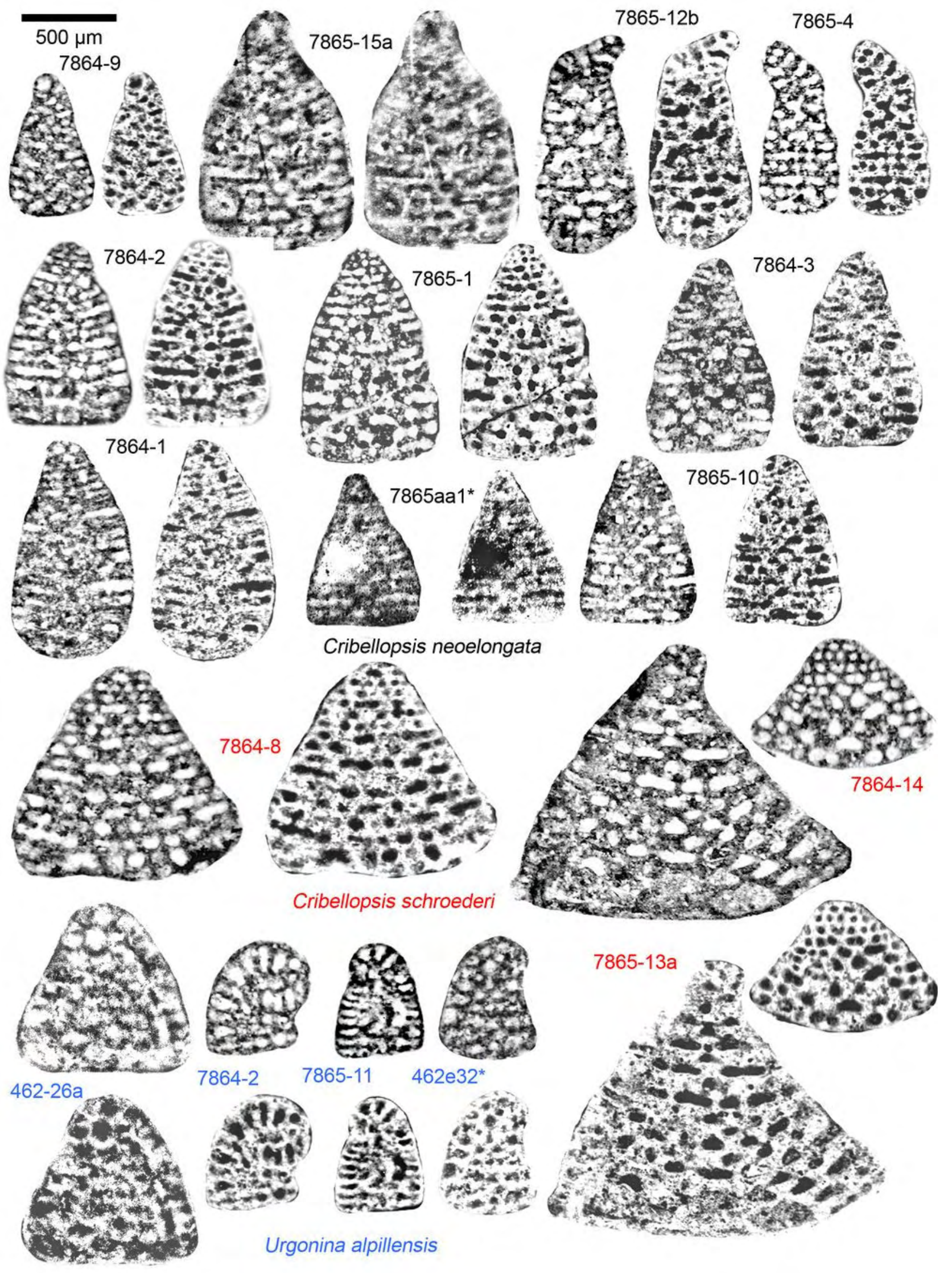

Plate 102: Orbitolinids of the Vandenheckei Zone at Col de Rousset. Cribellopsis neoelongata: 7864-1, 7864-2, 7864-3, 7864-9, 7865-1, 7865-4, 7865-10, 7865-12b, 7865-15a, 7865aa1*; Cribellopsis schroederi: 462-5a, 78648, 7864-14, 7865-13a; Urgonina alpillensis: 462-26a, 462e32*, 7864-2, 7865-11. Scale bar $=500 \mu \mathrm{m}$. 


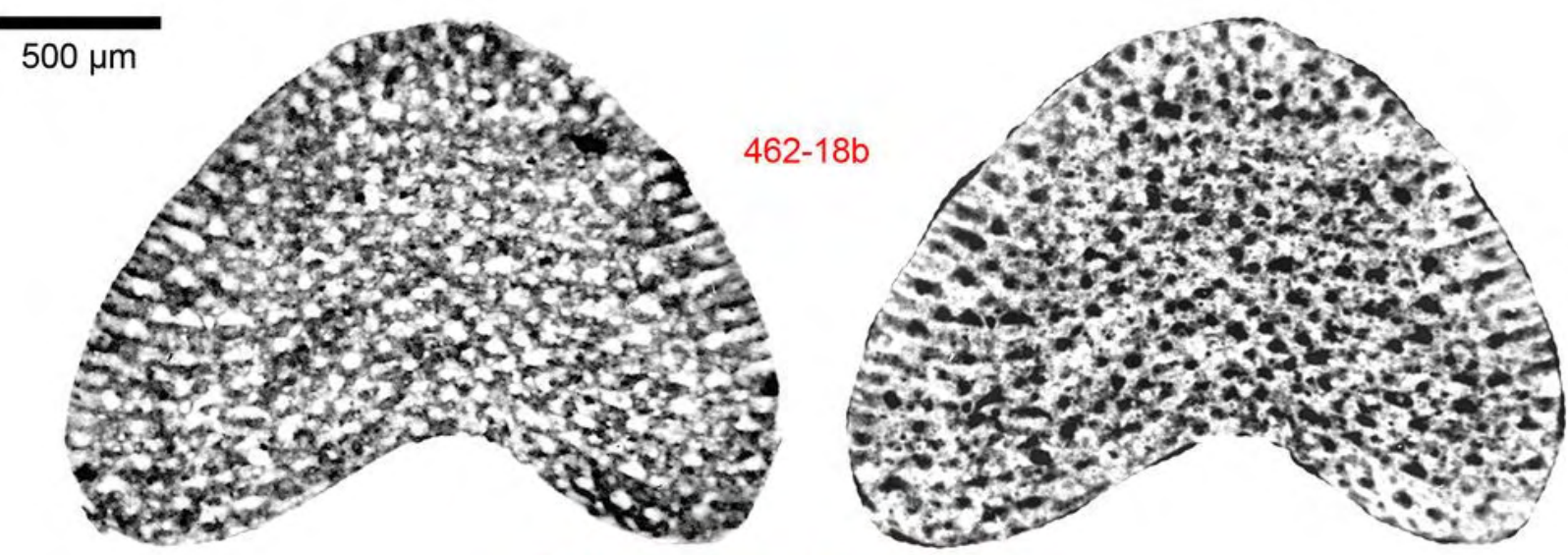

Paleodictyoconus actinostoma
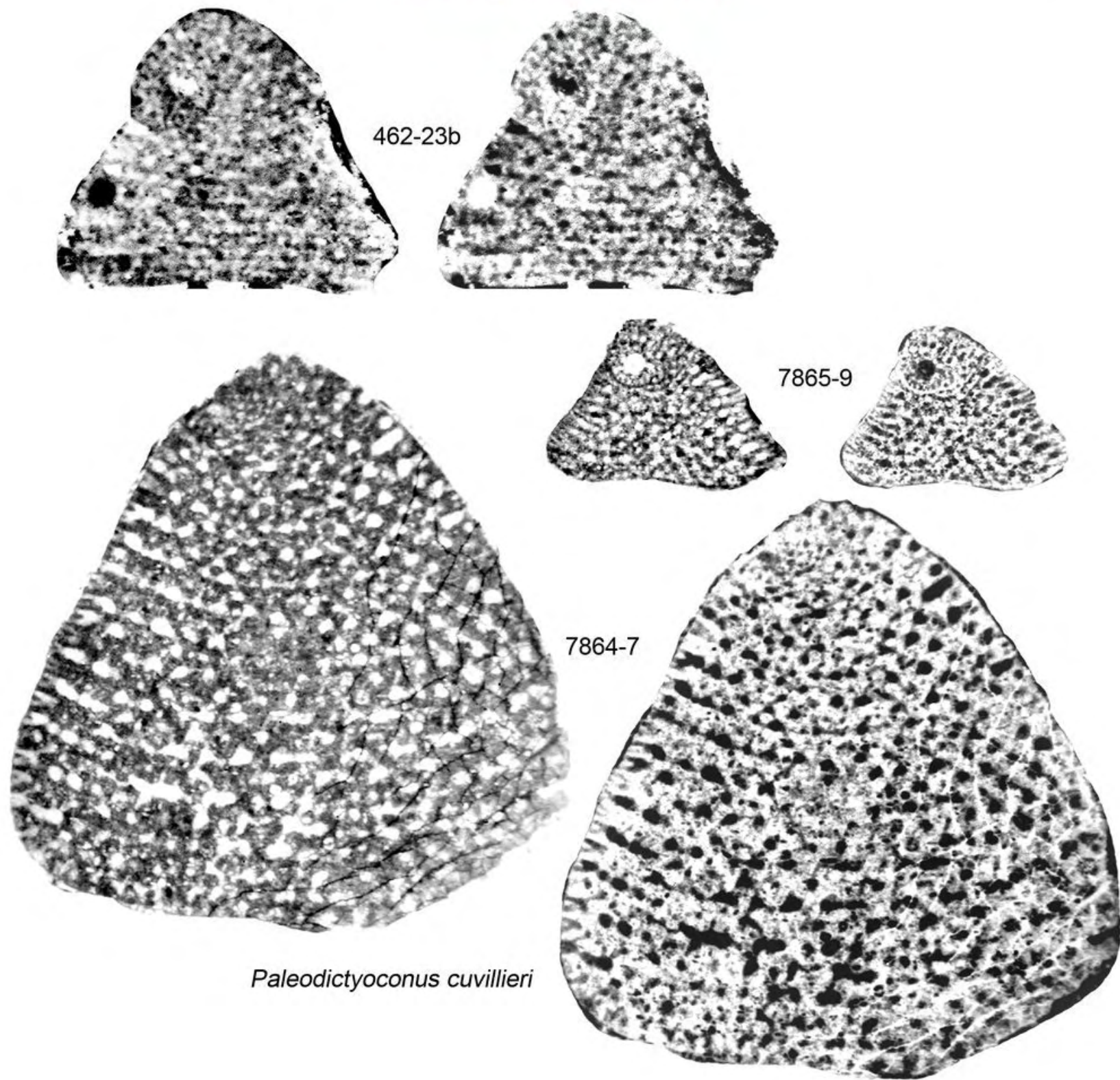

Plate 103: Orbitolinids of the Vandenheckei Zone at Col de Rousset. Paleodictyoconus actinostoma : 462-18b; Paleodictyoconus cuvillieri: 462-23b, 7864-7, 7865-9. Scale bar $=500 \mu \mathrm{m}$. 


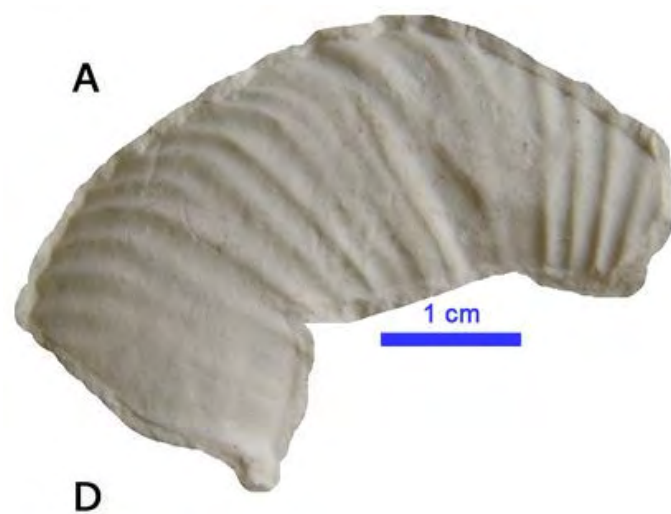

B

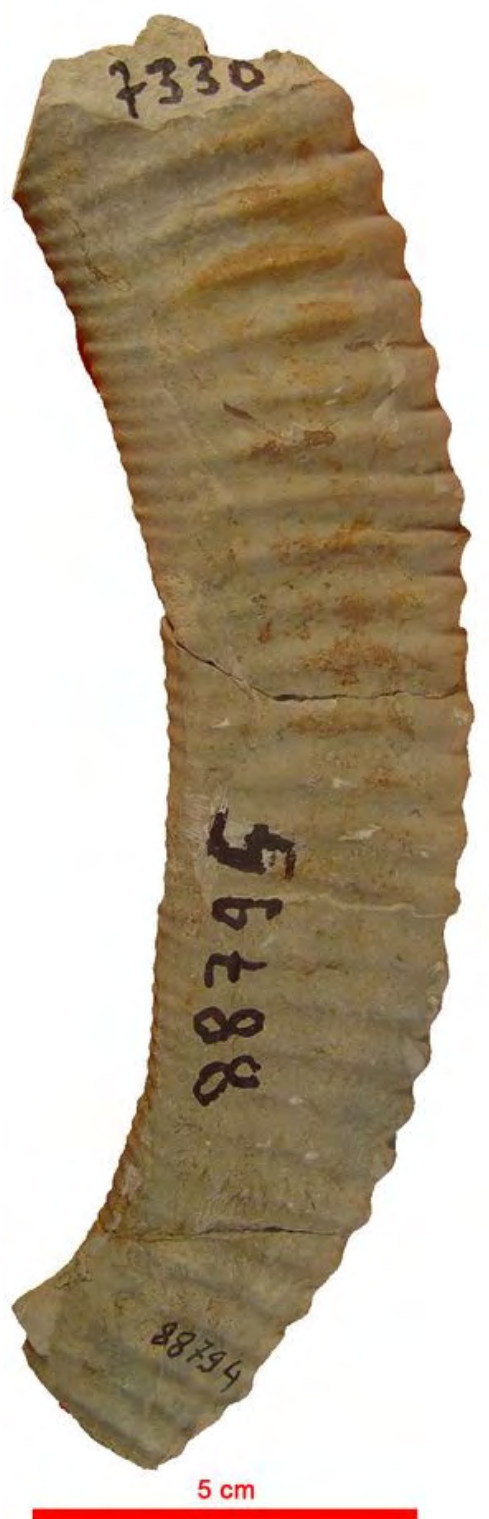

scale

$=5 \mathrm{~cm}$

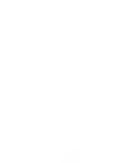

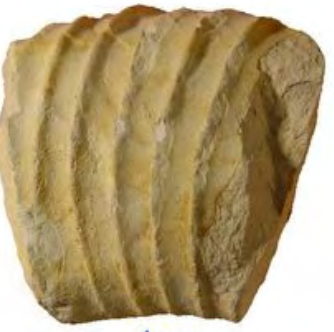

C

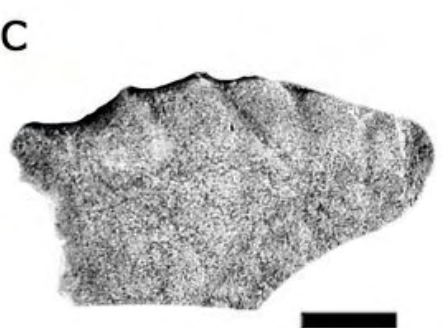

$\mathrm{cm}$

E
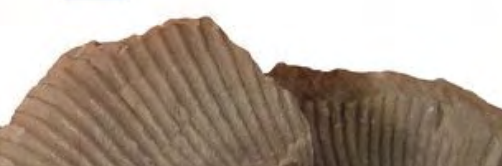

$\mathrm{cm}$
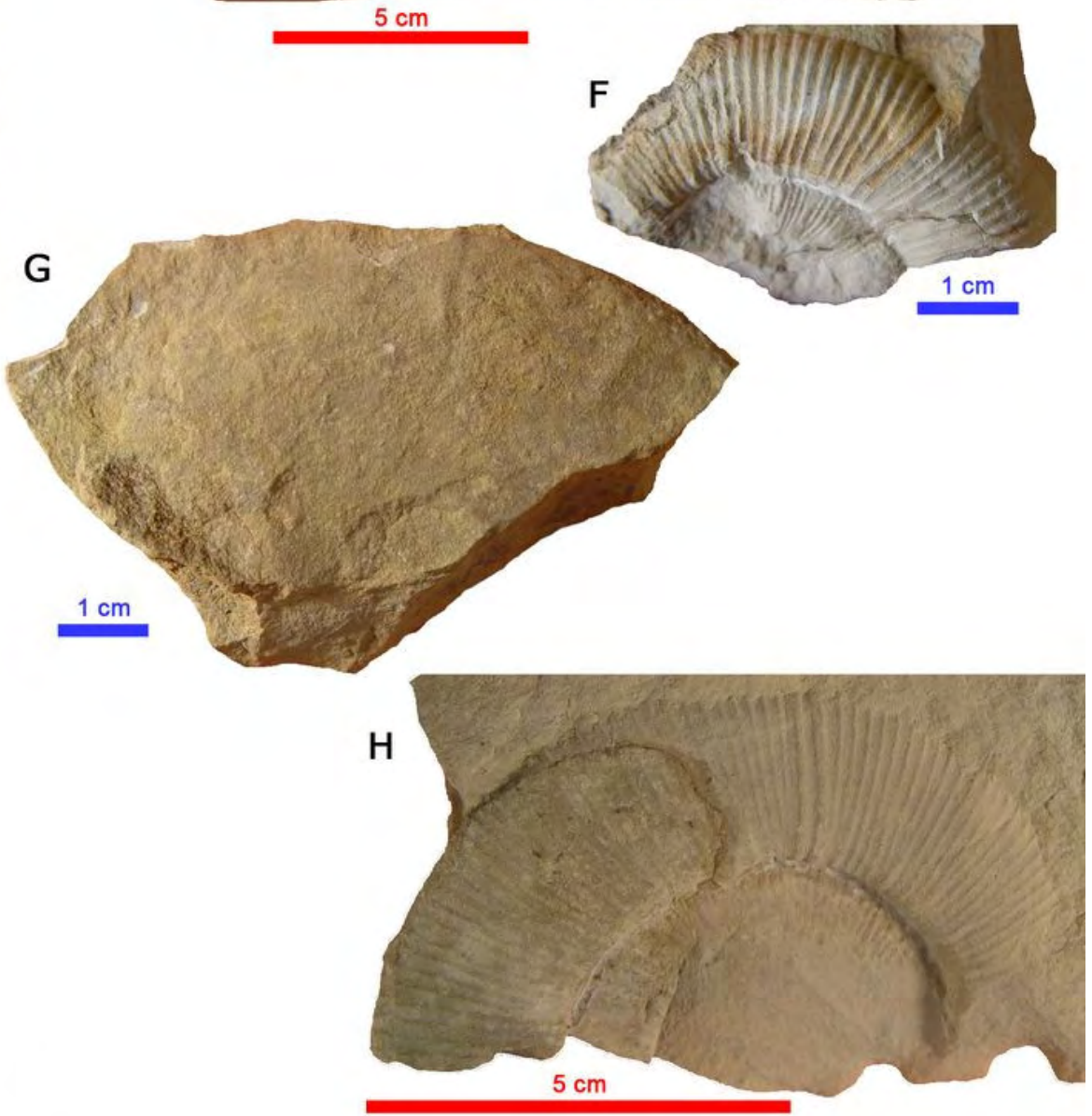

Plate 104: Ammonites of the Vandenheckei and Giraudi zones at La Charce. A) cast of Silesites seranonis, FSL 88810 ; B) Costidiscus recticostatus, FSL 88812; C) Gerhardtia sartousiana -RB- \{or ? -DB-\}, FSL 88808; D) Moutoniceras moutonianum -RB- \{or Moutoniceras eigenheeri -DB-\}, FSL 88795; E) Costidiscus olcostephanoides, FSL 88807 ; F) Costidiscus olcostephanoides, FSL 88802; G) Barremites hemiptychum, FSL 88800; H) Costidiscus olcostephanoides, FSL 88801 . Scale bars $=$ either $1 \mathrm{~cm}$ or $5 \mathrm{~cm}$. 


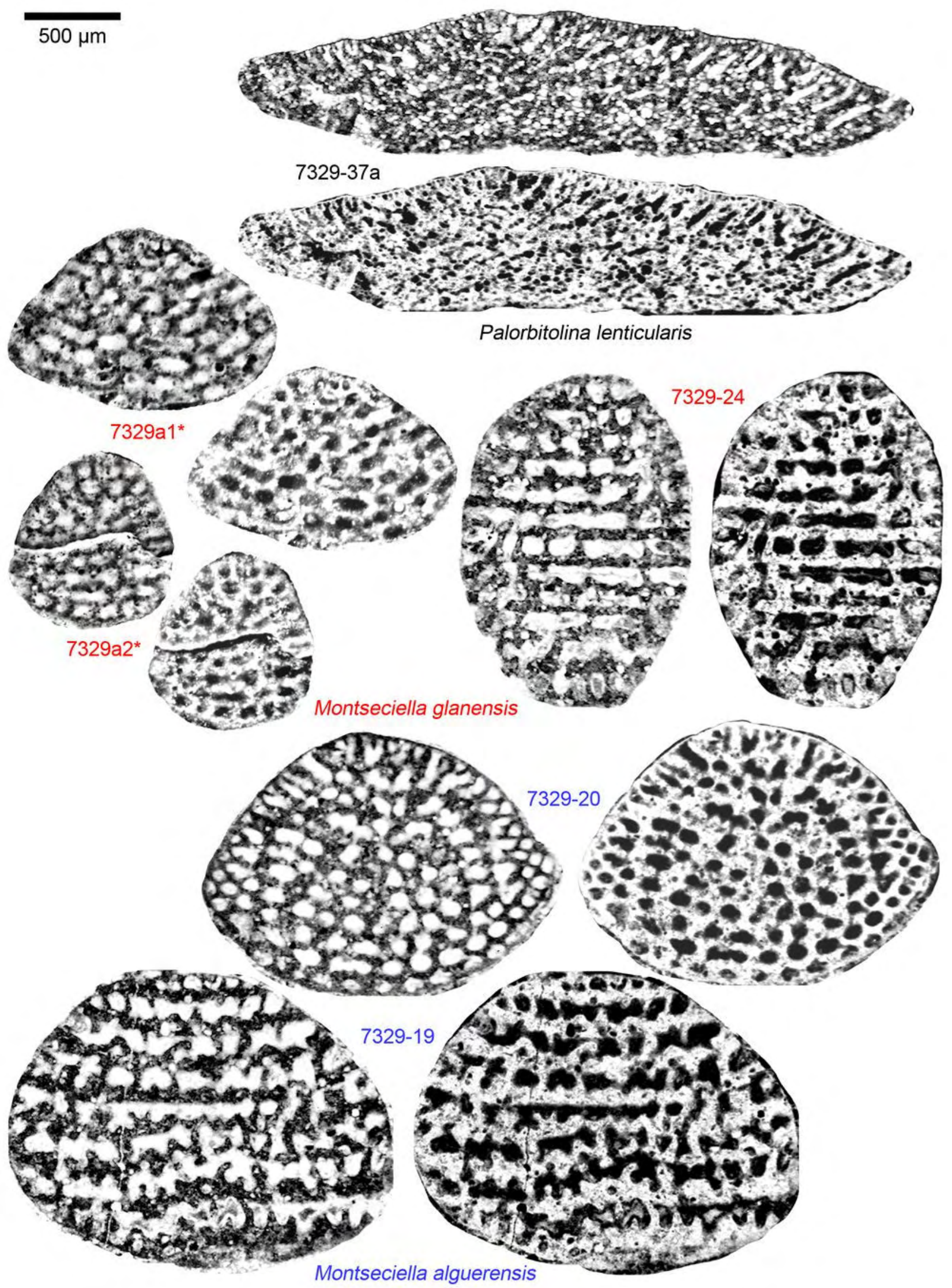

Plate 105: Orbitolinids of the Vandenheckei Zone at La Charce. Montseciella alguerensis: 7329-19, 7329-20; Montseciella glanensis: 7329-24, 7329a1*, 7329a2*; Palorbitolina lenticularis: 7329-37a. Scale bar $=500 \mu \mathrm{m}$. 

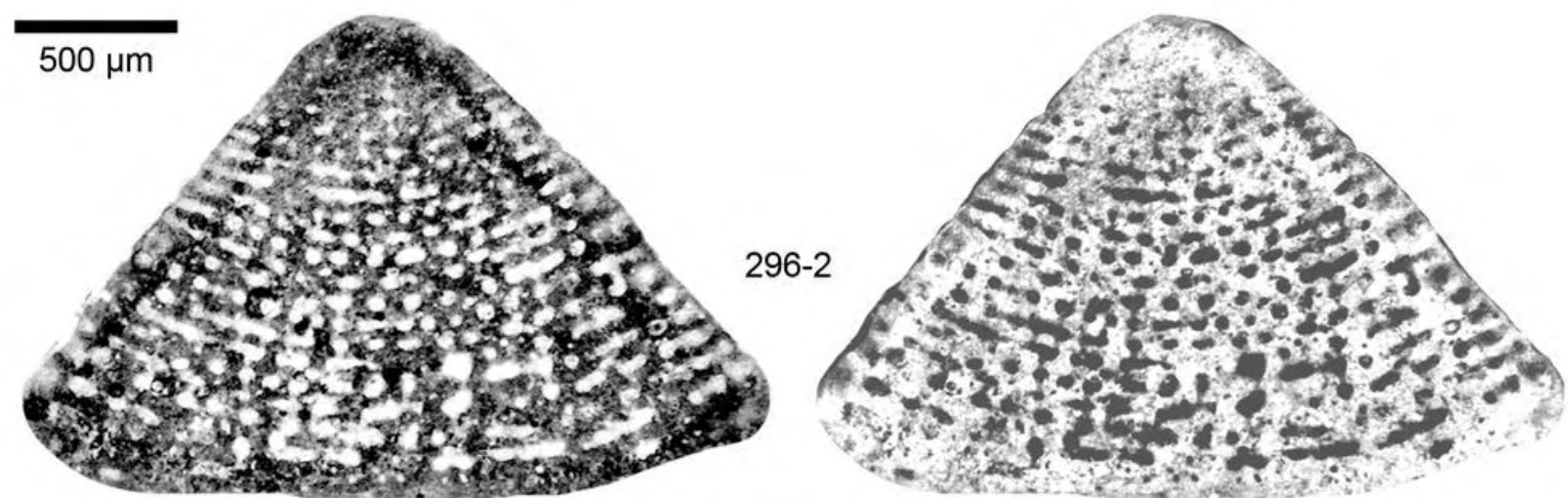

$7329-12$

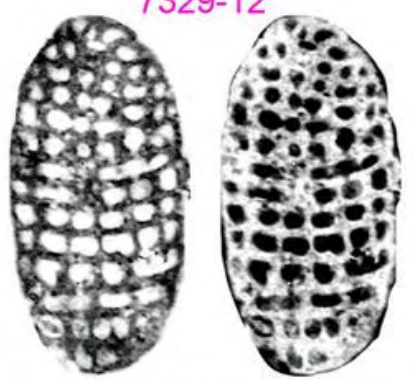

Paracoskinolina aff. sunnilandensis

Paracoskinolina maynci
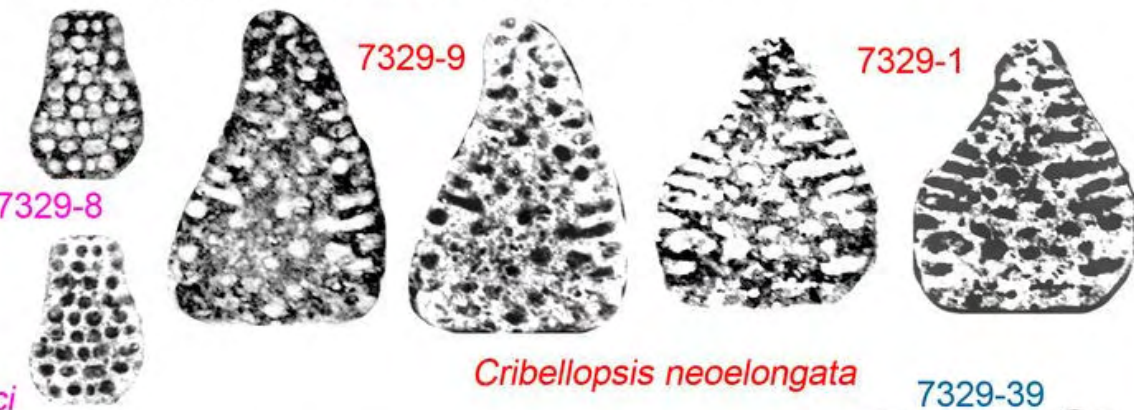

Cribellopsis neoelongata

7329-39
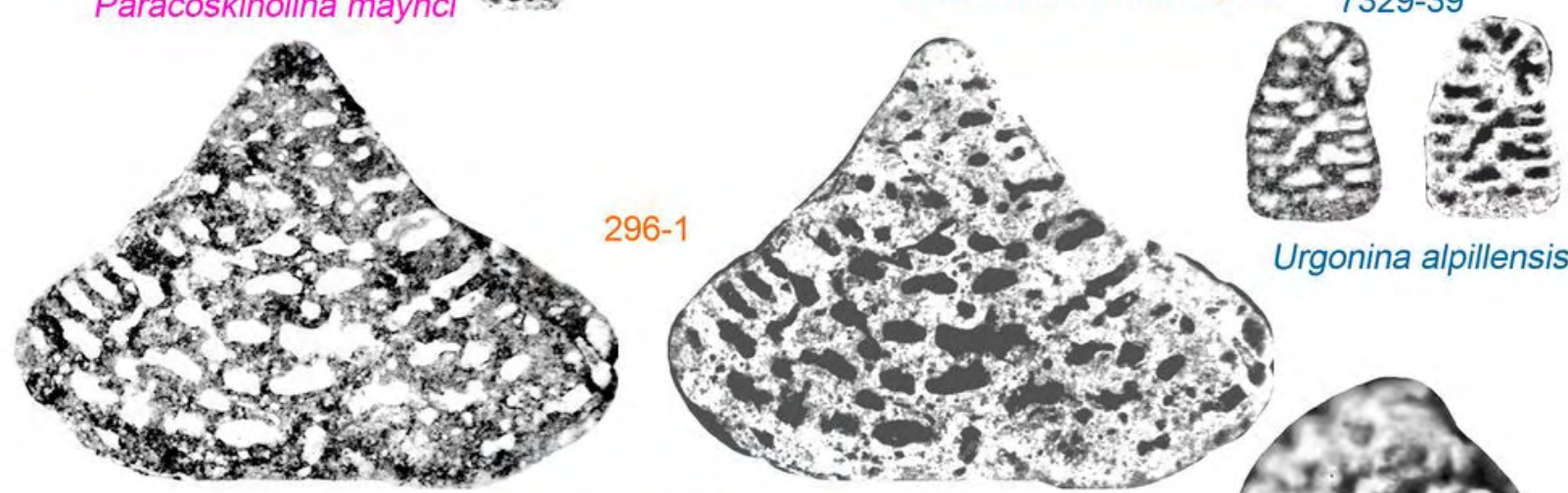

Urgonina alpillensis

Cribellopsis schroederi
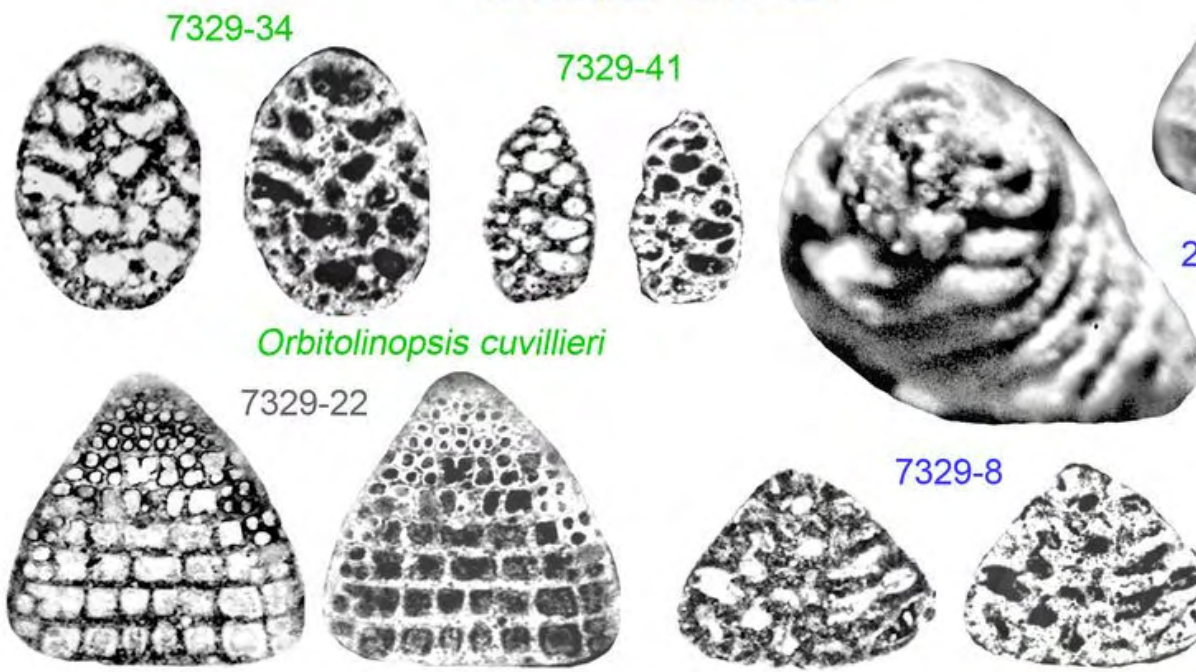

Paracoskinolina? reicheli
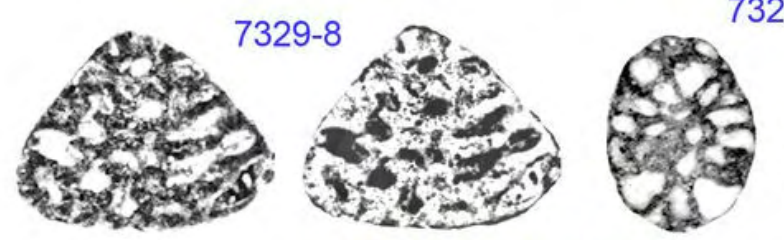

$329-8$

Falsurgonina pileola

Plate 106: Orbitolinids of the Vandenheckei Zone at La Charce. Cribellopsis neoelongata: 7329-1, 7329-9; Cribellopsis schroederi: 296-1; Falsurgonina pileola: 296a5a [loose specimen], 7329-8; Orbitolinopsis cuvillieri: 7329-34, 7329-41; Paracoskinolina maynci: 7329-8, 7329-12; Paracoskinolina ? reicheli: 7329-22; Paracoskinolina aff. sunnilandensis: 296-2; Urgonina alpillensis: 7329-39. Scale bar $=500 \mu \mathrm{m}$. 


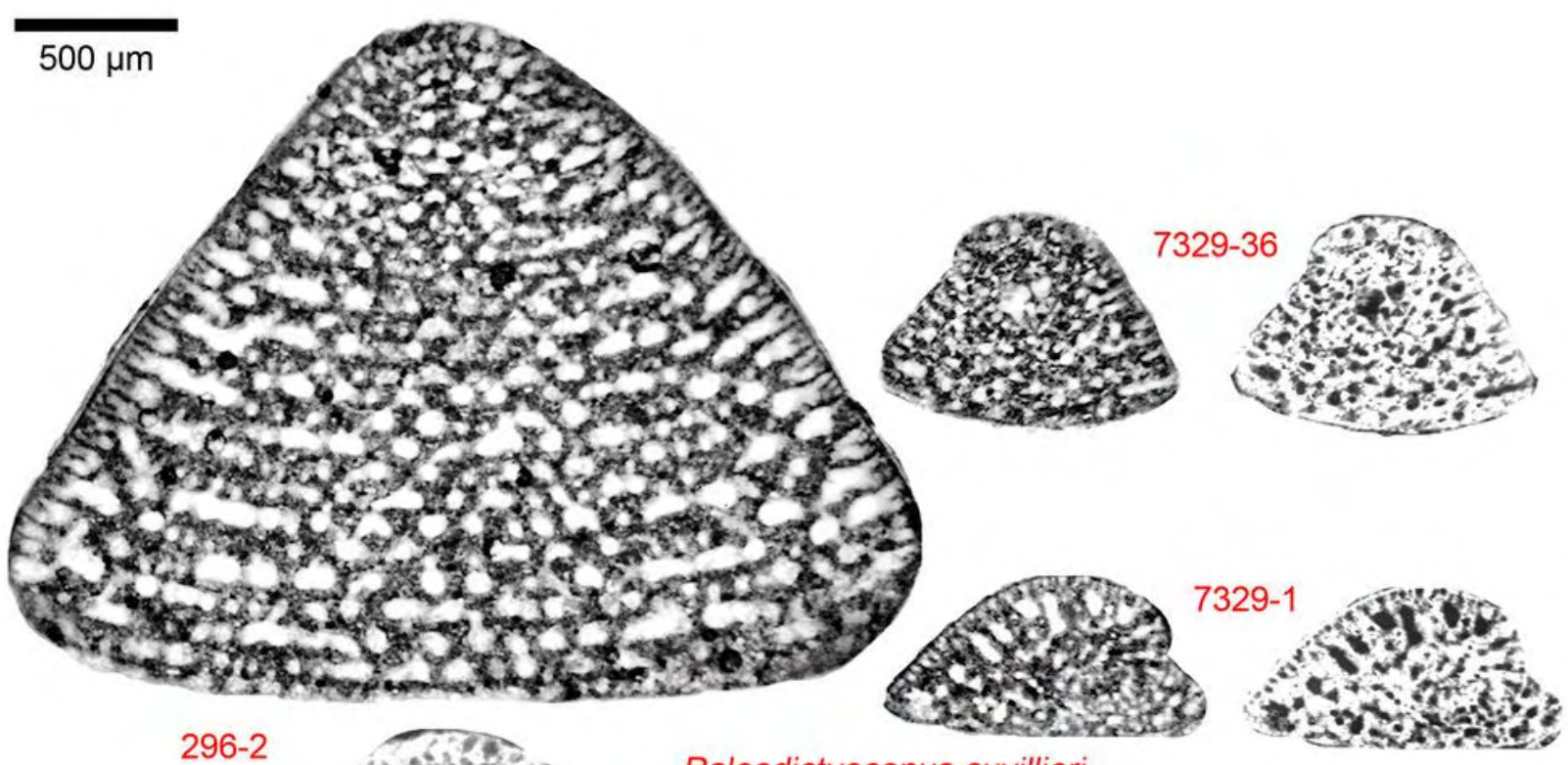

296-2

Paleodictyoconus cuvillieri astote?

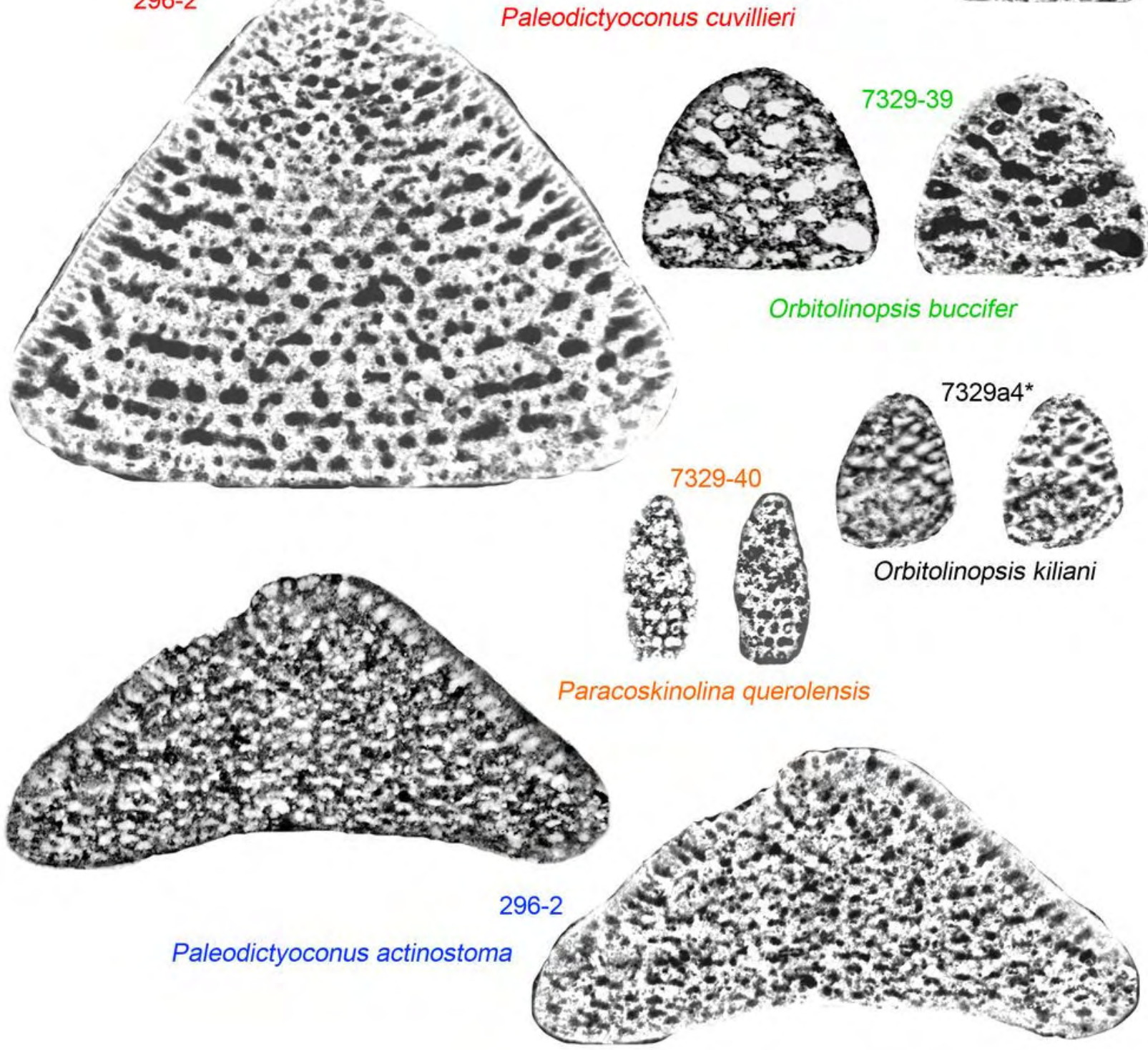

Plate 107: Orbitolinids of the Vandenheckei Zone at La Charce. Orbitolinopsis buccifer: 7329-39; Orbitolinopsis kiliani: 7329a4*; Paleodictyoconus actinostoma: 296-2; Paleodictyoconus cuvillieri: 296-2, 7329-1, 7329-36; Paracoskinolina querolensis: $7329-40$. Scale bar $=500 \mu \mathrm{m}$. 

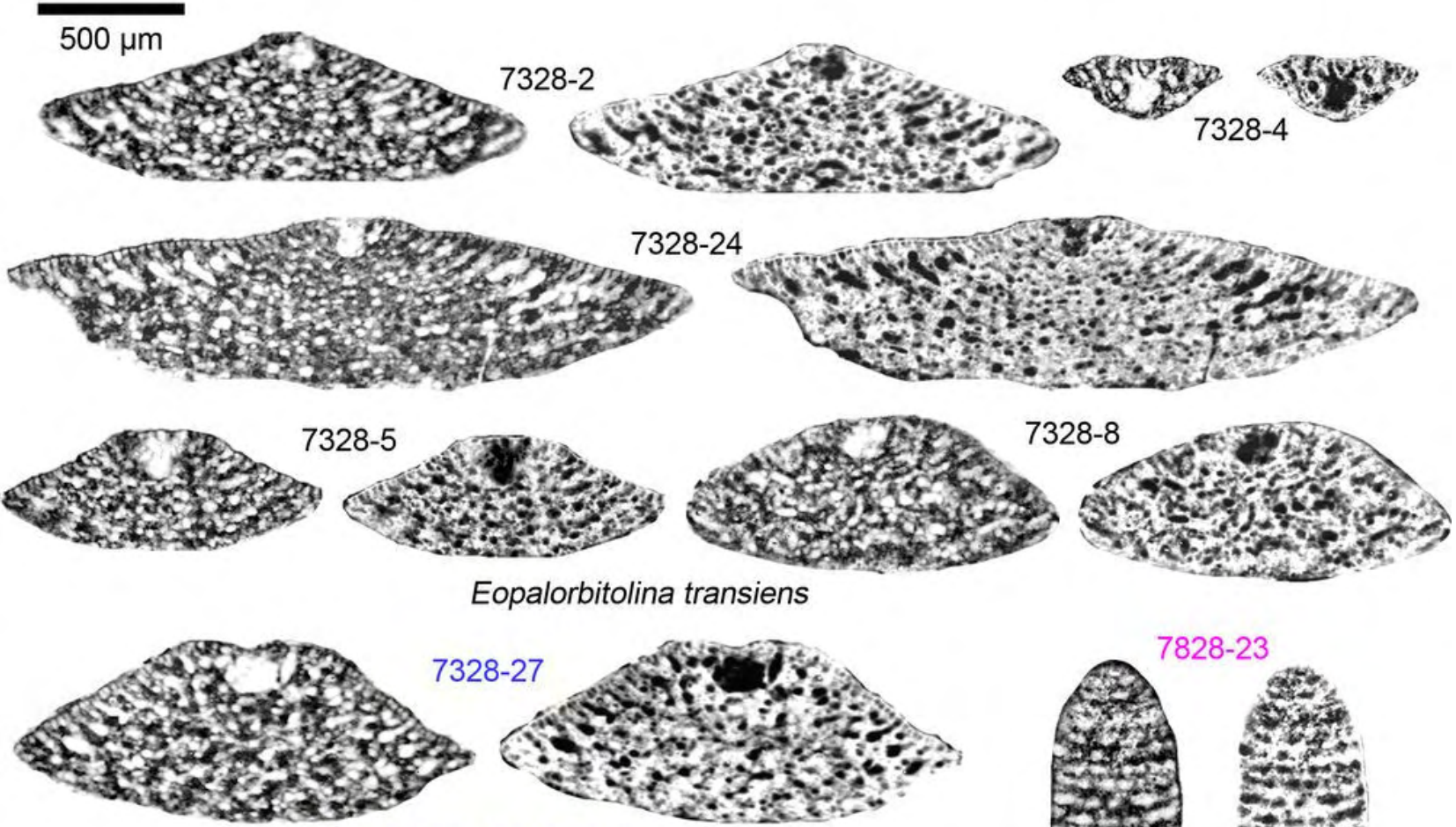

Palorbitolina lenticularis
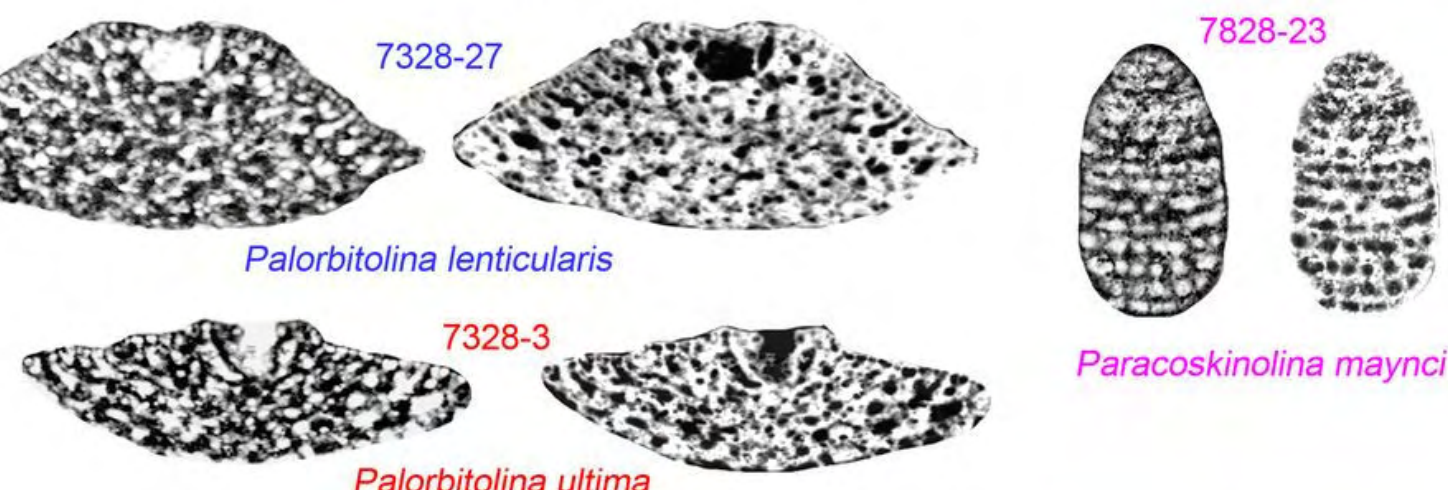

Paracoskinolina maynci

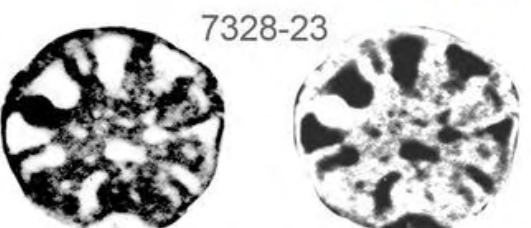

Orbitolinopsis cuvillieri

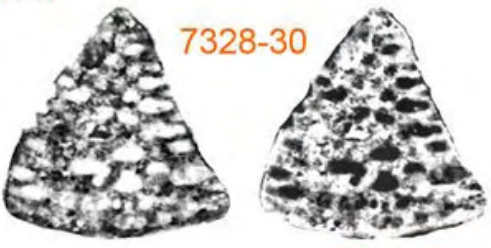

Orbitolinopsis kiliani

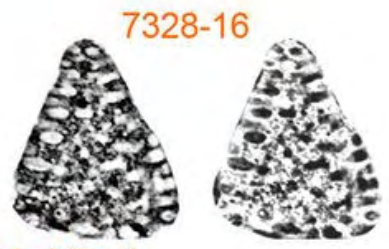

Fos 592

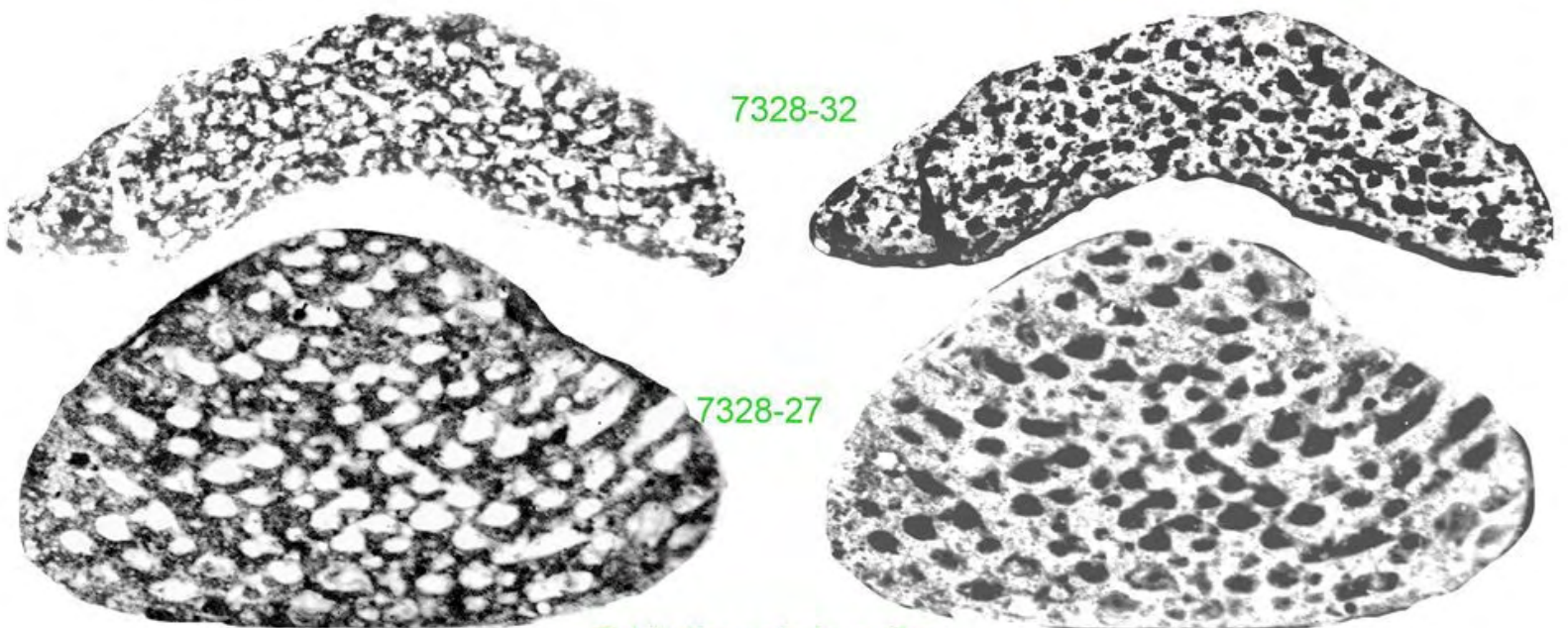

Orbitolinopsis buccifer

Plate 108: Orbitolinids of the Giraudi Zone at La Charce. Eopalorbitolina transiens: 7328-2, 7328-4, 7328-5, 73288, 7328-24; Orbitolinopsis buccifer: 7328-27, 7328-32; Orbitolinopsis cuvillieri: 7328-23; Orbitolinopsis kiliani: 7328-16, 7328-30; Palorbitolina lenticularis: 7328-27; Palorbitolina ultima: 7328-3; Paracoskinolina maynci: 732823. Scale bar $=500 \mu \mathrm{m}$. 

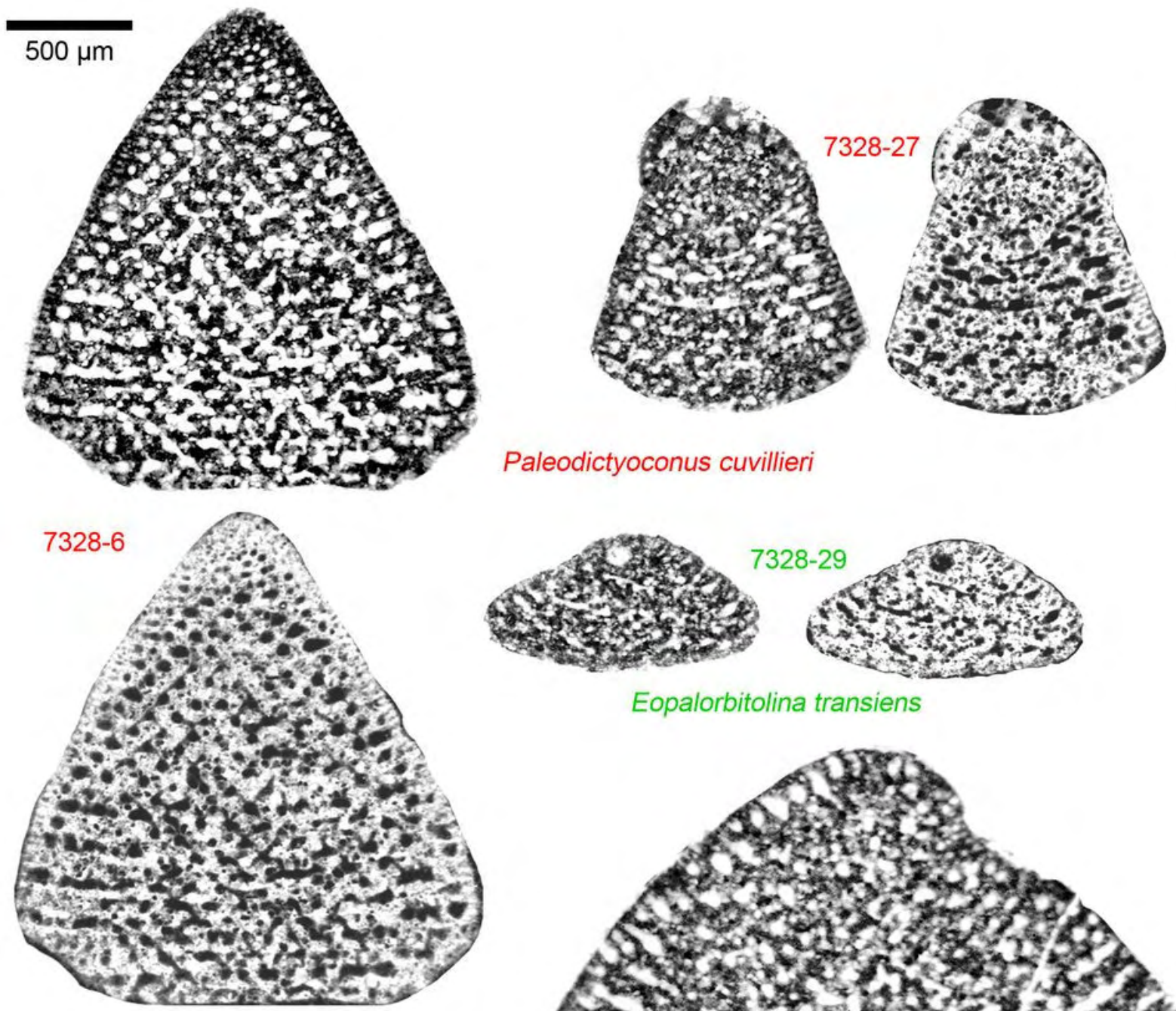

Paleodictyoconus cuvillieri

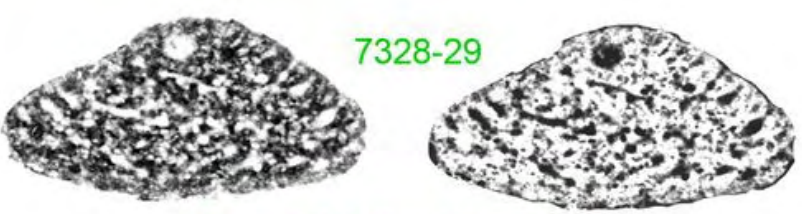

Eopalorbitolina transiens

7328-27

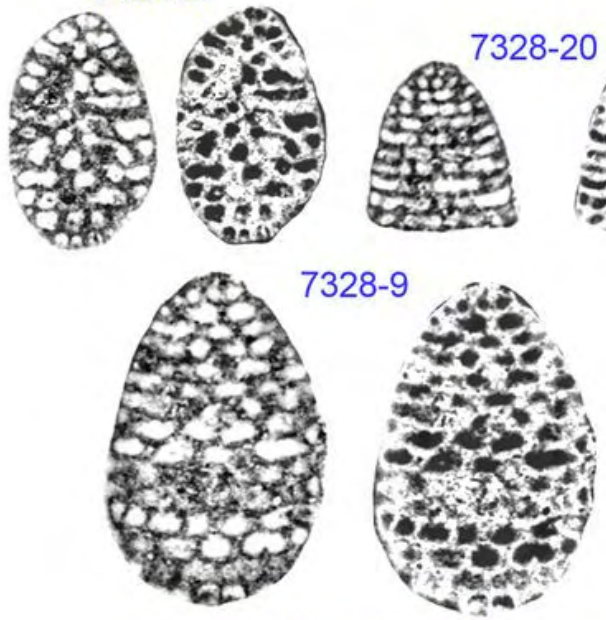

Cribellopsis neoelongata
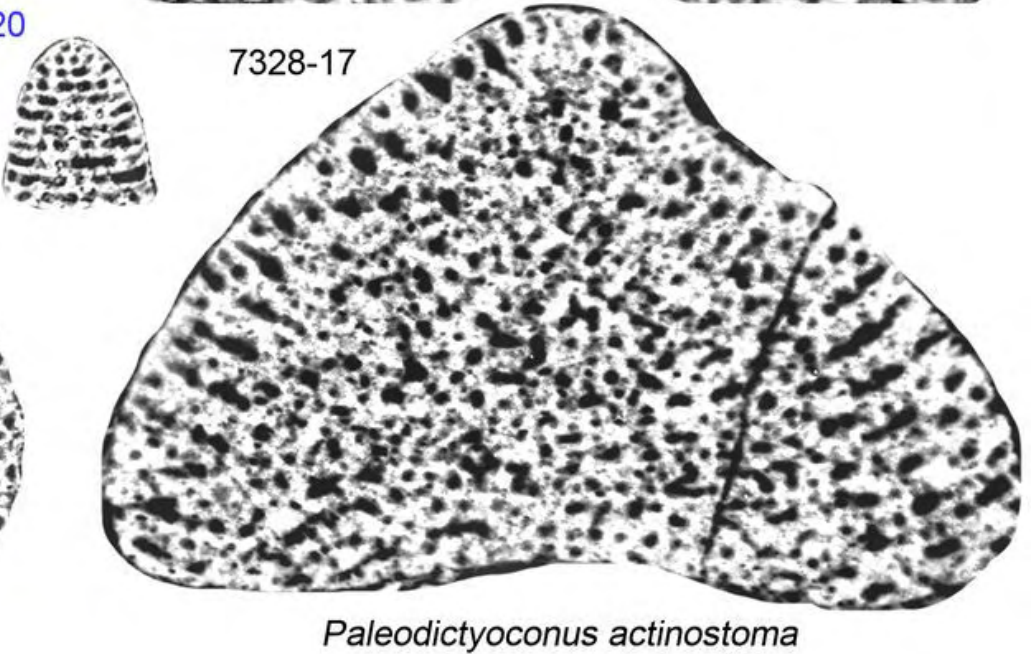

Plate 109: Orbitolinids of the Giraudi Zone at La Charce. Cribellopsis neoelongata: 7328-9, 7328-20, 7328-27; Eopalorbitolina transiens: 7328-29; Paleodictyoconus actinostoma: 7328-17; Paleodictyoconus cuvillieri: 7328-6, 732827. Scale bar $=500 \mu \mathrm{m}$. 
A

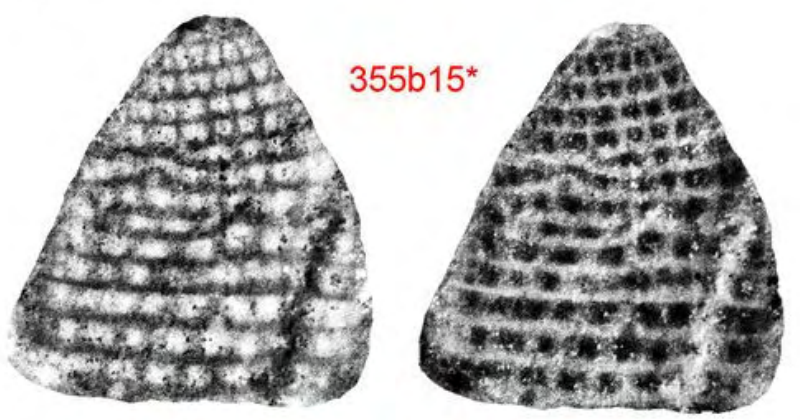

Paracoskinolina? praereicheli

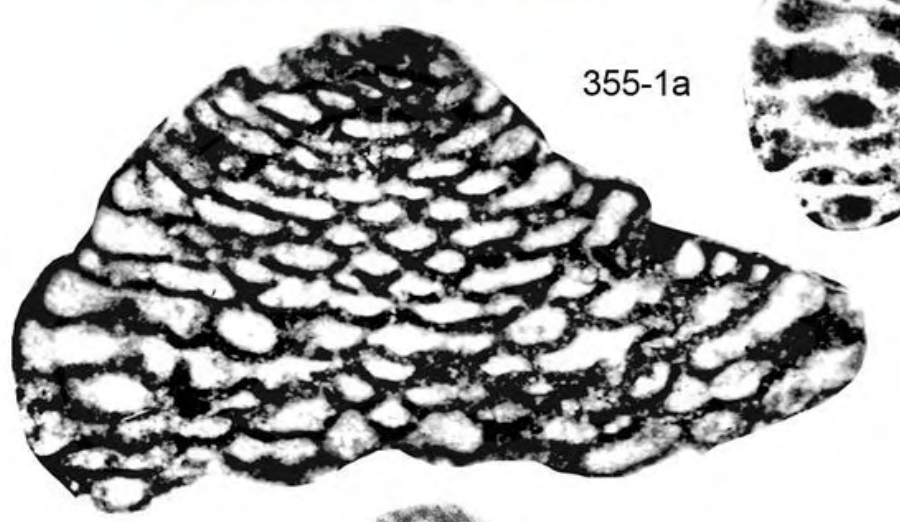

$500 \mu \mathrm{m}$
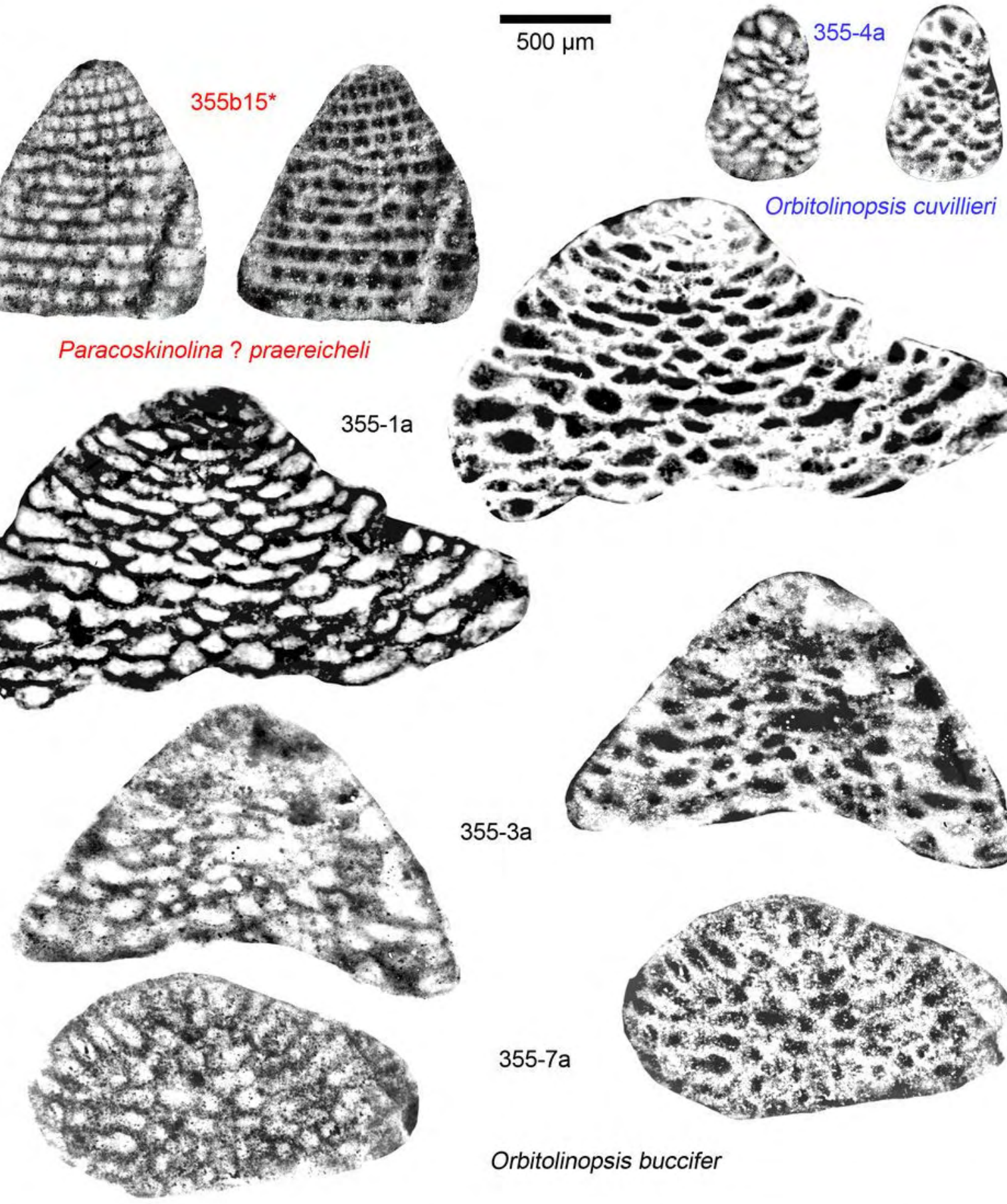

355-3a

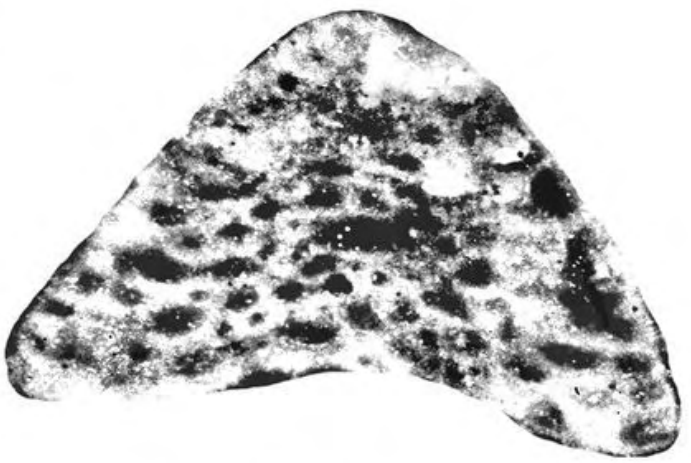

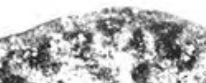

Ho. 10 to

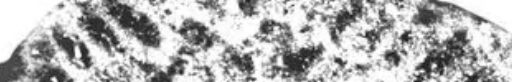

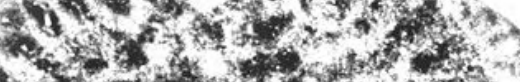

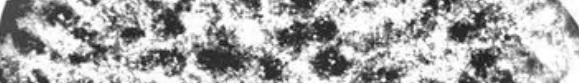

$355-7 a$

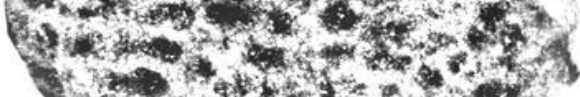

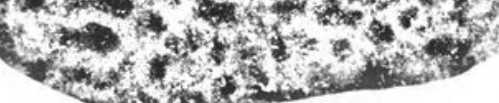

Orbitolinopsis buccifer
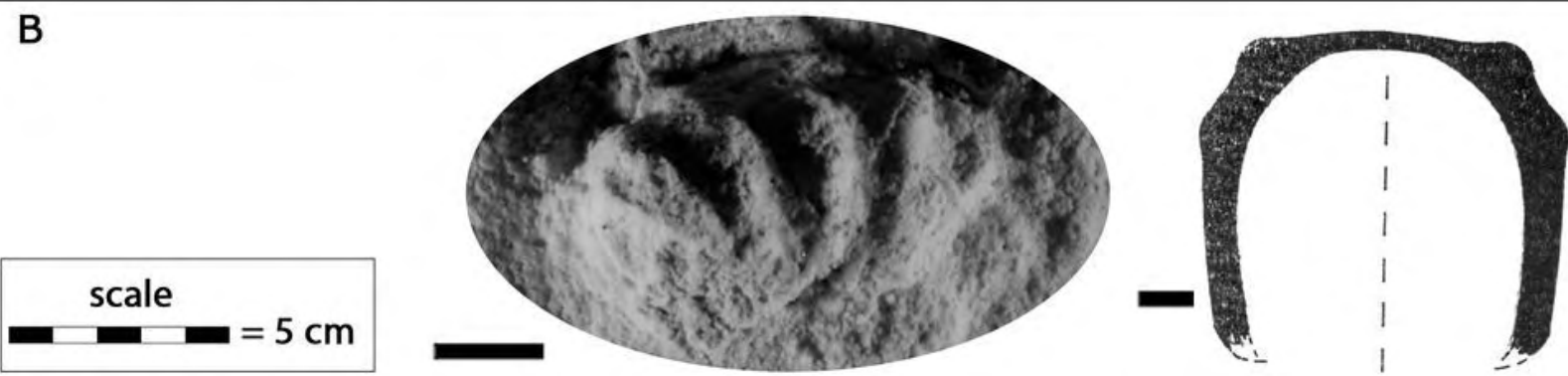

Plate 110: A) Orbitolinids of the Giraudi/Sarasini zones at Pont d'Arc. Orbitolinopsis buccifer: 355-1a, 355-3a, 355-

7a; Orbitolinopsis cuvillieri: 355-4a; Paracoskinolina ? praereicheli: 355b15*; B) Pseudocrioceras cf. baylei -RB- \{or ? Pseudocrioceras sp. -DB-\}, FSL 89446. Scale bar $(A)=500 \mu \mathrm{m}$, and ammonite scale bar $(B)=5 \mathrm{~cm}$. 


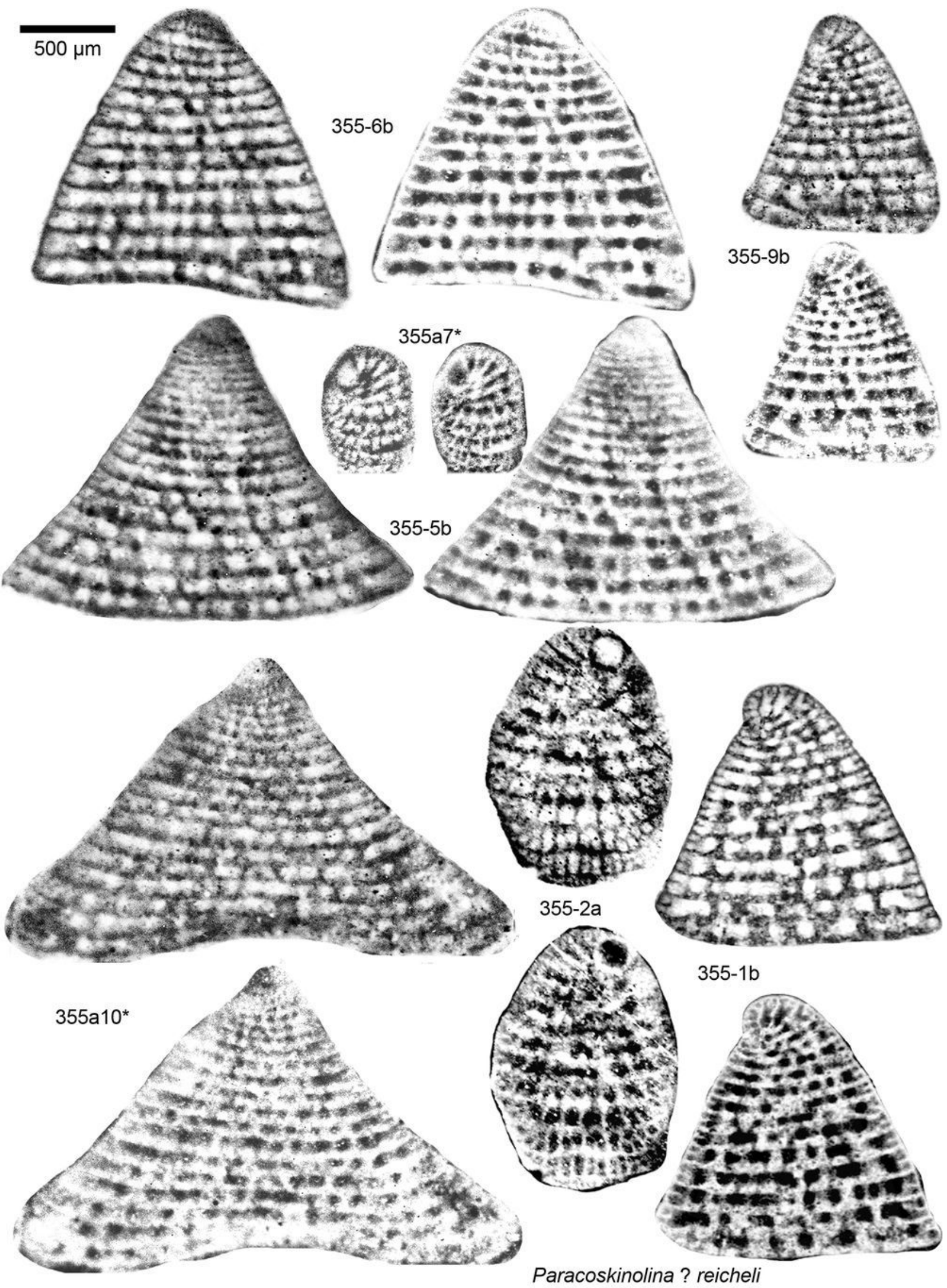

Plate 111: Orbitolinids of the Giraudi/Sarasini zones at Pont d'Arc. Paracoskinolina ? reicheli: 355-1b, 355-2a, 355$5 b, 355-6 b, 355-9 b, 355 a 7 *$, 355a10*. Scale bar $=500 \mu \mathrm{m}$. 


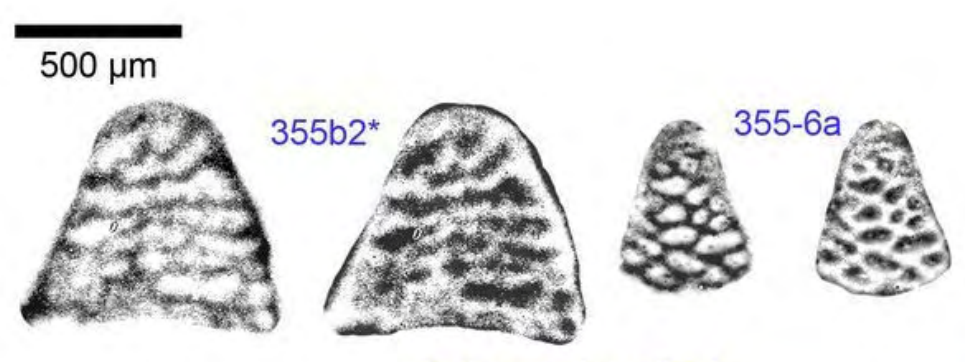

Falsurgonina pileola

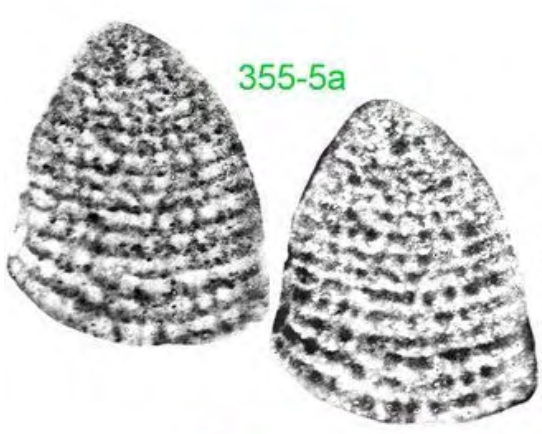

Paracoskinolina aff. sunnilandensis

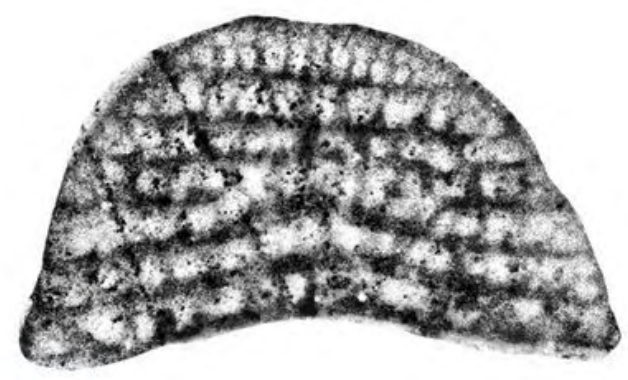

355b14a*

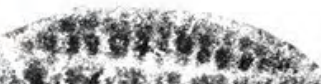

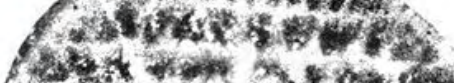

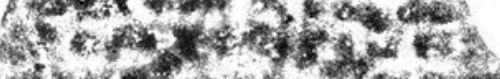

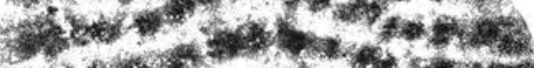

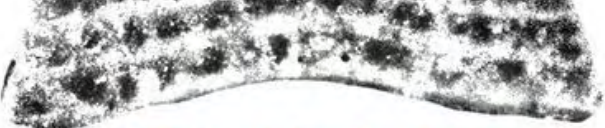

Montseciella alguerensis

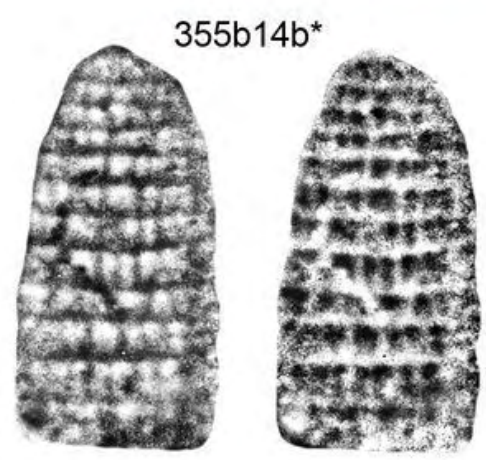

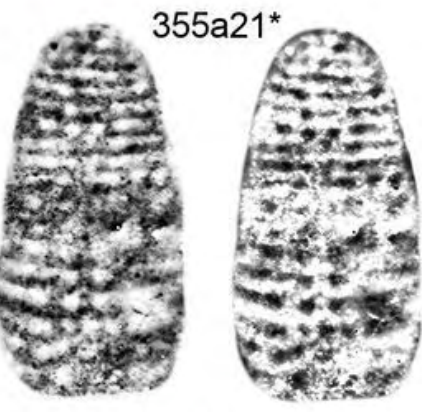

Paracoskinolina maynci
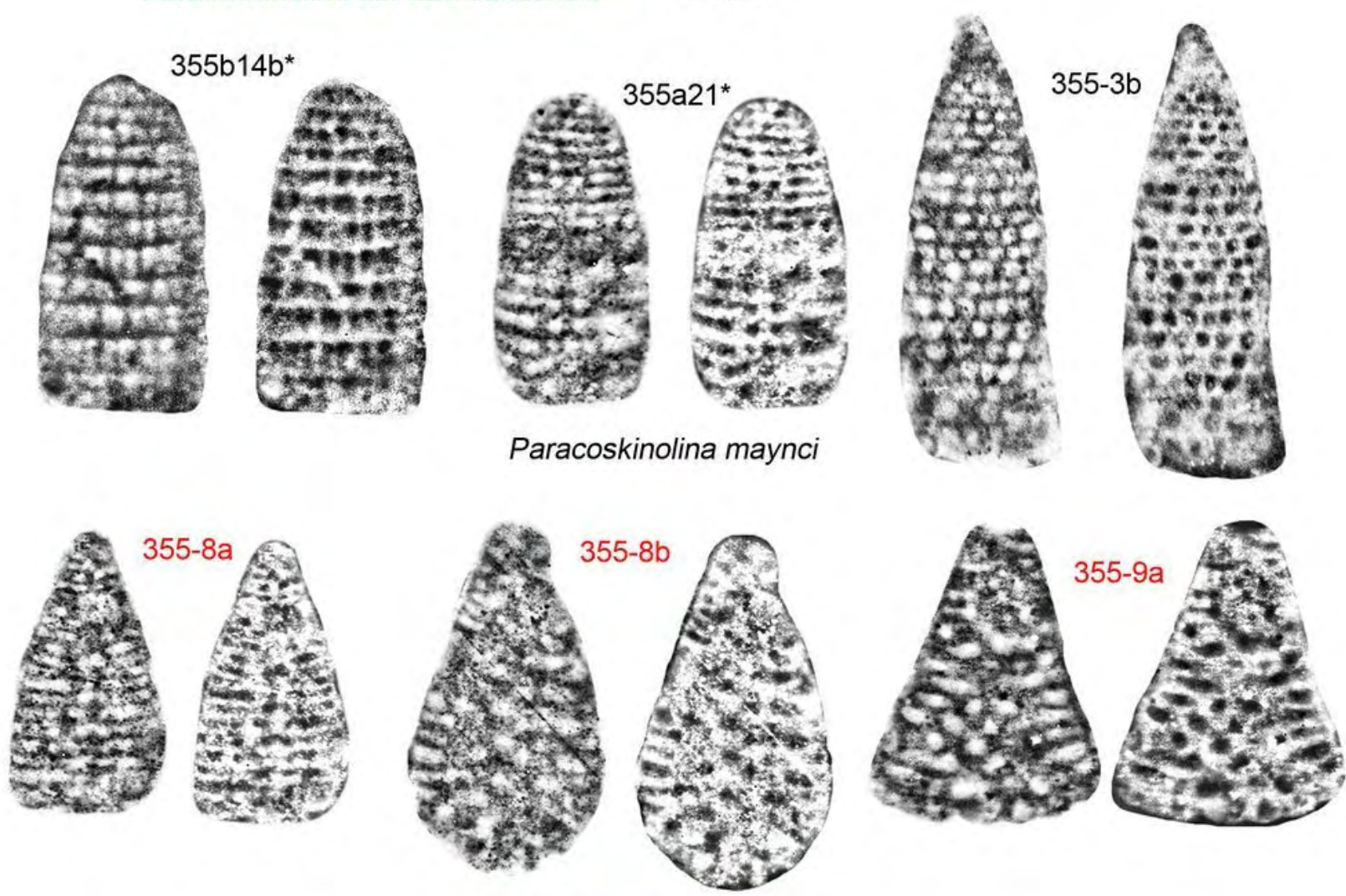

Cribellopsis neoelongata

Plate 112: Orbitolinids of the Giraudi/Sarasini zones at Pont d'Arc. Cribellopsis neoelongata: 355-8a, 355-8b, 3559a; Falsurgonina pileola: 355-6a, 355b2*; Montseciella alguerensis: 355b14a*; Paracoskinolina maynci: 355-3b, 355a21*, 355b14b*; Paracoskinolina aff. sunnilandensis: 355-5a, 355b17*. Scale bar $=500 \mu \mathrm{m}$. 

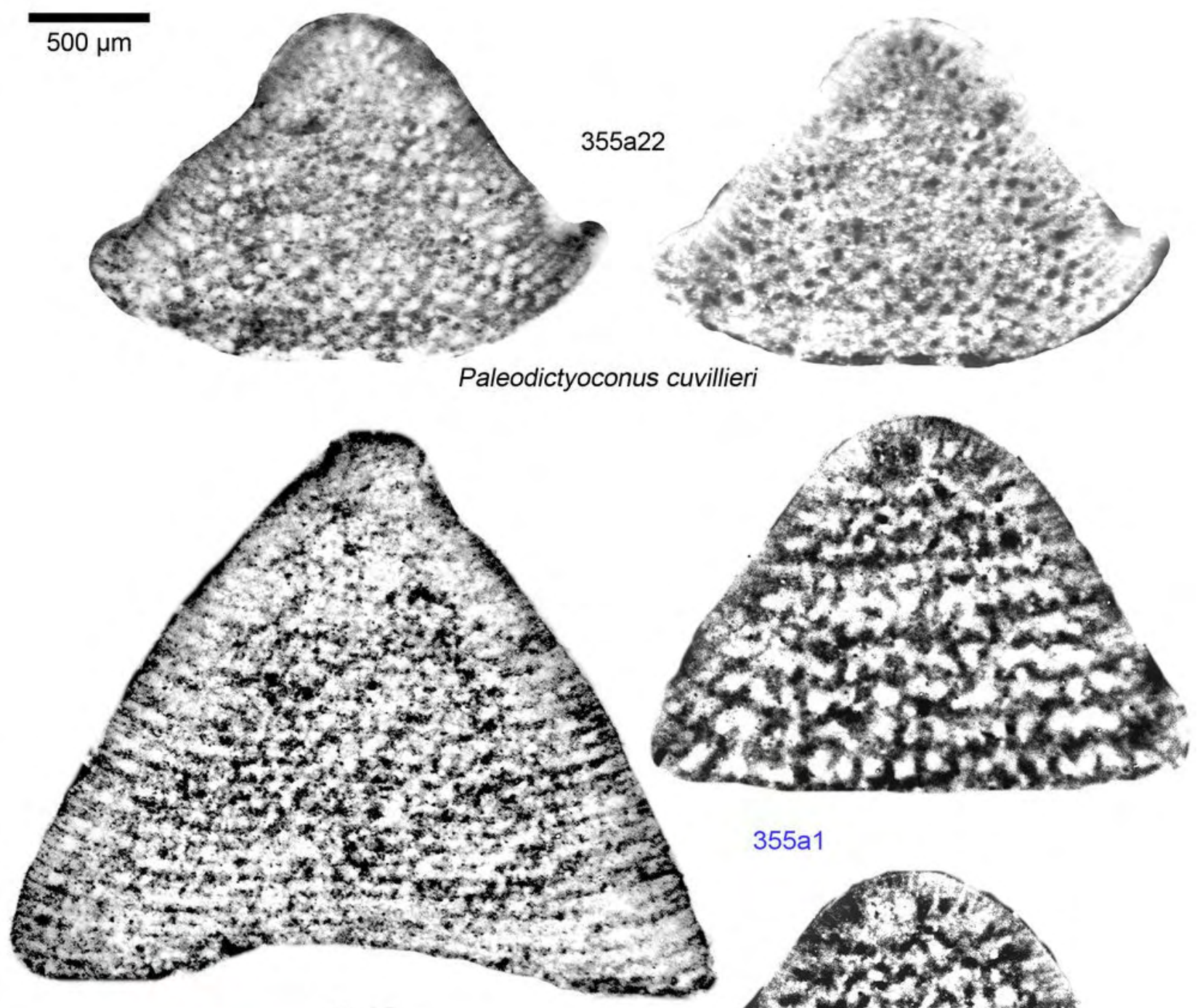

$355 a 1$
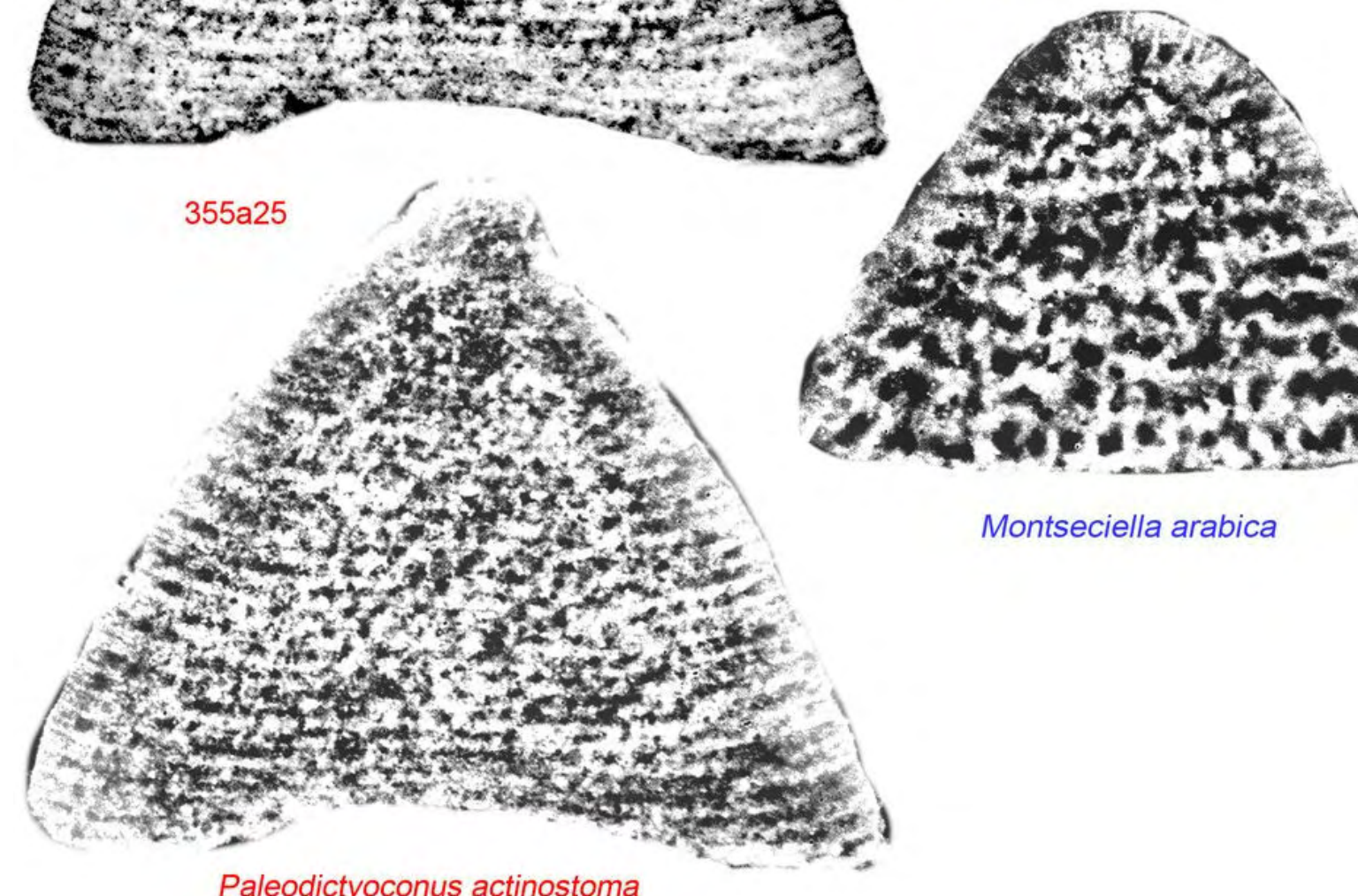


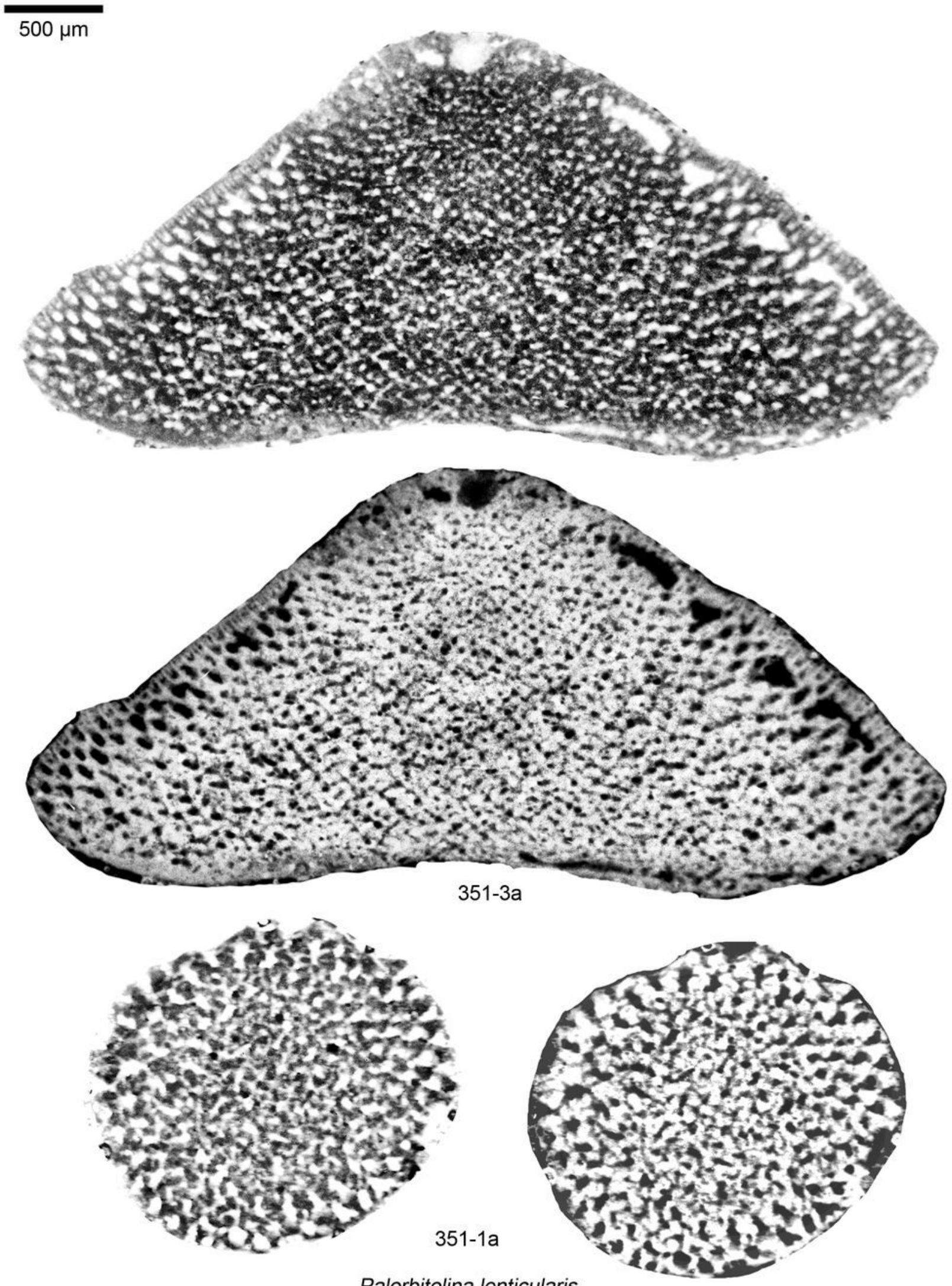

Palorbitolina lenticularis

Plate 114: Orbitolinids of the Giraudi/Sarasini zones at Pont d'Arc. Palorbitolina lenticularis: 351-1a, 351-3a. Scale bar $=500 \mu \mathrm{m}$. 
$500 \mu \mathrm{m}$

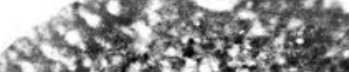

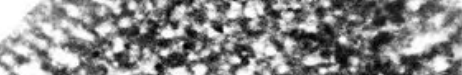

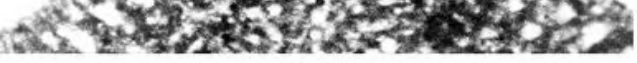
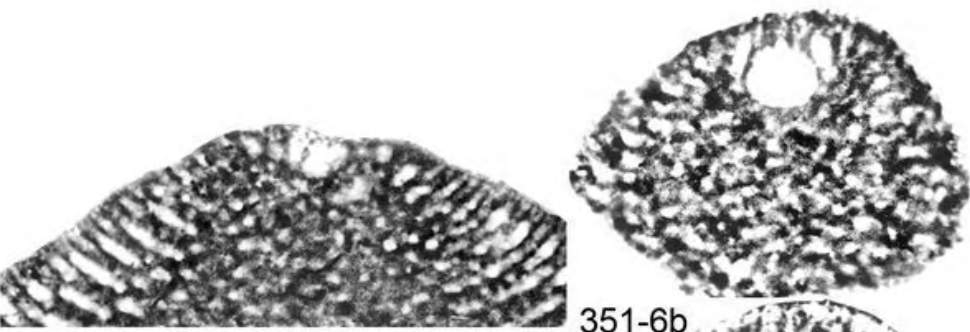

$351-8 b$

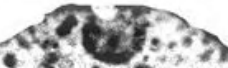

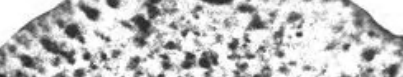
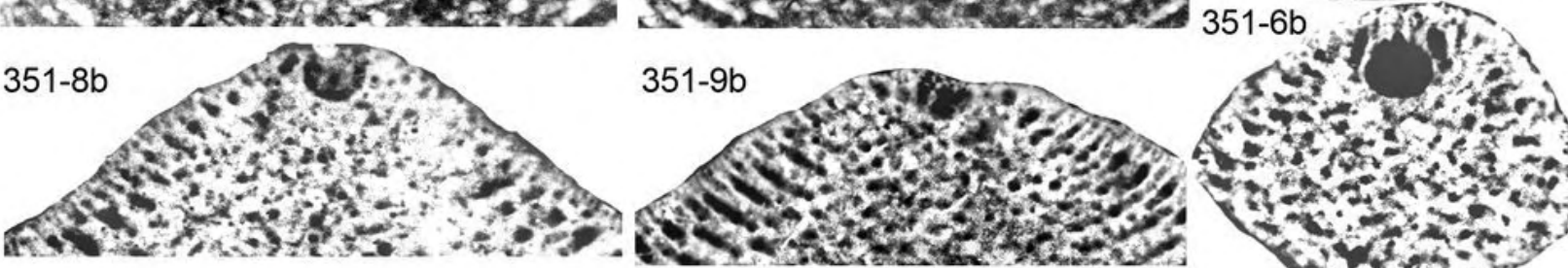

cond

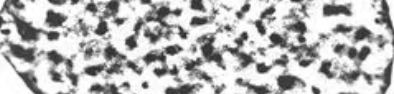

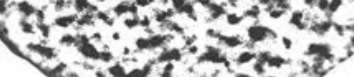

\section{Palorbitolina lenticularis}

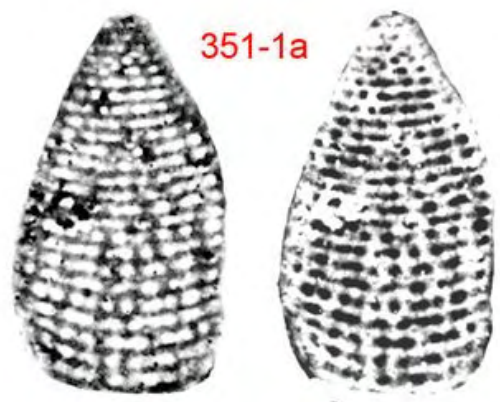

Paracoskinolina aff. sunnilandensis

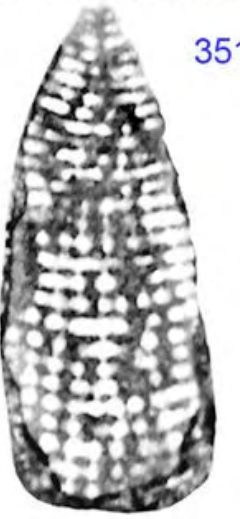

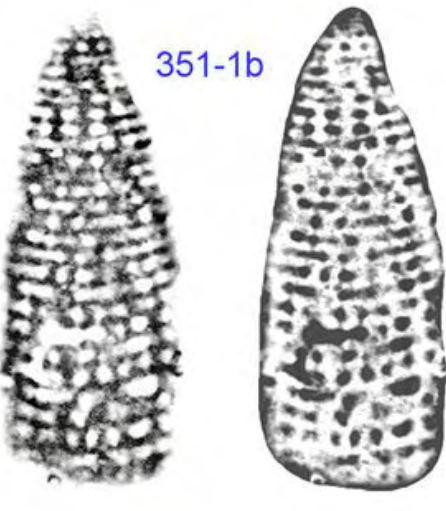

Paracoskinolina maynci
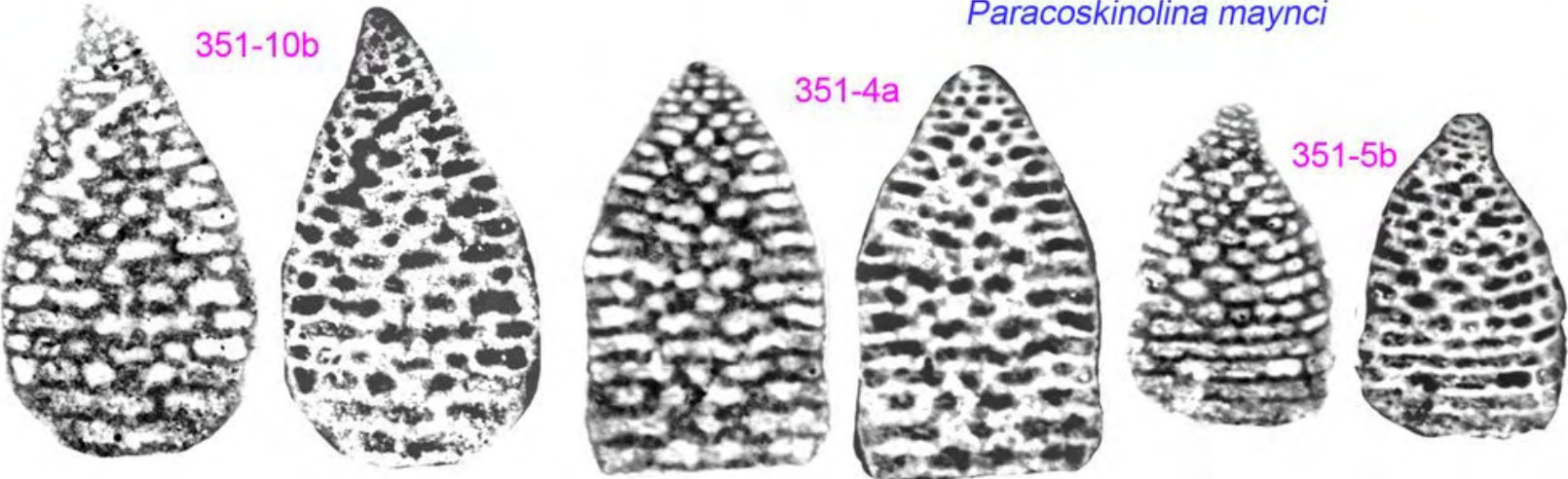

Cribellopsis neoelongata

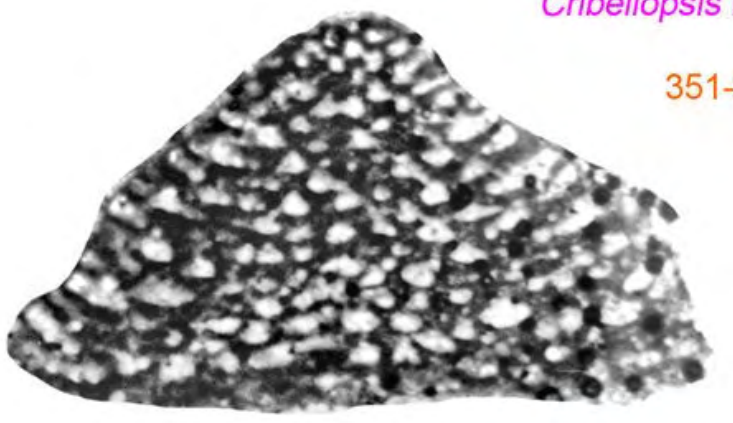

$351-2 a$

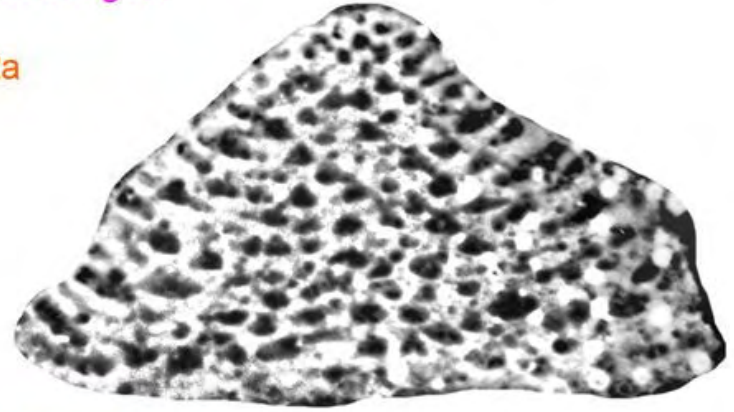

Cribellopsis schroederi

Plate 115: Orbitolinids of the Giraudi/Sarasini zones at Pont d'Arc. Cribellopsis neoelongata: 351-4a, 351-5b, 35110b; Cribellopsis schroederi: 351-2a; Palorbitolina lenticularis: 351-6b, 351-8b, 351-9b; Paracoskinolina maynci: 351-1b; Paracoskinolina aff. sunnilandensis: 351-1a. Scale bar $=500 \mu \mathrm{m}$. 

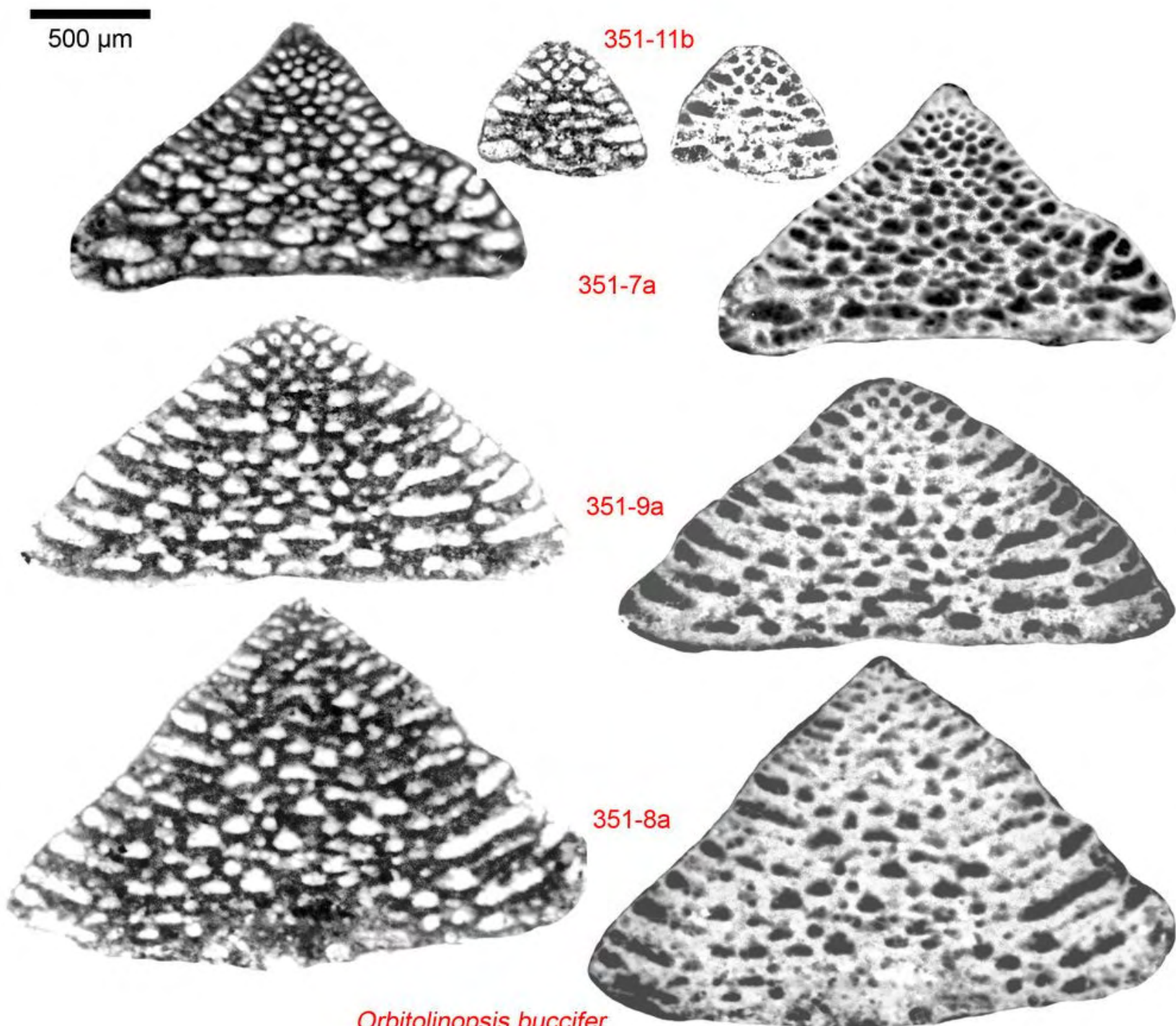

Orbitolinopsis buccifer
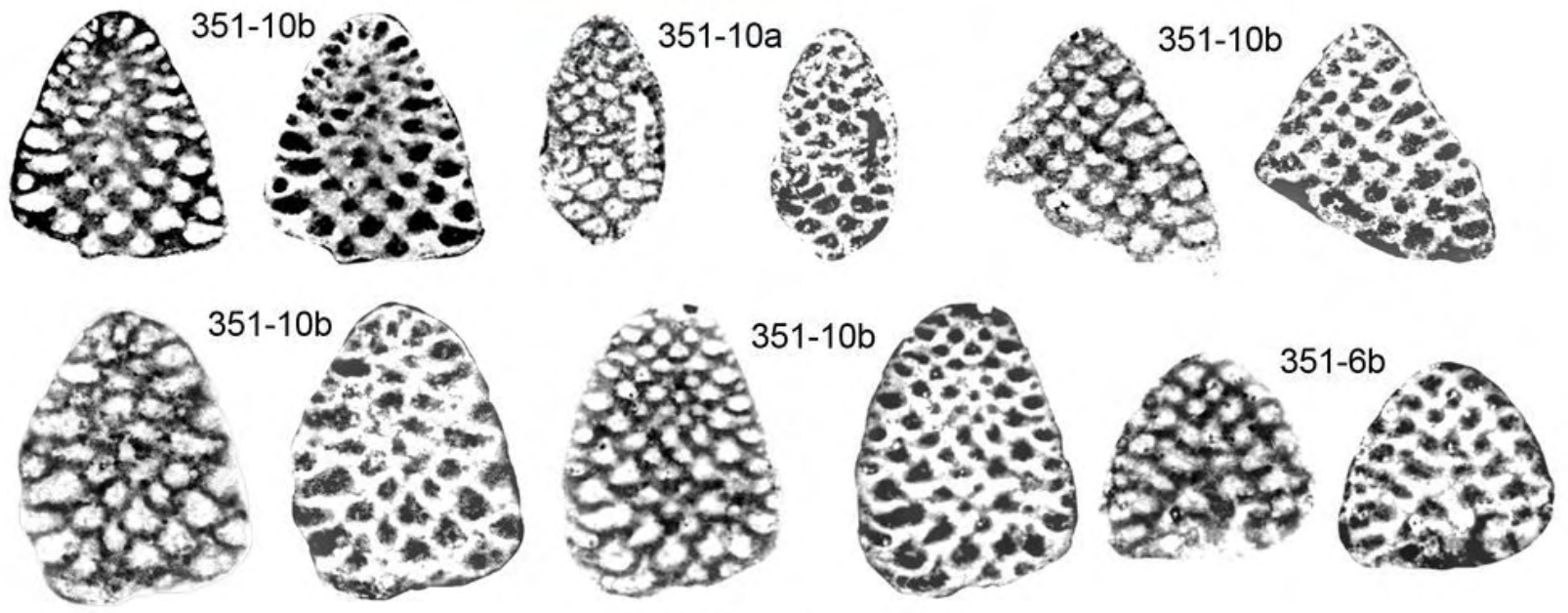

Orbitolinopsis cuvillieri

Plate 116: Orbitolinids of the Giraudi/Sarasini zones at Pont d'Arc. Orbitolinopsis buccifer: 351-7a, 351-8a, 351-9a, 351-11b; Orbitolinopsis cuvillieri: 351-6b, 351-10a, 351-10b. Scale bar $=500 \mu \mathrm{m}$. 
$500 \mu \mathrm{m}$
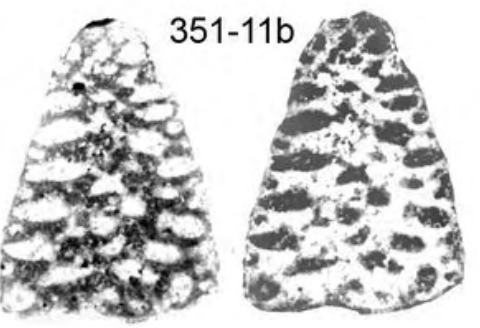
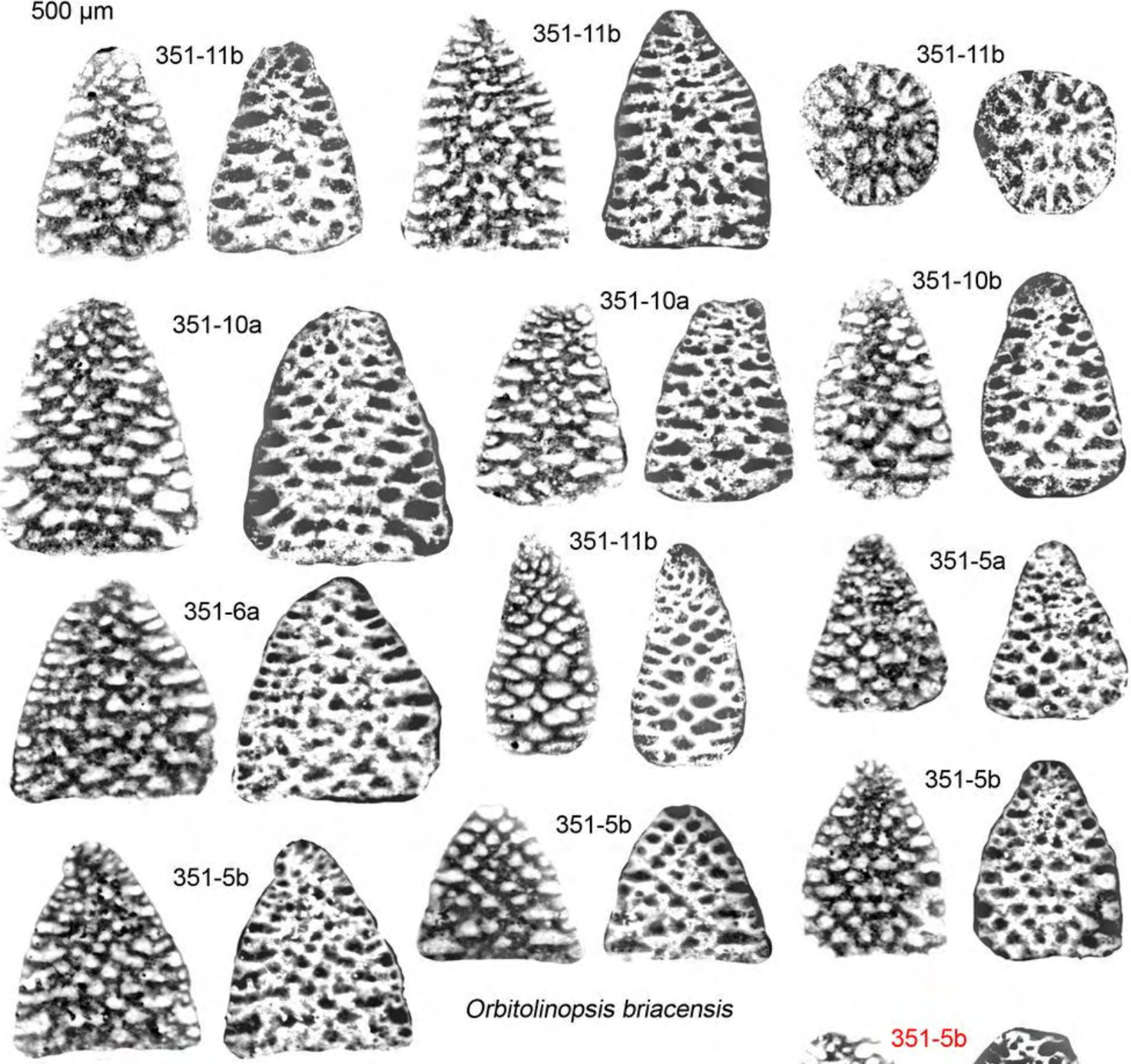

Orbitolinopsis briacensis
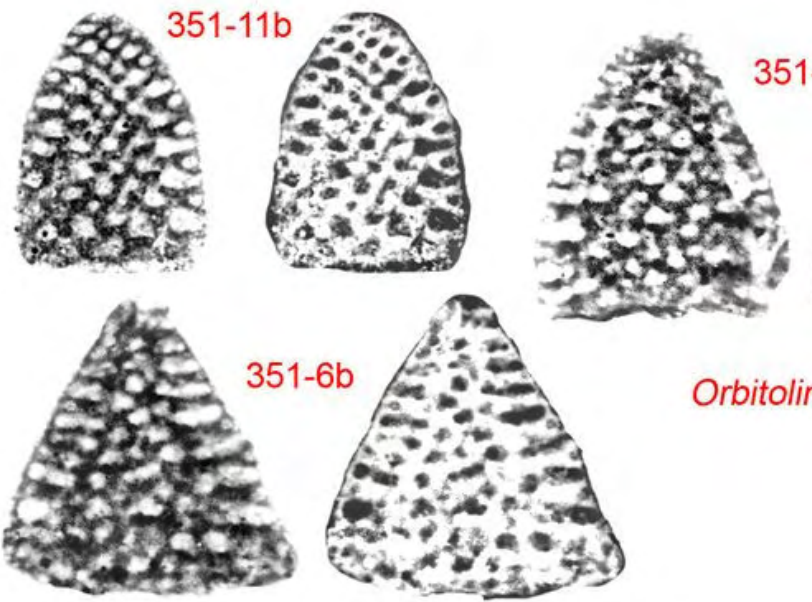

Orbitolinopsis kiliani
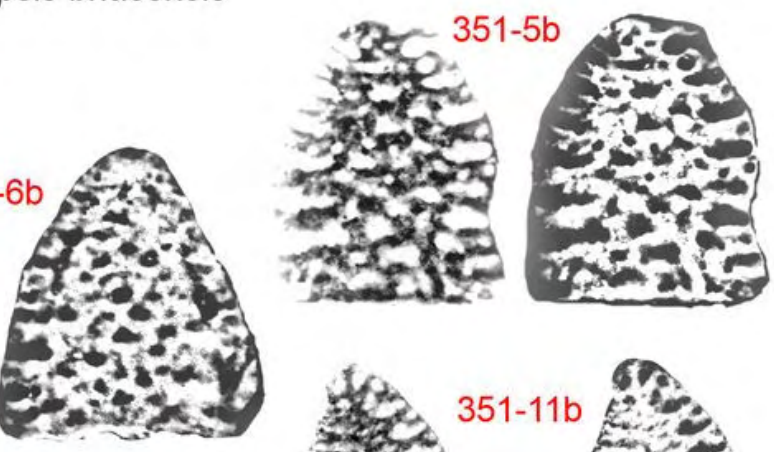

Plate 117: Orbitolinids of the Giraudi/Sarasini zones at Pont d'Arc. Orbitolinopsis briacensis: 351-5a, 351-5b, 3516a, 351-10a, 351-10b, 351-11b; Orbitolinopsis kiliani: 351-5b, 351-6b, 351-11b. Scale bar $=500 \mu \mathrm{m}$. 


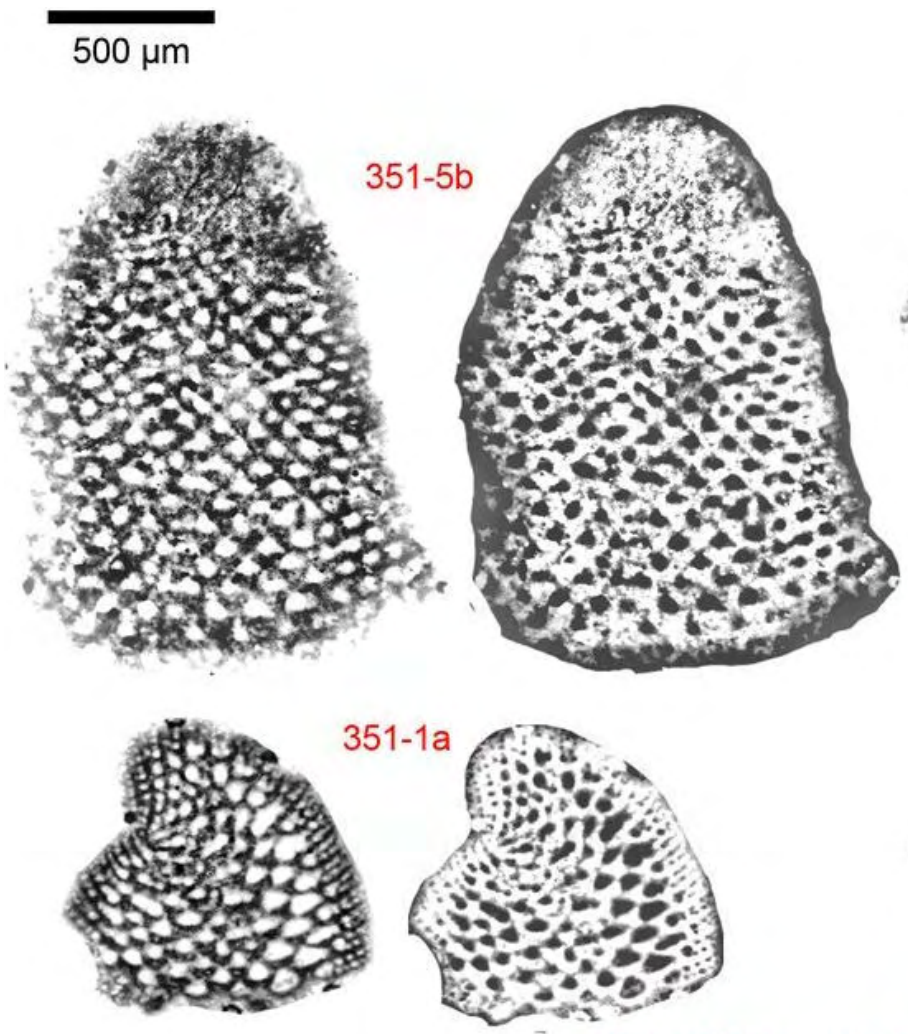

Paleodictyoconus cuvillieri
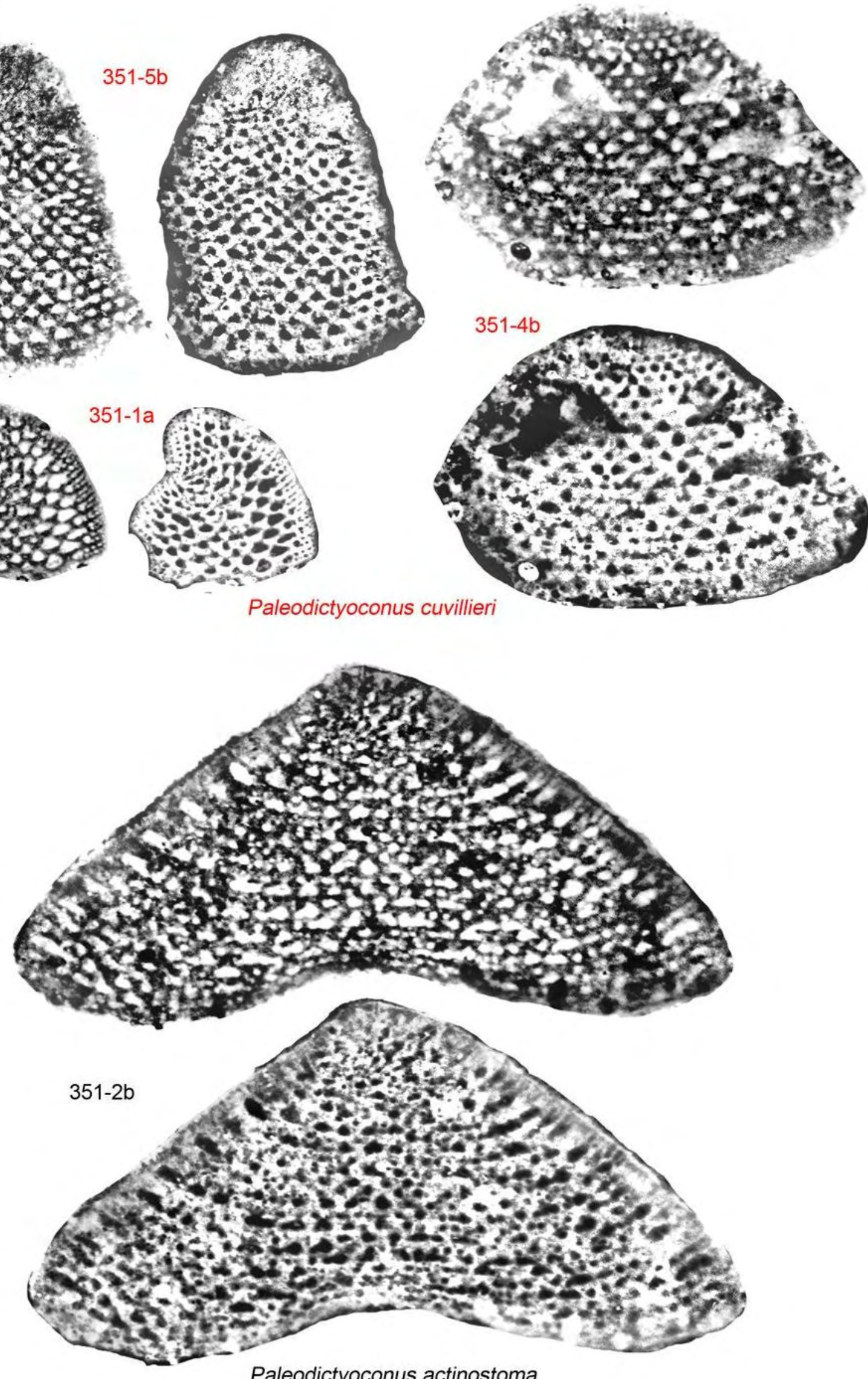

Paleodictyoconus actinostoma

Plate 118: Orbitolinids of the Giraudi/Sarasini zones at Pont d'Arc. Paleodictyoconus actinostoma: 351-2b; Paleodictyoconus cuvillieri: 351-1a, 351-4b, 351-5b. Scale bar $=500 \mu \mathrm{m}$. 
$500 \mu \mathrm{m}$
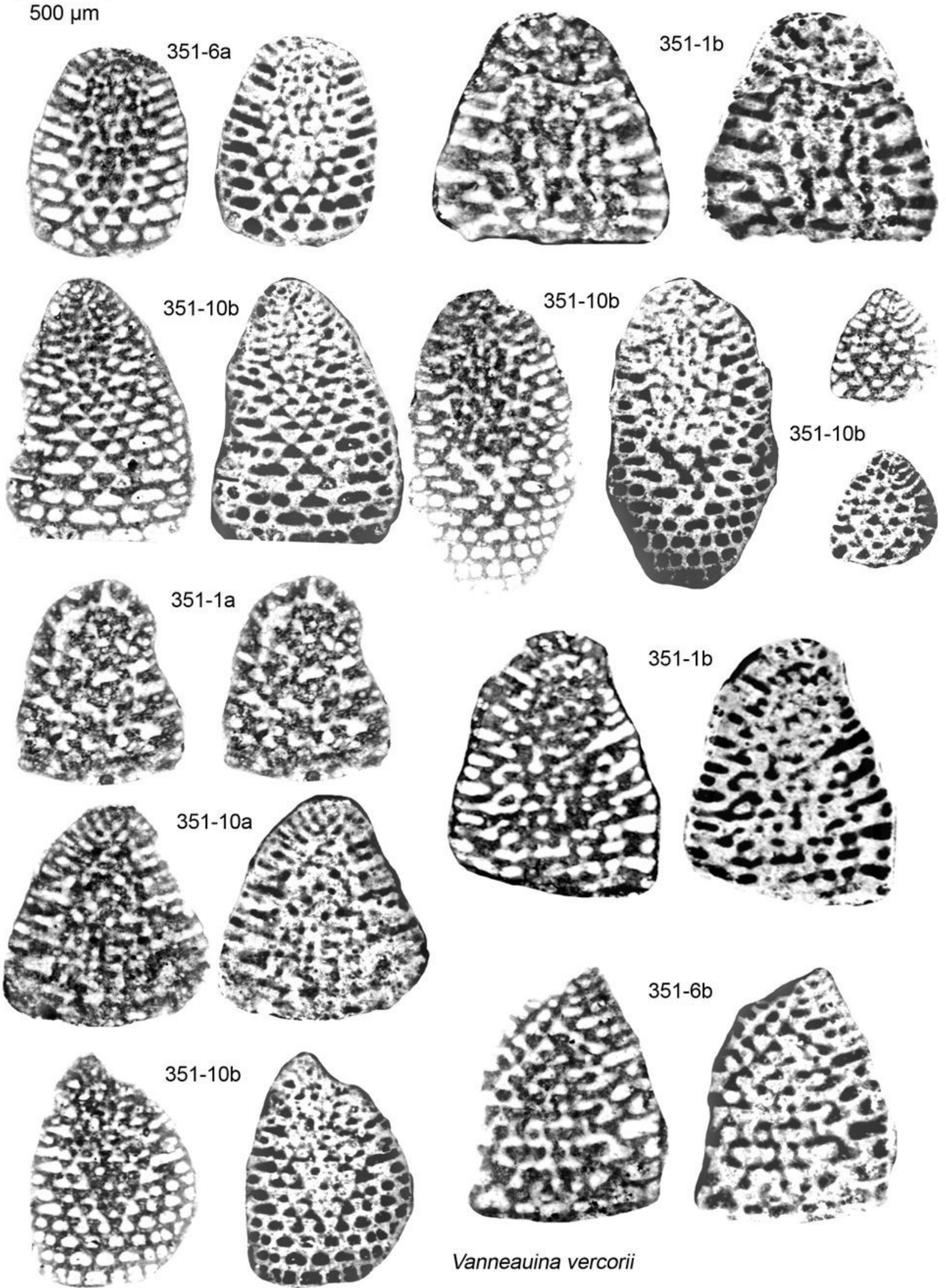

Vanneauina vercorii

Plate 119: Orbitolinids of the Giraudi/Sarasini zones at Pont d'Arc. Vanneauina vercorii: 351-1a, 351-1b, 351-6a, $351-6 b, 351-10 a, 351-10 b$, Scale bar $=500 \mu \mathrm{m}$. 

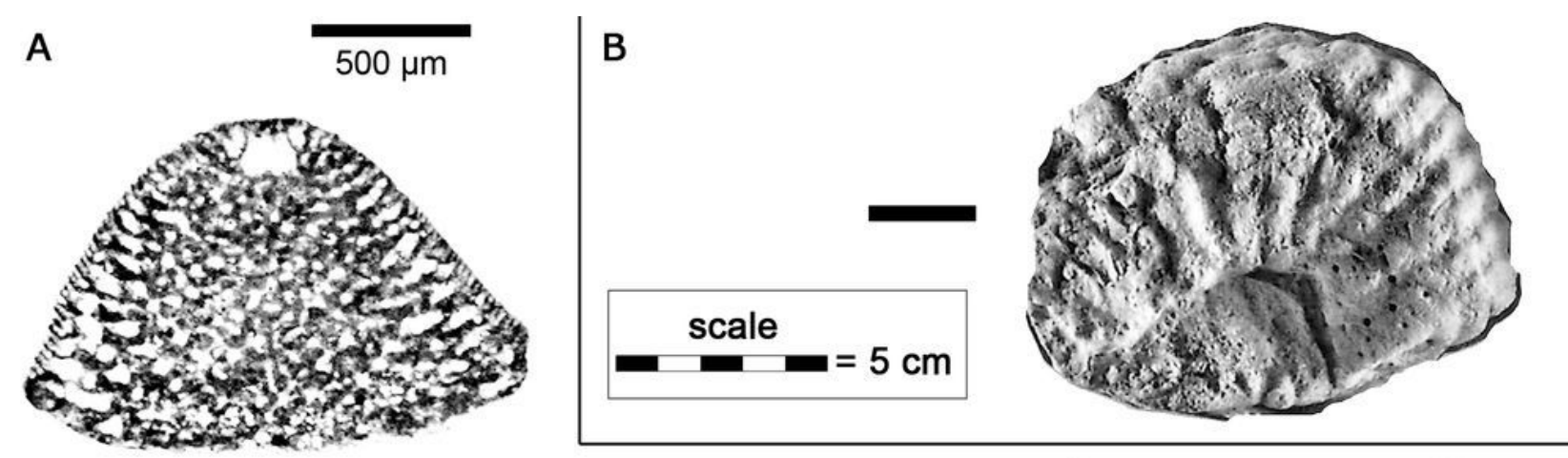

$228-4$
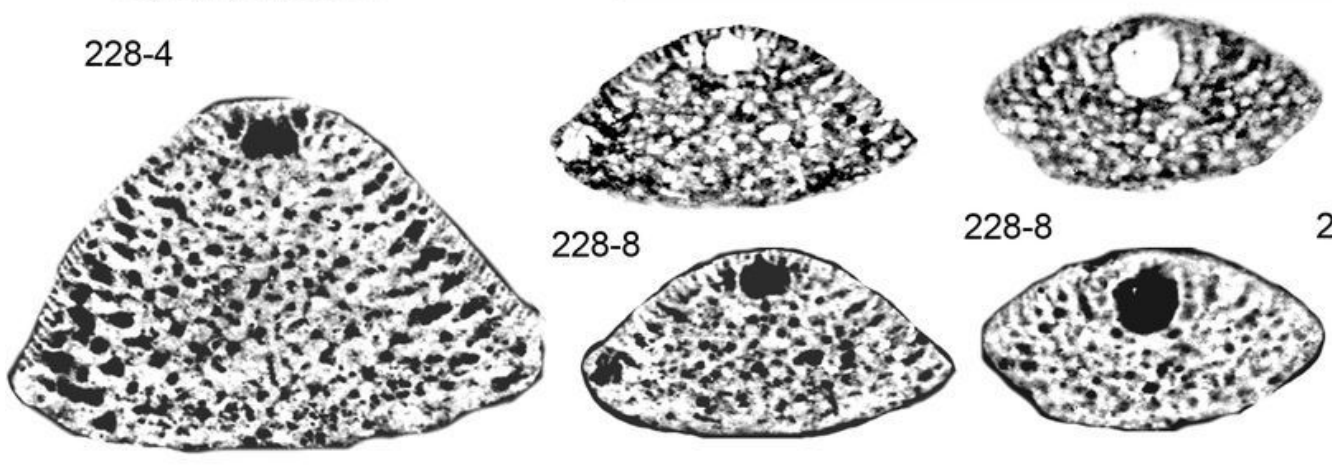

228-8

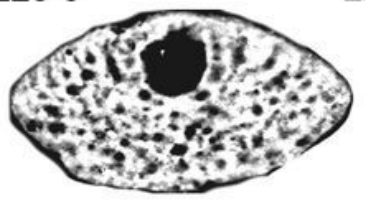

$228-8$
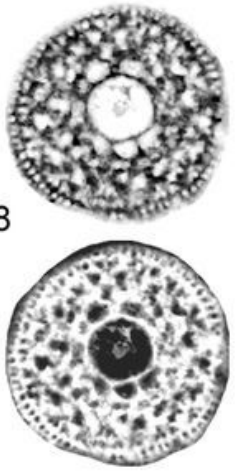
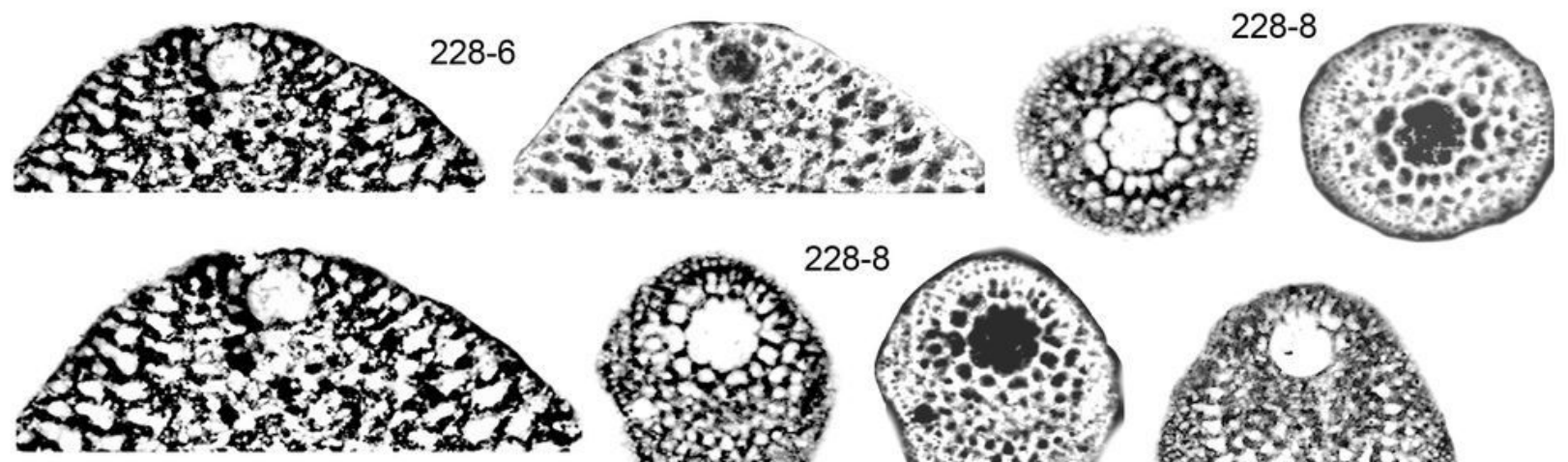

$228-6 \times 2$
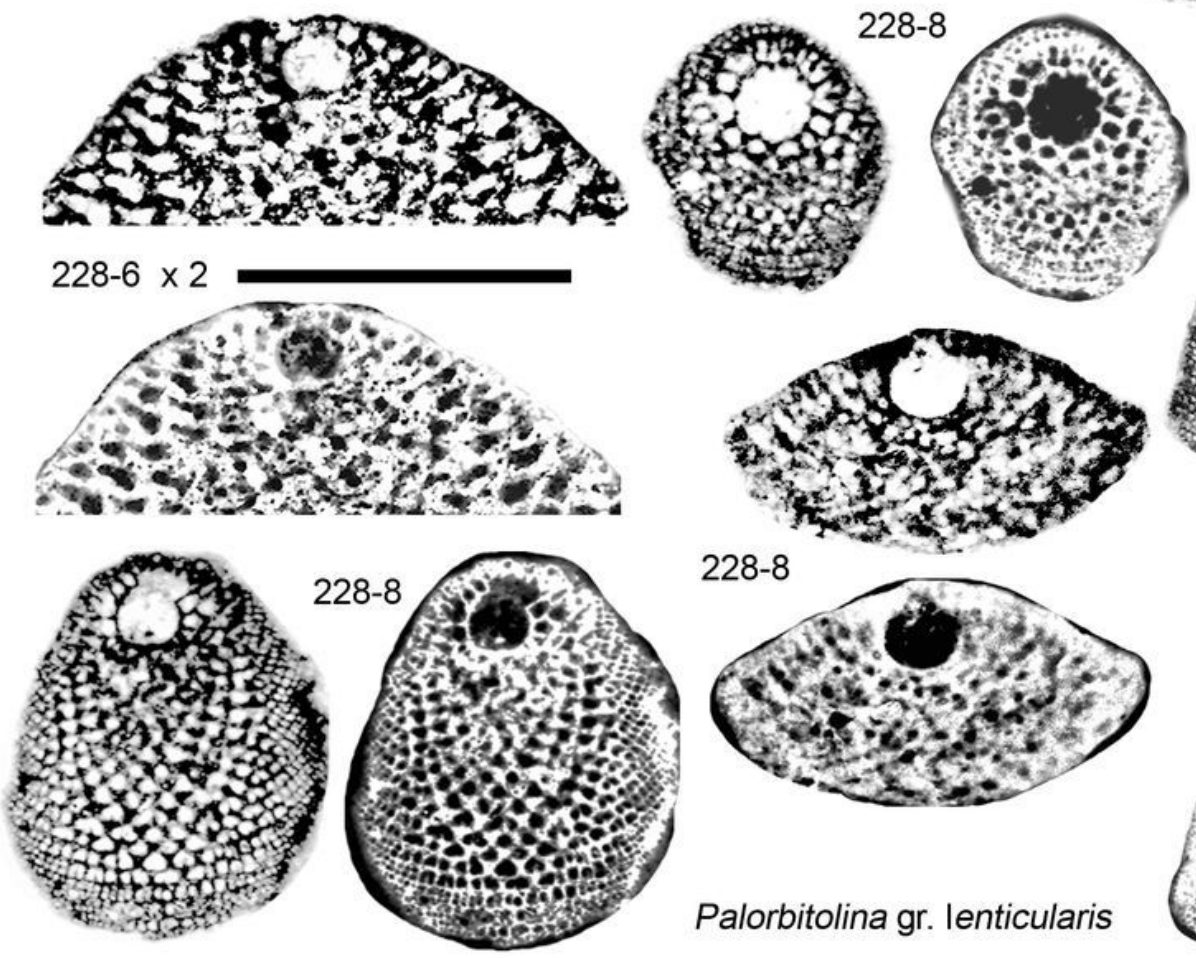

228-8

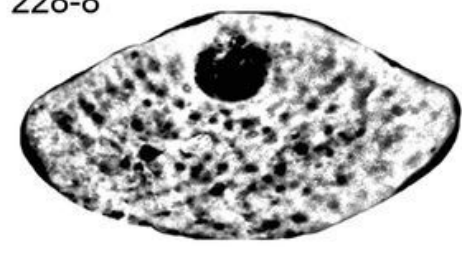

Palorbitolina gr. lenticularis
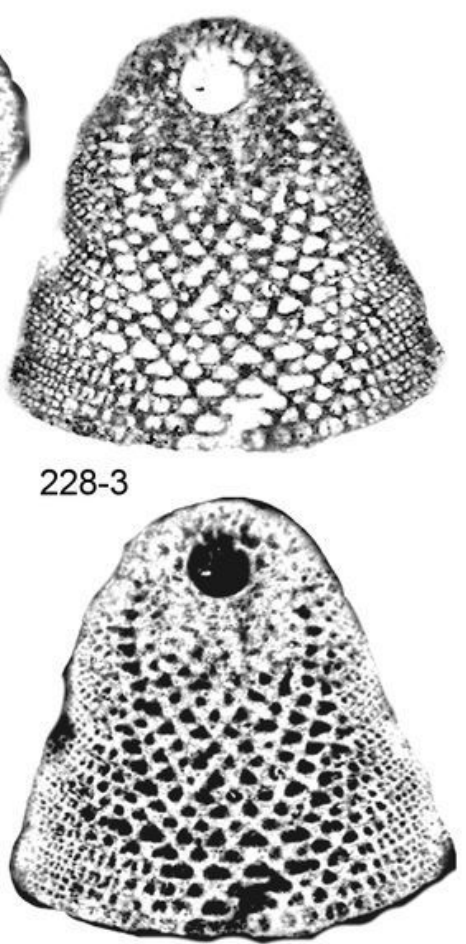

Plate 120: A) Orbitolinids of the Sarasini Zone at Orgnac. Palorbitolina lenticularis: 228-3, 228-4, 228-6, 228-8; B) Heteroceras cf. baylei, FSL 89455. Scale bar $(A)=500 \mu \mathrm{m}$, and ammonite scale bar $(B)=5 \mathrm{~cm}$. 

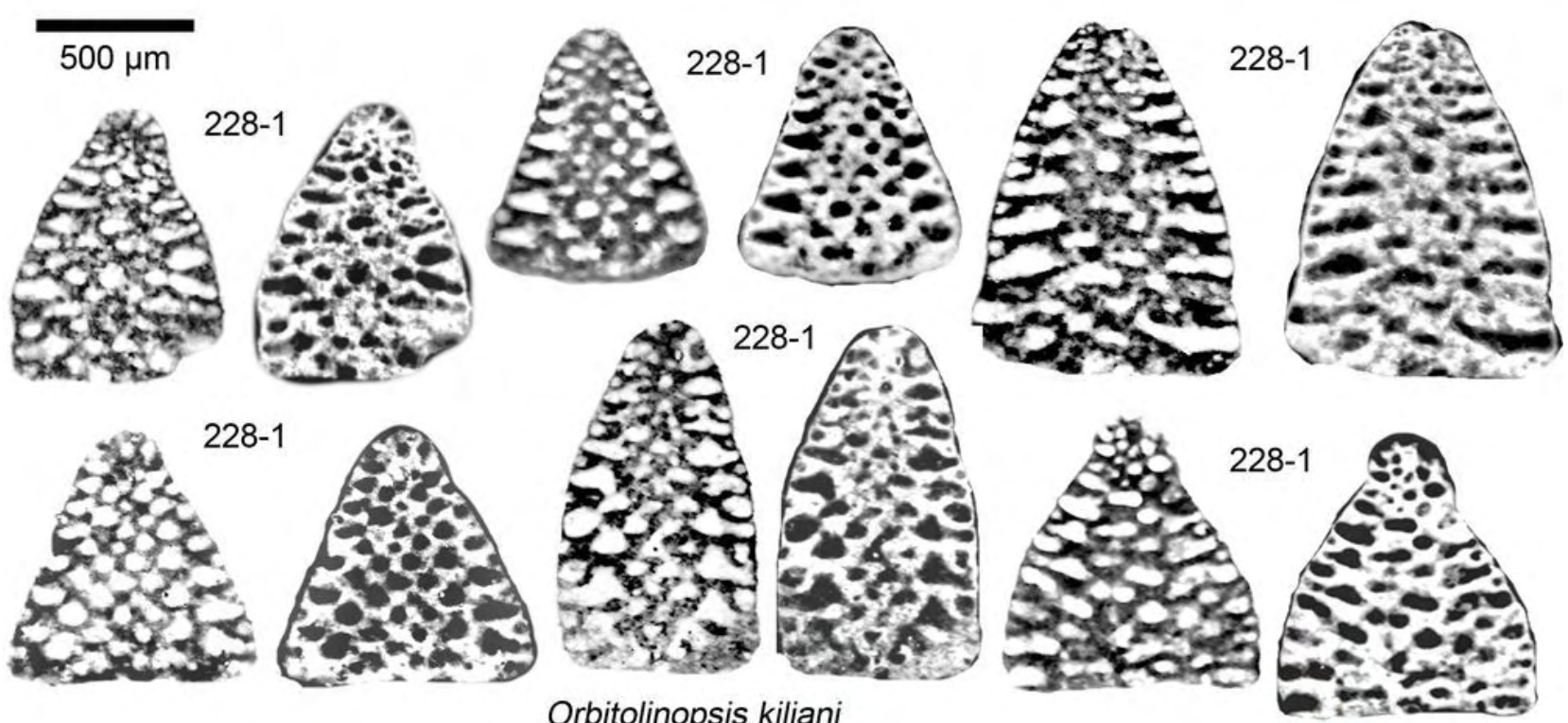

Orbitolinopsis kiliani
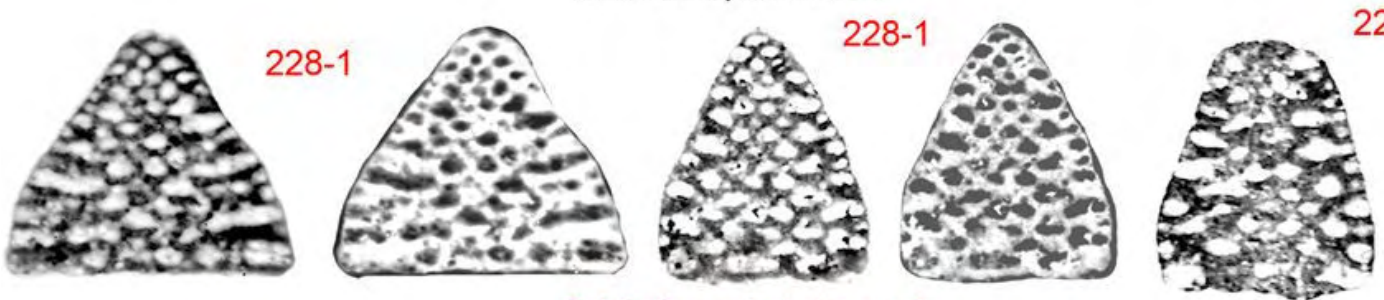

$228-1$

Orbitolinopsis briacensis
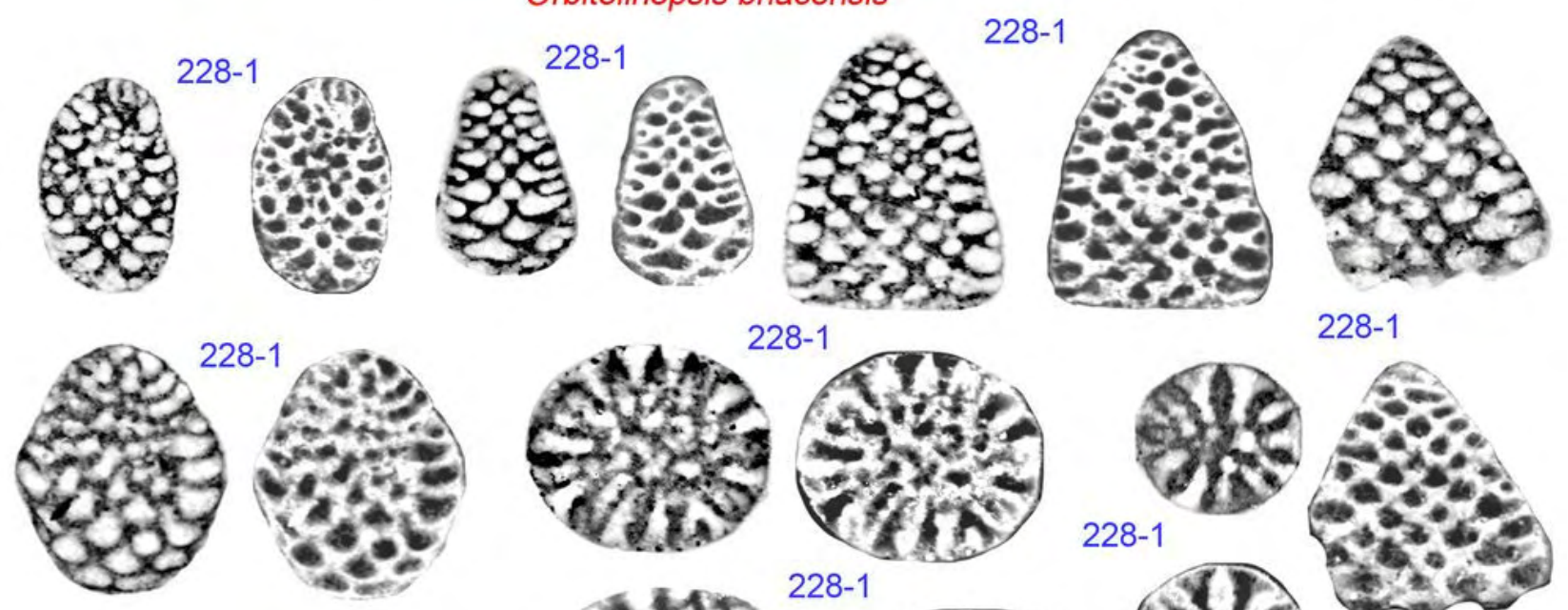

228-1

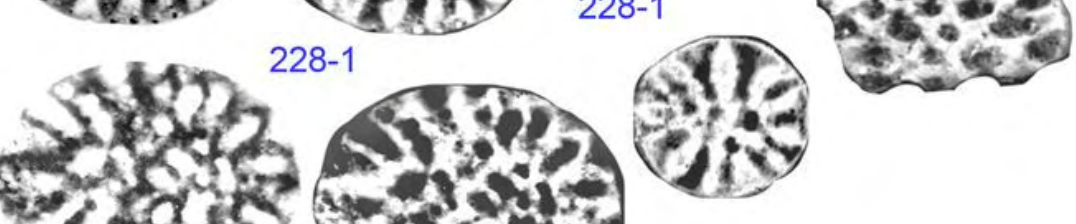

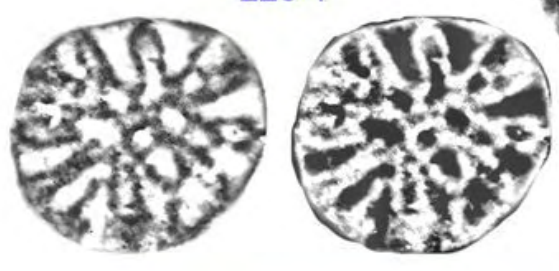

Orbitolinopsis cuvillieri
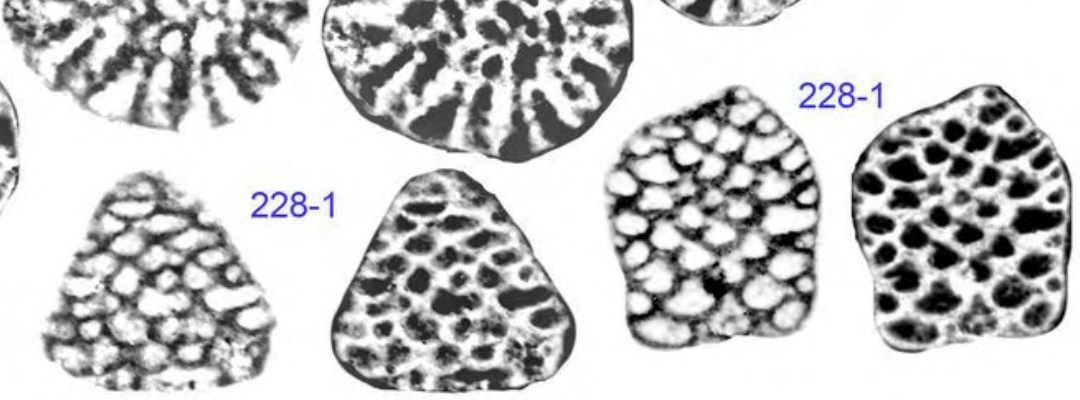

Plate 121: Orbitolinids of the Sarasini Zone at Orgnac. Orbitolinopsis briacensis: 228-1; Orbitolinopsis cuvillieri: 228-1; Orbitolinopsis kiliani: 228-1. Scale bar $=500 \mu \mathrm{m}$. 

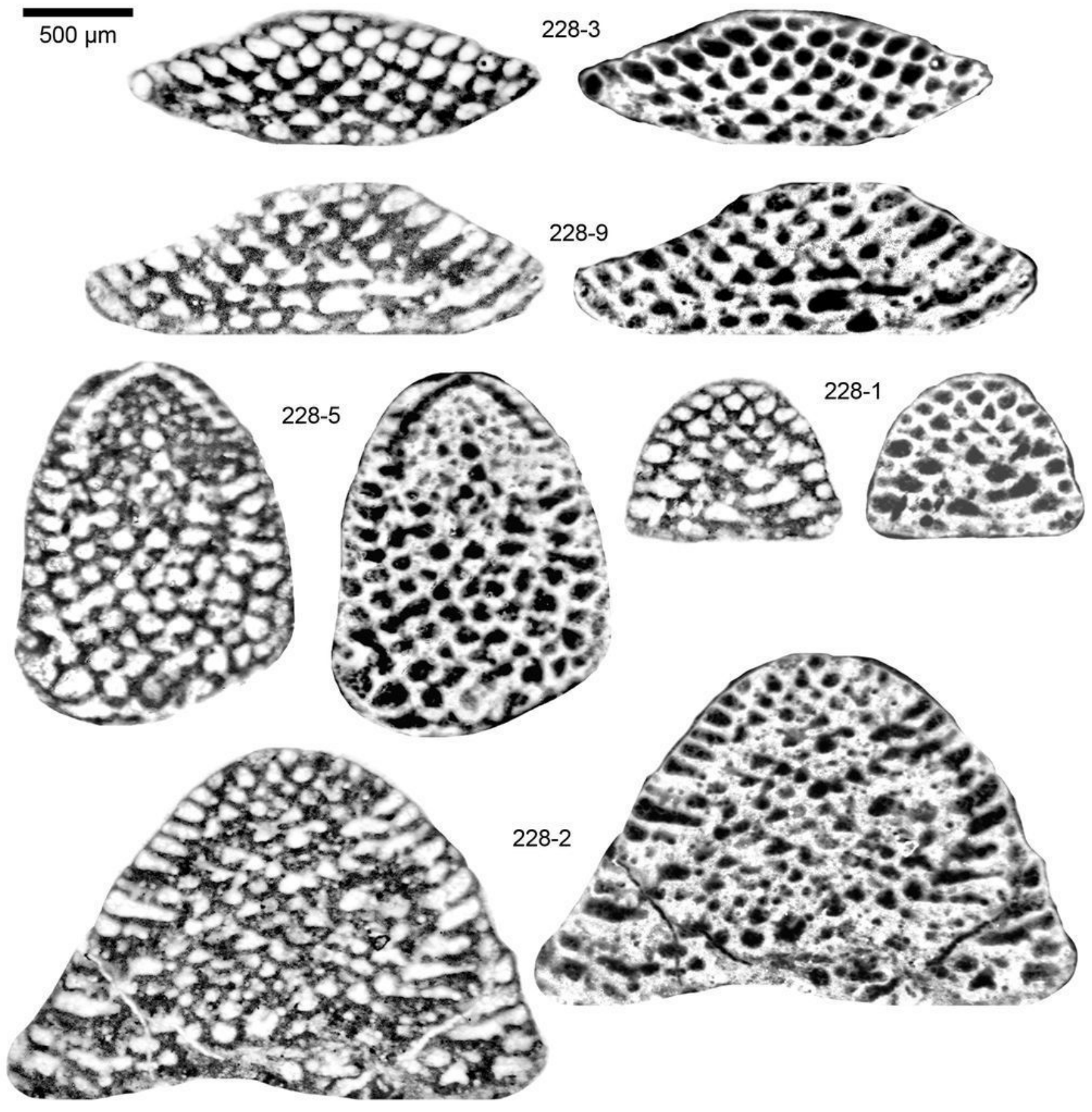

Orbitolinopsis buccifer

Plate 122: Orbitolinids of the Sarasini Zone at Orgnac. Orbitolinopsis buccifer: 228-1, 228-2, 228-3, 228-5, 228-9. Scale bar $=500 \mu \mathrm{m}$. 
$500 \mu \mathrm{m}$
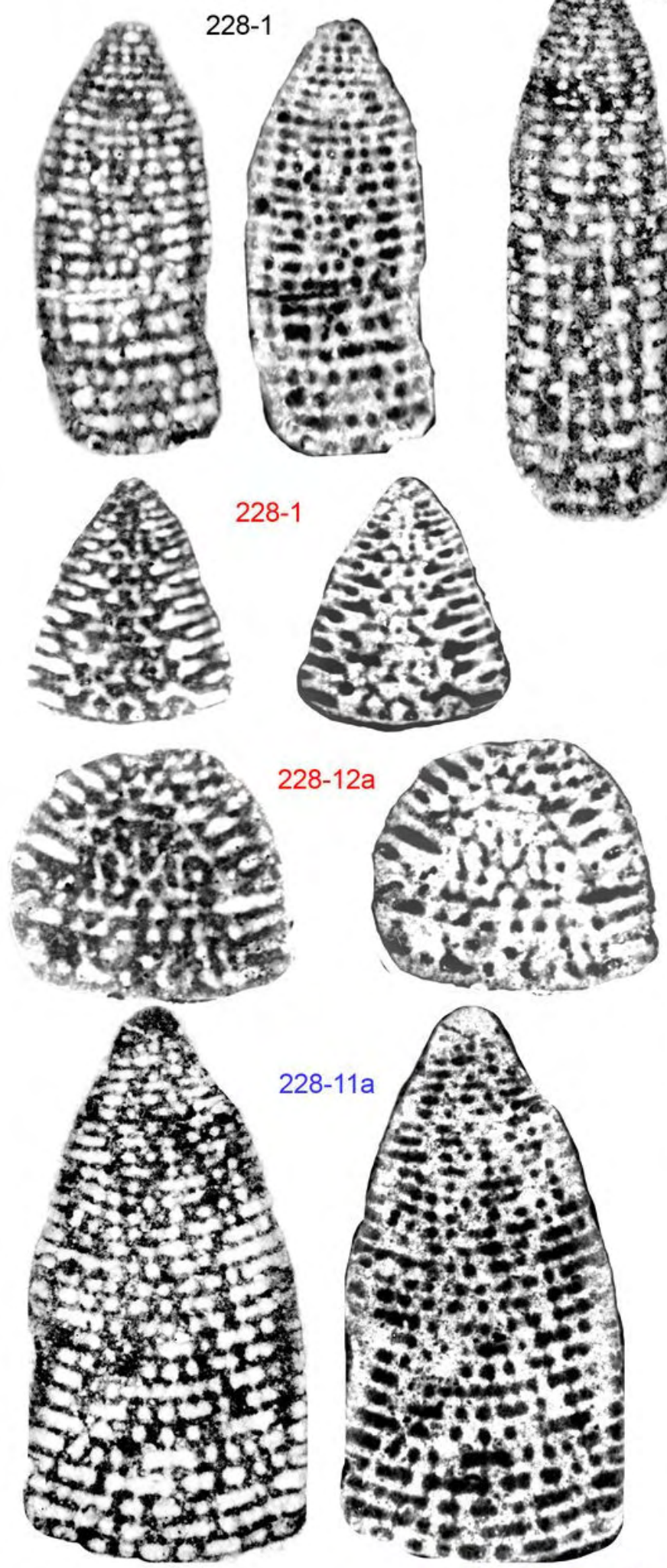
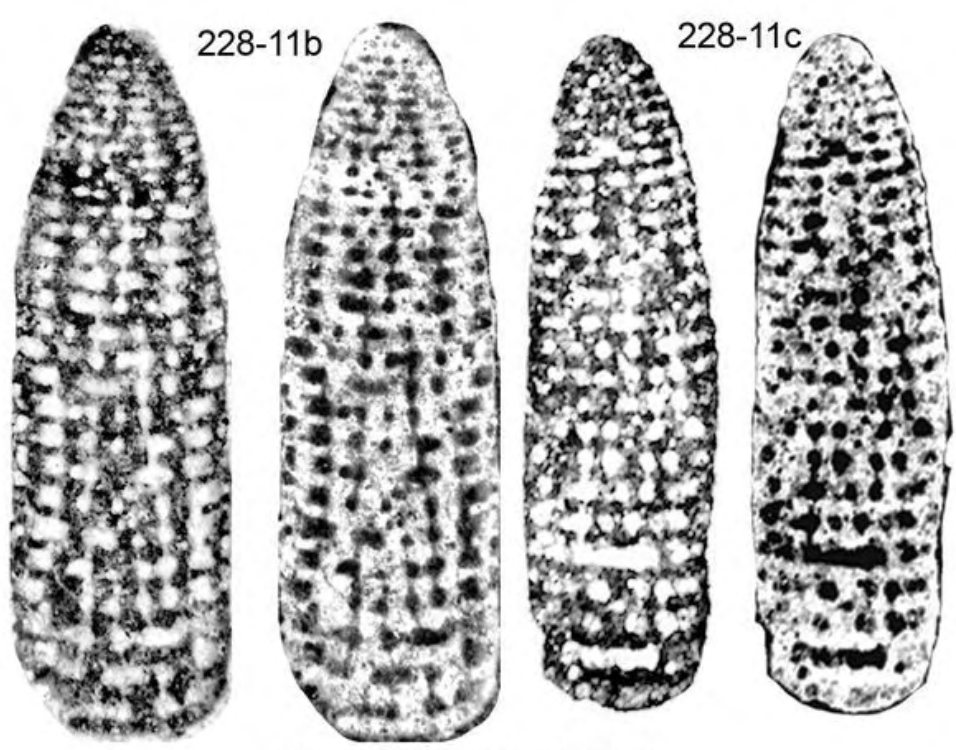

Paracoskinolina maynci
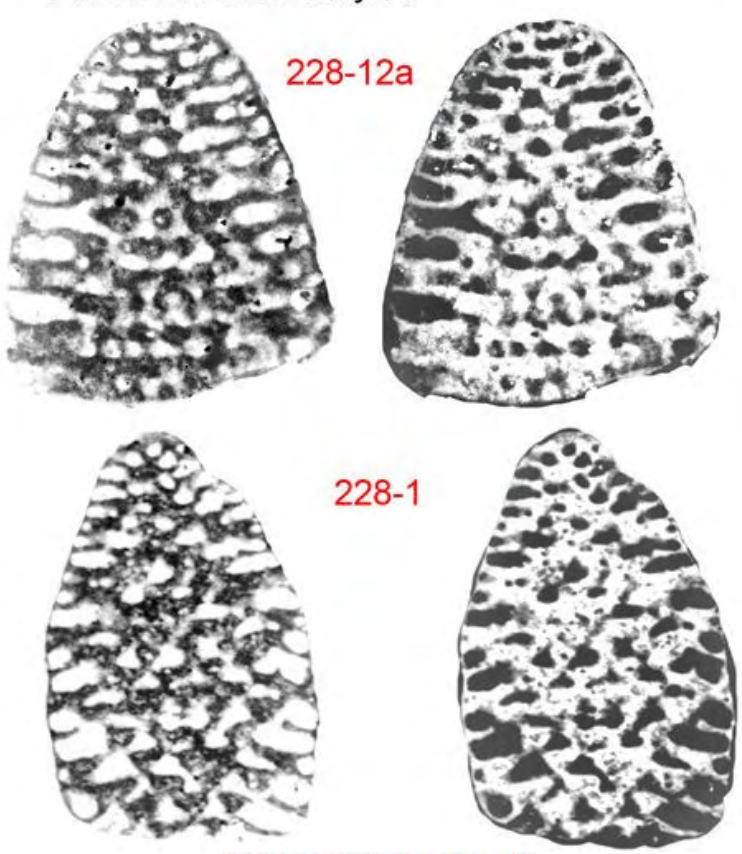

Vanneauina vercorii
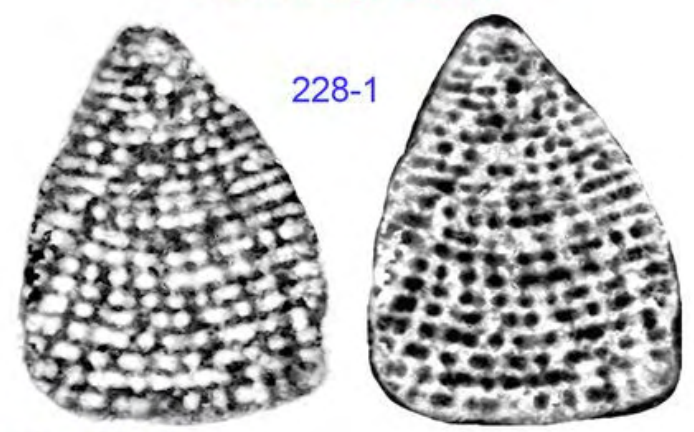

Plate 123: Orbitolinids of the Sarasini Zone at Orgnac. Paracoskinolina maynci: 228-1, 228-11b, 228-11c; Paracoskinolina aff. sunnilandensis: 228-1, 228-11a; Vanneauina vercorii: 228-1, 228-12a. Scale bar = 500 $\mu$ m. 

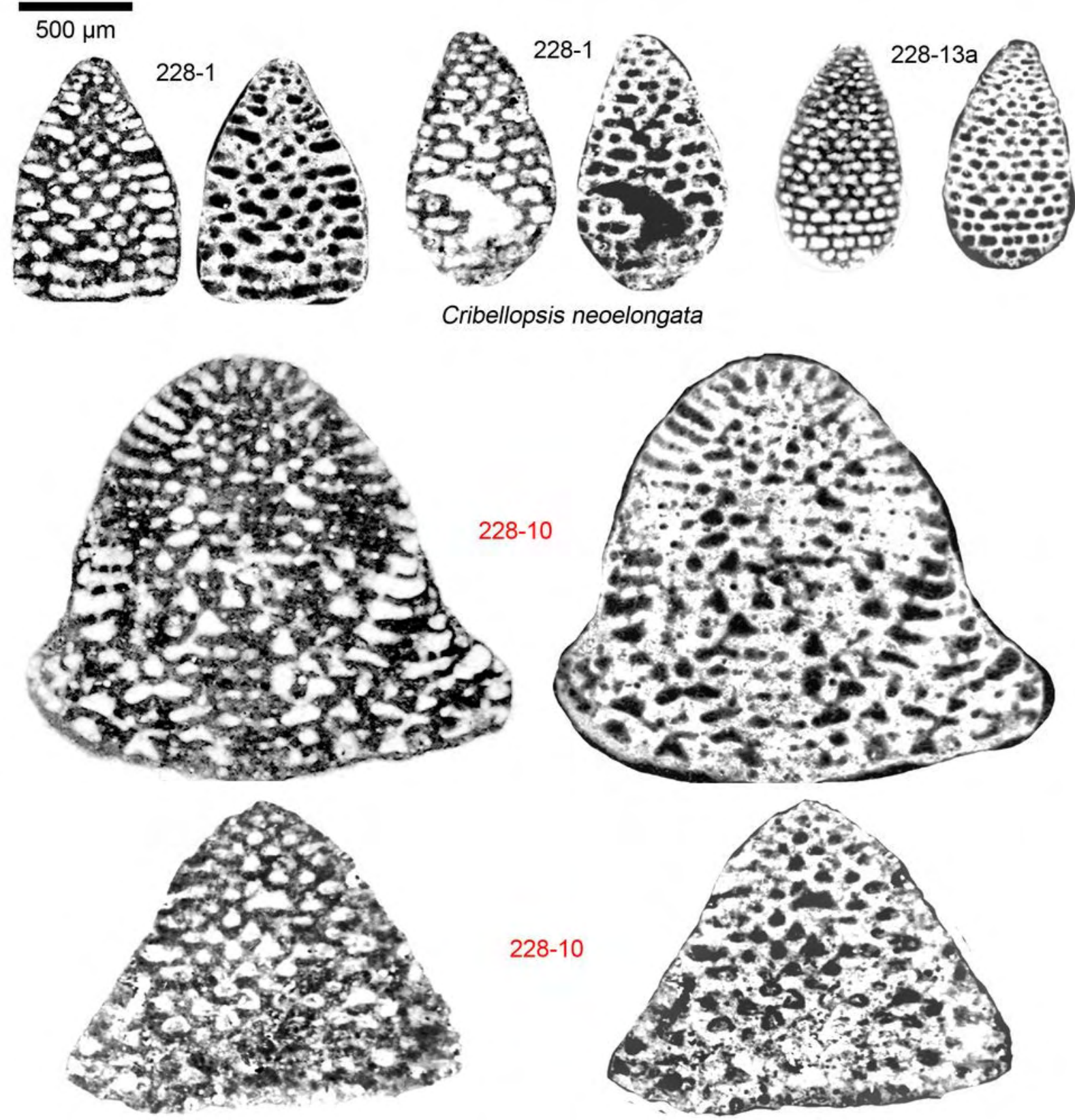

228-10
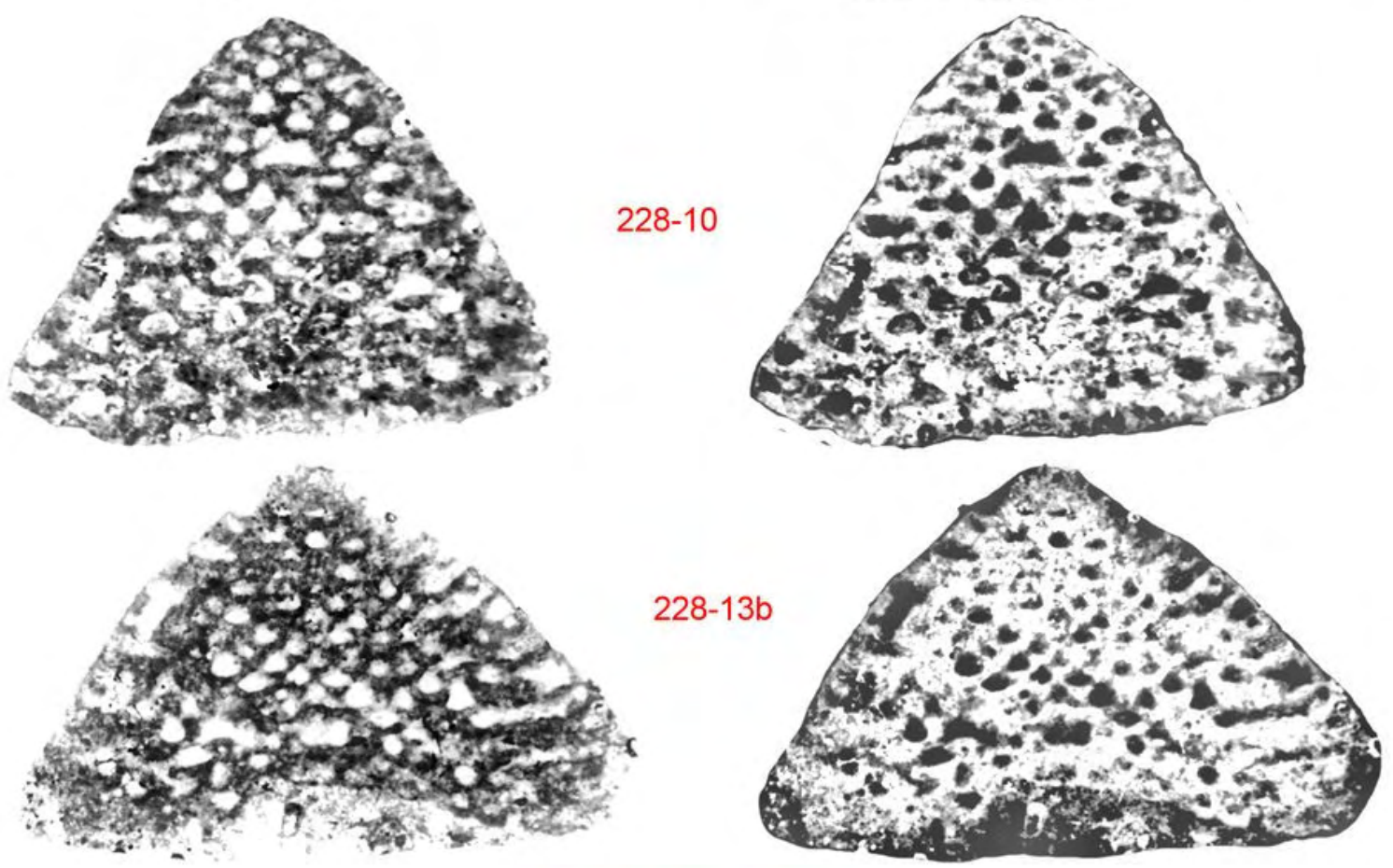

Cribellopsis schroederi

Plate 124: Orbitolinids of the Sarasini Zone at Orgnac. Cribellopsis neoelongata: 228-1, 228-13a; Cribellopsis schroederi: 228-10, 228-13b. Scale bar $=500 \mu \mathrm{m}$. 


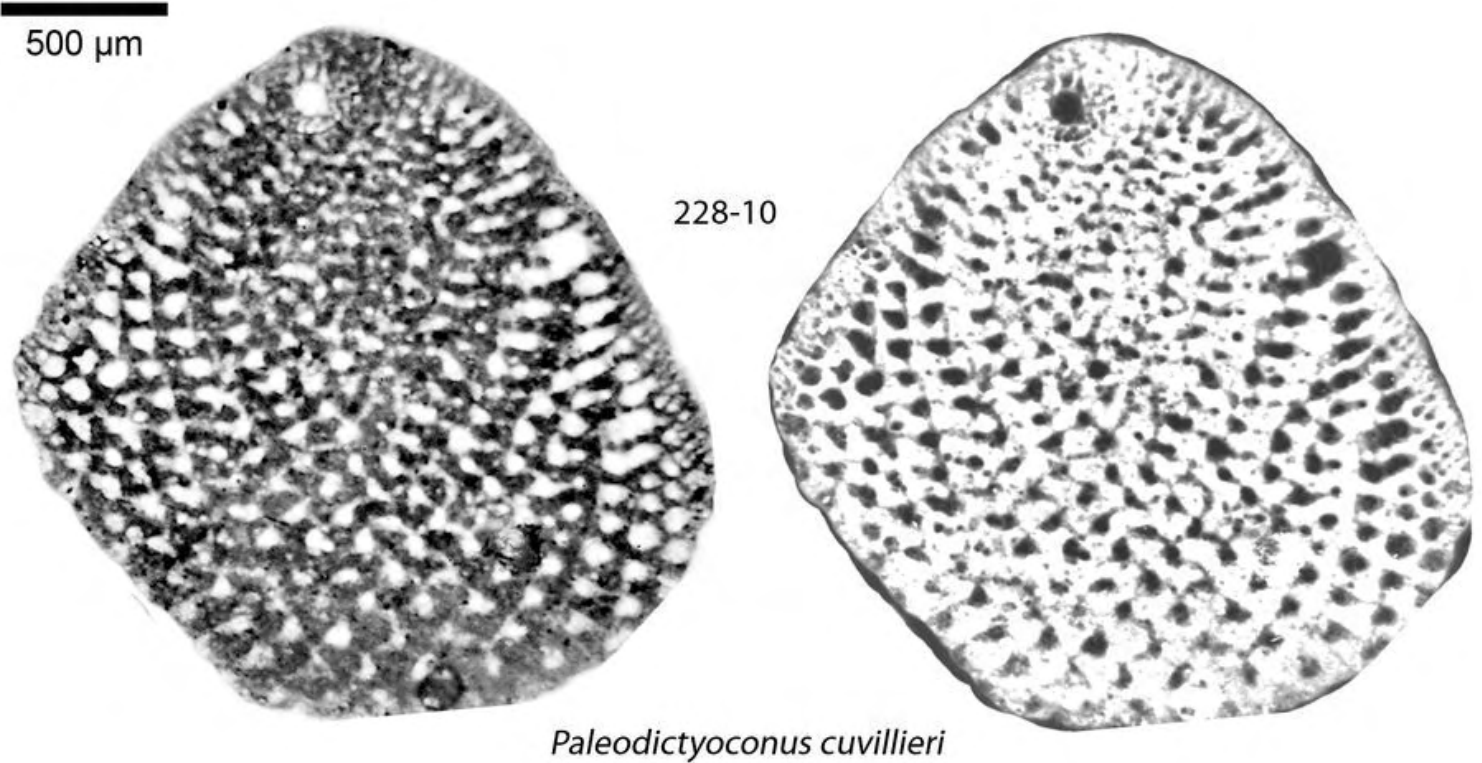

Paleodictyoconus cuvillieri
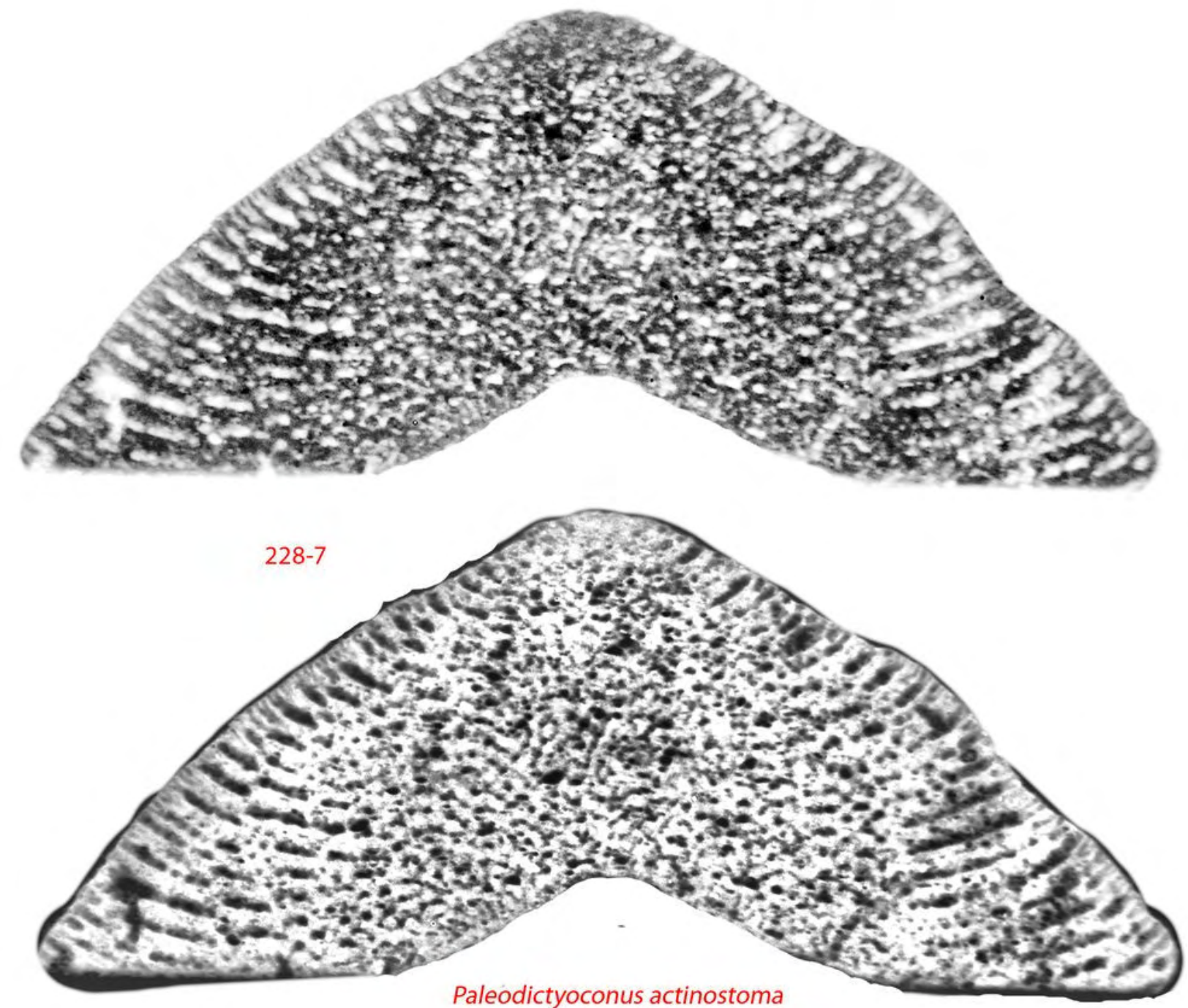

Plate 125: Orbitolinids of the Sarasini Zone at Orgnac. Paleodictyoconus actinostoma: 228-7; Paleodictyoconus cuvillieri: 228-10. Scale bar $=500 \mu \mathrm{m}$. 